A Dictionary of Scientific Terms 


\section{A DICTIONARY OF SCIENTIFIC TERMS}

PRONUNCIATION, DERIVATION, AND DEFINITION OF TERMS IN BIOLOGY, BOTANY, ZOOLOGY, ANATOMY, CYTOLOGY, EMBRYOLOGY, PHYSIOLOGY

BY

I. F. HENDERSON, M.A.

AND

W. D. HENDERSON, M.A., B.Sc., Pн.D., F.R.S.E.

OLIVER AND BOYD

EDINBURGH：TWEEDDALE COURT

LONDON : 33 PATERNOSTER ROW, E.C. 


\section{P R E F A C E}

THIS compilation was undertaken as it was thought desirable that there should be available to students and scientists, an up-to-date work somewhat on the lines of Stormonth's Manual of Scientific Terms (1879, republished 1903). It contains definitions of about ten thousand terms, including several hundred lately coined expressions, many of which have not hitherto appeared in a dictionary. The work is expected to supply a want felt by many students and other readers of the Biological Sciences, as the usual handy-sized dictionary contains comparatively few purely scientific terms. The subjects selected for treatment are Biology and its allies, Anatomy, Botany, Zoology, Embryology, Cytology, Physiology; and some terms in Bacteriology and Palaeontology are included.

In a first edition of a book of this kind, errors of omission are inevitable, as few people have convenient access to each textbook and treatise, even in one subject, as it makes its appearance Suggestions for additions will be welcomed and noted for future use, and should be accompanied by the name of the work in which the original definition is to be found; derivation offers no difficulty as a rule, but pronunciation might be indicated by coiners of entirely new terms.

In the etymological section, Greek words have been transliterated, as science and medical students are seldom acquainted with that language, and on the advice of an authority on Greek, the transliteration of certain combinations of letters represents the sound rather than the exact letters of the original; hence the frequent occurrence of such words as brangchia, hydor, etc.

This work was begun by Mr J. H. Kenneth, who compiled most of the primary lists from which the whole has been elaborated. Mr Kenneth had completed upwards of three 
hundred terms when ill-health prevented his continuing the work, and it was handed over to the present authors.

We have to acknowledge our indebtedness to Professor J. H. Ashworth of Edinburgh University, who has very kindly read over the manuscript and given us some suggestions for additions.

I. F. H.

Zoology Department,

UNIVERSITY OF BRISTOL. 


\section{NOTE AS TO PRONUNCIATION}

IT has seemed expedient in many cases to give alternatives, as different centres of learning have different types of pronunciation; again, as it is usage which determines correct pronunciation, and the terms are not everyday words, it will be long before a term which lends itself equally well to two methods will be fixed down to one.

As to many anatomical and other purely Latin terms, students will probably follow the type of pronunciation, English or Continental, learned at school; in the latter case, the second alternative or some modification of it will be employed. Those who can readily pronounce $c h$ as in loch, and who have so learned to pronounce the combination in Greek, will naturally introduce that sound into such words as branchial, brachycnemic; although the $k$ sound has been adopted in this as in other dictionaries, the other is not to be regarded as incorrect.

The sound-symbols have been made as simple as possible, only the broader differences of vowel-sounds having been included. A general indication of pronunciation, rather than a critically exact reproduction, is what is wanted for the average reader of scientific works.

In the case of words which have not previously appeared in a dictionary, and whose pronunciation is not clearly indicated by etymological or other rules, it remains for the coiner to indicate his preference. 


\section{SOUND-SYMBOLS USED IN PRONUNCIATION}

\begin{tabular}{|c|c|c|}
\hline$\vec{a}$ & as ins & fate. \\
\hline ă & ", & fat. \\
\hline & $"$ & far. \\
\hline & " & church. \\
\hline & $"$ & he. \\
\hline & $"$ & hen. \\
\hline & $"$ & her. \\
\hline$g$ & ") & go. \\
\hline gw & " & guano. \\
\hline$\overline{\mathbf{1}}$ & $"$ & pine. \\
\hline i. & " & pin. \\
\hline $\mathrm{j}$ & $"$ & gem. \\
\hline 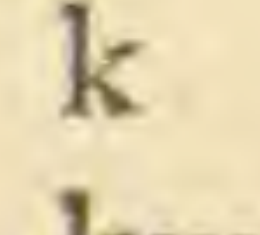 & " & \\
\hline $\mathrm{kw}$ & $"$ & ueen. \\
\hline & $"$ & ing. \\
\hline & , & \\
\hline
\end{tabular}

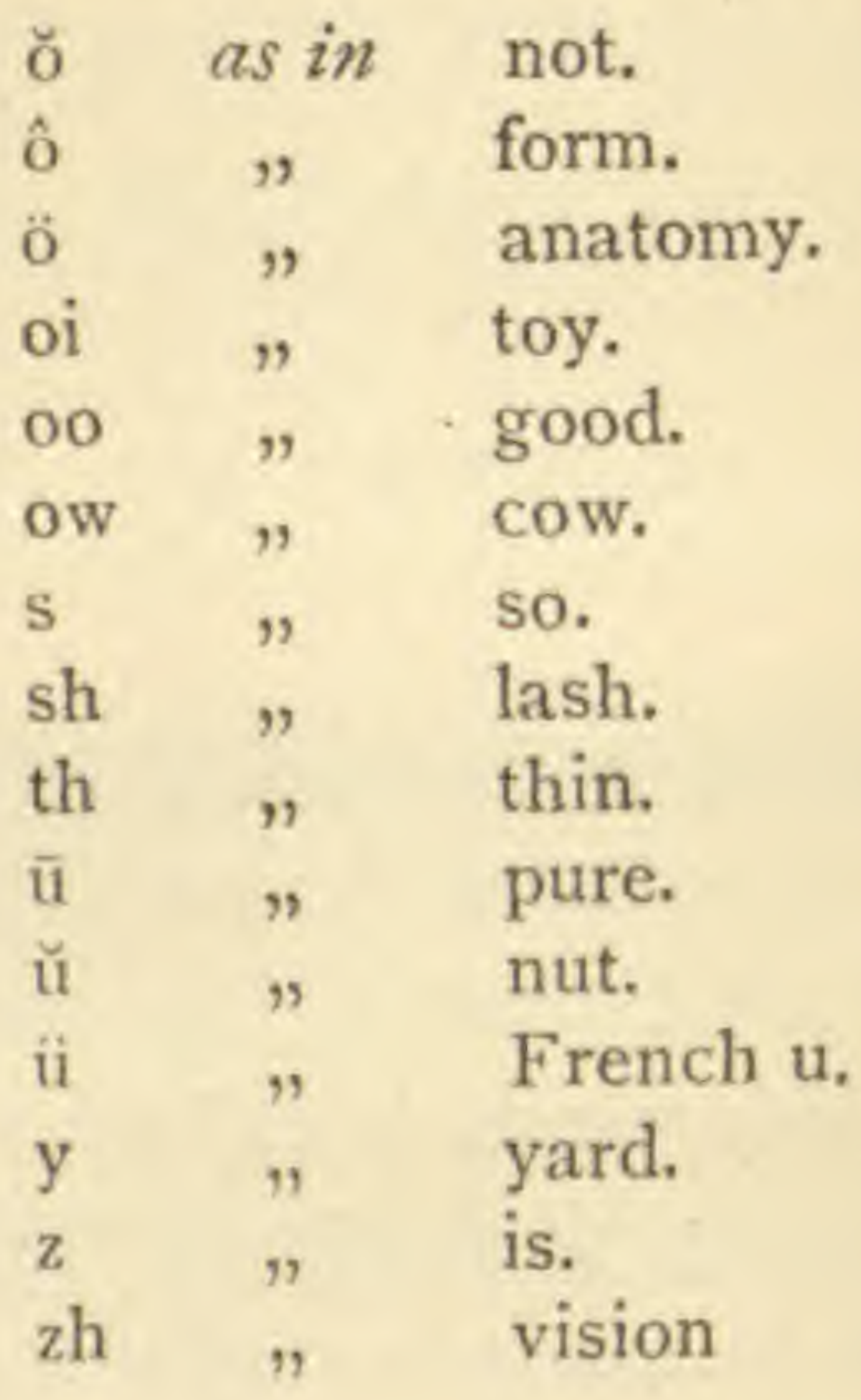

\section{ABBREVIATIONS}

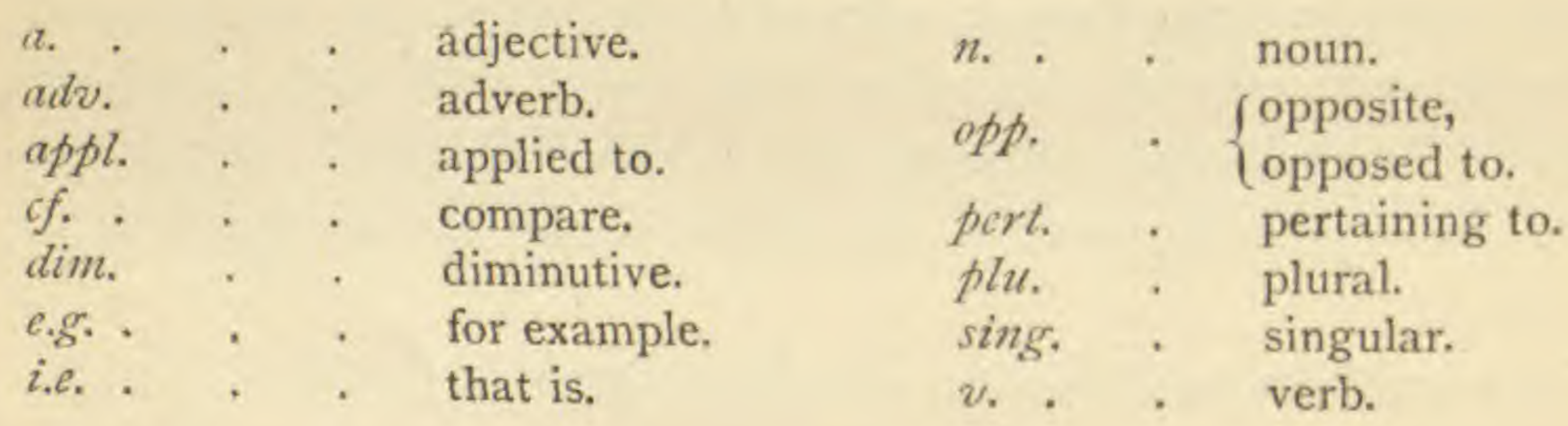

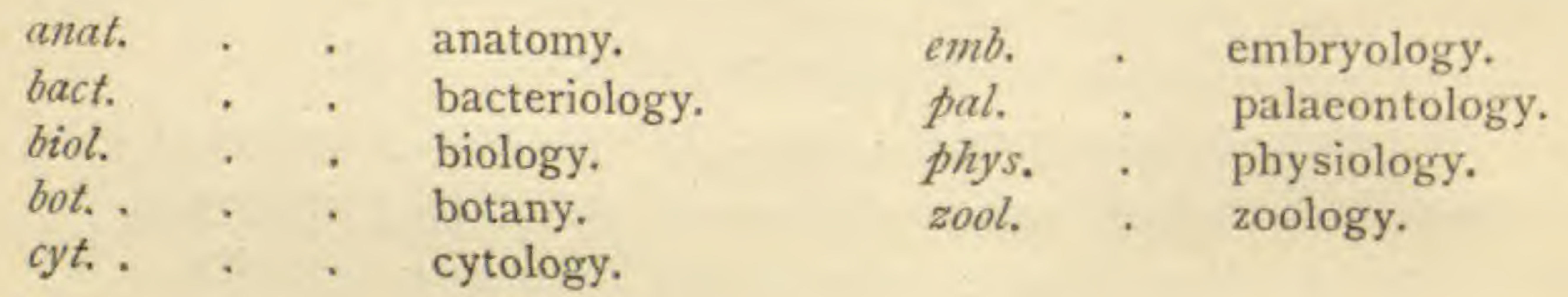

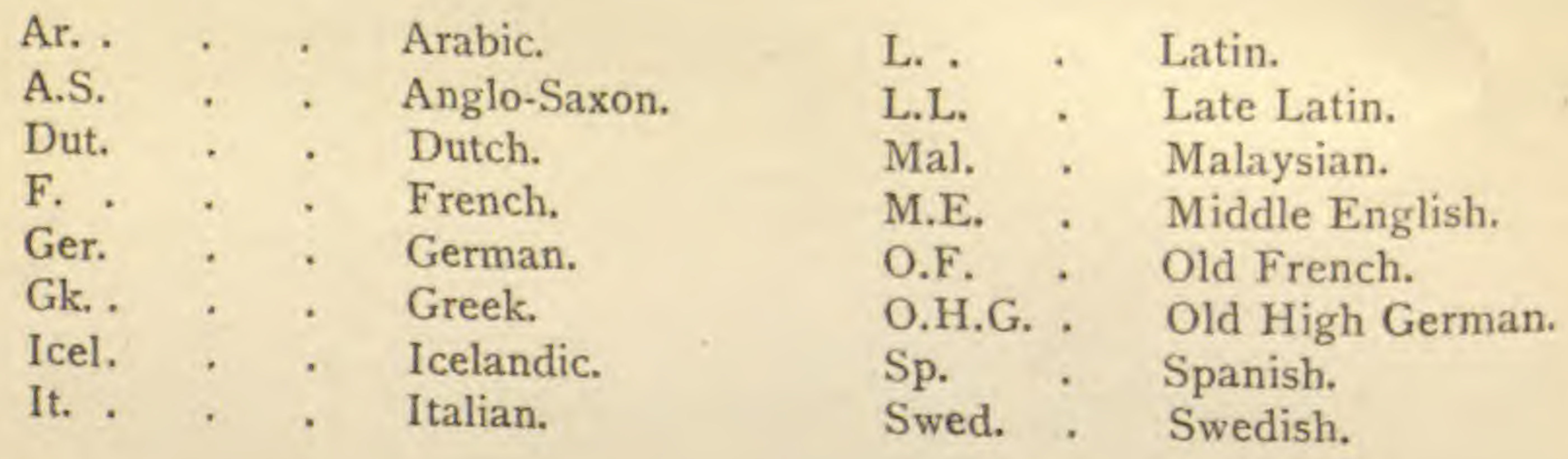




\section{A DICTIONARY OF \\ SCIENTIFIC TERMS}

ABA-

abactinal (ăbăk'tinnăl, ăbăktî́năl) $a$. [L. $a b$, from; Gk. aktis, ray.] $A p p l$. the area of an echinoderm body without tube-feet and in which the madreporite is usually included; abambulacral ; antambulacral ; $o p p$. actinal (zool.).

abambulacral (ăb'ămbūlā'krăl)a. [L. $a b$, from; ambulare, to walk.] $A p p l$. the area of an echinoderm body remote from that on which the tube-feet are found (zool.).

abaxial (ăbăk'siăl) a. [L. $a b$, from ; axis, axle.] Pert. that surface of any structure which is remote or turned away from the axis (biol.).

abaxile (ăbăk'sîl) $a$. [L. $a b$, from; axis, axle.] Appl. an embryo in which the axis has not the same direction as the axis of the seed (bot.).

abbreviated (ăbrē'vīâtěd) $a$. [L. $a d$, to ; brevis, short.] Shortened; curtailed.

abdomen (ăbdō'mĕn, ăb'dömĕn) $n$. [L. abdomen, belly.] The belly ; in vertebrates, the part of the body containing the digestive organs ; in Arthropods and certain Polychaets, the posterior part of the body ; in Synascidians, part of the zooid below the thorax (zool., anat.).

abdominal (ăbdómininăl) $a$. [L. $a b$ domen, belly.] Pert. abdomen; $a p p l$. structures, organs, or parts of organs situated in, on, or closely related to, the abdomen.

abdominal pores, - single or paired openings leading from the coelom to the exterior, in Cyclostomes and certain other fishes (zool.).

abdominal reflex, - contraction of abdominal wall muscles when the skin over the side of the abdomen is stimulated (phys.).

abdominal regions, - nine areas into which the abdomen is divided by
$\mathrm{ABO}-$

two horizontal and two vertical imaginary lines, viz., hypochondriac (2), lumbar (2), inguinal (2), epigastric, umbilical, hypogastric (anat.). abdominal ribs, - ossifications occurring in the fibrous tissue between skin and muscles of certain reptiles (zool.).

abdominal ring, - one of two openings in the fasciae of the abdominal muscles through which passes the spermatic cord in the male, and the round ligament in the female; inguinal ring (anat.).

abducens (ăbdū'sĕnz) $n$. [L, abducere, to lead away.] The sixth cranial nerve supplying the rectus externus which turns the eyeball outwards (anat.).

abduct (ăbdǔkt') v. [L, abducere, to lead away.] To draw away from the median axis (phys.).

abductor (ăbdŭk'tŏr) n. [L. abducere, to lead away.] A muscle that draws a limb or part outwards (anat.).

aberrant (ăbĕr'ănt) a. [L. aberare, to wander away.] $A p p l$. species with characteristics not strictly in accordance with the type (bot., zool.).

abiogenesis (ăbiöjën'ěsis) n. [Gk. $a$, not; bios, life; genesis, birth.] The production of living from non-living matter; archegony; autogony ; spontaneous generation (biol.).

abiology (ābīǒl'öjî) n. [Gk. $a$, not ; bios, life; logos, discourse.] The study of non-living things; anorganology.

abomasum (ăbömā'zŭm, ăbŏm'ăzŭm) $n$. [L. $a b$, from ; omasum, paunch.] The read or fourth chamber of the stomach of ruminants (zool.).

aboral (ăbō'răl) a. [L. $a b$, from; os, oris, mouth.] Away from, or opposite to, the mouth.

abort (ăbôrt') v. [L. abortus, pre- 
mature birth.] To be arrested in development; to be born prematurely (biol.)

abortion (ăbôr'shŭn) $n$. [L. abortus, premature birth.] Premature birth ; arrest of development of an organ (biol.).

abranchiate (âbrăng'kiāt) a. [Gk. $a$, without; brangchia, gills.] Without gills (zool.).

abrupt (ăbrŭpt')a. [L. $a b$, from ; rumpere, to break.] Appearing as if broken, or cut off, at the extremity. abruptly-acuminate,- - having a broad extremity, as a leaf, from which a point arises (bot.).

abruptly-pinnate,-having the main axis of the epipodium not winged, but bearing a number of secondary axes which are winged (bot.).

absciss (ăb'siss) a. [L. abscindere, to cut off.] $A p p l$. layer of cells just outside the cork-layer, to whose disorganization the fall of the leaf is due (bot.).

abscission (ăbšssh'ŭn) $n$. [L, abscindere, to cut off.] The separation of parts (bot.).

absorption (ăbsôrp'shŭn) $n$. [L. absorbere, to suck in.] The intussusception of fluid by living cells or tissues ; the passage of nutritive material through living cells (biol., phys.).

abstriction (ăbstrik'shŭn) n. [L. abstringere, to cut off.] The process of detaching spores (conidia) by the rounding off of the tips of the sporophores, as in mildews (bot.). abterminal (ăbtěr'minnăl) $a$. [L. $a b$, from ; terminus, end.] Going from the end inwards (phys.).

abysmal (ăbǐz'măl) a. [Gk. abyssos, bottomless.] Pert. depths of the ocean.

abyssal (ăbǐs'ăl) a. [Gk. abyssos, bottomless.] Pert. depths of the ocean ; $a p p l$. organisms or material usually found there (biol.).

acanaceous (ăkănā'shŭs) a. [Gk. akanos, thorn.] Bearing thorns or prickles, as leaves (bot.).

acantha (ăkăn'thă) n. [Gk, akantha, thorn.] Prickle (bot.); spinous process (zool.).

acanthaceous (ăkănthā'shŭs) a. [Gk. akantha, thorn.] Bearing prickles. acanthin (ăkăn'thĭn) n. [Gk, akantha, thorn.] A substance like chitin, strontium sulphate, forming the skeleton of the Radiolarians (phys.). acanthion (ăkăn'thĭŏn) n. [Gk. akantha, thorn.] The most prominent point on the nasal spine (anat.).

acanthocarpous (ăkăn'thökâr'pŭs) $a$. [Gk. akantha, thorn ; karpos, fruit.] Having the fruit covered with spines or prickles.

acanthocephalous (ăkăn'thökĕf'ălŭs, -sĕf-) a. [Gk. akantha, thorn; kephale, head.] With a hooked proboscis (zool.).

acanthocladous (ăkăn'thöklăd'ŭs) $a$. [Gk. akantha, thorn; klados, branch.] Having spiny branches.

acanthocyst (ăkăn'thösǐst) n. [Gk. akantha, thorn; kystis, bladder.] A sac containing lateral or reserve stylets in Nemerteans (zool.).

acanthophore (ăkăn'thöfōr) n. [Gk. akantha, thorn; pherein, to bear.] A conical mass, the basis of the median stylet in Nemerteans (zool.). acanthosphenote (ăkăn'thösfē'nōt) $a$. [Gk. akantha, thorn; sphen, wedge.] $A p p l$. an echinoid spine made up of solid wedges separated by porous tissue (zool.).

acanthozooid (ăkăn'thözō'oid) n. [Gk. akantha, thorn ; zoon, animal ; eidos, form.] The tail part of the proscolex of Cestodes as distinguished from the body or cystozooid (zool.).

acapnia (âkăp'nĭă) n. [Gk. akapnos, without smoke.] Diminution or want of carbon dioxide (phys.).

acaulescent (ăkôlěs'ěnt) $a$. [Gk. $a$, without; kaulos, stalk.] Having a shortened stem (bot.).

accelerator (ăksěl'ěrātŏr) $n$. [L. $a c$ celerare, to hasten.] Appl. muscle or nerve which increases the rate of action (phys.).

acceptor (ăksĕp'tŏr) $n$. [L. accipere, to accept.] A body or substance which receives and unites with another substance or gas introduced (phys.).

accessorius (ăksěsō'rǐus) $n$. [L. $a c$ cedere, to go to.] A muscle aiding in the action of another; the spinal accessory or eleventh cranial nerve (anat.).

accessory (ăksěs'örǐ) a. [L. accedere, 
to go to.] Additional or accompanying.

accessory bud, - an additional axillary bud (bot.).

accessory chromosome,-a chromosome found in the sex-cells of various animals which by its peculiar behaviour and the stage it appears at, is considered by some authorities to be the factor that determines sex. accessory nerve, - the eleventh cranial nerve (anat.).

accessory pancreatic duct,-Santorini's duct (anat.).

accommodation (ăkŏmödā'shŭn) $n$. [L. $a d$, to ; commodus, fitting.] The adjustment of the eye for receiving clear images of objects at different distances (phys.).

accrescent (ăkrěs'ĕnt) a. [L. accrescere, to increase.] Appl. plants that continue to grow after flowering, or calyx continuing to grow after pollination (bot.).

accretion (ăkrē'shŭn) $n$. [L, accrescere, to increase.] Growth by the external addition of new matter; in protozoology, agglomeration (biol.). accumbent (ăkŭm'bènt) $a$. [L. $a c$ cumbere, to lie on.] $A p p l$. embryo having cotyledons with their edges turned towards the radicle, as in Cruciferae (bot.).

acentrous (âsĕn'trŭs) $a$. [L. $a$, without; centrum, centre.] With no vertebral centra and with persistent notochord, as in certain fishes (zool.).

acephalous (âkěf'ălŭs, -sěf-) $a$. [Gk. $a$, not; kephale, head.] Having no structure comparable to the head, as in some molluscs (zool.).

acerate (ăs'ěrāt) a. [L. acer, sharp.] Needle-shaped; pointed at one end, $a p p l$. monaxon or oxeote spicules (zool.).

acerose (ăs'ĕrōs) a. [L. acer, sharp.] Narrow and slender, with a sharp point ; as a pine-leaf (bot.).

acervuline (ăsĕr'vūlǐn) $a$. [L. acervus, heap.] Irregularly heaped together, appl. foraminiferal tests (zool.).

acervulus (ăsĕr'vūlŭs) $n$. [LL. dim. of acervus, heap.] A small heap or cluster; especially of sporogenous mycelium (bot.). acervulus cerebri, - minute grains of a calcareous nature in the pineal gland, etc., of the brain (anat.).

acetabulum (ăsĕtăb'ūlŭm) $n$. [L. acetabulum, vinegar-cup.] The socket for the head of the femur, situated at the junction of the ilium, ischium, and pubis, all of which may or may not take part in its formation (anat.); in insects, the cavity of the thorax formed by the epimeron, sternum, and occasionally epigastrium, in which the legs are inserted; the large posterior sucker in leeches; one of the cotyledons of the ruminant placenta; the sucker on the arms of a Cephalopod (zool.).

acheilary (ăkī'lărì) a. [Gk. $a$, without ; cheilos, lip.] Having the labellum undeveloped, as in some orchids (bot.).

achene (ăkēn') n. [Gk. a, not; chainein, to gape.] A monospermal seed-vessel which does not open or crack (bot.).

Achillis tendo (ăkǐl'ǐs tĕn'dō) $n$. [Achilles, hero of the Iliad, who had a vulnerable heel; L. tendo, tendon.] The hamstring; the united strong tendon of the gastrocnemiusand solaeus muscles (anat.). achlamydeous (ăk'lămĭd'ěus) $a$. [Gk. $a$, without; chlamys, cloak.] Having neither calyx nor corolla (bot.).

achromatin (ăkrō'mătĭn) $n$. [Gk. $a$, without; chroma, colour.] The non-staining ground substance and linin of the nucleus (cyt.).

achromatinic (ăkrō'mătǐn'îk) a. [Gk. $a$, without ; chroma, colour.] Pert. achromatin, or resembling achromatin in its properties (cyt.).

acicular (ăsǐk'ûlăr) a. [L. acicula, small needle.] Like a needle in shape; sharp-pointed (bot.).

aciculum (ăsǐk'ûlŭm) $n$. [L. acicula, small needle.] One of the stiff basal setae in the parapodium of a worm (zool.).

acinaciform (ăsĭnăs'ífôrm) a. [L. acinaces, short sword; forma, shape.] Shaped like a sabre or scimitar; $a p p l$. leaf (bot.).

acinarious (ăsinnā'riǔs) a. [L. acinus, berry.] Having globose vesicles, as some Algae (bot.). 
acinus (ăs'ǐnŭs) $n$. [L. acinus, berry.] One of the pulpy drupes composing the fruit of bramble or raspberry (bot.); the sac-like termination of a branched gland (anat.).

acoelomate (ầé'lömāt) a. [Gk. $a$, without; koilos, hollow.] Appl. animals not having a true body cavity.

acoelomatous, acoelous, - acoelomate. acontia (ăkŏn'tiă, ăkŏn'shřă) $n$. plu. [Gk. akontion, small javelin.] Threadlike processes of the mesenteric filaments armed with stinging cells, in Actinians (zool.).

acotyledon (ấkŏtǐlé'dŏn) $n$. [Gk, $a$, without; kotyledon, a cup-shaped hollow.] A plant without a cotyledon (bot.).

acquired character, $-\mathrm{a}$ modification or mutilation, due to disease or to use or disuse of a special organ or organs, which has actually made its appearance during the lifetime of the individual (biol.).

acraspedote (ăkrăs'pĕdōt) $a$. [Gk. $a$, without; kraspedon, an edge or border.] Having no velum (zool.).

acrobryous (ăk'röbrí'ús) a. [Gk. akros, tip; bryein, to swell.] Growing at the tip only (bot.).

acrocarpous (ăk'rökâr'pŭs) a. [Gk. akros, tip; karpos, fruit.] Having the fructification terminating the axis (bot.).

acrocoracoid (ăk'rökŏr'ăkoid) n. [Gk. akros, tip; korax, crow; eidos, shape.] A process at the dorsal end of the coracoid in birds (zool.). acrocyst (ăk'rösǐst) n. [Gk. akros, tip ; kystis, bladder.] The spherical gelatinous cyst formed by the gonophore, when it projects after migration on the blastostyle beyond the mouth of the gonotheca, for the completion of the maturation of the generative cells (zool.).

acrodont (ăk'rödŏnt) a. [Gk. akros, tip; odous, tooth.] Appl. teeth which are ankylosed by their base to the summit of a parapet of bone (anat.).

acrodrome (ăk'rödrōm), acrodromous (ăkrŏd'römŭs) a. [Gk, akros, tip; dromein, to run.] Appl. leaf with nerves converging at its point (bot.). acrogenous (ăkrŏj'ènŭs) a. [Gk. akros, tip ; genos, offspring.] Increasing in growth at the summit or growing point (bot.).

acromial (ăkrō'mĭăl) a. [Gk. akros, summit; omos, shoulder.] Pert. the acromion, $a p p l$. artery, process, ligament, etc. (anat.).

acromio-clavicular (ăkrō'miö-klăvik' ülăr) $a$. [Gk. akromion, shouldersummit; L. claviculus, dim. of clavis, key.] Appl. ligaments covering the joint between the acromion and the clavicle (anat.).

acromion (ăkrō'miŏn) n. [Gk. akros, summit; omos, shoulder.] The ventral prolongation of the spina scapulae (anat.).

acropetal (ăk'röpĕt'ăl) a. [Gk. akros, summit; L. petere, to seek.] Appl. leaves or flowers developing from an axis so that the youngest arise nearest the apex (bot.).

acrorhagus (ăkrörā'gŭs) n. [Gk. akros, summit; rhax, grape.] A tubercle on the margin of certain Actinians, containing nematocysts (zool.).

acrosarc (ăk'rösârk) n. [Gk. akros, summit; sarx, flesh.] A pulpy berry resulting from the union of ovary and calyx (bot.).

acrosome (ăk'rösōm) n. [Gk. akros, tip; soma, body.] Body at the apex of a spermatozoon, the apical body (zool.).

acrospire (ăk'röspīr) $n$. [Gk. akros, summit ; speira, something twisted.] The first shoot or sprout, being spiral, at the end of a germinating seed (bot.).

acrospore (ăk'röspōr) $n$. [Gk. akros, tip; sporos, seed.] The spore at the end of a sporophore (bot.).

actinal (ăk'tinnăl, ăktî́năl) $a$. [Gk. aktis, ray.] Appl. area of an echinoderm body in which the tube-feet are situated; $a p p l$. the oral area with tentacles in Actinaria (zool.).

actine (ăk'tīn) n. [Gk, aktis, ray.] A star-shaped spicule (zool.).

actinenchyma (ăk'tiněng'kĭmă) $n$. [Gk. aktis, ray; en, in; chein, to pour.] Cellular tissue having a stellate appearance (bot.).

actinoblast (ăktĭn'öblăst) n. [Gk. aktis, ray; blastos, bud.] The mother-cell from which a spicule is developed (zool.). 
actinocarpous (ăk'tǐnökâr'pŭs) a. [Gk. aktis, ray; karpos, fruit.] $A p p l$. plants with flowers and fruit radially arranged (bot.).

actinodrome (ăktin'ödröm) a. [Gk. aktis, ray; dromos, a running.] Veined palmately (bot.).

actinogonidial (ăk'tĭnögŏnĭd'răl) $a$ [Gk. aktis, ray ; gonos, offspring.] Having radiately arranged genital organs as in Stelleroids (zool.).

actinoid (ăk'tĭnoid) a. [Gk. aktis, ray ; eidos, shape.] Rayed, star-shaped. actinomere (ăktīn'ömēr) n. [Gk. aktis, ray; meros, part.] A radial segment (zool.).

actinomorphic (ăk'tǐnömôr'fỉk), actinomorphous (ăk'tinömôr'fŭs) a. [Gk. aktis, ray; morphe, shape.] Appl. flowers which can be divided into like halves by a vertical section through the centre; radiosymmetrical.

actinost (ăk'tǐnŏst) n. [Gk, aktis, ray ; osteon, bone.] Basal bone of the fin-rays in Teleosteans (zool.).

actinostome (ăktǐn'östōm) n. [Gk. aktis, ray; stoma, mouth.] The five-rayed oral aperture of the starfish (zool.).

actinotrichium (ăk'tĭnötrǐk'íŭm) $n$. [Gk. aktis, ray; thrix, hair.] A delicate unjointed horny fibre of mesoblastic origin found at the edge of all the fins in adult Teleostomes, probably homologous with the ceratotrichia of Elasmobranchs (zool.).

actinotrocha (ăk'tĭnötrō'kă) n. [Gk. aktis, ray; trochos, wheel.] Freeswimming larval form of Phoronis (zool.).

actinula (ăktǐn'ūlă) n. [Gk. aktis, ray.] A larval stage in some Hydromedusae, in which a coelenteron, mouth, and tentacles are formed, and cell differentiation has taken place before the larva is set free from the parent form (zool.).

aculeate (ăkū'lěāt) a. [L. aculeus, prickle, thorn.] Having prickles or sharp points (bot.).

aculeiform (ăkülēififôrm) a. [L. aculeus, prickle; forma, shape.] Formed like a prickle or thorn (bot.).

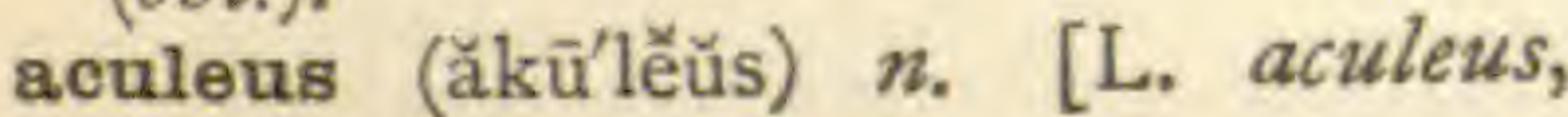

prickle.] A prickle growing from the bark, as in the rose (bot.); a sting (sool.).

acuminate (ăkū'mināt) a. [L. acumen. point.] Drawn out into a long point ; tapering (bot.); pointed (zool.).

acuminiferous (ăkūminnif'ěrŭs) $a, \quad$ [L. acumen, point ; ferre, to carry.] Having pointed tubercles (zool.).

acuminulate (ăk'ūmin'ūlāt) a. [L. acuminulus, dim. of acumen, point.] Having a very sharp tapering point. acute (ăkūt') a. [L. acutus, sharpened.] Ending in a sharp point.

acyclic (âsilk'lìk) $a$. [Gk. $a$, without ; kyklos, circle.] Appl. flowers in which the series of floral leaves are arranged in a spiral; $o p p$. cyclic (bot.).

adamantoblast (ădămăn'töblăst) $n$. [L. adamas, diamond; Gk. blastos, bud.] A cell of the internal epithelial layer of the mammalian enamel organ, columnar in shape; the enamel cell; in many of the lower forms the enamel organ consists only of such cells (zool.).

adambulacral (ăd'ămbūlā'krăl) $a$. [L. ad, to ; ambulare, to walk.] $A p p l$. ossicles or structure adjacent to the ambulacral areas in Echinoderms (zool.).

adaptation (ădăptā'shŭn) $n$. [L. $a d$, to ; aptare, to fit.] The process by which an organism becomes fitted to its environment; a structure or habit fitted for some special environment ; the fitting of cutaneous and other sensations to a point when discomfort ceases, as the physiological zero in the case of adaptation to temperature (phys.).

adduction (ădŭk'shŭn) $n$. [L. $a d$, to ; ducere, to lead.] The movement towards the median axis (phys.).

adductor (ădŭk'tŏr) $n$. [L. $a d$, to ; ducere, to lead.] Any muscle which brings one part towards another (anat.).

adeciduate (âdēš̆d'ūāt) a. [L. $a$, away from; de, from; cadere, to fall.] Not falling, or coming away, $a p p l$. evergreens (bot.); appl. placenta (zool.).

adelocodonic (ăd'ělöködŏn'îk, ădê'löködŏn'îk) a. [Gk, adelos, con- 
cealed; kodon, bell.] Appl. the undetached medusome of certain Gymnoblastea, which degenerates after discharging ripe sexual cells, as $o p p$. the free or phanerocodonic gonophore or medusome (zool.).

adelomorphic (ăd'ělömôr'fík, ădē'lömôr'fik) a. [Gk. adelos, concealed; morphe, shape.] Indefinite in form ; $a p p l$. central cells of peptic glands (anat.).

adelphous (âděl'fŭs) a. [Gk. adelphos, brother.] Joined together in bundles (bot.); used in compounds monadelphous and diadelphous, which see.

adenocheiri (ăd'ĕnökî'rī, -rē) n. plu. [Gk. aden, gland; cheir, hand.] Elaborate accessory copulatory organs, outgrowths of the atrial walls in the turbellarian genus Artioposthia (zool.).

adenodactyli (ăd'ěnödăk'tīlī, -lē) $n$. plu. [Gk. aden, gland; daktylos, finger.] Adenocheiri, which see (zool.).

adenoid (ăd'ěnoid) a. [Gk. aden, gland; eidos, shape.] Pert. or resembling a gland; pert. or resembling lymphoid tissue.

adenophore (ăd'ěnöfōr') n. [Gk. aden, gland; pherein, to carry.] The stalk of a nectar gland (bot.).

adenophyllous (ăd'ĕnöfil'ŭs) $a$. [Gk. aden, gland; phyllon, leaf.] Bearing glands on the leaves (bot.).

adenopodous (ădĕnŏp'ödŭs) $a$, [Gk. aden, gland; pous, foot.] Bearing glands on the peduncles (bot.).

adenostemonous (ăd'ěnöstěm'önŭs) $a$. [Gk. aden, gland; stemon, a spun thread.] Having glands on the stamens (bot.).

adesmy (ădĕs'mĭ) n. [Gk. adesmos, unfettered.] A break or division in an organ usually entire (bot.).

adetopneusic (ăd'ětǒpnū'šk) $a$. [Gk. adetos, free; pnein, to breathe.] Having papulae or dermal branchiae occurring beyond the abactinal surface, as in certain of the Stelleroids (zool.).

adherent (ădhé'rěnt) $a$. [L. $a d$, to ; haerere, to stick.] Pert. union of parts which are normally separate, as calyx and ovary ; adnate (bot.). haerere, to stick.] Condition of being united to, or separate from, one another, $a p p l$. elements of a whorl (bot.).

adhesive cells,-Glandular or specialized cells found in various animals; on the tentacles of Ctenophores, on the epidermis of certain Turbellarians, on the pedal disc of Hydra, etc.

adipose (ăd'ipōs) a. [L. adeps, fat.] Pert. or designating animal fat; fatty (phys.).

adipose tissue,--the special animal tissue for the formation and storage of fat (phys.).

adminicula (ăd'minnik'ūlă) $n . p l u$. [L. adminiculum, support.] Spines of certain pupae, assisting in wriggling motion (zool.).

adnate (ădnāt') a. [L. ad, to ; gnatus, born.] Pert. or designating the condition of being closely attached to the side of the petiole or stalk, as in the case of stipules or leaves; designating the condition of the anther when its back is attached throughout its whole length to the filament, or to its continuation the connective (bot.).

adnexa (ădněk'să) n.plu. [L. $a d$, to ; nectere, to bind.] Certain structures or parts of structures closely related to any organ (anat.).

adnexed (ădněkst') $a$. [L. ad, to ; nectere, to bind.] Reaching to the stem only (bot.).

adoral (ădo'răl) a. [L. ad, to ; os, mouth.] Near the mouth, or pert. the mouth (zool.).

ad-radius (ădrā'dựı) $n$. [L. $a d$, to ; radius, radius.]. The radius in Coelenterates midway between the perradius and the interradius, a radius of the third order (zool.).

adrectal (ădrěk'tăl) $a$. [L. $a d$, to ; rectum, rectum.] Near to or closely connected with rectum (zool.).

adrenal (ădrē'năl) a. [L. ad, to ; renes, kidneys.] Suprarenal.

adrenalin (ădrếnălǐn), adrenaline (ădrē'nălĭn, ădrē'nălēn) $n$. [L. $a d$, to; renes, kidneys.] A crystalline substance obtained from suprarenal extract (phys.).

adrostral (ădrōs'trăl) a. [L. $a d$, to ; 
rostrum, beak.] Near to or closely connected with the beak or rostrum (zool.),

adsorption (ădsôrp'shŭn) $n$. [L. $a d$, to ; sorbere, to suck in.] The concentration of a substance in solution in a liquid on a surface in contact with the surface of another phase ; the adhesion of molecules to solid bodies (phys.).

aduncate (ădŭng'kât) a. [L. aduncus, hooked.] Crooked; bent in the form of a hook.

advehent (ad'věhĕnt) a. [L. advehere, to carry to.] Appl. veins, same as afferent (anat.).

adventitious (ădvěntísh'ǔs) $a$. [L. $a d$, to ; venire, to come.] Accidental; $a p p l$. organs arising in abnormal positions (bot.).

aecidiospores (ēsĭd'iöspōrz', ās-) $n$. plu.

[L. aecidium, cup ; Gk. sporos, seed.]

The spores contained in an aecidium or clustercup (bot.).

aecidium (ēsǐd'iŭm, ās-) $n$. [L. aecidium, cup.] A cup-shaped structure containing simple sporophores, bearing rows of spores (bot.).

aegithognathous (ẽ jirthŏg'năthŭs, $\bar{a}^{\prime}$ gíthŏgnâ'thŭs) a. [Gk. aegithos, hedge-sparrow; gnathos, jaw.] With maxillo-palatines separate, vomers forming a wedge in front and diverging behind; $a p p l$. a type of palate found in the Carinatae (zool.).

aerial (āérruăl) a. [L. aer, air.] Inhabiting the air; appl. roots growing above ground, e.g. from stems of ivy, for purposes of climbing; also to small bulbs appearing in the axils of the leaves of certain plants (bot.).

aerobe (ā'ěrōb) n. [Gk. aer, air; bios, life.] An organism which grows only in the presence of oxygen; appl. bacteria.

aerobic (ăěrốb'îk) a. [Gk. aer, air ; bios, life.] Thriving only in abundance of oxygen (bact.).

aerocyst (a'ěrösı̌st) $n$. [Gk, aer, air ; kystis, bladder.] An air vesicle of Algae (bot.).

aerophyte (ă'ěröfït) $n$. [Gk. aer, air ; phyton, plant.] A land-plant growing attached to another plant; an epiphyte. aerostat (āeuröstăt) $n$. [L. aer, air ; stare, to stand.] An air-sac in insect body or in bird-bone (zool.). aerostatic (ă'ěröstăt'ǐk), a. [L. aer, air ; stare, to stand.] Pneumatic; containing air-spaces (zool.).

aerotaxis (ä'ěrötăk'siss) n. [Gk. aer, air; taxis, arrangement.] The movement of bacteria and other micro-organisms towards or away from oxygen (phys.).

aerotropism (äěrŏt'röpizm) n. [Gk. aer, air; trepein, to turn.] The reaction of plants to gases (bot.).

aesthacyte (ěs'thăsĩt) $n$. [Gk. aisthesis, sensation; kyfos, hollow.] A sensory cell of primitive animals, aesthesia (ĕsthé'ziă) n. [Gk, aisthesis, sensation.] Sensibility.

aestival (ěs'tǐvăl, ěstīivăl) a. [L. aestas, summer.] Produced in, or pert. summer.

aestivation (ěs'tivā'shŭn) $n$. [L. aestivus, pert. summer.] The mode in which the different parts of the flower are disposed in the flowerbud; praefloration; torpor during summer as in the case of some animals,

aethalium (ēthā'liŭm, āth-) n. [Gk. aithalos, soot.] An aggregation of plasmodia to form a compound fruit in Mycetozoa.

aetiology (ëtǐol'öjî) n. [Gk. aitia, cause; logos, discourse.] A branch of biology dealing with causes.

afferent (ăf'ěrěnt) a. [L. afferre, to bring.] $A p p l$. nerves carrying impulses to the nervous centres; $a p p l$. blood-vessels carrying blood to any particular organ or set of organs (anat.).

affinity (ăfin'îtř) $\boldsymbol{n}$. [L. affinis, related to.] Relationship; similarity in all essential organs (biol.).

aflagellar (ấflăjělăr) a. [Gr. a, without; L. flagellum, a whip.] Without a flagellum, a whip-like appendage in certain unicellular organisms; $a p p l$. the end of a trypanosome not furnished with a flagellum (zool.).

afterbirth (ăf'tërbërth) $n$. [A.S. aefter, behind; beran, to bring forth.] Placenta and foetal membranes expelled after the young is born (anat.). 
aftershaft (ăf'tërshăft) n. [A.S. aefter, behind; shaft.] A small tuft of down in the neighbourhood of the superior umbilicus in the feathers of most birds; in certain birds (e.g. moas, emu, cassowary) a second vane, which, usually shorter, but sometimes of equal length to the vane proper, arises near the superior umbilicus (zool.).

agametes (ăg'ămēts) n. plu. [Gk. $a$, without ; gamos, marriage.] Amoebulae which develop directly into adults without syngamy (zool.).

agamic (âgăm'îk) $a$. [Gk. $a$, without ; gamos, marriage.] Asexual ; appl. to a parthenogenic race (biol.); cryptogamic (bot.).

agamobium (ăg'ămō'břŭm) n. [Gk. $a$, without ; gamos, marriage ; bios, life.] The asexual stage in metagenesis (zool.); the sporophyte (bot.).

agamogenesis (ăg'ămöjěn'ěsı̌s) $n$. [Gk. $a$, without; gamos, marriage ; genesis, generation.] Parthenogenesis.

agamogenetic (ăg'ămöjěnět'îk) $a$. [Gk. $a$, without ; gamos, marriage ; genesis, birth.] Appl. asexual reproduction.

agamogony (ăg'ămŏg'önı̌) $n$. [Gk. $a$, without ; gamos, marriage ; gonos, offspring.] Schizogony, or reproduction without sexual process (biol.).

agamont (ăg'ămŏnt) $n$. [Gk. $a$, without ; gamos, marriage ; on, being.] A schizont, or that stage which gives rise to agametes (biol.).

agamous (ăg'ămŭs) $a$. See agamic.

agglomerate (ăglŏm’ĕrāt) a. [L. ad, to ; glomus, ball.] Clustered, as a head of flowers.

agglutination (ăglootǐnā'shŭn) $n$. [L. ad, to ; glutinare, to glue.] The forming of clumps or floccules by bacteria distributed in a medium, and their simultaneous loss of mobility (bact.).

agglutinin (ăgloot'ĩnĭn) n. [L. $a d$, to; glutinare, to glue.] A substance which is supposed to cause agglutination (phys.).

aggregate (ăg'rĕgāt) $a . \quad[\mathrm{L} \cdot a d$, to ; gregare, to collect into a flock.] Formed in a cluster (bot., zool.). aggregate fruit, - a fruit formed from the apocarpous gynoecium of a single flower, as the raspberry. aggregation (ăgrĕgā'shŭn) $n$. [L. $a d$, to ; gregare, to collect.] The peculiar movement of the protoplasm in the cells of the tentacles or tendrils of sensitive plants, which being due to previous contact, causes the tentacle or tendril to bend towards the point where the stimulus was applied (phys.).

aggressin (ăgrĕs'in in) $n$. [L. aggressus, attacked.] A toxic substance produced by pathogenic organisms inhibiting the defensive reactions of the host (phys.).

aglossate (âglŏs'-āt) $n$. [Gk. $a$, without; glossa, tongue.] Having no tongue (zool.).

agnathostomatous (ăgnâth'östŏm'ătŭs) a. [Gk. a, without; gnathos, jaw; stoma, mouth.] Having the mouth unfurnished with jaws, as in the lamprey (zool.).

agnathous (ăgnâth'ŭs) $a$. [Gk. $a$, without; gnathos, jaw.] Having no jaw (zool.).

agrostology (ăg'rǒstŏl'öjĩ) n. [Gk. agrostis, grass; logos, discourse.] That part of botany dealing with the systematic treatment of grasses (bot.).

air-bladder (ār'-blăd'ër) n. [L. aer, air ; A.S. bladre, bladder.] The swim-bladder, an air-sac formed by an outgrowth from the alimentary canal in many fishes (zool.).

air-cells, - thin-walled cavities in the ethmoidal labyrinth; numerous cavities in the mastoid (anat.).

air-sacs, - spaces filled with air and connected with the lungs, which increase the respiratory coefficient, and probably lessen the specific gravity in birds.

akaryote (âkăr'iōt) $n$. [Gk. $a$, without ; karyon, nut, nucleus.] A cell in which the nucleoplasm has not collected together to form a nucleus; a non-nucleated cell $\left(c y t_{\text {. }}\right)$.

akinete (â'kinnēt', ăk'ínēt) $n$. [Gk, $a$, not; kinein, to move.] A resting cell in certain green Algae, which will later reproduce (bot.).

ala (ắlă) n. [L. ala, wing.] Any winglike projection, e.g. of vomer 
(anat.); the lateral petal of a papilionaceous flower; the membranous expansion on some seeds or fruits (bot.).

alar (á'lăr) a. [L. ala, wing.] Winglike ; pert. alae; axillary (bot.); $a p p l$. ligaments, cartilages, etc. (anat.).

alary (ā'lărǐ) a. [L. ala, wing.] Wing-like.

alate (á'lāt) a. [L. ala, wing.] Broadlipped, $a p p l$. shells ; $a p p l$. a spicular system in Calcarea which is sagittal because of inequality of angles (zool.).

albescent (ălběs'ĕnt) a. [L. albescere, to grow white.] Growing whitish. albicant (ăl'bǐkănt) a. [L. albicare, to grow white.] Becoming white.

albinism (ăl'bǐnìzm) $n$. [L. albus, white.] The absence of pigmentation (zool.) ; state of having colourless chromatophores.

albino (ălbīnö, ălbënö) n. [Sp. albino, white, from L. albus.] A person with congenital deficiency of pigment in the skin, hair, and eyes (anat.); any animal with a similar deficiency on its body (zool.); a plant with colourless chromatophores, due to absent chloroplasts or undeveloped chromoplasts (bot.).

albumen (ălbü'mĕn) $n$. [L. albumen, white of egg.] The white of egg (zool.) ; nutritive material stored in the embryo (bot.).

albumin (ălbū'minn) $n$. [L. albumen, white of egg.] A protein occurring in blood serum, milk, and many animal and vegetabletissues (phys.). albuminous (ălbū'minŭs) a. [L. albumen, white of egg.] Pert. having, or of the nature of, albumen or albumin.

alburnum (ălbŭr'nŭm) n. [L. albus, white.] Sapwood or splintwood, the soft white substance between inner bark (cambium) and true wood (duramen); the outer young wood of a dicotyledonous stem (bot.).

alecithal (ălěs'íthăl) $a$. [Gk. $a$, with out; lekithos, yolk.] Appl. ova with little or no yolk (zool.).

aleurone (ălū'rōn) n. [Gk: aleuron, flour.] Appl. proteid grains found in general protoplasm and used as reserve food-materials (bot.).

alexin (ălěk'sin) $n$. [Gk. alexein, to ward off.] A substance in the blood which destroys bacteria (phys.).

algin (ăl'jĭn) n. [L. alga, seaweed.] A substance of a gelatin character obtained from certain Algae (phys.). algoid (ăl'goid) a. [L. alga, plant; Gk. eidos, shape.] Pert. resembling or of the nature of an Alga (bot.).

algology (ălgŏl'öjī) n. [L. alga, seaweed; Gk. logos, discourse.] The study of seaweeds or Algae (bot.).

alima (ăl'ı̌mă) n. [Gk. halimos, pert. sea.] A larval stage of certain Crustacea, e.g. Squilla (zool.).

alimentary (ăl'imern'tărĩ) a. [L. alere, to nourish.] Pert. the nutritive functions; appl. canal, tract, system, etc.

alisphenoid (ăl'ǐsfê'noid) $n$. [L. ala, wing; Gk, sphen, wedge ; eidos, form.] The wing-like portion of the sphenoid forming part of the cranium.

alitrunk (ăl'îtrŭngk) $n$. [L. ala, wing; truncus, trunk.] The thorax of an insect when fused with the first segment of the abdomen.

allantois (ălăn'töiss) $n$. [Gk. allas, sausage.] An embryonic organ, a membranous bag arising from the posterior part of the alimentary canal in the higher vertebrates, and acting as an organ of respiration or nutrition or both, and usually uniting with the chorion (emb.).

allassotonic (ălăs'ötŏn'îk) a. [Gk. allassein, to change ; tonos, strain.] Induced by stimulus, $a p p l$. movements of grown plants.

allelomorph (ălě́lömôrf) $n$. [Gk. allelon, one another; morphe, form.] In Mendelian inheritance one of any pair of alternątive characters (biol.).

alliaceous (ălīà'shŭs) a. [L. allium, garlic.] Pert. the allium or garlic family; having a smell or taste like garlic (bot.).

allogamy (ălŏg'ămì) $n$ : [Gk. allos, other; gamos, marriage.] Crossfertilization, as opp. autogamy (biol.). 
alloiogenesis (ăl'oiöjěn'ěš̌s) $n$. [Gk. alloios, different; genesis, descent.] The alternation in a life-history of a sexual and a non-sexual form ; alternation of generations (biol.).

allopelagic (ăl'öpĕlăj'îk) a. [Gk. allos, other; pelagos, sea.] Pert. organisms found at any depth of the sea uninfluenced by heat or cold (biol.). alloplasmatic (ăl'öplăsmăt'ǐk) $a$. [Gk. allos, other ; plasma, something moulded.] $A p p l$. the differentiated portion of cell protoplasm (cyt.).

alloplast (ăl'öplăst) $n$. [Gk. allos, other ; plastos, formed.] A morphological cell-unit of more than one kind of tissue (cyt.).

alluvial (ălū'viăl, ăloo-) a. [L. alluere, to wash to.] Pert. or found in deposits laid down by running water (pal.).

alsinaceous (ălsĭnā'shŭs) a. [Gk. alsine, chickweed.] Appl. a polypetalous corolla where intervals occur between the petals, as in the chickweed (bot.).

alteration theory, - explains the electromotive forces of nerve and musclebyalterations in the chemical composition of the tissue at the cross-section (phys.).

alternate (ăltĕr'nāt, ôltĕr'nāt) $a . \quad$ [L. alternus, one after another.] $A p p l$. leaves or branches occurring at different levels on opposite sides of the stem (bot.).

alternation of generations, - the occurrence in one life-history of two or more different forms differently produced, as in the polypoid and medusoid stages of Hydroids (biol.).

alternation of parts, - it is the general rule that leaves of the different whorls alternate in position with each other, sepals with petals, stamens with petals (bot.).

alternipinnate (ăltĕr'nĭpĭn'āt, ôl-) $a$. [L. alternus, one after another; pinna, wing.] $A p p l$. leaflets or pinnae arising alternately on each side of the mid-rib (bot.).

altrices (ăltrî'sēz, ăl'trǐsĕz) n. plu. [L. altrix, nourisher.] $A p p l$. birds whose young are hatched in a very immature condition (zool.).

alula (ăl'ūlă) $n$. [L. alula, dim. of ala, wing.] A small lobe separated off from the wing-base on its posterior edge in certain insects ; false wing of birds (zool.).

alveola (ălvē'ölă) $n$. [L. alveolus, a small cavity.] A pit on the surface of an organ (bot.).

alveolar (ălvēölăr) a. [L. alveolus, a small pit.] Pert. a tooth socket or alveolus; $a p p l$. artery, nerve, process, canal, in connection with the jaw-bone (anat.); appl. a particular stage in protoplasm ; and to small cavities in the lungs (zool.) ; alveolar point-see prosthion.

alveolate (ălvē'ölāt) $a$. [L, alveolatus, pitted.] Deeply pitted or honeycombed.

alveolus (ălvēöolŭs) n. [L. alveolus, a small pit.] A tooth socket or small pit or depression (anat.); the pyramidal ossicle supporting a tooth in the sea-urchin (zool.).

alveus (ăl'vĕŭs) $n$. [L. alveus, cavity.] A thin white layer on the ventricular surface of the hippocampus (anat.). amacrine (ăm’ăkrîn) a. [Gk. $a$, not ; makros, long; is, fibre.] Appl. cells occurring in the inner nuclear layer of the retina (anat.).

ambidextrous (ăm'bìděk'strŭs) $a$. [L. ambo, both; dexter; right.] Able to use both hands with equal ease.

ambiens (ăm'biěnz) $n$. [L. ambire, to go round.] A thigh muscle in certain birds, the action of which causes the toes to grasp the perch (zool.).

ambiparous (ămbịpărŭs) $a$. [L. $a m b o$, both; parere, to beget.] $A p p l$. buds as they contain the beginnings of both flowers and leaves (bot.).

ambisporangiate (ăm'bǐspörăn'jīât) a. [L. ambo, both; Gk. sporos, seed; anggeion, box.] Appl. plants with sporophylls bearing both megasporangia and microsporangia (bot.).

ainbital (ăm'bìtăl) a. [L. ambire, to go round.] $A p p l$. interambulacral and antambulacral plates of Asteroids; the outer skeleton of arm of Ophiuroids (zool.).

ambitus (ăm'bitŭs) $n$. [L. ambire, to go around.] The outer edge or margin of a thing; the outline of an echinoid shell viewed from the apical pole (zool.). 
amboceptor (ăm'bösĕp'tŏr) n. [L. ambo, both; capere, to take.] An antibody or specific immune body necessary for the ferment-like action of the complement on a toxin or a red blood corpuscle (phys.).

ambulacra (ăm'būlā'kră) $n$. plu. [L. ambulare, to walk.] Locomotor tube-feet of Echinoderms (zool.). ambulacralia (ăm'bülăkkrā'lĭă) $n$. plu. [L. ambulare, to walk.] Ambulacral plates, i.e. plates through which the tube-feet protrude (zool.). ambulacriform (ămbūlăk'rĭfôrm) $a$. [L. ambulare, to walk; forma, shape.] Having the form or appearance of a mbulacra (zool.).

amelification (ămĕl'ifikā'shŭn) $n$. [M.E. amell, enamel ; L. facere, to make.] Formation of tooth-enamel (anat.).

ameloblast (ăměl'öblăst) n. [M.E. amell, enamel; Gk. blastos, bud.] A columnar or hexagonal cell about five times as long as it is broad, an enamel-forming cell; a cell of the internal epithelium of the enamel organ (anat.).

amentaceous (ăměntā'shŭs) $a$. [L. amentum, a thong.] $A p p l$. plants bearing aments or catkins (bot.).

amentiferous (ămĕntĭf'ĕrŭs) $a$. [L. amentum, a thong ; ferre, to carry.] Amentaceous.

amentum (ămĕn'tŭm) $n$. [L. amentum, a thong.] A catkin, consisting of a bracted axis bearing unisexual flowers as in the poplar and willow (bot.).

ametabolic (âmět'ăbŏl'ı̂k) a. [Gk. $a$, without ; metabole, change.] Appl. insects that do not pass through any marked metamorphosis (zool.).

amicron (âmı̌k'rŏn) n. [Gk. $a$, without ; mikros, small.] An element so small that even the ultramicroscope can only indicate it as a diffuse illumination in the track of the beam ; $c f$. submicron (phys.).

amicronucleate (âmî́krönü'klễt) $a$. [Gk. a, without ; mikros, small ; L. nucleus, kernel.] Appl. fragments of certain Protozoa in which there is no micronucleus (zool.).

amitosis (âmĭtō'sǐs) n. [Gk. $a$, without ; mitos, thread.] Cell-division and cleavage of the nucleus with- out the thread-like formation of the nuclear material (cyt.).

ammonitiferous (ăm'ŏnĭtíf'ěrŭs) $a$. [Gk, Ammon, Jupiter; L. ferre, to carry.] Containing the fossil remains of Ammonites (pal.).

amoeba (ămē'bă) $n$. [Gk, amoibe, exchange.] A protozoon in which the shape is subject to constant alterations due to the formation and retraction of pseudopodia (zool.).

amoebiform (ămē'bǔfôrm) a. [Gk. amoibe, change ; L. forma, shape.] Shaped like or resembling an amoeba (biol.).

amoebocyte (ămē'bösīt) n. [Gk. amoibe, change; kytos, hollow.] Any cell having the shape or properties of an amoeba, especially certain cells in the coelom of Echinoderms; a leucocyte (zool.).

amoeboid (ămē'boid) a. [Gk, amoibe, change; eidos, shape.] Resembling an amoeba in shape or in properties (zool.).

amoebula (ămē'būlă) n. [Gk, amoibe, change.] The swarm-spore of a protozoan when furnished with pseudopodia (zool.).

amorphous (âmôr'füs) a. [Gk. $a$, without; morphe, shape.] Indeterminate, or of irregular form.

amphiarthrosis (ăm'fiârthrō'sǐs) $n$. [Gk. amphi, both; arthron, joint.] A slightly movable articulation, as a symphysis or syndesmosis (anat.). amphiaster (ăm'fiăs'tĕr) n. [Gk. amphi, both; aster, star.] The two asters connected by the achromatic spindle formed in mitotic cell division (cyt.).

amphibious (ămfỉb'ŭus) a. [Gk. amphi, both; bios, life.] Adapted for life either on land or in water (biol.).

amphiblastic (ăm'fỉblăs'tǐk) a. [Gk. amphi, both; blastos, bud.] Having unequal segmentation, appl. telolecithal ova with complete segmentation (biol.).

amphiblastula (ăm'fiblăs'tūlă) n. [Gk. amphi, both; blastos, bud.] Stage in the development of certain sponges, in which the posterior end of the embryo is composed of granular archaeocytes, and the anterior end of flagellate cells (zool.). 
amphibolic (ăm'fibŏl'îk) a. [Gk. amphi, both; ballein, to throw.] Capable of turning backwards or forwards, as the outer toe of certain birds (zool.).

amphicarpous (ăm'frikâr'pŭs) $a$. [Gk. amphi, both; karpos, fruit.] Producing fruit of two kinds (bot.).

amphicoelous (ăm'fĩsē'lǔs) $a$. [Gk. amphi, both; koilos, hollow.] Concave on both surfaces ; $a p p l$. vertebrae with the anterior and posterior surfaces of the centra hollow (zool.). amphicondylous (ăm'frǩ̆n'dĭlŭs) $a$. [Gk. amphi, both; kondylos, knob.] Having two occipital condyles (zool.).

amphidise (ăm'fĩdǐsk) $n$. [Gk. amphi, both; diskos, round plate.] Grapnelshaped spicules protecting the gemmules of some freshwater sponges (zool.).

amphigastria (ăm'frgăs'trĭă) n. plu. [Gk. amphi, both; gaster, stomach.] Ventral rudimentary leaves of foliose liverworts (bot.).

amphigony (ămfīg'önĩ) $n$. [Gk. amphi, both; gonos, offspring.] Sporogony or reproduction involving two individuals; $c f$. monogony (zool.).

amphikaryon (ăm'fřkăr'ionn) n. [Gk. amphi, both; karyon, nut.] An amphinucleus, a type of nucleus characterized by a large karyosome, in reference to the supposed encapsuling of the kinetic nucleus by the trophic nucleus (cyt.).

amphimixis (ăm'fimiı'šs) n. [Gk. amphi, both; mixis, mingling. The mingling of paternal and maternal characteristics by the union of the male and female pronucleus in fertilization (biol.).

amphiodont (ăm'fiödŏnt) $n$. [Gk. amphi, both; odous, tooth.] Appl. an intermediate state of mandible development in stag-beetles (zool.).

amphiont (ăm'fiŏnt) n. [Gk. amphi, both ; on, being.] A zygote or sporont formed by the coming together of two individuals (zool.).

amphiplatyan (ăm'fïplăt'iăn) a. [Gk. amphi, both; platys, flat.] Flat on both ends; $a p p l$. centra of vertebrae (zool.).

amphipneustous
[Gk. amphi, both; pnein, to breathe.] Having both gills and lungs throughout the life-history; also $a p p l$. the condition in most dipterous larvae of an open anterior and posterior pair of spiracles with the intermediate pairs closed (zool.). amphipodous (ămfíp'ödǔs) a. [Gk. amphi, both; pous, foot.] From Amphipoda, an order of Crustacea, of which the anterior three pairs of abdominal appendages are more strongly developed for swimming, the remaining three pairs being adapted for jumping, hence,-having feet both for walking and for swimming (zool.).

amphipyrenin (ăm'fīpīrē'nĭn) $n$. [Gk. amphi, both; pyren, stone of a fruit.] The substance of which the nuclear membrane in a cell is composed (biol.).

amphirhinal (ăm'fïrínăl) $a$. [Gk. amphi, both; rhis, nose.] Having two nostrils (zool.).

amphisarca (ăm'fĩsâr'kă) n. [Gk. amphi, both; sarx, flesh.] A superior indehiscent many-seeded fruit with pulpy interior and woody exterior (bot.).

amphispermous (ăm'fĩspĕr'mŭs) $a$. [Gk. amphi, both; sperma, seed.] Having the seed closely surrounded by the pericarp (bot.).

amphispore (ăm'fĩspōr') $n$. [Gk. amphi, both; sporos, seed.] A reproductive spore which functions as a resting spore in certain Algae (bot.).

amphisternous (ăm'fístĕr'nŭs) a. [Gk. amphi, both ; sternon, the breast.] $A p p l$. a type of sternum structure in the Atelostomata (zool.).

amphistomatic (ăm'fístömăt'îk) $a$. [Gk. amphi, both ; stoma, mouth.] Having stomata on both surfaces, $a p p l$. certain types of leaves (bot.).

amphistomous (ămfís'tömŭs) $a$. [Gk. amphi, both; stoma, mouth.] Having a sucker at each end of the body, as in certain worms (zool.). amphistylic (ăm'fīstîl'îk) a. [Gk. amphi, both ; stylos, pillar.] Having the lower jaw connected with the skull by both hyoid and quadrate, or by both hyoid and palatoquadrate (zool.). 
amphithecium (ămfithé'shiuum) $n$. [Gk. amphi, both; thekion, box.] The peripheral layer of cells in the sporangia of mosses (bot.).

amphitoky (ămfit'ökĭ) n. [Gk. amphi, both; tokos, birth.] Parthenogenetic reproduction of both males and females (zool.).

amphitriaene (ăm'fĭtrî̀ēn) $n$. [Gk. amphi, both; triaina, trident.] A doubletrident-shaped spicule (zool.). amphitrocha (ămfít'rökă) $n$. [Gk. amphi, both; trochos, wheel.] A free-swimming annelid larva with two rings of cilia (zool.).

amphitropal (ămfít'röpăl) $a$. [Gk. amphi, both; trope, turning.] Having the ovule inverted, with the hilum in the middle of one side (bot.).

amplectant (ămplěk'tănt) a. [L. amplecti, to embrace.] Clasping or winding tightly round some support, as tendrils in certain plants (bot.).

amplexicaul (ămplěk'sǐkôl) a. [L. amplecti, to embrace ; caulis, stem.] Clasping or surrounding the stem, as the base of a leaf (bot.).

ampliate (ăm'plīât) a. [L. ampliatus, made wider.] Having the outer edge of the wing prominent, as in certain insects (zool.).

ampulla (ămpool'ă, -pŭl'-) n. [L. ampulla, flask with narrow neck and globular body.] A membranous vesicle; part of the dilated tubule in the mammary gland; the dilated portion at one end of each of the semi-circular canals of the ear (anat.); the internal reservoirs on the ring canal of the watervascular system in Echinoderms; the terminal vesicle of sensory canals of Elasmobranchs (zool.); the submerged bladder of Utricularia (bot.).

ampullaceal (ămpŭlā'sě̆l) a. [L. ampulla, flask.] Flask-shaped, $a p p l$. arachnid spinning glands which furnish silk for foundations, lines, and radii (zool.).

ampullaceous (ămpŭlā'shŭs) $a . \quad[\mathrm{L}$. ampulla, flask.] Flask-shaped.

ampullary (ămpool'ărĭ, -pŭl'-) $a$. [L. ampulla, flask.] Pert. or resembling an ampulla (anat.). amyelinic (âmiělin'ík) $a$. [Gk. $a$, without; myelos, marrow.] Appl. non-medullated nerve-fibres (anat.). amygdala (ămig'dălă) $n$. [L. from Gk. amygdale, almond.] One of the palatal tonsils; a rounded lobe at the side of the vallecula of the cerebellum (anat.).

amyloplast (ăm'ílöplăst') $n$. [L. amylum, starch; Gk. plastos, formed.] A leucoplast or colourless starch-forming granule in plants (bot.).

amyloplastid,--amyloplast.

amylum (ăm'ílŭm) n. [L. amylum, starch.] Starch.

anabiosis (ăn'ăbīō'sǐs) n. [Gk. ana, up; bios, life.] Resuscitation after apparent death ; power of revivification as seen in certain Tardigrada (zool.).

anabolism (ănăb'ŏlizm) $n$. [Gk. ana, up; ballein, to throw.] The constructive chemical processes going on in living organisms whereby foodmaterial is transformed into protoplasm (phys.).

anacrogynous (ănăkrŏj'ǐnŭs) a. [Gk. an, not ; akros, apex ; gyne, female.] $A p p l$. certain liverworts in which the archegonia or female reproductive bodies do not arise at or near the apex of a shoot (bot.).

anacromyoidian (ănăk'rŏmīoid'iăn) $a$. [Gk. ana, up ; akros, apex; mys, muscle.] With the syringeal muscles attached at the dorsal ends of the bronchial semi-rings (zool.).

anaerobe (ănā'ěrōb) n. [Gk. an, without ; aer, air ; bios, life.] An organism capable of living in the absence of free-oxygen ; $a p p l$. bacteria.

anaesthesia (ăněsthè'zlă) $n$. [Gk. $a n$, without; aisthesis, feeling.] Insensibility (phys.).

anagenesis (ăn'ăjĕn'ěsis) $n$. [Gk.ana, again; genesis, birth.] Regeneration of tissues (phys.).

anal (a'́năl) a. [L. anus, anus.] Pert. or situated at or near the anus; appl. posterior median unpaired ventral fin of fishes, margin and nerve of insect wing, posterior ventral scute of reptiles (zool.).

analogues (ăn'ălŏgz) n. plu. [Gk. analogia, proportion.] Organs of 
different plants or animals with similar function but of dissimilar origin (biol.).

anamorphosis (ăn'ămôr'fösĭs) $n$. [Gk. ana, again ; morphe, form.] The evolution from one type to another through a long series of gradual changes (biol.).

anangian (ănăn'jŭăn) $a$. [Gk. $a$, without; anggeion, vessel.] $A p p l$. worms without a vascular system. (zool.).

anaphase (ăn'ăfāz) n. [Gk. ana, up ; phasis, appearance.] A stage in mitosis during the divergence of the daughter-chromosomes (biol.).

anaphylaxis (ăn'ăfĭlăk'sĭs) n. [Gk. ana, up; phylax, guard.] Condition of being hypersensitive to a serum, caused by the first or sensitizing dose (phys.).

anapophysis (ăn'ăpŏf'ǐsĭs) $n$. [Gk. ana, up; apo, from; phyein, to grow.] A small dorsal projection rising near the transverse processes in lumbar vertebrae (anat.).

anarthrous (ănâr'thrŭs) a. [Gk. $a$, without ; arthron, joint.] Having no distinct joints (zool.).

anastates (ăn'ăstāts) n. plu. [Gk. ana, up ; stanein, to make to stand.] The various materials that arise owing to metabolism in a cell, in the formation of complex from simple substances (biol.).

anastomosis (ănăs'tömó'š̆s) $n$. [Gk. ana, up ; stoma, mouth.] Union of ramifications of the leaf-veins (bot.) ; union of blood-vessels arising from a common trunk; union of nerves ; formation of a network or meshwork (anat.).

anatomy (ănăt'ömĩ) n. [Gk. ana, up ; tome, cutting.] The science that treats of the structure of plants and of animals; the structure of a plant or of an animal.

anatriaene (ăn'ătrî'ēn) n. [Gk. ana, up; triaina, a trident.] A triaene with backwardly directed cladi or branches (zool.).

anatropal (ănăt'röpăl), anatropous (ănăt'röpŭs) $a$. [Gk, ana, up ; trepein, to turn.] Inverted, appl. ovules with the hilum and micropyle close together and the chalaza at the other end (bot.). anaxial (ănăk'suăl) $a$. [Gk. $a$, without; axis, axis.] Having no distinct axis (biol.).

anchor (ăng'kŏr) n. [L. ancora, anchor.] The anchor-shaped spicule found in the skin of Holothurians (zool.).

anchylosis (ăng'kǐlō'sǐs) n. [Gk. angkylosis, stiffness.] The union of two or more bones or hard parts to form one part, e.g. of bone to bone, or tooth to bone (zool.).

anconeal (ăngkō'ně̆l) $a$. [L. ancon, elbow.] Pert. the elbow (anat.).

anconeus (ăng'könē'ŭs) $n$. [L. ancon, elbow.] Small extensor muscle situated over the elbow (anat.).

androconia (ăn'drökō'nǐă) $n$. plu. [Gk. aner, man; konia, dust.] Modified wing-scales producing a sexually attractive scent in certain butterflies (zool.).

androdioecious (ăn'drödiē'shŭs) $a$. [Gk. aner, man; dis, two; oikos, house.] Having perfect male flowers on different plants (bot.).

androecium (ăndré'shı̆ŭm) n. [Gk. aner, man; oikos, house.] The male reproducing organs of a plant; the stamens taken collectively (bot.).

androgonidia (ăn'drögŏnĭd'ǐă) $n$. plu. [Gk. aner, man ; gonos, offspring.] Male sexual elements formed after repeated divisions of parthenogonidia of volvox (zool.).

androgynal (ăndrŏj'inăl), $a$. [Gk. aner, man ; gyne, woman.] Hermaphrodite; bearing both staminate and pistillate flowers in the same bunch (bot.).

androgynary (ăndrŏj'innărĭ) a. Having flowers with stamens and pistils developed into petals (bot.).

androgynism (ăndrŏj'innizm) n. [Gk. aner, man; gyne, woman.] The condition of bearing both stamens and pistils; hermaphroditism (bot.). androgynous (ăndrŏjînŭs), - androgynal.

androphore (ăn'dröfồr) $n$. [Gk. aner, man ; pherein, to carry.] Stalk supporting the stamens (bot.); the stalk carrying the male gonophores in the Siphonophora (zool.).

androphyll (ăn'dröfïl) $n$. [Gk. aner, man; phyllon, leaf.] The leaf 
bearing the microspores; the microsphorophyll (bot.).

androsporangium (ăn'dröspörăn'jĭŭm) n. [Gk. aner, man ; sporos, seed ; anggeion, box.] A sporangium containing the androspores (bot.).

androspore (ăn'dröspōr $\left.{ }^{\prime}\right) \quad n$. [Gk. aner, man; sporos, seed.] An asexual zoospore which gives rise to a small male dwarf plant (bot.).

anemophily (ăn'ěmŏf'îlì) n. [Gk. anemos, wind; philein, to love.] Plant-fertilization by the agency of wind (bot.).

anemotropism (ăn'ěmŏt'röpǐzm) $n$. [Gk. anemos, wind; trepein, to turn.] Orientation of the body with regard to wind (zool.).

anenterous (ănĕn'tĕrŭs) $a$. [Gk. $a$, without; enteron, gut.] Having no alimentary tract (zool.).

anfractuose (ănfrăk'tūōs) a. [L. anfractus, a bending.] Wavy, sinuous (bot.).

angienchyma (ăn'jiěng'kĭmă) $n$. [Gk. anggeion, vessel ; engchein, to pour.] Vascular tissue (bot.).

angioblast (ăn'jiöblăst) n. [Gk. anggeion, vessel; blastos, bud.] One of the cells from which the lining of the blood-vessels is derived (emb.).

angiocarpous (ăn'jiökâr'pŭs) $a$. [Gk. anggeion, vessel; karpos, fruit.] Having the fruit enclosed in a cavity (bot.).

angiology (ăn'jiǒl'öjî̀) n. [Gk.anggeion, vessel ; logos, discourse.] The anatomy of the circulatory and lymphatic systems (anat.).

angiospermous (ăn'jiöspĕr'mŭs) $a$. [Gk. anggeion, vessel; sperma, seed.] Having seeds in a closed case, the ovary (bot.).

angiosporous (ăn'jiöspō'rŭs) a. [Gk. anggeion, vessel; sporos, seed.] Having spores contained in a theca or spore capsule (bot.).

angiostomatous (ăn'jiöstǒm'ătŭs) $a$. [Gk. anggeion, vessel; stoma, mouth.] Narrow-mouthed, appl. a certain order of Molluscs, and to a sub-order of snakes with nondistensible mouths (zool.).

angular (ăng'gūlăr) $n$. [L. angulus, corner.] One of the membrane bones of the lower jaw in most vertebrates (zool.).

angulo-splenial (ăng'gūlösplē'nǐăl) $n$. [L. angulus, corner; splenium, a patch.] The bone in Amphibia forming most of the lower and inner part of the mandible (zool.).

angustifoliate (ănggŭs'tǐfō'liāt) $a$. [L. angustus, narrow; folium, a leaf.] With narrow leaves (bot.). angustirostrate (ănggŭs'tĭrŏs'trāt) $a$. [L. angustus, narrow ; rostrum, a beak.] With narrow beaks or snouts (zool.).

animal pole,-in many ova the yolk is more or less aggregated at one pole, and as a result the segmentation at that pole is retarded; at the other pole, which is called the animal pole, the segmentation is more rapid and usually results in some form of overgrowth on the lower, retarded, or vegetable pole (emb.).

anion (ănīoun) $n$. [Gk, ana, up ; ion, going.] A negatively-charged particle or ion which moves up towards the anode or positive pole (phys.).

anisoearpous (ănǐ̀sökâr'pŭs) $a$. [Gk. a, not ; isos, equal ; karpos, fruit.] Having the number of carpels less than that of the other floral whorls (bot.).

anisocercal (ănî́sösĕr'kăl) a. [Gk. $a$, not; isos, equal; kerkos, tail.] With lobes of the tail-fin unequal (zool.).

anisoehela (ănî̀sökë'lă) n. [Gk. $a$, not; isos, equal; chele, claw.] A chela with the two parts unequally developed (zool.).

anisodactylous (ănǐsödăk'tǐlŭs) $a$. [Gk. $a$, not ; isos, equal ; daktylos, finger.] Having unequal toes, three toes forward, one backward ; refers to an old classification of birds (zool.).

anisogamous (ănî́sŏg'ămŭs) $a$. [Gk. $a$, not ; isos, equal ; gamos, marriage.] $A p p l$. a conjugation in which the gametes or conjugating bodies are differentiated in some manner (biol.).

anisogamy, - conjugation between sharply differentiated gametes.

anisognathous (ăn'ísŏgnâ'thŭs, ăn'İsŏg'năthŭs) a. [Gk. $a$, not ; isos, 
equal; gnathos, jaw.] Having the teeth in the upper and lower jaws unlike (zool.).

anisomerous (ănǐsŏm'ěrŭs) $a$. [Gk. a, not ; isos, equal ; meros, part.] Having unequal numbers of parts in the floral whorls (bot.).

anisopleural (ănǐsöploo'răl) $a$. [Gk. $a$, not ; isos, equal ; pleura, side.] Unsymmetrical bilaterally.

anisopogonous (ănǐsöpŏg'önŭs) $a$. [Gk. $a$, not ; isos, equal ; pogon, beard.] Unequally webbed with reference to feathers (zool.).

anisopterous (ănîsŏp'těrŭs) $a$. [Gk. $a$, not ; isos, equal ; pteron, wing.] Unequally winged; $a p p l$. seeds (bot.).

anisospore (ănĭsöspōr') n. [Gk. $a$, not ; isos, equal ; sporos, seed.] A dimorphic spore, the sexes differing in size (bot.).

anisostemonous (ănǐsöstĕm'ŏnŭs) $a$. [Gk. $a$, not ; isos, equal ; stemon, a spun thread.] Having the number of stamens unequal to the number of parts in the other floral whorls (bot.).

anisotropic (ănîsötrǒp'îk) $a$. [Gk, $a$, not; isos, equal; trepein, to turn.] $A p p l$. eggs with predetermined axis or axes (emb.).

ankylosis,- - see anchylosis.

anlage (ănlầ'gë) n. [Ger. anliegen, to lie on.] The first accumulation of cells in a developing embryo recognizable as the commencement of a structure, organ, or part (emb.).

annectent (ănĕk'těnt) $a$. [L. annectere, to bind together.] Linking, appl. intermediate species or genera (biol.).

annelid (ăn'ělìd) a. [L. annulus, ring; Gk. eidos, resemblance.] Constructed of ring-like segments, as one of the ringed worms (zool.).

annotinus (ănnŏt'innŭs) $n$. [L. annus, year.] A year old (bot., zool.).

annual (ăn'ūăl) $a . n$. [L. annus, year.] $A p p l$. structures or features that are marked off or completed yearly; living for a year only (bot.).

annual ring,- - one of the rings seen in sections of dicotyledons indicating the secondary growth of a year (bot.).

annular (ăn'ūlăr) a. [L. annulus, ring.] $A p p l$. certain fibrous bands or fascia in connection with the wrist and ankle, etc. (anat.); appl. certain vessels in xylem owing to the ring-like thickenings in their interior (bot.).

annulate (ăn'ūlāt) a. [L. annulus, ring.] Composed of ring-like segments ; having the colour arranged in ring-like bands or annuli, as in earthworm or leech (zool.).

annuli (ăn'ūlī) plu. of annulus.

annulus (ăn'ülŭs) $n$. [L. annulus, ring.] Any of the ring-like structures (anat.) ; the special ring in the fern sporangium, by the action of which the sporangium bursts; the remains of the veil in mushrooms ; the ring of cells in the moss capsule whose rupture causes the opening of the capsule (bot.); a ring of an Annelid (zool.).

anoestrum (ănē'strŭm) n. [Gk. an, not; oistros, gad-fly.] The nonbreeding period; the period of absence of sexual desire (biol.).

anomaly (ănŏm’ălí) $n$. [Gk. $a$, not ; homalos, even.] Any departure from the type characteristics (biol.).

anomophyllous (ăn'ŏmŏf'ílüs) $a$. [Gk. anomalos, uneven; phyllon, leaf.] With irregularly placed leaves (bot.).

anorganology (ăn'ôrgănŏl'öjĩ) $n$. [Gk. $a$, not ; organon, instrument ; logos, discourse.] The study of non-living things (biol.).

anosmatic (ănŏsmăt'îk) a. [Gk. a, without; osme, smell.] Having no sense of smell (phys.).

antambulacral (ănt'ămbūiā'krăl) $a$. [Gk. anti, against; L. ambulare, to walk.] Not situated on the ambulacral area (zool.).

antebrachium (ăn'těbrā'kǐŭm) n. [L. ante, before ; brachium, arm.] The fore-arm, or corresponding portion of the fore-limb (zool.).

antecubital (ăn'těkū'bìtăl) a. [L. ante, before; cubitum, elbow.] Anterior to the elbow (zool.).

antedorsal (ăn'tědôr'săl) $a$. [L. ante, before; dorsum, back.] Situated in front of the dorsal fin in fishes (zool.).

antemarginal (ăn'těmâr'jĭnăl) a. [L. ante, before; margo, an edge.] 
$A p p l$. sori of ferns when they lie within the margin of the frond (bot.). antenna (ăntĕn'ă) $n$. [L. antenna, a sail-yard.] A jointed feeler on the head of an insect or crustacean (zool.).

antennary (ăntĕn'ărĭ) $a$. [L. antenna, a sail-yard.] Like or pert. or situated near an antenna (zool.).

antennule (ăntěn'ūl) $n$. [L. dim. from antenna.] A small antenna or feeler, specifically the first pair of antennae in Crustacea (zool.).

anteposition (ăn'těpözish'ŭn) $n$. [L. ante, betore; ponere, to place.] Superposition of whorls in a flower typically alternating (bot.).

anterior (ănté'riŏr) a. [L. anterior, former.] Nearer the head end (zool., anat.); ventral in human anatomy; facing outwards from the axis (bot.).

anthela (ănthē'lă) $n$. [Gk. anthein, to bloom.] The cymose inflorescence of the rush-family (bot.).

anther (ăn'thĕr) n. [Gk. anthos, flower.] The part of the stamen which contains the pollen (bot.).

antheridiophore (ănthĕrìd'iofōr) $n$. [Gk. anthos, flower; idion, dim.; pherein, to bear.] A gametophore bearing antheridia (bot.).

antheridium (ănthĕrĭd'ium) n. [Gk. anthos, flower; idion, dim.] An organ or receptacle in which male sexual cells are produced (bot.).

antherozoids (ăn'thĕrözō'ídz) n. plu. [Gk. anthos, flower ; soon, animal.] Male sexual cells in antheridia (bot.).

antherozooids (ăn'thĕrözō'oidz) $n$. plu. [Gk. anthos, flower; zoon, animal ; eidos, resemblance.]. Antherozoids. anthocarpous (ăn'thökâr'pŭs) a. [Gk. anthos, flower; karpos, fruit.] $A p p l$. multiple fruits such as the strawberry (bot.).

anthocaulis (ăn'thökôl'ís) n. [Gk. anthos, flower; L. caulis, stem.] The pedicle of a late trophozooid stage of Madrepore development (zool.).

anthocodia (ăn'thökōtdǐă) n. [Gk. anthos, flower ; kodeia, head.] The distal portion of an alcyonarian zooid bearing mouth and tentacles (zool.). anthocyanin (ăn'thösī'ănĭn) n. [Gk. anthos, flower; kyanos, dark blue.] Blue or violet colouring matter in flowers (bot.).

anthocyathus (ăn'thösīăthŭs) n. [Gk. anthos, flower; kyathos, cup.] The discoid crown of the trophozooid stage in Madrepore development (zool.).

anthodium (ănthō'dĭum) n. [Gk. anthos, flower; eidos, resemblance.] The capitulum or head of flowers of a composite plant (bot.).

anthogenesis (ăn'thöjĕn'ěsǐs) n. [Gk. anthos, flower; gignesthai, to produce.] In certain aphids the production of both malesand females by asexual forms (zool.).

anthophilous (ănthŏf'îlŭs) a. [Gk. anthos, flower; philein, to love.] Fond of flowers; $a p p l$. certain insects either living among or feeding on flowers (zool.).

anthophore (ăn'thöfōr) n. [Gk, anthos, flower; pherein, to bear.] Elongation of the thalamus between calyx and corolla (bot.).

anthotaxis (ăn'thötăk'sĭs) n. [Gk. anthos, flower ; taxis, arrangement.] The arrangement of flowers on an axis (bot.).

anthoxanthine (ăn'thözăn'thĭn) $n$. [Gk, anthos, flower; xanthos, yellow.] Yellow colouring pigment of flowers (bot.).

anthropogenesis (ăn'thröpöjĕn'ěsǐs) $n$. [Gk. anthropos, man; genesis, descent, origin.] Theory of the descent of man.

anthropoid (ăn'thröpoid) a. [Gk. anthropos, man; eidos, resemblance.] Resembling man; appl. Simian apes (zool.).

anthropology (ăn'thröpǒl'öjīi) n. [Gk. anthropos, man; logos, discourse.] The natural history of man.

anthropomorphous (ăn'thröpömôr'füs) a. [Gk. anthropos, man; morphe, shape.] Resembling man.

antiae (ăn'tiē, ăn'tīā) n. plu. [L. antiae, forelock.] Feathers at the base of the bill-ridge of some birds (zool.).

antibody (ăn'tibŏd'î) n. [Gk. anti, against ; A.S. bodig, body.] A substance formed in the blood which antagonizes toxins (phys.). 
antibrachial (ăn'tǐbrā'kĭăl) a. [Gk, anti, against ; L. brachium, arm.] Pert. forearm; appl. fascia, muscles, nerves (anat.).

antibrachium (ăntǐbrā'kǐŭm),-antebrachium.

anticlinal (ăn'tǐklīnăl) a. [Gk. anti, against; klinein, to bend.] Appl. line of division of cells at right angles to the apex (bot.); in quadrupeds, $a p p l$. one of the lower thoracic vertebrae with upright spine towards which those on either side incline (zool.).

anticoagulin (ăn'tǐkōăg'ūlìn) $n$. [Gk. anti, against ; $\mathrm{L}$. cogere, to drive together.] A substance which prevents the coagulation of drawn blood, as hirudin (phys.).

anticubital,-antecubital.

antidromy (ăntĭd'römǐ) $n$. [Gk. anti, against; dromos, running.] Condition of spiral phyllotaxy with genetic spiral changing direction after each cycle (bot.).

antigen (ăn'tǐjĕn) $n$. [Gk. anti, against; genos, birth.] Appl. substances which, when injected into an animal, cause a series of physiologico-chemical changes resulting in the formation of antibodies in the blood (phys.).

antihelix (ăn'tǐhē'líks) n. [Gk. anti, against; helix, a convolution.] The curved prominence in front of the helix of the ear (anat.).

antimeres (ăn'tĭmērz) n. plu. [Gk. anti, against; meros, part.] A series of equal radial parts of the body of a radially symmetrical animal (zool.).

antipetalous (ăn'tīpět'ălŭs) a. [Gk. anti, against, opposite ; petalon, petal.] With stamens in front of petals (bot.).

antipodal (ăntǐp'ödăl) a. [Gk. anti, against; pous, foot.] Appl. group of three cells at chalazal end of embryo sac (bot.); $a p p l$. cone of astral rays opposite spindle fibres (cyt.).

antiseptic (ăn'tǐsěp'tīk) a. [Gk. anti, against; sepsis, putrefaction.] A substance which destroys harmful micro-organisms, one of the functions of gastric juice (phys.).

antispadix (ăn'tǐspä'diks) n. [Gk. anti, against; spadix, a palm branch.] A group of four modified tentacles in internal lateral lobes of Nautilus (zool.).

antisquama (ăn'tǐskwā'mă) n. [Gk. anti, against; L. squama, scale.] A basal lobe next the squama of insect wing ; the squama alaris or antitegula (zool.).

antitegula (ăn'tǐtěg' ūlă) n. [Gk. anti, against; L. tegula, tile.] Smaller lobe, nearer the base of wing, than alula (zool.).

antithrombin (ăn'tĭthrŏm'bĭn) n. [Gk. anti, against; thrombos, clot.] A substance formed in the liver which prevents clotting of the blood (phys.).

antitoxin (ăn'tĭtŏk'sĭn) n. [Gk. anti, against; toxikon, poison for arrows.] A substance which develops as a result of, and subsequently neutralizes, the injection of a specific poison introduced into the animal body (phys.).

antitragus (ăn'tǐtrăg'ŭs) $n$. [Gk. anti, against ; tragos, he-goat.] A prominence opposite the tragus of the ear (anat.).

antitrochanter (ăn'tǐtrökăn'tĕr) $n$. [Gk. anti, against; trochanter, a runner.] An articular surface on the ilium in birds against which the trochanter of the femur plays (zool.).

antitropal (ăntǐt'röpăl) $a$. [Gk. anti, against; trepein, to turn.] Inverted; $a p p l$. embryos with radicle directed away from the hilum (bot.). antitropous, - antitropal.

antlia (ănt'liă) $n$. [L. antlia, pump.] The spiral suctorial proboscis of the Lepidoptera (zool.).

antorbital (ăntôr'bìtăl) n. [L. ante, before; orbs, circle.] Situated in front of the orbit (zool.).

antrum (ăn'trŭm) n. [L. antrum, cavity.] A cavity or sinus; $a p p l$. maxillary sinus, and cavity of the pylorus (anat.).

anurous (ănū'rŭs) a. [Gk. $a$, without ; oura, tail.] Tailless.

anus (ā'nŭs) n. [L. anus, anus.] The posterior opening of the alimentary canal (anat.).

aorta (ầor'tă) n. [Gk. aorte, the great artery.] The great trunk artery 
which carries pure blood from the heart for distribution to various parts of the body through arteries and their branches (anat.).

aortic (ầr'tìk) a. [Gk. aorte, the great artery.] Pert. the aorta ; appl. arch, hiatus, isthmus, septum, etc. (anat.), regurgitation (phys.).

apatetic (ăp'ătĕt'1̂k) a. [Gk. apatet$i k o s$, fallacious.] Appl. misleading coloration (zool.).

aperispermic (âpěr' íspěr'mǐk) $a$. [Gk. $a$, without ; peri, around ; sperma, seed.] $A p p l$. seeds without nutritive tissue (bot.).

apetalous (âpět'ălŭs) $a$. [Gk. $a$, without; petalon, petal.] Having no petals (bot.).

apex (äpěks) $n$. [L. apex, summit.] The tip or summit, as of lungs, heart, etc. (anat.).

aphanipterous (ăf'ănǐp'těrŭs) $a$. [Gk. aphanes, unseen; pteron, wing.] Apparently without wings (zool,).

apheliotropism (ăf'èlǐ̌t'röpizm) $n$. [Gk. apo, away; helios, sun; trepein, to turn.] Tendency to turn away from light (biol.).

aphodal (ăf'ödăl) a. [Gk. apo, away ; hodos, way or path.] Appl. a type of canal system in sponges (zool.).

aphodus (ăf'ödŭs) $n$. [Gk. apo, away ; hodos, path.] The short tube leading from the flagellate chamber to the excurrent canal in one of the types of canal systems in sponges (zool.).

aphyllous (ăfil'ŭs) $a$. [Gk. $a$, without; phyllon, leaf.] Without foliage leaves (bot.).

aphylly (ăfilî́) n. [Gk. $a$, without ; phyllon, leaf.] Suppression or absence of leaves (bot.).

apical (ăp'íkăl) a. [L. apex, summit.] At the tip or summit, appl. cell at tip of a growing point (bot.); $a p p l$. aboral plates of Echinoderms (zool.).

apiculate (ăpı̌k'ūlāt) a. [L. apex, summit.] Forming abruptly to a small tip, as a leaf (bot.).

apilary (ăpil'ărǐ) $a$. [Gk. $a$, not ; pilos, felt cap.] Having the upper lip wanting or suppressed in the corolla (bot.).

aplacental (ăp'lăsěn'tăl) $a$. [L. $a$, not; placenta, flat cake.] Not developing a placenta, as in Monotremes (zool.).

aplanogamete (ầplăn'ögămēt') $n$. [Gk. a, not; planos, wandering ; gamete, wife.] A non-motile conjugating germ cell in various plants and animals (biol.).

aplanospore (åplăn'öspōr) n. [Gk. $a$, without; planos, wandering ; sporos, seed.] A non-motile resting spore of Algae for tiding over unfavourable circumstances (bot.).

aploperistomatous (ăp'löpĕr'istŏm'ătŭs) a. [Gk. aploos, single; peri, around; stoma, mouth.] Having a peristome with one row of teeth, as mosses (bot.).

aplostemonous (ăp'löstěm'ŏnŭs) $a$. [Gk. aploos, single; stemon, a spun thread.] Having a single row of stamens (bot.).

apneustic (ăpnū'stik) a. [Gk. a, without; pneustos, breath.] With closed tracheal system; $a p p l$. aquatic larvae of certain insects (zool.).

apocarpous (ăp'ökâr'pŭs) a. [Gk. $a p o$, away; karpos, fruit.] Having separate or partially united carpels (bot.).

apocyte (ăp'ösīt) n. [Gk. apo, away; kytos, hollow.] A multinucleate cell, a plurinucleate mass of protoplasm (cyt.).

apodal (ăp'ödăl) $a$. [Gk. $a$, without ; pous, foot.] Having no feet (zool.). apodema (ăp'ödē'mă) $n$. [Gk. $a p o$, away; demas, body.] An internal projection usually of thoracic segments, for muscle attachments, found in Arthropods (zool.).

apodous (ăp'ödŭs), - apodal.

apogamy (ăpŏg'ămǐ) $n . \quad[G k . a p o$, away ; gamos, marriage.] Development without the intervention of sexual organs (bot.).

apogeotropic (ăp'öjè'ötrŏp'îk) a. [Gk. apo, away; gaia, earth ; trepein, to turn.] Having the property of turning away from the earth (bot.).

apogeotropism (ăp'öjēōt'röpǐzm) $n$. [Gk. apo, away ; gaia, earth ; trepein, to turn.] Tendency to act apparently contrary to law of gravity - this is, to turn away from the earth (biol.).

aponeurosis (ăp'önūrō'š̌s) n. [Gk. apo, from; neuron, sinew] The 
flattened tendons of certain muscles (anat.).

apophyllous (ăp'öfîl'ǔs) $a$. [Gk. apo, away; phyllon, leaf.] Appl. the parts of a single perianth whorl when they are free leaves (bot.).

apophysis (ăpơf'ǐšs) n. [Gk. apo, away; phyein, to grow.] Process from a bone, usually for muscle attachment (anat.); a swelling at the base of the capsule in some mosses ; appl. small protuberance at apex of an ovuliferous scale in female cone of pine (bot.).

apoplasmodial (ăp'öplăsmō'diăl) $a$. [Gk. apo, away ; plasma, something moulded.] Not forming a typical plasmodium (zool.).

apopyle (ăp'öpīl) $n$. [Gk. apo, away ; pyle, gate.] The exhalent pore of a sponge (zool.).

aposematic (ăp'ösěmăt'îk) $a$. [Gk. apo, away; sema, signal.] Appl. warning colours which serve to frighten away enemies (zool.).

aposporogony (ăp'öspörŏg'önǏ) $n$. [Gk. apo, away; sporos, seed; gonos, birth.] The absence of sporogony (zool.).

apospory (ăpŏs'pörī) $n$. [Gk. apo, away ; sporos, seed.] The production of prothalli without the intervention of spore-formation in certain plants (bot.).

apostasis (ăpŏs'tăš̌s) $n$. [Gk. apo, away; stasis, standing.] Term $a p p l$. condition of abnormal growth of axis which thereby causes a separation of the perianth whorls from one another (bot.).

apostrophe (ăpŏs'tröfë) $n$. [Gk. apo, away ; trepein, to turn.] Arrangement of chloroplasts along the lateral walls of cells of leaves (bot.).

apothecium (ăp'öthê'šŭm, -shřum) $n$. [Gk. apo, away; theke, cup.] The ascocarp of Lichens (bot.).

apotropous (ăpŏt'röpŭs) $a$. [Gk, $a p o$, away; trepein, to turn.] Anatropal and with ventrally-situated raphe (bot.).

appendage (ăpěn'dāj) $n$. [L. $a d$, to; pendere, to hang.] An organ or part attached to a trunk, as a limb
(anat.).

appendicula (ăp'ěndǐk'úlăr) $a$. [L. ad, to ; pendere, to hang.] Pert. appendages; $a p p l$. skeleton of limbs as opposed to skeleton of trunk (anat.).

appendiculate (ăp'ěndǔk'ūlāt) a. [L. $a d$, to ; pendere, to hang.] Having a small appendage, as a stamen or filament (bot.).

appendix (ăpěn'dĩks) $n$. [L. $a d$, to ; pendere, to hang.] An outgrowth, especially the vermiform appendix (anat.).

applanate (ăp'lănāt) $a$. [L. $a d$, to ; planatus, flattened.] Flattened out (bot.).

apposition (ăp'özı̆sh'ŭn) $n$. [L. $a d$, to ; ponere, to place.] The formation of successive layers in the growth of a cell wall ; $c f$. intussusception (bot.).

aproterodont (ăp'rötěr'ödŏnt, âprō'tĕrödŏnt) $a$. [Gk. $a$, without ; proteros, first ; odous, tooth.] Having no teeth on the pre-maxillae (zool.).

apteria (ăptē'ruă) $n$. plu. [Gk. $a$, without; pteron, wing.] Naked or downcovered surfaces between the pterylae or feather-tracts (zool.).

apterous (ăp'tĕrŭs) $a$. [Gk. $a$, without ; pteron, wing.] Wingless (zool.); having no wing-like expansions on the stems or petioles (bot.).

apterygial (ăp'tĕrĭj'răl) $a$. [Gk. $a$, without; pteron, wing.] Wingless ; without fins (zool.).

apterygotous (ăp'těrigō'tŭs) a. [Gk. $a$, without ; pterygion, dim. of pteron, wing.] Resembling or pert. the primitive wingless insects or Apterygota (zool.).

aptychus (ăp'tǐkŭs) n. [Gk. $a$, without; ptyche, fold.] A horny or calcareous structure, possibly an operculum, of Ammonites (zool.).

aquatic (ăkwăt'ík, -wŏt-) a. [L. aqua, water.] Pert. water; living in or frequenting water (bot., zool.).

aqueduct (ăk'wědŭkt) $n$. [L. aqua, water; ducere, to lead.] A channel or passage as that of cochlea, and of vestibule of ear (anat.).

aqueous (ấkwě̃us) $a$. [L, aqua, water.] Watery, $a p p l$. fluid occupying the space between the lens and the cornea of the eye (anat.); appl. 
tissue consisting of thin-walled watery parenchymatous cells (bot.). arachnid (ărăk'nǐd) a. [Gk. arachne, spider.] Spider-like, pert. spiders (zool.).

arachnidium (ărăknid'ǐŭ) $n$. [Gk. arachne, spider.] The spinning apparatus of a spider, including spinning-glands and spinnerets (zool.).

arachnoid (ărăk'noid) a. [Gk. arachne, spider; eidos, form.] Like a cobweb; consisting of fine entangled hairs resembling a cobweb (bot.); appl. a thin membrane of the central nervous system, composed of delicate connective tissue with an endothelial covering on its free surfaces and lying between the dura and the pia mater (anat.); pert. or resembling a spider (zool.). arborescent (âr'bŏrěs'ěnt) $a$. [L. $a r$ borescens, growing like a tree.] Branched like a tree (bot.).

arboroid (âr'bŏroid) a. [L. arbor, tree; Gk. eidos, like.] Tree-like, designating general structure of a protozoan colony (zool.).

arbor vitae (âr'bŏr vī'tē, vē'tā) n. [L. arbor, tree; vita, life.] The tree of life, $a p p l$. arborescent appearance of the cerebellum in vertical section (anat.).

arbutean (ârbū'těăn) a. [L. arbutus, strawberry tree.] Of or pert. the strawberry tree (bot.).

arcade (ârkād') n. [L. ancus, a bow.] An arched channel or passage; a bony arch, as supra- and infratemporal arches in the skull (anat.). archaeocytes (âr'kēösīts) $n$.plu. [Gk. anchaios, ancient ; kytos, hollow.] Cells arising from undifferentiated blastomeres and ultimately giving rise to germ-cells and gametes (emb.).

archaeostomatous (âr'kēöstǒm'ătŭs) $a$. [Gk. archaios, primitive; stoma, mouth.] Having the blastopore persistent and forming the mouth (zool.). arch-centra (ârk'-sěn'tră) n. plu. [Gk. archi, beginning, first ; L. centrum, centre.] Centra formed by fusion of basal growths of primary arcualia external to chordal sheath; $c f$. chordacentra (zool.).

archebiosis (Âr'këbīósis) n. [Gk. arche, beginning; bios, life.] The origin of life (biol.).

archegoniophore (âr'këgō'nïöfōr) $n$. [Gk. arche, beginning; gonos, offspring; pherein, to bear.] Branches of mosses bearing archegonia (bot.). archegonium (âr'këgō'nǔm) $n$. [Gk. arche, beginning ; gonos, offspring.] A female organ in which the oospheres are formed, and in which the young plant begins its development (bot.).

archenteron (ârkĕn'tĕrŏn) n. [Gk. arche, beginning; enteron, gut.] The cavity of the gastrula which forms the primitive gut of the embryo (emb.).

archespore (âr'këspōr) n. [Gk. arche, beginning; sporos, seed.] The tetrahedral or meristematic cell of a sporangium (bot.).

archiamphiaster (âr'kiăm'fiăs'těr) $n$. [Gk. archi, first ; amphi, on both sides ; aster, star.] The amphiaster forming the first or second polar body in cell maturation (cyt.).

archiblast (âr'kǐblăst) $n$. [Gk. $a r c h i$, first; blastos, bud.] Egg protoplasm.

archiblastic (âr'kǐblăs'tìk) a. [Gk. archi, first ; blastos, bud.] Having total and equal segmentation (cyt.). archiblastula (âr'kỉblăs'tūlă) n. [Gk. archi, first ; blastos, bud.] Typical hollow ball of cells derived from an egg with total and equal segmentation (cyt.).

archicarp (âr'kỉkârp) n. [Gk. archi, first; karpos, fruit.] The spirally coiled region of the thallus of certain fungi (bot.).

archicerebrum (âr'kǐsĕr'ěbrŭm) $n$. [Gk. archi, first ; L.cerebrum, brain.] The primitive brain, as the supraoesophageal ganglia of higher Invertebrates (sool.).

archichlamydeous (âr'kǐklămìd'ê̌s) $a$. [Gk. archi, first ; chlamys, cloak.] Having no petals, or having petals entirely separate from one another (bot.).

archicoel (âr'kǐsēl) $n$. [Gk, archi, first ; koilos, hollow.] The primary body-cavity or space between the alimentary canal and ectoderm in development of various groups of animals (zool.). 
archigony (ârkig'önı̆) n. [Gk. archi, first; gonos, offspring.] The first origin of life by spontaneous generation (biol.).

archinephric (âr'kiněf'rìk) a. [Gk. archi, first; nephros, kidney.] Appl. the duct into which the pronephric tubules open (emb.).

archinephros (ầr'kĭnĕf'rŏs) n. [Gk. archi, first; nephros, kidney.] The primitive kidney (emb.).

archipallium (âr'kĭpăl'iuum) n. [Gk. archi, first ; L. pallium, a mantle.] The olfactory region of the cerebral hemispheres (phys.).

archipterygium (âr'kịptĕrījiŭum) $n$. [Gk. archi, first; pterygion, little wing.] Type of fin in which the skeleton consists of an elongated segmented central axis and two rows of jointed rays (zool.).

architype (âr'kītīp) $n$. [Gk. archi, first ; typos, type.] An original type from which others may be derived (biol.).

archoplasm (âr'köplăzm) $n$. [Gk. archon, ruler; plasma, something moulded.] The substance constituting the attraction sphere, astral rays, and spindle-fibres (emb.).

arcicentrous (âr'kĭsěn'trŭs) $a$. [L. arcus, bow ; centrum, centre.] $A p p l$. vertebral columns in which the centra are mainly derived from the arch tissue (emb., anat.).

arciferous (ârsif'ĕrŭs) a. [L. arcus, bow ; ferre, to carry.] Appl. pectoral arch of toads, etc., where the precoracoid and coracoid are widely separated and connected by a large arched epicoracoid (zool.).

arciform (âr'sĭfôrm) a. [L. arcus, bow ; forma, shape.] Shaped like an arch or bow (zool.).

arcocentrous (âr'kösěn'trŭs) $a$. [L. arcus, bow ; centrum, centre.] Appl. vertebral columns with inconspicuous chordal sheath and centra derived from arch tissue (zool.).

arcocentrum (âr'kösĕn'trŭm) n. [L. arcus, bow ; centrum, centre.] A centrum formed from parts of neural and haemal arches (zool.).

arcualia (âr'kūä'lǐă) n.plu. [L. arcus, bow.] Small cartilaginous pieces, dorsal and ventral, fused or free, on the vertebral column of fishes (zool.).

arcuate (âr'kūāt) a. [L. arcus, bow.] Curved or shaped like a bow.

ardellae (ârděl'ê) n. plu. [Gk, ardein, to sprinkle.] Small apothecia of certain lichens having the appearance of dust (bot.).

area (ä'rëă) $n$. [L. area,ground-space.] A surface, as area opaca, area vasculosa (emb.).

arenaceous (ărĕnā'shŭs) a. [L. arena, sand.] Having the properties or appearance of sand; sandy.

areola (ărē'ölă) $n$. [L. areola, dim. of area, space.] A small coloured circle round a nipple; the part of the iris bordering the pupil of the eye (anat.); one of the small spaces or interstices of a special kind of tissue (zool.); the areas defined by cracks on the surface of lichens (bot.). areolar (ărē'ölăr), areolate (ărē'ölāt) $a$. [L. areola, space.] Of or like an areola, having distinct spaces or interstices (bot.) ; areolar is appl. a kind of connective tissue with the fibres loosely attached (zool.).

argenteal (ârjĕn'tê̌l) a. [L. argenteus, silvern.] Appl. layer of the eye containing calcic crystals (zool.).

argenteous (ârjĕn'těŭs) $a$. [L. argenteus, silvern.] Like silver (bot.).

argenteum (ârjĕn'těŭm) n. [L.argentum, silver.] A dermal reflecting tissue layer of iridocytes without chromatophores in fishes (zool.).

aril (ăr'îl), arillus (ărỉl'ŭs) $n$. [F. arille, Sp. arillo, a small hoop.] An additional investment formed on a seed after fertilization (bot.).

arillode (ăr'́lōd) n. [F. arille, hoop ; Gk. eidos, like.] A false arillus arising from the micropyle as an expansion of the exostome (bot.).

arista (ărĭs'tă) $n$. [L. arista, beard of an ear of corn.] Awn; long-pointed process as in many grasses (bot.) ; a bristle borne by the antenna of many brachycerous Diptera (zool.).

Aristotle's lantern (Ar'istŏt'lz), - the masticating apparatus of the seaurchin (zool.).

armature (âr'mătūr) $n$. [L. arma, weapons.] Anything which serves to defend, as hairs, prickles, thorns (bot.); spines, stings, etc. (zool.). 
arolium (ărō'liŭm) n. [Gk, arole, protection.] Pad between the claws on tarsus of Orthoptera (zool.).

arrectores pilorum,-bundles of nonstriped muscular fibres associated with the hair follicles,- on contraction, they render the hair more erect (phys.).

arrhenoplasm (ărĕn'öplăzm) n. [Gk. arrenos, male ; plasma, something moulded.] Male plasm, in reference to the theory that all protoplasm consists of arrhenoplasm and thelyplasm (biol.).

arrhenotoky (ărĕnŏt'ökǐ) n. [Gk. arrenos, male; tokos, birth.] Production of males parthenogenetically (zool.).

arterial (ârtériăl) a. [L. arteria, artery.] Pert. an artery, or the system of channels by which the blood issues to the body from the heart; appl. blood, duct, gland (anat.).

arterial sclerosis,-hardening of the walls of the arteries, said to contribute to natural death ( $p h y s$.$) .$

arteriole (ârtërrīō) $n$. [L. arteriola, small artery.] A small or branch artery (anat.).

artery (âr'těrǐ) n. [L. arteria, artery.] A vessel which conveys blood from heart to body (anat.).

arthritic (ârthrit' ik) a. [Gk. arthron, joint.] Pert. or at joints (anat.).

arthrobranchiae (âr'thröbrăng'kiē, -kiā) n. plu. [Gk. arthron, a joint ; brangchia, gills.] Joint-gills, arising at the junction of thoracic appendages with trunk of Arthropods (zool.). arthrodia (ârthrō'dı̆ $n$. [Gk. arthron, joint.] A joint admitting of only gliding movements (anat.).

arthrodial (ârthrō'dǐl) a. [Gk. arthron, joint.] $A p p l$. the articular membranes connecting thoracic appendages with trunk, as in Arthropods (zool.).

arthromere (âr'thrömēr) $n$. [Gk. arthron, joint; meros, part.] An arthropod body-segment or somite (zool.).

arthropod (ân'thröpǒd) a. [Gk. arthron, joint ; pous, foot.] Of or pert. the Arthropoda (zool.).

arthropterous (ârthrŏp'těrŭs) a. [Gk. arthron, joint; pteron, wing.]
Having jointed fin-rays, as in fishes (zool.).

arthrospore (ârth'röspōr) n. [Gk. arthron, joint; sporos, seed.] A resting bacterial cell (bot.).

arthrosterigmata (âr'thröstĕrĭg'mătă) n.plu. [Gk, arthron, joint; sterigma, a support.] Jointed sterigmata (bot.). arthrostracous (ârthrŏs'trăkŭs) $a$. [Gk. arthron, joint ; ostrakon, shell.] Having a segmented shell (zool.).

articular (ârtǐk'ūlăr) a. [L. articulus, joint.] Pert. or situated at a joint or joints ; appl. cartilage, lamellae, surface, capsule, etc. (anat.).

articulated (ârtǐk'ūlātěd) $a$. [L. articulus, joint.] Jointed ; separating easily at certain points (bot.).

articulation (ârtikūīä'shŭn) n. [L. articulus, joint.] A joint, between bones or segments (zool.), or segments of a stem (bot.).

artifact (âr'tǐfăkt) $n$. [L. ars, art ; facere, to make.] Any appearance produced by a reagent or other artificial means (biol.).

artiodactyl (âr'tîödăktǐl) a. [Gk. artios, equal; daktylos, finger.] Having an even number of fingers or toes (zool.)

arytenoid (ăr'itēénoid) a. [Gk. arytaina, a pitcher.] Pitcher-like, $a p p l$. two cartilages at the back of the larynx, also glands, swellings, etc. (anat.).

asci (ăs'î, ăs'kī, ăs'kē) n. plu. [Gk. askos, bladder.] Membranous sporesacs of fungi within which the ascospores are formed (bot.).

ascidian (ăsĭd'iăn) a. [Gk, askidion, dim. of askos, bag.] Like an ascidian or sea-squirt (zool.).

ascidium (ăš̃d'iŭm) n., ascidia (ăsĭd'ră) plu. [Gk. askidion, little bag.] Pitcher-leaves, as in Nepenthes (bot.).

ascigerous (ăsǐj'ěrŭs) a. [Gk. askos, bag ; L. gerere, to bear.] Bearing asci, as certain hyphae in Fungi (bot.).

ascocarp (ăs'kökârp) n. [Gk. askos, bag; karpos, fruit.] The protective covering investing the asci (bot.).

ascogenous (ăskŏj'ěnŭs) a. [Gk. askos, bag; gignesthai, to produce.] Bearing asci (bot.).

ascogonium (ăs'kögö'nĭum) $n$. [Gk. 
askos, bag ; gignesthai, to produce.] A sac-like structure in which the reproductive bodies are formed (bot.).

ascospore (ăs'köspōr) n. [Gk. askos, bag; sporos, seed.] One of the spores contained in an ascus (bot.). ascus, - sing. of asci, which see.

asexual (âsěk'sūăl) $a$. [Gk. $a$, without; L. sexus, sex.] Having no apparent sexual organs; pathenogenetic or vegetative as $a p p l$. reproduction (biol.).

aspect (ăs'pěkt) $n$. [L. $a d$, to ; spectare, to look.] Look, appearance, point of view (biol.).

asperity (ăspĕr'îtı̌) $n$. [L. asper, rough.] Roughness as on certain leaves (bot.).

aspidobranchiate (ăs'pĭdöbrăng'kǐăt) a. [Gk. aspis, shield; brangchia, gills.] Pert. or resembling the Aspidobranchiata, a group of Gasteropods (zool.).

asplanchnic (âsplăngk'nǐk) a. [Gk. $a$, without ; splangchna, viscera.] Without alimentary canal (zool.).

asporous (âspō'rŭs) a. [Gk. $a$, without; sporos, seed.] Having no spores (bot.).

assimilation (ăsĭm'îlā'shŭn) $n$. [L. $a d$, to ; similis, like.] Conversion into protoplasm of ingested nutrient material (phys.).

association (ăsō'sīā'shŭn) $n$. [L. $a d$, to ; socius, fellow.] Adherence of gregarines without fusion of nuclei (zool.) ; appl. fibres connecting white matter of interior of brain with cortex of convolutions (phys.). astely (âstēliî) $n$. [Gk, a, without ; stele, pillar.] Absence of a central cylinder or axis (bot.).

aster (ăs'tĕr) n. [Gk. aster, a star.] The star-shaped achromatinic structure surrounding the centrosome during mitosis; the starshaped arrangement of the chromosomes during mitosis (cyt). asterion (ăstếriŏn) $n$. [Gk. aster, star.] The region of the posterolateral fontanelle where lambdoid, parieto-mastoid, and occipitomastoid sutures meet (anat.).

asteroid (ăs'tĕroid) a. [Gk, aster, star; eidos, resemblance.] Star-shaped; pertaining to the star-fish (zool.). asterospondylous (ăs'těröspŏn'dǔlŭs) a. [Gk. aster, star; sphondylos, vertebra.] Having centrum with radiating calcified plates (zool.).

astomatous (âstǒm'ătǔs) $a$. [Gk. $a$, without; stoma, mouth.] Nothaving a mouth (zool.); without epidermic pores or stomata (bot.).

astomous (âstō'mŭs) $a$. [Gk, $a$, without ; stoma, mouth.] Without a stomium or line of dehiscence; bursting irregularly (bot.).

astragalus (ăstrăg'ălüs) $n$. [Gk. astragalos, an ankle bone.] The second largest tarsal bone in man (anat.); a tarsal bone in Vertebrates. astrocentre (ăs'trösěn'tër) $n$. [L. aster, star; centrum, centre.] The centrosome (cyt.).

astrosphere (ăs'trösfēr) n. [Gk. aster, star; sphaira, ball.] The central mass of the aster without the rays; the aster exclusive of the centrosome ; the astral sphere (cyt.).

asymmetrical (âsǐmět'ríkăl) a. [Gk. $a$, without; syn, with; metron, measure.] Pert. want of symmetry; in the condition of having two sides unlike or disproportionate; $a p p l$. structures or organs which cannot be divided into similar halves by any vertical axis (biol.).

asymmetry (âsĭm'ětrĭ) $n$. [Gk. $a$, without ; syn, with; metron, measure.] Want of symmetry.

atavism (ăt’ăvǐzm) $n$. [L. atavus, ancestor.] Reversion, the occurrence of a characteristic of a remote ancestor not observed in the more immediate ancestors (biol.).

atavistic (ăt'ăv̌s'tīk) a. [L. atavus, ancestor.] Pert. marked by, or tending to atavism (biol.).

athalamous (âthăl'ămŭs) a. [Gk. $a$, without; thalamos, inner room.] Wanting a thalamus (bot.).

atlas (ăt'lăs) $n$. [Gk. atlas, a giant.] The first cervical vertebra articulating with the skull (anat.).

atokous (ăt'ökŭs) a. [Gk. atokos, childless.] Without offspring.

atoll (ăt'ôl, ătôl') n. [Mal. atoll.] A coral reef surrounding a body of water (zool.).

atrial (a'triăl) a. [L. atrium, a central 
room.] Pert. atrium; $a p p l$. cavity, pore, canal, siphon, lobes (zool.).

atriocoelomic (à'triösēlŏm' ${ }^{\prime} \mathrm{k}$ ) $a$. [L. atrium, central room; Gk. koilos, hollow.] Connecting the atrium and the coelom; $a p p l$. funnels, of uncertain function, in Cephalochorda (zool.).

atriopore (a'triöpōr) $n$. [L. atrium, central room; porus, channel.] The opening from the atrial cavity to the exterior in Cephalochorda (zool.).

atrioventricular (ātriövĕntrǐk'ūlăr) $a$. [L. atrium, chamber; ventriculus, small cavity.] Pert. the atrioventricular structure in the heart ; $a p p l$. bundles, groove, openings (anat.).

atrium (ấtriŭm) n. [L. atrium, chamber.] The two anterior cavities of the heart; the tympanic cavity (anat.) ; a chamber surrounding the pharynx in Tunicates and Cephalochordates (zool.).

atrochal (ăt'rökăl) a. [Gk. $a$, without; trochos, wheel.] Without the preoral circlet of cilia ; $a p p l$. trochophore stage when the preoral circlet is absent and the surface is covered uniformly with cilia (zool.).

atrophy (ăt'röfî) n. [Gk. $a$, without ; trephein, to nourish.] Emaciation; diminution in size and function of a part or organ (biol.).

atropous (ăt'röpŭs) $a$. [Gk, $a$, without ; trepein, to turn.] Appl. ovule in proper position, i.e. not inverted (bot.).

atterminal (ăttěr'minnăl) a. [L. $a d$, to ; terminus, end.] Towards a terminal; $a p p l$. current directed toward the thermal cross-section (phys.).

attraction (ătrăk'shŭn) $n$. [L. attractus, drawn to.] Any structure which apparently draws other things to it, as an attraction cone (cyt.).

auditory (ôd'ítŏrǐ) a. [L. audire, to hear.] Pert. the hearing apparatus, $a p p l$. organ, nucleus, ossicle, capsule, canal, meatus, nerve, tentacle, etc.

Auerbach's plexus, - a gangliated plexus of non-medullated nervefibres, found between the two layers of the muscular coat of the small intestine; the plexus myentericus (phys.).

augmentor (ôgmĕn'tŏr) a. [L. augere, to increase.] Appl. nerves rising from the sympathetic system and acting on the heart, with antagonistic relation to the vagi; accelerator (phys.).

aulostomatous (ôl'östŏm'ătŭs) $a$. [Gk. aulos, tube; stoma, mouth.] Having a tubular mouth or snout (zool.).

aural (ôr'ăl) a. [L. auris, ear.] Pert. ear or hearing.

auricle (ôr'ikl) n. [L. auricula, little ear.] The external ear; any earlike lobed appendage (zool.); the upper or anterior chamber on each side of the heart (anat.).

auricula (ôrǐk'ūlă) $n$. [L. auricula, little ear.] An auricle.

auricular (ôrǐk'ūlăr) a. [L. auricula, small ear.] Pert. an auricle; $a p p l$. artery, nerve, tubercle, vein (anat.). auricularia (ôrìk'ūlā'rŭă) $n$. [L, auricula, small ear.] A type of larva found among the Holothurians (zool.).

auriculars, $-n$. plu., ear coverts of birds.

auriculate (ôrǐk'ūlāt) a. [L. auricula, small ear.] Eared; appl. leaf with expanded bases surrounding the stem; $a p p l$. leaf with lobes separate from rest of blade ; hastate-auricled (bot.).

auriculo-ventricular (ôrǐk'ūlö-věntrǐk'ūlăr) a. Pert, or connecting the auricle and ventricle of the heart ; $a p p l$. bundle, valve (anat.).

aurophore (ôr'öfōr) $n$. [L. auris, ear; Gk. pherein, to bear.] An organ projecting from the base of pneumatophore of certain Siphonophores (zool.).

autacoid (ôt'ăkoid) $n$. [Gk, autos, self.] A term including both hormone and chalone (phys.).

autoblast (ôt'öblăst) n. [Gk. autos, self; blastos, bud.] An independent micro-organism.

autocatalysis (ôt'ökătăl'isiss) n. [Gk. autos, self ; kata, down; lysis, a loosing.] The dissolution or reaction of a cell or substance due to the influence of a product or secretion of its own ( $p h y s$.$) .$

autochthon (ôtŏk'thŏn) n. [Gk. autos, 
self; chthon, the ground.] An indigenous species of plant or animal (biol.).

autocyst (ôt'ösist) $n$. [Gk. autos, self; kystis, bladder.] A thick membrane formed by the Neosporidia separating them from the host tissues (zool.). autodermalia (ôt'ödĕrmăl'iă) n. plu. [Gk. autos, self; derma, skin.] Dermal spicules with axial cross within the dermal membrane (zool.). autoecious (ôtē'shŭs) a. [Gk. autos, self; oikos, house.] Appl. rusts whose aecidium form inhabits the same host as the uredoform stage (bot.).

autogamy (ôtŏg'ămĩ) n. [Gk, autos, self ; gamos, marriage.] Selffertilization (biol.).

autogenesis (ôt'öjën'ěsǐs) $n$. [Gk. autos, self; genesis, birth.] Spontaneous generation (biol.).

autogenetic (ôt'öjěnět'îk) a. [Gk. autos, self ; genesis, birth.] Reproducing spontaneously, $a p p l$. bodycells.

autogeny (ôtǒj'ěnǐ) $n$. Autogenesis.

autogony (ôtŏg'önı̌) n. [Gk. autos, self ; gonos, offspring.] Autogenesis.

autolysis (ôtŏl'ǐsı̆s) n. [Gk. autos, self; lysis, a loosing.] Selfdigestion.

automixis (ôt'ömǐk'sǐs) $n$. [Gk, autos, self ; mixis, mingling.] The union in a cell of chromatin derived from common parentage (biol.).

autonomic (ôt'önǒm'ík) a. [Gk, autos, self; nomos, province.] Selfgoverning, spontaneous; $a p p l$. nerves of sympathetic system and of certain involuntary muscles, and of secreting glands (phys.).

autonomous (ôtǒn'ömǔs), a. Autonomic.

autophagous (ôtǒf'ăgŭs) a. [Gk. autos, self; phagein, to eat.] Appl. birds capable of running about and securing food for themselves when newly hatched (zool.).

autophya (ôt'öfíăa) n.plu. [Gk. autos, self; phyein, to produce.] Elements in the formation of a shell secreted by the animal itself; of. xenophya (zool.).

autophyllogeny (ôt'öfịlŏj'ěnǐ) $n$. [Gk. autos, self; phyllon, leaf; genos, birth.] Growth of one leaf upon or out of another (bot.).

autophyta (ôt'öfî́'tă) $n$. plu. [Gk. autos, self; phyton, plant.] Plants which obtain food in the ordinary way ; $c f$. saprophyta (bot.).

autoskeleton (ôt'öskěl'ětŏn) n. [Gk. autos, self; skeletos, dried.] A true skeleton formed within the animal (zool.).

autostylic (ôt'östǐl'îk) a. [Gk. autos, self; stylos, pillar.] Having the mandibular arch self-supporting, and articulating with the skull direct (zool.).

autotomy (ôtǒt'ömǐ) n. [Gk. autos, self; tome, cutting.] Self-amputation of a part, as in certain worms and arthropods (zool.).

autotrophic (ôt'ötrŏf' '́k) $a$. [Gk. autos, self; trephein, to nourish.] Procuring food independently; $a p p l$. plants which are neither saprophytic nor parasitic (bot.).

autotropism (ôtŏt'röpǐzm) n. [Gk. autos, self; trepein, to turn.] Tendency to grow in a straight line; $a p p l$. plants unaffected by external influence (phys.).

autozooid (ôt'özōoid) n. [Gk. autos, self; zoon, animal ; eidos, resemblance.] An independent alcyonarian zooid or individual (zool.).

auxetics (ǒksět'îks) n. plu. [Gk. auxein, to increase.] A term appl. chemical agents which induce celldivision in leucocytes and other cells (cyt.).

auximone (ŏk'simōn) n. [Gk. auximos, promoting growth.] An accessory growth-stimulating or promoting factor in the food of plants (biol.).

auxospore (ŏk'söspōr) n. [Gk. auxein, to increase; sporos, seed.] A diatom which, having reached its limit of size, by bi-partition escapes from its valve, and uniting with a similar one gives rise to a new plant (bot.).

auxotonic (ǒk'sötŏn'îk) a. [Gk. auxein, to increase ; tonos, strain.] Induced by growth; $a p p l$. movements of immature plants; $o p p$. alassotonic (bot.) ; appl. contraction against an increasing resistance (phys.). 
avenaceous (ăvĕnā'shŭs) $a$. [L. avena, oats.] Pert. oats (bot.).

avicularium (ăvǐkūlā'rǐum) $n$. [L. avicula, dim. of avis, bird.] In Polyzoa a modified zooecium with muscular movable attachments resembling a bird's beak (zool.).

awn (ôn) n. [Ger. ahne, chaff.] The "beard" of grass, grain, etc. (bot.).

axial (ăk'šăl) a. [L. axis, axis.] Pert. axis or stem (biol.).

axial filament,- the central filament of any structure such as the stiff radiating pseudopodia of some of the Protozoa (zool.)

axial sinus, - a nearly vertical canal in the Echinoderms opening into the internal division of the oral ring sinus, and communicating aborally with the stone canal (zool.).

axial skeleton, - the skeleton of the head and trunk, as opp. the skeleton of the limbs (zool.).

axil (ăk'sǐl) n. [L. axilla, arm-pit.] The angle between a leaf or branch and the axis from which it springs (bot.).

axile (ăk'sǐl) a. [L. axilla, arm-pit.] Pert., situated in or belonging to the axis ; appl. placentation (bot.).

axilemma (ăk'silě̉m'ă) n. [L. axis, axis ; Gk, lemma, husk.] In medullated nerve fibres, the sheath supposed to surround the axial cylinder (anat.).

axilla (ăksil'ă) $n$. [L, axilla, arm-pit.] The arm-pit (anat.); an axil (bot.). axillary (ăk'š̌lărĭ, ăksīlărī) a. [L. axilla, arm-pit.] Pert. the axil; growing in the axil, as buds (bot.); pert. the arm-pit (anat.).

axipetal (ăksīp'êtăl) a. [L, axis, axis ; petere, to seek.] Passing towards the attachment of the axon, appl. nerve impulses (phys.).

axis (ăk'sis) $n$. [L. axis, axis.] The main stem or central cylinder (bot.); the fundamentally central line of a structure; the second cervical vertebra (anat.).

axis cylinder, - the central tract of a nerve fibre, the impulse transmitter (phys.).

axon (ăk'sŏn) n. [Gk. axon, axle.] The axis-cylinder process of a multipolar nerve-cell (anat.).

axoneme (ăk'sŏnēm) n. [Gk, axon, axle ; nema, thread.] One of the three threads of the main strand of an infusorian stalk (zool.).

axonost (ăk'sŏnŏst) n. [Gk. axon, axle; osteon, bone.] The basal portion of rods supporting the dermotrichia of fin-rays (zool.).

axopodium (ăk'söpō'diŭm) n. [Gk. axon, axle ; pous, foot.] A pseudopodium with axial filament (zool.).

axostyle (ăk'söstīl) $n$. [Gk. axon, axle ; stylos, pillar.] A slender flexible rod of organic substance forming a supporting axis for the body of many Flagellates (zool.).

azygobranchiate (âzígöbrăng'kīāt) $a$. [Gk. a, without ; zygon, yoke ; brangchia, gills.] Having the gills or ctenidia not developed on one side (zool.).

azygomatous (ấzīgŏm'ătŭs) a. [Gk. $a$, without ; zygoma, a bar.] Without a zygoma or cheek-bone arch (zool.).

azygos (ăzí'gŏs, ăzígŏs) $n$. [Gk. $a$, without; zygon, yoke.] An unpaired muscle, artery, vein, process (anat.).

azygosperm (âzí'göspěrm) n. [Gk. $a$, without ; zygon, yoke ; sperma, seed.] An azygospore.

azygospore (âzi'göspōr) $n$. [Gk, a, without ; zygon, yoke ; sporos, seed.] A spore developed directly from a gamete without conjugation (bot.).

azygous (ăzígŭs, ăz'igŭs) a. [Gk. $a$, without; zygon, yoke.] Unpaired.

\section{B}

bacca (băk'ã) n. [L. bacca, berry.] A pulpy fruit (bot.).

baccate (băk'ât) $a$. [L. bacca, berry.] Pulpy, fleshy (bot.),

bacciferous (băksiff'ěrŭs) a. [L. bacca, berry; ferre, to bear.] Berry-producing (bot.).

bacciform (băk'sǐfôrm) $a$, [L. bacca, berry; forma, shape.] Berryshaped (bot.).

bacillus (băsĭlŭs) $n$. [L. bacillum, small stick.] An elongated rodlike bacterium; a single-celled fungus (bot.).

bacteriology (băk'tērǐŏl'öjī) n, [Gk. 
bakterion, rod; logos, discourse.] The science dealing with the lifehistory, structure, and effects of Bacteria.

bacteriolysin (băktê'rïöli’sĭn) $n$. [Gk. bakterion, small rod ; lyein, to loose.] A substance which neutralizes the toxicity of or destroys Bacteria (phys.).

balancers (bălănsërz) n. plu. [L. bilanx, having two scales.] The halteres or poisers of dipterous insects (zool.).

balanoid (bălănoid) a. [Gk. balanos, acorn; eidos, like.] Pert. barnacles; acorn-shaped (zool.).

balausta (bălôs'tă) $n$. [Gk. balaustion, tree-blossom.] Any fruit, manycelled, many-seeded, indehiscent and with tough pericarps (bot.).

baleen (bălēn') $n$. [L. balaena, whale.] The horny plates attached to the upper jaw of true whales; whalebone (zool.).

balm (bâm) $n$. [L. balsamum, balsam.] A fragrant garden plant ; a soothing ointment (bot.).

balsamiferous (băl'sămǐf'ěrŭs) $a$. [L. balsamum, balsam ; ferre, to bear.] Producing balsam (bot.).

barb (bârb) n. [L.barba, beard.] One of delicate thread-like structures extending obliquely from a feather rachis, and forming the vane (zool.) ; a hooked hair-like bristle (bot.).

barbate (bâr'bāt) $a$. [L. barba, beard.] Bearded (bot., zool.).

barbel (bâr'běl) n. [L. barbus, barbel.] A tactile process arising from the head of various fishes (zool.).

barbellate (bârbělāt, bâr'bělāt) $a$. [L. barba, beard.] With stiff hooked hair-like bristles (bot.).

barbicel (bâr'bĭsěl) n. [L. barba, beard.] Small process on a feather barbule (zool.).

barbula (bâr'būlă) $n$. [L. barbula, dim. of $b a r b a$, beard.] Row of teeth of the peristome of mosses (bot.).

barbule (bâr'būl) n. [L. barbula, dim. of $b a r b a$, beard.] One of the small hooked processes fringing the barbs of a feather (zool.).

barotaxis (băroötăk'šss) n. [Gk. baros, weight ; taxis, arrangement.] The reaction against a pressure stimulus (phys.). basal (bā'săl) a. [L. basis, base.] Pert. at or near the base.

basal ganglia,-ganglia connecting cerebrum with other centres (phys.).

basal granule, - a thickening at the base of a flagellum, the centrosome, in certain Protozoa (zool.).

basal leaf,- - one of the leaves produced near the base of the stem (bot.).

basal placenta,-arises from the proximal end of ovary (bot.).

basal plates, - certain plates in Echinoderms, which are situated at the top or near the top of the stalk in Crinoids, and in Echinoids form part of the apical disc (zool.).

basal wall, - the first plane of division of the oospores of Ferns and Mosses (bot.).

basale (băsā'lē, băsâl'ā) n., basalia (băsắliă) plu. [L. basis, base.] A bone of variable structure arising from the fusion of pterygiophores and supporting fish fins (zool.).

basement membrane,- themembrane of a gland containing the acini or special secreting portions (anat.).

basialveolar (bä'siălvế'ölăr) a. [L. basis, base; alveolus, hollow.] Extending from basion to centre of alveolar arch (anat.).

basibranchial (bä'sǐbrăng'kiăl) n. [Gk. basis, base ; brangchia, gills.] The median ventral or basal skeletal portion of a branchial arch (zool.).

basichromatin (bā'sǐkrō'mătĭn) $n$. [Gk. basis, base ; chroma, colour.] The deeply staining substance of nuclear network; chromatin (cyt.).

basiconic sensillae,-upright conical clavate sense hairs, immovable at their base and having thin chitinous covering (zool.).

basicranial (bä'sìkrā'nŭl) a. [Gk. basis, base ; kranion, skull.] Situated at the base of the skull (zool.).

basidiophore (băsǐd'ioöfōr) $n$. [Gk. basis, base; pherein, to bear.] A sporophore which carries basidia (bot.).

basidiospore (băsǐd'ǐöspōr) n. [Gk. basis, base; sporos, seed.] A spore or gonidium abstricted from 
a basidium; a basidiogonidium (bot.).

basidium (băsĭd'iŭm) n. [Gk. basis, base.] A special cell of certain Fungi forming spores by abstriction (bot.).

basidorsal (bā'sǐdôr'săl) a. [L. basis, base ; dorsum, back.] Appl. a small cartilaginous neural plate which fuses with the neural process in the adult (emb.).

basifixed (bā'sĩfîksd) a. [L. basis, base ; figere, to make fast.] Attached by the base; innate, or having the filament attached to base of anther (bot.).

basifugal (bā'sǐfū'găl, bāsĩf'ūgăl) $a$. [L. basis, base; fugere, to flee.] Growing away from the base (bot.).

basigamous (băsĭg'ămŭs) $a$. [Gk. basis, base; gamos, marriage.] Having the oosphere reversed in the embryo-sac (bot.).

basihyal (bā'sǐhíăl) $n$. [Gk. basis, base ; hyoeides, Y-shaped.] Broad median plate, the basal or median ventral portion of the hyoid arch (zool.).

basilar (băs'îlăr) a. [L. basis, base.] Pert. or near the base ; $a p p l$. artery, crest, membrane, plexus (anat.), plate (emb.), style (bot.).

basilic (băsǐlîk) a. [Gk. basilikos, royal.] $A p p l$. a large vein on the inner side of the biceps of the arm (anat.).

basilingual (bā'sīlìng'gwăl) a. [L. basis, base ; lingua, tongue.] Appl. a broad flat cartilaginous plate, the body of the hyoid, in crocodiles, turtles, and amphibians (zool.).

basioccipital (bā'siǒksĭp'ítăl) $n$. [L. basis, base ; occiput, back of head.] The median ventral bone or element in the occipital region of the skull (anat.).

basion (bä'šŏn) $n$. [L. basis, base.] The middle of the anterior margin of the foramen magnum (anat.).

basiophthalmite (bā'sĩŏfthăl'mīt) $n$. [Gk. basis, base; ophthalmos, eye.] The proximal joint of the eye-stalk in Crustaceans (zool.).

basipetal (băsĭp'ětăl) a. [Gk. basis, base ; L. petere, to seek.] Developing from apex to base; appl. leaves and inflorescences (bot.). basipodite (băsǐp'ödīt) n. [Gk. basis, base; pous, foot.] The second or distal joint of the protopodite of certain limbs of Crustacea (zool.).

basipterygium (bä'sĭptěrǐj'iŭm) $n$. [Gk. basis, base; pterygion, little wing.] A large flat triangular bone in the pelvic fin of Teleosts, and a bone or cartilage in other fishes (zool.).

basipterygoid (bā'sīptěr'ìgoid) n. [Gk. basis, base ; pterygion, little wing.] A process of the basisphenoid in some birds (zool.).

basisphenoid (bā'sǐsfếnoid) $n$. [Gk. basis, base; sphen, wedge ; eidos, resemblance.] A cranial bone between the basioccipital and presphenoid (zool.).

basitemporal (bā'sĭtěm'pörăl) $n$. [L. basis, base ; temporalis, temporary.] A broad membrane bone covering the basisphenoidal region of the skull (zool.).

basivertebral (bā'sivěr'těbrăl) a. [L. basis, base ; vertebra, vertebra.] $A p p l$. vertebral veins emerging on the posterior surface (anat.).

basophil (bā'söfîl) a. [Gk. basis, base; philein, to love.] Appl. leucocytes having a strong affinity for basic dyes (phys.).

bast (băst) n. [A.S. baest, bast.] The inner fibrous bark of certain trees; the strong fibre obtained from certain trees; phloem (bot.).

bastard wing, - the ala spuria, consisting of three quill feathers borne on the first digit of bird's wing (zool.).

bathylimnetic (băth'îlimnĕt'îk) $a$. [Gk. bathys, deep; limnetes, living in marshes.] Living or growing in the depths of lakes or marshes.

bathypelagic (băth'ipělăj'ik) a. [Gk. bathys, deep; pelagos, sea.] Inhabiting the deep sea (sool.).

bathysmal (băthǐz'măl) a. [Gk.bathys, deep.] Pert. the deepest depths of the sea (rool.).

batrachian (bătrā'kǐăn) a. [Gk, batrachos, frog.] Relating to frogs and toads (zool.).

bdelloid (děloid) a. [Gk. bdella, leech; eidos, resemblance.] Leechlike, or having the appearance of a leech (zool.). 
beard (bērd) $n$. [A.S. beard, a beard.] Any of the arrangements of hairs on the heads of animals which resemble a man's beard (zool.); the barbed or bristly hair-like outgrowths on grain (bot.).

belemnoid (běl'ĕmnoid, bělěm'noid) $a$. [Gk. belemnon, dart ; eidos, resemblance.] Shaped like a dart (zool.); $a p p l$. styloid process (anat.).

bell nucleus, - a solid mass of cells, derived from the ectoderm and lying between the ordinary ectoderm and the mesogloea at the apex of the medusoid bud, which later becomes hollow and ultimately forms the sub-umbral cavity of the medusoid (zool.).

Bellini's ducts, - the larger ducts opening at the apex of a kidney papilla, and formed by the union of smaller collecting tubules (anat.).

benthos (běn'thŏs) n. [Gk. benthos, depths of the sea.] The fauna and flora of the bottom of the sea (biol.).

berry (bĕr'î) n. [A.S. berie, berry.] The egg of a lobster, or of a crayfish; the dark knob-like structure on the bill of the swan (zool.); a small, pulpy fruit (bot.).

betulin (bět'ūlinn) $n$. [L. betula, birch tree.] A substance derived from the outer bark of the birch (phys.).

biacuminate (bĭăkū'mināt) $a$. [L. bis, twice; acumen, point.] Having two tapering points (bot.).

biarticulate (bíârtík'ūlăt) a. [L. bis, twice ; articulus, joint.] Twojointed (bot., zool.).

bicapsular (bīkăp'sūlăr) a. [L. bis, twice ; capsula, little box.] Having two capsules or vessels (bot.).

biearinate (bīkăr'ināt) a. [L. bis, twice ; carina, keel.] With two keel-like processes (bot., zool.).

bicarpellate (bīkâr'pělāt) $a$. [L. bis, twice ; Gk. karpos, fruit.] With two carpels (bot.).

bicaudate (bīkốdāt) a. [L. bis, twice ; cauda, tail.] Possessing two taillike processes, as the wings of Lepidoptera (zool.).

bicellular (bīsěl'ūlăr) a. [L. bis, twice ; cellula, little cell.] Composed of two cells (bot.).

biceps (bísĕps) $n$. [L. bis, twice; caput, head.] A muscle with two heads or origins (anat.).

bicipital (bīsı̌p'ítăl) a. [L. bis, twice ; caput, head.] Pert. biceps (anat.).

bicipital groove, - a groove on the upper part of the humerus (anat.).

bicollateral (bī'kǒlăt'ěrăl) $a$. [L. bis, twice ; con, together; latus, side.] Having the two sides similar.

bicolligate (bīkŏl'ígāt) a. [L. bis, twice; cum, together; ligare, to bind.] With two stretches of webbing on the foot (zool.).

biconjugate (bìkŏn'joogāt) a. [L. bis, twice ; cum, with ; jugum, yoke.] With two similar sets of pairs (bot.).

bicornute (bīkôr'nūt) a. [L. bis, twice; cornu, horn.] With two horn-like processes (zool.).

bicostate (bīkǒs'tāt) a. [L. bis, twice ; costa, rib.] Having two longitudinal ridges or ribs, as in a leaf (bot.).

bicrenate (bīkrē'nāt) a. [L. bis, twice ; crena, notch.] Doubly crenate, as leaves with notched toothed margins (bot.).

biscuspid (bīkǔs'pĭd) a. [L.bis, twice ; cuspis, point.] Having two cusps or points (bot., zool.).

bicuspid, $-n$. A premolar tooth (anat.).

bicuspid valve,-the mitral valve of the heart (anat.).

bicyclic (bīsìk'likk) a. [L. bis, twice ; Gk. kyklos, circle.] Arranged in two whorls (bot.).

Bidder's ganglia, - a collection of nerve-cells in the frog, in the region of the auriculo-ventricular groove, whence fibres are distributed to the rest of the heart (zool.).

Bidder's organ, - a rudimentary ovary attached to the anterior end of the generative organs in both sexes in the toad; it disappears in old females, but is large in old males and has been known to become functional (zool.).

bidental (bĩdĕn'tăl) a. [L. bis, twice ; dens, tooth.] Having two teeth, or tooth-like processes.

bidenticulate ( $\mathrm{b}^{\prime}$ děntǐk'ūlāt) $a$. [L. bis, twice; dens, tooth.] With two small teeth or tooth-like processes, as some scales (zool.).

biennial (biěñ'iăl) a. [L. bis, twice; 
annus, year.] Lasting for two years (bot.).

bifacial (bīfā'siăl, bīfā'shăl, bīfās'yăl) a. [L. bis, twice; facies, face.] $A p p l$. leaves with distinct upper and lower surfaces; dorso-ventral (bot.).

bifarious (bīfā'rĭŭs) a. [L. bis, twice ; fari, to speak.] Arranged in two rows; one row on each side of an axis (bot.).

bifid (bĭf'id) $a$. [L. bis, twice; findere, to split.] Forked, opening with a median cleft (zool., bot.).

biflabellate (bî́flăbĕl'āt) a. [L. bis, twice; flabellum, fan.] Doubly flabellate, each side of the antennal joints sending out flabellate processes (zool.).

biflagellate (bīflăjěl'āt) a. [L. bis, twice ; flagellum, whip.] Having two lash-like appendages or flagella (zool., bot.).

biflex (bíflěks) a. [L. bis, twice; flectere, to bend.] With two curves.

biflorate (bīflō'rāt) a. [L. bis, twice ; flora, flowers.] Producing two flowers, or bearing two flowers (bot.).

bifoliate (bīfō'liāt) a. [L. bis, twice ; folium, leaf.] $A p p l$. compound leaf with two leaflets (bot.).

biforin (bif'örĭn) $\boldsymbol{n}$. [L. bis, twice ; foris, door.] An oblong raphidian cell opening at each end (bot.).

bifurcate (bífŭr'kāt) a. [L. bis, twice; furca, fork.] Forked; having two prongs (bot., zool.); having two joints, the distal V-shaped and attached by its middle to the proximal (zool.).

bigeminate (bījĕm'ināt) $a$. [L. bis, twice ; geminus, double.] Doublypaired ; twin-forked (bot.).

bijugate (bījoo'gāt) a. [L. bis, twice ; jugare, to join.] With two pairs of leaflets (bot.).

bilabiate (bīlā'biāt) a. [L. bis, twice ; labium, lip.] Two-lipped, as some corollas (bot.).

bilamellar (bỉlăm'ělăr, bīlăměl'ăr) $a$. [L. bis, twice; lamella, plate.] Formed of two plates; having two lamellae (bot., zool.).

bilaminar (billăm'inăr) a. [L. bis, twice; lamina, thin plate.] Having two plate-like layers; diploblastic (zool.).

bilateral (bîlăt'ĕrăl) a. [L. bis, twice; latus, side.] Having two sides symmetrical about an axis.

bile (bìl) $n$. [L. bilis, bile.] The secretion of the liver (phys.).

biliary (bil'iărĭ) a. [L. bilis, bile.] Conveying or pert. bile (phys.).

bilifcyanin (bǔl'ísî́ănìn) $n$. [L. bilis, bile; Gk. kyanos, dark blue.] A blue pigment found in renal calculi (phys.).

bilirubin (bill'ǐroo'bìn) $n$. [L. bilis, bile ; ruber, red.] A reddish-yellow bile pigment (phys.).

biliverdin (b̌llìvĕr'din) $n$. [L. bilis, bile; F. vert, green.] A green bile pigment formed by oxidation of bilirubin (phys.).

bilobate (bìlō'bāt) a. [L. bis, twice; Gk. lobos, rounded flap.] Having two lobes.

bilobular (bīlǒb'ūlăr) a. [L. bis, twice; L. lobulus, dim. of lobus, lobe.] Having two lobules.

bilocellate (bïllösěl'āt) a. [L. bis, twice ; locellus, dim. of locus, place.] Divided into two compartments (bot.).

bilocular (bīlǒk' ūlăr) a. [L. bis, twice; locus, place.] Containing two cavities or chambers (bot.).

biloculine (bīlǒk'ūlĭn) a. [L. bis, twice; loculus, little place.] Twochambered.

bilophodont (bĩlŏf'ödŏnt) a. [L. bis, twice; Gk. lophos, ridge ; odous, tooth.] Appl. molar teeth of tapir, which have ridges joining the two anterior and two posterior cusps (zool.).

bimaculate (bīmăk'ūlāt) $a$. [L. bis, twice; macula, spot.] Marked with two spots or stains (zool.).

bimanous (bìm'ănŭs) $a$. [L. bis, twice; manus, hand.] Having two hands; $a p p l$. certain of the primates (zool.).

bimastism (bīmăs'tǐzm) $n$. [L. bis, twice; Gk. mastos, breast.] Condition of having two manmae (sool.).

bimuscular (bïmŭs'kūlăr) $a$. [L. bis, twice; musculus, muscle.] Having two muscles (zool.).

binary fission, - the division of a cell into two by an apparently simple 
division of nucleus and cytoplasm (zool.).

binary nomenclature,-see binomial nomenclature.

binate (bínāt) $a$. [L. bini, two by two.] $A p p l$. leaf composed of two leaflets; growing in pairs (bot.).

binodal (bīnō'dăl) a. [L. bis, twice; nodus, nob.] Having two nodes, as the stem of a plant (bot.).

binomial (bīnō'miăl) a. [L. bis, twice; nomen, name.] Consisting of two names (biol.).

binomial nomenclature,-the system of double names given to plants and animals, - first the generic name, then the specific, as Felis (genus) tigris (species).

binomialism (bīnōmiălìzm) $n$. [L. bis, twice; nomen, name.] The system of binomial nomenclature (biol.).

binuclear (bīnū'klě̆r) a. [L. bis, twice ; nucleus, small nut.] Having two nuclei (biol.).

binucleate,-binuclear.

bioblast (bïöblăst) $n$. [Gk. bios, life ; blastos, bud.] A biophore (biol.).

biocellate (biösěl'āt) $a$. [L. bis, twice ; ocellus, dim. of oculus, eye.] Having two ocelli (zool.).

biochemistry (bïökěm'îstrì) $n$. [Gk. bios, life; chemos, juice.] The chemistry of living organisms (biol.).

biocoenosis (bī'ösēnō'siss) $n$. [Gk. bios, life ; koinos, common.] Association of forms of life on any given feeding area (biol.).

biodynamics (bî́ödinăm'îks) $n$. [Gk. bios, life ; dynamis, power.] The science of the active vital phenomena of animals (phys.).

biogen (bīöjën) $n$. [Gk, bios, life ; genos, offspring.] A hypothetical vital unit (biol.).

biogenesis (bî́öjĕn'ěsǐs) $n$. [Gk, bios, life ; genesis, birth.] The theory of the descent of living matter from living matter-omne vivum e vivo; opp. abiogenesis (biol.).

biogenetic law, - recapitulation theory.

biogenous (bīŏj'ěnŭs) $a$, [Gk. bios, life; genos, offspring.] Inhabiting living organisms, as Bacteria (biol.).

biogeny (bīŏjĕnǐ) $n$. [Gk. bios, life : genesis, birth.] The science of the evolution of organisms, comprising ontogeny and phylogeny (biol.).

biogeography (bî́öjēŏg'răfî) $n$. [Gk. bios, life; ge, earth; graphein, to write.] The part of biology dealing with the geographical distribution of plants (phytogeography) and animals (zoogeography); chorology. biological (biölöj'îkăl) a. [Gk. bios, life; logos, discourse.] Relating to the science of life (biol.).

biology (bïǒl'öjî) $n$. [Gk. bios, life ; logos, discourse.] The science of life.

biometrics (bīömĕt'rǐks) n. [Gk. bios, life; metron, measure.] The statistical study of living organisms.

biometry (bĩŏm'ětrǐ), biometrics.

bion (bî́ŏn) n. [Gk. bion, living.] An independent living organism.

bionergy (bīŏn'ěrjĭ) n. [Gk. bios, life : energeia, action.] Vital force.

bionomics (bīönŏm'r̂ks) n. [Gk. bios, life; nomos, law.] The study of organisms in relation to their environment.

biophore (bïöför) n. [Gk. bios, life ; pherein, to carry.] A hypothetical vital unit, of which a group forms a determinant.

biophyte (bīöfīt) $n$. [Gk. bios, life ; fhyton, plant.] A plant which gets sustenance from living organisms (biol.).

bioplasm (bïöplăzm) $n$. [Gk. bios, life ; plasma, something moulded.] Living matter; protoplasm (biol.).

bioplast (bî́öplăst) $n$. [Gk. bios, life ; plasma, something moulded.] A minute quantity of living protoplasm capable of reproducing itself (biol.).

biorgan (bîố'găn) n. [Gk. bios, life ; organon, instrument.] An organ in the physiological sense, not necessarily a morphological unit (biol.).

bios (bíŏs) n. [Gk. bios, life.] Organic life, plant or animal.

biostaties (bîööstăt'îks) n. [Gk. bios, life; statos, stationary.] The branch of physiology dealing with structure in relation to function (phys.).

biota (bīōtă) $n$. [Gk. bios, life.] The fauna and flora of a region.

biotic (bīŏt'̂k) a. [Gk. bios, life.] Pert. life ; vital (biol.).

biotonus (bìötōnŭs) n. [Gk. bios, 
life; tonos, strain.] The ratio between assimilation and dissimilation of the biogens ( $p h y s$. .).

biovulate (bīŏv'ülāt) a. [L. bis, twice; ovum, egg.] Containing two ovules (bot.).

bipaleolate (bīpăl'ěölāt) a. [L. bis, twice ; palea, chaff.] Furnished with two small paleae (bot.).

bipalmate (bīpăl'māt) a. [L. bis, twice; palma, palm of the hand.] Lobed with the lobes again lobed (bot.).

biparietal (bīpărīětăl) a. [L. bis, twice; paries, wall.] Linking up or connected with the two parietal eminences (anat.).

biparous (bǐp'ărŭs) a. [L. bis, twice ; parere, to beget.] Having two young at a time (zool.).

bipectinate (bīpěk'tǐnāt) a. [L. bis, twice; pecten, comb.] Having the two margins furnished with teeth like a comb (bot., zool.).

biped (bípěd) $n$. [L. bis, twice ; pes, foot.] A two-footed animal.

bipenniform (bīpěn'îfôrm) $a$. [L. bis, twice; penna, feather; forma, shape.] Feather-shaped, with the sides of the vane of equal size; $a p p l$. some muscles (anat.).

bipetalous (bīpět'ălŭs) a. [L. bis, twice; Gk.petalon, leaf.] With two petals (bot.).

bipinnaria (bīpinā'riă) $n$. [L. bis, twice; pinna, feather.] An asteroid larva with pre-oral and post-oral bands of cilia (zool.).

bipinnate (bīpln'āt) a. [L. bis, twice ; pinna, feather.] Having leaflets growing in pairs on paired stems (bot.).

bipinnatifid (bīpinăt'ifid) a. [L. bis, twice; pinna, feather; findere, to cleave.] With leaves segmented and these segments again divided (bot.).

bipinnatipartite (bípinnăt'ípârtīt) $a$. [L. bis, twice; pinna, feather; partiri, to divide.] Bipinnatifid, but with divisions extending nearly to the midrib (bot.).

bipinnatisect - (bípinăt'isěkt) $a$. [L. bis, twice ; pinna, feather ; secare, to cut.] Bipinnatifid, but with divisions extending to the midrib (bot.). biplicate (bìp'lǐkāt) a. [L. bis, twice ; plicare, to fold.] Having two folds. bipocillus (bî́pösı̌l'ǔs) $n$. [L. bis, twice; pocillum, a little cup.] A microsclere with curved shaft and cup-shaped expansion at each end (zool.).

bipolar (bīpó'lăr) a. [L. bis, twice ; Gk. polos, pivot.] Having a process at each end or pole, appl. nerve cells (anat.).

bipolarity (bỉpölăr'ítĩ) n. [L. bis, twice; Gk. polos, pivot.] The condition of having two polar processes; the condition of having two distinct poles, as the vegetative and animal poles in an egg (biol.).

biramose (bīrā'mōs) a. [L. bis, twice ; ramus, branch.] Divided into two branches.

biramous,-biramose.

birostrate (bīrŏs'trāt) a. [L. bis, twice; rostrum, beak.] Furnished with two beak-like processes.

birth pore, - the uterine pore of Trematodes and Cestodes; the birth-opening of the rediae of Trematodes (zool.).

biseptate (bīsěp'tāt) a. [L. bis, twice ; septum, fence.] Having two partitions.

biserial (bīsē'riăl) a. [L. bis, twice ; series, series.] Arranged in two rows.

biserrate (bīsěr'āt) a. [L. bis, twice; serra, saw.] Having marginal teeth which are themselves notched (bot.).

bisexual (bīsěk'sūăl, bīsěk'shūăl) a. [L. bis, twice; sexus, sex.] Having both male and female reproductive organs (biol.).

bistephanic (bî'stěfăn'îk) a. [L. bis, twice; Gk. stephanos, crown.] Joining the two points where the coronal suture crosses the superior temporal ridges (anat.).

bistipulate (bīstǐp'ūlāt) a. [L. bis, twice; stipula, stem.] Provided with two stipules (bot.).

bistratose (bîstrăt'ōs) a. [L. bis, twice; stratum, layer.] With cells arranged in two layers (bot.).

bisulcate (bīsǔl'kāt) a. [L. bis, twice ; sulcus, groove.] Havingtwogrooves (zool.).

bitemporal (bïtěm'pörăl) a. [L. bis, twice; temporalis, temporary.] 
Appl. the two temporal bones; a line joining the posterior ends of the two zygomatic processes (anat.).

biternate (bītěr'nāt) a. [L. bis, twice ; terni, three by three.] Ternate with each division itself again ternate (bot.).

bivalent (bīvā'lěnt, bǐv'ălěnt) $a$. [L. bis, twice; valere, to be strong.] Appl. a double chromosome (cyt.).

bivalve (bī'vălv) a. [L. bis, twice; valvae, folding doors.] Consisting of two plates or valves, as a mussel shell (zool.); or a seed-capsule of similar structure (bot.).

biventer cervicis (bîvēn'tĕr sĕrvi'sǐs) $n$. [L. bis, twice; venter, belly ; cervix, neck.] A muscle of the neck consisting of two fleshy broad ends with a narrow tendinous portion in the middle (anat.).

biventral (bīvĕn'trăl) $a_{3}$ [L. bis, twice; venter, belly.] Appl.muscles of the biventer type (anat.).

bivittate (bĩvit'āt) a. [L. bis, twice; vitta, band.] With two oil receptacles (bot.); with two stripes (zool.).

bivium (bĭv'iŭm) $n$. [L, bis, twice ; via, way.] Generally the posterior pair of ambulacral areas in certain Echinoidea; the two rays between which the madreporite lies (zool.).

bladder (blăd'ër) $n$. [A.S. blaedre, bag.] A membranous sac filled with air or fluid (bot., zool.).

bladderworm stage,- the cysticercus stage in tapeworms (zool.).

blade (blād) n. [A.S. blaed, leaf.] The flat part of the leaf of grasses (bot.).

blastaea (blăstē'ă) n. [Gk. blastos, bud.] A planaea or ciliated planula, a hypothetical stage in evolution (biol.).

blastelasma (blăs'tĕlăz'mă) n., blastelasmata (blăs'tělăz'mătă) plu. [Gk. blastos, bud; elasma, plate.] Any germ layer formed after the formation of the epiblast and hypoblast (emb.).

blastema (blăstē'mă) n., blastemata (blăstē'mătă) plu. [Gk, blastema, bud.] The formative substance in an egg; the primordium of an $\operatorname{organ}(e m b$.$) ; the thallus of a lichen$ (bot.). blastocarpous (blăs'tökâr'pŭs) $a$. [Gk. blastos, bud; karpos, fruit.] Developing while still surrounded by the pericarp (bot.).

blastocheme (blăs'tökēm) n. [Gk. blastos, bud ; ochema, vessel.] A reproductive individual in some Medusae (zool.).

blastochyle(blăs'tökīl)n. [Gk. blastos, bud; chylos, juice.] The fluid in a blastocoel, or segmentation-cavity (zool.).

blastocoel (blăs'tösēl) $n$. [Gk. blastos, bud; koilos, hollow.] Thesegmentation-cavity of a developing ovum (emb.).

blastocolla (blăs'tökŏl'ă) n. [Gk. blastos, bud; kolla, glue.] A gummy substance coating certain buds (bot.).

blastocyst (blăs'tösı̌st) $n$. [Gk. blastos, bud; kystis, bladder.] The germinal vesicle $(\mathrm{emb}$.).

blastoderm (blăs'tödĕrm) $n$. [Gk. blastos, bud; derma, skin.] 'The germinal disc (emb.).

blastodermic vesicle,-ahollow sphere of cells, an early stage in the development of a fertilized ovum (emb.).

blastodisc(blăs'tödǐsk) n. [Gk.blastos, bud; diskos, disk.] The germinal area of a developing ovum (emb.).

blastogenesis (blăs'töjĕn'ěsis) $n$. [Gk. blastos, bud; genesis, birth.] Gemmation or reproduction by budding; transmission of inherited characters by means of the germplasm only (biol.).

blastogenic (blăs'töjĕn'îk) a. [Gk. blastos, bud; genos, offspring.] $A p p l$. inactive idioplasm unalterable till time and place of activity are reached (emb.).

blastomere (blăs'tömēr) n. [Gk. blastos, bud ; meros, part.] One of the cells formed during the primary divisions of an egg (emb.).

blastoneuropore (blăs'tönư'röpōr) $n$. [Gk. blastos, bud ; neuron, nerve ; poros, passage.] A temporary passage connecting blastopore and neuropore (emb.).

blastophore (blăs'töfōr) n. [Gk.blastos, bud;pherein, to bear.] Embryonic origin of plumule (bot.) ; in Alcyonaria the reproductive body, giving rise usually to buds; the central part of the spermocyte mass in 
worms, which remains unchanged through spermatogenesis (zool.).

blastopore (blăs'töpōr) $n$. [Gk. blastos, bud; poros, passage.] The cavity leading into the archenteron of the gastrula (emb.).

blastosphere (blăs'tösfēr) n. [Gk. blastos, bud ; sphaira, globe.] The blastula, a hollow ball of cells (emb.).

blastostyle (blăs'töstīl) n. [Gk. blastos, bud; stylos, pillar.] In Hydrozoa, a columniform zooid with mouth and tentacles, or with mouth and tentacles absent, bearing gonophores (zool.).

blastozooid (blăs'tözōoid) n. [Gk. blastos, bud; zoon, animal ; eidos, resemblance.] A larval bud in case of precocious budding in Ascidians (zool.).

blastula (blăs'tūlă) $n$. [L. dim. of Gk. blastos, bud.] A hollow globe of cells, with wall usually one layer thick $(e m b$.).

blastulation (blăs'tūlā'shŭn) $n$. [L. blastula, little bud.] Formation of blastulae (emb.).

bleeding of plants,-exudation of watery sap from vessels at a cut surface, due to root-pressure (bot.).

blended inheritance,-mixed race or descent.

blendling (blĕn'dlĭng) $n$. [A.S. blandan, to mix.] A hybrid.

blepharoblast (blěf'ăröblăst) $n . \quad[\mathrm{Gk}$. blepharon, eye-lid; blastos, bud.] See blepharoplast.

blepharoplast (blëf'ăröplăst) n. [Gk. blepharon, eyelid; plastos, moulded.] A centrosome which is in relation to a motor cell organ, as to the flagellum of flagellates $(z \circ o l$.).

blight (blit) $n$. [A.S. blaecan, to grow pale.] A disease-producing insect or fungus ; a plant disease (bot.).

blind spot,- - the region of the retina of the eye where the optic nerve enters (anat.).

blister (blǐs'těr) $n$. [A.S. blowan, to blow.] A subcutaneous bubble or bladder filled with fluid; a plant disease.

blood (blŭd) $n$. [A.S. blód, blood.] The fluid circulating in the vascular system of animals, distributing foodmaterial and oxygen and collecting waste products (phys.). blood cells,-cells derived by mitosis from the ordinary mesoderm cells, at first somewhat similar to lymphocytes; the primitive haematoblasts (phys.).

blood crystals,-crystals of haemoglobin, haemin, or haematoidin, which form when blood is shaken up with chloroform or ether (phys.). blood dust, - the form in which fat is seen in blood cells, by means of the ultramicroscope (phys.).

blood islands, - isolated reddish patches in the mesoderm in which primitive erythroblasts are found enclosed in a mesodermal syncytium (phys.).

blood platelets, - colourless bodies about one-third the size of the red corpuscles, and nucleated when the red corpuscles are nucleated ( $p h y s$.$) .$

blood plates,- minuteamoeboid protoplasmic bodies found in the blood, each with a small nuclear-like structure (phys.).

blood serum,- - the fluid or plasma left after removal of the corpuscles and fibrin (phys.).

blood vessel,- any vessel or space in which blood circulates; strictly only used in regard to special vessels with well-defined walls (anat.).

bloom,-a layer of wax particles on the external surface of certain fruits, such as grapes, peaches; the flower of a plant (bot.).

blubber (blŭb'ër) n. [M.E. blober, a bubble.] The fat of whales, lying between the outer skin and muscle layer (zool.).

blue timber, - a wood disease produced by fungus, causing a bluish discoloration (bot.).

body blight, - a fungal disease of pear trees (bot.).

body cavity, - the coelom or space in which the viscera, etc., lie ; it is mesodermal in origin, and is schizocoelic or enterocoelic in development (anat.).

body cell, - a somatic as distinct from a germ cell.

body stalk, - a band of mesoderm connecting the caudal end of an embryo with the chorion (emb.). bone (bōn) n. [A.S.ban, bone.] Con- 
nective tissue in which the groundsubstance is impregnated with salts of lime (anat.).

book gill,- - gill composed of delicate leaf-like lamellae placed one over the other like leaves of a book, as seen in Limulus (zool.).

book lung,- - a gill similar to a book gill, but modified for air-breathing, and open to the exterior only by a small slit, as in Scorpions (zool.).

booted (boot'ěd) $a$. [O.F. boute, boot.] Equipped with raised horny plates of skin, as feet of some birds (zool.).

bordered pit, $-\mathrm{a}$ form of pit developed on the walls of tracheides, caused by a portion of the wall remaining unthickened (bot.).

bosselated (bǒs'êlātëd) a. [M.E. bosse, knob.] Covered with knobs, as some mollusc shells (zool.).

bosset (bŏs'ĕt) $n$. [M.E. bosse, knob.] The beginning of horn formation in deer in the first year (zool.).

bostryx (bŏs'trĭcks) n. [Gk. bostrychos, curl.] A cymose inflorescence with blooms on only one side of the axis (bot.).

botany (bǒt'ănǐ) n. [Gk. botane, pasture.] That branch of biology dealing with plants.

bothridium (bŏthrĩd'ium) $n$. [Gk. bothros, trench.] A muscular cupshaped outgrowth from scolex of Cestoids ; a phyllidium (zool.).

bothrium (bŏth'ruŭm) n. [Gk. bothros, trench.] A sucker; a sucking groove of Cestoids (zool.).

botryoidal (bŏt'rǐoidăl) a. [Gk. botrys, bunch of grapes.] Appl. tissue of branched canals surrounding the enteric canal in leeches (zool.).

botryose (bŏt'rīōs) a. [Gk. botrys, bunch of grapes.] Racemose; in the form of a bunch of grapes (bot.).

bouillon (boo'yŏng) n. [F. bouillir, to boil.] An infusion of beef for the cultivation of germs (phys.).

Bowman's capsule, - the vesicle of an excretory tubule, one side of which projects into the other, nearly filling the cavity (anat.).

Bowman's glands (bō'mănz),- serous glands in the corium of the olfactory mucous membrane (anat.). braccate (brăk'āt) a. [L. braccae, breeches.] Appl. birds having additional feathers on legs or feet (zool.).

brachelytrous (brăkěl'ǐtrŭs) $a$. [Gk. brachys, short; elytron, wing.] Having short elytra, or wing covers (zool.).

brachial (brā'kiăl) a. [L. brachium, arm.] Pert. arm, arm-like.

brachiate (brắ'kiāt) a. [L. brachium, arm.] Branched; having opposite paired branches on alternate sides (bot.).

brachiferous (brăkīf'ĕrŭs) a. [L. brachium, arm; ferre, to carry.] Branched.

brachigerous,--brachiferous.

brachiocephalic (brắk'iökĕfăl'ik, -sĕf-) a. [L. brachium, arm; Gk. kephale, head.] Pert. arm and head, appl. artery (anat.).

brachiocubital (brăk'iökū'bìtăl) a. [L. brachium, arm ; cubitum, forearm.] Pert. arm and forearm (zool.).

brachiolaria (brăkiölä'rǐă) $n$. [L. brachiolum, a small arm.] A larval stage in the metamorphosis of certain starfishes (zool.).

brachiorachidian (brăk'iörăkĭd'iăn) $a$. [L. brachium, arm; Gk. rhachis spine.] Pert. arm and spine.

brachium (brăk'ium) $n$. [L. brachium, arm.] An arm or branching structure ; the upper limb of vertebrates (zool.).

brachycerous (brăkǐs'ěrŭs) a. [Gk. brachys, short; keras, horn.] Shorthorned; with short antennae (zool.). brachycnemic (brăk'ǐknē'mǐk) $a$. [Gk. brachys, short; kneme, tibia.] Appl. arrangement of mesenteries of Zoanthids where the sixth protocneme is imperfect (zool.).

brachydont (brăk'îdŏnt) a. [Gk. brachys, short; odous, tooth.] Appl. molar teeth with low crowns (zool.).

brachyodont,--brachydont.

brachyourous (brăk'ioo'rŭs) $a$. Brachyural.

brachypleural (brăk'íploo'răl) a. [Gk. brachys, short; pleuron, side.] With short pleura or side plates (zool.).

brachypođous (brăkĭpöodŭs) $a$. [Gk. brachys, short; pous, foot.] With short legs (zool.), or stalk (bot.).

brachypterous (brăkĭp'těrŭs) $a$. [Gk. 
brachys, short; pteron, wing.] With short wings (zool.).

brachystomatous (brăk'ĩstŏm'ătŭs) $a$. [Gk. brachys, short ; stoma, mouth.] With short proboscis; appl. certain insects (zool.).

brachyural (brăk'în'răl) a. [Gk. brachys, short; oura, tail.] Having a short abdomen usually tucked in below the thorax; appl. certain crabs (zool.).

bract (brăkt) $n$. [L. bractea, thin plate of metal.] A floral leaf; a modified leaf in whose axil a flower arises (bot.); a hydrophyllium in Siphonophora; the distal exite of the sixth appendage of Apus (zool.).

bract scales, - small scales developed directly on the axis of cones; $c f$. ovuliferous scales (bot.).

bracteal (brăk'těăl) a. [L. bractea, thin metal plate.] Like a bract (bot.).

bracteate (brăk'těāt) $a$. [L. bractea, thin metal plate.] Having bracts (bot.).

bracted,-bracteate.

bracteiform (brăktēeiffôrm) a. [L. bractea, metal plate ; forma, shape.] Bracteal.

bracteolate (brăk'těölāt) a. [L.bractea, metal plate.] $A p p l$. flowers with bracteoles (bot.).

bracteole (brăk'těol) n. [L. bractea, metal plate.] Secondary bract at the base of flower (bot.).

bracteose (brăk'těōs) a. [L. bractea, metal plate.] With many bracts (bot.).

bractlet,-bracteole.

brain (brān) $n$. [M.E. brayne, brain.] The centre of the nervous system; the mass of nervous matter in vertebrates at the anterior end of the spinal cord, lying in the skull; in invertebrates, the supraoesophageal or suprapharyngeal ganglia (zool.).

branch (brănsh) $n$. [It. branca, claw.] A bough; a principal outgrowth from a stem or axis (bot.); a principal division of an artery, vein, or nerve (anat.).

branchia (brăng'kiă) n., branchiae (brăng'kiè, -kiā), plu. [Gk. brangchia, gills.] Gills (zool.). branchiac (brăng'kiăk) $a$. chia, gills.] Pert. gills.

branchial,-branchiac.

branchial arch,- - one of the bony or cartilaginous arches placed on the side of the pharynx posterior to the hyoid arch, and supporting gill bars (zool.).

branchiate (brăng'kīāt) a. [Gk. brangchia, gills.] Having gills (zool.).

branchicolous (brăngkǐk'ölŭs) $a$. [Gk. brangchia, gills; L. colere, to inhabit.] Parasitic on fish gills ; $a p p l$. certain Crustaceans (zool.).

branchiform (brăng'kǐfôrm) a. [Gk. brangchia, gills; L. forma, shape.] Gill-like (zool.).

branchihyal (brăng'kǐhīăl) a. [Gk. brangchia, gills; hyoeides, Y-shaped.] One of the elements of a branchial $\operatorname{arch}(z \circ o l$.).

branchiocardiac (brăng'kiökâr'diăk) $a$. [Gk. brangchia, gills ; kardia, heart.] Pert. gills and heart; $a p p l$. vessel given off ventrally from the ascidian heart (zool.).

branchiomere (brăng'kiömër) $n$. [Gk. brangchia, gills; meros, part.] A branchial segment (zool., emb.).

branchiopallial (brăng'kioöpăl'ǐla $a$. [Gk. brangchia, gills ; L. pallium, mantle.] Pert. gill and mantle of Molluscs (zool.).

branchiostegal (brăng'kǐos'těgăl) $a$. [Gk. brangchia, gills; stege, roof.] With or pert. a gill cover; appl. membrane, rays, etc. (zool.).

branchiostege (brăng'kiöstēj') n. [Gk. brangchia, gills; stege, covering.] The branchiostegal membrane (zool.).

branchlostegite (brăng'kǐŏs'těgīt) $n$. [Gk. brangchia, gills; stege, roof.] The expanded lateral portion of the carapace forming the gill cover in certain Crustaceans (zool.).

branchireme (brăng'kìrēm) $n$. [Gk. brangchia, gills; L. remus, oar.] A branchiate limb; any of the locomotory and respiratory limbs of a Branchiopod (zool.).

brand (brănd) n. [A.S. beornan, to burn.] A fungus producing a burnt appearance on leaves of trees (bot.).

bregma (brěg'mă) n. [Gk. bregma, fore part of head.] That part of 
the skull where frontals and parietals meet (anat.).

brevicaudate (brěvíikô'dāt) $a$. [L. brevis, short ; cauda, tail.] With a short tail (zool.).

brevifoliate (brěv'ífólliăt) $a$. [L. brevis, short; folium, leaf.] Having short leaves (bot.).

brevilingual (brěv'íling'gwăl) a. [L. brevis, short; lingua, tongue.] With short tongue (zool.).

breviped (brĕv'ípĕd) a. [L. brevis, short ; pes, foot.] Having short legs; appl. certain birds (zool.).

brevipennate (brěv'îpěn'āt) $a . \quad[\mathrm{L}$. brevis, short; penna, feather.] With short wings (zool.).

brevirostrate (brěv'ïrŏs'trāt) a. [L. brevis, short ; rostrum, beak.] With short beak or bill, of birds (zool.).

brevissimus oculi, - the obliquus inferior, the shortest muscle of the eye (anat.).

brochidodromous (brǒk'îdŏd'römŭs) $a$. [Gk. brochos, loop ; dromein, to run.] $A p p l$. nerves in leaves when they form loops within the blade (bot.).

bronchia (brŏng'kuă) n. plu. [Gk. brongchos, tube.] The subdivisions or branches of each bronchus (anat.).

bronchial (brŏng'kuăl) a. [Gk. brongchos, windpipe.] Pert. the bronchi.

bronchiole (brŏng'kiōl) n. [Gk. brongchos, windpipe.] A small terminal branch of the bronchi (anat.).

bronchopulmonary (brŏng'köpŭl'mönărǐ) a. [Gk. brongchos, windpipe ; L. pulmo, lung.] Pert. bronchi and lungs (anat.).

bronchotracheal (brŏng'kötră'kěăl) $a$. [Gk. brongchos, windpipe; L. trachea, trachea.] Pert. bronchi and trachea (anat.).

bronchovesicular (brŏng'kövěsik'úlăr) a. [Gk. brongchos, windpipe; L. vesicula, little sac.] Pert.bronchial tubes and the lung cells (anat.).

bronchus (brŏng'kŭs) n., bronchi (brŏng'kī,-kē) plu. [Gk. brongchos, windpipe.] Tubes connecting the trachea with the lungs (anat.).

brood pouch, - a sac-like cavity into which the eggs or embryos are placed, in which they pass a stage of their development; a space formed by overlapping plates attached to the bases of the thoracic limbs in certain Crustacea (zool.).

brown body, $-\mathrm{a}$ brown, rounded mass of compacted degenerate organs in some Polyzoa (zool.).

Brownian movements, - the passive vibratory movements of fine granules when suspended in a fluid.

brown funnels, - a single pair of organs on dorsal aspect of posterior end of pharynx, opening posteriorly into the atrium, and anteriorly into the coelom, supposed to be accessory excretory organs in Amphioxus (zool.).

bryology (brīŏlöjìi) n. [Gk. bryon, moss; logos, discourse.] The science dealing with mosses (bot.).

bryophyte (brīöfīit) n. [Gk, bryon, moss; phyton, plant.] Any of the mosses or liverworts (bot.).

bryozoon (brī'özöŏn) $n$. [Gk. bryon, moss ; zoon, animal.] A Polyzoon, so named from the moss-like appearance $(z o o l$.$) .$

buccal (bŭkál) a. [L. bucca, cheek.] Belonging to the cheek or mouth (anat.).

buccinator (bŭk'sǐnā'tŏr) $n$. [L. buccina, trumpet.] A broad thin muscle of the cheek (anat.).

buccolabial (bŭk'ölā'brăl) $a$. [L. bucca, cheek; labium, lip.] Pert. the mouth cavity and lips (anat.).

buccolingual (bŭk'ölǐng'gwăl) $a$. [L. bucca, cheek; lingua, tongue.] Pert. cheeks and tongue (anat.)

bucconasal (bŭk'önā'zăl) a. [L. bucca, cheek; nasus, nose.] Pert. cheek and nose ; appl. membrane (anat.).

buccopharyngeal (bǔk'öfăr'injēéăl, -fărĭn'jěal) a. [L. bucca, cheek; Gk. pharyng $x$, throat.] Pert. cheeks and pharynx (anat.).

bud (bủd) n. [M.E. budde, bud.] A rudimentary shoot, or flower (bot.); any outgrowth which will develop directly into an exact replica of the structure or organism from which it grew out (zool.).

budding (bŭd'ing) n. [M.E. budde, bud.] A method of reproduction seen in many primitive animals (zool.).

bulb (bŭlb) n. [L. bulbus, globular 
root.] A part resembling a bulb (anat.) ; a specialized underground bud with thick fleshy leaves which afford it nourishment during development (bot.).

bulbar (bŭl'băr) a. [L. bulbus, globular root.] Pert. a bulb or a bulb-like part ; generally $a p p l$. paralysis from a disease of the medulla oblongata (anat.).

bulbiferous (bŭlbĭf'ěrŭs) a. [L.bulbus, bulb; ferre, to carry.] Bulb-bearing (bot.).

bulbil (bǔl'bǐl) $n$. [L. bulbus, bulb.] A large and fleshy axillary bud which may fall and produce a new plant, as in some lilies (bot.).

bulbonuclear (bŭl'bönū'klěăr) $a$. [L. bulbus, bulb; nucleus, kernel.] Pert. medulla oblongata and the nuclei of the cranial nerves (anat.).

bulbous (bŭl'bŭs) a. [L. bulbus, bulb.] Like a bulb; developing from a bulb; having bulbs (bot.).

bulbus (bŭl'bŭs) $n$. [L. bulbus, bulb.] The knob-like part found in connection with various nerves (anat.). bulla (bool'ă, bŭl'ă) n. [L. bullla, water-bubble.] $A p p l$, the rounded prominence formed by the bones of the ear; the tympanic bulla (anat.).

bullate (bool'āt) a. [L. bulla, waterbubble.] Blistered-like; puckered like a savoy-cabbage leaf (bot.).

bunodont (bū'nödŏnt) a. [Gk. bounos, mound; odous, tooth.] Having molar teeth with low conical cusps (zool.).

bunoid (bü'noid) a. [Gk. bounos, mound.] Appl. cusps of cheekteeth, low and conical (zool.).

bunolophodont (bū'nölöf'ödŏnt) $a$. [Gk. bounos, mound; lophos, crest ; odous, tooth.] Between bunodont and lophodont in structure, appl. cheek-teeth (zool.).

bunoselenodont (bü'nösělē'nödŏnt) $a$. [Gk. bounos, mound; selene, moon; odous, tooth.] Having the internal cusps bunoid, the external selenoid ; appl. cheek-teeth (zool.).

bursa (bŭr'să) n. [L. bursa, purse.] A sac-like cavity; a sac filled with viscid fluid at joints to prevent friction (anat.).

bursa copulatrix,-a genital pouch in Lepidoptera and Turbellarians (zool.).

bursicule (bŭr'š̀kūl) $n$. [L. dim. of bursa, purse.] A small sac (zool.). butyrinase (bứtĭrĭnās) $n$. [L.butyrum, butter.] An enzyme occurring in blood serum (phys.).

byssal (bĭs'ăl) $a$. [Gk. byssos, fine flax.] Pert. the byssus (zool.).

byssus (bǐs'ŭs) $n$. [Gk. byssos, fine flax.] The tuft of strong filaments, secreted in a gland of certain bivalve Molluscs, by which they attach themselves to one another and to rocks, etc. (zool.)

\section{$C$}

cachalote (kăsh'ălŏt) $n$. [Sp. cachalote, the sperm whale.] The sperm whale (zool.).

cadophore (kăd'öfōr) n. [Gk. kados, urn; pherein, to bear.] A dorsal process in certain of the freeswimming Tunicates on which the buds are borne (zool.).

caducibranchiate (kădū'sǐbrăng'kiāt) a. [L. caducus, from cadere, to fall ; Gk. brangchia, gills.] With temporary gills (zool.).

caducous (kădū'kŭs) a. [L. caducus, from cadere, to fall.] Pert. parts that fall off very early, e.g. calyx (bot.).

caecum (sé'kŭm) n. [L. caecus, blind.] A blind diverticulum or pouch from some part of the alimentary canal (anat., zool.).

Caenogaea (sē'nōjē'ă) n. [Gk. kainos, recent; ge, land.] Azoogeographical region under which is included the Nearctic, Palearctic, and Oriental regions; $c f$. Eogaea; also spelt Cainogea.

caenogenesis (sē'nōjĕn'ěsīs) n. [Gk. kainos, recent; genesis, birth.] The non-phylogenetic processes in the development of any individual (zool.).

Caenozoic (sēnōzō'îk) a. [Gk. kainos, recent ; zoe, life.] Pert. the geological era from Mesozoic to recent times ; also Cainozoic.

caespitose (sěs'pĩtōs) a. [L. caespus. 
turf.] Pert. turf; having low, closely matted stems (bot.).

calamistrum (kăl'ămǐs'trŭm) n. [L. calamistrum, a curling iron.] A comb-like structure on the hind limbs of certain spiders (zool.). calamus (kăl'ămŭs) $n$. [L. calamus, a reed.] The quill of a feather (zool.).

calcaneum (kălkä'něŭm) n. [L.calx, heel.] The heel; a large bone in the tarsus which forms the heel and represents the fibulare in lower forms; a process on the metatarsus of birds (anat., zool.).

calcar (kăl'kăr) $n$. [L. calcar, a spur.] A hollow prolongation or tube at the base of a sepal or petal (bot.) ; a spur-like process on the leg or wing of birds which is not a digit ; a tibial spine in insects; a process of the calcaneum which supports the web between the leg and tail in bats; the pre-hallux of a frog (zool.).

calcareous (kălkā'rê̌us) a. [L. calcarius, limy.] Growing on soil derived from decomposition of calcareous rocks (bot.).

calcariform (kălkărífôrm) $a$. [L. calcar, a spur; forma, shape.] Spur-like.

calcarine (kăl'kărīn) a. [L. calcar, a spur.] Pert. the hippocampus minor (anat.).

calciferous (kălsĭf'ĕrŭs) a. [L. calx, lime; ferre, to carry.] Containing lime (biol.).

calcification (kălsĭfîkā'shŭn) $n$. [L. calx, lime ; facere, to make.] The deposition of lime salts in a tissue (biol.).

calcigerous (kălsīj'ěrŭs) a. [L. calx, lime; gerere, to carry.] Producing or containing lime salts (biol.).

caleivorous (kălsĭv'örŭs) a. [L. calx, lime; vorare, to devour.] Appl. plants which live on limestone (bot.).

calicle,-see calycle.

callosal (kălō'săl) a. [L. callosus, hard.] Pert. the corpus callosum (anat.).

callosities (kălŏs'îtǐz) n. plu. [L. callositas, hardness.] Hardened and thickened areas on the skin, or on the bark of a plant, which often project beyond the general surface (bot., zool.).

callus (kăl'ŭs) $n$. [L. callus, callous skin.] A growth of shell-like material within the umbilicus of a shell (zool.); the soft tissue that forms over the cut or damaged surface of any stem or branch (bot.).

caloricity (kălörǐs'îtĩ) $n$. [L. calere, to be warm.] In animals, the power of developing and maintaining a certain degree of heat (phys.). caltrop (kăl'trŏp) $n$. [A.S. coltraeppea sort of thistle.] A sponge spicule with four rays so disposed that any three being on the ground the fourth projects vertically upwards (zool.). Also spelt calthrops.

calvarium (kălvā'rǐŭm) n. [L.calvus, bald.] The dome or upper portion of the skull (anat.).

calycanthemy (kăl'îkăn'thĕmĩ) n. [Gk. kalyx, a calyx; anthemon, a flower.] Abnormal development of various parts of the calyx into petals (bot.).

calyciflorous (kăl'ǐsĭfló'rŭs) a. [L. calyx, a calyx; flos, a flower.] Appl. flowers in which stamens and petals are adnate to the calyx (bot.).

calyciform (kălís'îfôrm) a. [L. calyx, a calyx; forma, shape.] Calyx-like in shape (bot.).

calycine (kăl'îsin) a. [L. calyx, a calyx.] Pert. a calyx; cup-like (bot., zool.).

calycle (kăl'íkl) $n$. [L. calyculus, a little calyx.] An epicalyx (bot.); any of the cup-shaped cavities in a coral; a theca in a Hydroid (zool.).

calyptoblastic (kălīp'töblăs'tīk) $a$. [Gk. kalyptos, hidden; blastos, a bud.] Pert. Hydroids in which the reproductive persons or gonophores are enclosed in a gonotheca (zool.) calyptobranchiate (kălǐp'töbrăng'kiāt) a. [Gk. kalyptos, hidden; brangchia, gills.] With gills not visible from the exterior (zool.).

calyptra (kălǐp'tră) n. [Gk. kalyptra, a covering.] The cap-like remains of the archegonium found surrounding the apex of the capsule in mosses (bot.).

ealyptrogen (kălịp'tröjěn) n. [Gk. 
kalyptra, a cap; genesis, birth.] The special layer of cells lying at the apex of a growing root and giving origin to the root-cap (bot.). calyx (kā'lìks) n., calyces (kâ'lǐsềz) plu. [L. calyx, a calyx.] The outer whorl of floral leaves (bot.); the cup-like portion of the pelvis of the kidney (anat.); the theca of certain Hydroids, the cup-like body of the Crinoids (zool.).

cambiform (kăm'bǔfôrm) a. [L. cambium, change ; forma, shape.] Essentially similar to cambium cells (bot.).

cambiogenetic (kăm'biöjĕnĕt'îk) $a$. [L. cambium, change; genesis, birth.] Appl. cells which produce cambium (bot.).

cambium (kằm'bŭŭm) n. [L.cambium, change.] The soft tissue from which new root and bark are formed in the stems and roots of shrubs and trees (bot.).

Cambrian (kăm'brĭnn) a. [L. Cambria, Wales.] Pert. the earliest division of the Palaeozoic era (pal.).

cameration (kămĕrā'shŭn) $n$. [L. cameratio, vaulting.] Division into a large number of separate chambers (zool.).

eamerostome (kăm'ĕröstōm') n. [L. camera, a chamber; stoma, a mouth.] The hollowed-out under surface of the "hood" of certain Trogulidae (zool.).

camptodrome (kămp'tödrōm) a. [Gk. kamptos, flexible; dromos, a course.] Pert. leaf venation in which the secondary veins bend forward and anastomose before reaching the margin (bot.).

campylospermous (kăm'pillöspěr'mŭs) a. [Gk. kampylos, curved; sperma, a seed.] $A p p l$. seeds with a groove along the inner face (bot.).

campylotropous (kăm'pǐlŏt'röpŭs) $a$. [Gk. kampylos, curved; trope, a turning.] Pert. ovules in which the nucellus and embryo-sac are bent so that the micropyle points almost back to the placenta (bot.).

canal (kănăl') $n$. [L. canalis, a channel.] A duct; a tubular passage formed in or by some tissue; a groove in the hard or soft parts of various animals; a passage or groove found in the tissues of numerous plants.

canalicular (kănălǐk'ūlăr) $a$. [L. canaliculus, a small channel.] Pert. canals.

canalieulus (kănălǐk'ūlŭs) $n$. [L. canaliculus, a small channel.] Canaliculi (plu.) are small canals connecting the lacunae with one another or with the Haversian canals in bone; small channels for the passage of nerves through various bones (anat.).

canaliform(kănăl'îfôrm)a. [L. canalis, a canal ; forma, shape.] Canal-like (biol., anat.).

cancellous (kăn'sĕlŭs) a. [L. cancellosus, chambered.] Consisting of slender fibres and lamellae, which join to form a reticular structure; $a p p l$. the inner, more spongy, portion of bony tissue (anat.).

cancrisocial (kăng'krǐsō'shăl) a. [L. cancer, a crab; socius, an ally.] $A p p l$. animals which live on the shell of, or are commensal with, a crab (zool.).

canine (kănīn', kā'nīn) n. [L. canis, a dog.] The tooth next to the incisors; $a$., pert. the canine tooth, or to a ridge or groove on the surface of the superior maxillary (anat., zool.).

cannon bone (kăn'ŏn bōn) $n$. [L. canna, a reed.] The bone supporting the limb from hock to fetlock, the enlarged and fused metacarpals or metatarsals; in birds the tarsometatarsus (zool.).

canthus (kăn'thŭs) n. [Gk. kanthelia, a pack-saddle.] The angle where the upper and lower eyelids meet (anat.).

capillary (kăpĩl'ărĩ) a. [L. capillus, hair.] Minute; hair-like; $n$. one of the minute thin-walled vessels which form networks in various parts of the body, e.g. blood, lymph, or biliary capillaries (anat.).

capillitium (kăp'îlít'ium, kăp'îlǐsh'íŭm) $n$. [L. capillus, hair.] A peculiar protoplasmic network of filaments among which the spores are found in the sporangia of certain Fungi (bot.).

capitate (kăp'itāt) a. [L. caput, the 
head.] Enlarged or swollen at the tip (zool.); gathered together into a mass at the apex, as in some inflorescences (bot.).

capitellum (kăp'itěl'ŭm) $n$. [L.caput, the head.] An articulatory protuberance at the end of a bone, e.g. on the humerus for the articulation of the radius (anat.).

capitulum (kăpitt'ūlŭm) $n$. [L. caput, the head.] A knob-like swelling at the end of a bone (anat.); the part of the body of a Cirripede enclosed in the mantle as opposed to the peduncle; the swollen end of a hair or tentacle; the enlarged end of an insect proboscis; the exsert part of the head in ticks $(z 00 \mathrm{l}$.$) ; an inflorescence of sessile$ flowers or florets crowded together on a receptacle and usually surrounded by an involucre (bot.).

capreolate (kăprēöōlāt, kăp'rēölāt) $a$. [L. capreolus, a tendril.] Supplied with tendrils (bot.).

capsule (kăp'sūl) n. [L. capsula, a little box.] A sac-like membrane enclosing either the whole or a part of an organ (anat., zool.) ; any closed box-like vessel containing spores, seeds, or fruits (bot.).

capsuliferous (kăp'sūliff'ĕrŭs) $a$. [L. capsula, a little box ; ferre, to carry.] With or forming a capsule (biol., anat.).

capsuligerous, capsulogenous,-capsuliferous.

caput (kắp'ŭt) n. [L. caput, the head.] Head; a knob-like swelling at the apex (anat., zool.).

carapace (kărăpãs) n. [Sp. carapacho, covering.] A shield covering the whole or part of the back of certain animals,-it may be chitinous or bony (zool.).

carbohydrates (kâr'bōhī'drāts) n. plu. [L. carbo, coal; Gk. hydros, water.] Compounds of carbon, hydrogen, and oxygen, generally speaking aldehyde or ketone alcohols, or condensation products thereof (biol.).

carbon dioxide (kâr'bǒn dīǒk'sīd) $n$. [L. carbo, coal ; di, two; Gk. oxys, sharp.] Carbonic acid gas; a heavy, colourless gas produced by the decomposition of organic substances (phys.). carboniferous (kâr'bŏnĭf'ěrŭs) a. [L. carbo, coal ; ferre, to carry.] Pert. the entire period of the coal measures, or fossils found in these strata (pal.).

carcerule (kâr'sĕrool) $n$. [L. carcer, a prison.] A superior, dry, manycelled fruit, with indehiscent oneor few-seeded carpels cohering by their united styles to a central axis (bot.).

carcinology (kâr'sĭnŏl'öjǐ) n. [Gk. karkinos, a crab; logos, discourse.] The study of the group of animals known as Crustacea (zool.).

cardiac (kâr'dǐăk) a. [Gk. kardia, the heart.] Pert. near or supplying the heart; $a p p l$. sinus, artery, etc. (anat.).

cardiac impulse,- the motion caused by the rapid increase in the tension of the ventricle (phys.).

cardinal (kâr'dĭnăl) a. [L. cardo, a hinge.] Pert. the hinge of a bivalve shell, or to the cardo of many insects (zool.).

cardinal sinuses and veins,-veins uniting in Cuvier's duct, persistent in most fishes, embryonic in other vertebrates (zool.).

cardo (kâr'dō) n. [L. cardo, a hinge.] The hinge of a bivalve shell; the basal joint of the maxilla in insects (zool.).

carina (kărī'nă, kărē'nă) $n$. [L. carina, keel.] A keel-like ridge on certain bones, as the breast-bone of birds ; the median dorsal plate of a barnacle $(z \circ o l$.$) ; the portion of a leguminous$ flower in which the stamens and pistils are contained; a ridge on the bracts of certain grasses (bot.).

carinate (kăr'ínāt) a. [L. carina, a keel.] Having a ridge or keel (biol.).

cariniform (kărĭn'îfôrm) a. [L. carina, a keel; forma, shape.] Keelshaped (biol.).

carnassial (kârnăs'iăl) a. [L. caro, flesh.] Pert. cutting teeth of carnivores, the fourth premolar above and the first molar below,-in the upper the protocone is reduced, in the lower the metaconid (zool.).

carnivorous (kârnĭv'örŭs) a. [L.caro, flesh ; vorare, to devour.] Flesheating ; appl. carnivores (zool.), and 
certain plants which feed on the proteids of entrapped insects (bot.).

carotid (kărŏt'ĩd) a. [Gk. karos, heavy sleep.] Pert. the chief arteries in the neck (anat., zool.).

carpale (kârpăl'ā, kârpā'lē) n. [L. carpus, wrist.] One of the bones of the wrist (anat.).

carpels (kâr'pĕlz) n. plu. [Gk. karpos, fruit.] The modified leaves which carry the megasporangia (bot.).

carpocerite (kârpŏs'ĕrît) n. [L. carpus, wrist; Gk. keras, horn.] The fifth joint of the antenna in certain Crustaceans (zool.).

carpogenous (kârpŏj'ěnŭs) a. [Gk. karpos, fruit; genos, birth.] Appl. those cells in red Algae which form the carpogonium (bot.).

earpogonium (kâr'pögō'nŭŭm) n. [Gk. karpos, fruit; gignesthai, to be born.] The lower portion of the procarp, in some Thallophytes, which contains the female nucleus (bot.).

earpolith (kâr'pölǐth) n. [Gk. karpos, fruit ; lithos, stone.] A fossil fruit (bot.).

carpometacarpus (kâr'pömĕtăkâr'pŭs) n. [L. carpus, wrist; Gk. meta, after.] The portion of the wing skeleton of a bird formed by the fusion of the carpal and metacarpal bones (zool.).

carpophagous (kârpöf'ăgŭs) a. [Gk. karpos, fruit; phagein, to eat.] Feeding on fruit (zool.).

carpophore (kâr'pöfōr) n. [Gk. karpos, fruit ; pherein, to bear.] The part of the axis of a flower situate between or above the carpels, and to which the carpels are attached (bot.). carpophyte (kâr'pöfìt) n. [Gk. karpos, fruit ; phyton, a plant.] Such of the Thallophytes as form sporocarps (bot.).

earpopodite (kârpŏp'ödit) n. [L. carpus, wrist ; Gk. pous, a foot.] The third joint in the walking leg of certain Crustaceans (zool.).

carposperm (kâr'pöspěrm) n. [Gk. karpos, fruit ; sperma, a seed.] The oosphere in certain Thallophytes after fertilization (bot.).

carposporangium (kâr'pöspörăn'jiŭm) n. [Gk. karpos, fruit; sporos, a seed; anggeion, a vessel.] The terminal cells of the filaments that are developed from the fertilized carpogonium in some Thallophytes (bot.).

carpospore (kâr'pöspōr) n. [Gk. karpos, fruit; sporos, seed.] A spore of those formed at the end of the filaments which are developed from the carpogonium (bot.).

carpus (kâr'pŭs) n. [L. carpus, wrist.] The wrist; the region of the forelimb between forearm and metacarpus (anat., zool.).

cartilage (kâr'tîlăj) n. [L. cartilago, cartilage.] Gristle; a translucent, bluish-white tissue, firm and at the same time elastic, found for the most part in connection with bones of the skeleton, most of which are in the embryo represented by cartilage (anat., zool.).

caruncle (kărŭng'kl) $n$. [L. caruncula, a small piece of flesh.] A naked, fleshy excrescence (anat.). ; a fleshy outgrowth on the heads of certain birds, and on certain caterpillars ; a little horny elevation at the end of the beak of embryo chicks; the sucking-disc on the tarsi of certain mites (zool.); one of outgrowths from various regions of the testa of a seed, arising after fertilization (bot.). caryo,- - see karyo-.

caryopsis (kăr'ioŏp'siss) n. [Gk. karyon, a nut ; opsis, appearance.] A superior, one-celled, one-seeded, indehiscent fruit with a thin dry membranous pericarp inseparably united with the seed (bot.).

casein (kā'sēinn) $n$. [L. caseus, cheese.] A nucleoalbumin proteid of milk, separated by the action of rennet (phys.).

cassideous (kăsĭd'ěŭs) a. [L. cassis, a helmet.] Helmet-like (bot.).

caste (kăst) n. [L. castus, pure.] One of the distinct forms found among certain social insects (zool.).

castrate (kăs'trāt) a. [L. castrare, to castrate.] Pert. flowers from which the androecium has been removed (bot.).

cata-,-see kata-.

catalysis (kătăl'isiss) n. [Gk. kata, down; lysis, a loosing.] The acceleration or retardation of a reaction due to the presence of a 
substance which apparently remains unchanged, e.g. enzymes (biol.).

cataphyllary (kăt'ăfillărǐ) $a$. [Gk. kata, down; phyllon, a leaf.] Appl. rudimentary or scale-like leaves which act as the covering of buds, etc. (bot.).

catenoid (kăt'ěnoid) a. [L. catena, a chain.] Chain-like; $a p p l$. certain protozoan colonies (zool.).

catenulate (kătĕn'ūlāt) $a$. [L. catena, a chain.] Chain-like; $a p p l$. colonies of bacteria, colour-markings on butterfly wings, shells, etc. (zool.). eaterpillar (kăt'ěrpil'ăr) $n$. [L.L. cattus, a cat ; L. pilosus, hairy.] The young worm-like larva of many insects (zool.).

catkin (kăt'kǐn) n. [A.S. catkin, a little cat.] A kind of spike with unisexual flowers and pendulous rachis (bot.).

cauda (kồdă) $n$. [L. cauda, a tail.] A tail, or tail-like appendage; the posterior part of an organ, e.g. cauda equina, cauda epididymis (anat.); a tube at the posterior end of the abdomen of certain insects suggesting the presence of an eleventh segment (zool.).

caudal (kốdăl) a. [L. cauda, a tail.] Of or pert. a tail, e.g. caudal fin, the terminal fin of a fish (zool.).

caudate (kốdāt) a. [L. cauda, a tail.] Having a tail, e.g. caudate nucleus, a mass of gray matter in the corpus striatum (anat.).

eaudatolenticular (kôdā'tölěntǐk'ūlăr) a. [L. cauda, a tail ; lens, a lentil.] $A p p l$. the caudate and lenticular nuclei of the corpus striatum (anat.). caudex (kốděks) n. [L. caudex, a dry stump.] The axis or stem of a woody plant (bot.).

caudicle (kốdìkl) n. [Dim. of L. cauda, a tail.] The stalks of the pollinia in orchids (bot.).

caul (kôl) n. [M.E. calle, a covering.] An enclosing membrane (anat.).

caulescent (kồlěs'ěnt) a. [L. caulis, a stalk.] With leaf-bearing stem above ground (bot.).

caulicolous (kôlík'ölǔs) a. [L. caulis, a stalk; colere, to inhabit.] Appl. Fungi which grow on the stems of other plants (bot.).

cauliform (kôl'ífôrm) a. [L. caulis, a stalk; forma, shape.] Stem-like (bot.).

cauligenous (kôlïj'ěnŭs) a. [Gk. kaulos, a stem; genos, birth.] Borne on the stem (bot.).

cauline (kốlinn) a. [L. caulis, a stalk.] $A p p l$. leaves growing on the upper portion of a stem; $a p p l$. vascular bundles not passing into the leaves (bot.).

caulocarpous (kốlökâr'pŭs) a. [Gk. kaulos, a stem; karpos, a fruit.] With fruit-bearing stem (bot.).

caulome (kốlōm) n. [Gk. kaulos, a stem.] The stem structure of a plant as a whole (bot.).

cavernosus (kăv'ěrnō'sŭs) a. [L. cavernosus, chambered.] Full of cavities; hollow, or resembling a hollow ; appl. tissue, nerve, arteries (anat.).

cavicorn (kăv'íkôrn) a. [L. cavus, hollow; cornu, horn.] Hollowhorned; $a p p l$. certain of the ruminants (zool.).

eavity (kăv'îtî) n. [L.cavus, hollow.] A hollow, enclosed or cup-shaped; e.g. amniotic, glenoid cavity (anat.). cavum (kä'vŭm) n. [L. cavus, hollow.] The lower division of the concha caused by the origin of the helix ; any hollow or chamber in which an organ or part thereof lies (anat.).

cell (sĕl) $n$. [L. cella, a compartment.] A small cavity or hollow; a unit mass of protoplasm, usually containing a nucleus (biol.).

cellifugal (sělíf'ügăl) $a$. [L. cella, a cell; fugere, to flee.] Moving away from a cell (phys.).

cellipetal (sělǐp'ětăl) a. [L. cella, a cell ; petere, to seek.] Moving towards a cell (phys.).

cell lineage, - the derivation of a tissue or part from a definite blastomere of the embryo (biol.).

cell membrane, - a membranous cellwall (biol.).

cell organ,- - a part of a cell having a special function, as a centrosome (biol.).

cell plate,- - the equatorial thickening of the spindle fibres from which the partition wall arises during the division of plant cells (cyt.).

cell sap, - the more fluid ground substance of the cell or nucleus (cyt.). 
cellular (sěl'ūlăr) a. [L. cellula, a small cell.] Pert. or consisting of cells (biol.).

cellulose (sěl'ūlōs) $n$. [L. cellula, a small cell.] A carbohydrate forming the main part of the cell walls of plants, also found in the tests of tunicates (biol.).

cell-wall, - the investing portion of a cell, which may be extremely delicate, or may be strong and thick as in plants (cyt.).

cement (sěměnt') $n$. [L. caementum, mortar.] A substance chemically and physically allied to bone, investing the root, neck, and crowns of teeth (zool.).

censer mechanism,- the method of seed distribution by which seeds are jerked out from the fruit only by a high wind (bot.).

centradenia (sĕn'trădēénĭă) n. [L. centrum, a centre.] The name given to the type of siphonophore colony found in the Disconectae (zool.).

central (sĕn'trăl) a. [L. centrum, a centre.] Situated in the centre; pert. a vertebral centrum (anat.).

centrale (sĕntrā'lē, sĕntrăl'ā) $n$. [L. centrum, a centre.] A bone in the wrist or ankle situated between the proximal and distal rows (zool.).

centric (sĕn'trĭk) a. [L. centrum, a centre.] $A p p l$. leaves which are cylindrical or terete (bot.).

centrifugal (sĕntrĭf'ügăl) $a$. [L. centrum, a centre ; fugere, to flee.] $A p p l$. compact cymose inflorescences having the youngest flowers towards the outside (bot.); $a p p l$. nerves transmitting impressions from nerve centre to parts supplied by nerve (anat.).

centriole (sěn'triōl) n. [L. centrum, a centre.] The central particle of the centrosome, in some authors; in others, the centrosome itself (cyt.).

centripetal (sěntrĭp'ětăl) a. [L. centrum, a centre; petere, to seek.] Appl. racemose inflorescences having the youngest flowers at the apex (bot.); $a p p l$. nerves transmitting impressions from peripheral extremities to nerve centres (anat.). centripetal canals, - blind canals growing from the circular canal backwards towards the apex of the bell in certain Trachomedusae (zool.).

centrodesmose (sěn'tröděs'mōs), centrodesmus (sěn'tröděs'mŭs) $n$. [Gk. kentron, a centre ; desmos, a band.] The fibril or system of fibrils temporarily connecting the two centrosomes (cyt.).

centrodorsal (sěn'trödôr'săl) $a$. [L. centrum, a centre; dorsum, a back.] Appl. the plate in the middle of the aboral surface of unstalked Crinoids (zool.).

centrogenous (sĕntrŏj'ĕnŭs) $a$. [Gk. kentron, a centre; genos, descent.] $A p p l$. a skeleton of spicules which meet in a common centre and grow outwards (zool.).

centrolecithal (sěn'trölěs'îthăl) $a$. [Gk. kentron, a centre; lekithos, yolk.] Appl. an ovum with its yolk aggregated in the centre (biol.).

centroplasm (sĕn'tröplăzm) $n$. [Gk. kentron, a centre; plasma, something moulded.] The substance of the centrosphere (cyt.).

centrosome (sěn'trôsōm) n. [Gk. kentron, a centre; soma, body.] A cell-organ, being the centre of dynamic activity in mitosis, and consisting of centriole and attraction-sphere (cyt.).

centrosphere (sěn'trösfēr) $n$. [Gk. kentron, a centre ; sphaira, a ball.] The central mass of the aster and centrosome; the astrosphere; the attraction sphere $(c y t$.).

centrum (sĕn'trŭm) $n$. [L. centrum, a centre.] The main body of a vertebra, from which the neural and haemal arches arise (zool.).

cephalanthium (kěf'ălăn'thĭŭm, sěf-) n. [Gk. kephale, a head; anthos, a flower.] The capitulum in composite plants (bot.).

cephaletron (kěf'ălētrŏn, sĕf-) $n$. [Gk. kephale, the head; etron, the belly.] The anterior region of a Limulid (zool.).

cephalic(kěrăl'ík, sěf-)a. [Gk.kephale, the head.] Pert. the head; in the head region.

cephalis (kěf'ăliss, sĕf-) n. [Gk. 
kephale, the head.] The uppermost chamber of monaxonic Radiolarian shells (zool.).

cephalization (kěf'ălǐzā'shŭn, sěf-) $n$. [Gk. kephale, the head.] Increasing importance of the anterior end in animal development (zool.).

cephalont (kěf'ălŏnt, sĕf-) $n$. [Gk. kephale, the head.] A sporozoan about to proceed to spore-formation (zool.).

cephalopods (kěf'ălöpǒdz, sĕf-) $n$. plu. [Gk. kephale, the head; pous, the foot.] Animals with muscular, sucker-bearing arms on the head region (zool.).

cephalostegite (kěf'ălöstěg'ît, sĕf-) $n$. [Gk. kephale, head; stege, roof.] The anterior part of the cephalothoracic shield (zool.).

cephalostyle (kěf'ălöstîl, sěf-) $n$. [Gk. kephale, head; stylos, a pillar.] The anterior end of the notochord enclosed in its sheath, in chondrocrania (zool.).

cephalotheca (kěf'ălöthē'kă, sěf-) $n$. [Gk. kephale, head ; theke, a case.] The head integument in the pupa of insects (zool.).

eephalothorax (kěf'ălöthō'răks, sĕf-) $n$. [Gk. kephale, head; thorax, breast.] The body-region formed by the fusion of head and thorax in Arachnids and Crustaceans (zool.). cephalotrocha (kĕf'ălötrō'kă, sěf-) $n$. [Gk. kephale, head; trochos, a wheel.] A Turbellarian larva with eight processes arranged round the mouth (zool.).

cerata (kěr'ătă, sěrā'tă) n. plu. [Gk. keras, horn.] Lobes or leaf-like processes acting as gills on the back of nudibranch molluscs (zool.). ceratium (sěrā'shiǔm, sěrā'trŭm) $n$. [Gk. keration, little horn.] A siliqua without the replum (bot.).

ceratohyal (kěr ătöhîăl, sěr-) $n$. [Gk. keras, horn; hyoeides, $\mathrm{Y}$-shaped.] The component of the hyoid arch next below the epihyal (zool.).

cercal (sĕr'kăl) a. [Gk. kerkos, tail.] Pert, the tail (zool.).

cercaria (sěrkā'ruă) n. [Gk. kerkos, tail.] A trematode larva with a slightly heart-shaped body and long tail (zool.).

cerci (sĕr'kè, sĕr'sī) n. plu. [Gk. kerkos, tail.] Jointed appendages at the end of the abdomen in many Arthropods (zool.).

cere (sēr) n. [L. cera, wax.] A swollen fleshy patch at the proximal end of the bill in birds, on which the nostrils open.

cerebellar (sĕr'ěbĕl’ăr) $a$. [L.cerebrum, the brain.] Pert. the hind-brain (anat.).

cerebellum (sěr'ěbĕl'úm) $n$. [L. cerebrum, the brain.] The fourth division of the brain arising from the differentiation of the anterior part of the third primary vesicle (anat.).

cerebral (sěr'ěbrăl) a. [L. cerebrum, the brain.] Pert. the brain; pert. the anterior part of the brain or cerebral hemispheres.

cerebrifugal (sěr'ěbrĭfū'găl) a. [L. cerebrum, the brain; fugere, to flee.] $A p p l$. nerve fibres which pass from brain to spinal cord (phys.).

cerebroganglion (sěr'ěbrögăng'glǐŏn) n. [L. cerebrum, the brain; Gk. ganglion, a swelling.] The brain, or supra-oesophageal ganglia of invertebrates (zool.).

cerebropedal (sěr'ěbröpĕ'dăl) $a$. [L. cerebrum, the brain; pes, a foot.] $A p p l$. nerve strands connecting the cerebral and pedal ganglia in Molluscs (zool.).

cerebrospinal (sĕr'ěbröspīnăl) a. [L. cerebrum, the brain; spina, the spine.] Pert. brain and spinal cord (anat.).

cerebrovisceral (sĕr'ěbrövĩs'ěrăl) $a$. [L. cerebrum, the brain; viscera, viscera.] Appl. the connective joining the cerebral and visceral ganglia in Molluscs (zool.).

cerebrum (sĕr' ĕbrŭm) $n$. [L.cerebrum, the brain.] The fore-brain, or hemispheres, arising from the differentiation of the first primary vesicle (zool.).

ceriferous (sěríf'ĕrŭs) $a$. [L. cera, wax ; ferre, to carry.] Appl. waxproducing organs (biol.).

cernuous (sěr'nūŭs) $a$. [L. cernuus, with face turned downwards.] Drooping ; pendulous (bot.).

ceroma (sêró'mă) $n$. [Gk. keroma, ointment.] The cere of birds (zool.). 
cerous (sétrús) a. [L. cera, wax.] Appl. a structure resembling a cere (zool.).

cerumen (sĕroo'měn) $n$. [L. cera, wax.] The wax-like secretion from the ceruminous glands of the ear (phys.).

cervical (sêrvī'kăl) a. [L. cervix, the neck.] $A p p l$. structures connected with the neck, as nerves, bones, blood-vessels, also to the cervix or neck of an organ (anat., zool.).

cervix (sĕr'vǐks) $n$. [L. cervix, a neck.] The neck or narrow mouth of an organ, as cervix uteri (anat.).

chaeta (két'tă) $n$. [Gk. chaite, hair.] A seta or bristle of certain worms (zool.).

chaetiferous (kētǐf'ĕrŭs) a. [Gk. chaite, hair; L. ferre, to bear.] Bristle-bearing ; chaetigerous.

chaetophorous (kētǒf'örŭs) a. [Gk. chaite, hair; pherein, to bear.] Bristle-bearing; $a p p l$. worms and certain insects (zool.).

chaetotaxy (kế'tötăk'sĭ) n. [Gk. chaite, hair; taxis, arrangement.] The bristle-patterns on an insect (zool.).

chalaza (kălā'ză) n. [Gk. chalaza, hail, tubercle.] One of the two spiral bands attaching the yolk to the membrane of a bird's egg (zool.) ; the base of the nucellus of an ovule from which the integuments arise (bot.).

chalazogamy (kălăzŏg'ămĩ) $n$. [Gk. chalaza, hail, tubercle; gamos, marriage.] Fertilization in which the pollen-tube pierces the chalaza of the ovule, instead of entering by the micropyle; $c f$. porogamy (bot.). chalice (chălíis) $n$. [L. calix, calyx.] Appl. simple gland cells in the epithelia of the frog (zool.); any modified columnar epithelial gland cell (anat.).

chalones (kăl'ōnz) n. plu. [Gk. chalinos, curb.] Substances which depress activity (phys.).

channelled (chăn'ěld) a. [L. canalis, a canal.] Having grooves; canaliculate (bot.).

chasmogamy (kăzmŏg'ămǐ) n. [Gk. chasma, opening ; gamos, marriage.] The opening of a mature flower to ensure fertilization (bot.). chasmophyte (kăz'möfît) n. [Gk. chasma, opening ; phyton, a plant.] A plant which grows in nooks and crannies of rocks (bot.).

cheek (chēk) $n$. [A.S. céoce, the cheek.] The fleshy wall of the mouth in mammals; the side of the face; in invertebrates the lateral portions of the head, as the fixed and free cheeks of Trilobites (zool., anat.).

cheiropterygium (kīrŏptěrīj'iŭm) $n$. [Gk. cheir, hand; pteryx, wing.] The pentadactyloid typical limb of higher vertebrates.

chela (kē'lă) n. [Gk. chele, claw.] The claw borne on certain limbs of Crustaceans and Arachnids (zool.).

chelicerae (kēlìs'ĕrē, -rā) n. plu. [Gk. chele, claw ; keras, horn.] Anterior chelate or sub-chelate appendages of Arachnids (zool.).

cheliferous (kēlíf'ěrŭs) a. [Gk. chele, claw ; L. ferre, to bear.] Supplied with chelae or claws (zool.).

cheliform (kē'lífôrm) a. [Gk, chele, claw ; L. forma, shape.] Claw-like; $a p p l$. appendages (zool.).

chelophores (kểlöfōrz) n. plu. [Gk. chele, claw; pherein, to bear.] The first pair of appendages in the Pycnogons (zool.).

chemoreflex (kěm'örēflěks) n. [Gk. chemos, juice; L. reflectere, to bend back.] A reflex caused by chemical stimulus ( $p h y s$.$) .$

chemosynthesis (kĕm'ösin'thěsĭs) $n$. [Gk. chemos, juice; syn, with; tithenai, to place.] The building up of chemical compounds in plants by means of chemical reactions (bot.).

chemotaxis (kěm'ötăk'siss) n. [Gk. chemos, juice ; taxis, arrangement.] The sensitiveness of cells or microorganisms to chemical stimulus, which is either attractive or repellent, exhibiting respectively positive or negative chemotaxis (biol.).

chemotropism (kĕmŏt'röpǐzm) $n$. [Gk. chemos, juice; trope, a turning.] Curvature of a plant towards or away from chemical stimuli (bot.); response to chemical stimulus (biol.). chevron (shĕv'rŏn) a. [L. caper, a goat.] Appl. V-shaped bones articulating with the ventral surface 
of the spinal column in the caudal region of many vertebrates (zool.). chiasma (kiăz'mă) n. [Gk. chiazein, to mark with a cross. I A decussation, as optic chiasma (anat.).

chiastoneural (kīăs'tönū'răl) a. [Gk. chiastos, diagonally arranged; neuron, a nerve.] Appl. certain Gastropods in which the visceral nerve cords cross and form a figure 8 (zool.).

chilaria (kīlā'rĭă) n. plu. [Gk. cheilos, lip.] A pair of processes between the sixth pair of appendages in Limulus (zool.).

chilidium (kīlǐírŭm) n. [Gk, cheilos, lip.] A shelly plate covering the deltidial fissure in the dorsal valve of certain Brachiopods (zool.).

chitin (kítĭn) $n$. [Gk. chiton, a tunic.] A carbohydrate derivative forming the skeletal substance in Arthropods (zool.).

chlamydate (klăm'îdāt) a. [Gk. chla . mys, a cloak.] Supplied with a mantle (zool.).

chlamydeous (klămĭd'ěuss) a. [Gk. chlamys, a cloak.] Pert. flower and envelope (bot.).

chlamydospore (klăm'îdöspōr) n. [Gk. chlamys, cloak; sporos, seed.] A thick-walled resting spore found in many Fungi, as yeast (bot.).

chloragen (klō'răjĕn) $a$. [Gk. chloros, grass green; genos, descent.] Appl. yellow cells found in connection with the alimentary canal of the earthworm, and other Annelids ; also chloragogen (zool.).

chloranthy (klörăn'thî) $n$. [Gk.chloros, grass green; anthos, flower.] Reversion of floral leaves back to ordinary green leaves $(b o t$.).

chlorophyll (klóröfili) $n$. [Gk. chloros, grass green ; phyllon, a leaf.] The green colouring matter found in plants and in some animals (biol.). chloroplast (klō'röplăst) $n$. [Gk. chloros, grass green; plastos, moulded.] A chlorophyll-carrying plastid (bot.).

chloroplastid (klō'röplăs'tĩd) n. [Gk. chloros, grass green; plastos, moulded.] A minute granule or plastid containing chlorophyll, found in plant-cells exposed to light (biol.). chlorosis (klörō'sǐs) n. [Gk. chloros, grass green.] A diseased condition in plants owing to lack of certain minerals, due mainly to want of light (bot.).

chlorotic (klörŏt' 1k) a. [Gk. chloros, grass green.] Appl. plants or organs of plants devoid of chlorophyll (bot.).

choana (kōănă) n. [Gk. choane, funnel.] Any funnel-shaped opening (anat.).

choanocyte (kóănösīt) n. [Gk. choane, funnel; kytos, hollow.] A cell with a funnel-shaped rim or collar round the base of the flagellum (zool.).

choanoid (kó'ănoid) a. [Gk. choane, funnel; eidos, like.] Funnelshaped; $a p p l$. eye muscle in Reptiles (zool.).

choanosome (kō'ănösōm) n. [Gk. choane, funnel; soma, body.] In sponges, the inner layer with flagellate cells (zool.).

choledoch (kǒl'ědŏk) a. [Gk. chole, bile; dochos, containing.] Appl. common bile duct.

choleic (kölë'ik) a. [Gk. chole, bile.] Pert. acid contained in ox bile (phys.).

cholesterin (kölěs'tĕrĭn) $n$. [Gk. chole, bile; stereos, solid.] A white fatty alcohol found in nerve tissue, bile, yolk, and other animal substances (phys.).

choline (kờllìn, -ēn) n. [Gk. chole, bile.] A crystalline base found in plants and animals with composition $\mathrm{C}_{5} \mathrm{H}_{15} \mathrm{O}_{2} \mathrm{~N}$ (phys.).

cholochrome (kölökrōm) n. [Gk. chole, bile; chroma, colour.] A bile pigment (phys.).

cholohaematin (kō'löhĕ́mătǐn) $n$. [Gk. chole, bile; haima, blood.] A pigment developed in the bile of ruminants after exposure to the air (phys.).

chondral (kôn'drăl) a. [Gk. chondros, cartilage.] Pert. cartilage (anat.).

chondrification (kôn'drĭfíkā'shŭn) $n$. [Gk. chondros, cartilage; L. facere, to make.] Conversion into cartilage (phys.).

chondrigen (kôn'drījĕn) $n$. [Gk. chondros, cartilage; genos, descent. The base matrix of all cartilaginous substance, a collagen ( $p h y s$. .). 
chondrin (kôn'drĭn) n. [Gk. chondros, cartilage.] A gelatinous substance obtained from cartilage ( $p h y s$.$) .$

chondriosomes (kôndrīösōmz') n. plu. [Gk. chondros, cartilage; soma, body.] Permanent feebly refractive bodies found in cell protoplasm, which are probably combinations of fatty acids or of phosphate of albumen (biol.).

chondroblast (kôn'dröblăst) n. [Gk. chondros, cartilage; blastos, bud.] A cartilage-producing cell (phys.).

chondroclast (kôn'dröklăst) $n$. [Gk. chondros, cartilage ; klastos, broken down.] A cell which breaks up or destroys cartilage cells (phys.).

chondrocranium (kôn'drökrā'niŭm) $n$. [Gk. chondros, cartilage ; kranion, skull.] The skull when in a cartilaginous condition, either temporarily as in embryos, or permanently as in some fishes (zool., anat.).

chondrogenesis (kôn'dröjĕn'ěsǐs) $n$. [Gk. chondros, cartilage; genesis, descent.] The production or formation of cartilage (phys.).

chondromucoid (kôn'drömū'koid) $n$. [Gk. chondros, cartilage; L. mucus, mucus; Gk. eidos, form.] A whitish amorphous powder found in cartilage (phys.).

chondrophore (kôn'dröfōr) n. [Gk. chondros, cartilage; pherein, to bear.] A structure which supports the inner hinge cartilage in a bivalve shell (zool.).

chondroskeleton (kôn'dröskěl'ětŏn) $n$. [Gk. chondros, cartilage; skeleton, a dried body.] A cartilaginous skeleton (zool.).

chondrosteous (kôndrŏs'těŭs) a. [Gk. chondros, cartilage ; osteon, bone.] Having a cartilaginous skeleton (zool.).

chondrosterual (kôn'dröstĕr'năl) $a$. [Gk. chondros, cartilage ; sternon, the breast.] Pert. rib cartilages and sternum (anat.).

chone (kōn) n. [Gk. choane, a funnel.] A passage through the cortex of sponges with one or more external openings, and one internal opening provided with a sphincter (zool.).

chorda (kôr'dă) n. [Gk. chorde, a string.] The notochord ; in plural, tendinous cords attached to the valves of the heart (anat.).

chordacentra (kôr'dăsěn'tră) $n$. plu. [Gk. chorde, a string; L. centrum, centre.] Centra formed by the conversion of the chordal sheath into a number of rings (zool.).

chordate (kôr'dāt) a. [Gk. chorde, a string.] Having a notochord (zool.).

chordotonal (kôr'dötō'năl) a. [Gk. chorde, a string; tonos, a tone.] $A p p l$. rod-like or bristle-like structures, auditory in nature, in various parts of the body of insects (zool.).

choriocapillaris (kō'riökăpĭlărĭs, -kăp'ı̀lā'rǐs) n. [Gk. chorion, chorion; L. capillaris, a capillary.] The innermost vascular layer of the choroid coat of the eye (anat.).

chorioid,-choroid.

chorion (kō'rǐŏn) n. [Gk. chorion, a skin.] An embryonic membrane external to and enclosing the amnion (emb.).

chorionic (kōriǒn'îk) a. [Gk. chorion, a skin.] Pert. the chorion (emb.).

chorioretinal (kō'riörĕt'inăl) a. [Gk. chorion, a skin; L. retina, the retina.] Pert. choroid and retina (anat.).

choripetalous (kō'rĭpět'ălŭs) a. [Gk. choris, separate; petalon, a leaf.] Having separate petals (bot.).

choriphyllous (kō'rinfil'ŭs) a. [Gk. choris, separate; phyllon, a leaf.] Having the perianth parts distinct (bot.).

chorisepalous (kō'rǐsềp'ălŭs) a. [Gk. choris, separate ; sepalon, a sepal.] Having the sepals separate (bot.).

chorisis (kö'risis) n. [Gk. choris, separate.] Increase in number of parts of a floral whorl due to division of its primary members; duplication (bot.).

choroid (kō'roid) a. [Gk. chorion, skin; eidos, form.] Appl. delicate and highly vascular membranes; $n$. the layer of the eye between retina and sclerotic (anat.).

choroidal (köroid'ăl) a. [Gk. chorion, skin; eidos, form.] Pert. the choroid (anat.).

chorology (körǒl'öjì) n. [Gk. choros, place; logos, discourse.] The 
science which deals with the distribution of organs (biol.).

chromaffin (krömăf'inn) $a$. [Gk. chroma, colour; L. affinis, related.] $A p p l$. cells forming the medullary parts of the suprarenal bodies, on account of their yellow colour after treatment with chromic salts ; chromophil (phys.).

chromatic (krömăt'îk) a. [Gk. chroma, colour.] Colourable by means of staining reagents (biol.).

chromatic sphere, - the sphere formed by coalescence of chromosomes after the anaphase in mitosis (bot.).

chromatin(krō'mătǐn) n. [Gk. chroma, colour.] A substance in the nucleus which contains nucleic acid proteids and stains with basic dyes (biol.).

chromatogen organ, - a brownish lobed body, the axial organ of certain Echinoderms (zool.).

chromatoid grains,--readily stainable grains in cell-protoplasm, probably of an albuminous nature (cyt.).

chromatolysis (krō'mătŏl'îsis) $n$. [Gk. chroma, colour ; lyein, to break up.] Disintegration and final disappearance of the chromatin in injured nerve-cells (phys.).

chromatophore (krō'mătöfōr) n. [Gk. chroma, colour; pherein, to bear.] The general term $a p p l$. coloured plastids of plants and animals $(c y t$.$) ; a pigment cell, which under$ control of the sympathetic nervous system can be altered in shape to produce a colour change (zool.).

chromatoplasm (krō'mătöplăzm) $n$. [Gk. chroma, colour ; plasma, something moulded.] The colour or pigment matter in cells (cyt.).

chromatospherite (krō'mătösferrîit) $n$. [Gk. chroma, colour; sphaira, a globe.] A nucleolus, which see (cyt.).

chromidia (krömı̆d'íă) n. plu. [Gk. chroma, colour.] Extra-nuclear particles of chromatin (cyt.).

chromidiosomes (krömǐd'ïösōmz') $n$. plu. [Gk. chroma, colour; soma, body.] The smallest chromatin particles of which the chromidial mass is made up (cyt.).

chromoblast (kró'möblăst) n. [Gk. chroma, colour; blastos, a bud.] An embryonic cell giving rise to a pigment cell (biol.). chromogen (krō'möjĕn) n. [Gk. chroma, colour; genos, birth.] The material in plants which will develop into colouring matter (bot.).

chromogenic (krō'möjĕn'îk) a. [Gk. chroma, colour ; genos, birth.] Colour-producing; appl. organisms, as bacteria (bot.).

chromomere (krō'mömēr) n. [Gk. chroma, colour; meros, part.] One of the chromatin granules of which a chromosome is formed, and which corresponds to an id (cyt.).

chromophanes (krō'möfānz) n. plu. [Gk. chroma, colour; phainein, to show.] Red, yellow, and green oil globules found in the retina of birds, reptiles, fishes, and marsupials (zool.).

chromophil (krō'möfil) a. [Gk. chroma, colour ; philein, to love.] Chromaffin, which see.

chromophilous (krömǒf'ílŭs) a. [Gk. chroma, colour; philos, loving.] Staining readily (biol.).

chromophore (krō'möfōr) n. [Gk. chroma, colour; pherein, to bear.] Any substance to whose presence colour in a compound is due (phys.).

chromoplast (krōmöplăst) $n$. [Gk. chroma, colour ; plastos, moulded], also chromoplastid. A coloured plastid or pigment body other than a chloroplast (biol.).

chromoproteid (krō'möprō'tê̌íd) n. [Gk. chroma, colour; protos, first.] Substance formed by combination of a proteid and a pigment (phys.). chromosome (krō'mösōm) n. [Gk. chroma, colour ; soma, body.] One of the deeply staining bodies, the number of which is definite for the cells of a species, into which the chromatin resolves itself during karyokinesis (cyt.).

chrysalis (krǐs'ălis) n. [Gk. chrysos, gold.] The pupa stage of certain insects (zool.).

chrysocarpous (kriss'ökâr'pŭs) a. [Gk. chrysos, gold; karpos, fruit.] With golden fruit (bot.).

chrysophyll (kris'öfil) n. [Gk. chrysos, gold; phyllon, a leaf.] A yellow colouring matter in plants, a decomposition product of chlorophyll (bot.). 
chylaceous (kīlā'shŭs) a. [Gk. chylos, juice.] Of a chyle-like nature ; pert. chyle (phys.).

chyle (kîl) n. [Gk. chylos, juice.] Lymph containing globules of emulsified fat found in the lacteals during digestion (phys.).

chylifaction (kî́lifăk'shŭn) n. [Gk. chylos, juice; L. facere, to make], also chylification. The formation of chyle (phys.).

chyliferous (kīliff'ěrǔs) a. [Gk. chylos, juice; L. ferre, to carry.] Chyleconducting; $a p p l$. tubes or vessels (phys.).

chylific (kīlíf'ìk) a. [Gk. chylos, juice ; L. facere, to make.] Chyle-producing; $a p p l$. the true stomach of insects (zool.).

chylocaulous (kỉlöcôl'ŭs) a. [Gk. chylos, juice; L. caulis, a stem.] With fleshy stems (bot.).

chylocyst (kî́lösǐst) n. [Gk. chylos, juice ; kystis, a bladder.] The chyle receptacle (anat.).

chylophyllous (kî'löfîl'ǔs) a. [Gk. chylos, juice; phyllon, a leaf.] With fleshy leaves; $a p p l$. certain desert plants (bot.).

chylopoiesis (kî'löpoiē'sǐs) n. [Gk. chylos, juice; poiein, to produce.] The production of chyle (phys.).

chyme (kim) $n$. [Gk. chymos, juice.] The partially digested food after leaving the stomach (phys.).

chymification (kímífíkā'shŭn) $n$. [Gk. chymos, juice; L. facere, to make.] The process of converting food into chyme (phys.).

cicatricial tissue, - newly-formed fibrillar connective tissue which closes and draws together wounds (anat.).

cicatricle (š̉ $\left.{ }^{\prime} a ̆ t r i ̄ k ' 1\right), \quad$ eicatricula (sǐk'ătrìk'ūlă) $n$. [L. cicatrix, a wound.] The blastoderm in bird and reptile eggs (emb.); a small scar in the place of previous attachment of an organ (zool.); the mark left after the healing up of a wound in plants (bot.).

eicatrix (sǐk'ătrǐks, sỉkā'trǐks) n. [L. cicatrix, a wound.] Cicatricle, which see.

eicinnal (sǐsĭn'ăl) a. [Gk. kikinnos, a curled lock.] $A \not p p l$. uniparous cymose branching in which the daughter axes are developed right and left alternately (bot.).

cilia (sîl'iă) $n$. plu. [L. cilium, an eyelid.] Hairlike vibratile outgrowths of the ectoderm or processes found in many cells (biol.) ; barbicels of a feather (zool.); marginal hairlike processes (bot.); eyelashes (anat.).

ciliary (šll'ıărì) a. [L. cilium, an eyelid.] Pert. cilia; $a p p l$. certain structures in the eyeball (anat., zool.).

ciliate (šll'îat) a. [L. cilium, an eyelid.] Provided with cilia (biol.).

ciliated epithelium,-an epithelium found lining various passages, usually with columnar cells, the free edge of each of which has a bunch of fine tapering vibratile hairlike outgrowths (zool., phys.).

ciliograde (š̃llı̈ögrād) a. [L. cilium, an eyelid; gradus, a step.] Progressing by ciliary movement (zool.). eiliospore (sǐl'iöspōr) $n$. [L. cilium, an eyelid; Gk. sporos, a seed.] A protozoan swarm-spore with a coat of cilia (zool.).

cilium (sill'ı̆m) $n$. [L. cilium, an eyelid.] Sing. of cilia, which see.

cinchonin (š̌n'könĭn) $n$. [Named after a Countess Chinchon.] A white alkaloid found in various types of Rubiaceae (bot.).

cincinnus (s̆nsĭn'ŭs) $n$. [Gk. kikinnos, a curled lock.] A scorpioid cyme (bot.).

cinclides (sing'klìděz) $n$. plu. [Gk. kingklis, a latticed gate.] Perforations in the body wall of certain Anthozoa for the extrusion of acontia (zool.).

cinclis (sĭng'kliss) n. [Gk. kingklis, a latticed gate.] Sing. of cinclides, which see.

cingulate (sìng'gūlāt) a. [L. cingulum, a girdle.] Having a girdle or cingulum (biol.).

cingulum (sĭng'gūlŭm) $n$. [L. cingulum, a girdle.] Any structure which is like a girdle; a ridge round the base of the crown of a tooth ; a tract of fibres connecting the callosal and hippocampal convolutions of the brain; the outer ciliary zone on the disc of rotifers (anat., zool.). 
circinate (sër'sināt) a. [Gk. kirkinos, a circle.] Rolled on the axis, so that the apex is the centre (bot.).

circulation (sër'kūlā'shŭn) $n$. [L. circulatio, act of circulating.] The regular movement of any fluid within definite channels in the body (anat., phys.); the streaming movement of the protoplasm of plant cells (bot.).

circulus (sër'kūlǔs) $n$. [L. circulus, a circle.] Any ringlike arrangement of blood-vessels caused by branching or connection with one another, as circulus major of iris (anat.).

circumduction (sër'kŭmdŭk'shŭn) $n$. [L. circum, around; ductus, led.] The form of motion exhibited by a bone describing a conical space with the articular cavity as apex (anat., phys.).

circumferential (sër'kŭmf ĕrĕn'shăl) $a$. [L. circum, around ; ferre, to bear.] $A p p l$. cartilages which surround certain articulatory fossae (anat.).

circumflex (sër'kŭmflěks) a. [L. circum, around ; flectere, to bend.] Bending round; $a p p l$. certain arteries, veins, nerves (anat.).

circumfluence (sërkŭm'flooěns) $n$. [L. circum, around; fuens, flowing.] In Protozoa, the engulfing of food by the protoplasm flowing round and enveloping it after contact (zool.).

circumnutation (sër'kŭmnūtā'shŭn) $n$. [L. circum, around; nutare, to swim.] The irregular elliptical or spiral movement exhibited by the apex of a growing stem or shoot (bot.).

circumoesophageal (sër'kŭmēsŏf'ăjē'ăl) a. [L. circum, around; Gk. oisophagos, the gullet.] $A p p l$. structures or organs surrounding or passing along the gullet (zool.). circumpolar (sër'kŭmpō'lăr) $a$. [L. circum, around ; polus, end of axle.] $A p p l$. animals found at the Poles (zool.).

circumscissile (sër'kŭmsǐs'îl) $a$. ' [L. circum, around; scindere, to cut.] Appl. the form of dehiscence exhibited by a pyxidium (bot.).

circumvallation (sër'kŭmvălā'shŭn) $n$,

[L. circum, around; vallare, to

wall.] In Protozoa, the ingestion of food by the sending out of pseudopodia which ultimately surround without touching it (zool.).

cirrate (surr'āt) a. [L. cirratus, having ringlets.] Having cirri (zool.).

cirrhus and cirrhi,- - see cirrus.

cirrose (sirōs', sirrōos) a. [L. cirrus, a lock.] With cirri (zool.); with tendrils (bot.).

cirrus (šrr'ŭs) n., cirri (šrr'ī) plu. [L. cirrus, a lock.] Tendrils (bot.); the appendages of barnacles; the jointed filaments of the axis or of the aboral surface of crinoids ; the barbels of fishes; the respiratory and tactile appendages of worms; the organs of copulation in some molluscs and trematodes; hairlike structures on the appendages of insects (zool.).

cladanthous (klădăn'thŭs) $a$. [Gk. klados, a sprout ; anthos, a flower.] Having terminal archegonia on short lateral branches (bot.).

cladautoicous (klăd'ôtoik'üs) a. [Gk. klados, a sprout; autos, self ; oikos, house.] With antheridia on a special stalk (bot.).

cladocarpous (klăd'ökâr'pŭs) a. [Gk. klados, a sprout; karpos, a fruit.] Cladanthous, which see.

cladode (klăd’öd) n. [Gk. klados, a sprout.] A branch arising from the axil of a true leaf, resembling a foliage leaf, and consisting of a single internode (bot.).

cladogenous (klădŏj'ěnŭs) a. [Gk. klados, a sprout; genos, birth.] Cladanthous, which see.

cladome (klădōm') $n$. [Gk. klados, a sprout.] The group of superficially situated rays in a triaene (zool.).

cladophyll (klăd'öfĩl) n. [Gk. klados, a sprout ; phyllon, a leaf.] Cladode, which see.

cladoptosis (klăd'ŏptō'sǐs) n. [Gk. klados, a sprout ; ptosis, falling.] The annual shedding of twigs instead of leaves (bot.).

cladose (klăd'ōs, klădōs') a. [Gk. klados, a sprout.] Branched (biol.).

cladotyle (klăd'ötîl) n. [Gk, klados, a sprout ; tylos, a knob.] A rhabdus with one actine branched, the other tylote (zool.).

clasmatocyte (klăzmăt'ösīt, klăs'mătösit) n. [Gk. klasma, a fragment ; 
kytos, hollow.] A soft, much vacuolated, very variable cell in areolar tissue (phys.).

claspers (klăs'përz) n. plu. [M.E. claspen, to hold.] Rod-like processes on the pelvic fins of certain male elasmobranchs ; any modification of an organ or part to enable the two sexes to clasp one another (zool.) ; tendrils or climbing offshoots (bot.).

clathrate (klăth'rāt) a. [Gk. klethra, a lattice.] Lattice-like (biol.).

claustrum (klôs'trŭm) n. [L. claustrum, a bar.] In the cerebral hemispheres, a thin layer of grey substance lateral to the external capsule, bounding the lentiform nucleus (anat.).

clava (klă'vă) $n$. [L. clava, a club.] The knob-like end of the antennae of certain insects (zool.) ; the elongated swelling at the end of the fasciculus gracilis (anat.).

clavate (klă̌v'ât) a. [L. clava, a club.] Club-shaped ; thickened at one end (biol.).

clavicle (klăv'íkl) n. [L. clavis, a key.] The bone forming the anterior portion of the shoulder girdle (anat.); in animals, ventral.

clavicularium (klăvik'úlā'riǔm) $n$. [L. clavis, a key.] The epiplastron of Chelonia, probably corresponding to the clavicles of other forms (zool.).

clavula (klăv'ülă) n. [L. clava, a club.] A monactinal modification of a triaxon spicule; one of the minute ciliated spines on the fascioles of Spatangidae (zool.); the clavate sporophore of certain Fungi (bot.).

clavus (klắvŭs) n. [L.clavus, a nail.] The part of an elytron lying next to the scutellum in Hemiptera (zool.).

claw (klô) n. [A.S. clawu, a claw.] The stalk of a petal (bot.); a sharp curved nail on a finger or toe; the forceps of certain crustaceans; a curved process on the limbs of insects (zool.).

clearing foot,- the filamentous process of the exopodite of the second maxilla in the Phyllocarida (zool.).

cleavage (klē'vāj) n. [A.S. cleofan, to cut.] The series of karyo- kinetic divisions which change the egg into a multicellular embryo (cyt.).

cleavage nucleus, - the nucleus of the fertilized egg, produced by the orderly and intimate union of the male and female pronuclei (cyt.).

cleistocarp (klístökârp) n. [Gk. kleistos, closed ; karpos, a fruit.] Cleistothecium, which see.

cleistocarpous (klī'stökâr'pŭs) a. [Gk. kleistos, closed; karpos, a fruit.] $A p p l$. mosses with non-operculate capsules (bot.).

cleistogamous (klīstŏg'ămŭs) a. [Gk. kleistos, closed; gamos, marriage. Pert. or possessed of characteristics of cleistogamy (bot.).

cleistogamy (klî'stŏg'ămĩ) n. [Gk. kleistos, closed ; gamos, marriage.] State of having small inconspicuous flowers which are self-fertilizing and do not open; fertilization without opening (bot.).

cleistợgene (klî́stöjēn) n. [Gk. kleistos, closed ; genos, birth.] A plant with cleistogamous flowers (bot.).

cleistothecium (klī'stöthē'shüŭm) $n$. [Gk. kleistos, closed; theke, a box.] An ascocarp which remains closed and produces its spores internally (bot.).

eleithrum (kli'thrŭm) n. [Gk. kleithron, a key.] The pair of additional clavicles in Stegocephalia (pal.); the clavicular element of the pectoral girdle in some fishes (zool.).

elinandrium (klinnăn'driŭm) $n$. [Gk. kline, bed; aner, a man.] A cavity in the "column" between the anthers in Orchids (bot).

clinidium (klǐniัd'ǐm) $n$. [Gk. kline, a bed.] A filament in a pycnidium which produces spores (bot.).

clinosporangium (klī'nöspörăn'jiŭm) n. [Gk. kline, bed; sporos, seed; anggeion, a vessel.] Pycnidium, which see.

clitellum (klítěl'úm) $n$. [L. clitellae, a pack-saddle.] The saddle or swollen glandular portion of the skin of certain worms (zool.).

elitoris (klit'örǐs) $n$. [Gk. kleiein, to enclose.] An erectile organ, homologous with the penis, at the upper part of the vulva (anat.).

clivus (klívŭs) n. [L. clivus, a hill.] 
A shallow depression in the sphenoid, behind the dorsum sellae (anat.).

eloaca (klōā'kă, klō'ăkă) n. [L. cloaca, a sewer.] The common chamber into which intestinal, genital, and urinary canals open, in vertebrates except most mammals (zool.).

clone (klōn) n. [Gk. klon, a twig.] Desma, which see.

elonus (klö'nŭs) n. [Gk, klonos, violent motion.] A series of muscular contractions when the individual contractions are discernible; incomplete tetanus ( $p h y s$.).

clump (klŭmp) v. [Ger. klump, a mass.] To form lumps or knots (bot.).

clypeal (klíp'ěăl) a. [L. clypeus, a shield.] Pert. the clypeus of insects (zool.).

clypeate (klìp'ěãt) a. [L. clypeus, a shield.]. Round or buckler-like (biol.) ; having a clypeus (zool.).

clypeola (klīpēölă), clypeole (kliṕéōl) $n$. [L. clypeus, a shield.] A sporophyll in the spike of an Equisetum (bot.).

elypeus (klïp'ěŭs) n. [L. clypeus, a shield.] A shield on the anteromedian part of an insect's head (zool.); a band of tissue round the mouth of a perithecium of certain Fungi (bot.).

enemidium (nēmīd'ǐum, knēmìd'iŭm) n. [Gk. knemis, a legging.] The lower part of a bird's leg devoid of feathers.

enemis (nē'mǐs, knếmǐs) n. [Gk. knemis, a legging.] The shin or tibia (zool., anat.).

enida (nī'dă, knî'dă) n. [Gk. knide, a nettle.] A cnidoblast.

enidoblast (ní'döblăst, knī'döblăst) $n$. [Gk. knide, a nettle; blastos, a bud.] A stinging cell; a gobletshaped cell with a long barbed thread and poisonous fluid in the interior, and a trigger-like process projecting externally, found in certain Coelenterates (zool.).

enidocil (nī'döš̌l, knī'dösíl) $n$. [Gk. knide, a nettle ; L. cilium, an eyelid.] A minute process projecting externally from a cnidoblast (zool.). enidophore (nî'döfōr, knî'döfōr) $n$. [Gk. knide, a nettle; pherein, to bear.] A modified zooid which bears nematocysts, of the nature of a dactylozooid (zool.).

cnidopod (nī'döpŏd, knídöpŏd) $n$. [Gk. knide, a nettle; pous, a foot.] The drawn-out basal part of a nematocyst, embedded in the mesogloea (zool.).

cnidosac (nī'dösăk, knī'dösăk) n. [Gk. knide, a nettle; L. saccus, a bag.] A kidney-shaped swelling or battery, often protected by a hood, found on the dactylozooids of Siphonophores (zool.).

coadaptation (kōădăptā'shŭn) $n$. [L. cum, with; $a d$, to ; aptare, to fit.] The correlated variation in two mutually dependent organs (phys.). coagulation (kōăgūlā'shŭn) n. [L. cum, with ; agere, to drive.] Curdling or clotting; the changing from a liquid to a viscous or solid state by chemical reaction (phys.).

coagulin (kōăg'ülín) $n$. [L. cogere, to drive together.] Any substance capable of coagulating albuminous substances (phys.).

coagulum (kōăg'ulŭm) $n$. [L. cogere, to drive together.] Any coagulated mass (phys.).

coarctate (kôârk'tāt) a. [L. coarctare, to press together.] Closely connected (biol.); having abdomen separated from thorax by a constriction (zool.).

coarctate larva or pupa,-semipupa ; pseudopupa; a larval stage of certain Diptera (zool.).

cocei (kŏk'sī) n. plu. [Gk. kokkos, a seed.] Septicidal carpels; spore mother cells of certain hepatics (bot.); rounded cells, as some bacteria (bact.).

coccogone (kŏk'ögōn) n. [Gk. kokkos, a seed; gonos, birth.] A reproductive cell in certain Algae (bot.).

coecoid (kǒk'oid) a. [Gk. kokkos, a seed ; eidos, form.] Pert. a coccus ; spherical or globose (bot., bact.).

coceolith (kŏk'ölith) n. [Gk. kokkos, a seed; lithos, a stone.] A calcareous spicule in certain of the Flagellates (zool.).

coccospheres (kǒk'ösfērz) n.plu. [Gk. kokkos, a seed; sphaira, a globe.] Collections of undigested shells in certain Radiolarians (zool.). 
coccus (kŏk'ŭs) n. [Gk. kokkos, a seed.] Sing. of cocci, which see. coccygeal (kŏksı̌j'ě̆l) a. [Gk. kokkyx, the cuckoo.] Pert. or in the region of the coccyx (anat., zool.).

coccyx (kŏk'sǔks) n. [Gk. kokkyx, the cuckoo.] The part of the vertebral column beyond the sacrum.

cochlea (kŏk'lěă) n. [Gk. kochlias, a snail.] A division of the ear spirally coiled like a snail's shell (anat.).

cochlear (kŏk'lě̆r) a. [Gk. knchlias, a snail.] Pert. the cochlea (anat.).

cochleariform (kǒk'lěăr ífôrm) $a$. [Gk. kochlias, a snail ; L. forma, shape.] Spoon-shaped (zool.); pert. the thin plate of bone separating the tensor tympani canal from the Eustachian tube (anat.).

cochleate (kōk'lěāt) a. [Gk. kochlias, a snail.] Screw-like (anat.).

cocoon (kökoon') n. [F. cocon, a shell.] The protective case of many larval forms before they become pupae; the covering formed by many animals for their eggs (zool.).

coelenterate (sēlěn'těrāt) a. [Gk. koilos, hollow; enteron, intestine.] Pert. Coelenterata (zool.).

coelenteron (sēlěn'těrŏn) $n$. [Gk. koilos, hollow ; enteron, intestine.] The cavity in the body of a Coelenterate (zool.).

coeliac (sē'liăk) a. [Gk. koilia, belly.] Pert. the abdominal cavity; appl. arteries, veins, nerves (anat.).

coeloblast (sē'löblăst) $n$. [Gk. koilos, hollow; blastos, a bud.] A division of the embryonic endoblast (emb.).

coelogastrula (sē'lögăs'troolă) $n$. [Gk. koilos, hollow; gaster, stomach.] A gastrula developed from a blastula with a segmentation cavity $(z \circ o l$.).

coelom (sē'lǒm) n. [Gk. koilos, hollow.] A cavity of the body derived from the mesoblast (emb.).

coelomate (sélömāt, sēlō'māt), - see coelomic.

coelomic (sēlǒm'îk) a. [Gk. koilos, hollow.] Pert. or having a coelom (zool.).

coelomoduet (sēlō'mödǔkt) n. [Gk. koilos, hollow ; L. ducere, to lead.] The duct leading directly from the genital cavity to the exterior in Cephalopods and in Annulates (zool.).

coelomopores (sēlō'möpōrz) n. plu. [Gk. koilos, hollow; poros, a passage.] Ducts leading directly from the pericardial cavity of Nautilus to the exterior (zool.).

coelomostome (sēlō'möstōm) n. [Gk. koilos, hollow; stoma, mouth.] The external opening of a coelomoduct (zool.).

coelosperm (sē'löspĕrm) $\boldsymbol{n}$. [Gk. koilos, hollow; sperma, seed.] A carpel, hollow on its inner surface (bot.).

coelozoic (sē'lözō'îk) a. [Gk. koilos, hollow; zoon, an animal.] Appl. a trophozoite of a sporozoan when situated in some cavity of the body (zool.).

coenanthium (sēnăn'thǐŭm) n. [Gk. koinos, common; anthos, flower.] An inflorescence with a nearly flat receptacle having slightly upcurved margins (bot.).

coenenchyma (sēněng'kĭmă), coenenchyme (sēněng'kīm) $n$. [Gk. koinos, common; engchyma, infusion.] The common tissue which connects the polyps or zooids of a compound coral (zool.).

coenobium (sēnōbiŭm) $\boldsymbol{n}$. [Gk. koinos, common; bios, life.] A unicellular colony with no marked distinction between vegetative and reproductive units (biol.).

coenoblast (sē'nöblăst) $n$. [Gk. koinos, common ; blastos, a bud.] A germ layer which gives origin to the endoderm and mesoderm (zool.).

coenocyte (sē'nösīt) $n$. [Gk. koinos, common; kytos, a hollow.] A plant body in which the constituent protoplasts are not separated by cell walls (bot.).

coenoecium (sēnē'shiŭm) n. [Gk. koinos, common; oikos, a house.] The common groundwork of a polyzoan colony (zool.).

coenogamete (sē'nögămēt) $n$. [Gk. koinos, common; gamos, union.] A gamete with more than one nucleus (bot.).

coenosarc (sē'nösârk) n. [Gk. koinos, common; sarx, flesh.] The common tissue which unites 
the various polyps in a compound colony (zool.).

coenosteum (sēnǒs'těŭm) n. [Gk. koinos, common; osteon, a bone.] The common colonial skeleton in corals (zool.).

coenurus (sēnū'rŭs) n. [Gk. koinos, common; oura, a tail.] A metacestode with large bladder, from the walls of which a very large number of heads are formed (zool.).

coherent (köhē'rĕnt) a. [L. cohaerere, to stick together.] With similar parts united (bot.).

cohesion (köhëzhŭn) n. [L.cohaerere, to stick together.] The condition of union of the separate parts of a floral whorl (bot.).

cohort (kō'hôrt) $n$. [L. cohors, an enclosure.] Used in earlier classifications to denote a somewhat indefinitely limited group (biol.).

coleopterous (kǒl'ě̌̆p'tĕrŭs) a. [Gk. koleos, a sheath ; pteron, a wing.] Having the anterior wings hard and used as elytra (zool.).

coleorhiza (kǒl'ěrini'ză) n. [Gk. koleos, a sheath; rhiza, a root.] The layer surrounding the radicle (bot.).

colic (kǒl'ik) a. [Gk. kolon, the colon.] Pert. the colon (anat.).

collagen (kǒl'ăjĕn) n. [Gk. kolla, glue; genos, offspring.] A protein substance, probably an anhydride of gelatin, occurring as the chief constituent of the white fibres of connective tissue and the organic part of the bones ( $p h y s$. .).

collar (kŏlăr) $n$. [M.E. coler, a collar.] The choana of a collared cell; a prominent fold behind the proboscis in the Hemichorda; the fleshy rim projecting beyond the edge of a snail shell; any structure likened to a collar (zool.).

collateral (kǒlăt'ĕrăl) a. [L. cum, with; latera, sides.] Side by side; $a p p l$. bundles, as collateral bundle, with xylem and phloem in contact on one side only (bot.) ; $a p p l$. fine lateral branches from the axon of a nerve cell (anat.).

collateral circulation, - circulation established through anastomosis with other parts when the chief vein is obstructed ( $p$ hys.). collenchyma (kŏlĕng'kĭmă), collenchyme (kǒlěng'kīm) $n$. [Gk. kolla, glue; engchyma, infusion.] Parenchymatous tissue, with cells elongated and thickened at the angles (bot.); the middle layer of sponges (zool.).

collencyte (kǒl'ěnsît) n. [Gk. kolla, glue; kytos, hollow.] A clear cell with thread-like pseudopodia found in sponges (zool.).

colleterium (kŏl'ětē'rĭum) n. [Gk. kolla, glue.] A mucus-secreting gland in the female reproductive system of insects (zool.).

colleters (kŏlë'tĕrz) $n$. plu. [Gk. kolla, glue.] The hairs, usually secreting a gluey substance, which cover many resting buds (bot.).

colletocystophore (kŏlē'tösǐst'öfōr) $n$. [Gk. kolla, glue; kystis, a bladder; pherein, to bear.] The statorhab of Haliclystus (zool.).

collieulus (kǒlikk'ūlŭs) $n$. [L. colliculus, a little bill.] One of the prominences of the corpora quadrigemina; a rounded elevation near the apex of the antero-lateral surface of the arytaenoid cartilage (anat.).

colloblast (kŏl'öblăst) $n$. [Gk. kolla, glue; blastos, a bud.] A cell on the tentacles and pinnae of Ctenophores, which carries little globules of adhesive substance (zool.).

colloid (kŏl'oid) n. [Gk, kolla, glue ; eidos, form.] A gelatinous substance which does not readily diffuse through an animal or vegetable membrane; opp. crystalloid.

collophore (kǒl'öför) n. [Gk. kolla, glue; pherein, to bear.] The ventral tube of the Collembola (zool.).

collum (kŏl'ŭm) n. [L. collum, the neck.] Any collar-like structure (biol.); the basal portion of the sporogonium in mosses (bot.).

colon (kō'lŏn) n. [Gk. kolon, the colon.] The second portion of the intestine of insects; the part of the large intestine stretching from its junction with the small intestine to the rectum (zool., anat.).

colony (kŏl'ŏnǐ) $n$. [L. colonia, a farm.] Any collection of organisms living together, appl. ants, bees; a group of animals or plants living 
together and somewhat isolated; a group of bacteria in a culture (biol.) ; term appl. all the "persons" in a colonial Coelenterate (zool.).

columella (kǒl'üměl'ă) $n$. [L.columen, a column.] A prolongation of the stalk into the sporangium (bot.); the central pillar in the skeleton of some corals; the rod, partly bony, partly cartilaginous, connecting the tympanum with the inner ear in birds, reptiles, and amphibians; the central pillar in gasteropod shells (zool.); the axis of the cochlea (anat.).

columellar (kǒl'ùmĕlăr) a. [L. columen, a column.] Pert. a columella.

column (kŏl'ŭm), columna (kŏlŭm'nă) $n$. [L. columen, a column.] Any structure likened to a column, as spinal column; the actinian body; the stalk of a crinoid; a longitudinal bundle of nerve fibres in the white matter of the spinal cord ( $\mathrm{zool}$.); the nasal septum edge; thick muscular strands found in the ventricle of the heart (anat.); the stamens in the mallows; the united stamens and pistil in the orchids (bot.).

columnals (kǒlŭm'nălz) n. plu. [L. columen, a column.] Stem ossicles in crinoids (zool.).

columnar (kŏlŭm'năr) a. [L.columen, a column.] Pert. a column or columna.

coma (kō'mă) n. [Gk. kome, hair.] A terminal cluster of bracts as in the pine-apple; hairs found on certain seeds (bot.); stupor (phys.). comb-ribs, combs,-see swimmingplates.

comes (kō'mê̌z) n. [L. comes, a companion.] A blood-vessel that runs alongside a nerve (anat.).

comitalia (kǒmítăl'iă) n. plu. [L. comitari, to accompany.] Small di- or tri-actine spicules which accompany the principal spicules in sponges (zool.).

commensal (kŏměn'săl) n. [L. cum, with ; mensa, a table.] An organism living with another and sharing the food, both species as a rule benefiting by the association.

comminator (kŏm'ínātŏr) a. [L.cum, with ; minari, to threaten.] Appl. muscles which connect adjacent jaws in Aristotle's lantern (zool.). commissure (kŏm'îsūr) n. [L. cum, together ; mittere, to send.] The union-line between two parts; a connecting band of nerve tissue (zool., anat.); the carpellary cohesion plane (bot.).

communistic (kŏm'unnı̌s'tìk) a. [L.communis, common.] Appl. animals which live or have their nests together.

comose (kō'mōs) a. [L. comosus, hairy.] Furnished with a tuft of hairs (bot.).

compass (kŏm'păs) n. [L. cum, together; passus, a pace.] A curved bifid structure, part of Aristotle's lantern (zool.).

complemental male,- - a purely male form, usually small, found living in close proximity to the ordinary hermaphrodite form in certain animals, as barnacles.

complexus (kŏmplěk'sŭs) $n$. [L.cum, together ; plectere, to knit.] An aggregate ; appl. muscles (anat.). complicant (kǒm'plikănt) $a$. [L.cum, together; plicare, to fold.] Folding over one another; $a p p l$. the elytra of certain insects (zool.).

complicate (kǒm'plǐkāt) a. [L. cum, together; plicare, to fold.] Folded; $a p p l$. insect wings (zool.); appl. leaves folded longitudinally so that the right and left halves are in contact (bot.).

composite (kŏm'pöš̌t) a. [L. cum, together; ponere, to place.] Having the characteristics peculiar to the Compositae (bot.).

compound (kǒm'pownd) a. [L. cum, together ; ponere, to place.] Made up of several elements; $a p p l$. flowers, leaves, eyes.

compressor (kŏmprěs'ŏr) n. [L. cum, together ; premere, to press.] Something that serves to compress; appl. muscles (anat.).

conarium (könā'rǔŭm) n. [Gk. konarion, a little cone.] Transparent deep-sea larva of Vellella with red endoderm (zool.).

concentric (kŏnsěn'trǐk) a. [L. cum, together ; centrum, a centre.] Having a common centre (biol.); 
$a p p l$. bundles with wood in centre surrounded by bast (bot.).

conceptacle (kŏnsĕp'tăkl) n. [L.concipere, to conceive.] A depression in the thallus of certain Algae in which the reproductive organs are borne (bot.).

concha (kŏng'kă) n. [Gk. kongche, shell.] The cavity which opens into the meatus (anat.) ; the external ear; a projection from the lateral wall of the olfactory organ (zool.). conchiform (kŏng'kîfôrm) a. [Gk. kongche, a shell ; L. forma, shape.] shaped like a concha; shellshaped (biol.).

conchiolin (kŏngkīölín) n. [Gk. kongche, a shell.] The organic substance that forms the basis of the shells of molluscs.

conchology (kŏngkŏl'öjī) n. [Gk. kongche, a shell; logos, discourse.] The branch of zoology dealing with molluscs or their shells.

conchula (kŏng'kūlă) n. [Gk. kongche, a shell.] The conspicuous protuberant lip of the modified sulcus in Peachia (zool.).

concolorate (kŏnkŭl'örāt) a. [L.cum, with; color, colour.] Similarly coloured on both sides; appl. wings of insects.

concrescence (kŏnkrĕs'ĕns) $n$. [L. cum, together; crescere, to grow. The growing together of parts (biol.). conducting (kŏndǔk'ting) $a$. [L. conducere, to lead together.] Conveying ; $a p p l$. tissues, bundles (bot.). conduction (kŏndŭk'shŭn) $n$. [L. conducere, to lead together.] The transference of soluble matter from one part of a plant to another (bot.). conduetivity (kŏn'dŭktǐv'îtǐ) $n$. [L. conducere, to lead together.] Power of transmitting stimuli from a part irritated to others more or less remote (phys.).

conduplicate (kǒndū'plīkāt) a. [L. conduplicare, to fold together.] Complicate, which see.

condylar (kŏn'dǐlăr) a. [Gk. kondylos, a knuckle.] Pert. a condyle (anat.). condyle (kơn'dǐl) n. [Gk. kondylos, a knuckle.] A process on a bone for purposes of articulation.

condyloid (kŏn'dîloid) a. [Gk. kondylos, a knuckle; eidos, form.
Shaped like, or situated near a condyle (anat., zool.).

cone (kōn) n. [Gk. konos, a cone.]

The female flower of the Coniferae, with woody axis and spirallyarranged carpels (bot.); a conical elevation on an egg just before fertilization (emb.); a conical or flask-shaped cell of the retina (anat.).

cone of origin,-the small clear area at the point of exit of the axon (anat.).

cone-bipolars,-bipolar cells whose inner ends ramify in contact with the dendrites of the ganglionic cells (anat.).

confluence (kŏn'flooĕns) $n$. [L. cum, with; fluere, to flow.] The angle of union of the superior sagittal and transverse sinuses of the occipital bone (anat.).

congenerie (kŏn'jĕnĕr'î) $a$. [L. congener, of the same race.] Belonging to the same genus (biol.).

congenital (kŏnjĕn'îtăl) a. [L. cum, with; gignere, to beget.] Present at birth (anat.).

conglobate (kŏnglō'bāt) a. [L. cum, together; globus, a ball.] Ballshaped; $a p p l$. the gland on the lower side of the ductus ejaculatorius in insects (zool.).

conglomerate (kŏnglŏm'ěrāt) $a$. [L. cum, together; glomerare, to wind.] Bunched or crowded together (bot.). conical (kŏn'îkăl) a. [Gk. konos, a cone.] Cone-shaped; $a p p l$. calyx, ventricle, etc. (biol.).

conidial (kŏnĭd'iăl) a. [Gk. konis, dust.] Pert. a conidium.

conidiiferous (kŏnĭd'ĩff'ěrŭs) a. [Gk. konis, dust; L. ferre, to bear.] Giving rise to conidia (bot.).

conidiophore (kŏnǐd'ǐöfōr) $n$. [Gk. konis, dust ; pherein, to bear. A branch of the hyphae which bears the conidia (bot.).

conidium (kŏnĭd'ium) n. [Gk. konis, dust.] A fungal spore asexually produced and carried usually on sterigmata (bot.).

coniferous (könĭf'ĕrŭs) a. [Gk. konos, a cone ; L. ferre, to bear.] Conebearing (bot.).

conjugation (kŏn'joogā'shŭn) $n$. [L. 
cum, together with; jugare, to yoke.] The temporary union or complete fusion of two gametes or unicellular protists, which involves the fusion of their nuclei or at least a nuclear exchange (biol.).

conjunctiva (kŏnjŭngktīivă) $n$. [L. cum, together; jungere, to join.] The mucous membrane of the eye, lining the eyelids and reflected over the fore part of the sclera and cornea (anat.).

connate (kŏn'nāt, kŏnāt') a. [L.cum, together; natus, born.] Firmly joined together from birth (biol.).

connate-perfoliate,-joined together at the base so as to surround the stem (bot.).

connective (kŏnĕk'tǐv) n. [L. cum, together; nectere, to bind.] A connecting band of nerve tissue between two ganglia (zool.); the tissue separating the two lobes of an anther (bot.).

connective tissue, - a mesoblastic tissue with a large amount of intercellular substance in which fibres are developed (anat.).

connivent (kŏnī'vĕnt) a. [F.conniver, to wink.] Converging (biol.).

conoid (kō'noid) a. [Gk. konos, a cone ; eidos, form.] Cone-like, but not quite conical (biol.).

conoid ligament, - one of the fasciculi of the coraco-clavicular ligament (anat.).

conoid tubercle, - a small rough eminence on the posterior border of the clavicle, serving for the attachment of the conoid ligament (anat.).

consensual (kŏnsĕn'sūăl) a. [L. consentire, to feel together.] Appl. involuntary action correlated with voluntary action (phys.).

constant (kŏn'stănt) a. [L. constans, unchanged.] Changeless; invariable; appl. characters, structures (zool.).

constricted (kŏnstrǐk'těd) a. [L. constrictus, drawn together.] Compressed at regular intervals (bot.).

constrictor (kŏnstrǐk'tŏr) n. [L.constrictus, drawn together.] Amuscle which compresses or constricts, e.g., constrictor urethrae (anat.). contabescence (kŏn'tăbĕs'ĕns) $n$. [L. contabescere, to waste away.] Stamen abortion (bot.).

context (kŏn'těkst) n. [L. cum, together; texere, to weave.] The layers developed between the hymenium and the true mycelium in certain Fungi (bot.).

continuity (kŏn'tĭnū'îtǐ) n. [L.continuus, continuous.] Succession without a break, as continuity of the germ plasm (zool.).

continuous (kŏntǐn'ūŭs) a. [L. continuus, uninterrupted.] Not segmented or articulated (biol.).

contorted (kŏntôr'tĕd) a. [L. contorquere, to twist together.] Twisted; $a p p l$. aestivation in which one leaf overlaps the next with one margin, and is overlapped by the previous on the other (bot.).

contortuplicate (kŏn'tŏrtū'plǐkãt) $a$. [L. cum, with ; torquere, to twist ; plicare, to fold.] A bud with contorted and plicate leaves (bot.).

contour (kŏn'toor) $n$. [F. contourner, to twist.] Outline of a figure or body; $a p p l$. the outermost feathers that cover the body of a bird, the contour feathers (zool.).

contractile (kŏntrăk'tǐl) a. [L. cum, together; trahere, to draw.] Capable of contracting (biol.).

contractile cell, - any cell in a sporangium or an anther wall which by hygroscopic contraction helps to open them (bot.).

contractile flbre-cells, - elongated, spindle-shaped, more or less polyhedral, nucleated muscle-cells, containing a central bundle of fibrillae (anat.).

contractile vacuole,- a small spherical vesicle, found in the cytoplasm of many Protista, which appears and disappears with regularity (biol.).

contractility (kŏn'trăktîl'î̀i) n. [L. cum, together; trahere, to draw.] The power by which muscle-fibres are enabled to contract (phys.).

contracture (kŏntrăk'tūr) n. [L. contractus, drawn together.] Contraction of muscles persisting after the stimulus has been removed, seen especially in strong direct stimulation, and as death approaches (phys.). 
conuli (kŏn'ūlī) n. plu. [Gk. konos, a cone.] The tent-like projections on the surface of certain Sponges caused by the principal skeletal elements (zool.).

conus (könŭs) $n$. [Gk. konos, a cone.] Any cone-shaped structure, as the conus arteriosus, a structure between the ventricle and aorta in fishes and amphibians (zool.); the diverticulum of the right ventricle from which the pulmonary artery arises; conus medullaris, the tapering end of the spinal cord (anat.).

convergence (kŏnvĕr'jĕns) $n$. [L. convergere, to incline together.] The development of similar characters in organisms belonging to different groups (biol.).

convolute (kŏn'völüt) a. [L. cum, together; volvere, to wind.] Rolled together; $a p p l$. leaves and cotyledons (bot.); appl. shells in which the outer whorls overlap and conceal the inner (zool.).

convolution (kŏn'völü'shŭn) $n$. [L. cum, together; volvere, to wind.] A coiling or twisting, as of the brain, the intestine (anat.).

coprodaeum (kŏp'rödē'ŭm) n. [Gk. kopros, dung; odos, a way.] The division of the cloaca which receives the rectum (zool.).

coprolite (kŏp'rölīt) n. [Gk. kopros, dung; lithos, a stone.] Petrified faeces.

coprophagous (kŏprŏf'ăgŭs) a. [Gk. kopros, dung; phagein, to eat.] Feeding on dung; $a p p l$. insects.

copula (kŏp'ūlă) $n$. [L. copula, a bond.] A ridge in the development of the tongue formed by the union of the ventral ends of the second and third arches (anat.).

copularium (kŏp'ūlä'rǐum) $n$. [L. copula, a bond.] A cyst formed in gregarines round two associated gametocytes (zool.).

copulation (kớp'ūlä'shŭn) n. [L. copula, a bond.] Sexual union; coition (biol.).

coracoid (kŏrăkoid) a. [Gk. korax, a crow ; eidos, form.] Pert. the bone or process in the pectoral girdle (zool.).

coracoid bone,- - the part of the pectoral girdle between scapula and sternum (zool.). coracoid ligament, - the ligament which stretches over the suprascapular notch (zool.).

coracoid process, - the rudimentary coracoid element in most mammals fused to the scapula (zool.).

coralliferous (kŏr'ălíf'ĕrŭs) a. [Gk. korallion, coral ; L. ferre, to bear.] Coral-forming; made of coral (zool.).

coralline (kŏr'ălīn) a. [Gk. korallion, coral.] Resembling a coral; appl. Hydroids and Polyzoa; composed of coral (zool.) ; appl. certain Algae (bot.).

corallite (kŏr'ălīt) n. [Gk. korallion, coral.] Cup of a single polyp of coral (zool.).

coralloid (kŏrăloid) a. [Gk. korallion, coral; eidos, form.] Resembling, or branching like a coral (biol.).

corallum (kŏrăl'ǔm)n. [Gk. korallion, coral.] The skeleton of a compound coral (zool.).

corbicula (kôrb̌̌k'ūlă) n. [L. corbis, a basket.] The pollen apparatus of a bee; the fringe of hair on the tibia (zool.).

corbula (kôr'būlă) $n$. [L. corbis, a basket.] The phyllactocarp of Aglaeophenia, etc., a stem with alternate branches rising upwards and forming a pod-like structure (zool.).

cord (kôrd) n. [Gk. chorde, a cord.] Any chord-like structure, as spinal, spermatic cord (anat.).

cordate (kôr'dāt) a. [L. cor, the heart.] Heart-shaped (bot.).

cordiform (kôr'difôrm) a. [L. cor, the heart; forma, shape.] Heart-shaped (biol.).

cordiform tendon,- the central aponeurosis of the diaphragm (anat.).

cordylus (kôr'dúlŭs) n. [Gk. kordyle, a swelling.] An intertentacular exumbral structure with core of vacuolated cells and flattened ectoderm (zool.).

coriaceous (kō'rīà'shŭs) a. [L. corium, leather.] Leathery; $a p p l$. leaves (bot.).

corium (kō'rŭŭm) n. [L. corium, leather.] The middle division of an elytron (zool.); the deeper-seated layer of the skin, consisting of a vascular connective tissue?(anat.). 
cork (kôrk) n. [Sp. alcorque, cork.] A tissue derived usually from the outer layer of the cortex in woody plants (bot.).

corm (kôrm), cormus (kôr'mŭs) $n$. [Gk. kormos, a trunk.] An enlarged solid subterranean stem, rounded in shape, composed of two or more internodes and covered externally by a few thin membranous scales or cataphyllary leaves (bot.).

cormel (kôr'mĕl) n. [Gk. kormos, a trunk.] A secondary corm produced by an old corm (bot.).

cormidium (kôrmĭd’ĭum) n. [Gk, kormos, a trunk.] An aggregation of individuals in a Siphonophore, borne on the coenosarc and capable of liberation therefrom (zool.).

cormoid (kôr'moid) a. [Gk. kormos, a trunk ; eidos, form.] Like a corm (bot.).

cormophylogeny (kôr'möfīlǒj'ěnǐ) $n$. [Gk. kormos, a trunk; phyle, a tribe ; genos, offspring.] The development of families or races (biol.).

cormophyte (kôr'möfīt) n. [Gk. kormos, a trunk; phyton, a plant.] A plant which possesses stem, root, and leaf (bot.).

cormous (kôr'mŭs) a. [Gk. kormos, a trunk.] Corm-producing (bot.).

cornea (kôr'něă) $n$. [L. cornu, horn.] The transparent covering on the anterior surface of the eyeball (anat., zool.); the outer transparent part of each element of a compound eye (zool.).

corneagen (kôr'něăjĕn') a. [L. cornu, horn; Gk. genos, offspring.] Corneaproducing; $a p p l$. cells lying immediately below the cuticle, which secrete the cuticular lens and are renewed on ecdysis (zool.).

corneal (kồr'něăl) a. [L. cornu, horn.] Pert. the cornea.

corneous (kôr'ně̆ŭs) a. [L. cornu, horn.] Horny; $a p p l$. the sheath covering the bills of birds.

corniculate (kôrnìk'ūlāt) a. [L.cornu, horn.] Having horns (zool.).

corniculate cartilages,-two small, conical, yellow elastic cartilages articulating with the summit of the arytaenoid cartilages (anat., zool.). corniculum (kôrnǐk'ūlŭm) n. [L. cornu, horn.] A small horn or horn-like process.

cornua (kôr'nūă) n. plu. [L. cornu, horn.] Horn-like prolongations; $a p p l$. bones, nerve tissues, cavities, etc.

cornucopia (kôr'nūkō'pĭă) n. [L. cornu, horn; copia, plenty.] The horizontal portion of the taeniae of the fourth ventricle (anat.).

cornute (kôrnūt') a. [L. cornu, horn.] With horn-like processes (bot.).

corolla (körŏl'ă) n. [L. corona, a crown.] The petals of a flower (bot.).

corollaceous (kŏrólā'shŭs) $a$. [L. corona, a crown.] Pert. a corolla (bot.).

corolliferous (kŏr'ŏlíf'ĕrŭs) a. [L. corona, a crown ; ferre, to bear.] Having a corolla (bot.).

corona (körö'nă) $n$. [L. corona, a crown.] A cup-shaped body formed by the union of scales on the perianth leaves at the junction of claw and limb (bot.); the theca and arms of a Crinoid; the ciliated disc of certain animals (zool.); the head or upper portion of any structure (anat.).

corona radiata,-the layer of cells immediately surrounding the mammalian egg ( $(\mathrm{mb} b$.) ; the fibres of the internal capsule (anat.).

coronal (kŏrŏnăl) a. [L. corona, a crown.] Situated or lying in the coronal sutural plane (anat.).

coronary (kŏrŏnărĭ) a. [L. corona, a crown.] Crown-shaped or crownlike ; appl. arteries, bones, sinuses, ligaments (anat., zool.).

coronary arteries,-arteries supplying the tissue of the heart itself (anat.).

coronary bone, - a small conical bone in the mandible of reptiles; the small pastern bone of the horse (zool.).

coronary sinus, - a venous channel in the posterior part of the coronary sulcus and covered by muscular fibres from the left atrium (anat.). coronated (kŏr'önā'těd) a. [L. corona, a crown.] Supplied with a crown (zool., bot.).

coronet (kŏr'önĕt) $n$. [L. corona, a 
crown.] The burr of an antler (zool.).

coronoid (kŏrŏonoid) a. [Gk. korax, a crow ; eidos, form.] Shaped like a beak; appl. processes (anat.).

corpora adiposa, - the fat bodies of amphibians, attached to the dorsal wall of the body cavity (zool.).

corpora cavernosa,--erectile masses of tissue, stiffening the anterior surface of the penis (anat., zool.).

corporaquadrigemina,-four rounded eminences which form the dorsal part of the mesencephalon (anat.). corpus (kôr'pŭs) n., corpora (kôr'pöră) plu. [L. corpus, a body.] Any fairly homogeneous structure which forms part of an organ (anat.).

corpus spongiosum, - a mass of erectile tissue forming the posterior wall of the penis (anat., zool.).

corpuscle (kôr'pŭsl, kŏrpŭs'l) $n$. [L. corpusculus, a small body.] A protoplasmic cell, floating freely in some fluid, or embedded in some matrix; $a p p l$. various sensory structures (anat.); any small protoplasmic mass of definite function or shape (bot.).

correlation (kŏr'ělä'shŭn) $n$. [L.L. correlatio, relationship.] Similarity or mutual relationship (biol.).

corrugator (kŏr'oogā'tŏr) a. [L. cum, together ; rugare, to wrinkle.] Wrinkled or wrinkling; $a p p l$. muscles (anat.).

cortex (kôr'těks) $n$. [L. cortex, bark.] The extrastelar fundamental tissue of the sporophyte (bot.); the outer or more superficial part of an organ (anat.).

cortical (kôr'tǔkăl) a. [L. cortex, bark.] Pert, the cortex.

corticate (kôr'tǐkāt) a. [L. cortex, bark.] Having a special outer covering (anat., biol.).

corticiferous (kôr'tĭsĭf'ěrŭs) $a$. [L. cortex, bark; ferre, to carry.] Forming or having a bark-like cortex (bot.).

corticostriate (kôr'tîköstrīāt) a. [L. cortex, bark; stria, a channel.] $A p p l$. fibres which join the corpus striatum to the cerebral cortex (anat.).

cortina (kôrtī'nă) n. [L. cortina, a curtain.] The velum in Agarics (bot.). cortinate (kôr'tĭnāt) a. [L. cortina, a curtain.] Having a velum; of a cobweb-like texture (bot.).

Corti's organ, - the organon spirale, placed on the inner portion of the membrana basilaris of the ear (anat.).

corymb (kŏr'ĭmb) n. [Gk. korymbos, a cluster of flowers.] A raceme with lower pedicels elongated so that the top is nearly flat (bot.).

corymbose (kǒr'ímbōs) a. [Gk. korymbos, a cluster of flowers.] Pert. or like a corymb; arranged in a corymb (bot.).

cosmine (kŏs'miñn) $n$. [Gk. kosmios, regularly.] The outer regular layer of dentine-like material in ganoid scales (zool.).

cosmopolite (kǒzmŏp'ölīt) a. [Gk. kosmos, world; polites, citizen.] World-wide in distribution (biol.).

costa (kŏs'tă) $n$. [L. costa, a rib.] A rib; anything rib-like in shape (anat.) ; anything rib-like, as a ridge on shell, coral, insect-wing (zovl.).

costal (kŏs'tăl) a. [L. costa, a rib.] Pert. ribs or rib-like structures; $a p p l$. the bony shields of Chelonia ; pert. the primary brachial series in crinoids (zool.); pert. a main rib (bot.).

costalia (kŏstắlǐă) $n$. plu. [L. costa, a rib.] The supporting plates in the theca of the Cladoidea (zool.). costate (kŏs'tāt) a. [L. costa, a rib.] With one or more longitudinal ribs (bot.); with ridges or costae (zool.). coterminous (kōtĕr'mǐnŭs) $a$. [L. cum, with; terminus, an end.] Of similar distribution (biol.).

cotyledon (kŏt'illë'dŏn) n. [Gk. kotyle, a cup.] The primary or first leaf of an embryonic sporophyte (bot.); the definite patches of villi on the placenta of a mammal (zool.).

cotyledonary (kŏt'ilēe'dŏnărī) a. [Gk. kotyle, a cup.] Pert. cotyledons (bot.); with cotyledons on the placenta (zool.).

cotyloid (kǒt'ı́loid) a. [Gk. kotyle, a cup ; eidos, form.] Cup-shaped ; pert. the cotyloid cavity (anat.).

cotylophorous (kŏt'rlǒf'örŭs) a. [Gk. kotyle, a cup; pherein, to bear.] With a cotyledonary placenta (zool.). 
cotype (kō'tīp) n. [L. cum, with ; typus, an image.] An additional type specimen, frequently collected in the same place at the same time, or a specimen from a description of which, along with others, the type is drawn up (biol.).

cover-scales,-small scales arranged spirally and developed directly on the axis of a cone of the Coniferae (bot.).

covert (kŭv'ërt) $n$. [F. couvrir, to cover.] Appl. the feathers covering the bases of the quills in birds. cowled (kowld) a. [L. cucullus, a hood.] Furnished with or shaped like a hood.

coxa (kŏk'să) n. [L. coxa, hip.] The proximal joint of an insect leg (zool.).

coxal (kŏk'săl) a. [L. coxa, hip.] Pert. the coxa (zool.).

coxopodite (kŏksŏp'ödīt) n. [L. coxa, hip ; Gk. pous, a foot.] The proximal part of the protopodite of a crustacean limb (zool.).

crampon (krăm’́ŏn) n. [O.H.G. chramph, crooked.] An aerial root, as in the ivy (bot.).

cranial (krä'nı̆ăl) a. [Gk. kranion, the head.] Pert. the skull, or that part which encloses the brain; appl. nerves, muscles, blood-vessels, bones, etc.

craniate (krā'nǐāt) a. [Gk. kranion, the head.] Having a skull (zool.).

craniology (krā'nǐŏl'öjî) n. [Gk. kranion, the head; logos, discourse.] The study of the skull (anat.).

craniometry (krā'nǐŏm'ětrǐ) n. [Gk. kranion, the head; metron, a measure.] The science of the measurement of skulls.

cranium (krā'nǐŭm) n. [Gk, kranion, the head.] The skull of any craniate, or more particularly, that part enclosing the brain (anat., zool.).

craspedodromous (krăs'pēdŏd'römŭs) a. [Gk. kraspedon, an edge ; dromein, to run.] With nerves running directly from mid-rib to margin (bot.).

craspedote (krăs'pēdōt) a. [Gk. kraspedon, an edge.] Having a velum (zool.).

eraspedum (krăs'pēdŭm) n. [Gk. kraspedon, an edge.] A mesenteric filament of sea-anemones (zool.).

craticular (krătík'ūlăr) a. [L. craticula, a gridiron.] Crate-like ; $a p p l$. a stage in the life-history of a diatom where new valves are formed before the old are lost (bot.).

creatine (krē'ătĭn) n. [Gk. kreas, flesh.] A nitrogenous substance found in the muscles, brain, and blood of vertebrates (phys.).

creatinine (krēăt'innēn) n. [Gk. kreas, flesh.] A nitrogenous substance found in muscles and urine ( $p h y s$. .). cremaster (krĕmăs'tĕr) $n$. [Gk. kremannunai, to hang.] A thin muscle in the spermatic cord (anat.); a stout terminal abdominal spine in subterranean insect pupae; the anal hooks for pupae suspension (zool.).

cremocarp (krěm'ökârp) n. [Gk. kremannunai, to hang; karpos, fruit.] An inferior, dry, indehiscent, two-celled, two-seeded fruit (bot.).

crenate (krễnāt, krĕn'āt) a. [L.crena, a notch.] With scalloped margins (bot.).

crenulated (krĕn'ūlātěd) $a$. [Dim. of L. crena, a notch.] With margins minutely crenate (bot.).

crepis (krếpis) $n$. [L. crepis, unknown.] The term $a p p l$. the fundamental spicule by deposition of silica upon which a desma is formed (zool.).

crepitation (krĕpitā'shŭn) $n$. [L. crepare, to crack.] In insects, the discharge with an explosive sound of a fluid (zool.).

crepuscular (krěpǔs'kūlăr) $a$. [L. crepusculum, dusk.] Flying before sunrise or in twilight; $a p p l$. certain insects and birds (zool.).

crescent (krěs'ĕnt) $n$. [L. crescere, to grow.] A term appl. various crescentic structures found in glands (anat.).

crescents of Gianuzzi (jânoot'sē), small crescent-shaped bodies with polyhedral granular cells lying between the cells and the membrana propria in certain alveoli of the salivary glands (anat.).

crest (krěst) n. [L. cresta, a crest.] 
A ridge on a bone; a fleshy longitudinal ridge as in newts (zool.).

cretaceous (krĕtā'shŭs) a. [L. creta, chalk.] $A p p l$. the entire period between the Jurassic and Tertiary, or the upper division of this period (pal.)

cribellum (krǐběl'üm) n. [L. cribrum, a sieve.] A special spinning organ found only in certain spiders (zool.). cribriform (krǐb'rǐfôrm) a. [L.cribrum, a sieve ; forma, shape.] Sieve-like (bot., anat., zool.).

cribriform cell,-sieve cell (bot.). cribriform organ,- the folded membrane carrying papillae in the interradial angles of certain starfishes (zool.).

cribriform plate, - the horizontal portion of the ethmoid perforated with many foramina for the exit of the olfactory nerves (anat., zool.).

cricoid (kriḱ'oid) n. [Gk. krikos, a ring; eidos, form.] A ring-like cartilage in the larynx, articulating with the thyroid and the arytaenoid cartilages (anat.).

erissal (krǐs'ăl) a. [L. crissare, to move the haunches.] Pert. the crissum (zool.).

erissum (krĭs'üm) n. [L. crissare, to move the haunches.] The circumcloacal region of a bird, or the feathers thereon (zool.).

crista (krĭs'tă) $n$. [L. crista, a crest.] A crest or ridge; the projection from the ectoloph into the median valley in lophodont molars (zool.).

crochet (krŏch'ět) $n$. [F. crochet, a small hook.] The projection of the protoloph in lophodont molars (zool.).

crop (krŏp) n. [M.E. croppe, top of a plant.] A sac-like dilatation of the gullet of a bird ; a similar structure in an insect or worm (zool.).

cross (krŏs) n. [M.E. crois, a cross.] An organism produced by the mating of parents of different breeds (biol.).

crotaphite (krōt'ăfît) n. [Gk. krotaphos, of the temples.] The temporal fossa (anat.).

erotchet (krŏch'ět) n. [F. crochet, a small hook.] A curved chaeta, notched at the end (zool.).

crown (krown) n. [L. corona, a crown.] The grinding surface of a tooth; the distal part of an antler; the crest, the head; the cup and arms of a crinoid (zool.).

erucial ligaments, - two ligaments which connect the femur and tibia in the knee-joint (anat.).

cruciate (kroo'shīāt, kroo'šàt) a. [L. crux, cross.] With leaves or petals in the form of a cross (bot.); $\mathrm{Y}$-shaped or +-shaped, appl. muscles, ligaments (anat.).

cruor (kroo'ơr) $n$. [L. cruor, blood.] The clots in coagulated blood (phys.).

cruorin (kroo'ŏrĭn) n. [L. cruor, blood.] Haemoglobin (phys.).

crura cerebri, - two cylindricalmasses at the base of the brain, they emerge from the pons and disappear into the substance of the cerebral hemispheres (anat.).

crural (kroo'răl) a. [L. crus, leg.] Pert. the thigh (anat.).

crureus (kroo'rěus) $n$. [L. crus, leg.] The vastus internus muscle of the thigh (anat.).

crus (krŭs) n., crura (kroo'ră) plu. [L. crus, leg.] The shank; any body likened to a leg or to a pair of legs (anat.).

crusta (krŭs'tă) n. [L. crusta, a shell.] The ventral part of the substantia nigra of the cerebral peduncles (anat.); the cement layer in teeth (zool.).

crustaceous (krŭstā'shŭs) a. [L. crusta, a shell.] With crustacean characteristics (zool.).

crypt (kript) $n$. [Gk. kryptos, hidden.]

A simple glandular tube or cavity (anat.).

cryptocarp (krĭp'tökârp) n. [Gk. kryptos, hidden; karpos, fruit.] A fruit-like structure which is really the sporophyte phase in the Red Algae (bot.).

cryptogam (krĭp'tögăm) $n$. [Gk. kryptos, hidden; gamos, union. A name given to that group of plants for the supposed reason that sexual reproduction was concealed; $c f$. phanerogam (bot.).

eryptoneurous (krĭp'tönū'rŭs) a. [Gk. kryptos, hidden; neuron, nerve.] With no definite or distinct nervous system (zool.). 
cryptostomata (krĭp'töstŏm'ătă) $n$.plu.

[Gk. kryptos, hidden; stoma, mouth.] Non-sexual conceptacles in the Fucaceae (bot.).

cryptozoic (krīp'tözōîk) a. [Gk. kryptos, hidden; zoon, animal.] Appl. fauna dwelling in darkness, or under stones, bark, etc. (biol.).

crystallin (kris'tălĭn) n. [Gk. krystallos, ice.] A globulin which is the principal chemical constituent of the lens of the eye (phys.).

crystalline (krǐs'tălīn) a. [Gk. krystallinos, crystalline.] Transparent; $a p p l$. various structures (anat.).

crystalloid (krǐs'tăloid) n. [Gk. krystallos, ice; eidos, form.] A substance which in solution readily diffuses through an animal membrane; $o p p$. colloid; $a p p l$. crystal of proteid matter found in oily seeds (bot.).

ctene (tēn, ktēn) n. [Gk. kleis, a comb.] The swimming-plates of Ctenophores (zool.).

ctenidium (těnĭd'î̆m, ktěnĭd'ĭŭm) $n$. [Gk. kteis, a comb.] The respiratory apparatus in the Mollusca, feather-like or comb-like in appearance (zool.).

etenocyst (tĕn'ösist, ktěn'ösǐst) $n$. [Gk. kteis, a comb; kystis, abladder.] The aboral sense organ of the Ctenophora (zool.).

ctenoid (těn'oid, ktē'noid) a. [Gk. kteis, a comb; eidos, resemblance.] With a comb-like margin, appl. scales (zool.).

ctenophoral (tĕnŏf'örăl, ktĕnŏf'örăl) a. [Gk. kteis, a comb; pherein, to bear.] Supplied with swimmingplates (zool.).

cubital (kū'bităl) a. [L. cubitalis, of the elbow.] Pert. the ulna (anat., zool.).

cubitus (kü'bĭtŭs) n. [L. cubitus, the elbow.] The ulna, forearm (anat.); the primary vein in an insect's wing (zool.).

cuboid (kū'boid) a. [Gk. kuboeides, cube-like.] Nearly cubic in shape (anat.) ; n., the outermost of the distal tarsal bones (zool.).

cuboidal (kūboid'ăl) a. [Gk. kuboeides, cube-like.] Pert. the cuboid (anat., zool.).

cucullate (kū'kǔlāt) a. [L. cucullus, a cap.] With hood-like sepals or petals (bot.) ; with prothorax hoodshaped (zool.).

cuirass (kwē'răs, kwērăs') n. [F. cuirasse, a leathern jacket.] Bony plates or scales arranged like a cuirass (zool.).

culm (kŭlm) n. [L. culmus, a stalk.] The stem of grasses and sedges (bot.).

culmen (kŭl'mĕn) $n$. [L. cellere, to push.] The ridge of a bird's beak $(z \circ o l$.$) ; the anterior raised part of$ the monticulus (anat.).

cultellus (kŭltěl'ŭs) n. [L. cultellus, a little knife.] A sharp knife-like organ, one of the mouth-parts of certain blood-sucking flies (zool.).

culture (kŭl'tūr) $n$. [L. colere, to till.] The cultivation of micro-organisms in prepared media (bact.).

cumulus (kū'mūlŭs) $n$. [L. cumulus, a heap.] The corona radiata (emb.). cuneate (kū'něāt) a. [L. cuneus, a wedge.] Wedge-shaped; $a p p l$. leaves with broad abruptly-pointed apex, and tapering to the base (bot.).

cuneiform (kūnē'îfôrm) a. [L. cuneus, a wedge; forma, shape.] Pert. the distal tarsal bones (anat.).

cuneus (kū'nềŭs) n. [L. cuneus, a wedge.] A division of the elytron of certain insects (zool.); a wedgeshaped area between the calcarine fissure and the medial part of the parieto-occipital fissure (anat.).

cup (kŭp) n. [A.S. cuppe, a cup.] Any structure resembling a cup (biol.).

cupula (kü'pūlă) $n$. [L. cupula, a little tub.] The bony apex of the cochlea; the apex of the lungs (anat.).

cupule (kŭp'ül) n. [L. cuppa, a cup.] The involucre of the female flower of the oak, etc.; the gemmaebearing cup of Marchantia (bot.); a small sucker of various animals (zool.).

curviserial(kŭr'visēériăl) a. [L.curvus, a curve; series, a row.] Appl. phyllotaxis in which the divergence is such that the orthostichies themselves are slightly twisted spirally (bot.).

cushion (koosh'ün) n. [M.E.cuischen, 
a cushion.] The central thick region in the prothallus of a fern (bot.).

cusp (kŭsp) n. [L. cuspis, a point.] A prominence, as on teeth (anat.); a sharp point (bot.).

cuspidate (kŭs'pĭdāt) $a$. [L. cuspidare, to make pointed.] Terminating in a point; $a p p l$. leaves (bot.); pointed; $a p p l$. teeth (zool.).

cutaneous (kūtā'nêus) a. [L. cutis, the skin.] Pert. the skin.

cuticle (kü'tǐkl) $n$. [L. cutis, skin.] An outer skin or pellicle (zool., anat.); the epidermis (bot.).

cuticular (kūtǐk'ūlăr) a. [L. cutis, skin.] Pert. the cuticle or external integument.

cuticular transpiration,-transpiration through the cuticle, of gases, etc. (phys.).

cutin (kū'tĭn) $n$. [L. cutis, skin.] A substance allied to cellulose found in the external layers of the thickened epidermal cells (bot.).

cutinization (kū'tĩnīzā'shŭn) n. [L. cutis, skin.] The deposition of cutin in the external cells, thereby forming a cuticle (bot.).

cutis (kü'tǐs) $n$. [L.cutis, skin.] The corium, or deeper layer of the skin (anat.).

Cuvierian organs (kūvērrăn), glandular tubes extending from the cloaca of Holothurians (zool.).

cyanic (siăn'ík) a. [Gk. kyanos, dark blue.] Appl. flowers of a blue colour (bot.).

cyanophilous (sīănŏf'ílŭs) a. [Gk. kyanos, blue; philein, to love.] With special affinity for blue or green dyes; $a p p l$. a structure in a cell (zool.).

cyanophyll (siăn'öfil) $n$. [Gk. kyanos, blue; phyllon, a leaf.] A bluishgreen colouring matter in plants (bot.).

cyathium (siăth'iŭm) n. [Gk. kyathos, a cup.] The peculiar inflorescence in Euphorbia, a cup-shaped involucre with marginal glandular scales, and inside, stamens and a stalked gynoecium, each stamen and the gynoecium being a separate flower (bot.).

eyathozooid (sîăthözōoid) n. [Gk. kyathos, cup ; zoon, animal ; eidos, shape.] The primary zooid in certain Tunicates (zool.).

cyathus (sīăthŭs) $n$. [Gk. kyathos, a cup.] A small cup-shaped organ; the gemma-cup of Marchantia (bot.). cycle $\left(\mathrm{si}^{\prime} \mathrm{kl}\right) n$. [Gk. kyklos, a circle.] The circulation of a fluid through a definite series of vessels (anat.).

cyclic (sî́klikk) a. [Gk. kyklos, a circle.] Having the parts of the flower arranged in whorls (bot.).

cyclical (sǐ́klǐkăl) a. [Gk. kyklos, a circle.] Cyclic.

cyclocoelic (sī'klösē'lǐk)a. [Gk. kyklos, a circle; koilia, intestines.] With the intestine coiled in one or more distinct spirals (zool.).

cyclogenous (sīklŏj'ěnŭs) a. [Gk. kyklos, a circle; genos, offspring.] Exogenous; $a p p l$. a stem growing in concentric circles (bot.).

cycloid (síkloid) a. [Gk. kyklos, a circle ; eidos, shape.] $A p p l$. scales whose free border presents an even curve (zool.).

cyclosis (sīklō'sǐs) $n$. [Gk, kyklosis, a whirling round.] The movement or circulation of protoplasm within a cell (biol.).

cyclospermous(sî'klöspĕr'mŭs) $a$. [Gk. kyklos, a circle ; sperma, a seed.] With embryo coiled in a circle or spiral (bot.).

cyclospondylic (sî'klöspŏndìl'îk) a. [Gk. kyklos, a circle ; sphondylos, a vertebra.] $A p p l$. centra in which the internal calcareous matter is confined to the middle zone (zool.). cylinder (šll'indër) $n$. [Gk. kylindros, a cylinder.] Any region marked by definite tissue (bot.).

cylinđrical (sǐlǐn'drǔkăl) a. [Gk. kylindros, a cylinder.] Appl. leaves rolled on themselves, or to solid cylinder-like leaves (bot.).

cymbiform (sĭm'bǐfôrm) $a$. [L. cymba, a boat; forma, shape.] Boatshaped.

cyme (sīm) $n$. [L. cyma, a young sprout of cabbage.] Any determinate inflorescence (bot.).

cynarrhodium (sinărō'diŭm), cynarrhodon (sĭnărō'dŏn) n. [Gk. kyon, a dog ; rhodon, a rose.] An etaerio with the achenes placed on a concave thalamus (bot.).

cynopodous (sinŏp'ödŭs) a. [Gk. 
kyon, a dog; pous, a foot.] With non-retractile claws (zool.).

eyphella (sīfĕl'ă) n. [Gk. kyphella, hollow of the ear.] A small cup found on the thallus of certain Lichens (bot.).

cypsela (sı̌p'sělă) n. [Gk. kypsele, a hollow vessel.] An inferior bicarpellary achene (bot.).

cyst (šst) n. [Gk. kystis, a bladder.] The enclosing membrane (as distinct from the protoplasm) around a resting cell or apocyte (zool.); a bladder or air vesicle in certain Seaweeds (bot.).

cystein (sis'tê̌n) $n$. [Gk. kystis, a bladder.] A proteid decomposition product (phys.).

cystenchyma (sǐstěng'kĭmă) n. [Gk. kystis, a bladder; engchyma, infusion.] A parenchyma in sponges with large vesicular cell-structure (zool.).

cystencytes (š̌s'těnsīts) n. plu. [Gk. kystis, a bladder; kytos, hollow.] In sponges, collencytes which have acquired a vesicular structure (zool.).

cystic (šs'tǐk) $a$. [Gk, kystis, a bladder.] Pert. a cyst (biol.) ; pert. the gall or urinary bladder (anat.).

cysticercoid (sís'tísěr'koid) a. [Gk, kystis, a bladder; kerkos, a tail; eidos, form.] Appl. the bladderworm stage of tape-worms (zool.). eysticercus (š̃s'ť̌sĕr'kŭs) n. [Gk. kystis, a bladder; kerkos, a tail.] The larval form or bladderworm stage of certain tape-worms (zool.). cysticolous (sǐstĩk'ölŭs) a. [Gk. kystis, a bladder; L. colere, to inhabit.] Living in a cyst (zool.).

cystid (š̌s'ťd) n. [Gk. kystis, a bladder.] A fossil form of any of the Cystoidea (pal.).

eystidium (sǐstǐd'ium) $n$. [Gk. kystis, a bladder.] A large inflated cell in the hymenial layer of some Fungi (bot.).

cystoarian (š̌s'töä'rǐăn) a. [Gk. kystis, a bladder.] Appl. gonads when they are enclosed in coelomic sacs, as in most Teleosts; opp. gymno$\operatorname{arian}(z o o l$.$) .$

cystocarp (sis'tökârp) n. [Gk. kystis, a bladder; karpos, fruit.] Cryptocarp, which see. cystocyte (š̌'tösīt) $n$. [Gk. kystis, a bladder; kytos, hollow.] Cystencyte, which see.

cystogenous (š̌stŏj'ĕnŭs) $a$. [Gk. kystis, a bladder ; genos, offspring.] Cell-forming ; appl. large nucleated cells in the cercaria of Distomum which secrete the cyst (zool.).

eystolith (sis'tölïth) $n$. [Gk. kystis, a bladder; lithos, a stone.] An irregular mass of calcium carbonate found in epidermal cells, as in the nettle (bot.).

cyston (sǐs'tŏn) $n$. [Gk. kystis, a bladder.] A dactylozooid in the Siphonophora modified for excretory purposes (zool.).

cytase (sī'tās) n. [Gk. kytos, hollow.] An enzyme responsible for digesting hemi-celluloses (bot.).

cytaster (sītăs'těr) n. [Gk. kytos, hollow; aster, a star.] A starshaped achromatinic figure consisting of the attraction-sphere and aster rays (cyt.).

cytoblast (sī'töblăst) n. [Gk. kytos, hollow; blastos, a bud.] The cell nucleus; one of the hypothetical vital units of which a cell is formed (cyt.).

cytoblastema (sî'töblăstē'mă) $n$. [Gk. kytos, hollow; blastema, growth.] The formative material from which cells were supposed to arise (cyt.).

cy tochylema (sî́tökīlē'ma) $n$. [Gk. kytos, hollow; chylos, juice.] Cytolymph, which see.

cytococcus (sî́tökŏk'ǔs) n. [Gk. kytos, hollow; kokkos, a grain.] The nucleus of a fertilized egg (zool.).

eytocyst (sî'tösĭst) n. [Gk. kytos, hollow; kystis, a bladder.] The envelope formed by the remains of the host-cell within which the protozoan parasite multiplies (zool.).

cytode (sîtōd) n. [Gk. kytos, hollow ; eidos, form.] A non-nucleated protoplasmic mass (cyt.).

cytodiaeresis (sĩ'tödièrěsiss) n. [Gk. kytos, hollow ; diairesis, division.] Mitosis.

eytogamy (sītŏg'ămĩ) n. [Gk. kytos, hollow ; gamos, union.] Conjugation (zool.).

eytogenesis (sĩ'töjěn'ěš̌s) $n$. [Gk, 
kytos, hollow ; genesis, descent.] The development or formation of cells (biol.).

cytogenous (sītǒj'ěnŭs) $a$. [Gk. kytos, hollow ; genos, offspring.] Producing cells; $a p p l$. lymphatic tissue (phys.).

cytoglobin (sî́töglō'bĭn) $n$. [Gk. kytos, hollow; L. globus, a globe.] A proteid which retards coagulation of the blood (phys.).

eytohyaloplasma (sîtöhï'ălöplăz'mă) n. [Gk. kytos, hollow; hyalos, glass; plasma, something moulded.] The substance of the cytomitome (cyt.).

cytology (sītǒl'öjī) n. [Gk. kytos, hollow; logos, discourse.] The branch of biology dealing with the structure, functions, and life-history of cells.

cytolymph (sítölïmf) n. [Gk. kytos, hollow; L. lympha, water.] The ground-substance of cytoplasm (cyt.).

cytolysin (sî'tölísinn) n. [Gk. kytos, hollow ; lysis, a loosing.] A substance inducing cytolysis (phys.).

eytolysis (sĩtŏl'ísis) n. [Gk. kytos, hollow ; lysis, a loosing.] Cell-dissolution ; cell-degeneration ( $p h y s$.$) .$ cytomeres (sî́tömērz) $n$. plu. [Gk. kytos, hollow; meros, a part.] The cells in Carystropha formed by the division of the schizont, and themselves giving rise to the merozoites (zool.).

cytomicrosome (sî'tömī'krösōm) $n$. [Gk. kytos, hollow; mikros, small ; soma, body.] A microsome of the cytoplasm; $o p p$. nucleomicrosome (cyt.).

cytomitome (sî́tömītōm) n. [Gk. kytos, hollow; mitos, a thread.] The cytoplasmic threadwork (cyt.). cytomorphosis (sī'tömôr'fösǐs, sī'tömŏrfö'sis) n. [Gk. kytos, hollow ; morphosis, a shaping.] The lifehistory of cells; the series of structural modifications of cells or successive generations of cells (cyt.),

eyton (sí'tŏn) n. [Gk. kytos, hollow.] The body of a nerve cell (phys.).

cytophan (sî'töfăn) n. [Gk. kytos, hollow; phaneros, visible.] Theovoid matrix surrounding the karyophans in the spironeme and axoneme fibres in the stalk of an Infusorian (zool.).

cytopharynx (sĩ'töfắr'ingks) n. [Gk. kytos, hollow ; pharyngx, the gullet.] A tube-like structure leading from the mouth into the endoplasm in certain protozoan cells (zool.).

cytophil (sîttöfîl) a. [Gk. kytos, hollow; philein, to love.] Pert. haptophorous groups; having an affinity for cells (phys.).

cytoplasm (sî'töplăzm) n. [Gk. kytos, hollow; plasma,something moulded.] The substance of the cell-body exclusive of the nucleus; $c f$. nucleoplasm (cyt.).

eytoproct (sítöprŏkt) n. [Gk. kytos, hollow; proktos, anus.] A cellanus (zool.).

eytopyge (sî́töpīj) n. [Gk. kytos, hollow; pyge, the rump.] Cytoproct, which see.

cytoreticulum (síttörĕtǐk'ülŭm) $n$. [Gk. kytos, hollow ; L. reticulum, a little net.] The cytoplasmic threadwork (cyt.).

cytosine (sî́tösĭn) $n$. [Gk. kytos, hollow.] A cleavage product of protein (phys).

eytosome (sītösōm) n. [Gk. kytos, hollow ; soma, body.] The body of the cell as opposed to that of the nucleus (cyt.).

cytostome (si'töstōm) n. [Gk. kytos, hollow; stoma, a mouth.] A cellmouth.

cytotaxis (sĩ'tötăk'šss) n. [Gk. kytos, hollow ; taxis, arrangement.] $\mathrm{Cy}$ totropism, which see.

eytothesis (sîtŏth'ěšs) n. [Gk. kytos, hollow ; thesis, something set down.] The regenerative tendency of a cell or neuron (phys.).

cytotoxin (sïtötǒk'sĭn) n. [Gk. kytos, hollow; toxikon, poison.] A cellpoisoning substance formed in the blood serum (phys.).

cytotrophoblast (sí'tötrō'föblăst) $n$. [Gk. kytos, hollow ; trophe, nourishment ; blastos, a bud.] The inner layer of the trophoblast, or layer of Langhans (anat.).

cytotropism (sītŏt'röpǐzm) n. [Gk. kytos, hollow ; trope, a turning.] The mutual attraction of two or more cells $(c y t)$. 
cytozoic (sītözōî̀) a. [Gk. kytos, hollow; zoon, an animal.] Appl. the trophozoite of a sporozoon when situated within a cell (zool.).

cytula (sìt'ūlă) $n$. [Gk. kytos, hollow.] The fertilized ovum or parent cell (cyt.).

\section{D}

dacryon (dăk'rǐon) n. [Gk. dakryon, tear.] The point of junction of the anterior border of the lacrimal with the frontal (anat.).

dactyl (dăk'tîl) n. [Gk, daktylos, finger.] A digit or finger (anat.).

dactylar (dăk'tîlăr) a. [Gk. duktylos, finger.] Pert. finger or digit (anat.). dactylopodite (dăk'tillŏp'ödīt) $n$. [Gk. daktylos, finger; pous, foot.] The distal joint in certain limbs in the Crustaceans, especially the thoracic limbs (zool.).

dactylopore (dăk'tǐlöpōr') n. [Gk. daktylos, finger; poros, exit.] The opening in the skeleton of the Milleporina through which a dactylozooid protruded when alive (zool.).

dactylopterous (dăk'tǐlŏp'těrŭs) $a$. [Gk. daktylos, finger ; pteron, wing.] With the anterior rays of the pectoral fins more or less free (zool.).

dactylozooid (dăk'tìlözō'oid) n. [Gk. daktylos, finger; zoon, animal; eidos, resemblance.] A hydroid modified for the special function of catching prey, it may be long, with tentacles or with short knobs, with or without a mouth (zool.).

dactylus (dăk'tǐlŭs) n. [Gk. daktylos, finger.] Part of the tarsus of an insect (zool.).

dart (dârt) $n$. [O.F. dart, dagger.] Anything resembling a dart, $a p p l$. crystalline structure in Molluscs (zool.).

dart sac, - a small sac containing a dart of limey material attached to the vagina near its orifice in Gastropods (zool.).

dartoid (dâr'toid) a. [Gk. dartos, flayed.] Pert. the dartos (anat.).

dartos (dâr'tŏs) n. [Gk. dartos, flayed.] A thin layer of non-striped muscle fibres around the base of the scrotum (anat.).

Darwinian tubercle, - the slight prominence on the helix near the point where it bends downwards (anat.).

Darwinism (Dâr'wìnizm) $n$. [Darwin.] The theory of the origin of species by natural selection working on the slight variations that occur, thereby selecting those fittest to survive (biol.).

dasypaedes (dă'sĭpē'děz) n. plu. [Gk. dasys, hairy; pais, child.] birds whose young are downy at hatching (zool.).

daughter (dốtër) n. [A.S. dohtor, daughter.] Offspring of the first generation with no reference to sex, as daughter-cell, daughter-nucleus, etc. (biol.).

deamination (dēăm'înāshŭn) $n$. [L. de, down; Gk. ammoniacum, a resinous gum.] The conversion of ammonium salts into urea, partly accomplished in the liver (phys.).

death (děth) $n$. [M.E. deth, death.] The complete and permanent cessation of all vital functions in any organism (biol.).

death-point, - the temperature above or below which micro-organisms cannot exist (biol.).

decalcify (dēkăl'sĭfī) $v$. [L. de, away ; calx, lime.] To treat with acids for the removal of the calcareous part (anat.).

decamerous (děkăm'ĕrŭs) a. [Gk. deka, ten; meros, part.] With the various parts arranged in tens (bot.). decapod (děk'ăpŏd) a. [Gk. deka, ten; pous, foot.] In Crustacea, with five pairs of legs on the thorax; in Cephalopods, with ten arms (zool.).

decapodiform (děk'ăpŏd'îfôrm) a. [Gk. deka, ten ; pous, foot; L. forma, shape.] Resembling a decapod, usually said of insect larvae (zool.).

decemfid (děsĕm'fîd) a. [L. decem, ten; findere, to cleave.] Cut into ten segments (bot.).

decemfoliate (děs'ěmfō'liât) $a$. [L. decem, ten; folium, leaf.] Tenleaved (bot.).

decemjugat (děs'ěmjoo'gāt) $a$. [L. decem, ten; jugare, to join.] With ten pairs of leaflets (bot.). 
decempartite (děs'ěmpâr'tīt) a. [L. decem, ten ; partiri, to divide.] Tenlobed; divided into ten lobes (bot.). decidua (dēsĭd'ūă) $n$. [L. de, away ; cadere, to fall.] The mucous membrane lining the uterus, that is cast off after parturition (anat.).

decidual (dēsǐd'ūăl) $a$. [L. de, away ; cadere, to fall.] Pert. decidua (anat.).

deciduate (dēsĭd'ūāt) a. [L. de, away ; cadere, to fall.] Characterized by having a decidua; partly formed by the decidua (zool.).

deciduous (dēsĭd'ūŭs) a. [L. de, away ; cadere, to fall.] Falling at the end of the period of growth (bot.) ; falling at maturity (zool.).

declinate (děk'lināt) a. [L. de, away; clinare, to bend.] Bending aside in a curve, as the anther filament in the horse-chestnut (bot.).

decollated (dēkŏl'ātěd) $a$. [L. de, away; collum, neck.] With the apex of the spire wanting (zool.).

decomposed (dë'kŏmpōzd') a. [L. de, away ; cum, with; ponere, to place. Not in contact; not adhering, said of the barbs of a feather when they are separate (zool.).

decompound (dē'kŏmpound') a. [L. de, away; cum, with; ponere, to place.]. When the monopodial branching is very complete, and the ultimate wings are little developed, the leaf is called decompound (bot.).

decumbent (dēkŭm'bĕnt) $a$. [L. decumbere, to lie down.] Appl. stems which trail on the ground, but rise at the apex (bot.).

decurrent (dēkŭr'ĕnt) a. [L. de, away ; currere, to run.] Having the leaf base prolonged down the stem as a winged expansion or rib (bot.). decussate (děk'ŭsāt, dēkŭs'āt) a. [L. decussare, to cross like an X.] Having paired leaves, succeeding pairs crossing at right angles (bot.).

decussation (dẽ'kŭsā'shŭn) $n$. [L. decussare, to cross like an X.] The condition when opposite leaves are arranged so thateach pair crosses the previous at right angles (bot.); the crossing of nerves or bands of nerve-fibres when there is an interchange of fibres (anat.). deduplication (dēdū'plǐkā'shŭn) $n$. [L. de, intensive; duplicare, to double.] The augmentation of parts of a flower by splitting during development (bot.).

defaecation (dē'fēkā'shŭn) $n$. [L. defaecatio, voiding of excrement.] The expulsion of faeces (phys.).

defensive (dēfěn'siv) $a$. [L. defendere, to defend.] Protective; $a p p l$. proteid substances which destroy the toxic substances of bacteria (phys.) ; $a p p l$. numerous organs or parts of organs in various animals (zool.).

deferred (dēfěrd') a. [L. deferre, to bring down.] Appl. shoots that are given out from dormant buds when stem or branch has been destroyed (bot.).

definite (děf'inñt) a. [L. definire, to limit.] Fixed, constant; appl. inflorescences with primary axis terminating early in a flower; $a p p l$. stamens limited to twenty in number (bot.).

definitive (dēfín'ítǐv) a. [L. definire, to limit.] Complete, fully developed (biol.).

defoliate (dēfó'liūt) a. [L. defoliare, to strip of leaves.] Bared at the annual fall (bot.).

degeneration (dējěnĕrā'shŭn) $n$. [L. degener, base.] Return to a simpler condition; retrogressive evolution (biol.).

deglutition (dēglootǐsh'ǔn) $n$. [L. deglutire, to swallow down.] The process of swallowing (phys.).

dehiscence (dēhǐs'ĕns) $n$. [L. de, away; hiscere, to gape.] The opening of an organ or structure along certain lines or in a definite direction (bot.).

Deiter's cells (dî'tĕrz),-supporting cells between the rows of outer hair-cells in the organ of Corti (anat.).

delamination (dēlăm'ĩnāshŭn) $n$. [L. de, down; lamina, a layer.] The dividing off of cells to form new layers (emb.).

deliquescent (děl'îkwěs'ěnt) $a$. [L. deliquescere, to become fluid.] Having the lateral buds the more vigorously developed so that the main stem seems to divide into a number of irregular branches (bot.). 
delomorphous (dē'lömôr'fŭs) a. [Gk. delos, visible; morphe, shape.] With definite form, $a p p l$. oxyntic cells of the gastric glands (anat.).

delthyrium (dělthî'riŭum) n. [Gk. delos, visible ; thyrion, little door.] The opening between the hinge and beak for the peduncle exit in many Brachiopods (zool.).

deltidium (děltǐd'rŭm) n. [Gk. $\Delta$, delta.] A plate covering the delthyrium (zool.).

deltoid (děl'toid) a. [Gk. $\Delta$, delta ; eidos, resemblance.] More or less triangular in shape, $a p p l$. nerves, muscles, etc. (anat.) ; appl. the oral plates on the calyx of the Blastoids (zool.).

demersal (dēměr'săl) a. [L. demergere, to demerse.] Sunk; $a p p l$. fish eggs which sink to the bottom (zool.).

demiplate (děm'ǐplāt) $n$. [L. dimidius, half; platus, flat.] Plate cut off by the fusion of adjoining plates behind it from the central suture line of the ambulacral area in Echinoderms (zool.).

demisheath (děm'îshēth) $n$. [L. dimidius, half; A.S. sceath, sheath.] One of the protecting covers of the ovipositor (zool.).

demoid (dē'moid) a. [Gk. demos, the common people.] Abundant (pal.).

dendriform (děn'drĭfôrm) $a$. [Gk. dendron, tree; L. forma, shape.] Tree-like (biol.).

dendrite (děn'drï) n. [Gk. dendron, tree.] A branched tree-like protoplasmic process of a nerve cell (anat.).

Dendrogaea (děn'dröjēăă) n. [Gk. dendron, tree ; gaia, earth.] A zoogeographical region, including all the Neotropical region except temperate South America (biol.).

dendron (děn'drŏn) $n$. See dendrite. dens (děnz) n. [L. dens, tooth.] Tooth, or tooth-like process (anat.).

dental (děn'tăl) a. [L. dens, tooth.] Pert. teeth; appl. nerves, bloodvessels, canals, furrows, papillae, tissue, etc. (anat.).

dentary (děn'tărǐ) a. [L. dens, tooth.] Pert. dentaries, membrane bones in lower jaw of many vertebrates (zool.). dentate (děn'tāt) $a$. [L. dens, tooth.] With sharp saw-like teeth on the marg in (sool., bot.).

dentate eiliate, - with teeth and hairs on the margins; appl. leaves (bot.).

dentate crenate,- - with marginal teeth somewhat rounded (bot.).

denticles (děn'tǐklz) n. plu. [L. dens, tooth.] The paragnaths of certain Polychaets; the teeth within the secondary orifice in Polyzoa; the scales of certain Elasmobranchs (zool.).

dentinal (dĕn'tĭnăl) a. [L. dens, tooth.] Pert. dentine (anat.).

dentine (děn'tĭn) $n$. [L. dens, tooth.] A hard, highly elastic substance composing the greater part of every tooth, a collagen (anat.).

dentition (děntǐsh'ün) $n$. [L. dens, tooth.] The number, arrangement, and kind of teeth in the jaws of an animal (anat.).

depigmentation (dēpig'měntā'shŭn) $n$. [L. de, away; pingere, to paint.] The destruction of colour in a cell, either by natural or experimental physiological processes (phys.).

deplanate (děp'lănāt) $a$. [L. deplanare, to level.] Levelled, flattened (bot.).

depressant (dēprěs'ănt) $n$. [L. deprimere, to lower.] Anything that lowers vital activity (phys.).

depressed (dēprěst') a. [L. deprimere, to lower.] Flattened in a vertical direction (biol.).

depressomotor (dēprěs'ömō'tŏr) $n$. [L. deprimere, to lower ; movere, to move.] Any nerve which lowers muscular activity (anat.).

depressor (dēprěs'ŏr) n. [L. deprimere, to lower.] Any muscle which lowers or depresses any structure; $a p p l$. a nerve which lowers the activity of an organ (anat.).

derm (děrm) $n$. [Gk. derma, skin.] The layers of the integument below the epidermis (anat.).

derma (děr'mă) $n$. See derm.

dermal (děr'măl) a. [Gk. derma, skin.] Pert. derma, or skin (anat.). dermalia (děrmắliă) $n$. plu. [Gk. derma, skin.] Microscleres in the dermal membrane in Sponges (zool.). 


\section{dermarticulare}

(děr'mârtǐk'ūlā'rē, -ârā) n. [Gk. derma, skin; L. articulare, to divide into joints.] The goniale (zool.).

dermatogen (děr'mătöjĕn) $n$. [Gk. derma, skin ; gignesthai, to produce.] The young or embryonic epidermis in plants (bot.).

dermatoplasm (dĕr'mătöplăzm') $n$. [Gk. derma, skin; plasma, something moulded.] The cell-wall protoplasm (bot.).

dermatoplast (děr'mătöplăst') $n$. [Gk. derma, skin ; plastos, moulded.] A protoplast with a supposed cell-wall (biol.).

dermatopsy (děr'mătŏp'sĩ) n. [Gk. derma, skin; opsis, sight.] Condition of seeing with the skin, i.e. with a skin sensitive to light (zool.).

dermatosome (dĕr'mătösōm $\left.{ }^{\prime}\right) n$. [Gk. derma, skin; soma, body.] One of vital units forming a cell-membrane (bot.).

dermic (dĕr'mǔk) a. [Gk. derma, skin.] Pert. skin, or derived from the skin (zool.).

dermis (dĕr'mis) $n$. [Gk. derma, skin.] See derm.

dermoblast (děr'möblăst') $n$. [Gk. derma, skin; blastos, bud.] The layer of mesoblast which gives rise to the derma (anat.).

dermoossification (děr'möŏs'îfíkā'shŭn) n. [Gk. derma, skin; L. os, bone; fieri, to become.] A bone formed in the skin (zool.).

dermosclerites (děr'mösklĕr'its) n.plu. [Gk. derma, skin; skleros, hard.] Masses of spicules found in the tissues of the Alcyonidae (zool.).

dermoskeleton (děr'möskěl'ětǒn) $n$. [Gk. derma, skin; skeletos, dried.] See exoskeleton.

dertrotheca (děr'tröthē'ka) n. [Gk. dertron, beak; theke, cup.] The horny casing of the maxilla of birds (zool.).

dertrum (děr'trŭm) n. [Gk. dertron, beak.] Any modification of the casing of the maxilla in birds (zool.).

descendence (dēsĕn'dĕns) $n$. [L. de, down; scandere, to climb.] Descent from some ancestor, usually a common ancestor (biol.).

descending (dēsěn'ding) a. [L. de, down; scandere, to climb.] Directed towards the caudal region; $a p p l$. blood-vessels, nerves, etc. (anat.).

desegmentation (dēsěg'mĕntā'shŭn) n. [L. de, from; segmentum, piece cut off.] Fusion of segments originally separate (zool.).

deserticolous (dězěrtǐk'ölŭs) $a$. [L. desertus, solitary; colere, to inhabit.] Desert-inhabiting (zool.).

desma (děs'mă) $n$. [Gk. desma, bond.] The megasclere which forms the characteristic skeletal network of the Lithistida, an irregular branched spicule (zool.).

desmactinic (děs'măktǐn'îk) a. [Gk. desma, bond; aktis, ray.] With the podia continued upwards to the apical plate, $a p p l$. Stelleroidea ; cf. Iysactinic (zool.).

desmogen (děs'möjĕn) $n$. [Gk. desma, bond ; gignesthai, to produce.] Merismatic tissue (bot.).

desmognathous (děsmǒg'năthŭs) $a$. [Gk. desma, bond; gnathos, jaw.] Having the maxillo-palatines fused with one another in the middle line owing to certain other peculiarities in the skull; $a p p l$. birds (zool.).

desquamation (děs'kwămā'shŭn) $n$. [L. de, away; squama, scale.] The shedding of the cuticle or epidermis in flakes (zool.).

determinant (dētěr'minnănt) $n$. [L. determinare, to limit.] A hypothetical unit, being an aggregation of biophores determining the development of a cell or an independently variable group of cells (biol.).

determinate (dētěr'minnāt) $a$. [L. determinare, to limit.] With certain limits; $a p p l$. inflorescence with the primary axis terminated early with a flower-bud (bot.); appl. cleavage (emb.).

detorsion (dētôr'shŭn) n. [L. de, away; torquere, to twist.] Torsion in an opposite direction to that of the original, resulting in a more or less posterior position of the anus and circumanal complex (zool.).

deuterocerebrum (dü'těrösěr'ěbrŭm) n. [Gk. deuteros, second; kerebron, brain.] That portion of the Crustacean brain from which the antennular nerves arise (zool.). 
deuterocone (dū'těrökōn') n. [Gk. deuteros, second; konos, cusp.] A mammalian premolar cusp corresponding to the molar protocone (anat.).

deuteroproteose (dü'těröprō'těōs) n. [Gk. deuteros, second; protein, to be first.] A secondary product from the gastric and pancreatic digestion of proteids (phys.).

deuterostoma (dū'těröstō'mă) $n$. [Gk. deuteros, second; stoma, mouth.] A mouth formed secondarily, as distinct from the gastrula mouth (zool.).

deuterotoky (dū'těrŏt'ökř) $n$. [Gk. deuteros, second; tokos, birth.] Reproduction of both sexes from parthenogenetic eggs ; $c f$. arrhenotoky and thelyotoky (zool.).

deuterozooid (dū'těrözōoid) $n$. [Gk. deuteros, second; zoon, animal; eidos, resemblance.] A zooid produced by budding from a primary zooid (zool.).

deuthyalosome (dūthī'ălösōm) n. [Gk. deuteros, second; hyalos, glass; soma, body.] The nucleus remaining in the ovum after the formation of the first polar body (cyt.).

deutoblast (dū'töblăst) $n$. deuteros, second; blastos, bud.] The amoeba-like bodies formed from the protoblasts in the zygote of Microclossia, and liberated to multiply in the blood (zool.).

deutocerebron (dū'tösĕr'èbrŏn) $n$. [Gk. deuteros, second; kerebron, brain.] That portion of the brain of certain insects which corresponds with the deuterocerebrum of Crustaceans (zool.) ; also deutocerebrum.

deutomalae (dü'tömälēe, -măl'ā) n. plu. [Gk. deuteros, second; malon, cheek.] The broad plate in the Chaetognatha covering the under part of the head and partially enclosing the mouth, formed by the fusion of the second pair of mouth appendages (zool.).

deutomerite (dūtŏm'ĕrît) $n$. deuteros, second; meros, The posterior division of a Gregarine body (zool.).

deutoplasm (dū'töplăzm) n. [Gk. deuteros, second; plasma, some- thing moulded.] The yolk or food material in the cytoplasm of an ovum; $o p p$. protoplasm (cyt.).

deutoscolex (dū'töskō'lěks) n. [Gk. deuteros, second; skolex, head.] A secondary scolex produced by budding, in the bladder-worm stage of certain tape-worms (zool.).

deutovum (dūtō'vŭm) $n$. [Gk.deuteros, second; L. ovum, egg.] A stage in the metamorphosis of certain mites in which the outer envelope becomes brown and hard, and splits longitudinally, exposing the thin inner membrane (zool.).

development (děvěl'ǒpměnt) $n$. $[\mathrm{F}$. développer, to unfold.] The changes undergone byan organism on reaching maturity (biol.).

dexiotropic (děk'siötrŏp'îk) a. [Gk. dexzos, right; trepein, to turn.] Having the whorls turning from left to right; appl. shells (zool.); $a p p l$. spiral cleavage $(c y t$.$) .$

dextral (děk'străl) a. [L. dexter, right-hand.] See dexiotropic.

dextrin (děk'strĭn) n. [L. dexter, right-hand.] A soluble substance derived from starch by exposure to a high temperature for a short time (phys.).

dextrorse (děkstrôrs', děk'strôrs) $a$. [L. dexter, right; vertere, to turn.] Growing in a spiral which twines from left to right (bot.).

diachaenium (dĩăkē'nǐum) n. [Gk. dis, twice; $a$, not; chanein, to gape.] Each part of a cremocarp (bot.).

diacranteric (dîăkrăntěr'îk) a. [Gk. dia, asunder; kranteres, wisdom teeth.] With a diastema between the front and back teeth, as in snakes (zool.).

diactinal (diăk'tǐnăl) a. [Gk, dis, twice; aktis, ray.] With two rays pointed at the ends (zool.).

diadelphous (dî́ăděl'fŭs) a. [Gk. dis, twice ; adelphos, brother.] Having the stamens in two bundles owing to the fusion of the filaments (bot.).

diadematoid (dîăděm'ătoid) a. [Gk. diadema, crown ; eidos, shape.] of Echinoids, having the pore plates arranged as follows: three primaries with occasionally a secondary 
between the aboral and the middle primary (zool.).

diadromous (dîădrō'mŭs) $a$. [Gk. diadromos, wandering.] Having the nerves radiating in a fan-like manner (bot.).

diaene (dièn') n. [Gk. dis, twice-on analogy of triaene, from Gk. triaina, trident.] A form of triaene, with one of the cladi reduced or absent (zool.).

diageotropism (dīăjēōt'röpǐzm) $n$. [Gk. dia, through; gaia, earth; trepein, to turn.] The tendency in certain parts of plants to take a position at right angles to the direction of gravity (bot.).

diagnosis (dîăgnō'sĭs) $n$. [Gk. dia, through ; gignoskein, to know.] A concise description of an organism with full distinctive characters (biol.).

diagnostic (dīăgnǒs'tǐk) a. [Gk. dia, through; gignoskein, to know.] Differentiating the species or genus, etc., from others similar (biol.).

diaheliotropism (dīăhēlǐot' röpǐzm) $n$. [Gk. dia, through; helios, sun ; trepein, to turn.] The tendency of certain parts of plants to take up a position at right angles to the rays of light (bot.).

dialyneury (díălı̌nū'rǐ) n. [Gk. dia, through ; lyein, to loose ; neuron, nerve.] In certain Gastropods, having the pleural ganglia united to the opposite branch of the visceral nerve by an anastomosis of the pallial nerve (zool.).

dialypetalous (dĩălĭpět'ălǔs) a. [Gk. dia, asunder; lyein, to loose ; petalon, petal.] Polypetalous (bot.). dialyphyllous (dĩălifil'ǔs) a. [Gk. dia, asunder; lyein, to loose ; phyllon, leaf.] With separate leaves (bot.).

dialysepalous (dīălı̌sěp'ălŭs) $a$. [Gk. dia, asunder; lyein, to loose ; sepalon, sepal.] Polysepalous (bot.).

dialystely (dīălĭstē'lî̀) n. [Gk. dia, asunder; lyein, to loose; stele, post.]. A condition in which the steles in the stem remain more or less separate (bot.).

diancistra '(dĩăngkǐs'tră) n. [Gk. dis, twice ; angkistron, hook.] A spicule resembling a stout sigma, but the inner margin of both hook and shaft thins out to a knife edge and is notched (zool.).

diandrous (dīăn'drŭs) a. [Gk. dis, twice; aner, man.] Having two free stamens $(b o t$.).

diapedesis (diăpěd'ěš̌s, díăpědē'sǐs) $n$. [Gk. diapedesis, leaping through.] Emigration of white blood corpuscles through the walls of the capillaries into the surrounding tissue (phys.).

diaphototropism (dīăfötŏt'röpǐzm) $n$. [Gk. dia, through; phos, light ; trepein, to turn.] See diaheliotropism.

diaphragm (dîăfrăm) $n$. [Gk. diaphragma, midriff.] The wall which separates the small cell, the prothallus, from the rest of the macrospore in Hydropterideae; a septum at the nodes in Equisetum (bot.); a sheet of muscular tissue attached to the introvert in worms ; the single strongly developed septum in the Terebelliformia; the perforated tissue that subdivides the tentacle cavity in Polyzoa; the transverse septum separating the cephalothorax from the abdomen in certain Arachnids; a special fan-shaped muscle spreading from the anterior end of the ilia to the oesophagus and base of the lungs in Anura; a partition partly muscular, partly tendinous, separating the cavity of the chest from the abdominal cavity (zool.).

diaphragma (di'ăfrăg'mă) n. See diaphragm.

diaphysis (dīăf'îšs) $n$. [Gk. dia, through; phyein, to bring forth.] The shaft of a bone as distinguished from the epiphysis (anat.); the abnormal growth of an axis or shoot (bot.).

diapophysis (dïăpŏf'íšs) n. [Gk. dia, through; phyein, to produce.] The lateral or transverse process of the neural arches of Anura (zool.).

diarch (dīârk) a. [Gk. dis, twice ; arche, origin.] With two xylem and two phloem bundles; $a p p l$. root in which the protoxylem bundles meet and form a plate of tissue across the cylinder with the phloem bundle on each side (bot.). diarthrosis (dî́ârthrō'sǐs) $n$. [Gk. dia 
through ; arthroun, to fasten by a joint.] An articulation allowing considerable movement (anat.).

diastase (dî́ăstās) n. [Gk. dia, through; histanai, to set.] An enzyme which acts principally in converting starch into sugar (phys.).

diastatic (dînăstăt'îk) a. [Gk. dia, through; histanai, to set.] Pert. diastase, or having similar properties (phys.).

diastema (dīăs'těmă, dî'ăstê'mă) $n$. [Gk. diastema, space.] A space in a jaw without teeth, usually between two types of teeth (zool.).

diaster (diăs'těr) n. [Gk. dis, twice ; aster, star.] The stage in mitosis where the daughter chromosomes are grouped near the spindle poles ready to form a new nucleus (cyt.).

diastole (dīăs'tölē) n. [Gk. diastole, difference.] The rhythmical relaxation of the heart; the rhythmical expansion of a contractile vacuole (zool.).

diastomatic (dĩ̌ăstömăt'îk) a. [Gk. dia, through; stoma, pore.] Through the stomata or pores, giving off gases from the spongy parenchyma through the stomata (bot.).

diathesis (diăth'ěsı̌s) n. [Gk. dia, through; tithenai, to place.] A congenital predisposition to some class of diseases or type of development (biol.).

diatom (dî́ătŏm) $n$. [Gk. dia, through; temnein, to cut.] Any unicellular microscopic form of Alga with walls of silica (bot.).

diatropism (diăt'röpǐzm) n. [Gk. dia, through; trepein, to turn.] The tendency of plants or organs of plants to place themselves at right angles to the line of action of the stimulus (bot.).

diaxon (diäk'sŏn) a. [Gk, dis, twice ; axon, axis.] With two axes, as certain sponge spicules (zool.).

diaxone (diăk'sön) n. [Gk dis, twice ; axon, axis.] A nerve-cell with two cylinder axes (anat.).

diblastula (dīblăs'tūlă) $n$. [Gk. dis, twice; blastos, bud.] A coelenterate embryo consisting of two layers arranged round a central cavity (zool.). dibranchiate (dībrăng'kiāt) a. [Gk. dis, twice ; brangchia, gills.] With two gills (zool.).

dicellate (dīsěl'āt) a. [Gk. dikella, a two-pronged hoe.] With two prongs; $a p p l$. sponge spicules (zool.).

dichasium (dīkāz'ıum) n. [Gk. dichazein, to divide in two.] An inflorescence in which two buds always develop just below the terminal bud (bot.).

dichlamydeous (dî'klămǐd'ěŭs) $a$. [Gk. dis, twice; chlamys, cloak.] Having both calyx and corolla (bot.).

dichogamy (dǐkŏg'ămĩ) n. [Gk. dicha, in two ; gamos, union.] The maturing of the microsporophylls and the macrosporophylls at different times, thus ensuring crosspollination (bot.).

dichoptic (dìkŏp'tǐk) a. [Gk. dicha, in two; opsis, sight.] With the eyes quite separate (zool.).

dichotomous (dīkŏt'ömŭs) a. [Gk. dicha, in two; temnein, to cut.] Pert., situated near, or characterized by dichotomy (bot.).

dichotomy (dīkǒt'ömǐ) n. [Gk. dicha, in two; temnein, to cut.] Branching which results from the division of a growing point with two equal parts (bot., zool.).

dichromatic (dî'krömăt'îk) a. [Gk. di, two; chroma, colour.] With two colour varieties (biol.).

diclinous (dî'klinnus, dīklînǔs) $a$. [Gk. di, two; kline, bed.] With the stamens and pistils on separate flowers (bot.).

dicoccous (dìkŏk'ŭs) a. [Gk. di, two ; kokkos, seed.] Having two oneseeded coherent capsules (bot.).

dicostalia (dì'kŏstắliă) $n$. [Gk. di, two; L. costa, rib.] The secundibranchs or second brachial series in a Crinoid (zool.).

dicotyledon (dīkŏtîlē'dŏn) n. [Gk. di, two; kotyledon, cup-shaped hollow.] A plant with two seedleaves (bot.).

dictyodromous (dỉk'tǐŏd'römŭs) $a$. [Gk. diktyon, net ; dromein, to run.] Net-veined, when the smaller veins branch and anastomose freely (bot.). dictyogen (dĩk'tiöjĕn) n. [Gk. diktyon, 
net; gignesthai, to produce.] A net-leaved plant, $a p p l$. usually to monocotyledons (bot.).

dietyonalia (dik'tiŏnắliă) $n$. [Gk. diktyon, net.] The principal parenchyma spicules of the Dictyonina and of many Lyssacina (zool.).

dictyostelic (ď̌k'tǐöstělǐk) a. [Gk. diktyon, net; stele, stele.] Polystelic (bot.).

dictyotic (dik'trǒót'îk) a. [Gk. diktyon, net.] Having the whole skeleton laid down at once (zool.).

dictyotic moment,-lorication moment, which see.

dicyelic (dīsǐk'lìk) a. [Gk, di, two ; kyklos, circle.] Having a row of per-radial infrabasals, $a p p l$. theca of Crinoids (zool.); having two whorls (bot.).

didactyl (dĩdăk'tîl) a. [Gk. di, two ; daktylos, finger.] Having two fingers or two toes (zool.).

didymous (dìd'ı̌mŭs) a. [Gk. didymos, twin.] Growing in pairs (bot., zool.).

didynamous (dīdĭn'ămŭs) $a$. [Gk. di, two; dynamis, power.] With four stamens, two long, two short (bot.).

diencephalon (dïěnkĕf'ălŏn, -sěf'-) $n$. [Gk. dia, between; engkephalon, brain.] See thalamencephalon (anat.).

differentiation (dîf'ěrěn'shǐā'shŭn) $n$. [L. differre, to differ.] The modification in structure of various organs of the body owing to a division of labour (zool.).

diffluence (dïf'looĕns) $n$. [L. dis, away; fluere, to flow.] Disintegration by the formation of large vacuoles whose walls break on bursting (biol.).

diffuse (dǐfüs') a. [L. diffundere, to pour.] Widely spread (biol.).

digastric (dīgăs'trǐk) a. [Gk. di, two ; gaster, belly.] Two-bellied, appl. muscles fleshy at the ends, tendinous in the middle (anat.).

digenesis (dījěn'ěsiss) n. [Gk. dis, twice; gignesthai, to produce.] Alternation of generations.

digenetic (dījěnět'îk) a. [Gk, dis, twice; gignesthai, to produce.] Pert. digenesis (biol.).

digenoporous (dîj'jěnǒp'örŭs) $a$. [Gk. dis, twice ; genos, birth ; poros, pore.]
With two genital pores, said of many Turbellaria (zool.).

digestion (dījěs'chŭn) $n$. [L. digestio, digestion.] The process by which nutrient materials are rendered absorbable by the working of various juices and mechanical action (phys.).

digestive (dijjěs'tĭv) a. [L. digestio, digestion.] Pert. digestion, or having the power of aiding in digestion (phys.).

digit (dij'it) $n$. [L. digitus, finger.] A division of the limb in any vertebrate above Fishes (zool.).

digital (dij'îtăl) a. [L. digitus, finger.] Pert. finger or digit, also appl. things resembling a digit (zool.).

digital (dij'îtăl) $n$. [L. digitus, finger.] The distal joint of a spider's pedipalp (zool.).

digitaliform (dij'îtăl'îfôrm) a. [L. digitus, finger; forma, shape.] Finger-shaped, appl. corollae which are like the finger of a glove (bot.).

digitate (dij'îtāt) a. [L. digitus, finger.] Having the parts arranged like the fingers in a hand (bot.); with fingers (zool.); finger-shaped (bot., zool.).

digitiform (dîj'îtǐfôrm) a. [L. digitus, finger; forma, shape.] Fingershaped; appl. roots (bot.).

digitigrade (dīj'îtǐgrād) a. [L.digitus, finger; gradus, step.] Having feet, the digits of which only touch the ground in walking (zool.).

digitinervate (dij'îtiněr'vät) a. [L. digitus, finger; nervus, a sinew.] Having the veins radiating out from the base like the fingers of a hand, with usually five or seven veins; $a p p l$. leaves (bot.).

digitipartite (dij'îtǐpâr'tīt) a. [L. digitus, finger ; partire, to divide.] Having the leaves divided up in a hand-like pattern (bot.).

digitipinnate (dij'î́tǐpin'ât) a. [L. digitus, finger; pinna, leaf.] Having digitate leaves of which the leaflets are pinnate (bot.).

digitule (dij'îtūl) n. [L. digitus, finger.] Any small finger-like process; small process on the insect tarsi (zool.).

digoneutic (dī'gönū'třk) a. [Gk. dis, twice; goneuein, to produce.] Breeding twice a year (zool.). 
digonoporous (dígönŏp'örŭs) $a$. [Gk. dis, twice; genos, birth; poros, pore.] With two distinct genital apertures, male and female (zool.). digynous (dǐj'inŭs) a. [Gk. di, two; gyne, woman.] Having two carpels (bot.).

dihybrid (dīhíbrĭd) $n$. [Gk. dis, twice ; L. hibrida, mixed offspring.] A cross whose parents differ in two distinct characters (biol.).

dilatator (dǐl'ătā'tŏr) n. [L. dilatare, to expand.] See dilator.

dilated (dīlā'těd) a. [L. dilatare, to flatten.] Expanded or flattened; $a p p l$. parts of insects, etc., with a wide margin (zool.).

dilator (dīlā'tŏr) n. [L. dilatare, to expand.] Name appl. any muscle that expands or dilates any organ (anat.).

dilophous (dīlöf'ús) $a$. [Gk. $d i$, two ; lophos, crest.] Any tetractinal spicule with two of its rays forked like a crest (zool.).

diluvial (dîlū'viăl) a. [L. diluvium, deluge.] Pert. the present, in geological reckoning (pal.).

dimerous (dĭm'ěrŭs) a. [Gk. dis, twice; meros, part.] Having each whorl of two parts (bot.); with a two-jointed tarsus (zool.).

dimidiate (dǐmìd'īat) a. [L.dimidius, half.] Having only one-half developed (biol.); having the capsule split on one side (bot.).

dimorphism (dìmôr'fizm) n. [Gk. dis, twice; morphe, shape.] Condition of having stamens of two different lengths, of having two different kinds of leaves, flowers, etc. (bot.). State of having two different forms of one sex; of having two different kinds of zooids; of having two different kinds of offspring; of having broods which, owing to differing conditions, differ in size or colouring (zool.).

dimyaric (dìm'iăr'ik) a. [Gk. dis, twice; mys, muscle.] Having two adductor muscles (zool.).

dinomic (dinǒm'îk) a. [Gk. dis, twice ; nomos, division.] $A p p l$.an organism restricted to two of the biogeographical divisions of the globe (biol.).

dioecious (diế'shŭs) a. [Gk. dis, twice; oikos, house.] Having the sexes separate (zool.); having the male and female flowers on different individuals (bot.).

dioptrate (dīóp'trāt) a. [Gk. dis, twice; root opt, to see.] Having the eyes or the ocelli separated by a narrow line (zool.).

dipetalous (dīpět'ălǔs) a. [Gk. dis, twice; petalon, petal.] Having two petals (bot.).

diphycercal (dîf'isĕr'kăl) a. [Gk. diphyes, twofold; kerkos, tail.] With a tail in which the vertebral column runs straight to the tip, thereby dividing the fin symmetrically (zool.).

diphygenic (diff'̌jĕn'îk) a. [Gk. diphyes, twofold; genos, birth.] With two types of development of the embryo (zool.).

diphyođont (dîf'iödŏnt') a. [Gk. diphyes, twofold; odous, tooth.] With deciduous and permanent sets of teeth (zool.).

diplanetic (dî́plănět'îk) a. [Gk. dis, twice; planetikos, inclined to wander.] With two distinct types of zoospores (bot.).

diplarthrous (dǐplâr'thrŭs) $a$. [Gk. diploos, double; arthron, joint.] With the tarsal or carpal bones of one row articulating with two bones in the other (zool.).

dipleurula (dîploor'ūlă) $n$. [Gk. dis, twice; pleuron, side.] Any of the bilaterally symmetrical larvae of the Echinoderms; an echinopaedium (zool.).

diploblastic (dip'löblăs'tı̌k) a. [Gk. diploos, double; blastos, bud.] Having two distinct germ layers (zool.).

diplocardiac (dīp'lökâr'diăk) a. [Gk. diploos, double; kardia, heart.] With the two sides of the heart quite distinct (zool.).

diplocaulescent (díp'lökôlěs'ěnt) $a$. [Gk. diploos, double; kaulos, stem.] With secondary stems (bot.).

diploe (dīp'lōē) n. [Gk. diploos, double.] The cancellous tissue between the outer and inner lamellae of certain skull bones (anat.).

diplogangliate (dìp'lögăng'glīât) a. [Gk. diploos, double; ganglion, 
ganglion.] With the ganglia usually arranged in pairs (zool.).

diplogenesis (dip'löjĕn'ěsiss) n. [Gk. diploos, double; genos, birth.] The supposed change in the germ plasm that accompanies the "use and disuse" changes occurring in the body tissues (biol.).

diploic (dipplōílk) a. [Gk. diploos, double.] Occupying channels in the cancellous tissue of certain bones (anat.).

diplonephridia (díp'löněfrìd'íă) $n$. plu. [Gk. diploos, double; nephros, kidney.] Nephridia derived partly from ectoderm, partly from mesoderm (zool.).

diploneural (dip'lönū'răl) a. [Gk. diploos, double; neuron, nerve.] Supplied with two nerves (anat.).

diploperistomous (dip'löpěrís'tömŭs) a. [Gk. diploos, double; peri, around; stoma, mouth.] Having a double projection or peristome (bot.).

diploplacula (dìp'löplăk'ūlă) n. [Gk. diploos, double; plakoeis, flat.] A flattened blastula consisting of two layers of cells (biol.).

diplopore (dīp'löpōr) $n$. [Gk. diploos, double; poros, pore.] Respiratory organ in the Cystoidea (zool.).

diplosome (dīp'lösōm) n. [Gk. diploos, double; soma, body.] A double centrosome lying outside the nuclear membrane (cyt.).

diplosphene (dīp'lösfën) $n$. [Gk. diploos, double; sphen, wedge.] A wedge-shaped process on the neural arch of the vertebrae of certain fossil Reptiles (pal.).

diplospondylic (dịp'löspoondỉl'îk) $a$. [Gk. diploos, double; sphondylos, vertebra.] With two centra to each myotome, or with one centrum and a well-developed intercentrum (zool.).

diplostemonous (dīp'löstĕm'önŭs) $a$. [Gk. diploos, double; stemon, warp.] With two whorls of stamens in regular alternation with the perianth leaves (bot.).

diplotegia (dip'lötējjǔă) n. [Gk. diploos, double; tegos, roof.] An inferior fruit with dry indehiscent pericarp (bot.).

dipnoan (dīp'nōăn) a. [Gk. dis, twice; pnein, to breathe.] Breathing by gills and lungs (zool.).

diprotodont (dīprō'tödŏnt) a. [Gk. dis, twice ; protos, first ; odous, tooth.] Having the two anterior incisors large and prominent, the rest of the incisors and canines being smaller or absent (zool.).

dipterocecidium (dǐp'těrösēsǐd'íŭm) n. [Gk. dis, twice; pteron, wing ; kekis, gall nut.] A gall caused by any insect (biol.).

dipterous (dìp'těrŭs) a. [Gk. dis, twice; pteron, wing.] With two wings or wing-like expansions (bot., zool.).

directive body, - a polar body (cyt.).

directive mesenteries, - in Zoantharia, the dorsal and ventral pairs of mesenteries (zool.).

directive sphere,-attraction sphere (cyt.).

dise (disk) n. [Gk. diskos, disc.] Any flattened portion like a disc in shape (bot., zool.); the circumoral area in many animals ; the circular areas at the opposite poles of many animals (zool.); any modification of the thalamus (bot.); the area marking the entrance of the optic nerve into the eye; cup-shaped tactile structures in the skin; the mass of cells of the membrana granulosa which projects into the cavity of the egg follicle (anat.).

disc-florets, - the inner florets borne on the abbreviated and reduced peduncle in many inflorescences (bot.).

discal (dĭs'kăl) a. [Gk. diskos, disc.] Pert. any disc-like structure.

discal (dǐs'kăl) $n$. [Gk. diskos, disc.] A large cell at the base of the wing of lepidopterous insects completely enclosed by wing-nervures; also in some Diptera (zool.).

disciflorous (dis'kǐfló'rŭs, dǐs'îfo'o'rŭs) a. [Gk. diskos, disc; L. flos, flower.] With flowers in which the receptacle is large and disclike (bot.).

discoblastic (dis'köblăs'tǐk) a. [Gk. diskos, disc; blastos, bud.] Pert. meroblastic eggs in which the area of segmentation is disc-shaped (zool.).

discoblastula (dǐs'köblăs'tūlă) n. [Gk. 
diskos, disc; blastos, bud.] A blastula formed from a meroblastic egg with disc-like blastoderm (zool.).

discocarp (dǐs'kökârp) n. [Gk. diskos, disc ; karpos, fruit.] A special enlargement of the thalamus below the calyx (bot.).

discoctasters (diss'kǒktăs'tërz) n. plu. [Gk. diskos, disc ; okto, eight ; aster, star.] Sponge spicules with eight rays terminating in discs, each disc corresponding in position to the corners of a cube ; a modified hexactine (zóol.).

discodactylous (dǐs'ködăk'tǐlǔs) $a$. [Gk. diskos, disc ; daktylos, finger.] With suckers at the ends of the fingers (zool.).

discohexactine (dĩs'köhěksăk'tǐñ) n. [Gk. diskos, disc; hex, six; actis, ray.] A sponge spicule with six equal rays meeting at right angles (zool.).

discohexaster (d'̌s'köhĕksăs'tër) n. [Gk. diskos, disc ; hex, six ; aster, star.] A hexactine with the rays ending in discs (zool.).

discoid (dis'koid) a. [Gk. diskos, disc ; eidos, resemblance.] Flat and circular; disc-shaped.

discoidal (dǐskoi'dăl) a. [Gk. diskos, disc ; eidos, like.] Disc-like ; appl. segmentation in which the blastoderm forms a one-layered disc or cap which spreads over the yolk (emb.).

discontinuous variation, - - see mutation.

disconula (dǐskŏn'ülă) $n$. [Gk. diskos, disc.] An eight-rayed stage in the larval development of certain Coelenterates (zool.).

diseooctaster (dìs'kööktăs'tër), - see discoctasters.

discoplacenta (dís'köplăsěn'tă) $n$. [Gk. diskos, disc ; L. placenta, placenta.] A placenta with the villi on a circular cake-like disc (zool.).

discus proligerus, - in a Graafian follicle, the mass of cells immediately surrounding the ovum (emb.).

disjunct (disjŭngkt') a. [L. dis, apart ; jungere, to join.] Having the body regions separated by deep constrictions (zool.).

disjunctive symbiosis, - a mutually helpful condition of symbiosis although there is no direct connection between the partners (biol.). disk,--see dise.

dispermous (dīspĕr'mŭs) a. [Gk. dis, twice; sperma, seed.] Having two seeds (bot.).

dispermy (dīspěr'mĩ) n. [Gk. dis, twice ; sperma, seed.] The entrance of two spermatozoa into an ovum (biol.).

dispersal (dǐspěr'săl) n. [L. dis, apart; spargere, to strew.] The actual scattering or distributing of organisms on the earth's surface (biol.).

dispireme (dīspī'rêm) n. [Gk. dìs, twice ; speirema, skein.] The stage of karyokinesis in which each daughter nucleus has given rise to a spireme (cyt.).

displacement (dîsplās'měnt) $n$. [O.F. desplacier, to displace.] An abnormal position of any part of a plant due to its shifting from its normal place of insertion (bot.).

dissected (dǐsěk'těd) $a$. [L. dis, apart ; secare, to cut.] Having the lamina cut into lobes, the incisions reaching nearly to the midrib (bot.).

dissepiment (dǐsěp'îmĕnt) $n$. [L. dis, apart; saepire, to hedge in.] The partition found in some compound ovaries (bot.); in Corals, one of the oblique calcareous partitions stretching from septum to septum and closing the interseptal loculi below (zool.).

dissilient (dǐsilliěnt) a. [L. dis, apart ; salire, to leap.] Springing open; $a p p l$. capsules of various plants which dehisce explosively (bot.).

dissoconch (dǐs'ökŏngk') n. [Gk. dissos, double; kongche, shell.] The shell of a veliger larva (zool.).

dissogeny (dǐsŏj'ěnǐ) $n$. [Gk. dissos, double; genos, birth.] The condition of having two sexually mature periods in the same animal-one in the larva, one in the adult (zool.).

dissogony (dísŏg'önî), - -see dissogeny. distal (dìs'tăl) a. [L. dis, apart; stare, to stand.] Standing far apart, $a p p l$. bristles, etc.; pert. end of any structure farthest from the middle line of the organism (biol.).

distichalia (dístikā'liă) n. plu. [Gk. distichos, with two rows.] In 
Crinoids, the secondary brachalia, fixed or free (zool.).

distichous (dis'tîkŭs) a. [Gk. distichos, with two rows.] Pert. alternate leaves, so arranged that the first is directly below the third (bot.).

distractile (dǐstrăk'tǐl) a. [L. dis, apart; trahere, to draw.] Widely separate; appl. usually to longstalked anthers (bot.).

distribution (dǐs'trĭbū'shŭn) $n$. [L. dis, apart ; tribuere, to allot.] The range of an organism or group in the biogeographical divisions of the globe (biol.).

dithecal (dīthē'kăl) a. [Gk. dis, twice ; theke, box.] Two-celled (bot.).

ditokous (dit'ökŭs) a. [Gk. dis, twice ; tokos, birth.] Producing two at a time, either eggs or young (zool.).

ditrematous (dittrē'mătŭs) a. [Gk. dis, twice ; trema, opening.] With separate genital openings; with anus and genital openings separate (zool.).

ditrochous (dìt'rökŭs) a. [Gk. dis, twice; trochos, runner.] With a divided trochanter, or second joint of the limb (zool.).

diurnal (diŭr'năl) a. [L. dies, day.] Opening during the day only (bot.); active in the day-time (zool.).

divaricate (dīvăr'íkāt) a. [L. dis, apart; varicare, to straddle. Widely divergent; bifid; forked (bot., zool.).

divaricators (dī'vărīkā'tŏrz) n. plu. [L. dis, apart ; varicare, to straddle.] Muscles stretching from the ventral valve to the cardinal process, and by their contraction opening the shell (zool.).

divergency (dǐvĕr'jĕnsǐ) n. [L. dis, apart; vergere, to bend.] The fraction of a stem circumference, usually constant for a species, which separates two consecutive leaves in a spiral (bot.).

divergent (divěr'jĕnt) $a$. [L. dis, apart; vergere, to bend.] Separated from one another ; $a p p l$. leaves (bot.).

diverticulum (dî́věrtǐk'ūlŭm) $n$. [L. de, away; vertere, to turn.] A tube or sac, blind at the distal end, branching off from a canal or cavity (zool.). divided (divis'děd) a. [L. dividere, to divide.] With the lamina cut by incisions which reach the midrib; $a p p l$. leaves (bot.).

division (dǐvǐzh'ün) $n$. [L. dividere, to divide.] One of the smaller groups of organisms which together form a larger group (biol.) ; one of the separate parts of which any structure may be composed (biol.).

dizoic (dīzóîk) a. [Gk. dis, twice; zoon, animal.] Pert. spore containing two sporozoites (zool.).

dodecagynous (dō'děkăj'ínŭs) a. [Gk. dodeka, twelve; gyne, woman.] Having twelve pistils (bot.).

dodecamerous (dō'děkăm'ěrŭs) $a$. [Gk. dodeka, twelve ; meros, part.] Having each whorl composed of twelve parts (bot.).

dodecandrous (dō'dĕkăn'drŭs) $a$. [Gk. dodeka, twelve; aner, man.] Having at least twelve stamens (bot.).

dolabriform (dölăb'rĭfôrm) a. [L. dolabra, mattock; forma, shape.] Axe-shaped (biol.).

dolichostylous (dǒl'r̂köstī'lŭs) a. [Gk. dolichos, long; stylos, pillar.] Pert. long-styled anthers in dimorphic flowers (bot.).

dolioform (dólǐöfôrm) a. [L. dolium, jar; forma, shape.] Shaped like a barrel (zool.).

dominant characters,-see Mendelism.

dormant (dôr'mănt) a. [L. dormire, to sleep.] Resting; $a p p l$. any structure or feature which may develop later (biol.).

dorsal (dôr'săl) a. [L. dorsum, back.] Pert. or lying near the back as $o p p$. the ventral surface (anat.); pert. surface farthest from the axis; the upper surface of the thallus or prothallus of ferns, etc. (bot.).

dorsalis (dôrsắlìs) n. [L. dorsum, back.] The artery which supplies the back of any organ (anat.).

dorsiferous (dồrsìferrŭs) $a$. [L. dorsum, back; ferre, to carry.] With the sori on the back of the leaf (bot.); carrying the young on the back (zool.).

dorsifixed (dôr'sífik'st) a. [L. dorsum, back; fingere, to fix.] Having the 
filament attached to the back of the anther, which is immovable (bot.).

dorsigrade (dôr'sĭgrād) a. [L. dorsum, back; gradus, step.] Having the back of the digit on the ground when walking (zool.).

dorsispinal (dôr'sīspīnăl) a. [L. dorsum, back; spina, spine.] Pert. or referring to the back and spine (anat.).

dorsiventral (dôr'sivě̌n'trăl) a. [L. dorsum, back; venter, belly.] With upper and lower surfaces distinct (bot.).

dorsocentral (dôr'sösĕn'trăl) a. [L. dorsum, back; centrum, centre.] Pert. mid-dorsal surface; pert. aboral surface of Echinoderms (zool.).

dorsolumbar (dôr'sölüm'băr) $a$. [L. dorsum, back; lumbus, loin.] Pert. lumbar region of the back (zool.).

dorsoumbonal (dôr'söŭmbō'năl) $a$. [L. dorsum, back; umbo, umbo.] Lying on the back near the umbo (zool.).

dorsoventral (dôr'sövěn'trăl) $a$. [L. dorsum, back; venter, belly.] Pert. structures which stretch from the dorsal to the ventral surface (zool.).

dorsulum (dôr'sūlŭm) $n$. [L. dorsum, back.] The upper surface lying between the collar and scutellum; the mesonotum (zool.).

dorsum (dôr'sŭm) n. [L. dorsum, back.] The sulcular surface of Anthozoa; the tergum or notum of Insects and Crustacea ; the back or higher animals (zool.).

drepanium (drĕpā'niŭm) n. [Gk. drepanon, sickle.] A helicoid cyme with the secondary axes developed in a plane parallel to that of the main peduncle and its first branch (bot.).

dromaeognathous (drō'měŏg'năthŭs) a. [Gk. dromein, to run; gnathos, jaw.] Having a palate in which the palatines and pterygoids do not articulate, owing to the intervention of the vomer (zool.).

dromotropic (drồmötrŏp'îk) a. [Gk. dromos, course; trepein, to turn.] Bent in a spiral (bot.).

drone (drōn) $n$. [A.S. dran.] The male of any species of bee (zool.).

drupaceous (droopä'shŭs) a. [Gk. druppa, berry.] Pert. drupe; bearing drupes ; drupe-like (bot.).

drupe (droop), n. [Gk. druppa, berry.] A superior, one-celled fruit with one or two seeds and a fleshy sarcocarp, a hard endocarp and the pericarp separable into its component parts (bot.).

drupels (droop'ělz) n. plu. [Gk. druppa, berry.] The individual components of the fruit of the raspberry (bot.).

duct (dǔkt) n. [L. ducere, to lead]; also ductus. Any tube which conveys fluid or other substance (anat.); a tube formed by a series of cells which have lost their walls at the points of contact (bot.).

ductless glands,- glands which do not communicate with any organ directly by means of a duct, $\varepsilon . g$. spleen (anat.).

ductule (dük'tūl) $n$. [L. ducere, to lead.] The fine thread-like terminal portion of a duct (anat.). ductus (dŭk'tŭs) n. [L. ducere, to lead.] See duct.

ductus ejaculatorius, - the common duct into which the vasa deferentia open in Insects; a narrow muscular tube at the end of the vas deferens in various invertebrates (zool.).

duodenal (dū'ödē'năl) a. [L. duodeni, twelve each.] Pert. duodenum (anat.).

duodenum (dū'ödē'nŭm) n. [L. duodeni, twelve each.] That portion of the small intestine next to the pyloric end of the stomach (anat.).

duplication (dü'plikā'shŭn) n. [L. duplex, double.] See chorisis.

duplicature (dū'plìkāttūr) n. [L. duplex, double.] A circular fold near the base of the protrusible portion of a polyzoan polypide (zool.).

duplicident (düplis'ídĕnt) $a$. [L. duplex, double; dens, tooth.] Having two pairs of incisors in the upper jaw, one behind the other (zool.).

duplicodentate (dû'pliköděn'tāt) $a$. [L. duplex, double; dens, tooth.] With the marginal teeth on the leaf bearing smaller teeth-like structures (bot.). 
dura mater (dū'ră mā'těr, door’ă măt'ĕr) n. [L. dura, hard; mater, mother.] The tough membrane lining the whole cerebro-spinal cavity (anat.).

dura spinalis, - the tough membrane lining the spinal canal (anat.).

duramen (dūrā'měn) $n$. [L. durare, to harden.] The hard, darker central region of a tree-stem; the heart wood (bot.).

dwarf male,- the small three- or fourcelled plant formed from the androspore of Oedogonium (bot.) ; a small, usually simply formed, individual in many classes of animals, either free or carried by the female (zool.).

dyad (díăd) $n$. [Gk. dyas, two.] The half of a tetrad group (cyt.).

dyaster (di'ăstër) n. [Gk. dyas, two ; aster, star.] "The double group of chromosomes during the anaphases of cell-division" (cyt.).

dyne (dīn) n. [Gk. dynamis, power.] The unit of force in the C.G. system of physical units (phys.).

dysmerism (dǐs'měrǐzm) n. [Gk. dys, hard; meros, part.] An aggregate of unlike parts (biol.).

dysmerogenesis (dǐs'mĕröjĕn'ěsiss) $n$. [Gk. dys, hard ; meros, part ; genesis, birth.] Segmentation resulting in unlike parts (biol.).

dysoxidize (dǐsŏk'sīiiz) v. [Gk. dys, hard; oxys, sharp.] To find difficult to oxidize (phys.).

dyspnoea (dǐs'pnēă) n. [Gk. dys, hard; pnein, to breathe.] Difficulty in breathing (phys.).

dysteleology (dís'tělěŏl'öjî) $n$. [Gk. dys, hard; telos, end; logos, discourse.] Haeckel's doctrine of purposelessness in nature (biol.).

dzierzon (dzēr'tsŏn) theory, - the belief that the males of the honey-bee are always produced from unfertilized eggs (zool.).

\section{E}

$\operatorname{ear}(\overline{\mathrm{e}} \mathrm{r}) n$. [A.S.eare.] The auditory organ (anat.); the various structures among invertebrates supposed to have an auditory function; the specialized tufts of hair or feathers which are close to, or similar to an external ear or pinna (zool.); an ear-shaped structure; the spike of any cereal (bot.).

eared (ērd) $n$. [A.S. eare.] Having external ears or pinnae; with tufts of feathers resembling ears (zool.) ; having long bristles or processes, as in the grains of corn, etc. (bot.).

ebracteate (ēbrăk'těāt), ebracteolate (ēbrăk'těölāt) a. [L. ex, from; bracteatus, covered with a gold plate.] Without bracts, or without bracteoles, reduced leaves on the flower-stalk (bot.).

ecalcarate (ēkăl'kărāt) a. [L. ex, without ; calcar, spur.] Having no spur (zool.) ; with no spur-like process on the petals (bot.).

ecardinal (ēkâr'dīnăl) a. [L. $e x$, without ; cardo, hinge.] Having no hinge; also ecardinate (zool.).

ecarinate (ēkăriñnāt) a. [L. $e x$, without ; carina, keel.] Not furnished with a keel or keel-like ridge (bot., zool.).

ecaudate (ēkốdāt) a. [L.ex, without ; cauda, tail.] Without a tail (zool.).

ecblastesis (ĕk'blăstē'šs) $n$. [Gk. $e k$, out of ; blastos, bud.] A proliferation of the main axis of an inflorescence (bot.).

ecdemic (ěkdĕm'ǐk) a. [Gk, $e k$, out of ; demos, people.] Not native.

ecderon (ĕk'dĕrŏn) n. [Gk. $e k$, out ; deros, skin.] The outer or epidermal layer of the skin (anat.).

ecderonic (ĕk'dĕrŏnı̌k) a. [Gk. $e k$, out; deros, skin.] Ectodermic; epiblastic (emb.).

ecdysis (ĕkdī'siss) $n$. [Gk, $e k$, out ; dyein, to enter.] The act of moulting any particular cuticular layer or structure (zool.).

echinate (ěk'innāt) a. [Gk. echinos, spine.] Furnished with spines or bristles (zool.).

echinochrome (ěk'ínökrōm', ēkīnökrōm) n. [Gk. echinos, spine; chroma, colour.] A colouring pigment found in Echinoderms (zool.). echinoid (ěk'innoid, ěkînoid) a. [Gk. echinos, spine.] Pert. sea-urchins (zool.).

echinopaedium (ěk'īnöpē'diŭm, ěkī'nöpē'diŭm) n. [Gk. echinos, spine ; pais, child.] See dipleurula. 
echinopluteus (ěk'înöploo'těŭs, ěkínöploo'těus) n. [Gk. echinos, spine ; L. pluteus, shed.] The larva or pluteus of echinoids, from its supposed resemblance to an upturned easel (zool.).

echinulate (ěkĭn'ūlāt) $a$. [Gk. echinos, spine.] Having small spines (zool.). ecology (ēkŏl'öjî̀) n. [Gk. oikos, house ; logos, discourse.] That part of biology which deals with the relationship between organisms and their surroundings (biol.).

ectental (ěktěn'tăl) line,-the line where the ectoderm and endoderm meet at the blastopore of a gastrula (cyt.).

ectethmoid (ěktěth'moid) n. [Gk. ektos, without; ethmos, sieve ; eidos, resemblance.] The lateral ethmoid bone (anat.).

ecthoraeum (ěk'thŏrē'ŭm) n. [Gk. ekthroskein, to leap out.] The thread of a nematocyst (zool.).

ectoblast (ěk'töblăst) n. [Gk. ektos, without; blastos, bud.] See epiblast.

ectobronchium (ĕk'töbrŏng'kŭŭm) $n$. [Gk. ektos, without ; brongchos, windpipe.] See ectobronchus.

ectobronchus (ěk'töbrŏng'kŭs) $n$. [Gk. ektos, without; brongchos, windpipe.] A lateral branch of the main bronchus in birds (zool.).

ectocarpous (ĕk'tökâr'pŭs) a. [Gk. ektos, without; karpos, fruit.] Having the gonads of ectodermal origin (zool.).

ectochonđrostosis (ĕk'tökŏndrŏstō'sǐs) n. [Gk. ektos, without; chondros, cartilage; osteon, bone.] The deposition of lime-salts beginning in the perichondrium and gradually invading the cartilage (anat.).

ectochone (ěk'tökōn) n. [Gk. ektio, without ; choane, funnel.] A funnelshaped chamber into which the ostia in certain Sponges lead (zool.). ectocoelic (ěk'tösē'lik) a. [Gk. ektos, outside; koilos, hollow.] Pert. structures situated outside the enteron of the Coelenterates (zool.). ectocondyle (ěk'tökŏn'dĭl) n. [Gk. ektos, outside; kondylos, knob.] The outer condyle of a bone (anat.).

ectocranial (ěk'tökrā'niăl) a. [Gk. ektos, outside; kranion, skull.] Pert. outside of skull (anat.).

ectocuneiform (ěk'tökūnē'ifôrm) $n$. [Gk. ektos, outside; L. cuneus, wedge; forma, shape.] A bone in the distal row of the tarsus (anat.).

ectocyst (ĕk'tösǐst) n. [Gk. ektos, outside; kystis, bladder.] The outer layer of the zoecial wall in Polyzoa (zool.).

ectoderm (ěk'tödĕrm) n. [Gk. ektos, outside; derma, skin.] The outer layer of a multicellular animal, when composed of cells (zool.); the epidermis in higher mammals (anat.).

ectogenous (ĕktŏj'ěnŭs) $a$. [Gk. ektos, outside ; gignesthai, to produce.] Able to live an independent life ; appl. Bacteria (bot.).

ectoglia (ěktǒg'liă) n. [Gk. ektos, outside; glia, glue.] An outer layer of cells in the central nervous system (anat.).

ectolecithal (ěk'tölěs'íthăl) a. [Gk. ektos, outside ; lekithos, yolk of an egg.] Having the yolk surrounding the formative protoplasm (zool.).

ectoloph (ĕk'tölŏf) n. [Gk. ektos, outside ; lophos, crest.] The ridge stretching from the paracone to the metacone in a lophodont molar (anat.).

ectomere (ěk'tömēr) n. [Gk. ektos, outside; meros, part.] An epiblast cell which gives rise to ectoderm (cyt.).

ectoparasite (ěk'töpăr'ăsīt) n. [Gk. ektos, outside ; para, beside ; sitos, food.] A parasite that lives on the exterior of an organism (zool.). ectopatagium (ěk'töpătā'jĭum) n. [Gk. ektos, outside; L. patagium, border.] The part of the winglike membrane of bats carried on the metacarpals and the phalanges (sool.).

ectophyte (ěk'töfît) n. [Gk. eklos, outside; phyton, plant.] Name given to an external parasite in the plant world (bot.).

ectoplasm (ěk'töplăzm) n. [Gk. ektos, outside ; plasma, something moulded.] The external layer of protoplasm in a cell, usually slightly modified (biol.); the ectosarc in a 
protozoan cell (zool.); the layer next the cell-wall (bot.).

ectosarc (ěk'tösârk) $n$. [Gk. ektos, outside ; sarx, flesh.] The external, often highly specialized, layer of protoplasm in a Protozoon (zool.).

ectosome (ěk'tösōm) n. [Gk. ektos, outside; soma, body.] The enveloping portion of a Sponge containing no flagellated chambers (zool.).

ectosphere (ěk'tösfēr) n. [Gk. ektos, outside; sphaira, globe.] The outer zone of the attraction sphere (cyt.).

ectospore (ěk'töspōr) n. [Gk. ektos, outside; sporos, seed.] The spore formed at the end of each sterigma in the Basidiomycetes (bot.).

ectostosis (ěk'tŏstō'sǐs) n. [Gk. ektos, outside; osteon, bone.] Formation of bone in which the ossification begins under the perichondrium and either surrounds or replaces the cartilage (anat.).

ectotheca (ĕk'töthé'kă) n. [Gk. ektos, outside; theke, cup.] The outer coating of the gonotheca in certain Hydroids (zool.).

ectotrophic (ěk'tötrŏ'fik)a. [Gk, ektos, outside; trephein, to nourish.] Finding nourishment from outside; $a p p l$. Fungi which surround the roots of the host with a web of hyphae (bot.). ectoturbinal (ěk'tötŭr'bĭnăl) $n$. [Gk. ektos, outside; L. turbo, whirl.] One of the divisions of the ethmoturbinals (zool.).

ectozoon (ěk'tözốŏn) n. [Gk. ektos, outside; zoon, animal.] An external parasite (zool.).

edaphic (ēdăf'ìk) a. [Gk. edaphos, soil.] Pert. or influenced by the conditions of the soil (phys.).

edentate (ëdĕn'tāt) a. [L. $e x$, without; dens, tooth.] Without teeth (zool.) ; without tooth-like projections (bot.).

edriophthalmic (ěd'riǒfthăl'mǐk) $a$. [Gk. edra, seat; ophthalmos, eye.] Having sessile eyes; $a p p l$. certain Crustacea (zool.).

efferent (ěf'ĕrĕnt) a. [L. ex, out; ferre, to carry.] Conveying from, appl. vessels, lymphatics, etc. (anat.); carrying outwards, appl. impulses carried outwards by the motor nerves (phys.).

egest (éjěst') $v$. [L. ex, out ; gerere, to carry.] To throw out ; to void; to excrete (phys.).

egg (ĕg) $n$. [Icel. egg.] The matured germ-cell of a female plant or animal (biol.).

egg-albumin,- the chief constituent of the white of egg, known to be a mixture of glucoproteids (phys.).

egg-apparatus,-the two synergids and ovum proper, near the micropyle in the embryo sac of seed plants (bot.).

egg-case, - a protective covering formed by many animals for their eggs (zool.).

egg-cell,-the ovum proper apart from any layer of cells derived from it or from other cells (zool.).

egg-membrane, - the layer of tough tissue lining the shell of an egg (zool.).

egg-nucleus, - the female pronucleus (cyt.).

egg-tooth, - a small horny and calcareous structure on the tip of the beak by means of which the embryo breaks the shell (zool.).

ejaculation (ējăk'ūlā'shŭn) $n$. [L.ex, out ; jacere, to throw.] Act of suddenly ejecting a fluid from a duct (phys.).

ejaculatory (ějăk'ülătörì) $a$. [L. $e x$, out; jacere, to throw.] Throwing out, appl. function of certain ducts (phys.).

elaborate (ēlăb'örāt) v. [L. $e x$, out ; laborare, to work.] To change from a crude state to a state capable of assimilation (phys.); to form complex organic substances from simple materials (bot.).

elaeoblast (ělēööblăst) $n$. [Gk. elaion, oil; blastos, bud.] A mass of nutrient material at the posterior end of the body in certain Tunicates (zool.).

elaeodochon (ěl'éōd'ökŏn) n. [Gk. elaiodochos, oil-containing.] The preen-gland or oil-gland in birds (zool.).

elaioplast (ělīöplăst') $n$. [Gk, elaion, oil ; plastos, moulded.] A plastid in a plant cell which forms or helps to form oil globules (bot.). 
elastic fibres,-special fibres, often branched and highly resistant to the action of boiling water, but easily acted on by tryptic digestion (phys.).

elastic fibro-cartilage,-consists of cartilage cells and a matrix pervaded by a network of yellow elastic fibres which branch and anastomose in all directions (anat.). elastic tissue, $\rightarrow$ a type of connective tissue in which elastic and yellowish fibres are mixed with the nonelastic fibres (phys.).

elastin (ēlăs'tĭn) $n$. [Gk. elauein, to drive.] The substance which forms elastic tissues (phys.).

elater (ĕl'ătër) n. [Gk. elater, driver.] One of the cells in certain plants with a spiral thickening in the wall which assists in dispersing the spores (bot.).

electric organ,-modifications of muscles or groups of muscles which discharge a considerable amount of electric energy, found in certain Fishes (zool.).

electroplax (ělěk'tröplăks) n. [Gk. elektron, amber; plax, anything broad and flat.] One of the constituent plates of an electric organ, which are arranged at right angles to the axis of the primitive muscle (zool.).

electrotonic (ělěk'trötŏn'îk) a. [Gk. elektron, amber; tonos, tension.] Pert.astate of electric tension (phys.).

electrotonus (ēlěktrŏt'önŭs) $n$. [Gk. elektron, amber; tonos, tension.] The modified condition of a nerve when subjected to a constant current of electricity (phys.).

eleidin (ělé'ídin) n. [Gk. eleos, wandering.] A substance found as small granules in the stratum granulosum of the epidermis, probably a stage in the formation of keratin (phys.).

element (ěl'ěměnt) $n$. [L. elementum, unit.] A substance that cannot be separated into simpler substances (phys.).

eleutherodactyl (ělü'thěrödăk'tîl) $a$. [Gk. eleutheros, free; daktylos, finger.] Having the hind toe free (zool.).

eleutheropetalous (ělü'thěröpět'ălŭs) a. [Gk. eleutheros, free; petalon, petal.] Having the petals or the components of the whorl free or separate (bot.),

eleutherophyllous (ělū'thěröf îl'ŭs) $a$. [Gk. eleutheros, free; phyllon, leaf.] Having the components of the perianth whorls free (bot.).

eleutherosepalous (ělū'thěrösê̌p'ălŭs) a. [Gk. eleutheros, free; sepalon, sepal.] Having the sepals free and separate (bot.).

elliptical (ělìp'tǐkăl) a. [Gk. elleipsis, a falling short.] Oval-shaped; $a p p l$. leaves of about the same breadth at equal distances from base and apex, which are slightly acute (bot.).

elytriform (ēlít'rífôrm) a. [Gk. elytron, sheath; L. forma, shape.] Shaped like an elytrum (zool.).

elytroid (ēlît'roid) a. [Gk. elytron, sheath ; cidos, resemblance.] Resembling an elytrum (zool.).

elytrum (ēlǐ́t'rŭm) n. [Gk. elytron, sheath.] The anterior wing of certain insects, hard and case-like ; one of the scales or shield-like plates found on the dorsal surface of some worms (zool.).

emarginate (ēmâr'jīnāt) a. [L. ex, out ; marginare, to delimit.] Having a triangular notch at the apex (bot.); having the tip notched (zool.). embole (ĕm'bölē) $n$. [Gk. embole, putting into place.] Invagination (emb.).

embolic (ĕmbǒl'îk) a. [Gk. embolos, anything pointed.] Pushing or growing in (emb.).

embolium (ěmbōllŭm) $n$. [Gk. embolos, pointed.] The outer or costal part of the wing in certain insects (zool.).

embolomerous (ĕm'bölŏm'ěrŭs) $a$. [Gk. embolos, anything pointed; meros, part.] Having two vertebral rings in each segment due to the union of the hypocentra with the neural arch, and the union of the two pleurocentra below the notochord (anat.).

embryo (ĕm'brīō) n. [Gk. embryon, embryo.] Any young organism in the early stages of its development before it has become selfsupporting (biol.). 
embryo cell,-one of the two cells formed from the first division of the fertilized egg in certain plants, developing later into the embryo, the other developing into the suspensor (bot.).

embryo sac,- the megaspore (bot.).

embryogeny (ĕmbriój'ěni) n. [Gk. embryon, embryo; genos, birth.] The processes by which the embryo is formed (emb.).

embryology (ěmbrǐŏl'öjǐ) $n$. [Gk. embryon, embryo ; logos, discourse.] That part of biology dealing with the formation and development of the embryo (biol.).

embryonic (ĕmbrǐŏn'îk) a. [Gk. embryon, embryo.] Pert. embryo (biol.). embryophore (ëm'briöfōr) n. [Gk. embryon, embryo ; pherein, to bear.] The ciliated mantle enclosing the embryo in many tape-worms, and formed from the superficial blastomeres of the embryo (zool.).

embryotegia (ĕmbrïötējjĭă) $n$. [Gk. embryon, embryo; tegos, roof.] The small hardened portion of the testa which marks the micropyle in some seeds and separates like a little lid at the period of germination (bot.).

embryotrophy (ĕm'brǔot'röfî) $n$. [Gk. embryon, embryo; trephein, to nourish.] The nourishment of the embryo, or the means adapted to that purpose (emb.).

emergence (ëmĕr'jĕns) $n$. [L.ex, out ; mergere, to dip.] Any of the outgrowths which arise from the subepidermal tissue (bot., zool.).

emersed (ēměrs't) a. [L. ex, out ; mergere, to dip.] Rising above the surface of the water; $a p p l$. leaves (bot.).

eminence (ĕm'ĭnĕns) n. [L. eminens, eminent.] Ridge or projection on the surface of bones (anat.).

eminentia (ěm'íněn'shǐă) $n$. plu.

eminens, eminent.] Eminences.

emissary (ĕm’ĩsărĭ) a. [L. emittere,

to send out.] Coming out ; name $a p p l$. veins passing through apertures in the cranial wall and establishing connection between the sinuses inside and the veins outside (anat.).

empodium (ĕmpō'drŭm) n. [Gk. en, in; pous, foot.] A small variable median structure between the claws of many insects' feet (zool.).

emulsin (ēmŭl'sĭn) n. [L. emulgere, to milk out.] An enzyme found in certain plants (bot.).

enamel (ěnăm'ĕl) n. [O.F.esmaillier, to coat with enamel.] The hard material containing over 90 per cent. calcium and magnesium salts which forms a cap over the dentine, or may form a complete coat to the tooth or scale in which it is found (anat.).

enamel cells, - the cells which form the enamel and are collectively known as the enamel organ.

enantioblastic (ĕnăn'tiöblăs'tǐk) $a$. [Gk. enantios, opposite; blastos, bud.] Formed at the end of the seed opposite the placenta (bot.).

enarthrosis (ĕn'ârthrō'sĭs) $n$. [Gk.en, in; arthron, joint.] Ball-and-socket joint (anat.).

encephalocoel (ěnkĕf'ălösēl, -sĕf-) $n$. [Gk. enkephalos, within the head; koilos, hollow.] The cavity within the brain (zool.).

encephalon (ěnkĕf'ălŏn, -sĕf-) $n$. [Gk. enkephalos, within the head.] The brain (anat.).

encephalospinal (ĕnkĕf'ălöspīnăl, -sĕf-) a. [Gk. enkephalos, with in the head; L. spina, spine.] Pert. the brain and spinal cord (anat.).

enchylema (ĕn'kīlē'mă) n. [Gk. en, in ; chylos, juice.] The more fluid protoplasm in a cell (biol.).

encyst (ĕnsĭst') $\%$. [Gk. en, in ; kystis, bladder.] Of a cell or small animal, to surround itself with an outer coat or capsule (biol.).

encystation (ĕnsǏstā'shŭn) n. [Gk. en, in ; kystis, bladder.] Formation of a cyst or capsule (biol.).

encystment (ĕnsǐst'mĕnt) $n$. [Gk. en, in ; kystis, bladder.] Formation of a firm, resistant envelope or capsule (biol.).

endarch (ĕnd'ârk) a. [Gk. endon, within; arche, beginning.] With a central protoxylem, or with several surrounding a central pith (bot.).

endaspidean (ĕnd'ăspìd'ěăn) a. [Gk. endon, within; aspis, shield.] With the scutes extending on the inner surface of the tarsus (zool.). 
end-bulbs,-minute cylindrical or oval bodies, consisting of a capsule containing a semi-fluid core in which the axis cylinder terminates either in a bulbous extremity or in a coiled plexiform mass (anat.).

endemic (ĕndĕm'îk) $a$. [Gk. en, in ; demos, the people.] Restricted to a certain region or part of a region (biol.).

enderon (ĕn'dĕrŏn) $n$. [Gk. en, in ; deros, skin.] The inner or endodermal layer (anat.).

enderonic (ĕn'dĕrŏn'îk) $a$. [Gk. en, in ; deros, skin.] Endodermal.

endites (ĕndīts') n. plu. [Gk. endon, within.] The offshoots on the mesial border of the appendages of certain Crustacea (zool.).

endoblast (ĕn'döblăst) $n$. [Gk. endon, within; blastos, bud.] The hypoblast (emb.).

endocardiac (ĕn'dökâr'dǐăk) a. [Gk. endon, within ; kardia, heart.] Situated within the heart (anat.).

endocardial (ĕn'dökâr'dǐăl), - see endocardiac.

endocardium (ĕn'dökâr'dǐŭm) $n$. [Gk. endon, within; kardia, heart.] The thin smooth membrane which lines and gives the glistening appearance to the inner surface of the heart (anat.).

endocarp (ĕn'dökârp) $n$. [Gk. endon, within; karpos, fruit.] The innermost layer of the pericarp, usually hard and stony, in drupaceous fruits (bot.).

endocarpoid (ěn'dökâr'poid) a. [Gk. endon, within; karpos, fruit.] Having the disc-like ascocarps embedded in the thallus (bot.).

endochondral (ěn'dökôn'drăl) a. [Gk. endon, within ; chondros, cartilage.] Beginning or forming inside the cartilage, usually $a p p l$. ossification (anat.).

endochone (ĕn'dökōn) n. [Gk. endon, within ; choane, funnel.] Spacious sub-cortical crypt in the tissue of Sponges from which the incurrent canals start (zool.).

endochrome (ěn'dökrōm) plate,-a band of yellowish chromatophores found in the protoplasmic portion of certain Diatoms (bot.).

endochylous (ěn'dökīlǔs) a. [Gk. endon, within ; chylos, juice.] With the water-cells within the internal tissue (bot.).

endocoelar (ĕn'dösē']ăr) a. [Gk.endon, within ; koilos, hollow.] Pert. the inner wall of the coelom, i.e. the splanchnic wall (zool.).

endocone (ĕn'döcōn) n. [Gk. endon, within; konos, cone.] One of the conical structures formed in certain cephalopod shells ( $p a l$.).

endocranium (ĕn'dökrä'nŭŭm) $n$. [Gk. endon, within ; kranion, skull.] The process on the inner surface of the cranium of certain insects (zool.).

endocrine (ěn'dökrǐn) a. [Gk. endon, within ; krinein, to separate.] $A p p l$. organs of internal secretion (phys.). endocycle (ĕn'dösí'kl) n. [Gk. endon, within; kyklos, circle.] A layer of tissue separating the internal phloem from the endodermis (bot.).

endocyclic (ěn'dösı̌k'lìk) $a$. [Gk. endon, within ; kyklos, circle.] With the mouth remaining in the axis of the coil of the gut, $a p p l$. Crinoids; having an apical system with a double circle of plates surrounding the anus, appl. Echinoids (zool.); pert. endocycle (bot.).

endocyst (ěn'dösǐst) $n$. [Gk. endon, within ; kystis, bladder.] The soft body wall of a zooid in a Polyzoan (zool.).

endoderm (ĕn'dödĕrm) n. [Gk. endon, within; derma, skin.] The hypoblast ; the epithelium of the digestive and respiratory organs, and of the glands appended to the digestive tract $(e m b$.).

endoderm disc, - the posterior unpaired thickening on the ventral surface of the blastoderm of the crayfish (zool.).

endoderm Iamella, - a thin sheet of endoderm stretching between adjacent radial canals, and between the circular canal and the enteric cavity in certain Coelenterates (zool.).

endodermis (ěn'döděr'mǐs) $n$. [Gk. endon, within; derma, skin.] The innermost layer of the cortex in plants (bot.).

endogamy (ĕndŏgămĩ) n. [Gk.endon, within; gamos, marriage.] Zygote formation within the cyst by the 
reciprocal fusion of the division products of the daughter nuclei (zool.).

endogastric (ĕn'dögăs'trǐk) $a$. [Gk. endon, within ; gaster, belly.] Having the curvature of the body with the enclosing shell towards the ventral side (zool.).

endogenous (ĕndŏj'ěnŭs) $a$. [Gk. endon, within ; genos, birth.] Developing from a deep-seated layer (bot.).

endogenous multiplication, - see spore formation.

endogeny (ĕndŏj'ěnĭ) n. [Gk. endon, within ; genos, birth.] Development from a deep-seated layer (biol.).

endognath (ĕn'dögnâth') $n$. [Gk. endon, within; gnathos, jaw.] The inner branch of the oral appendages of Crustacea (zool.).

endognathion (ĕn'dögnâth'ǐon) $n$. [Gk. endon, within; gnathos, jaw.] The mesial segment of the maxilla in man, bearing a central incisor (anat.).

endogonidium (ĕn'dögönĭd'iŭm) $n$. [Gk. endon, within; gonos, offspring.] A gonidium formed in a receptacle ; the colony-forming cells in such forms as Volvox (bot.).

endolabium (ĕn'dölā'biŭm) n. [Gk. endon, within; L. labium, lip.] A membranous lobe in the interior of the mouth on the middle parts of the front of the labium (zool.).

endolaryngeal (ĕn'dölăr'ínjē'ăl, -lărĭn'jěal) a. [Gk. endon, within; laryngx, larynx.] Pert. inside of, or situated in, the larynx (anat.).

endolymph (ĕn'dölïmf) $n$. [Gk. endon, within; L. lympha, water.] The fluid in the inner labyrinth of the ear (anat.).

endolymphangial (ĕn'dölĭmf ăn'jĭăl) $a$. [Gk. endon, within; L. lympha, water; Gk. anggeion, vessel.] Situated in a lymphatic (anat.).

endolymphatic (ěn'dölímfăt'îk) $a$. [Gk. endon, within; L. lympha, water.] Pert. Iymphatics (anat.).

endometrium (ĕn'dömět' riŭm) $n$. [Gk. endon, within ; metra, womb.] The mucous lining of the womb (anat.).

endomysium (ĕn'dömǐz'ium) n. [Gk. endon, within ; mys, muscle.] The delicate connective tissue which separates the muscle fibres from one another (anat.).

endoneurium (ěn'dönū'rŭum) $n$. [Gk. endon, within ; neuron, nerve.] The delicate connective tissue holding together and supporting the nerve fibres within the funiculus (anat.).

endoparasite (ĕn'döpăr'ăsīt) $n$. [Gk. endon, within ; para, beside ; sitos, food.] Any organism living parasitically in another (biol.).

endoperidium (ĕn'döpěrĭd'ư̆m) $n$. [Gk. endon, within; peridion, little pouch.] The inner layer of coat of peridium (bot.).

endophragm (ĕn'döfrăm) $n$. [Gk. endon, within; phragma, fence.] A septum formed by the cephalic and thoracic apodemes in Crustacea (zool.).

endophragmal (ĕn'döfrăg'măl) a. [Gk. endon, within; phragma, fence.] Belonging to or pert. the endophragm (zool.).

endophyte (ěn'döfīt) $n$. [Gk. endon, within; phyton, plant.] A plant growing within another, either as parasite or otherwise (bot.).

endophytic (ĕn'döfit'îk) a. [Gk. endon, within; phyton, plant.] Living in the cavities of other plants (bot.).

endoplasm (ĕn'döplăzm) n. [Gk. endon, within; plasma, something moulded.] The endosarc, or inner portion of the protoplasm in a cell (biol.).

endoplastule (ěn'döplăs'tūl) $n$. [Gk. endon, within; plastos, moulded.] The micronucleus of certain Protists (biol.).

endopleura (ĕn'döploo'ră) $n$. [Gk. endon, within; pleura, side.] The inner seed-coat (bot.).

endopleurite (ěn'döploo'rīt) n. [Gk. endon, within; pleura, side.] The epimeral portion of the apodeme (zool.).

endopodite (ĕndŏp'ödìt) n. [Gk. endon, within; pous, foot.] The inner or mesial branch of a biramous crustacean limb, or the only part of the biramous limb remaining (zool.).

endoral (ĕndō'răl) a. [Gk. endon, within; L. os, mouth.] Pert. structures situated in the vestibule of certain Protozoa (zool.). 
endorhachis (ĕn'dörā'kĭs) n. [Gk. endon, within; rhachis, stem.] A layer of connective tissue lining the canal of the vertebral column and the cavity of the skull (anat.).

endosare (ĕn'dôsârk) n. [Gk. endon, within; sarx, flesh.] See endoplasm.

endosiphuncle (ĕn'dösĭfŭng'kl) $n$. [Gk. endon, within; L. siphunculus, little tube.] The tube leading from the protoconch to the siphuncle in certain Cephalopods ( $p a l$. .).

endoskeleton (ĕn'döskěl'ětŏn) $n$. [Gk. endon, within ; skeletos, hard.] The inner skeleton as opposed to the exoskeleton (zool.).

endosmosis (ĕn'dŏsmō'sǐs) $n$. [Gk. endon, within; osmos, pushing influence.] The passage inwards through a permeable or semipermeable membrane of a less concentrated solution (phys.).

endosome (ĕn'dösōm) n. [Gk. endon, within; soma, body.] The chromatinic mass near the centre of a vesicular type of nucleus (cyt.).

endosperm (ĕn'döspěrm) $n$. [Gk. endon, within; sperma, seed.] The female prothallium (bot.).

endospore (ĕn'döspōr) n. [Gk. endon, within; sporos, seed.] The inner coat of the sporocyst in some Protozoa (zool.); an asexual spore ; the inner coat of a spore wall (bot.).

endosporium (ĕn'döspō'rǐŭ), - see endospore.

endosteal (ěndŏs'těăl) a. [Gk, endon, within; osteon, bone.] Pert. the endosteum (anat.).

endosternite (ĕn'döstĕr'nīt) $n$. [Gk. endon, within ; L. sternum, sternum.] The internal skeletal plate for the attachment of muscles; a free skeleton situated in the prosoma between the alimentary canal and the nerve cord in Arachnids (zool.).

endosteum (ěndǒs'těŭ) $n$. [Gk. endon, within; osteon, bone.] The internal periosteum lining the cavities of bones (anat.).

endostosis (ěn'dǒstō'sīs) n. [Gk. endon, within ; osteon, bone.] Ossification which begins in the cartilage (anat.).

endostracum (ĕndǒs'trăkŭm) $n$. [Gk. endon, within; ostrakon, shell.] The inner layer of the shell (zool.).

endostyle (ĕn'döstīl) n. [Gk. endon, within ; stylos, pillar.] A band of thickened epithelium on the oesophageal wall of a Tornaria ; two ventral longitudinal folds separated by a groove in the pharynx of the Tunicates; a longitudinal groove lined by ciliated epithelium on the ventral wall of the pharynx of Amphioxus (zool.).

endotheca (ĕn'döthē'kă) n. [Gk. endon, within; theke, box.] The whole system of dissepiments in any given calyx of a coral; the oval surface of any Cystidea (zool.).

endothecial (ěn'döthē'kǐăl, -shǐăl) $a$. [Gk. endon, within; theke, box.] Pert. the endothecium; with asci in an ascocarp (bot.).

endothecium (ĕn'döthē'kiŭm, -shiŭm) $n$. [Gk. endon, within ; theke, box.] The central region of an epibasal octant of the oospore of liverworts and mosses; the inner lining of an anther (bot.).

endothelium (ĕn'döthē'liŭm) $n$. [Gk. endon, within; thele, nipple.] A squamous epithelium which lines the serous cavities, the heart, blood, and lymphatic vessels (anat.).

endothorax (ĕn'döthō'răks) $n$. [Gk. endon, within; thorax, chest.] The apodeme system in a crustacean thorax (zool.).

end-plates, - the ramified expansions within the muscular fibre which form the ends of a motor nerve (anat.).

end-sac,- the sac-like vestigial portion of the coelom in the excretory glands of certain Crustacea (zool.).

endysis (ĕndi'sı̌s) n. [Gk. endysis, putting on.] The development of a new coat $(z \circ o l$.).

energesis(ĕn'ĕrjē'sis) n. [Gk.energein, to be active.] The process by which energy is liberated through katabolic action (phys.).

energid (ĕn'ěrjĭd) n. [Gk. en, in ; ergon, work.] Any living uninucleated protoplasmic unit with or without a cell wall (bot.)

enervose (ēnĕr'vōs) $a$. [L. $e x$, without; nervus, sinew.] Having no veins, $a p p l$. certain leaves (bot.). 
engraved (ĕngrāv'd) a. [A.S.grafan, to dig.] With irregular linear grooves on the surface (zool.).

ensiform (ĕn'šfôrm) a. [L. ensis, sword ; forma, shape.] Swordshaped (biol.).

entelechy (ěntěl'ěkĭ) $n$. [Gk. en, in ; telos, end; echein, to hold.] The realisation of forms in plant and animal life which have the power of reproducing their kind (biol.).

entepicondylar (ěntěpǐkŏn'dîlăr) $a$. [Gk. entos, within; epi, upon; kondylos, knob.] Pert. the lower or condylar end of the humerus (anat.).

enteric (ĕn'tĕrik) a. [Gk. enteron, gut.] With an alimentary canal (zool.).

enterocoel (ĕn'tĕrösēl') $n$. [Gk. enteron, gut; koilos, hollow.] A coelom which has arisen either as a pouch-like outgrowth of the archenteric cavity, or as a series of such outgrowths (emb.).

enteron (ěn'tĕrŏn) n. [Gk. enteron, gut.] The alimentary tract (zool.). entire (ĕntīr') a. [M.E. enter, untouched.] With a continuous margin; appl. leaves (bot.).

entoblast (ën'töblăst) $n$. [Gk. entos, within; blastos, bud.] The endoderm; the nucleolus (zool.).

entobranchiate (ĕn'töbrăng'kīāt) $a$. [Gk. entos, within ; brangchia, gills.] Having internal gills (zool.).

entobronchium (ěn'töbrŏng'kĭŭm) $n$. [Gk. entos, within; brongchos, windpipe.] The dorsal secondary branch of the bronchus in birds (anat.).

entobronchus(ĕn'töbrŏng'kŭs), -entobronchium.

entochondrostosis (ĕn'tökŏndrŏstō'sĭs) $n$. [Gk. entos, within; chondros, cartilage; osteon, bone.] Ossification from within outwards (zool.).

entocodon (ěn'tökō'dŏn) n. [Gk. entos, within; kodon, bell.] The lens-shaped mass of cells in the development of a medusoid which sink below the level of the superficial ectoderm, and ultimately develop a cavity (zool.).

entocoel (ĕn'tösēl) n. [Gk. entos, within; koilos, hollow.] The space enclosed by a pair of mesenteries in the Anthozoa (zool.). entocondyle (ĕn'tökŏn'dǐl) $n$. [Gk. entos, within ; kondylos, knob.] The condyle on the mesial surface of a bone (anat.).

entoconid (ĕn'tökō'nĭd) n. [Gk. entos, within; konos, cone.] The posterointernal cusp of a lower molar (zool.). entocuneiform (ĕn'tökūnē'ífôrm) $n$. [Gk. entos, within; kuneos, wedge ; L. forma, shape.] The most internal of the distal row of tarsal bones (anat.).

entocyemate (ĕn'tösīê'māt) a. [Gk. entos, within; kyema, embryo.] With embryos having amnion and allantois (emb.).

entoderm, - see endoderm.

entodermal, - see endodermal.

entogastric (ĕn'tögăs'trǐk) a. [Gk. entos, within; gaster, belly.] Pert. interior of stomach; appl. gastric budding in Medusae (zool.).

entoglossal (ĕn'töglǒs'ăl) a. [Gk. entos, within; glossa, tongue.] Lying in the substance of the tongue (anat.).

entomology (ěn'tömŏl'öjǐ) n. [Gk. entomon, insect; logos, discourse.] That portion of zoology dealing with Insects (zool.).

entomophilous (ĕn'tömŏf'îlŭs) $a$. [Gk. entomon, insect; philein, to love.] Pollinated by the agency of insects (bot.).

entophyte (ĕn'töfīt) $n$. [Gk. entos, within; phyton, plant.] Endophyte.

entoplastron (ĕn'töplăs'trŏn) $n$. [Gk. entos, within; F. plastron, breastplate.] The anterior median plate in the chelonian plastra, often called the episternum, and probably homologous with the interclavicle of other Reptiles (zool.).

entopterygoid (ĕn'töptěr'iggoid) $n$. [Gk. entos, within; pteryx, wing ; eidos, resemblance.] The inner bone adjoining the palate in Fishes (zool.).

entosphere (ĕn'tösfēr) n. [Gk. entos, within ; sphaira, globe.] The inner portion - of the attraction sphere (biol.).

entosternite (ĕn'töstĕr'nīt) $n$. [Gk. entos, within; sternon, breast.] Endosternite.

entosternum (ĕntöstĕr'nŭm) n. [Gk. entos, within ; sternon, breast.] The 
entoplastron; an internal process of the sternum of numerous Arthropods (zool.).

entoturbinals (ĕn'tötŭr'bĭnălz) $n$. plu.

[Gk. entos, within ; L. turbo, whorl.]

One of the divisions of the ethmoturbinals (zool.).

entovarial (ěn'tövä'rǐăl) a. [Gk. entos, within; L. ovum, egg.] Pert. canal formed in the ovaries of certain Fishes by the insinking and closure of a groove formed by the covering epithelium (zool.).

entozoa (ĕn'tözōă) n. plu. [Gk. entos, within; zoon, animal.] A general name for all internal parasites (zool.).

entozoic (ĕn'tözōîk) a. [Gk. entos, within; zoon, animal.] Living within the body or substance of another plant or animal (zool.).

entrochite (ěntrō'kït) $n$. [Gk. en, in ; trochos, wheel.] The joint of the fossil stem of a stalked Crinoid (pal.). envelope (ěn'vĕlöp) $n$. [F. enveloppe, covering.] One of the outer coverings of an egg (zool.); any surrounding structure, e.g. floral envelop (bot.).

environment (ĕnvī'rŏnmĕnt) $n$. [F. environ, about.] The sum-total of the external influences acting on an organism (biol.).

enzootic (ěn'zöŏt'ík) $a$. [Gk. en, in ; zoon, animal.] Afflicting animals (zool.).

enzyme (ĕn'zïm) $n$. [Gk. en, in ; zyme, leaven.] A chemical or unorganized soluble ferment (phys.).

Focene (é'ösēn) $n$. [Gk. eos, dawn ; kainos, recent.] The earliest or oldest division of the Tertiary system (pal.).

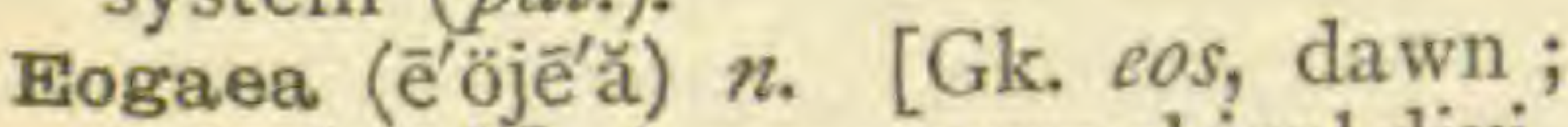
gaia, land.] A zoogeographical division including Africa, S. America, and Australasia ; $c f$. Caenogaea.

eosinophile (éöösin'öfill) a. [Gk. eos, dawn; philein, to love.] $A p p l$. cells which readily stain a brilliant red colour when treated with a mixed stain containing eosin (phys.). epacme (ĕpăk'mē) n. [Gk. epi, upon ; akme, point.] The stage in the phylogeny of a group just previous to its reaching its summit ( $p a l$.).

epalaceous (é'pălä'shŭs) a. [L.ex, without; pala, shovel.] Not spadeshaped (bot.).

epaleaceous (e'pălēā'shŭs) $a$. [L. $e x$, without; palea, chaff.] With receptacles which do not contain chaff (bot.).

epalpate (ēpăl'pāt) a. [L.ex, without; palpus, palp.] Not furnished with palpi (zool.).

epapillate (ēpăp'îlāt) $a$. [L. $e x$, without ; papilla, nipple.] Not having papillae (zool.).

epapophysis (ěp'ăpŏf'ísǐs) n. [Gk. epi, upon; apophysis, offshoot.] A median process arising from the centre of the neural arch of a vertebra (anat.).

eparterial (ěp'ârtē'ruăl) a. [Gk. epi, upon; L. arteria, artery.] Situated above an artery; $a p p l$. branch of right bronchus (anat.).

epaulettes (ěp'ôlěts) n. plu. [F. epaule, shoulder.] Branched or knobbed processes projecting from the outer side of the oral arms of many Scyphozoa; horizontally placed crescentic ridges of cilia in the Echinopluteus (zool.).

epaxial (ěpăk'siăl) a. [Gk. epi, upon ; L. axis, axis.] Above the axis; usually $a p p l$. axis formed by vertebral column (anat.).

epedaphic (ěp'ēdăf'ik) a. [Gk. epi, upon; edaphos, soil.] Pert. climatic conditions (bot.).

epencephalon (ěp'ěnkĕf'ălŏn, -sěf-) $n$. [Gk. epi, upon; engkephalon, the brain.] The cerebellum (anat.).

ependyma (ěpěn'dimă), ependyme (ĕpĕndīm') n. [Gr. ependyma, outer garment.] The layer of cells lining the cavities of the brain and spinal cord (anat.).

ependymal (ěpěn'dimăl) a. [Gk, ependyma, outer garment.] Pert. ependyma.

ephebic (ĕfē'bǐk) a. [Gk. cpi, upon; hebe, puberty.] Pert. stage in phylogeny between the early or childhood stage and the old-age stage of a group (pal.).

ephemerals (ëfěm'èrălz) n. plu. [Gk. ephemeros, daily.] Annual plants with duration of life-cycle so shortened as to enable several generations to follow one another during a single season (bot.). 
ephippium (ěfīp'ŭŭ) $n$. [Gk. epi, upon; hippos, horse.] The pituitary fossa, or fossa hypophyseos of the sphenoid (anat.); a thickened and indurated part of the shell which separates from the rest at ecdysis and forms a protective case for the eggs in certain Cladocera (zool.).

ephyra (ĕf'ǐră) $n$. [Gk. Ephyra, a nymph's name.] The small freeswimming jelly-fish stage of certain Scyphozoa, produced by strobilation of the Scyphistoma (zool.).

ephyrula (ĕfír'ūlă),-ephyra.

epibasal (ěp'íbā'săl) $a$. [Gk. epi, upon; L.basis, base.] Pert. upper segment of an oospore, ultimately giving rise to the shoot (bot.).

epibenthos (ĕp'íběn'thŏs) n. [Gk.epi, upon; benthos, depths.] Fauna and flora found between the low-water mark and the hundred fathoms' line (biol.).

epiblast (ĕp'íblăst) $n$. [Gk. epi, upon ; blastos, bud.] The outer layer of the gastrula; the ectoblast (emb.).

epiblema (ěp'íblē'mă) $n$. [Gk. epiblema, cover.] The outermost layer of the root-tissue (bot.).

epibolic (ĕp'íbŏl'ık) a. [Gk. epi, upon; ballein, to throw.] Growing so as to cover over; $a p p l$. type of gastrulation (emb.).

epiboly (ěpib'ölǐ) $n$. [Gk. epi, upon; ballein, to throw.] Growth of one part over another in embryonic stages (emb.).

epibranchial (ěp'íbrăng'kŭăl) $a$. [Gk. epi, upon; brangchia, gills.] Pert. the second upper element in a branchial arch (zool.).

epicalyx (ĕp'îkā'lìks) n. [Gk. epi, upon ; kalyx, cup.] The stipules, fused in pairs, producing an apparent outer or extra calyx; a structure just below the calyx produced by the aggregation of bracts or bracteoles (bot.).

epicanthus (ěp'ikăn'thŭs) n. [Gk. epi, upon; kanthos, corner.] A prolongation of the upper eyelid over the inner angle of the eye (anat.).

epicardium (ěp'íkâr'diŭm) n. [Gk. epi, upon; kardia, heart.] The visceral part of the pericardium (anat.); a tubular prolongation of the branchial sac in many Ascidians, which takes part in budding (zool.). epicarp (ĕp'íkârp) n. [Gk. epi, upon ; karpos, fruit.] The outer layer of the pericarp (bot.).

epicentral (ěp'ísěn'trăl) a. [Gk. epi, upon; kentron, centre.] Attached to or arising from the vertebral centra; appl. usually to intermuscular bones (anat.).

epicerebral (ěp'îsĕr'ěbrăl) $a$. [Gk. epi, upon; L. cerebrum, brain.] Situated above the brain (anat.).

epichilium (ĕp'íkı̌l'iŭm) $n$. [Gk. epi, upon; cheilos, lip.] The terminal lobe of the lower petal of an orchid (bot.).

epichordal (ěp'îkôr'dăl) a. [Gk. epi, upon; chorde, cord.] Upon the notochord; $a p p l$. vertebrae in which the ventral cartilaginous portions are almost completely suppressed (zool.).

epicoele (ӗp'îsēl) $n$. [Gk. epi, upon; koilos, hollow.] The cavity of the mid-brain in the lower vertebrates; the cerebellar cavity (anat.); a perivisceral cavity formed by invagination (zool.).

epicoelia (ĕp'isé'liŭ) n. [Gk. epi, upon; koilia, cavity.] Epicoele.

epicondylar (ĕp'îkŏn'dĭlăr) a. [Gk. epi, upon; kondylos, knob.] Pert. the epicondyle (zool.).

epicondyle (ěp'îkŏn'dǐl) $n$. [Gk. epi, upon; kondylos, knob.] The outer protuberance at the lower or distal end of the humerus (anat.).

epicoracoid (ěp'îkŏr'ăkoid) a. [Gk. epi, upon; korax, crow; eidos, resemblance.] Pert. an element usually cartilaginous in nature at the sternal end of the coracoid in Amphibians, Reptiles, and Monotremes (zool.).

epicormic (ĕp'îkôr'mǐk) a. [Gk. epi, upon; kormos, trunk of a tree.] Growing from a dormant bud (bot.).

epicotyl (ěp'îkŏt'îl) $n$. [Gk. epi, upon ; kotyle, vase.] The axis of a plumule (bot.).

epicotyledonary (ěp'îkŏt'îlě̀d'ŏnărǐ) $a$. [Gk. epi, upon; kotyle, vase.] Above the cotyledons (bot.).

epicoxite (ĕp'íkǒk'sît) n. [Gk. epi, upon; L. coxa, hip.] A small 
process at the posterior end of the toothed part of the coxae of the second, third, fourth, and fifth pairs of appendages in the Eurypterida (pal.).

epicranial (ĕp'îkrā'nı̌ăl) a. [Gk. epi, upon; kranion, skull.] Pert. cranium ; appl. muscles, bones, etc. (anat.).

epicranium (ĕp'îkrā'nĭŭm) n. [Gk. epi, upon; kranion, skull.] The region between and behind the eyes in an insect's head (zool.); the structure covering the cranium (anat.).

epieritic (ěp'íkrĭt'îk) a. [Gk. epi, upon; krinein, to judge.] Pert. return and accurate localization of elaborate sensations after an operation (phys.).

epicyte (ěpisīt) n. [Gk. epi, upon ; kytos, hollow.] The external layer of the ectoplasm in certain Protozoa (sool.).

epidemes (ĕp'ĩdēmz) n. plu. [Gk. epi, upon; demas, body.] In certain insects, small pieces closely related with the articulation of the wings (zool.).

epidermis (ěp'ídĕr'mǐs) $n$. [Gk. cpi, upon; derma, skin.] The outermost protective layer of stems, roots, and leaves, occasionally it may be the outer layer of the ground tissue (bot.); the external layer of the skin, a non-vascular stratified epithelium of ectodermic origin ; the single layer of ectoderm in many invertebrates (zool.).

epididymis (ěp'ídíd'ímiss) $n$. [Gk. epi, upon ; didymos, testicle.] A mass at the back of the testicle composed chiefly of the vasa efferentia ; generally speaking, the greatly coiled anterior end of the Wolffian duct (anat., zool.).

epidural (ěp'idū'răl) a. [Gk. epi, upon; L. dura, hard.] Pert. dura mater; $a p p l$. space between the dura mater and the wall of the vertebral column (anat.).

epigamic (ĕp'ígăm'îk) a. [Gk. epi, upon ; gamos, marriage.] Tending to attract the opposite sex (zool.).

epigamous (ěpig'ămŭs) $a$. [Gk. cpi, upon; gamos, marriage.] Designating that stage in polychaete worms in which the immature forms become heteronereid, whilst the sexual elements are ripening (zool.).

epigaster (ĕp'ígăs'tër) $n$. [Gk. epi, upon ; gaster, belly.] That part of the embryonic intestine which later develops into the gut ( $\mathrm{cmb}$.).

epigastric (ĕp'igăs'trǐk) a. [Gk. epi, upon ; gaster, belly.] Pert. anterior wall of the abdomen ; middle region of the upper zone of the artificial divisions of the abdomen (anat.).

epigastrium (ĕp'ĩgăs'trĭŭm) n. [Gk. epi, upon; gaster, stomach.] The epigastric region (anat.); the sternal portions of the meso- and metathorax of insects (zool.).

epigeal (ĕp'íjē'ăl) a. [Gk. epi, upon ; gaia, land.] Living near the ground, appl. insects (zool.); borne above the ground, $a p p l$. cotyledons when they form first foliage leaves (bot.). epigenesis (ĕp'ijĕn'ěsĩs) n. [Gk. $e p i$, upon ; gignesthai, to be born.] The theory of generation, that the embryo is an entirely new creation, not a mere unfolding of preformed structures (biol.).

epigeous (ĕp'íjē'ǔs), - see epigeal (bot.).

epiglottis (ĕp'íglŏt'ǐs) $n$. [Gk. epi, upon ; glotta, tongue.] A thin leafshaped lamella of fibro-cartilage, yellowish in colour, between the root of the tongue and the entrance to the larynx (anat.) ; the epistome in Polyzoa ; the epipharynx in Insects (zool.).

epignathous (ĕp'ĭgnâ'thŭs, ěpig'năthŭs) a. [Gk. epi, upon; gnathos, jaw.] Having the upper jaw longer than the lower (zool.).

epigonium (ěp'ígō'nĭum) $n$. [Gk. $e p i$, upon; gone, seed.] The young sporangial sac in the Liverworts (bot.).

epigynous (ĕpijj'inŭs) a. [Gk. $e p i$, upon ; gyne, woman.] Having the various whorls adnate to the ovary, thus apparently inserted in the ovary (bot.).

epigyny (ĕpij̄inĩ) $n$. [Gk. epi, upon; gyne, woman.] The condition of having the whorls apparently inserted in the ovary (bot.).

epihyal (ěp îhíăl) a. [Gk. epi, upon; hyoeides, $\mathrm{Y}$-shaped.] Pert, the upper 
portion of the ventral part of the hyoid arch; $n$. the upper element of the ventral portion (zool.).

epilabrum (ĕp'îlắb'rŭm) $n$. [Gk. epi, upon; L. labrum, -lip.] A process at the side of the labrum in Myriapods (zool.).

epimandibular (ěp'ǐmăndỉb'ūlăr) $a$. [Gk. epi, upon; L. mandibulum, jaw.] Pert. a bone in the lower jaw of vertebrates (zool.).

epimeral (ěpim'ĕrăl) a. [Gk. epi, upon; meros, part.] Pert. epimeron. epimere (е̌p'ímēr) $n$. [Gk. epi, upon; meros, part.] The upper region, or dorsal muscle-plate of the mesothelial wall (emb.).

epimerite (ěpim'ěrīt) $n$. [Gk. epi, upon; meros, part.] The deciduous portion of the protomerite in certain Gregarines (zool.).

epimeron (ĕpĭm'ĕrŏn) n. [Gk. epi, upon ; meros, part.] A portion of the pleuron in insects which may be posterior or nearly as far forward as the episternum; a portion of the arthropod segment between the tergum and the limb insertions (zool.).

epimorphosis (ĕp'ímôr'fösiss) $n$. [Gk. epi, upon; morphe, change.] That type of regeneration in which a proliferation of new material precedes the development of the new part (biol.).

epimysium (ӗp'imìz'ŭm) $n$. [Gk. epi, upon; mys, muscle.] The sheath of areolar tissue which invests the entire muscle; $c f$. perimysium (anat.).

epinasty (ĕp'ínăs'tǐ) $n$. [Gk. epi, upon; nastos, pressed close.] The more rapid growth of the upper surface of a dorso-ventral organ, e.g. a leaf, thus causing an unrolling or downward curvature (bot.).

epineural (ĕp'ĩnū'răl) a. [Gk. cpi, upon; neuron, nerve.] Arising from the neural arch of a vertebra (anat.); pert. canal immediately below the radial nerve cord in the Ophiuroidea, which represents the missing ambulacral groove (zool.).

epineurium (ěp'ǐnū'rǐŭm) $n$. [Gk. epi, upon; neuron, nerve.] The external sheath of a nerve cord (anat.). epiotic (е̌p'iot'îk) a. [Gk. epi, upon; ous, the ear.] Pert. the upper element of the bony capsule of the ear (anat.).

epiparasite (ĕp'ípăr'ăsīt) $n$. [Gk. epi, upon; para, beside ; sitos, food.] Ectoparasite.

epipetalous (ĕp'ípĕt'ălŭs) a. [Gk. epi, upon; petalon, petal.] Having the stamens inserted on the petals (bot.). epipharyngeal (ěp'îfăr'injēăl, ěp'ífărĭn'jě̆l) a. [Gk. epi, upon; pharyngx, throat.] Pert. the upper or dorsal aspect of the pharynx (zool.).

epipharynx (ěp'îfắrĭngks) $n$. [Gk. epi, upon; pharyngx, throat.] A projection on the roof of the mouth cavity of certain insects ; the membranous lining of labrum and clypeus drawn out with the labrum to form a piercing organ, as in Diptera (zool.).

epiphragm (ěp'Îfrăm) $n$. [Gk. epiphragma, covering.] A layer of hardened mucous matter, or a calcareous plate, closing the opening of certain gastropod shells (zool.); the membrane which closes the capsule in certain Mosses; a closing membrane in the sporophores of certain Fungi (bot.).

epiphysial (ěp'ífíz'ǔla) a. [Gk. epi, upon; phyein, to grow.] Pert. or similar to the epiphysis (zool.).

epiphysis (ěpíf'ísǐs) $n$. [Gk.epi, upon; phyein, to grow.] Any part or process of a bone which is formed from a separate centre of ossification and later fuses with the bone ; the pineal body (anat., zool.); a stout bar firmly fused to the alveolus of each jaw and articulating with the rotulae in sea-urchins; certain of the processes on the tibia of insects (zool.). epiphyte (ĕp'îïit) $n$. [Gk. epi, upon ; phyton, plant.] Plant which lives on other plants, but is not parasitic (bot.).

epiphytic (ěp'ifit'îk) a. [Gk. epi, upon; phyton, plant.] Pert. or similar to an epiphyte (bot.).

epiphytotic (ĕp'ifitǒt'îk) a. [Gk. epi, upon ; phyton, plant.] Pert. disease epidemic in plants (bot.).

epiplankton (ěp'îplăng'ktŏn) $n$. [Gk. epi, upon; plangktos, wandering.] 
That portion of the plankton from the surface to the hundred fathoms line (zool.).

epiplasm (ěp'íplăzm) $n$. [Gk. epi, upon ; plasma, something moulded.' Cytoplasm of a brood mother-cell remaining over unused in brood formation (biol.).

epiplastron (ěp'íplăs'trŏn) $n$. [Gk. epi, upon ; F. plastron, breast-plate.] One of the anterior pair of bony plates in the plastron of Chelonians (zool.).

epipleura (ĕp'íploo'ră) n. [Gk. epi, upon; pleuron, rib.] One of riblike structures in Teleosts which are not preformed in cartilage ; an uncinate process in birds; the turned down outer margin of the elytra of certain beetles (zool.).

epiploic (ěp'íplōík) a. [Gk, epiploon, caul of the entrails.] Pert. the omentum.

epiploic foramen,-the opening between the bursa omentalis and the large sac of the peritoneum; the foramen of Winslow (anat.).

epiploon (ěp'íplōón) $n$. [Gk. epiploon, caul of the entrails.] The great omentum (anat.); insect adipose tissue (zool.).

epipodial (ěp'ípō'dĭăl) a. [Gk. epi, upon ; pous, foot.] Pert. the epipodium.

epipodite (ěpĭp’ödīt) $n$. [Gk. epi, upon ; pous, foot.] A process arising from the basal joint of the crustacean limb and usually extending into the gill chamber (zool.). epipodium (ĕp'ípō'dǔ̆m) n. [Gk. epi, upon ; pous, foot.] The embryonic leaf-lamina (bot.); ridge or fold running along the entire edge of the creeping sole of the foot of Gastropods, often beset with papillae; the raised ring on an ambulacral plate surrounding the two pores through which the tube-feet project in Echinoidea (zool.).

epiprecoracoid (ěp'íprēkǒrăkoid) n. [Gk. epi, upon ; L. pre, before ; Gk. korax, crow ; eidos, resemblance.] A small cartilage at the ventral end of the precoracoid in some turtle pectoral girdles (zool.).

epipteric (ĕp'îptěr'îk) a. [Gk. epi, upon; pteron, wing.] Pert. or shaped like, or placed above the wing; $a p p l$. a small bone in the skull between the parietal and the sphenoidal ala (anat.).

epipterygoid (ěp'îptĕr'ígoid) $n$. [Gk. $e p i$, upon ; ptery $x$, wing.] A small bone extending nearly vertically downwards from the prootic to the pterygoid; also called columella (zool.).

epipubic (ěp'ĩpū’bǐk) a. [Gk. epi, upon; L. pubes, adult.] Pert. or borne upon the pubis; appl. certain cartilages or bones principally in marsupials (zool.).

epipubis (ěp'ípū'bǐs) $n$. [Gk. epi, upon ; L. pubes, adult.] An unpaired cartilage or bone borne anteriorly on the pubis (zool.).

epirhizous (ĕp'írî́zŭs) a. [Gk. epi, upon; rhiza, root.] Growing upon a root (bot.).

episepalous (ěp'ísěp'ălŭs) $a$. [Gk. epi, upon; sepalon, sepal.] Adnate to the sepals (bot.).

episkeletal (ěp'ískěl'ětăl) $a$. [Gk. epi, upon; skeletos, hard.] Outside the endoskeleton (zool.).

episperm (ĕp'íspěrm) n. [Gk. epi, upon ; sperma, seed.] The testa or outer coating of the seed (bot.).

episporangium (ěp'íspörăn'jŭum) $n$. [Gk. epi, upon; sporos, seed; anggeion, vessel.] An indusium (bot.).

epispore (ĕp'íspōr) n. [Gk. eppi, upon ; sporos, seed.] The outer layer of the wall of a sporocyst (zool.).

episternalia (ĕp'istěrnălliă) n. plu. [Gk. epi, upon; sternon, breastbone.] Two small elements preformed in cartilage frequently intervening in development between the clavicles and the sternum, and ultimately fusing with the sternum (zool.).

episternite (ěp'ístĕr'nīt) n. [Gk. epi, upon; sternon, breast-bone.] One of the portions of an ovipositor formed from the side portions of a somite (zool.).

episternum (ěp'ĩstěr'nŭm) $n$. [Gk. epi, upon ; sternon, breast-bone.] The interclavicle; also applied to an anterior cartilaginous element of the sternum; a lateral division of an arthropod somite, usually 
above the sternum and more anteriorly placed than the epimeron (zool.).

epistoma (ĕp'îstō'mă) $n$. [Gk. epi, upon ; stoma, mouth.] The region between the antenna and the mouth in Crustacea; a small lobe overhanging the mouth in the Polyzoa and containing a part of the body cavity ; that portion of the insect's head immediately behind the labrum; a portion of the rostrum of certain Diptera (zool.).

epistome,- - see epistoma.

epistrophe (ĕpus'tröfēē) n. [Gk. epistrophe, turning towards.] The position assumed by the chloroplasts along the outer and inner walls when exposed to diffuse light (bot.).

epistropheus (ěp'ĩstrō'feǔsu, ěp'îstrō'fyūs) $n$. [Gk. epistropheus, turning.] The axis vertebra (anat.).

epithalamus (ĕp'íthălămŭs) $n$. [Gk. epi, upon; thalamos, chamber.] The trigonum habenulae, the pineal body and the posterior commissure of the brain (anat.).

epithalline (ěp'ithăl'în) a. [Gk. epi, upon ; thalla, stem.] Growing upon the thallus (bot.).

epitheca (ěp'ithë'kă) n. [Gk. epi, upon; theke, cup.] An external layer surrounding the lower part of the theca in many Corals (zool.). epithecium (ĕp'îthē'kiŭm, ěp'îthēshiŭm) n. [Gk. epi, upon; theke, cup.] The surface of the sporecases in Lichens and Fungi (bot.). epithelial (ěp'îthēliăl) a. [Gk. epi, upon ; thele, nipple.] Pert. epithelium.

epithelium (ěp'ithēliŭm) n. [Gk. epi, upon; thele, nipple.] Any cellular tissue covering a free surface or lining a tube or cavity (biol.).

epithem (ĕp'íthĕm) n. [Gk. epi, upon; tithenai, to put.] A group of specialized colourless parenchyma cells surrounding a space in the tissue of a plant and forming a hydathode (bot.); an excrescence on the beak of birds (zool.).

epithema, - see epithem. epitheme,-see epithem. epitokous (ěpütökŭs) a. [Gk. epi, upon; tokos, birth.] Designating the heteronereid stage of certain Polychaetes (zool.).

epitrichial (ěp'ítrǐk'iăl) a. [Gk. epi, upon; thrix, hair.] Pert. or resembling the epitrichium (emb.).

epitrichium (ěp'itrik'ıumm) n. [Gk. epi, upon; thrix, hair.] An outer layer of the epidermis in the foetus of many mammals, usually shed before birth (emb.).

epitrochlea (ěp'ítrǒk'lěă) n. [Gk. epi, upon; trochos, wheel.] The inner condyle at the distal end of the humerus (anat.).

epitympanic (ěp'î́timpăn'îk) a. [Gk. epi, upon; L. tympanum, kettledrum.] Situated above the tympanum (zool.).

epixylous (ĕp'îksīlŭs, ĕpǐk'sīlŭs) $a$. [Gk. epi, upon; xylon, wood.] Growing upon wood (bot.).

epizoic (ěp'izố'̂k) a. [Gk. epi, upon ; zoon, animal.] Pert. animals living on or attached to the body of another animal (zool.).

epizoon (ěp'izōóŏn) $n$. [Gk. cpi, upon ; zoon, animal.] An animal living on another; an external parasite (zool.).

epizootic (ěp'îzōŏt'̂́k) a. [Gk. epi, upon; zoon, animal.] Common among animals (sool.).

epizygal (ĕp'ízígăl) $n$. [Gk. epi, upon; zygon, yoke.] The upper ossicle in a syzygial pair of brachials or columnars in the Crinoids (zool.).

eponychium (ĕp'ónik'ium) n. [Gk. epi, upon; onyx, nail.] The thin cuticular fold which overlaps the lunula of the nail (anat.); the dorsal portion of a neonychium (emb.).

epoophoron (ěp'öŏförŏn) $n$. [Gk. epi, upon; oon, egg; pherein, to bear.] A rudimentary organ, the remains of the Wolffian body of the embryo, lying in the mesosalpinx between the ovary and the uterine tube (anat.).

equal ( $\overline{\mathrm{e}}^{\prime} \mathrm{kw}$ ăl) $a$. [L. aequalis, equal.] Having the portions of the lamina equally developed on the two sides of the midrib; $a p p l$. leaves (bot.).

equation division, - in mitosis, by the longitudinal splitting of the 
chromatin thread all the ancestral germ-plasms are equally distributed in the daughter nuclei (cyt.).

equatorial (ě̌k'wătótriăl) plate,- - the group of chromosomes lying at the equator of the spindle during mitosis (cyt.).

equibiradiate (ěk'wỉbīrā'dīât) $a$. [L. aequus, equal ; bis, twice ; radius, radius.] With two equal rays (zool.).

equicellular (ě̌k'wisěl'úlăr) a. [L. aequus, equal; cellula, cell.] Composed of equal cells (zool.).

equilateral (ềk'wǐlăt'ĕrăl) $a$. aequus, equal ; latus, side.] Having the sides equal; $a p p l$. shells which are symmetrical about a transverse line drawn through the umbo (zool.).

equitant (ĕk'witănt) a. [L. equitare, to ride.] Having the bases overlapping, saddlewise, the leaves above them (bot.).

equivalve (ěk' 'wivălv') a, [L. aequus, equal ; valva, valve.] Having the two halves of the shell exactly alike in form and size (zool.).

erect (ērěkt') a. [L. erigere, to raise up.] Not decumbent (bot.).

erectile (ērěk'tǐl) a. [L. erigere, to raise up.] Capable of being erected (zool.).

erectile tissue, - a tissue capable of being made rigid and dilated by the distention of the blood-vessels within it (anat.).

erection (ērěk'shŭn) $n$. [L. erigere, to raise up.] The state of a part which has become swollen and distended through the accumulation of blood in the erectile tissue (phys.).

erector (ērěk'tŏr) n. [L. erigere, to raise up.] A muscle which raises up an organ or part (anat.).

oremochaetous (ěr'ēmökēturs) $a$. [Gk. eremos, lonely ; chaeta, bristle.] Having no regularly arranged system of pointed bristles; $a p p l$. flies (zool.).

ergaloid (ěr'găloid) a. [Gk. ergates, worker.] Having the adults sexually capable though wingless (sool.). ergastoplasm (ěrgăs'töplăzm) $n$. [Gk. ergazesthai, to work; plasma, something moulded.] Archoplasm (biol.). ergatandrous (ĕrgătăn'drŭs) $a$. [Gk. ergates, worker; aner, man.] Having worker-like males (zool.).

ergatogynous (ĕr'gătŏj'innŭs) a. [Gk. ergates, worker; gyne, woman.] Having worker-like females (zool.). ergot (ĕr'gŏt) $n$. [O.F. argot, spur.] A small bare patch found on the limbs of the horse-tribe, representing the last remnant of the naked palm of the hand and sole of the foot (anat.).

eriophyllous (ěr'iöflil'ǔs) a. [Gk. erion, wool; phyllon, leaf.] Having leaves with a cottony appearance (bot.).

erose (êrōs') a. [L. erodere, to wear away.] Having the margin irregularly notched (bot.).

erosion (ērózzhŭn) $n$. [L. erodere, to wear away.] Decay which usually starts at the apex of many gastropod shells (zool.).

erostrate (ērŏs'trāt) $a$. [L. ex, without ; rostrum, beak.] Having no beak ; $a p p l$. anthers (bot.).

ersaeome (ěr'sēōm) n. [Gk. erse, young.] The free monogastric generation of Siphonophora (zool.). eruciform (ê̌roo'sifôrm) $a$. [L. eruca, caterpillar; forma, shape.] Having the shape of, or resembling a caterpillar; $a p p l$. insect larvae (zool.).

erumpent (êrŭm'pěnt) $a$. [L. $e x$, out ; numpere, to break.] Breaking out suddenly; $a p p l$. fungal hyphae (bot.).

erythrin (ĕrĭth'rīn) n. [Gk. erythros, red.] A red colouring matter found in certain Algae (bot.).

erythrism (ěrith'rǐzm) n. [Gk. erythros, red.] A condition due to excessive amount of red colouring matter in the feathers (zool.).

erythroblasts (ěrīth'röblăsts) $n$. plu. [Gk. erythros, red; blastos, bud.] Amoeboid nucleated cells, derived from the mesoderm, which later contain haemoglobin and develop into red blood corpuscles (phys.).

erythrocyte (ěrith'rösīt) n. [Gk.eryth ros, red; kytos, hollow.] A red blood corpuscle (anat.).

erythrophilous (ěr' ithrǒf'ilŭs) $a$. [Gk. erythros, red; philein, to love.] Having special affinity for red dyes; 
$a p p l$. structures in a cell or to a type of cells (biol.).

erythrophyll (ĕrǐth'röfill) $n$. [Gk. erythros, red; phyllon, leaf.] A red colouring matter found in some leaves (bot.).

erythrozym (ĕrǐth'rözīm) $n$. [Gk. erythros, red; zyme, leaven.] One of the enzymes capable of acting upon the glucosides (bot.).

erythrozyme (ěrĭth'rözīm) n. [Gk. erythros, red; zyme, leaven.] An enzyme capable of decomposing ruberythric acid (phys.).

escape (ěskāp') n. [M.E. escapen.] A plant originally cultivated, now found wild (bot.).

esculent (ěs'kūlěnt) a. [L. esculentus, edible.] Suitable for food.

escutcheon (ĕskŭch'ŭn) n. [O.F. escuchon, shield.] The area on the rump of many quadrupeds which is either variously coloured or has the hair specially arranged; the mesoscutellum of certain insects; the ligamental area of certain bivalves (zool.).

eseptate (ēsěp'tāt) $a$. [L. $e x$, without ; septum, division.] Not supplied with septa (biol.).

esophagus (ēsŏf'ăgŭs),- - see oesophagus.

esoteric (ěs'ötěr'ík) a. [Gk. esoterikos, arising within.] Arising within the organism (phys.).

espathate (ēspă'thāt) a. [L.ex, without; spatha, sheath.] Having no spathe (bot.).

esquamate (ēskwā'māt) a. [L. ex, without; squama, scale.] Having no scale (bot.).

estipulate (ēstíp'ūlāt) $a$. [L.ex, without ; stipula, stem.] Having no stipules (bot.).

estivation (ěs'tǐvā'shŭn), - see aestivation (bot., zool.).

estuarine (ěs'tūărî̀n) a. [L. aestus, swell of the sea.] Pert. or found in an estuary; $a p p l$. plants and animals (biol.).

etaerio (ētếriōo) n. [Gk. etairia, an association.] A fruit composed of achenes or drupelets carried on an enlarged receptacle (bot.).

etheogenesis (ĕth'ěöjěn'ěsĭs) $n$. [Gk. etheos, youth ; gignesthai, to produce.] A kind of parthenogenesis producing males, said to exist in some Protozoa (zool.).

Ethiopian (e'thǐo'pǐăn) n. [Gk. aithiops, burned face.] A zoogeographical region including Africa south of the Sahara and southern Arabia (zool.).

ethmoid (ěth'moid) a. [Gk. ethmos, sieve ; eidos, shape.] Pert. bones which form a considerable part of the walls of the nasal cavity (anat.). ethmoidal (ĕthmoi'dăl) a. [Gk. ethmos, sieve; eidos, shape.] Pert. region of the ethmoids (anat.).

ethmoidal notch, - a quadrilateral space separating the two orbital parts of the frontal (anat.).

ethmolysian (ěth'mölís'iăn) a. [Gk. ethmos, sieve; lyein, to loosen.] Pert. an apical system in which the madreporite extends backwards till it separates the two posterolateral genitals (zool.).

ethmopalatine (ěth'möpăl'ătĭn) $a$. [Gk. ethmos, sieve; L. palatus, palate.] Found in the ethmopalatine region, or stretching from the ethmoid to the palatine (zool.).

ethmophract (ěth'möfrăkt) a. [Gk. ethmos, sieve; phrassein, to fence in.] Pert. a simple, compact, apical system with the pores occurring only in the right anterior corner (zool.).

ethmoturbinals (ĕth'mötŭr'bĭnălz) $n$. plu. [Gk. ethmos, sieve; L. turbo, whorl.] Cartilages or bones in the cavity of the nostril which are folded so as to increase the olfactory area (zool.).

ethmovomerine (ěth'mövō'mĕrĭn) $a$. [Gk. ethmos, sieve; L. vomer, ploughshare.] Pert. the ethmoid and vomer regions (zool.).

ethmovomerine cartilage, - the plate of cartilage which forms the septum of the nose in the early stages of the embryo (emb.).

ethnology (ĕthnŏl'öjĭ) n. [Gk. ethnos, nation;logos, discourse.] Thescience which deals with the different races of mankind, their distribution, relationship, and peculiarities (biol.).

ethology (ěthǒl'öjǐ) n. [Gk. ethos, custom; logos, discourse.] Bionomics.

etiolation (ē'tioōlā'shŭn) $n$. [F.étioler, 
to blanch.] The condition produced in plants reared in darkness (bot.).

etiolin (é'tiölĩn) $n$. [F. étioler, to blanch.] A yellowish pigment found in the chloroplasts of plants grown in darkness (phys.).

etiology (ē'tǐol'öjī̌), - see aetiology.

euaster (ūăs'tër) n. [Gk. eu, good; aster, star.] An aster in which the rays meet at a common centre (zool.). eucephalous (ūkěf'ălŭs, -sĕf-) $a$. [Gk. eu, good; kephale, head.] With well-developed head; $a p p \vec{l}$. certain insect larvae (zool.).

eucone (ūkōn') a. [Gk. eu, good; konos, cone.] Having the crystalline cones fully developed in the single elements of the compound eye (zool.).

eudipleural (ū'díploo'răl) a. [Gk.eu, good ; dis, double ; pleuron, side.] Symmetrical about a median plane ; bilaterally symmetrical (zool.).

eudoxome (ūdŏk'sōm) n. [Gk. eu, well; doxa, credit.] A monogastric free-swimming stage of a Siphonophore in which there is no nectocalyx (zool.).

eugenics (ūjēn'íks) n. [Gk. $e u$, well ; genos, birth.] The science dealing with the improvement of stock; usually referred to betterment of human race (biol.).

euglenoid (ūglēn'oid) $a$. [Gk. eu, well ; glene, pupil of eye.] Pert. or like Euglena ; appl. characteristic movement of Euglena (biol.).

eumerism (u'měrǐzm) n. [Gk. eu, well ; meros, part.] An aggregation of like parts (biol.).

eumerogenesis (ü'měröjěn'ěšs) $n$. [Gk. eu, well ; meros, part ; gig. nesthai, to produce.] Segmentation in which the units are similar at least for a certain time (biol.).

euplastic (üplăs'tík) a. [Gk.eu, well ; plastos, moulded.] Readily organized, easily forming a tissue (phys.). euryhaline (ü'rȟhălî̃n) a. [Gk, eurys, broad; halinos, marine.] Appl. marine animals adaptable to a wide range of salinity; $c f$. stenohaline (biol.).

eurypylous (ū'rĭpīlŭs) a. [Gk. eurys, broad; pyle, gate.] Wide at the opening; $a p p l$. canal system of
Sponges in which the chambers open directly into the excurrent canals by wide apopyles, and receive the water from the incurrent canals through the prosopyles (zool.).

eusporangiate (ū'spörăn'jiăt) a. [Gk. eu, well ; sporos, seed; anggeion, vessel.] Having the sporogenous tissue derived from the inner cell that follows the periclinal division of the superficial initial ; $f f$. leptosporangiate (bot.).

Eustachian(ūstā'kı̆an) a. [It. Eustachi, Italian physician.] Pert. canal connecting tympanic cavity with pharynx (anat.).

Eustachian valve, - a rudimentary valve guarding the orifice of the inferior vena cava in the atrium of the heart (anat.).

eustele (ü'stēl) $n$. [Gk. eu, well ; stele, pillar.] The arrangement of the vascular tissue into collateral bundles with the conjunctive tissue between, as in a typical Dicotyledon (bot.).

eustomatous (ũstŏm'ătŭs) $a$. [Gk. eu, well ; stoma, mouth.] Having a distinct mouth-like opening (zool.).

euthenies (ūthĕn'îks) $n$. [Gk. euthenein, to thrive.] The science of the betterment of the human race on the side of intellect and morals ; the psychological as distinct from the physiological improvement, or eugenics (biol.).

euthyneurous (ü'thǐnū'rŭs) a. [Gk. euthus, straight; neuron, nerve.] Having the visceral loop of the nervous system untwisted (zool.).

evagination (ē'văjīnā'shŭn) n. [L. $e$, out ; vagina, sheath.] The process of unsheathing, or product of this process ; an outgrowth (biol.).

evanescent (ěv'ăněs'ěnt) $a$. [L. evanescere, to vanish.] Disappearing early; $a p p l$. flowers which fade quickly (bot.).

eviscerate (ēvǐs'ěrât) $v . \quad$ [L. ex, out ; viscera, entrails.] To disembowel ; to eject the viscera, as Holothurians do on capture (zool.).

evolute (é'vǒlūt) a. [L. evolvere, to unroll.] Turned back; unfolded (bot.).

evolution (ě́völü'shŭn) n. [L. evol- 
vere, to unroll.] The gradual development of organisms from preexisting organisms (biol.).

exalate (ĕksā'lāt) a. [L. $e x$, without; ala, wing.] Not having wing-like appendages (bot.).

exalbuminous (ĕk'sălbū'minŭs) $a$. [L. $e x$, without ; albumen, white of egg.] Without albumen ; $a p p l$. seeds without endosperm or perisperm, or both (bot.).

exannulate (ěksăn'ūlāt) $a$. [L. ex, without ; annulus, ring.] Having a sporangium not furnished with an annulus or ring; $a p p l$. certain ferns (bot.).

exarch (ĕk'sârk) $n$. [L. ex, without ; Gk. arche, beginning.] With the protoxylem strands in touch with the pericycle (bot.).

exasperate (ěksăs'pĕrāt, ĕgzăs'pěrāt) a. [L. ex, without; asperare, to make rough.] Furnished with hard, stiff points (bot.).

excentric (ĕksěn'trǐk) a. [L. ex, without; centrum, centre.] Onesided; having the two portions of the lamina unequally developed (bot.).

exciple (ěk'sĭpl) $n$. [L. excipula, receptacles.] The outer covering of the apothecium in certain Lichens (bot.). excitation (ĕk'sĭtä'shŭn) $n$. [L. ex, out ; citare, to rouse.] The act of producing or increasing the stimulation; the stimulation thus produced (phys.).

excitatory cells,-motor cells in the sympathetic nervous system (phys.). excite (ěksīt') v. [L. ex, out ; citare, to rouse.] To start or increase the vital activities of an organism or part thereof (phys.).

excitonutrient (ělisi'tönū'triěnt) $a$. [L. ex, out; citare, to rouse ; nutriens, feeding.] Causing or increasing the nutrient activities (phys.).

exclusion (ĕkskloo'zhŭn) $n$. [L. $e x-$ cludere, to exclude.] Act of expelling, or the product of the expulsion (phys.).

exconjugant (ěkskŏn'joogănt) $n$. [L. ex, out ; conjugare, to yoke.] An organism which is leading an independent life after conjugation with another (zool.). excreta (ěkskrē'tă) n. plu. [L. excretum, separated.] Waste material eliminated from the body or any tissue thereof ( $p h y s$.$) ; deleterious$ substances formed within a plant (bot.).

excrete (ěkskrēt') v. [L. ex, out ; cernere, to sift.] To eliminate waste material from the body (phys.); to withdraw useless materials from the place of most active metabolism in the plant (bot.).

excretion (ĕkskrē'shŭn) $n$. [L. ex, out ; cernere, to sift.] Act of eliminating waste material, or the product of the elimination (phys.).

excurrent (ěkskŭr'ěnt) a. [L. ex, out; currere, to run.] Pert. ducts, channels, or canals in which there is an outgoing flow (zool.); with undivided main stem; having the midrib projecting beyond the apex (bot.).

excurved (ěkskŭrvd') $a . \quad$ [L. ex, out ; curvare, to curve.] Curved outwards from the centre (zool.).

exfoliation (ěksfö'liāâshün) $n$. [L. ex, out; folium, leaf.] The shedding of the leaves or scales from a bud (bot.).

exhalent (ěkshā'lĕnt) a. [L. ex, out ; halare, to breathe.] Capable of carrying from the interior outwards (zool.).

exindusiate (ěk'sĭndū'žāt) $a$. [L.ex; out ; indusium, cover.] Having the sporangia uncovered or naked (bot.).

exine (ěk'sin), - see extine.

exinguinal (ěk'sĭn'gwĭnăl) a. [L.ex, out ; inguen, groin.] Occurring outside the groin; pert. second joint of an arachnid leg (zool.).

exites (ěksīts') n. plu. [Gk. exo, without.] Offshoots on the outer lateral border of the axis of certain arthropod limbs (zool.).

exocardiac (ěk'sökâr'diăk) $a$. [Gk. exo, without; kardia, heart.] Situated outside the heart (zool.).

exocarp (ěk'sökârp) n. [Gk. exo, without ; karpos, fruit.] 'The outer layer of the pericarp (bot.).

exoceipital (ěk'sŏksĩp'îtăl) $a$. [L. ex, without; occiput, back of head.] Pert. a bone on each side of the foramen magnum (zool.). 
exochorion (ěk'sökō'rǐŏn) n. [Gk. exo, without; chorion, chorion.] The outer layer of the membrane secreted by the follicular cells surrounding the egg in the ovary of Insects (zool.).

exocoel (ěk'sösēl) $n$. [Gk. exo, without ; koilos, hollow.] The space between the mesenteries of adjacent couples in certain Zoantharia (zool.).

exocoelar (ĕk'sösē'lăr) a. [Gk. exo, without ; koilos, hollow.] Pert. the parietal wall of the coelom; pert. space between adjacent couples of mesenteries in the Zoantharia (zool.).

exocoelom (ěk'sösē'lŏm) n. [Gk. exo, without ; koilos, hollow.] The extra-embryonic body cavity of the embryo (emb.).

exoderm (ěk'södĕrm) n. [Gk. exo, without ; derma, skin.] The dermal layer of Sponges supposed by Haeckel to be equal to ectoderm of other animals (zool.).

exodermis (ěk'söděr'mìs) $n$. [Gk. exo, without; L. dermis, skin.] See ectoderm.

exogamete (ĕk'sögămēt') $n$. [Gk. exo, without; gametes, mate.] A reproductive cell which fuses with one derived from another source (zool.).

exogamy (ěksŏg'ămĭ) n. [Gk. exo, without; gamos, marriage.] Conjugation or fusion of isogametes with others of a different brood (biol.).

exogastrically (ěk'sögăs'trǐkălī) $a d v$. [Gk. exo, without; gaster, belly.] Where the shell is coiled towards the dorsal surface of the body (zool.).

exogenous (ěksŏj'ěnŭs) a. [Gk. exo, without; genos, race.] Developed from superficial tissue, the superficial meristem (bot.); growing from parts which were previously ossified (zool.).

exognathion (ěk'sögnâth'înn) $n$. [Gk. exo, without; gnathos, jaw.] The maxillary portion of the upper jaw ; the maxilla with exception of endognathion and mesognathion (anat.).
[Gk. exo, without ; peridion, a small wallet.] The outer layer of the spore case in certain Fungi (bot.).

exoplasm (ěk'söplăzm) $n$. [Gk. exo, without; plasma, something moulded.] The ectoplasm (biol.).

exopodite (ěksŏp'ödìt) $n$. [Gk, exo, without; pous, foot.] The outer branch of a typical biramous crustacean limb (zool.).

exoskeleton (ěk'söskěl'ětŏn) $n$. [Gk. exo, without; skeletos, hard.] A hard supporting structure secreted by the ectoderm or by the skin (zool.).

exosmosis (ěk'sŏsmō'sǐs) n. [Gk. exo, without; osmos, impulse.] The passing out through a membrane of a gas or fluid, a phase in osmosis (phys.).

exospore (ěk'söspōr) n. [Gk. exo, without ; sporos, seed.] The outer coating of the sporangial wall; one of the conidia (bot.).

exosporium (ěk'söspō'rĭŭm) $n$. [Gk. exo, without; sporos, seed.] The outer layer of the sporangial wall (bot.).

exostome (ěk'söstōm) ni. [Gk. exo, without; stoma, mouth.] The opening or foramen in the outer wall of the ovule (bot.).

exostosis (ěk'sǒstō'sĭs) n. [Gk. exo, without; osteon, bone.] The formation of knots on the surface of wood (bot.); the formation of knob-like outgrowths of bone at a damaged portion, or of dental tissue in a similar way (anat.).

exotheca (ěk'söthē'kă) n. [Gk. exo, without; theke, box.] The extracapsular tissue of a Coral (zool.).

exothecal (ěk'söthē'kăl) a. [Gk. exo, without; theke, box.] Pert. tissue outside the theca of a Coral (zool.).

exothecate (ěk'söthë'kät) a. [Gk. exo, without; theke, box.] Having an exotheca (zool.).

exotic (ĕksŏt'ik, ěgzŏt'îk) a. [Gk. exotikos, foreign.] Signifying an introduced or non-endemic plant (bot.).

exotospore (ěksō'töspōr) $n$. [Gk, exotikos, foreign; sporos, seed.] A sporozoite (zool.).

exotropism (ěksŏt'röpizm) n. [Gk. 
exo, without ; trepein, to turn.] The curvature away from the axis, exhibited by a laterally geotropic organ (bot.).

expiration (ĕk'spirā'shün) $n$. [L. $e x$, out; spirare, to breathe.] The act of emitting air from the lungs; the act of emitting volatile substances from the lungs, or from any internal cavity (phys.).

exseulptate (ěkskŭlp'tāt) a. [L. ex, out; sculpere, to carve.] Having the surface marked with more or less regularly arranged raised lines with grooves between (zool.).

exscutellate (ĕk'skūtěl'āt) $a$. [L. ex, without; scutellum, shield.] Having no scutellum; $a p p l$. Insects (zool.).

exserted (ěksĕr'tĕd) a. [L. exserere, to stretch out.] Protruding; $a p p l$. stamens which project beyond the corolla (bot.); protruding beyond some including organ or part (zool.).

exsertile (ěksĕr'ť̌ll) a. [L. exserere, to stretch out.] Capable of extrusion (biol.).

exsufflation (ĕks'sŭflā'shŭn) $n$. [L. ex, out ; sufflare, to blow.] Forced expiration from the lungs (phys.).

extend (ěkstěnd') $v_{\text {. }} \quad[$ L. ex, out ; tendere, to stretch.] To straighten out, as $o p p$. to flex or bend any organ (phys.).

extension (ĕkstĕn'shŭn) $n$. [L. $e x$, out; tendere, to stretch.] Straightening out of an organ (phys.).

extensor (ĕkstĕn'sŏr) n. [L. ex, out ; tendere, to stretch.] Any muscle which extends a limb or part thereof (anat.).

exterior (ĕkstē'rǐŏr) a. [L. externus, on the outside.] Situated on the side away from the axis or definitive plane (biol.).

external (ěkstĕr'năl) a. [L. externus, outside.] Near the outside, away from the mesial plane (anat.).

extine (ěk'stîn) n. [L. exter, on the outside.] The outer coat of the pollen grain (bot.).

extra-axillary (ěk'strâ-ăksı̌l'ărǐ) $a$. [L. exter, outside; axilla, armpit.] Arising above the axil of a leaf, said of branches which develop from the upper bud when there are more than one in connection with the axil (bot.).

extrabranchial (ěk'strâbrăng'kiăl) $a$. [L. exter, outside; Gk. brangchia, gills.] Arising outside the branchial arches (zool.).

extracapsular (ĕk'strâkăp'sūlăr) $a$. [L. exter, outside; capsula, cup.] Arising or situated outside the capsule; $a p p l$. ligaments, etc., in connection with a joint (anat.) ; $a p p l$. protoplasm lying outside the central capsule in some Protozoa (zool.).

extracellular (ěk'strâsěl'ūlăr) $a$. [L. exter, outside; cellula, little cell.] Occurring outside the cell (biol.).

extraembryonic (ěk'strâěm'brǐŏn'îk) a. [L. exter, outside; Gk. embryon, foetus.] Situated outside the embryo proper (emb.).

extraenteric (ĕk'strâěntěr'ík) $a$. [L. exter, outside; Gk. enteron, gut.] Outside the alimentary tract (zool.).

extrafloral (ěk'strâflō'răl) a. [L. exter, outside; flos, flower.] Situated outside the flower (bot.).

extranuclear (ěk'strânū'klě̌r) $a$. [L. exter, outside; nucleus, nucleus.] Pert. structures or forces acting outside the nucleus; situated outside the nucleus (biol.).

extraocular (ěk'strâŏk'ūlăr) a. [L. exter, outside; oculus, eye.] Exterior to the eye; $a p p l$. antennae of Insects (zool.).

extrastapedial (ěk'strâstăpē'diăl) $a$. [L. exter, outside ; stapes, stirrup.] Extending beyond the stapediocolumellar junction (anat.).

extrastelar (ĕk'strâstē'lăr) a. [L. exter, outside; Gk. stele, column.] Pert. ground tissue outside the vascular tissue (bot.).

extravaginal (ěk'strâvăj'inăl) $a$. [L. exter, outside; vagina, sheath.] Forcing their way through the sheath, as the shoots of many plants (bot.).

extravasate (ěkstrăv'ăsāt) v. [L. exter, outside; vas, vessel.] To force its way from the proper channel into the surrounding tissue; said of blood, etc. (phys.).

extraventricular (ěk'strâvěntrǐk'úlăr) a. [L. exter, outside; venter, 
belly.] Situated or arising beyond the ventricle (phys.).

extremity (ěkstrěmitî̌) $n$. [L. $e x$ tremitas, limit.] The limb, or distal portion of a limb; or the distal end of any limb-like structure (biol., anat.).

extrinsic (ěkstrĭn'sǐk) a. [L. extrinsecus, on the outside.] Pert. muscles not wholly within the part (anat.).

extrorse (ěkstrôrs') a. [L. extrorsus, outwardly.] Turned away from the axis (bot.).

exudation (ěk'sūdã'shŭn) n. [L. exudere, to sweat.] Any discharge through an incision or pore, e.g. gums, resins, moisture, etc. (biol.).

exumbral (ěksŭm'brăl) a. [L. ex, out ; umbra, shade.] Pert. the rounded or convex upper surface of a jelly-fish (zool.).

exumbrella (ěk'sŭmbrĕlă) $n$. [L.ex, out ; umbra, shade.] The upper rounded or convex surface of a jelly-fish (zool.).

exuviae (ĕgzǘvễ) n. plu. [L. exuere, to pull off.] Cast-off skins, etc., of animals (zool.).

eye (ī) n. [M.E. ighe.] The organ of sight or vision; one of the pigment spots in various animals and in many of the lower plants (biol.); the bud of a tuber (bot.).

eye-ball,--the globular capsule of the vertebrate eye; also the capsule and its contents.

eye spots,--certain pigment spots in many of the lower plants and animals, and also in some vertebrates, which are supposed to have an ocular function (biol.).

\section{F}

$\mathbf{F}_{1}$,-used for convenience to denote the first filial generation, or the hybrids arising from a first cross, successive generations arising from this one being denoted by $\mathrm{F}_{2}, \mathrm{~F}_{3}$, etc. $\mathrm{P}_{1}$ denotes the parents of the $F_{1}$ generation, $\mathrm{P}_{2}$ the grandparents, and so on (biol.).

fabella (făbělăa $n$. [L. fabella, small bean.] A small fibro-cartilage ossified in the gastrocnemius (anat.).

fabiform (fā'bǐfôrm) $a$. [L. faba, bean ; forma, shape.] Bean-shaped.

Fabrician system,-a classification of the arthropoda based on the anatomy of the mouth parts (zool.).

facet (făs'ĕt) $n$. [L. facies, face.] A smooth, flat, or rounded surface for articulation (anat.); an ocellus (zool.).

facial (fã'shăl) a. [L. facies, face.] Pert. face; $a p p l$. artery, nerve, bone, vein, etc. (anat.).

Paciolingual (fä́shīölǐng'gwăl) a. [L. facies, face; lingua, tongue.] Pert. or affecting the face and tongue (anat.).

facultative(făk'ŭltā'tǐv)a. [L. facultas, faculty.] Having the power of living under different conditions (biol.).

facultative parasites, - parasites which may be normally self-dependent, but which are adaptable to parasitic or semiparasitic mode of life ; cf. obligatory parasites (biol.).

faeces (fē'sêzz) $n$. plu. [L. faeces, dregs.] The excrement or waste matter from the bowels (anat.).

falcate (fál'kāt) a. [L. falx, sickle.] Sickle-shaped; hooked (biol.).

falciform (f́ăl'siffôrm) a. [L. falx, sickle; forma, shape.] Sickleshaped or scythe-shaped (anat., zool.).

falciform ligament, - a dorso-ventral fold of the peritoneum, attached to under surface of diaphragm and the anterior and upper surfaces of the liver (anat.).

falcula (făl'kūlă) n. [L. falcula, little hook.] A curved scythe-like claw (zool.).

falculate (fâl'kūlāt) a, [L. falcula, little hook.] Curved, and sharp at the point.

Fallopiantubes(fălō'piăn), - the upper portions of the oviduct in man and mammals; the anterior portions of the Müllerian ducts (anat.).

false ribs, - those ribs whose cartilaginous ventral ends do not join the sternum directly, if at all (anat.).

falx (fălks) n., falees (făl'sěz) plu. [L. falx, sickle.] A sickle-shaped fold of the dura mater (anat.). 
family (făm'ilì) $n$. [L. familia, household.] Term used in classification, signifying one group of an Order (biol.).

fan (făn) $n$. [A.S. fann, fan.] A bird's tail feathers (zool.).

fang (făng) $n$. [A.S. fang, grip.] A long-pointed tooth, especially the poison tooth of snakes (zool.); the root of a tooth (anat.).

faradisation (făr'ădǐzā'shŭn) $n$. [Faraday, electrician.] Method of stimulation inducing partial or complete tetanus (phys.).

farina (fărềnă, fărīnă) $n$. [L. farina, flour.] The pollen of plants (bot.); the fine mealy-like powder found on some insects (zool.).

farinaceous (făr'inā'shŭs) $a$. [L. farina, flour.] Covered with fine mealy-like dust (zool.).

farinose (fărînōs) $a$. [L. farina, flour.] Covered with fine powder or dust (bot., zool.).

fascia (făs'ĭă, făsh'ǔa) $n$. [L. fascia, band.] An ensheathing band of connective tissue (anat.).

fascial (făs'ǐăl, făsh'íăl) $a$. [L. fascia, bundle.] Pert. a fascia, ensheathing and binding (anat.).

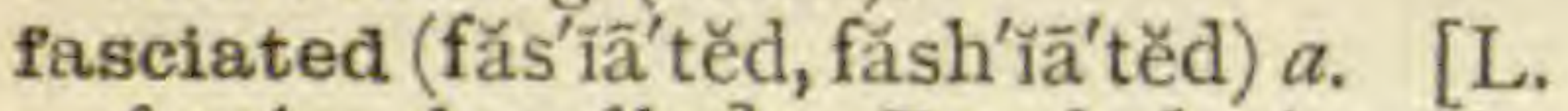
fascia, bundle.] Banded (zool.); arranged in fascicles; $a p p l$. stems or branches malformed and flattened (bot.).

fascicle (făs'îkl) n. [L. fasciculus, dim. of fascia, bundle.] A small bundle or tuft, as of fibres (anat.) or of leaves (bot.).

fascicular (făsìk'ūlăr) a. [L. fasciculus, dim. of fascia, bundle.] Pert. a fascicle; arranged in bundles or tufts; $a p p l$. cambium, tissue (bot.).

fasciculus (făsĭk'ūlŭs) $n$. [L. fasciculus, little bundle.] A fascicle; the direct pyramidal tract (anat.).

fasciola (fãsīölă) $n$. [L. fasciola, a small bandage.] A narrow colour band (zool.) ; a delicate lamina continuous with the dentate gyrus (anat.).

fasciole (făs'î̄l) $n$. [L. fasciola, a small bandage.] A ciliated band on certain Echinoids for sweeping fresh water over the surrounding parts (zool.).

fastigiate (făstǐj'iầt) a. [L. fastigare, to slope up.] With branches parallel and erect (bot.); in pyramidal or conical form (zool.).

fat (făt) $n$. [A.S. faett, fat.] Adipose tissue ; any part of animal tissue which has its cells filled with a greasy or oily reserve material (phys.).

fatigue (fătēg') n. [L. fatigare, to weary.] The effect produced by long stimulation on the cells of an organ (phys.).

Pauces (fôs'ěz) $n$. plu. [L. fauces, throat.] The upper or anterior part of the throat between palate and pharynx (anat.); the mouth of a spirally coiled shell (zool.).; the throat of a corolla (bot.).

fauna (fôn'a) $n$. [L. faunus, a god of the woods.] All the animals peculiar to a country, area, or period (biol.).

faunal region,--an area characterized by a special group or groups of animals (zool.).

favella (fávěl'ă) $n$. [L. favus, honeycomb.] A conceptacle of certain red Algae (bot.).

faveolate (făvēölāt) a. [L. faveolus, dim. of favus, honeycomb.] Honeycombed or alveolate.

faveolus (făvëölŭs) $n$. [L. faveolus, small honeycomb.] A small depression or pit; alveola (bot.).

favose (făvōs') a. [L. favus, honeycomb.] Like a honeycomb ; alveolate (bot.).

feather-veined,-appl. leaf in which the veins run out from the mid-rib in a regular series at an acute angle (bot.).

feces,-see faeces.

fecundity (fēkŭn'dĭtǐ) n. [L.fecundus, fertile.] Power of a species to multiply rapidly (biol.).

female (fémāl) $n$. [L. femina, woman.] A pistillate flower (bot.); a female animal, i.e. an egg-producing or young-producing animal (zool.) symbol $q$.

female pronucieus, - the nucleus left in the ovum after maturation.

femoral (fém'örăl) a. [L. femur, thigh.] Pert. the thigh; appl. artery, vein, nerve, etc. ; crural (zool.).

femur (fé'mŭr) n. [L. femur, thigh.] The proximal bone of the hind 
limb in man and vertebrates (anat.); the third joint in an insect's leg counting from the proximal end (zool.).

fenchone (fĕn'chōn) n. [Ger. fenchel, fennel.] A ketone, the essential oil in oil of fennel (phys.).

fenestra (fěněs'tră) n. [L. fenestra, window.] An opening in a bone, or between two bones (anat.); a pit on the head of the cockroach; a transparent spot on the wings of insects (zool.).

Penestrate (fěněs'trāt) a. [L. fenestra, window.] Having small perforations or transparent spots, appl. insects' wings (zool.); having numerous perforations, $a p p l$. leaves (bot.).

fenestrule (fěnĕs'trool) $n$. [L. fenestra, window.] A small opening between the branches of a polyzoan colony (zool.).

feral (fế'răl) a. [L. fera, wild animal.] Wild, or escaped from cultivation and reverted back to the wild state (zool.).

ferment (fĕr'mĕnt) $n$. [L. fermentum, ferment.] A substance, organized or unorganized, capable of producing fermentation (phys.).

fermentation (fër'měntā'shŭn) $n$. [L. fermentum, ferment.] Any of the transformations occurring in organic substances caused by the presence of a ferment (phys.).

ferruginous (fĕroo'jĭnŭs) $a$. [L.ferruginus, rusty.] Having the appearance of a rusty spot (bot.).

fertile (für'tǐll) $a$. [L. fertilis, fertile.] Capable of producing; of eggs or seeds capable of developing (biol.).

fertilization (fěr'tiliňză'shŭn) $n$. [L. fertilis, fertile.] The orderly and intimate union of male and female pronuclei (biol.); the process of pollination (bot.).

fetlock (fět'lǒk) n. [Icel. fet, step; lokka, tuft of hair.] The tuft of hair behind a horse's pastern joint ; the pastern joint itself (zool.).

fibre (fíbër) $n$. [L. fibra, band.]. A strand of nerve, muscle, connective, or bast-tissue (bot., zool.).

fibril (fín bril) $n$. [L. fibrilla, a small fibre.] A small thread-like structure or fibre, a component part of a fibre (anat.); a root-hair ; a slender filiform outgrowth on some Lichens (bot.).

fibrillae (fībrìl'ē) $n$. plu. [L. fibrilla, small fibre.] The thread-like branches of roots (bot.); minute elastic fibres secreted within spongin cells; minute muscle-like threads found in various Infusorians (zool.).

fibrillate (fítbrīlāt) a. [L. fibrilla, small fibre.] Having fibrillae or hair-like structures (bot.).

fibrillose (fí̄brǔlōs, fíbrìl'ōs) a. [L. fibrilla, small fibre.] Furnished with fibrils; $a p p l$. mycelia of certain Fungi (bot.).

fibrin (fín'brĭn) $n$. [L. fibra, band.] An insoluble proteid found in blood after coagulation, it is readily digested in gastric juice (phys.).

fibrinogen (fïbrin'öjĕn) $n$. [L. fibra, band; Gk. gignesthai, to produce.] A soluble constituent of blood which yields fibrin and produces coagulation (phys.).

fibro-cartilage (fítbrö-kâr'tīlăj) n. [L. fibra, band; cartilago, gristle.] A kind of cartilage whose matrix is mainly composed of fibres similar to connective tissue fibres, found at articulations, cavity margins, and osseous grooves (anat.).

fibrous (fíbrŭs) a. [L. fibra, band.] Composed of fibres; appl. tissue (anat.); roots (bot.).

fibula (fíb'ülă) $n$. [L. fibula, buckle.] The outer and smaller bone of the shin (anat.).

fibulare (fỉ 'ūlā'rē, -ârā) $n$. [L. fibula, buckle.] The outer element of the proximal row of the tarsus (anat.).

filament (fil'ăměnt) $n$. [L. filum, thread.] The stalk of the anther (bot.); the stalk of a down-feather (zool.).

filicauline (fillíkôl'în) a. [L. filum, thread; caulis, stalk.] With a thread-like stem (bot., zool.).

filiciform (filis'ífôrm) a. [L. filix, fern; forma, shape.] Shaped like the frond of a fern (bot.).

filicoid (fîl'îkoid) a. [L. filix, fern; Gk. eidos, like.] Shaped like or resembling a fern (bot.).

filiform (fílilifôrm) a. [L. filum, thread; forma, shape.] Thread. like. 
filiform papillae,-papillae on the tongue ending in numerous minute slender processes (anat.).

filigerous (fîllĭ'ĕrŭs) a. [L. filum, thread; gerere, to carry.] With thread-like outgrowths or flagella (zool.).

fillet (fíl'ĕt) $n$. [L. filum, thread.] Band of white matter in the brain; the lemniscus of the mid-brain (anat.).

flloplume (fïl'öploom) $n$. [L. filum, thread; pluma, feather.] A delicate hair-like feather with long axis and a few free barbs at the apex (zool.).

filopodia (fî̀l'öpō'diă) n. plu. [L. flum, thread; Gk. pous, foot.] Thread-like pseudopodia of Protozoa (zool.).

filose (fî́lōs) a. [L. flum, thread.] Slender ; threadlike ; $a p p l$. pseudopodia of Protozoa (zool.).

filtration (fíltrā'shŭn) $n$. [F. filtrer, to strain.] Appl. the iridial angle of the cornea (anat.) ; straining, as of lymph through capillary walls (phys.).

fllum terminale, - the terminal thread, a slender grey filament, of the spinal cord (anat.).

fimbria (fim'briă) $n$, fimbriae (fïm'brīē) plu. [L. fimbria, fringe.] Any fringe-like structure (anat., bot.) ; a prolongation of the hippocampus (anat.); delicate processes fringing the mouth of tubes or ducts, as of the oviduct; or the siphons of molluscs (zool.).

fimbriated (fím'briā'tĕd) $a$. [L. fimbria, fringe.] Fringed at the margin, as petals (bot.), as tubes or ducts (zool.).

fin (fin) $n$. [A.S. finn, fin.] A fold of skin with fin-rays and skeletal supports, corresponding in the case of the paired fins to limbs, found in most fishes (zool.).

finials (fin'ı̌ălz) n. plu. [L. finis, end.] The ossicles of the distal rami of Crinoids which do not branch again (zool.).

fin-rays,-horny supports of the fins (zool.).

fissilingual (fîs'îling'gwăl) $a$. [L. fissus, cleft; lingua, tongue.] With bifid tongue (zool.). fission (fǐsh'ŭn) $n$. [L. fissus, cleft.] Cleavage of cells; division of a unicellular organism into two or more parts, thereby reproducing its kind (biol.).

fissiparous (fĩsı̌p'ărŭs) a. [L. fissus, cleft; parere, to beget.] Reproducing by binary or multiple fission (biol.).

fissiped (fǐš̃pĕd) $n$. [L. fissus, cleft ; pes, foot.] With cleft feet, that is, with digits of feet separated (zool.).

fissirostral (fís'irrǒs'trăl) a. [L. fissus, cleft; rostrum, beak.] With deeplycleft beak (zool.).

flssure (fĩsh'ūr) $n$. [L. fissus, cleft.] A cleft, deep groove, or furrow dividing an organ into lobes, or sub-dividing and separating certain areas of the lobes (anat.).

fix (fiks) v. [L. fixus, fixed.] To kill, and preserve; to establish (biol.).

fixation muscles, - muscles which prevent disturbance of the equilibrium of the body generally, and fix limbs in the case of limb-movements (anat.).

flabellate (flăbĕl'āt) a. [L. flabellare, to fan.] Fan-shaped.

flabellate antennae,-pectinate antennae with long processes (zool.).

flabelliform (flăběl'îfôrm) $a$. [L. flabellum, dim. of flabrum, breeze ; forma, shape.] Fan-shaped.

flabellinerved (flăbĕl'iněrvd) $a$. [L. flabellum, little breeze; nervus, sinew.] $A p p l$. leaves with many radiating nerves (bot.).

flabellum (flăběl'ŭm) n. [L. flabellum, fan.] Any fan-shaped organ or structure; the distal exite of a branchiopodan limb; the epipodite of certain crustacean limbs (zool.).

flagellate (flăj'ělāt) a. [L. flagellum, whip.] Furnished with flagella; like a flagellum (bot., zool.).

flagelliform (flăjělîfôrm) a. [L. flagellum, whip ; forma, shape.] Lash-like; like a flagellum (bot., zool.).

flagellula (flăjěl'ūlă) $n$. [L. flagellula, dim. of flagellum, whip.] A flagellate zoospore (zool.).

flagellum (flăjěl'ŭm) $n$. [L. flagellum, whip.] The lash-like process of many Protista; a long slender runner or creeping stem (bot.). 
flame cells, - the terminal cells of the branches of the excretory system in many worms, with cavity continuous with the lumen of the duct, and containing a cilium or bunch of cilia, the motions of which give a flickering appearance similar to that of a flame; a pronephridiostome (zool.).

flavescent (flăvěs'ĕnt) a. [L. flavescere, to turn yellow.] Growing yellow.

flex (flëks) $v$. [L. flectere, to bend.] To bend ; $a p p l$. movement of limbs (anat.).

flexor (flĕk'sŏr) n. [L. flexus, bent.] A muscle which bends a limb (or part) by its contraction (anat.).

flexuous (flěk'sūŭs) a. [L. flexus, bent.] Curving in a zig-zag manner (bot.).

flexure (flěk'sūr) $n$. [L. flexus, bent.] A curve or bend; $a p p l$. the curve in the embryonic brain, the curve of the intestine (anat.).

float (flōt) $n$. [A.S. flota, ship.] The pneumatophore of Siphonophores (zool.) ; a large spongy mass serving as a float in some Pteridophytes (bot.).

flosting ribs,-ribs not uniting at their ventral end with the sternum (anat.).

floccose (flŏk'ōs) a. [L. floccus, a lock of wool.] Covered with wool-like tufts.

floccular (flŏk'ūlăr) a. [L. floccus, lock of wool.] Pert. the flocculus (anat.).

flocculence (flŏk'ūlĕns) $n$. [L. floccus, lock of wool.] Adhesion in small flakes, as of a precipitant (phys.).

floceulent (flǒk'ülĕnt) a. [L. floccus, lock of wool.] Covered with a soft waxy substance giving the appearance of wool (zool.); covered with small woolly tufts (bot.).

floceulus (flŏk'ūlŭs) $n$. [L. floccus, lock of wool.] A small accessory lobe on each lateral lobe of the cerebellum (anat.).

floccus (flǒk' ǔs) $n$. [L. floccus, lock of wool.] The tuft of hair terminating a tail; the downy plumage of young birds (zool.); a mass of hyphal filaments in Algae and Fungi (bot.). flora (flóră) n. [L. flos, flower.] The plants peculiar to a country, area, or period (bot.).

floral (flō'răl) a. [L. flos, flower.] Pert. the flora of a country or area ; pert. flowers (bot.).

florescence (flörěs'ěns) $n$. [L. flos, flower.] Bursting into bloom (bot.).

floret (flŏr'ět) $n$. [L. flos, flower.] One of the small individual flowers of a composite flower (bot.).

floricome (flŏr'îkōm) $n$. [L. flos, flower; coma, hair.] A form of branched hexaster spicule (zool.).

floscelle (flǒsĕl') $n$. [L. floscuíus, a little flower.] The flower-like structure in some Echinoids round the mouth composed of the five bourrelets and the five phyllodes (zool.).

floss (flŏs) n. [F. floche, soft.] A downy or silky substance (bot.); the loose pieces of silk in a cocoon (zool.).

flower (flow'ër) $n$. [L. flos, flower.] The blossom of a plant, comprising generally sepals, petals, stamens, and pistils; a leafy shoot adapted for reproductive purposes (bot.).

fluviatile (floo'viătǐl) a. [L. fluviatilis, pert. river.] Growing in or near streams (bot.); inhabiting and developing in streams, $a p p l$. certain insect larvae (zool.).

fluviomarine (floo'viömărēn') a. [L. fuvius, stream; mare, the sea.] Found in rivers and in the sea (zool.); pert. rivers and the sea (bot., zool.).

fluvioterrestrial (floo'viötĕrěs'trǐăl) $a$, [L. fluvius, stream; terra, land. Found in streams and in the land beside them (zool.).

flux (flǔks) $n$. [L. fluere, to flow.] Term $a p p l$. species that are not yet stable (biol.).

foetal (fe'tăl) a. [L. foetus, off'spring.] Embryonic; pert. a foetus (emb.).

foetid glands,-small sac-like glands in Orthoptera which secrete an ill-smelling fluid (zool.).

foetus (fē'tŭs) $n$. [L.foetus, offspring.] An embryo in the egg or in the uterus (emb.).

Poliaceous (fō'liā'shŭs) a. [L. folium, leaf.] Having the form or texture of a foliage leaf (bot.); thin; leaflikeı(zool.). 
foliar (fō'lĭ̆r) a. [L. folium, leaf.] Pert. or consisting of leaves (bot.).

foliobranchiate (fō'liöbrăng'kīāt) $a$. [L. folium, leaf; Gk. brangchia, gills.] Possessing leaf-like gills (zool.).

Poliolae (fō'liölē) n. plu. [L. folium, leaf.] Leaf-like appendages of the telum (zool.).

foliolate (fó'liölāt) a. [L. folium, leaf.] Pert. leaflets (bot.).

foliole (fólirōl) $n$. [L. folium, leaf.] Small leaf-like organ or appendage $(z o o l$.$) ; a leaflet (bot.).$

foliose (fō'līōs) $a$. [L. folium, leaf.] With many leaves (bot.).

folium (fō'lĭm) $n$. [L. folium, leaf.] A flattened plate-like structure in the cerebellum (anat.).

follicle (föl'íkl) $n$. [L. folliculus, small sac.] A capsular fruit which opens on one side only (bot.); a cavity or sheath (zool.).

follicular (fŏlìk'ūlăr) a. [L. folliculus, a small sac.] Pert., like or consisting of follicles.

folliculate (fólikk'ūlät), - follicular.

folliculose (fŏlìk'ūlös) a. [L. folliculus, a small bag.] Having follicles (bot.).

fontanelle (fơn'tănĕl') n. [F. fontanelle, a little fountain.] A gap or space between bones in the cranium closed only by membrane (anat.).

fonticulus (fŏntǐk'ülŭs) $n$. [L. fonticulus, dim. of fons, fountain.] The depression at the anterior end of the sternum (anat.).

food-vacuole, - a small vacuole containing fluid and small foodparticles, contained in the endosarc of many Protista.

foot (foot) $n$. [A.S. fot, foot.] An embryonic structure in ferns through which nourishment is obtained from the prothallus; the basal portion of the sporophyte in Mosses (bot.) ; an organ of locomotion, differing widely in different animals, from the tube-foot of Echinoderms, the muscular foot of Gastropods and Molluscs, the tarsus of Insects, to the foot of vertebrates and man (zool.).

foramen (fơrā'mĕn) n. [L. foramen, an opening.] The opening through the coats of the ovule (bot.); any small perforation (anat.). foramen magnum,-the opening in the occipital region of the skull through which the spinal cord passes (anat., zool.).

foraminate (fơrămiñāt) $a$. [L. foramen, opening.] Pitted; having many foramina (zool.).

foraminiferous (fŏrăm'inif'ěrŭs) $a$. [L. foramen, opening; ferre, to carry.] Containing shells of the Foraminifera (zool.).

Porceps (fŏr'sĕps) $n$. [L. forceps, a pair of tongs.] The clasper-shaped anal cerci of some Insects; the large fighting or seizing claws of crabs and lobsters (zool.).

forcipated (fôr'sīpātěd) a. [L.forceps, pair of tongs.] Resembling forceps, or forked like a forceps ( $z \circ o l$.).

forcipulate (fŏrsı̌p'ūlāt) $a$. [L. forceps, pair of tongs.] Shaped like a small forceps ; $a p p l$. asteroid pedicellariae (zool.).

forfex (fŏrfěks') n. [L. forfex, pair of shears.] A pair of anal organs which open and shut transversely, occurring in certain Insects (zool.).

forficate (fôr'fikät) a. [L. forfex, shears.] Deeply notched (zool.).

formation (formā'shŭn) $n$. [L. forma, shape.] Structure arising from an accumulation of deposits (pal.).

Pormative (fôr'mătǐv) a. [L. forma, shape.] Appl. matter which is living and developable (phys.).

fornicated (fồ'nìkā'těd) a. [L.fornix, vault.] Concave within, convex without; arched (zool.).

fornix (fôr'nìks) $n$. [L. fornix, vault.] An arched sheet of white longitudinal fibres beneath the corpus callosum (anat.); one of the arched scales in the orifice of some flowers (bot.).

fossa (fŏs'ă) $\pi$. [L. fossa, ditch.] A ditch or trench-like depression (anat.).

fossette (fŏsĕt') $n$. [L. fossa, ditch.] A small pit; a socket containing the base of the antennule in Arthropods (zool.).

fossil (fós'îl) $n$. [L. fossilis, dug up.] Petrified animal or plant, or portion thereof, found in rocks (biol.).

fossiliferous (fŏs'illif'ěrŭs) a. [L. fossilis, dug up; ferre, to carry.] Containing fossils (biol.). 
Possorial (fŏsōriăl) $n$. [L. fossor, digger.] Adapted for digging; $a p p l$. claws, feet (zool.).

fossula (fŏs'ūlă) $n$. [L. fossa, ditch.] A small pit with reduced septa on one side of a corallite cup in the Rugosa (pal.).

fossulate (fós'ūlāt) a. [L. fossa, ditch.] With slight hollows or grooves (zool.).

fossulet (fǒs'ūlĕt) $n$. [L. fossa, ditch.] A long narrow depression (zool.).

fovea (fớvěă) $n$. [L. fovea, depression.] A small pit or fossa (anat.); a small hollow at the leaf base in Isoetes containing a sporangium (bot.).

foveate (fō'vêât) a. [L. fovea, depression.] Pitted.

foveola (fōvēölă) $n$. [L. foveola, small pit.] A small pit ; a shallow cavity in bone (anat.); a small depression just above the fovea in the leaf of Isoetes (bot.).

foveolate (fō'vēölāt) a. [L. foveola, small pit.] Having regular small depressions (bot., zool.).

fragmentation (frăg'mĕntā'shŭn) $n$. [L. frangere, to break.] Division into small portions (biol.); nuclear division by simple splitting (biol.).

free (frē) a. [A.S. freo, acting at pleasure.] Motile; unattached; distinct ; separate.

frenate (frē'nāt) $a$. [L. frenum, bridle.] Having a frenum or frenulum (zool.).

frenulum (frĕn'ûlŭm) n., frenula (frěn'ūlă) plu. [L. frenulum, dim. of frenum, bridle.] A fold of membrane, as of tongue, clitoris, etc. (anat.); a process on the hind-wing of Lepidoptera for attachment to fore-wing ; a thickening of the subumbrella of certain Scyphomedusae (zool.).

frenum (frē'nŭm) n., frena (frē'nă) plu. [L. frenum, bridle.] A frenulum; a fold of integument at junction of mantle and body of Cirripedes, ovigerous in Pedunculata (zool.).

frond (frŏnd) $n$. [L. frons, leafy branch.] A leaf, especially of a fern (bot.).

frondescence (frŏndĕs'ĕns) $n$. [L. frondescere, to put forth leaves.] Development of leaves (bot.). frons (frŏnz) n. [L. frons, forehead.] The forehead.

frontal (frŭn'tăl) a. [L. frons, forehead.] In the region of the forehead; $a p p l$. artery, vein, lobe, convolution, etc. (anat.); appl. headorgan of Nemertines; a prostomial ridge of Polychaetes; palps of certain Nereids (zool.).

frontocerebellar fibres,-fibres passing from the frontal region to the cerebellum (phys.).

fronto-ethmoidal (frŭn'tö-ěthmoid'ăl) a. Pert. the frontal and ethmoidal bones; appl. suture (anat.).

frontonasal (frŭn'tönā'zăl) a. [L. frons, forehead; nasum, nose.] Pert. forehead or frontal region and the nose; $a p p l$. ducts and processes (emb.).

frontonasal ducts,-ducts connecting the nasal cavities with the frontal sinuses (anat.).

frontosphenoidal (frŭn'tösfēnoid'ăl) $a$. [L. frons, forehead; Gk. sphen, wedge.] Pert. frontal and sphenoid bones; appl. a process of the zygomatic articulating with the frontal (anat.).

fructification (frŭk'tĭfîkā'shŭn) $n$. [L. fructus, fruit; facere, to make.] Fruit formation (bot.).

frugivorous (froojiv'örǔs) a. [L. frux, fruit ; vorare, to devour.] Fruiteating; $a p p l$. certain animals (zool.).

fruit (froot) $n$. [F. fruit, from L. fructus, fruit.] The fertilized and developed ovary of a plant (bot.).

frustule (frŭs'tūl) n. [L. frustulum, a small fragment.] The protoplasmic cell of a diatom (bot.).

frutescent (frootěs'ěnt) $a$. [L. frutex, shrub.] Shrub-like (bot.).

frutex (froo'těks) n. [L. frutex, shrub.] Shrub (bot.).

fruticose (froo'tīkōs) a. [L. frutex, shrub.] Shrub-like (bot.).

fruticulose (frootīk'ūlōs) a. [L. frutex, shrub.] Like a small shrub (bot.).

fucivorous (füsǐv'örŭs) a. [L. fucus, rock-lichen; vorare, to devour.] Eating seaweed; $a p p l$. certain animals (zool.).

fucoid (fü'koid) a. [L. fucus, rocklichen.] Pert. or resembling seaweed (bot.).

fugacious (fügä'shŭs) a. [L. fugax, 
swift.] Evanescent; falling off early ; appl. petals, etc. (bot.).

fulcrate (fül'krāt) a. [L. fulcrum, a support.] Having a fulcrum.

fulcrum (fúl'krŭm) a. [L. fulcrum, a support.] A supporting organ such as a tendril or stipule (bot.); part of the incus in the mastax of Rotifers ; spine-like scales on anterior fin-rays of many Ganoids (zool.).

function (fŭngk'shŭn) $n$. [L. functus, performed.] The normal action proper to any organ or part (phys.).

functional (füngk'shŏnăl) $a$. [L. functus, performed.] Acting normally; acting or working part of an organ as distinct from the remainder (phys.).

fundiform (fŭn'dufôrm) a. [L. funda, sling; forma, shape.] Looped; $a p p l$. a ligament of the penis (anat.).

fundus (fün'dŭs) $n$. [L. fundus, bottom.] The base of an organ, as of stomach, etc. (anat.).

fungicolous (fŭnjǐk'ölüs) a. [L. fungus, mushroom; colere, to inhabit.] Parasitic on Fungi (bot.).

fungiform (fŭn'jifôrm) a. [L.fungus, mushroom; forma, shape.] Fungoid or shaped like a fungus ; $a p p l$. tongue papillae (anat.).

fungivorous (fŭnjĭv'örŭs) $a$. [L. fungus, mushroom; vorare, to devour.] Appl.fungus-eating animals (zool.).

fungous (fŭng'gŭs) a. [L. fungus, mushroom.] With character or consistency of fungus (bot.).

funicle (fü'nǐkl) $n$. [L. funiculus, a small cord.] An ovule stalk (bot.); a small cord or band of fibres especially in brain (anat.); a large double strand of cells passing from aboral end of coelom to aboral wall of zooecium of Molluscoidea (zool.).

funicular (fūnǐk'ūlăr) $a$. [L. funiculus, small cord.] Consisting of a small cord or band; pert. a funiculus (anat., zool.).

funiculus,-see funicle.

funnel (fŭn'ěl) $n$. [L. fundibulum, funnel.] The siphon of Cephalopods (zool.).

funnelform (fün'ělfôrm) a. [L. fundere, to pour; forma, shape.] Widening gradually from a narrow base; infundibuliform (bot.).

furca (fŭr'kă) $n$. [L. furca, fork.] The apophysis or entothorax of insect metathorax (zool.).

furcal (fŭr'kăl) a. [L. furca, fork.] Forked; $a p p l$. a branching nerve of the lumbar plexus (anat.).

furcate (für'kāt) a. [L. furca, fork.] Branching like the prongs of a fork.

furciferous (fŭrsĭf'ĕrŭs) a. [L. furca, fork ; ferre, to carry.] Bearing a forked appendage, as some Insects (zool.).

furcula (für'kūlă) n. [L. furcula, dim. of furca, fork.] A forked process or structure, the merrythought bone (anat.); a transverse ridge in the embryonic pharynx (emb.).

furred (fürd) a. [M.E. furren, a sheath.] Having short decumbent hairs thickly covering the surface (zool.).

fuscin (füs'kĭn) $n$. [L. fuscus, tawny.] A brown pigment in the retinal epithelium (phys.).

fusi (fǘzī) n. plu. [L. fusus, spindle.] In spiders, organs composed of two retractile processes which issue from the mammulae and form the threads (zool.).

fusiform (fǘzifôrm) a. [L. fusus, spindle ; forma, shape.] Spindleshaped; tapering gradually at both ends (zool.).

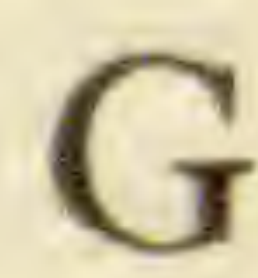

galactase (gălăk'tās) n. [Gk. gala, milk.] An enzyme, trypsin-like in action, found in milk ( $p h y s$.$) .$

galactophorous (găl'ăktơf'örŭs) $a$. [Gk. gala, milk ; pherein, to carry.] Lactiferous; $a p p l$. ducts of mammary glands (anat.).

galactosis (găl'ăktō'sǐs) n. [Gk. gala, milk.] Milk production (phys.).

galbulus (găl'būlŭs) $n$. [L. galbulus, cypress nut.] A modified cone with fleshy scales, as in cypress (bot.).

galea (găl'ěă) n. [L. galea, helmet.] A helmet-shaped petal, or other 
similarly-shaped structure (bot.); a muscle of the scalp (anat.); the outer division of the endopodite of the first maxillae of insects (zool.). galeate (gấl'ễa $) a$. [L. galea, helmet.] Helmet-shaped (bot.).

gall (gôl) n. [A.S. gealla, gall.] Bile, the secretion of the liver (phys.); any excrescence on plants caused by disease (bot.).

gall-bladder,-a small pear-shaped or spherical sac which stores the bile (anat.).

galvanotaxis (găl'vănötăk'šss) n. [It. Galvani, physiologist.] Response or reaction to electrical stimulus (phys.). galvanotropism (găl'vănŏt'röpizm) $n$. [It. Galvani, physiologist; Gk. trope, a turning.] Galvanotaxis.

gametal (gămē'tăl) a. [Gk. gametes, spouse.] Pert. a gamete; reproductive (biol.).

gametangium (găm'ētăn'jŭum) n. [Gk. gametes, spouse ; anggeion, vessel.] A structure producing sexual cells (bot.).

gametes (gămēts') n. plu. [Gk. gametes, spouse.] Cells derived from gametocytes which conjugate and form zygotes (zool.); sexual cells (biol.).

gametic (gămĕt'ík) a. [Gk. gametes, spouse.] Pert. gamete (biol.).

gametids (gămē'tǐdz) n. plu. [Gk. gametes, spouse.] Primary sporoblasts destined to become gametes (zool.).

gametocyte (gămē'tösīt) n. [Gk. gametes, spouse; kytos, hollow.] The mother-cell of a gamete $(z \circ o l$.$) .$ gametogenesis (gămëtöjĕn'ěsĭs) $n$. [Gk. gametes, spouse ; genesis, birth.] Gamete formation (biol.).

gametogeny (găm'ētŏj'ěnǐ) $n$. [Gk. gametes, spouse; genos, birth.] Gametogenesis.

gametogonium (gămē'tögō'nĭŭm) $n$. [Gk. gametes, spouse ; gonos, offspring.] A cell producing a gamete, a gametocyte (bot.).

gametophore (gămē'töfōr) n. [Gk. gametes, spouse ; pherein, to bear.] A special part of a gametophyte on which gametangia are borne (bot.). gametophyll (gămét'öfill) n.
gametes, spouse; phyllon, leaf. $\mathrm{A}$ A modified leaf bearing sexual organs; a micro- or (bot.).

gametophyte (gămē'töfīt)] $n$. [Gk. gametes, spouse; phyton, plant.] The gamete-forming phase in alternation of plant generations ; the sexual generation of plants; $c f$. sporophyte (bot.).

gamic (gămî̀) a. [Gk. gamos, marriage.] Fertilized (biol.).

gamobium (gămō'biŭm) n. [Gk. gamos, marriage; bios, life.] The sexual or medusoid generation in hydrozoan colonies (zool.).

gamodesmic (găm’öděs'mǐk) a. [Gk. gamos, marriage ; desma, bond.] Having the vascular bundles fused together instead of separated by connective tissue (bot.).

gamogastrous (găm'ögăs'trŭs) a. [Gk. gamos, marriage; gaster, belly.] $A p p l$. a pistil formed by union of ovaries, but with styles and stigmata free (bot.).

gamogenesis (găm'öjĕn'ěsǐs) $n$. [Gk. gamos, marriage ; genesis, descent.] Sexual reproduction (biol.).

gamogenetic '(găm'öjěnět'îk) a. [Gk. gamos, marriage ; genesis, descent.] Reproduced from union of sex elements; sexual (biol.).

gamogony (gămŏg'önǐ) n. [Gk. gamos, marriage; gone, descent.] Sporogony in Protozoa (zool.).

gamont (gămŏnt') n. [Gk. gamos, marriage; ons, a being.] A sporont (zool.).

gamopetalous (găm'öpět'ălŭs) a. [Gk. gamos, marriage; petalon, petal.] With coherent petals; monopetalous (bot.).

gamophyllous (găm'öfil'ŭs) a. [Gk. gamos, marriage; phyllon, leaf.] With united perianth leaves; monophyllous (bot.).

gamosepalous (găm'ösẹ̌p'ălŭs) $a$. [Gk. gamos, marriage ; sepalon, sepal.] With coherent sepals; monosepalous (bot.).

gamostele (găm'östēl') n. [Gk. gamos, marriage; stele, pillar.] A stele formed from the fusion of several steles (bot.).

gamostelic (găm'östếlik) a. [Gk. gamos, marriage; stele, pillar.] $A p p l$. the condition in which the steles of a polystelic stem are fused together (bot.). 
gamostely (găm'östē'li) n. [Gk. gamos, marriage; stele, pillar.] The arrangement of polystelic stems when the separate steles are fused together surrounded by pericycle and endodermis (bot.).

gangliar (găng'gliăr) a. [Gk. gangglion, little tumour.] Pert. a ganglion or ganglia.

gangliate (găng'glīàt) a. [Gk. gangglion, little tumour.] Having ganglia.

gangliform (găng'glĭfôrm) $a$. [Gk. ganggtion, little tumour; L. forma, shape.] In the form of a ganglion. ganglioblast (găng' gliöblăst) $n$. [Gk. gangglion, little tumour; blastos, bud.] The mother-cell of a gangliocyte (anat.).

gangliocyte (găng'gliösīt) n. [Gk. gangglion, little tumour; kytos, hollow.] A ganglion cell outside the central nervous system (anat.).

ganglioid (găng'glioid) a. [Gk. gangglion, little tumour ; cidos, resemblance.] Like a ganglion (anat.).

ganglion (găng'gliǒn) n. [Gk. gangglion, little tumour.] A mass of nervous matter containing nerve cells and giving origin to nerve fibres; a nerve centre (anat.).

ganglionated (găng'glǐonă'těd) $a$. [Gk. ganggtion, little tumour.] Supplied with ganglia (anat.).

ganglioneural (găng'glïönū'răl) $a$. [Gk. gangglion, little tumour; neuron, nerve.] Appl. a system of nerves, consisting of a series of ganglia connected by nerve strands (zool.).

ganglioneuron (găng'gliönü'rŏn) $n$. [Gk. gangglion, little tumour ; neuron, nerve.] A nerve cell of a ganglion (anat.).

ganglionic (găng'gliŏn'îk) $a, \quad[\mathrm{Gk}$. gangglion, little tumour.] Pert. consisting of, or in the neighbourhood of a ganglion; $a p p l$. a layer of the retina, arteries, arterial system of brain (anat.).

ganglioplexus (găng'gliöplěk'sŭs) $n$. [Gk. gangglion, little tumour; L. plexus, twisted.] A diffuse ganglion (anat.).

ganoid (găn'oid) a. [Gk. ganos, sheen; eidos, resemblance.] Appl. scales of ganoid fishes, rhomboidal, joined like parquetry and consisting of a layer of bone with a superficial enamel layer (zool.).

ganoin (găn'öìn) n. [Gk. ganos, sheen.] The outer layer of a ganoid scale, formed by the corium (zool.).

gape (gāp) $n$. [A.S. geapan, to open wide.] The distance between the open jaws of birds, fishes, etc. (zool.).

Gasserian ganglion,-a large ganglion on the sensory root of the fifth cranial nerve (anat.).

gasteromycetous (găs'těrömīsē'tŭs) $a$. [Gk. gaster, belly; mykes, a mushroom.] Having the spores developed in a peridium (bot.).

gastraea (găstrē'ă) n. [Gk. gaster, stomach.] A hypothetical gastrulalike animal; the ancestral Metazoan, according to Haeckel (zool.).

gastraeum (găstrë'ŭm)n. [Gk. gaster, stomach.] The ventral side of the body (anat.).

gastral (găs'trăl) a. [Gk. gaster, stomach.] Pert. stomach, as the gastral cavity, cortex, layer, etc. (anat.).

gastralia (găstrầ'liă) n. plu. [Gk. gaster, stomach.] Microscleres in the gastral membranes of Hexactinellids (zool.).

gastric (găs'trǐk) a, [Gk. gaster, belly.] Pert. or in the region of the stomach; appl. arteries, glands, nerves, veins (anat.).

gastrin (găs'trĭn) n. [Gk. gaster, stomach.] The hormone which is the result of the action of the salivary products on the gastric mucous membrane ( $p h y s_{\text {. }}$ ).

gastrocentrous (găs'trösěn'trŭs) $a$. [Gk. gaster, stomach ; L. centrum, centre.] $A p p l$. vertebrae with centra formed by pairs of interventralia, while the basiventralia are reduced ( $800 \mathrm{l}$.).

gastrocnemius (găs'tröknē'mǐus) $n$. [Gk. gaster, belly; kneme, the tibia.] The large muscle of the calf of the leg (anat.).

gastrocoel (găs'trösēl) n. [Gk. gaster, belly; koilos, hollow.] The archenteron of a gastrula (emb.). gastrocolic (găs'trökǒl'îk) a. [Gk. gaster, stomach; kolon, the gut.] 
Pert. stomach and colon; appl. a ligament (anat.).

gastroduodenal (găs'trödū'ödē'năl) $a$. [Gk. gaster, stomach ; L. duodeni, twelve each.] Pert. stomach and duodenum; appl. an artery (anat.).

gastroepiploic (găs'tröěp'îplō'îk) $a$. [Gk. gaster, stomach ; epiploon, the great omentum.] Pert. stomach and the great omentum; $a p p l$. arteries, veins (anat.).

gastrointestinal (găs'tröintěs'tĭnăl) $a$. [Gk. gaster, stomach; L. intus, within.] Pert. stomach and intestines (anat.).

gastrolienal (găs'tröliēénăl) a, [Gk. gaster, stomach; L. lien, the spleen.] Pert. the stomach and spleen ; appl. ligament (anat.).

gastrolith (găs'trölìth) n. [Gk. gaster, stomach ; lithos, stone.] A mass of calcareous matter found at certain seasons on each side of the gizzard of Crustaceans (zool.).

gastroparietal (găs'tröpărīětăl) $a$. [Gk. gaster, stomach; L. paries, wall.] Pert. stomach and body wall (anat.).

gastrophrenic (găs'tröfrěn'îk) a. [Gk. gaster, stomach ; phrenos, midriff.] Pert. stomach and diaphragm; appl. ligament (anat.).

gastropod (găs'tröpŏd) n. [Gk. gaster, stomach; pous, foot. $\mathrm{A}$ mollusc with a ventral muscular disc adapted for creeping (zool.).

gastropores (găs'tröpōrz) n. plu. [Gk. gaster, stomach ; poros, channel.] The larger pores, for nutrient persons, of hydroid Corals (zool.).

gastropulmonary (găs'tröpŭl'mönărǐ) a. [Gk. gaster, stomach; L. pulmo, lung.] Pert. stomach and lungs (anat.).

gastrosplenic (găs'trösplěn'îk) $a$. [Gk. gaster, stomach; splen, the spleen.] Pert. stomach and spleen (anat.).

gastrostege (găs'tröstēj) n. [Gk. gaster, belly; stege, roof.] A ventral scale of snakes (zool.).

gastrovascular (găs'trövăs'kūlăr) $a$. [Gk. gaster, stomach ; L. vasculum, a small vessel.] Serving both digestive and circulatory purposes, as canals of some Coelenterates (zool.). gastrozooid (găs'trözōoid) n. [Gk. gaster, stomach; zoon, animal ; eidos, resemblance.] In coelenterate colonies, the nutrient person with mouth and tentacles (zool.).

gastrula (găs'troolă) n. [Gk. gaster, stomach.] The cup- or basinshaped structure formed by invagination of a blastula (emb.).

gastrulation (găs'troolā'shŭn) $n$. [Gk. gaster, stomach.] The formation of a gastrula from a blastula by invagination (emb.).

geitonogamy (gî'tŏnŏg'ămī) n. [Gk. geiton, neighbour; gamos, marriage.] Fertilization of a flower by another from the same plant (bot.).

gelatigenous (jěl'ătīj'ěnǔs) a. [L. gelare, to congeal; Gk. genos, offspring.] Gelatine - producing (anat.).

gelatine (jël’ătĭn) $n$. [L. gelare, to congeal.] A jelly-like substance obtained from animal tissue (phys.).

gelatinous (jělăt'ínŭs) $a$. [L. gelare, to congeal.] Jelly-like in consistency (zool.).

geminate (jĕmiñnāt) a. [L. gemini, twins.] Growing in pairs; binate (bot.).

geminiflorous (jĕm'innĭfló'rŭs) $a . \quad[\mathrm{L}$. gemini, twins ; flos, flower.] Appl. a plant whose flowers are arranged in pairs (bot.).

gemma (jěm'ă) n., gemmae (jĕm'ẽ, jĕm'ā) plu. [L. gemma, bud.] A bud or outgrowth of a plant or animal which develops into a new organism (biol.); hypothetical units (cyt.).

gemmaceous (jěmā'shŭs) a. [L. gemma, bud.] Pert. gemmae or buds.

gemmate (jěm'āt) a. [L. gemma, bud.] Reproducing by bud-formation.

gemmation (jĕmā'shŏn) $n$. [L.gemma, bud.] Bud-formation by means of which new independent individuals are developed in plants and animals (biol.).

gemmiferous (jěmíf'ĕrŭs) $a$. [L. gemma, bud ; ferre, to bear.] Budbearing; gemmate.

gemmiform (jěm'ifôrm) a. [L. gemma, bud; forma, shape.] Shaped like 
a bud ; $a p p l$. pedicellariae of Echinoderms (zool.).

gemmiparous (jĕmīpărŭs) a. [L. gemma, bud; parere, to produce.] Gemmiferous.

gemmulation (jĕm'ūlā'shŭn) n. [L. gemma, bud.] Gemmule-formation. gemmule (jěm'ūl) $n$. [L. gemmula, little bud.] A pangen (cyt.); one of the internal buds of Porifera arising asexually and coming into activity on the death of the parent organism (zool.).

gena (jēnnă) n., genae (jē'nē) plu. [L. gena, the cheek.] The cheek or side part of the head; the anterolateral part of an insect's head (zool.).

genal (jē'năl) a. [L. gena, cheek.] Pert. the cheek; appl. the facial suture of Trilobites and the angle of the cheek (zool.).

geneology (jē'něŏl'öjī) n. [Gk. gene, descent ; logos, discourse.] The study of the development of individual and race; Embryology and Palaeontology combined.

genera (jěn'ěră), - see genus.

generalized (jën'ěrălīz'd) $a$. [L. generalis, of one kind.] Combining characteristics of two or more groups, as in many fossils (pal.).

generation (jĕn'ĕrā'shŭn) $n$. [L.generatio, reproduction.] Production; formation; the individuals of a species equally remote from a common ancestor,-see alternation of generations.

generative (jěn'ěrā'tǐv) a. [L. genus, race.] Concerned in reproduction; appl. the smaller of two cells into which a pollen grain primarily divides (bot.).

generic (jěněr'ik) a. [L. genus, race.] Common to all species of a genus, - see binomial nomenclature.

genesis (jěn'ěsǐs) $n$. [Gk. gignesthai, to produce.] Formation, production, or development of a cell, organ, individual, or species.

genetic (jěnět'ík) a. [Gk. gignesthai, to produce.] Pert. production.

genetic spiral,-in spiral phyllotaxis, the imaginary spiral line following the points of insertion of successive leaves (bot.).

genetios (jěnĕt'íks) n. [Gk. gignesthai, to produce.] That part of Biology dealing with heredity and variation.

genial (jěn'řăl, jěnīăl) a. [Gk. geneion, the chin.] Pert. the chin; appl. chin-plates of Reptiles (zool.).

genicular (jěnǐk'úlăr) $a$. [L. geniculum, little knee.] Pert. region of the knee ; appl. arteries, etc., also to ganglion of facial nerve (anat.).

geniculate (jěnı̌k'ūlāt) $a$. [L. geniculum, little knee.] Bent like a kneejoint; $a p p l$. a ganglion of the facial nerve (zool.); having the upper part of the filament forming an angle more or less obtuse with the lower (bot.).

geniculum (jěnǐk'ūlŭm) $n$. [L. geniculum, little knee.] The part of the facial nerve in the temporal bone where it turns abruptly towards the stylo-mastoid foramen (anat.).

genioglossal (jĕnî'öglŏs'ăl) $a$. [Gk. geneion, chin ; glossa, tongue.] Connecting the chin and tongue; $a p p l$. muscles (anat.).

geniohyoid (jěnīöhî'oid) a. [Gk. geneion, chin ; hyoeides, $\mathrm{Y}$-shaped.] Pert. chin and hyoid; appl. muscles (anat.).

genital (jěn'îtăl) $a$. [L. gignere, to beget.] Pert. the region of the reproductive organs; $a p p l$. corpuscles, glands, ridge, tubercle, etc. (anat.).

genitals (jĕn'îtălz) n.plu. [L.gignere, to beget.] The organs of reproduction, especially the external organs (anat.).

genitoanal (jěn'ítöā'năl) a. [L. gignere, to beget ; anus, the vent.] In the region of the genitals and anus (anat.).

genitocrural (jěn'îtökroo'răl) a. [L. gignere, to beget; crus, leg.] In the region of the genitals and thigh ; $a p p l$, a nerve (anat.).

genitoenteric (jěn'îtöěntěrík) a. [L. gignere, to beget ; Gk. enteron, gut.] Pert. genitals and intestine (anat.).

genitofemoral (jěn'îtöfěm'örăl) $a$. [L. gignere, to beget; femur, thighbone.] Genitocrural.

genoblast (jěn'öblăst) $n$. [Gk. genos, offspring ; blastos, bud.] A mature germ-cell exclusively male or female $(c y t)$. 
genu (jĕn'ū) n. [L. genu, knee.] A knee-like bend in an organ or part ; the anterior end of the corpus callosum (anat.).

genus (jënŭs) n., genera (jĕn'ěră) plu. [L. genus, race.] A group of closely related species, in classification of plants or animals.

genys (jē'nĭs) n. [Gk. genys, jaw.] See gonys.

geobios (jē'öbí'ŏs) n. [Gk. ge, earth ; bios, life.] Terrestrial life-one of Haeckel's terms (biol.).

geoblast (jë'öblăst) $n$. [Gk. ge, earth ; blastos, bud.] A germinating plumule of which the cotyledons remain underground (bot.).

geocarpic (jé'ökâr'pìk) a. [Gk. ge, earth ; karpos, fruit.] Having the fruits maturing underground (bot.).

geology (jēŏl'öjî) n. [Gk. ge, earth ; logos, discourse.] The science dealing with the structure, activities, and history of the earth.

geomalism (jēŏm’ălǐzm) n. [Gk. ge, earth ; omalos, level.] Response to the influence of gravitation (bot.). geophilous (jēŏf'ílŭs) $a$. [Gk. ge, earth ; philein, to love.] Living in or on the earth, the ground.

geophyte (jēëöfït) $n$. [Gk. ge, earth ; phyton, plant.] A plant which grows in the earth (bot.).

geotaxis (jë'ötăk'sǐs) n. [Gk. ge, earth ; taxis, arrangement.] Response to the laws of gravity.

geotonus (jếötōónŭs) n. [Gk. ge, earth; tonos, tension.] Normal position in relation to gravity (bot.). geotropism (jēŏt'röpǐzm) n. [Gk. ge, earth; trepein, to turn.] Tendency to respond to stimulus of gravity by turning towards it, as the downward growth of a root (bot.).

gephyrocercal (gěf'îrösěr'kăl, jěfî́rösĕr'kăl) a. [Gk. gephyra, bridge ; kerkos, tail.] Appl. secondary di. phycercal caudal fin brought about by the reduction of the extreme tip of the heterocercal or homocercal fin (zool.).

geratology (jĕr'ătǒl'öjǐ) n. [Gk. geras, old age; logos, discourse.] Study of the factors of decadence.

germ (jërm) n. [L. germen, bud.] A unicellular micro-organism; a seed (bot.); a developing egg (zool.). germ-cell,-a reproductive cell, lopp. somatic ; a primitive male or female element (biol.).

germ centre,-an area of lymphcorpuscle division in nodules of lymph gland tissue (anat.).

germ-disc,-a small green cellular plate of the germ tube of liverworts (bot.).

germ layer,-an early differentiated layer of cells (emb.).

germ nucleus,-an egg or sperm nucleus (emb.).

germ plasm,-idioplasm; the physical basis of inheritance.

germ pore,- - the exit pore of a germ tube in the spore integument (bot.). germ stock, - the stolon in certain Tunicates (zool.).

germ theory,- - biogenesis ; the theory that living organisms can be produced or developed only from living organisms (biol.).

germ tube,- the short filamentous tube put forth by a germinating spore (bot.).

germ vitellarium,-an organ of Platyhelminths producing both ova and vitelline material (zool.).

germ yolk gland,-in some Rhabdocoels, an embryonic structure consisting of the fertile portion of the egg and a sterile portion which functions as a yolk gland feeding the fertile portion (zool.).

germarium (jĕrmā'rĭŭm) $n$. [L. germen, bud.] An ovary (zool.).

germen (jër'mĕn) $n$. [L. germen, bud.] A mass of undifferentiated cells, the primary form of the germ cells.

germinal (jĕr'minnăl) a. [L. germen, bud.] Pert. a seed, a germ-cell, or reproduction.

germinal bands, - two sets of rows of cells in early development of Annulates (zool.).

germinal cells, - the cells concerned in reproduction, set apart early in embryonic life (emb.).

germinal dise, - the disc-like area of an egg yolk on which segmentation first appears (emb.).

germinal epithelium,- the layer of columnar epithelial cells covering the stroma of an ovary (emb.).

germinal layers, - the primary layers 
of cells in a developing ovum, epiblast, hypoblast, and later mesoblast (emb.).

germinal spot,- the nucleus of an ooplasm (emb.).

germinal vesicle, - the nucleus of an egg, before formation of polarbodies (emb.).

germination (jěr'minnā'shŭn) $n$. [L. germen, bud.] Beginning of growth; budding; development (bot.).

germiparity (jĕr'mĭpăr'ítĩ) $n$. [L. germen, bud; parere, to beget.] Reproduction by germ-formation.

germogen (jěr'möjěn') $n$. [L. germen, bud; Gk. genos, offspring.] The central cell of the gastrula-like phase, or infusorigen, in the development of the Rhombozoa; the residual nucleus, or unused portion, after formation of the rhombogen by division of the primary germogen or primitive central cell (zool.).

gestation (jĕstā'shŭn) $n$. [L. gerere, to carry.] The intra-uterine period in the development of an embryo $(e m b$.).

giant cells,--large nerve-cells in Annelids; myeloplaxes; osteoclasts ; large multinuclear protoplasmic masses found in marrow, spleen (anat.).

giant fibres,-greatly enlarged and modified nerve-fibres running longitudinally through the ventral nerve cord of some invertebrates, as Worms (zool.).

gibbous (gỉ'ús) a. [L. gibbus, humped.] Inflated; saccate or pouched, as the lateral sepals of Cruciferae (bot.).

gill (gîl) n. [M.E. gille, gill.] A plate-like or filamentous outgrowth ; respiratory organ of water-inhabiting animals (zool.); one of a number of lamellae radiating from the stalk of a mushroom (bot.).

gill arch, - part of the visceral skeleton in the region of functional gills; branchial arch (zool.).

gill basket, - the branchial skeleton of lampreys, composed of continuous cartilage (zool.).

gill book, - the respiratory organ of certain Arachnids, consisting of a large number of leaf-like structures between which the water circulates (zool.).

gill cleft, - a branchial cleft formed on the side of the pharynx (zool.).

gill cover, - an operculum.

gill helix, - a spirally coiled gill-like organ in certain Clupeidae (zool.). gill plume, - the gill or ctenidium of the majority of Gastropods (zool.).

gill pouch, - an oval pouch containing gills and communicating directly or indirectly by a duct with the exterior, seen in Myxine and Petromyzon (zool.).

gill rakers, - small spine-like structures attached in a single or double row to branchial arches to prevent escape of food (zool.).

gill remnants, - epithelial, postbranchial, or suprapericardial bodies arising in the pharynx of higher vertebrates (zool.).

gill rods,-oblique gelatinous rods supporting the pharynx in Cephalochorda (zool.).

gill slits, $-\mathrm{a}$ series of perforations leading from pharynx to the exterior, persistent in lower vertebrates, embryonic in higher (zool.).

gingival (jĭnjī́văl) a. [L. gingivae, gums.] Pert. the gums.

ginglymoid (ğng'glìmoid) a. [Gk. gingglymos, hinge - joint.] Constructed like a hinge-joint (anat.). ginglymus (ğng'glìmŭs) $n$. [Gk. gingglymos, hinge-joint.] An articulation constructed to allow motion in one plane only (anat.).

girdle (gër'dl) n. [A.S. gyrdan, to gird.] In appendicular skeleton, the supporting structure at shoulder and hip, each consisting typically of one dorsal and two ventral elements (anat.).

gizzard (gǐzărd) n. [M.E. gizer, gizzard.] In birds, the muscular grinding chamber of the alimentary canal; the proventriculus of insects (zool.).

glabella (glăbělăa $n$. [L. glaber, bald.] The space on the forehead between the superciliary ridges (anat.); the elevated median region of the cephalic shield of Trilobites (pal.).

glabrate (glăb'rāt) a. [L. glaber, smooth.] Becoming smooth; glab- 
rescent ; with a nearly smooth surface (bot.).

glabrescent, - see glabrate.

glabrous (glăb'rŭs) $a$. [L. glaber, smooth.] With a smooth, even surface.

gladiate (glăd'iāt) a. [L. gladius, sword.] Shaped like a sword (bot.). gladiolus (glăd'îólŭs) $n$. [L.gladiolus, small sword.] The middle or largest part of the sternum (anat.).

gladius (glăd’iuss) $n$. [L. gladius, sword.] The pen of a cuttle-fish (zool.).

gland cell,-an isolated secreting cell ; a cell of glandular epithelium.

glands (glăndz) n. plu. [L. glans, an acorn.] Single cells or masses of cells specialized for the elaboration of secretions either for use in the body or for excretion (anat.).

glandula (glăn'dūlă) $n$. [L. glandula, small acorn.] An arachnoid granulation on the outer surface of the dura mater (anat.).

glandular (glăn'dūlăr) a. [L. glandula, small acorn.] Pert. a gland; with secreting function (zool.); bearing a gland (bot.).

glandular epithelium, - the tissue of glands, composed of polyhedral columnar or cubical cells whose protoplasm contains the material secreted (phys.).

glandular tissue,-tissue of single or massed cells, parenchymatous and filled with granular protoplasm, adapted for secretion of aromatic substances (bot.).

glandule (glăn'dūl) n.,-see glandula. glandulose-serrate (glăn'dūlōs-sĕr'āt) a. [L. glandula, small acorn ; serratus, sawn.] Having the serrations tipped with glands (bot.).

glans (glănz) $n$. [L. glans, acorn.] A nut; a hard, dry, indehiscent one-celled fruit like an acorn (bot.); a gland, especially the glans penis (anat.).

glaucescent (glôsěs'ěnt) a. [L. glaucus, sea-green.] Somewhat glaucous (bot.).

glaucous (glôk'ŭs) a. [L. glaucus, sea-green.] Covered with a bluishgreen bloom (bot.).

gleba (glē'bă) $n$. [L. gleba, clod.] The central part of the sporophore in certain Fungi; the spore-forming apparatus in certain plants (bot.).

glebula (glē'būlă) n. [L. glebula, small clod.] A small prominence on a lichen thallus (bot.).

glenohumeral (glē'nöhū'mĕrăl) $a$. [Gk. glene, socket; L. humerus, the humerus.] Pert. glenoid fossa and humerus; appl. ligaments (anat.).

glenoid (glē'noid) a. [Gk. glene, socket; eidos, resemblance.] Like a socket; $a p p l$. especially to the cavity into which the head of the humerus fits, the mandibular fossa, and ligaments (anat.).

glenoidal labrum, - a fibro-cartilaginous rim attached round the margin of glenoid cavity and acetabulum (anat.).

glia (glíă, glēă) $n$. [Gk, glia, glue.] A cell of the neuroglia ; a supporting cell of nervous tissue (phys.).

Glisson's capsule, - a thin fibrous capsule within the tunica serosa of the liver (anat.).

globate (glō'bāt) a. [L. globus, globe.] Globe-shaped.

globigerina ooze (glöbǔj'ĕrî'nă ooz),sea-bottom mud, which is largely composed of foraminifera shells (zool.).

globin (glō'bĭn) $n$. [L. globus, globe.] The protein constituent of haemoglobin (phys.).

globoid (glō'boid) n. [L. globus, globe; Gk. eidos, resemblance.] A spherical body of aleurone grains; a double phosphate of calcium and magnesium (bot.).

globose (glōbōs') a. [L. globus, globe.] Spherical or globe-shaped.

globular (glǒb'ülăr) a.,--see globose. globule (glǒb'ūl) $n$. [L. globulus, small globe.] Any minute spherical structure; the antheridium of Characeae (bot.).

globulin (glǒb'ūlìn) $n$. [L. globus, globe.] A proteid such as fibrinogen, vitellin (phys.).

globulose (glǒb'ūlōs) a. [L. globus, globe.] Spherical; consisting of, or containing globules.

glochidiate (glökǐd'îât) a. [Gk. glochis, arrow-point.] Furnished with barbed hairs (bot.). 
glochidium (glökĭd'iŭum) n. [Gk. glochis, arrow-point.] Hairs bearing barbed processes seen on the massulae of certain Rhizocarps (bot.); the larva of fresh-water mussels such as Unio and Anodon (zool.).

gloea (glē'ă) n. [Gk, gloia, glue.] An adhesive secretion of some Protozoa (zool.).

glomerular (glờměr'ūlăr) $a$. [L. glomus, ball.] Pert. or like a glomerulus (anat.).

glomerulate (glŏmĕr'ūlāt) a. [L. glomus, ball.] Arranged in clusters.

glomerule (glŏm'ĕrūl) n. [L. glomus, ball.] A condensed cyme of almost sessile flowers; a compact cluster (bot.).

glomeruliferous (glŏmĕr' ūliff'ěrŭs) $a$. [L. glomus, ball; ferre, to carry.] Having the flowers arranged in glomerules (bot.).

glomerulus (glŏměr'ülŭs) $n$. [L. glomus, ball.] A network of capillary blood-vessels; the inturned portion of a Bowman's capsule (zool.); an oval body terminating the olfactory fibre in the rhinencephalon (anat.).

glomus (glō'mŭs) n., glomera (glŏm'ěră) plu. [L. glomus, ball.] A number of glomeruli run together (zool.); the coccygeal and carotid skeins of the suprarenal glands (anat.),

glossa (glŏs'ă) n. [Gk. glossa, tongue.] A tongue-like projection in the middle of the labium of insects (zool.).

glossal (glŏs'ăl) a. [Gk. glossa, tongue.] Pert. the tongue.

glossarium (glŏsā'rium) n. [Gk. glossa, tongue.] Theslender-pointedglossa of certain Diptera (zool.).

glossate (glǒs'āt) a. [Gk. glossa, tongue.] Having a tongue or tongue-like structure (zool.).

glossoepiglottic (glŏs'öĕp'íglŏt'îk) $a$. [Gk. glossa, tongue; epi, upon ; glotta, tongue.] Pert. tongue and epiglottis; appl. folds of mucous membrane (anat.).

glossohyal(glŏs'öhīăl) n. [Gk. glossa, tongue; hyoeides, $\mathrm{Y}$-shaped.] The median basihyal of fishes (zool.). glosso-kinaesthetic area, - a brain area in Broca's convolution immediately connected with speech (phys.). glossopalatine (glǒs'öpăl'ătīn) $a$, [Gk. glossa, tongue; L. palatus, the palate.] Connecting tongue and palate; $a p p l$. arch, muscle (anat.).

glossophagine (glŏsŏf'ăjǐnn) a. [Gk. glossa, tongue; phagein, to eat.] Securing food by means of the tongue (zool.).

glossopharyngeal (glŏs'öfărĭn'jě̆l, -făr'ínjē'ál) a. [Gk. glossa, tongue ; pharynx, gullet.] Pert. pharynx and gullet; $a p p l$. the ninth cranial nerve (anat.).

glossopodium (glǒs'öpō'dǐŭm)n. [Gk. glossa, tongue; pous, foot.] The sheathing leaf-base of Isoetes (bot.):

glossotheca (glŏs'öthē'kă) n. [Gk. glossa, tongue; theke, box.] The proboscis-covering part of a pupal integument of insects (zool.).

glottis (glŏt'is) n. [Gk. glotta, tongue.] The opening into the windpipe (anat.).

glucase (glook'ãs) n. [Gk. glykus, sweet.] A plant enzyme which produces grape sugar from maltose (bot.).

glucoproteins, - compounds of protein with a carbohydrate, including mucins and mucoids (phys.).

glucosamine (glook'ösăm'în) $n$. [Gk. glykus, sweet.] A nitrogenous substance with a reducing power, obtained from chitin, and dextrorotary (phys.).

glucose (glook'ōs) n. [Gk. glykus, sweet.] The grape sugar of plants and animals (phys.).

gluma (gloom'à) $n$. [L. gluma, husk.] A bract at the base of a grass inflorescence or spikelet (bot.).

glumaceous (gloomā'shŭs) a. [L. gluma, husk.] Dry and scaly like glumes (bot.).

glume (gloom) n.,- - see gluma.

glumiferous (gloomif'ěrŭs) $a$. gluma, husk; ferre, to bear.] Bearing or producing glumes (bot.). glumiflorus (gloom'îfo'rŭs) $a$. [L. gluma, husk; flos, flower.] Having flowers with glumes or bracts at their bases (bot.). 
gluteal (gloot'ě̃l) a. [Gk. gloutos, buttock.] Pert. or in the region of the buttocks ; appl. artery, muscle, nerve, tuberosity, vein (anat.).

gluten (gloot'ĕn) $n$. [L. gluten, glue.] A tough substance obtainable from some grains.

gluteus (gloot'ěŭs) $n$. [Gk. gloutos, buttock.] Name given to certain muscles of the buttock (anat.).

glutinous (gloot'ínŭs) $a$. [L. gluten, glue.] Having a sticky or adhesive surface (bot.).

glycerin (glïs'ĕrĭn) n. [Gk. glykos, sweet.] The sweet principle of natural fats and oils (phys.).

glycerol (glǐs'ĕrôl) n.,- see glycerin.

glycogen (glî́köjën) n. [Gk. glykos, sweet.] Animal starch (phys.).

glycolysis (glīkǒl'ǐsǐs) n. [Gk. glykos, sweet ; lyein, to loosen.] Decomposition of sugar by hydrolysis (phys.).

glycosecretory (glî́kösēkrē'törǐ) $a$. [Gk. glykos, sweet; L. secretus, set apart.] Connected with the secretion of glycogen (phys.)

gnathic (gnâth'îk, năth'ik) a. [Gk. gnathos, jaw.] Pert. the jaw (zool.). gnathism (gnâth'ĩm, nâth'ĩzm) $n$. [Gk. gnathos, jaw.] Formation of jaw with reference to the degree of projection.

gnathites (gnâth'îts, năth'îts) $n$. plu. [Gk. gnathos, jaw.] The buccal appendages of insects.

gnathobase (gnâth'öbās, năth'öbās) $n$. [Gk. gnathos, jaw ; basis, base.] An inwardly turned masticatory process on the protopodite of appendages near the mouth in Crustacea (zool.).

gnathopod (gnâth'öpŏd, năthöpŏd) $n$. [Gk. gnathos, jaw ; pous, foot.] Any Crustacean limb in the oral region modified to assist with the food (zool.).

gnathopodite (gnâthŏp'ödīt, năthŏp'ödīt) n. [Gk, gnathos, jaw ; pous, foot.] A maxilliped of an Arthropod (zool.).

gnathostegite (gnâthŏs'těgīt, năthŏs' tějīt) n. [Gk. gnathos, jaw ; stege, roof.] A covering plate for the mouth parts of some Crustaceans (zool.).

gnathostomatous (gnâth'östŏm'ătŭs, năth'östŏm'ătŭs) a. [Gk. gnathos, jaw ; stoma, mouth.] With jaws at the mouth.

gnathotheca (gnâth'öthē'kă, năth'öthé'kă) n. [Gk. gnathos, jaw ; theke, case.] The horny outer covering of a bird's lower jaw (zool.).

goblet cells,-mucus-secreting cells of most columnar epithelia (phys.). gomphosis (gomfō'šs) n. [Gk.gomphos, a bolt.] Articulation by insertion of a conical process into a socket, as of roots of teeth into alveoli (anat.).

gonad (gốn'ăd) n. [Gk. gone, descent.] A sexual gland, either ovary or testis (zool.).

gonaduct (gŏn'ădưkt) $n$, [Gk. gonos, offspring; L. ducere, to lead.] A genital duct ; a duct leading from the gonad to the exterior; a gonoduct (zool.).

gonangium (gŏnăn'jĭum) $n$. [Gk. gone, seed; anggeion, vessel.] $\mathrm{A}$ gonotheca, a dilated cup of perisarc protecting the blastostyle of Calyptoblastea (zool.).

gonapophyses (gŏn'ăpŏf'isěz) $n$. plu. [Gk. gone, seed ; apo, from ; phyein, to grow.] The chitinous outgrowths subserving copulation in insects; the component parts of the sting (zool.).

goniale (gŏn'îāē, gōnǐâl'ā) n. [Gk. gonia, corner.] In some vertebrates, a bone of the lower jaw beside the articular (anat.).

gonidangium (gŏn'îdăn'jiŭm) n. [Gk. dim. of gone, seed; anggeion, vessel.] A structure producing or containing gonidia (bot.).

gonidia (gŏnìd'iă) n. plu. ; gonidium (gŏnĭd'ium) sing: [Gk. dim. of gone, seed.] Asexual non-motile reproductivecells produced upon gametophytes (bot.).

gonidial (gonnid'ǐăl) a. [Gk. dim. of gone, seed.] Pert. gonidia (bot.).

gonidiferous (gŏnǐdif'ěrŭs) $a$. [Gk. dim. of gone, seed; L. ferre, to carry.] Bearing or producing gonidia (bot.).

gonidimium (gŏn'îdím'ǐŭm) n. [Gk. dim. of gone, seed.] A gonidial structure smaller than a gonidium and larger than a gonimium (bot.). 
gonidiogenous (gŏnĭd'ǐŏj'ĕnŭs) $\alpha$. [Gk. dim. of gone, seed ; genos, offspring.] Bearing or producing gonidia; gonidiferous (bot.).

gonidioid (gŏnìd'ioid) a. [Gk. dim. of gone, seed ; eidos, resemblance.] Like a gonidium; $a p p l$. certain Algae (bot.).

gonidiophore (gŏnǐd'iöōō) $n$. [Gk. dim. of gone, seed; pherein, to bear.] An aerial hypha supporting a gonidangium (bot.).

gonidiophyll (gŏnĭd'iöfïl) $n$. [Gk. dim. of gone, seed; phyllon, leaf.] A gametophyte leaf bearing gonidia (bot.).

gonimium (gŏnĭm'iŭm) n. [Gk. gonimos, productive.] A bluishgreen gonidium of certain Lichens (bot.).

gonimoblasts (gŏn'imöblăsts) $n$. plu. [Gk. gonimos, productive; blastos, bud.] Filamentous outgrowths of a fertilized carpogonium of certain Algae (bot.).

gonion (gō'nǐŏn) n. [Gk. gonia, angle.] The angle point on the lower jaw (anat.).

gonoblast (gŏn'öblăst) $n$. [Gk. gonos, offspring ; blastos, bud.] A reproductive cell (zool.).

gonoblastid (gŏn'öblăs'tĭd) $n$. [Gk. gonos, offspring ; blastos, bud.] A blastostyle of Hydrozoa (zool.).

gonocalyx (gŏn'ökā'likss) n. [Gk. gonos, offspring; kalyx, a cup.] The bell of a medusiform gonophore (zool.).

gonocheme (gŏn'ökēm)n. [Gk.gonos, offspring ; ochema, support.] A medusoid bearing sex-cells in the Hydrozoa (zool.).

gonochorism (gǒn'ökō'rĭzm) n. [Gk. gonos, offspring; chorisein, to divide.] The history or development of sex distinction.

gonocoele (gơn'ösēl) n. [Gk. gone, seed ; koilos, hollow.] The cavity containing the gonads (zool.).

gonocytes (gŏn'ösīts) n. plu. [Gk. gone, seed; kytos, hollow.] Sexual cells of Sponges; the mother-cells of ova and spermatozoa (zool.).

gonodendron (gŏn'ödĕn'drŏn) n. [Gk. gonos, offspring; dendron, tree.] A branching blastostyle in Physalia (zool.). gonoduct (gŏn'ödŭkt') n., - see gonaduct.

gonophore (gŏn'öfōr) n. [Gk. gone, seed; pherein, to bear.] An elongation of the thalamus between corolla and stamens (bot.); a reproductive zooid in a hydroid colony (zool.).

gonoplasm (gŏn'öplăzm)n. [Gk. gone, seed ; plasma, something moulded.] The generative part of protoplasm (cyt.).

gonopore (gŏn'öpōr) n. [Gk. gone, seed; poros, channel.] The reproductive aperture of female Nematodes (zool.).

gonosome (gŏn'ösōm) n. [Gk. gone, seed; soma, body.] All the reproductive zooids of a hydrozoan colony (zool.).

gonosphaerium (gŏn'ösfē'rŭŭm) $n$. [Gk. gone, seed; sphaira, globe.] An oosphere (bot.).

gonostyle (gŏn'östīl) n. [Gk. gone, seed; stylos, pillar.] The blastostyle; sexual palpon or siphon of Siphonophora (zool.).

gonotheca (gŏn'öthē'kă) $n$. [Gk. gone, seed; theke, cup.] A transparent protective expansion of the perisarc round a blastostyle or gonophore (zool.).

gonotome (gŏn'ötōm) n. [Gk. gone, seed; temnein, to cut.] An embryonic segment containing the primordium of the gonad, comparable to a nephrotome (emb.).

gonozooid (gǒn'özōoid) n. [Gk. gone, seed ; zoon, animal ; eidos, resemblance.] A gonophore or reproductive individual of a hydrozoan colony; a zooid containing a gonad (zool.).

gonydial (gŏnĭd'ǐăl) a. [Gk. genys, lower jaw.] Pert. a gonys (zool.). gonys (gŏn'is) $n$. [Gk. genys, lower jaw.] The lower part of a bird's bill (zool.).

Graafian (grâf' ıăn, grāf'iăn) follicle,a vesicular spherical capsule surrounding an ovum, the cells of the capsule being morphologically equal to the ovum; an ovisac with developing ova.

gracilis (grăs'ílís) $n$. [L. gracilis, slender.] A superficial muscle of the thigh (anat.).

graduated (grăd'ūātěd) a. [L.gradus, 
step.] Tapering; becoming longer or shorter by steps.

grain (grān) n. [L. granum, grain.]

Theseed of cereals; a granular prom-

inence on the back of a sepal (bot.).

graminifolious (grăm'innifo'ólǐus) $a$. [L. gramen, grass; folium, leaf.] With grass-like leaves (bot.).

graminivorous (grăm'innìv'örŭs) $a$. [L. gramen, grass ; vorare, to eat.] Grass-eating (zool.).

granellae (grăněl'ē) n.plu. [L. dim. of granum, grain.] Small oval, refractile granules consisting chiefly of barium sulphate, found in the tubes of certain Sarcodina (zool.).

granellarium (grăn'ělā'rĭŭm) $n$. [L. dim. of granum, grain.] The system of granellae-containing tubes of Sarcodina (zool.).

granose (grăn'ōs) a. [L. granum, grain.] In appearance like a chain of grains, like some insect antennae ; moniliform (zool.).

granular (grăn'ūlăr) a. [L. granum, grain.] Consisting of grains or granules; appearing as if made up of granules (zool.).

granulation (grăn'ūlā'shŭn) n. [L. granum, grain.] A grain-like elevation or eminence; $a p p l$. arachnoid elevations on the outer surface of the dura mater (anat.).

granule (grăn'ūl) n. [L. granulum, small grain.] A small particle of matter; a small grain (bot.).

granule cells, - ovoid or spheroid cells formed of soft protoplasm containing basiphil granules.

granule glands, - the prostate glands of flatworms.

graphiohexaster (grăf'ı̈h̆ěksăs'tër) $n$. [Gk. graphein, to write; hex, six; aster, star.] A hexaster spicule with long outwardly-directed filamentous processes from four of the rays (zool.).

grater (grātër) n. [O.F. grater, to scrape.] One of the denticles of a Eunice (zool.).

gravity (grăv'ítí) n. [L. gravis, heavy.] The force of attraction of all bodies towards each other; the tendency of terrestrial bodies to be drawn towards the earth's centre (phys.).

green glands, - the excretory organs of certain Crustacea (zool.). gregaloid (grĕgăloid) a. [L. grex, flock; Gk. eidos, like.] Appl. a colony of Protozoa of indefinite shape, usually with a gelatinous base, formed by incomplete division of individuals or partial union of adults (zool.).

gregarious (grĕgā'rǔs̆s) a. [L. grex, flock.] Tending to herd together; colonial ; growing in clusters (biol.). grey matter,-nerve tissue abundantly supplied with nerve cells, of greyish colour, internal to white matter in spinal cord, external in cerebrum (anat.).

grey nerve-fibres,-semitransparent, grey or yellowish-grey, gelatinous non-medullated nerve-fibres, comprising most of the fibres of the sympathetic system and some of the cerebro-spinal (anat.).

groin (groin) $n$. [Icel. grein, branch.] The depressed part of the body between abdomen and thigh (anat.). groove (groov) $n$. [Dut. groef, channel.] Any channel, furrow, or depression, as carotid, costal, optic, primitive vertebral groove (anat.).

group (groop) $n$. [F. groupe, group. A number of plants, or animals, related to one another, and considered collectively (biol.).

growing point, - a part of the plant body at which cell-division is localized, generally terminal and composed of meristematic cells (bot.).

growth, -increase in substance of plant or animal, due to anabolism being greater than katabolism (biol.).

growth rings,-see annual rings (bot.).

grumose (groom'ōs) a. [L. grumus, hillock.] Clotted ; knotted ; collected into granule masses (bot.).

grumous (groom'ŭs), - see grumose. guanin (gwân'în) n. [Peruvian, huano, dung.] A substance contained in guano, also in some plants and certain mammalian glands; that found in fish corium forms the basis of artificial pearl (biol.).

guanylic (gwăn'îlik) a. [Peruvian, huano, dung.] Appl. a nucleic acid, yielding guanin, found in the pancreas (phys.). 
guard (gârd) $n$, [O.F. garder, to guard.] The rostrum of a Belemnite (pal.).

guard cells,-cells surrounding the stomata of the aerial epidermis of plant tissue (bot.).

gubernacular (goo'bĕrnăk'ūlăr) $a$. [L. gubernare, to govern.] Pert. the gubernaculum.

gubernaculum (goo'běrnăk'ūlŭm) $n$. [L. gubernare, to govern.] A cord stretching from the epididymis to the wall of the scrotum (anat.); strands of blastostylar ectoderm between gonophore and gonotheca in the Hydromedusae; a posterior flagellum functioning as a rudder (zool.).

guest insect, -an insect living or breeding in the nest of another (zool.).

gula (gü'lă) $n$. [L. gula, gullet.] The upper part of the throat; the median ventral piece of an insect's head (zool.).

gular (gū'lăr) $n$. [L. gula, gullet.] An anterior unpaired horny shield on the plastron of Chelonia (zool.).

gullet (gŭl'ět) $n$. [L. gula, gullet.] The oesophagus; a muscular canal extending from mouth cavity to stomach; the canal between the cell-mouth or cytostome and the endoplasm of Ciliata (zool.).

gum (gŭm)n. [L.gummi, gum.] An exudation of certain plants and trees; a vegetable mucilage (bot.).

gummiferous (gŭmíf'ĕrŭs) $a$. [L. gummi, gum; ferre, to carry.] Gum-producing or exuding (bot.).

gummosis (gŭmō'sis) $n$. [L. gummi, gum.] Condition of plant tissue when cell-walls become gummy (bot.).

gums (gŭmz) n. plu. [A.S. goma, jaw.] The thick tissues investing the jaws (anat.).

gustatory (gŭs'tătörĭ) a. [L. gustare, to taste.] Pert. sense of taste ; appl. cells, hairs, pores, nerves (anat.).

gustatory calyculus, - a taste bud; an end-cell or end-organ of taste consisting of a group of gustatory cells (anat.).

gut (güt) n. [A.S. gut, a channel.] The intestine or part thereof, according to the structure of the animal (zool.).

gutta (gŭt'ă) n. [L. gutta, drop.]
A small spot of colour on an insect's wing or elsewhere (zool.). guttation (gŭtā'shŭn) $n$. [L. gutta, drop.] Formation of drops of water on plants from moisture in the air (bot.).

guttiform (gŭt'îfôrm) a. [L. gutta, drop ; forma, shape.] Drop-like; in the form of a drop (zool.).

guttulate (gŭt'ūlāt) a. [L. guttula, small drop.] In the form of a small drop, as markings (zool.).

gymnanthous (jĭmnăn'thŭs) $a$. [Gk. gymnos, uncovered; anthos, flower.] With no floral envelope; achlamydeous (bot.).

gymnetrous (jĭmnē'trŭs) a. [Gk. gymnos, naked; etron, abdomen.] Without an anal fin (zool.).

gymnoarian (jĭmnöā'riăn) a. [Gk. gymnos, naked.] Appl. gonads when naked, or not enclosed in coelomic sacs; $o p p$. cystoarian (zool.).

gymnoblastic (jǐm'nöblăs'tǐk) a. [Gk. gymnos, naked; blastos, bud.] Without hydrothecae and gonothecae; $a p p l$. certain of the Coelenterates (zool.).

gymnocarpous (jǐm'nökâr'pŭs) $a$. [Gk. gymnos, uncovered; karpos, fruit.] With naked fruit; $a p p l$. Lichens with uncovered apothecia, Mosses with expanded hymenium (bot.).

gymnocidium (jǐm'nösĭd'ŭm) $n$, [Gk. gymnos, uncovered.] A basal swelling of certain moss capsules (bot.).

gymnocyte(jǐm'nösīt)n. [Gk. gymnos, uncovered ; kytos, hollow.] A cell without a defining cell-wall (biol.).

gymnocytode (jĭm'nösī'tōd), - a cytode without cell-wall or nucleus - a term used by Haeckel (biol.).

gymnogenous (jǐmnǒj'ěnŭs) $a$. [Gk. gymnos, naked; genos, offspring.] Naked when born; $a p p l$. birds. (zool.).

gymnogynous (jĭmnŏj'innŭs) a. [Gk. gymnos, naked; gyne, woman.] With exposed ovary (bot.).

gymnoplast (jĭm'nöplăst) $n$. [Gk. gymnos, naked; plastos, formed.] Protoplasm without definite formation or cell-wall (biol.).

gymnorhinal (jimm'nörīnăl) a. [Gk. 
gymnos, naked; rhis, nose.] With nostril region not covered by feathers, as in some birds (zool.). gymnosomatous (jĭm'nösöm'ătŭs) $a$. [Gk. gymnos, naked; soma, body.] Having no shell or mantle, as certain Molluscs (zool.).

gymnospermous (jǐmnöspĕr'mŭs) $a$. [Gk. gymnos, uncovered ; sperma, seed.] Having seeds not enclosed in a true ovary, as in the Conifers (bot.).

gymnospore (jĭm'nöspōr) n. [Gk. gymnos, naked; sporos, seed.] A naked germ not enclosed in a protective envelope (biol.).

gymnostomatous (jīm'nöstŏm'ătŭs) $a$. [Gk. gymnos, naked; stoma, mouth.] Naked-mouthed; having no peristome (zool., bot.).

gynaecophoral groove,-see gynaecophore.

gynaecophore (jĭnē'köfōr) n. [Gk. gyne, woman; pherein, to carry.] The canal or groove of certain Worms formed by an inrolling of the sides, in which the female is carried (zool.).

gynandrism (jĭnăn'drǐzm) n. [Gk. gyne, woman; aner, man.] Hermaphroditism.

gynandromorphism (jĭnăn'drömôr'fizm) n. [Gk. gyne, woman ; aner, man; morphe, form.] Condition of having one side characteristically male, the other female, from external aspect.

gynandrophore (jĭnăn'dröfōr') $n$. [Gk. gyne, woman; aner, man ; pherein, to carry.] An axial prolongation bearing a sporophyll (bot.).

gynandrosporous (jĭnăn'dröspō'rŭs) a. [Gk. gyne, woman ; aner, man; sporos, seed.] With androspores adjoining the oogonium, as in some Algae (bot.).

gynandrous (jĭnăn'drŭs) a. [Gk. gyne, woman; aner, man.] Having the stamens fused with the pistils, as in some Orchids (bot.).

gynantherous (jĭnăn'thĕrŭs) a. [Gk. gyne, woman; anthos, flower.] Having the stamens converted into pistils (bot.).

gynobase (jǐnöbās) n. [Gk. gyne, woman ; L. basis, base.] A gynoecium-bearing receptacle of certain plants; the condition in which the style appears to arise from the ovary (bot.).

gynobasic style,- a style arising from the base of the carpel (bot.).

gynodioecious (jǐ̌nödiē'shŭs) $a$. [Gk. gyne, woman; dis, twice; oikos, house.] Dimorphic, with some plants producing only female flowers (bot.).

gynoecium (jǐnē'sĭŭm) n. [Gk. gyne, woman; oikos, house.] The pistils, carpels, or female organs of a flower (bot.).

gynogonidia (jînögŏnid'iă) $n$. plu. [Gk. gyne, woman; gonos, offspring.] Female sexual elements formed after repeated division of parthenogonidia in Mastigophora (biol.).

gynomonoecious (jî'nömŏnē'shŭs) $a$. [Gk. gyne, woman; monos, alone ; oikos, house.] Appl. plants with pistillate flowers only (bot.).

gynophore (jǐnöför) n. [Gk. gyne, woman; pherein, to carry.] A stalk supporting the ovary; an elongation of the thalamus between stamens and pistil (bot.).

gynostegium (jî'nöstē'jǐum) n. [Gk. gyne, woman; stege, roof.] A protective covering for a gynoecium (bot.).

gynostemium (jî'nöstē'mǐŭm) $n$. [Gk. gyne, woman ; stemon, warp.] The column composed of pistil and stamens in Orchids (bot.).

gyration (jīrä'shŭn) $n$. [L. gyrare, to revolve.] Rotation, as of cells; a whorl of a spiral shell (zool.).

gyrose (jî́rōs) a. [L. gyrare, to revolve.] With undulating lines; sinuous (bot.).

gyrus (jî'rŭs) n., gyri (jî'rī) plu. [L. gyrus, circle.] A cerebral convolution; a ridge between two grooves (anat.).

\section{$\mathrm{H}$}

habenula (hăbĕn'ūlă) n. [L. habena, strap.] A name appl. certain band-like structures (anat.).

habituation (hăbĭt'ūā'shŭn) n. [L. habituare, to bring into a habit.] The adjustment effected in a cell by which subsequent contacts of 
the same stimulus produce diminishing effects (phys.).

hadrocentric (hăd'rösĕn'trǐk) a. [Gk. hadros, thick; kentron, centre.] With the phloem surrounding the xylem (bot.).

haemachrome (hĕ'măkrōm) n. [Gk. haima, blood; chromos, colour.] The colouring matter found in the blood (phys.).

haemacyanin,-see haemocyanin.

haemacyte (hĕ́măsīt) $n$. [Gk. haima, blood; kytos, hollow.] A blood corpuscle (anat., phys.).

haemad (hë'măd) adv. [Gk. haima, blood.] Situated on same side of vertebral column as the heart (zool., anat.).

haemal (he'măl) a. [Gk. haima, blood.] Pert. blood or bloodvessels; also situated on the same side of the vertebral column as the heart (zool.).

haemamoeba (hĕm'ămē'bă) $n$. [Gk. haima, blood ; amoibos, exchanging.] Protozoon with an amoeboid trophozoitic stage parasitic in a red blood-corpuscle (zool.).

haemapoietic (hĕ̌m'ăpoiět'îk) $a$. [Gk. haima, blood; poiein, to form.] Blood-forming.

haemapophysis (hěm'ăpŏf'ísĭs) $n$. [Gk. haima, blood; apo, from; phyein, to grow.] One of plate-like or spine-like processes growing from the latero-ventral surfaces of a vertebral centrum (anat.).

haematal (hĕm'ătăl) a. [Gk. haima, blood.] Pert. blood or blood-vessels.

haematid (hĕ̌m'ătĭd) $n$. [Gk. haima, blood.] Red blood-corpuscle.

haematin (hěm'ătīn) $n$. [Gk. haima, blood.] A blue-black substance formed by the decomposition of haemoglobin, and probably containing iron (phys.).

haematobic (hêm'ătō'bǐk) $a$. [Gk. haima, blood; bios, life.] Living in the blood (zool.).

haematobium (hềm'ătō'bǐŭm) $n$. [Gk. haima, blood ; bios, life.] Any organism, plant or animal, living in the blood (biol.).

haematoblast (hĕm'ătöblăst) $n$. [Gk. haima, blood; blastos, bud.] Any cell that-will develop into a red blood-corpuscle (emb.). haematochrome (hĕm'ătökrōm) $n$. [Gk. haima, blood ; chromos, colour.] A red colouring matter found in certain Algae (bot.).

haematocryal (hĕm'ătökrīăl) a. [Gk. haima, blood; kryos, cold.] Coldblooded (zool.).

haematocyanin (hěm'ătösīănĭn) $n$. [Gk. haima, blood; kyanos, dark blue substance.] A colourless substance in the blood of Molluscs and Arthropods which becomes blue when oxydized (zool.).

haematocytozoon (hěm'ătösi'tözōóŏn) n. [Gk. haima, blood; kytos, hollow; zoon, animal.] An intra-corpuscular blood parasite (zool.).

haematodocha (hĕm'ătödō'kă) $n$. [Gk. haima, blood; doche, receptacle.] A fibro-elastic bag, normally collapsed and spirally disposed round the base of the bulb, the basal portion of the palpal organ in the Araneae (zool.).

haematogen (hěm'ătöjĕn) n. [Gk. haima, blood; gignesthai, to produce.] A pseudo-nuclein containing iron (phys.).

haematogenesis (hĕm'ătöjěn'ěsis) $n$. [Gk. haima, blood; gignesthai, to produce.] The formation of blood (phys.).

haematogenous (hĕm'ătǒj'ěnŭs) $a$. [Gk. haima, blood; gignesthai, to produce.] Formed in the blood (phys.).

haematoidin (hĕm'ătoid'inn) $n$. [Gk. haima, blood ; eidos, resemblance.] An iron-free pigment found in blood-stains (phys.).

haematolysis (hěm'ătŏl'isšs) $n$. [Gk. haima, blood; lyein, to dissolve.] Breaking up of blood corpuscles, hence reduced coagulability (phys.).

haematophagous (hĕm'ătŏf'ăgŭs) $a$. [Gk. haima, blood ; phagein, to eat.] Feeding on the blood, or obtaining nourishment from the blood (zool.).

haematophyte (hěm’ătöfīt) $n$. [Gk. haima, blood; phyton, plant.] Any vegetable micro-organism of the blood (phys.).

haematoporphyrin (hěm'ătöpôr'firrinn) n. [Gk. haima, blood; porphyra, purple.] An iron-free substance formed by the decomposition of haematin (phys.). 
haematosis (hĕm'ătō'sis) n. [Gk. haimatoein, to change to blood.] Blood-formation (phys.).

haematothermal (hĕm'ătöthĕr'măl) $a$. [Gk. haima, blood; thermos, warm.] Warm-blooded (zool.).

haematozoon (hĕm'ătözōón) n. [Gk. haima, blood; zoon, animal.] Any animal parasitic in the blood (zool.).

haemic (hĕm'îk) $a$. [Gk. haima, blood.] Pert. blood (phys.).

haemin (hě̆m'inn) n. [Gk. haima, blood.] Haematin hydrochloride (phys.).

haemochromogen (hềm'ökrō'möjĕn) n. [Gk. haima, blood; chroma, colour; gignesthai, to produce.] The colour producing component of haemoglobin (phys.).

haemocoele (hĕm'ösēl) $n$. [Gk. haima, blood; koilos, hollow.] An expanded portion of the blood system which replaces the true coelom (zool.).

haemocyanin (hê̌m'ösīănĭn), - see haematocyanin.

haemocytolysis (hĕ̌m'ösītŏl'ǐsǐs) $n$. [Gk. haima, blood; kytos, hollow ; lyein, to dissolve.] The breaking up of the red blood-corpuscle by solution (phys.).

haemocytotrypsis (hĕ̌m'ösî'tötrĭp'sĭs) n. [Gk. haima, blood; kytos, hollow; tribein, to rub.] Breaking up of blood by pressure (phys.).

haemoerythrin (hềm'öěrith'rĭn) $n$. [Gk. haima, blood; erythros, red.] A red pigment found in the blood of Worms, etc., probably performing the same functions as haemoglobin (zool.).

haemoglobin (hě̆m'öglō'bìn) n. [Gk. haima, blood ; globos, sphere.] The red colouring matter of blood (phys.).

haemoid (hĕm'oid) a. [Gk. haima, blood ; eidos, resemblance.] Resembling blood (phys.).

haemolymph (hềm'ölímf) n. [Gk. haima, blood; lymphe, fluid.] A fluid found in the coelom of some invertebrates, which is regarded as equivalent to the blood and lymph of the higher forms (zool.).

haemolysin (hếm'ǒlísinn) $n$. [Gk. haima, blood ; lyein, to dissolve.] A substance developed in the blood serum capable of destroying red blood-corpuscles (phys.).

haemolysis (hěmǒl'isiss), - see haematolysis.

haemoplasmodium (hĕm'öplăsmō'dǐum) n. [Gk. haima, blood; plasma, something moulded.] A unicellular animal parasite of the blood (zool.).

haemotropic (hĕm'ötrŏp'îk) a. [Gk. haima, blood; trepein, to turn.] Affecting or acting upon the blood (phys.).

haemozoin (hē'mözō'in) n. [Gk. haima, blood; zoon, animal.] Granules of a black pigment usually called melanin, but without the chemical characteristics of true melanin (phys.).

hair (hār) n. [A.S. haer.] A threadlike or filamentous outgrowth of the epidermis of animals (zool.); any outgrowth of the epidermis consisting of one or more cells, and very varied in shape (bot.).

hair cell, - any of the columnar cells bearing long stiff processes or hairs, found in the inner ear near the points of entrance of the nerve fibres (anat.).

hair follicle, - the tubular sheath formed by an invagination of the epidermis and surrounding the base of a hair (anat.).

hair worm, - any of the small Nematodes (zool.).

half-inferior, - having the ovary but partially adherent to the calyx (bot.).

half-terete,-rounded on one side, flat on the other (bot.).

haliplankton (hăl'íplăng'ktŏn) $n$. [Gk. hals, the sea ; plangktos, wandering.] The floating organisms in the sea ; cf. limnoplankton.

hallux (hăl'ǔks) $n$. [L. hallux, the great toe.] The first digit of the hind-limb (anat.).

halobios (hăl'öbî'ŏs) n. [Gk. hals, sea; bios, life.] The sum total of living plants and animals in the sea (biol.).

halolimnic (hăl'ölím'nìk) a. [Gk. hals, sea; limme, marsh.] Pert. or referring to marine organisms modified to live in fresh water (zool.). 
halophilous (hălŏf'îlŭs) $a$. [Gk. hals, salt ; philein, to love.] Salt-loving (bot.).

halophyte (hăl'öfīt) n. [Gk. hals, salt ; phyton, plant.] Shore plants ; plants capable of thriving on saltimpregnated soils (bot.).

halteres (hăl'tĕrê̌z) n. plu. [Gk. halter, weight used in jumping.] A pair of small capitate bodies representing the rudimentary posterior wings in Diptera, which are said to be balancers (zool.).

hamate (hăm'āt) a. [L. hamatus, hooked.] Hooked or hookedshaped at the tip.

hamatum (hămă'tŭm)n. [L. hamatus, hooked.] The unciform bone in the carpus, probably corresponding to the fourth and fifth distalia of a typical pentadactyl limb (zool.).

hamirostrate (hăm'îrŏs'trāt) $a$. hamus, hook; rostrum, beak.] Having a hooked beak (zool.).

hamose (hắmōs) a. [L. hamus, hook.] Hooked (bot.).

hamular (hăm'ūlăr) a. [L. hamus, hook.] Hooked; hook-like (zool.).

hamulus (hăm'ūlŭs) $n$. [L. hamulus, little hook.] A hook, or hook-like process (anat.); the minute hooklike process on the distal barbules which aid in the interlocking of the barbs of a feather (zool.).

hapaxanthous (hăp'ăksăn'thŭs) $a$. [Gk. hapax, once; anthos, flower.] With only a single flowering period (bot.).

haplocaulescent (hăp'lökôlěs'ĕnt) $a$. [Gk. haploos, simple; L. caulis, stem.] With a simple axis, i.e., capable of producing seed on the main axis (bot.).

haplochlamydeous (hăp'löklămìd'ěus) a. [Gk. haploos, simple ; chlamys, cloak.] Having rudimentary leaves in connection with the sporophylls (bot.).

haplodont (hăp'lödŏnt) a. [Gk.haploos, simple; odous, tooth.] Having the molars with simple crowns (zool.).

haploid (hăp'loid) a. [Gk. haploos, simple; eidos, like.] Having the number of chromosomes characteristic of the germ-cells for the organism in question (biol.).

haploperistomous (hăp'löpěris'tömŭs) a. [Gk. haploos, simple; peri, around; stoma, mouth.] Having a peristome with a single row of teeth ; appl. Mosses (bot.).

haplopetalous (hăp'löpĕt'ălŭs) $a$. [Gk. haploos, simple ; petalon, petal.] With a single row of petals (bot.). haptera (hăp'tĕră) $n$. plu. [Gk, haptein, to fasten.] Special disc-like outgrowths from the stem-like portion of certain Algae, which serve as organs of attachment (bot.).

haptophores (hăp'töförz) n. plu. [Gk. haptein, to fasten ; pherein, to carry.] The combining qualities of the molecule of a toxin ; $c f$. toxophores (phys.).

harmonic suture, - an articulation brought about by the apposition of fairly smooth edges or surfaces (anat.).

harmosone (hâr'mösōn) n. [Gk. armozo, I regulate.] One of the class of hormones which influence growth (phys.).

Hassall's concentric corpuscles,cell nests in the reticulum of the thymus gland (anat.).

hastate (hăs'tāt) $a$. [L. hasta, spear.] Spear-shaped, more or less triangular with the two basal lobes divergent (bot.).

haulm (hôm) n. [A.S. healm.] The stem of such plants as peas; the stem of a grass (bot.).

haustellate (hôs'tělāt) a. [L. haurire, to suck.] Having a proboscis adapted for sucking (zool.).

haustellum (hôstěl'ŭm) $n$. [L. haurire, to suck.] A proboscis adapted for sucking (zool.).

haustorial (hôstō'rǐăl) a. [L. haurire, to drink.] Pert. or resembling a haustorium (bot.).

haustorium (hôstō'riŭm) n. [L. haurire, to drink.] An outgrowth of the stem of certain plants, which serves as a means of drawing food from the host plant (bot.).

haversian canals [Havers, English physician], - the small canals in bone in which the blood-vessels lie (anat.).

bead (hĕd) $n$. [A.S. heafod.] The anterior part of a vertebrate body containing the brain, skull, eyes, 
ears, etc. ; the anterior end of most invertebrate animals containing the cerebral ganglia; the antlers of deer $(z o o l$.$) ; the top of a plant when$ it consists of a mass of leaves ; a compact inflorescence (bot.).

head case, - the outer hard covering of an insect's head (zool.).

head cell,- - one of the cells found on the manubrium of the antheridium of Chara (bot.).

head kidney, - the pronephric portion of the kidney, in vertebrates usually represented only in the embryo; a nephridium usually developed in the cephalic segment of invertebrates (zool.).

heart (hârt) n. [A.S. heorte.] A hollow muscular organ with a varying number of chambers which by rhythmic contraction keeps up the circulation of the blood (zool., anat.); the core or central portion of a tree or fruit (bot.).

heat (hēt) $n$. [A.S. haetu.] A kind of energy manifested in various ways; the sensation of warmth produced by stimulation of special organs ; the period of sexual desire (phys.).

heat spot, - any of the special areas on the skin at which nerve endings sensitive to heat are found ( $p h y s$.).

hectocotylus (hĕk'tökŏt'ílŭs) $n$. [Gk. hekaton, hundred; kotyle, vessel.] One of the arms of a male cephalopod specialized to effect transference of sperms to eggs (zool.).

hedonic (hēdŏn'îk) glands,-skin glands found in certain reptiles which secrete muskand are specially active at the rutting season.

heel (hêl) $n$. [A.S. hêla.] The hinder part of the foot; the posterior tarsal portion of the foot ; the talon or talonid of a tooth (zool.).

hekistotherm (hēkǐs'töthĕrm) $n$. [Gk. hekistos, least; therme, heat.] A plant that thrives with the minimum of heat, as alpine plants (bot.).

helieine (hěl'îsiñ a. [Gk. helix, spiral.] Spiral ; convoluted ; hoisted; $a p p l$. certain convoluted and dilated arteries in the penis; pert. outer rim of the pinna (anat.).

helicoid (hěl'îkoid) a. [Gk. helix, spiral; eidos, like.] Spiral; shaped like a snail's shell; pert. genus Helix (zool.) ; pert. type of sympodial branching in which the sympodium consists of the fork branches of the same side (bot.).

helicoid cyme,-an inflorescence produced by the suppression of the successive axes on the same side, thus causing the sympodium to be spirally twisted (bot.).

helicotrema (hěl'íkötrē'mă) $n$. [Gk. helix, spiral; trema, hole.] A small opening near the summit of the cochlea by which the two scalae communicate with one another (anat.).

heliosis (hē'liō'sǐs) n. [Gk. helios, sun.] The production of discoloured spots or markings on leaves through the concentration of the sun on them (bot.).

heliotaxis (hë'liötăk'sǐs) n. [Gk. helios, sun; taxis, arrangement.] Response to the stimulus of the sun's rays.

heliotropism (hē'lǐŏt'röpǐzm) n. [Gk. helios, sun ; trepein, to turn.] The tendency of growing organisms or parts thereof to respond to the stimulus of sunlight (biol.).

helix (hē'likss) $n$. [Gk. helix, spiral.] The outer rim of the ear (anat.); the coiled spiral arrangement of certain structures in the invertebrates (zool.).

helmet (hěl'mĕt) n. [O.F. helmet, head covering.] The process of the bill of hornbills; the bony plates covering the head of certain extinct Fishes ; the galea of Insects (zool.).

helminthology (hěl'mĭnthŏl'öjĩ) $n$. [Gk. helmins, worm; logos, discourse.] The study of the natural history, anatomy, etc., of Worms, especially parasitic forms (zool.).

helotism (hěl'ŏtǐzm) n. [Gk. Helos, Laconian town.] Symbiosis in which the one organism enslaves the other and forces it to labour in its behalf, e.g. in Lichens, in some species of ants (biol.).

hemelytron (hěměl'ítrŏn) $n$. [Gk. hemi, half; elytron, wing.] The thickened forewing of certain Insects ; the elytra of certain Worms (zool.). 
hemelytrum, hemelytron.

hemibasidium (hěm'íbăsĭd'iŭm) $n$. [Gk. hemi, half; basis, base.] The promycelium of the Ustilaginales (bot.).

hemibathybial (hĕm'íbăthǐb'îăl) $a$. [Gk. hemi, half; bathys, depths.] Pert. plankton between the littoral and bathybial zones (biol.).

hemibranch (hĕmíbrăngk) $n$. [Gk. hemi, half; brangchia, gills.] A gill with gill filaments on one side only (zool.).

hemichordate (hĕm'îkôr'dāt) $a$. [Gk. hemi, half; chorde, string.] Possessing a more or less rudimentary notochord (zool.).

hemicyclic (hĕm'isílklik) a. [Gk. hemi, half; kyklos, round.] With some of the floral whorls cyclic, others spiral (bot.).

hemielytron,-hemelytron.

hemiepiphyte (hěm'ǐĕp'ífit) $n$. [Gk. hemi, half; epi, upon; phyton, plant.] A plant whose seeds germinate on another plant, but later send roots to the ground (bot.).

hemignathous (hěm'ignăth'ǔs) $a$. [Gk. hemi, half; gnathos, jaw.] Having one jaw shorter than the other, as in some birds (zool.).

hemimetabolic (hěm'ímĕt'ăbŏl'îk) $a$. [Gk. hemi, half; meta, after; ballein, to change.] Having an incomplete metamorphosis, i.e. the larva has a strong resemblance to the adult (zool.).

hemiparasitic (hĕm'ípărăsĭt'î) $a$. [Gk. hemi, half; para, beside ; sitos, food.] Pert. a plant which is capable of carrying on photosynthesis, but not sufficiently to supply all food material (bot.).

hemipenis (hěmipē'nǐs) n. [Gk. hemi, half; L. penis, penis.] One of the paired copulatory organs in lizards and snakes (zool.).

hemipterous (hĕmìp'tĕrŭs) a. [Gk. hemi, half; pteron, wing.] Pert. Hemiptera (zool.).

hemisaprophyte (hĕm'ísăp'röfīt) $n$. [Gk. hemi, half; sapros, dung; phyton, plant.] A plant living partly by photosynthesis, partly by obtaining food from the humus (bot.). hemisome (hĕm'isōm) n. [Gk. hemi, half; soma, body.] The symmetrical half of an animal about a median vertical plane (zool.).

hemisphere (hěm'îsfēr) $n$. [Gk. hemi, half; sphaira, globe.] One of the cerebral hemispheres (zool.).

hemisystole (hĕm'ĩsis'tölē) n. [Gk. hemi, half ; syn, with; stellein, to set.] Contraction of one ventricle of the heart (phys.).

hemitropous (hěmit'röpŭs) $a$. [Gk. hemi, half; trepein, to turn.] Turned half round, having an ovule with the hilum on one side and the micropyle, etc., opposite in a plane parallel to the placenta (bot.).

hemorrhoidal (hĕm'öroi'dăl) $a$. [Gk. haima, blood; rhein, to flow.] Rectal ; $a p p l$. arteries and veins (anat.).

Henle's layer, - a single stratum of nucleated cubical cells in the inner root sheath of a hair follicle (anat.).

Henle's loop, - the loop of a kidney tubule within the apical portion of the pyramid (anat.).

hepar (hē'pâr) $n$. [L. hepar, liver.] Liver or any organ having a similar function (anat., zool.).

hepatic (hěpăt'ik) $a$. [L. hepar, liver.] Pert. like or associated with the liver (zool.) ; pert. Hepatics (bot.).

hepatocolic (hěp'ătökǒl'îk) $a$. [L. hepar, liver ; colon, large intestine.] Pert. liver and colon (zool.).

hepatocystic (hěp'ătösı̌s'tǐk) $a$. [L. hepar, liver; Gk. kystis, bladder.] Pert. liver and gall-bladder (zool.).

hepatoduodenal (hěp'ătödū'ödē'năl) $a$. [L. hepar, liver; duodeni, twelve each.] Pert. liver and duodenum (anat.).

hepatoenteric (hĕp'ătöěntěr'ik) $a$. [L. hepar, liver ; Gk. enteron, gut.] Of or pert. liver and intestine.

hepatogastric (hěp'ătögăs'trǐk) $a$. [L. hepar, liver; Gk. gaster, belly.] Pert. liver and stomach (anat.).

hepatopancreas, - the digestive gland in many invertebrates, supposed to perform a function similar to that of the liver and of the pancreas in higher forms (zool.).

hepatoportal (hěp'ătöpör'tăl) $a$. [L. hepar, liver; portare, to carry.] 
Pert. or designating the portal circulation of the liver (zool.).

hepatorenal (hĕp'ătörē'năl) $a$. [L. hepar, liver; renes, kidneys.] Pert. liver and kidney (zool.).

hepatoumbilical (hěp'ătöŭmbìl'íkăl) a. [L. hepar, liver ; umbo, umbo.] Joining liver and umbilicus (anat.).

heptagynous (hěptăj'innŭs) $a$. [Gk. hepta, seven ; gyne, female.] With seven pistils (bot.).

heptamerous (hĕptăm'ěrŭs) $a$. [Gk. hepta, seven ; meros, part.] Having the whorls of the flower in sevens (bot.).

heptandrous (hĕptăn'drŭs) a. [Gk. hepta, seven; aner, man.] Having seven stamens (bot.).

heptastichous (hěptăs'tǐkŭs) a. [Gk. hepta, seven ; stichos, row.] Having the leaves arranged in sevens (bot.).

herb (hĕrb) n. [M.E. herbe.] Any seed plant which has not a woody stem (bot.).

herbaceous (hĕrbā'shŭs) a. [L. herbaceus, grassy.] Pert. or resembling a herb, or similarly formed (bot.).

hercogamy (hěrkŏg'ămì) n. [Gk. herkos, barrier ; gamos, birth.] The condition in which self-fertilization is impossible (bot.).

hereditary (hĕrěd'ítărǐ) $a$. [L. hereditas, heirship.] Transmitted or possibly transmissible from parent to offspring, as a special quality or condition (biol.).

heredity (hěrěd'ítǐ) $n$. [L. hereditas, heirship.] The organic relation between successive generations (biol.).

hermaphrodite (hĕrmăf'rödit) $n$. [Gk. hermaphroditos, combining both sexes.] Any organism having both male and female reproductive organs (biol.).

hermaphroditism (hĕrmăfrŏd'ítízm) $n$. [Gk. hermaphroditos, combining both sexes.] The condition of having both male and female reproductive organs in one individual (biol.).

herpetology (hĕr'pětǒl'öjī) $n$. [Gk. herpeton, reptile; logos, discourse.] That part of zoology dealing with the structure, habits and classification of Reptiles (zool.). hesperidium (hěs'pĕrĭd'ǐŭm) $n . \quad[G k$. Hesperia, Westernland.] A superior, many-celled, few-seeded indehiscent fruit, having epicarp and mesocarp joined together, and an endocarp projecting into the interior as membranous partitions which divide the pulp into chambers (bot.).

heteracanthous (hĕt'ěrăkăn'thŭs) $a$. [Gk. heteros, other; akanthe, spine.] Having the spines in the dorsal fin asymmetrical (zool.).

heteractinal (hět'ĕrăk'tĭnăl) $a$. [Gk. heteros, other; aktis, ray.] Pert. nail-like spicules, having a disc of six to eight rays in one plane, and a stout ray rising at right angles to these (zool.).

heterandrous (hĕt'ĕrăn'drŭs) $a$. [Gk. heteros, other; aner, man.] With the stamens of different lengths or shape (bot.).

heterauxesis (hĕt'ěrôksēésĭs) $n, \quad[\mathrm{Gk}$. heteros, other; auxein, to grow.] Irregular or asymmetrical growth of organs (bot.).

heteraxial (hět'ěrăk'šăl) a. [Gk. heteros, other; axis, axis.] With three unequal axes (zool.).

heteroblastic (hět'ěröblăs'tík) a. [Gk. heteros, other; blastos, bud.] With an indirect development (zool.).

heterocarpous (hět'ěrökâr'pŭs) $a$. [Gk. heteros, other; karpos, fruit.] Bearing two distinct types of fruit (bot.).

heterocellular (hět'ěrösěl'ūlăr) $a$. [Gk. heteros, other; L. cellula, cell.] Composed of more than one type of cells (bot.).

heterocephalous (hět' ěrökĕf'ălŭs,-sĕf-) a. [Gk. heteros, other; kephale, head.] Having the pistillate flowers on separate heads from the staminate flowers (bot.).

heterocereal (hět'ěrösĕr'kăl) a. [Gk. heteros, other; kerkos, tail.] Having the vertebral column terminating in the upper lobe of the fin, which is usually larger than the lower; appl. tail fins (zool.).

heterocercy (hět'ěrösěr'sǐ) n. [Gk. heteros, other; kerkos, tail.] The condition of having a heterocercal tail (zool.).

heterochlamydeous (hět'ěröklămǐd'ěŭs) a. [Gk. heteros, other; chlamys, 
cloak.] Having a calyx differing from corolla in colour, texture, etc. (bot.).

heterochromous (hĕt'ĕrökrō'mŭs) $a$. [Gk. heteros, other; chroma, colour.] Having disc and marginal florets differently coloured (bot.).

heterochronism (hět'ěrökrō'nīzm) $n$. [Gk. heteros, other; chronos, time.] A departure from the typical sequence in time of the formation of the organs (biol.).

heterochrosis (hět'ěrökrō'š̌s) n. [Gk. heteros, other ; chrosis, colouring.] Abnormal coloration (zool.).

heteroclinous (hĕt'ěröklî'nŭs) $a$. [Gk. heteros, other ; kline, bed.] Heterocephalous (bot.).

heterocoelous (hět'ěrösē'lŭs) a. [Gk. heteros, other; koilos, hollow.] Pert. vertebrae with saddle-shapedarticulatory centra (zool.).

heterocysts (hět'ěrösǐsts) $n$. plu. [Gk. heteros, other; kystis, bladder.] The clear cells occurring at intervals on the filaments of certain Algae, and marking the limits of the hormogonia (bot.).

heterodactylous (hět'ěrödăk'tǐlŭs) $a$. [Gk. heteros, other; daktylos, toe.] With the first and second toes turned backwards (zool.).

heterodont (hět'ěrödǒnt) $a$. [Gk. heteros, other; odous, tooth.] Having the teeth differentiated for various purposes (zool.).

heterodromous (hět'ěrŏd'römŭs) $a$. [Gk. heteros, other; dromein, to run.] Having the genetic spiral of the stem leaves turning in a different direction to that of the branch leaves (bot.).

heteroecious (hĕt'ěrē'shŭs) a. [Gk. heteros, other; oikos, house.] Passing different stages of its life on different hosts (bot.).

heterogamous (hět'ěrŏg'ămŭs) $a$. [Gk. heteros, other; gamos, marriage.] With unlike gametes; having two types of flowers; having indirect pollination methods (biol.).

heterogamy (hĕt'ěrŏg'ămĨ) $a$. [Gk. heteros, other; gamos, offspring.] Alternation of generations (biol.).

heterogangliate (hět'ěrögăng'glīāt) a. [Gk. heteros, other; gangglion, ganglion.] With widely separated and asymmetrically placed nerveganglia (zool.).

heterogenesis (hět'ěröjěn'ěšss) $n$. [Gk. heteros, other ; gignesthai, to produce.] Spontaneous generation ; alternation of generations (biol.).

heterogeny (hět'ěrǒj'ěnǐ) n. [Gk. heteros, other; genos, race.] Having several distinct generations succeeding one another in a regular series (biol.).

heterogonous (hět'ěrŏg'önŭs) a. [Gk. heteros, other; gonos, birth.] Pert. heterogenesis (biol.).

heterogony (hět'ěrŏg'önǐ). $n$. [Gk. heteros, other ; gonos, birth.] Having two kinds of flowers differing in length of stamen (bot.); alternation of generations (biol.).

heterogynous (hĕt'ĕrŏj'innǔs) a. [Gk. heteros, other; gyne, woman.] With two types of females (zool.).

heterokaryote (hĕt'ěrökăr'īōt) a. [Gk. heteros, other; karyon, nut.] Having two distinct types of nuclei (zool.).

heterokinesis (hět'ěrökǐnē'sı̌s) $n$. [Gk. heteros, other; kinein, to move.] Qualitative or differential division of the chromosomes (biol.).

heterolecithal (hět'ěrölěs'íthăl) $a$. [Gk. heteros, other; lekithos, yolk.] Having unequally distributed deutoplasm (biol.).

heterology (hět'ĕrŏl'öjīi) n. [Gk. heteros, other; logos, discourse.] The non-correspondence of parts owing to different origin or different elements (biol.).

heteromallous (hět'ěrŏm'ălŭs) a. [Gk. heteros, other; mallos, lock of wool.] Spreading in different directions (bot.).

heteromastigate (hĕt'ěrömăs'tĭgāt) $a$. [Gk. heteros, other; mastix, lash.] Having two different types of flagella (zool.).

heteromastigote (hět'ěrömăs'tĭgōt), - heteromastigate.

heteromerous (hět'ěrŏm'ěrŭs) a. [Gk. heteros, other; meros, part.] Having the whorls consisting of an unequal number of parts (bot.).

heterometabolic (hět'ěrömět'ăbŏl'îk) a. [Gk. heteros, other; metabole, change.] Having incomplete metamorphosis (zool.). 
heteromorphic (hĕt'érömôr'fík) $a$. [Gk. heteros, other; morphe, shape.] Having different forms at different times (zool.).

heteromorphism (hĕt'ěrömôr'fizm) $n$. [Gk. heteros, other; morphe, shape.] The state or quality of being heteromorphic (biol.).

heteromorphosis (hět'ěrömôr'fösı̌s) $n$. [Gk. heteros, other; morphe, shape.] The production of a part in an abnormal position, by any organism; a case of regeneration, when the new part is different from that removed (biol.).

heteromorphous (hět'ěrömôr'fŭs) $a$. [Gk. heteros, other; morphe, shape.] Pert. an irregular structure, or departure from the normal (biol.).

heteronereis (hět'ĕröně́rě̌is) $n$. [Gk. heteros, other; nereis, nereis.] A free-swimming dimorphic sexual stage of Nereis and other marine worms (zool.).

heteronomous (hět'ěrŏn'ömŭs) $a$. [Gk. heteros, other; nomos, law.] Subject to different laws of growth; specialized on different lines (biol.).

heteropelmous (hět'ěröpěl'mŭs) $a$. [Gk. heteros, other; pelma, sole of foot.] Having the flexor tendons of the toes bifid (zool.).

heteropetalous (hět'ěröpët'ălŭs) $a$. [Gk, heteros, other; petalon, petal.] With dissimilar petals (bot.).

heterophagous (hět'ěrŏf'ăgŭs) $a$. [Gk. heteros, other; phagein, to eat.] Having young which are immature and require feeding at birth; appl. birds (zool.).

heterophyadic (hĕt'ĕröfiăd'ík) a. [Gk. heteros, other; phyas, shoot.] Producing separate shoots, one vegetative, one reproductive (bot.).

heterophyllous (hět'ěröfül'ŭs) $a$. [Gk. heteros, other; phyllon, leaf.] Bearing foliage leaves of different shape on different parts of the plant (bot.).

heteroplasia (hĕt'ěröplā'ziă) $n$. [Gk. heteros, other; plassein, to mould.] The development of one tissue from another of a different kind (zool.).

heteroplasm (hĕt'ĕröplăzm) $n$. [Gk. heteros, other; plasma, something moulded.] Tissue formed in abnormal places (biol.). heteroproteose (hĕt'ëröprō'tê̌ös) $n$. [Gk. heteros, other; protos, first.] One of the primary products formed by the action of gastric juices on proteids (phys.).

heterorhizal (hět'ěrörî́zăl) $a$. [Gk. heteros, other; rhiza, root.] With roots coming from no determinate point (bot.).

heterosporous (hět'ěröspō'rŭs, hĕt'ĕrŏs'pörŭs) a. [Gk. heteros, other ; sporos, seed.] Producing two kinds of spores (bot.).

heterostemonous (hět'ěröstěm'önŭs) a. [Gk. heteros, other; stemon, stamen.] With unlike stamens (bot.).

heterostrophy (hět'ěrŏs'tröf Ĩ) $n$. [Gk. heteros, other; strophe, turning.] The condition of being coiled in a direction opposite to the normal (zool.).

heterostyled (hět'ĕröstīlld) $a$. [Gk. heteros, other; stylos, pillar.] Having unlike styles; or unequal styles (bot.).

heterostyly (hět'ěröstīllĩ) $n$. [Gk. heteros, other; stylos, pillar.] Condition of being heterostyled (bot.).

heterotaxis (hět'ěrötăk'sǐs) $n$. [Gk. heteros, other ; taxis, arrangement.] Abnormal or unusual arrangement of organs or parts (biol.).

heterotomy (hět'ěrŏt'ömí) $n$. [Gk. heteros, other; temnein, to cut.] The condition of having the parts of the perianth whorls unequal or dissimilar (bot.); irregular dichotomy in Crinoids (zool.).

heterotopy (hět'ěrǒt ${ }^{\prime}$ öpĭ) n. [Gk. heteros, other; topos, place.] Displacement (biol.).

heterotrichous (hět'ěrŏt'rǐkŭs) $a$. [Gk. heteros, other; thrix, hair.] Having two types of cilia (zool.).

heterotrophic (hět'ěrötrŏf'ìk) a. [Gk. heteros, other ; trephein, to nourish.] Getting its nourishment from outside; $a p p l$. parasitic plants (bot.).

heterotropic,-heterotropous.

heterotropous (hĕt'ĕrŏt'röpŭs) $a$. [Gk. heteros, other; trepein, to turn.] Pert. an ovule with hilum and micropyle at opposite ends in a plane parallel to the placenta (bot.). heterotypic (hět'ěrötīp'îk) a. [Gk. 
heteros, other; L. typus, type.] Pert. mitotic division in which the daughter chromosomes remain united and form rings (biol.).

heteroxenous (hět'ěrŏk'sĕnŭs) a. [Gk. heteros, other; xenos, guest.] Occurring on or infesting more than one kind of host (biol.).

heterozy gosis (hět'ěrözīgō'sǐs) $n$, [Gk. heteros, other; zygein, to yoke.] Condition or state of being heterozygote (biol.).

heterozygote (hět'ěrözí'gōt) n. [Gk. heteros, other; zygein, to yoke.] A mendelian hybrid which contains one or more recessive characters and therefore does not breed true (biol.).

hexacanth (hĕk'săkănth) a. [Gk. hex, six ; akantha, thorn.] Having six hooks; $a p p l$. embryos of flatworms (zool.).

hexactinal (hěk'săk'tĭnăl) a. [Gk, hex, six ; aktis, ray.] Pert. spicules with six rays (zool.).

hexactine (hěk'săk'tîn) n. [Gk, hex, six; aktis, ray.] A spicule with six equal and similar rays meeting at right angles (zool.).

hexactinian (hěk'săktǐn'ǐăn) $a$. [Gk, hex, six; aktis, ray.] With the tentacles or mesenteries in multiples of $\operatorname{six}(z o o l$.).

hexacyclic (hěk'săsî́klǐk) a. [Gk. hex, six; kyklos, circle.] Having the floral whorls consisting of six parts (bot.).

hexagynous (hěksăj'innŭs) a. [Gk. hex, six; gyne, woman.] Having six pistils (bot.).

hexamerous (hěksăm'ěrŭs) $a$. [Gk. hex, six; meros, part.] Occurring in sixes or arranged in sixes (bot.).

hexandrous (hěksăn'drŭs) $a$. [Gk. hex, six; aner, man.] Having six stamens (bot.).

hexapetaloid (hěk'săpět'ăloid) $a$. [Gk. hex, six; petalon, petal; eidos, like.] With a petaloid perianth of six parts (bot.).

hexapetalous (hěk'săpĕt'ălŭs) $a$. [Gk. hex, six; petalon, petal.] Having six petals (bot.).

hexaphyllous (hěk'săfíl'ŭs) a. [Gk. hex, six; phyllon, leaf.] Having six leaves (bot.). hexapod (hĕk'săpŏd) $a$. [Gk. hex, six; pous, foot.] Pert. animal with six legs (zool.).

hexapterous (hěksăp'tĕrŭs) $a$. [Gk. hex, six; pteron, wing.] Having six wing-like processes or expansions (bot.).

hexarch (hěk'sârk) a. [Gk. hex, six ; arche, beginning.] Having six radiating vascular strands; $a p p l$. roots (bot.).

hexasepalous (hěk'săsềp'ălŭs) $a$. [Gk. hex, six; sepalon, sepal.] Having six sepals (bot.).

hexaspermous (hěk'săspĕr'mŭs) $a$. [Gk. hex, six; sperma, seed.] Having six seeds (bot.).

hexastemonous (hěk'săstěm'önŭs) $a$. [Gk. hex, six ; stemon, stamen.] Having six stamens (bot.).

hexaster (hĕksăs'tër) n. [Gk. hex, six; aster, star.] A variety of the hexactine in which the rays branch and produce star-shaped figures (zool.).

hexastichous (hĕksăs'tǐkŭs) $a$. [Gk. hex, six; stichos, row.] Having the parts arranged in six rows (bot.).

hexicology (hěk'sǐkŏl'öjī) n. [Gk. hexis, habit ; logos, discourse.] Bionomics (biol.).

hiatus (hīà'tŭs) $n$. [L. hiare, to gape.] Any large opening (anat.).

hibernaculum (hî'běrnăk'ūlŭm) $n$. [L, hibernaculum, winter residence.] Specially modified winter bud, found in certain fresh-water Polyzoa (zool.).

hibernate (hī'bĕrnät) v. [L. hibernus, wintry.] To pass the winter in a resting state (biol.).

hibernating glands,-lymph glands of richly vascularized fatty tissue occurring in some Rodents and Insectivores (anat.).

hidrosis (hĭdrō'siss) n. [Gk. hidros, sweat.] Excretion of sweat; perspiration (phys.).

high (hī) a, [A.S. hēh.] Having a more complex and more highly differentiated structure.

hiliferous (hīlïf'ĕrŭs) a. [L. hilum, trifle ; ferre, to carry.] Having a hilum (bot.).

hilum (h'́lŭm) $n$. [L. hilum, trifle.] The scar on the ovule where it 
was attached to the placenta ; the eye of a seed; the nucleus of a starch grain (bot.).

hilus (hìlŭs) $n$. [L. hilum, trifle.] A small notch or opening; a small opening or depression usually where the blood-vessels, etc., enter (anat., zool.).

hind brain,- the rhombencephalon, that portion of the brain derived from the third embryonic vesicle (anat.).

hind gut, - a diverticulum of the yolksac extending into the tail-fold in the human embryo; the posterior portion of the alimentary tract (anat.).

hinge joint, - a joint in which the articulatory surfaces are so moulded to one another as to permit motion in one direction only (anat.).

hinge ligament, - the tough elastic substance joining the two valves of a bivalve shell (zool.).

hinge line,- - the line of articulation of the two valves in a bivalve shell (zool.).

hinge tooth,- one of the projections found on the hinge line in bivalves (zool.).

hip-joint,- the ball-and-socket joint between femur and hip-girdle (anat.).

hippocampal (hǐp'ökăm'păl) a. [Gk. hippos, horse; kampos, sea-monster.] Pert. the hippocampus (anat.).

hippocampus (hĭp'ökăm'pŭs) $n$. [Gk. hippos, horse; kampos, sea-monster.] A curved eminence that extends throughout the entire length of the floor of the inferior cornu of the lateral ventricle (anat.).

hirsute (hër'sūt) a. [L. hirsutus, hairy.] Covered with hair-like feathers, $a p p l$. birds; having stiff, hairy bristles (zool.); having stiff, hairy covering (bot.).

hirudin (bǐrū'dìn) n. [L. hirudo, leech.] A substance obtained in solution from the head of leeches which renders drawn blood noncoagulable ; an anticoagulin (phys.).

hispid (hǐs'pìd) a. [L. hispidus, rough.] Having stiff hairs, spines, or bristles (bot., zool.).

histoblast (hǐs'töblăst) n. [Gk. histos, tissue; blastos, bud.] One of the units of any tissue (anat.) ; imaginal discs (zool.).

histochemistry (hǐs'tökěm'ístrĩ) n. [Gk. histos, tissue ; chemos, juice.] The chemistry of animal tissues (biol.).

histocyte (hĭs'tösīt) n. [Gk. histos, tissue; kytos, hollow.] A tissue cell as distinguished from a germ cell (zool.).

histogenesis (hǐs'töjĕn'ěsı̆s) n. [Gk. histos, tissue; gignesthai, to produce.] Formation and development of tissue (biol.).

histogenic (hǐs'töjĕn'îk) a. [Gk. histos, tissue ; gignesthai, to produce.] Tissue-producing; $a p p l$. the separate merismatic layers in a stratified growing point (bot.); tissue-producing (zool.).

histohaematin (hǐs'töhếmătĭn) $n$. [Gk, histos, tissue ; haima, blood.] One of the animal pigments with a great affinity for oxygen, and so supposed to be respiratory (phys.).

histology (hǐstǒl'öjī) n. [Gk. histos, tissue; logos, discourse.] The science which treats of the minute structure of tissues (biol.).

histolysis (hǐstǒl'ĩsǐs) n. [Gk. histos, tissue ; lyein, to dissolve.] The dissolution of organic tissues (biol.); that process by which most of the pupal internal organs dissolve into a creamy fluid, except certain cells round which the new imaginal tissues are formed (zool.).

histone (hǐs'tōn) n. [Gk. histos, tissue.] An albuminose body derived from nucleo-histone (phys.).

histophyly (hǐstǒf' '́lǐ) n. [Gk. histos, tissue; phyle, tribe.] The phylogenetic history of any group of cells (biol.).

histotrophic (his'tötrǒf'ik) a. [Gk. histos, tissue ; trephein, to nourish.] Pert. or connected with tissue formation (phys.).

histozoic (his'tözōílk) a. [Gk. histos, tissue; zoon, animal.] Living within tissues; $a p p l$. trophozoitic stage of certain Sporozoa (zool.).

histozyme (hìs'tözìm) n. [Gk. histos, tissue ; zyme, leaven.] An enzyme found in the kidneys of certain 
animals capable of decomposing hippuric acid (phys.).

hoch (hŏk) $n$. [A.S. hoh, heel.] The tarsal joint, or the region of the tarsal joint (zool.).

holaretic (hǒlârk'tìk) a. [Gk. holos, whole; arktos, bear.] Pert. species found in a zoogeographical region including the northern parts of the new and old worlds (zool.).

holaspidean (hŏl'ăspìd'ěnn) $a$, [Gk. holos, whole ; aspis, shield.] With a single series of large scales on the posterior aspect of the tarsometatarsus (zool.).

holcođont (hǒl'ködŏnt) a. [Gk. holkos, furrow; odous, tooth.] Having the teeth in a long continuous groove (zool.).

holdfast, - the sucker or disc on the thallus of certain Algae (bot.).

holobenthic (hŏl'öběn'thǐk) $a$. [Gk. holos, whole; benthos, depths.] Living in the depths of the sea throughout life (zool.).

holoblastic (hǒl'öblăs'tîk) a. [Gk. holos, whole; blastos, bud.] Pert. eggs in which the cleavage is total (emb.).

holobranch (hǒl'öbrăngk) n. [Gk. holos, whole; brangchia, gills.] A gill in which gill filaments are borne on both sides (zool.).

holochlamydate (hǒl'öklăm'îdāt) $a$. [Gk. holos, whole ; chlamys, cloak.] Having no notch on the margin of the mantle (zool.).

holochroal (hŏl'ökrō'ăl) a. [Gk. holos, whole ; chros, touch.] Having eyes with globular or biconvex lenses closely crowded together, so that the cornea is continuous over the whole eye (zool.).

hologastrula (hŏl'ögăs'troolă) n. [Gk. holos, whole; gaster, stomach.] A gastrula formed from a holoblastic egg (emb.).

holognathous (hŏl'ögnăth'ŭs) $a$. [Gk. holos, whole; gnathos, jaw.] Having the jaw in a single piece (zool.).

holomastigote (hǒl'ömăs'tĭgōt) $a$. [Gk. holos, whole; mastix, whip.] Having one type of flagellum scattered evenly over the body (zool.).

holometabolic (hŏl'ömĕt'ăbŏl'îk)
[Gk. holos, whole ; meta, after ; ballein, to change.] Having complete metamorphosis (zool.).

holometabolism (hŏl'ömĕtăb'ölǐzm) $n$.

[Gk. holos, whole; metabole, change.] State of having complete metamorphosis (zool.).

holomorphosis (hŏl'ömôr'fösĭs) $n$. [Gk. holos, whole; morphe, shape.] Regeneration in which the entire part is replaced (zool.).

holonephros (hŏl'önĕf'rŏs) n. [Gk. holos, whole; nephros, kidney.] The hypothetical continuous excretory organ (anat.).

holophytic (hǒl'öfít'îk) a. [Gk, holos, whole; phyton, plant.] Obtaining the whole of its food after the manner of a plant (zool.).

holoplanktonic (hŏl'öplăngktŏn'îk) a. [Gk. holos, whole; plangktos, wandering.] Living near the surface throughout life (zool.).

holoptic (hǒlǒp'tīk) a. [Gk. holos, whole; ops, eye.] Having the eyes of the two sides meeting in a coadapted line of union (zool.).

holorhinal (hǒl'örî́năl) a. [Gk. holos, whole; rhis, nose.] Having nares with the posterior margin rounded, not cleft (zool.).

holoschisis (hŏlŏs'kǐsǐs) n. [Gk. holos, whole; schizein, to cut.] Amitosis (emb.).

holosericeous (hŏl'ösěrĭsh'ǔs) a. [Gk. holos, whole; L. sericus, silken.] Completely covered with silky hair-like structures (bot.); having a silky lustre or sheen (zool.).

holostomatous (hŏl'östŏm'ătŭs) $a$. [Gk. holos, whole ; stoma, mouth.] With the margin of the aperture entire (zool.).

holosystolic (hŏl'öš̌s'tŏlǐk) a. [Gk. holos, whole ; systole, contraction.] Pert. the complete systole (phys.).

holotrichous (hǒlŏt'rikŭs) a. [Gk. holos, whole ; thrix, hair.] Having a uniform covering of cilia over the body (zool.).

holozoic (hǒl'özō'îk) a. [Gk. holos, whole; zoon, animal.] Obtaining the whole of its food after the manner of animals; ingulfing proteids (zool.).

homacanth (hŏm'ăkănth) a. [Gk. homos, like; akantha, spine.] 
Having the spines of the dorsal fin symmetrical (zool.).

homaxon (hŏm'ăksŏn) a. [Gk. homos, alike ; axon, axis.] Built up around equal axes (zool.).

homaxonic,-homaxon.

homeokinesis (hô̆m'ěökǐne'sǐs) $n$. [Gk. homoios, same ; kinein, to move.] Mitosis with an equal division of the chromatinic elements to the daughter nuclei (biol.).

homeotely (hō'měǒt'ělǐ) n. [Gk. homoios, same; telos, end.] Evolution from homologous parts, but with less close resemblance (biol.).

homeozoic (hǒ̆m'ě̈zōîrk) a. [Gk. homoios, same; zoon, animal.] Pert. a region or a series of regions with identical fauna or flora (biol.).

homoblastic (hŏm'öblăs'tǐk) a. [Gk. homos, alike; blastos, bud.] Having direct embryonic development; arising from similar cells (emb.).

homocarpous (hô̆m'ökâr'pŭs) $a$. [Gk. homos, alike; karpos, fruit.] Bearing one kind of fruit (bot.).

homocercal (hŏ́m'ösĕr'kăl) $a$. [Gk. homos, same; kerkos, tail.] Having a tail with equal or nearly equal lobes, and axis ending near the middle of the base; usually this type is derived from the heterocercal type (zool.).

homocerebrin (hổm'ösěr'ěbrĭn) $n$. [Gk. homos, alike; L. cerebrum, brain.] A substance identical with cerebrin (phys.).

homochlamydeous (hô̆m'öklămìd'exŭs) a. [Gk. homos, same ; chlamys, cloak.] Having the outer and inner perianth whorls alike (bot.).

homochromous (hŏm'ökrō'mŭs) $a$. [Gk. homos, alike ; chroma, colour.] With the whole of the capitular florets of one colour (bot.).

homodermic (hŏm'ödĕr'mik) a. [Gk. homos, same; derma, skin.] Sprung from the same embryonic layer (biol.).

homodont (hŏm'ödŏnt) a. [Gk. homos, same; odous, tooth.] Having the teeth all alike, not differentiated (zool.). homodromous (hơ̆mŏd'römŭs) $a$.

[Gk. homos, same; dromein, to run.] Having the genetic spiral alike in direction in both stem and branches (bot.).

homodynamy (hŏm'ödǐn'ămǐ) $n$. [Gk. homos, same; dynamis, power.] Metameric homology (biol.).

homoeosis (hömë'ösǐs) $n$. [Gk. homoiosis, likeness.] The assumption by one part of the likeness of another part, as the modification of an antenna into a foot, or of a petal into a stamen; metamorphy (biol.). homogamous (hŏmŏg'ămŭs) a. [Gk. homos, same; gamos, marriage.] Characterized by homogamy (biol.).

homogamy (hŏmŏg'ămí) n. [Gk. homos, same ; gamos, marriage.] Interbreeding due to some type of isolation, e.g. physiological isolation (zool.); having the flowers all alike, having the stamens and pistils mature at the same time (bot.).

homogangliate (hờm'ögăng'glīāt) $a$. [Gk. homos, same; ganglion, knot.] Having the ganglia of the nerve loops symmetrically arranged (zool.).

homogen (hö̀m'öjĕn) n. [Gk. homos, same; genos, race.] One of a group having a common origin ; one of a series of identically derived parts (zool.).

homogeneous (hömöjḗněŭs),- -homogenous.

homogenesis (hŏm'öjĕn'ěsĭs) n. [Gk. homos, same; genesis, birth.] The type of reproduction in which like begets like (biol.).

homogenous (hö̆mŏj'ěnŭs) $a$. [Gk. homos, same ; genos, race.] More or less alike owing to descent from a common stock (biol.).

homogeny (hớmŏj'ěnî) $n$. [Gk. homos, same; genos, race.] Correspondence between parts due to common descent (biol.).

homogony (hổmŏg'önĩ) n. [Gk. homos, same; gonos, offspring.] Condition of having one type of flower with equally long stamens and pistil (bot.).

homoiomerous (hôxmoiŏm'ěrŭs) $a$. [Gk. homoios, like; meros, part.] 
Having the Algae distributed equally through the fungoid mycelium, in a lichen (bot.).

homoiothermal (hŏ́moi'öthĕr'măl) $a$. [Gk. homoios, like ; thermos, hot.] Warm-blooded (zool.).

homolecithal (hŏ́m'ölěs'íthăl) $a$. [Gk. homos, same; lekithos, yolk.] Having little deutoplasm, which is equally distributed (emb.).

homologous (hô̆mŏl'ögŭs) a. [Gk. homos, same; logos, discourse.] Resembling in structure and origin (biol.).

homologue (hốm'ölōg) n. [Gk. homos, same ; logos, speech.] One of a series of structures similar in structure and origin (biol.).

homology (hŏ̀mŏl'öjī) $n$. [Gk. homos, same; logos, speech.] The similarity in structure and development of organs or parts (biol.).

homomallous (hŏ̌m'ömăl'ús, hömŏm'ălŭs) a. [Gk. homos, same; mallos, lock of wool.] Curving uniformly to one side ; appl. leaves (bot.).

homomorphism (hồm'ömôr'fĩzm) $n$. [Gk. homos, same ; morphe, shape.] The condition of having perfect flowers of only one type (bot.); hemimetabolism (zool.).

homomorphosis (hớm'ömôr'föšss) $n$. [Gk. homos, same ; morphe, shape.] The condition of having the newly regenerated part like the part removed (biol.).

homonculus (hŏmŏn'kūlǔs) $n$. [L. homunculus, little man.] The small miniature of the human foetus seen in the spermatozoon, according to the Animalculists (biol.).

homonomy (hŏmŏn'ömı̌) n. [Gk. homos, same; nomos, law.] The homology existing between parts arranged on transverse axes (biol.).

homonym (hŏ̀m'önĭm) n. [Gk. homos, same; onyma, name.] A name preoccupied, and so unsuitable according to the law of priority (biol.).

homopetalous (hŏ̌m'öpět'ălŭs) $a$. [Gk. homos, same; petalon, petal.] Having all the petals alike (bot.).

homophyadic (hŏm'öfiăd'ík) a. [Gk. homos, same; phyas, shoot.] Producing only one kind of shoot (bot.). homophylic (hŏm'öfiłl'ík) a. [Gk. homos, same; phyle, race.] $\mathrm{Re}$ sembling one another owing to a common ancestry (biol.).

homophyllous (hŏm'öfil'ús) a. [Gk. homos, same; phyllon, leaf.] Bearing leaves which are all of one kind (bot.).

homoplast (hŏm'öplăst) n. [Gk. homos, same; plastos, moulded.] An organ formed of similar plastids (bot.).

homoplastic (hŏ̀m'öplăs'tǐk) $a$. [Gk. homos, same ; plastos, moulded.] Pert. homoplasty (biol.).

homoplasty (hŏm'öplăs'tî) n. [Gk. homos, same; plastos, moulded.] Convergence; resemblance in form or structure between different animals or organs due to evolution along similar lines (biol.).

homoplasy, - homoplasty.

homopterous (hŏmŏp'těrŭs) $a$. [Gk. homos, same; pteron, wing.] Having the wings alike (zool.).

homosporous (hô̆mŏs'pörŭs) a. [Gk. homos, same; sporos, seed.] Producing only one kind of spore (bot.).

homostyled (hŏ̀m'östīld) $a$. [Gk. homos, same ; stylos, pillar.] With uniform styles (bot.).

homothermous, - homoiothermal.

homotropous (hŏmŏt'röpŭs) $a$. [Gk. homos, same; trepein, to turn.] Erect; having the micropyle and chalaza at opposite ends; $a p p l$. ovules (bot.).

homozygote (hŏ́m'özî'gōt) n. [Gk. homos, same; zygein, to yoke.] An organism in which the characters are stable, resulting from the union of zygotes bearing similar characters (biol.).

homozygous (hŏ́m'özī'gŭs) a. [Gk. homos, same; zygein, to yoke.] Stable (biol.).

honey-dew, - a sugary exudation found on the leaves of many plants (bot.); a sweet secretion produced by certain insects, e.g. Aphids (zool.).

hooded (hood'ěd) a. [A.S. hōd.] Bearing a hood-like petal; rolled up like a cone of paper, as in certain leaves (bot.); having the head conspicuously and differently 
coloured from the rest of the body ; having crests on the head; having wing-shaped expansions on the neck, as in the cobra (zool.).

hordeaceous (hôr'dēā'shŭs) a. [L. hordeum, barley.] Pert. or resembling barley (bot.).

horizontal (hŏr'izŏn'tăl) a. [Gk. horizon, bounding.] Growing in a plane at right angles to the primary axis (bot.).

hormogonium (hôr'mögō'nǔŭm) $n$. [Gk. hormos, chain ; goneia, genera tion.] That portion of an algal filament between two heterocysts which, breaking away, acts as a reproductive body (bot.).

hormones (hôrmōn'z) n. plu. [Gk. hormao, to excite.] The secretions of ductless glands which pass into the blood - vessels by osmosis (phys.).

horn (hôrn) $n$. [A.S. horn.] The process on the head of many animals; any projection from an animal resembling a horn; a tuft of feathers as in an owl; a spine in fishes; a tentacle in snails (zool.) ; an awn ; any pointed projection or process (bot.).

horn core, - the central bony part in the hollow-horned ruminants (zool.).

host (hōst) $n$. [L. hostis, stranger.] Any organism in which another organism spends a part or the whole of its existence, and derives some of its nourishment therefrom (biol.).

house (hows) $n$. [A.S. hüs.] The external gelatinous-like covering secreted by certain Tunicates (zool.).

humeral (hü'mĕrăl) a. [L. humerus, the shoulder.] Pert. shoulder region (anat.); pert. or naming the anterior basal angle of the wing of an insect, one of the horny plates on the plastron of a turtle (zool.).

humerus (hū'mĕrŭs) $n$. [L. humerus, shoulder.] The bone of the upper $\operatorname{arm}$ (anat., zool.).

humistratous (hū'mǐstrā'tŭs) a. [L. humus, earth ; sternere, to spread.] Spreading over the surface of the earth (bot.).

humour (hü'mŏr) n. [L. humor, moisture.] The fluid of the eye (anat.); any fluid or juice (phys.). humus (hū'mŭs) $n$. [L. humus, earth.] A dark soil-like material formed by the decomposition of vegetable or animal matter (bot.).

hunger (hŭng'gër) $n$. [A.S. hungor.] The sensation caused normally by the lack of food (phys.).

husk (hŭsk) $n$. [M.E. huske.] The outer coating of various seeds (bot.).

hyaline (híălĭn) a. [Gk. hyalos, glass.] Clear ; transparent ; free from inclusions (biol.).

hyalogen (hīălöjĕn) n. [Gk. hyalos, glass; gignesthai, to produce.] Any of the substances found in animal tissues which are insoluble and related to mucoids (phys.).

hyaloid (hîăloid) a. [Gk.hyalos, glass.] Glassy ; transparent (phys.).

hyaloid membrane,- - a delicate membrane enveloping the vitreous body of the eye (anat.).

hyalomucoid (h'̄ălöm $\left.\bar{u}^{\prime} k o i d\right) n$. [Gk. hyalos, glass; L. mucus, mucus ; Gk. eidos, like.] One of the nonphosphorized gluco-proteids in the vitreous humour (phys.).

hyaloplasm (híălöplăzm) n. [Gk. hyalos, glass ; plasma, something moulded.] The ground substance of the cell as distinguished from the microsomes, or as distinguished from the reticulum or spongioplasm (zool.) ; the ectoplasm or peripheral zone in plant cells (bot.).

hyaloplasma,- -hyaloplasm.

hyalopterous (h'ílŏlŏp'tĕrŭs) a. [Gk. hyalos, glass; pteron, wing.] Having transparent wings (zool.).

hyalosome (hīălösōm $) n$. [Gk. hyalos, glass; soma, body.] A nucleolarlike body in a cell-nucleus, only slightly stainable by nuclear or plasma stains (biol.).

hybrid (hi'brĭd) n. [L. hibrida, a cross.] Any cross-bred animal or plant (biol.).

hybridism (híbrìdǐzm) n. [L. hibrida, a cross.] The state or quality of being a hybrid (biol.).

hybridization (hī'brĭdîzā'shŭn) $n$. [L. hibrida, a cross.] Act or process of hybridizing; state of being hybridized (biol.).

hybridize (hî'brĭdīz) v. [L. hibrida, a cross.] To interbreed, to produce hybrids (biol.). 
hydathode (hī'dăthōd) $n$. [Gk. hydor, water; odos, way.] An epidermal structure specialized for the secretion of water (bot.).

hydatid (hī'dătĭd) n. [Gk. hydatis, watery vesicle.] Any vesicle or sac filled with a clear watery-like fluid, and containing encysted stages of the larval tapeworms (zool.).

hydatiform (hīdăt'îfôrm) $a$, [Gk. hydatis, watery vesicle; L. forma, shape.] Resembling a hydatid (zool.).

hydatigenous (hī'dătǐj'ěnŭs) a. [Gk. hydatis, watery vesicle ; gignesthai, to produce.] Producing or forming hydatids (zool.).

hydranth (hï'drănth) $n$. [Gk. hydor, water; anthos, flower.] A nutritive zooid in a hydroid colony (zool.).

hydrocaulis (hī'drökôl'ís) n. [Gk. hydor, water; kaulos, stalk.] The branching vertical portion of the coenosarc in a hydroid colony (zool.).

hydrocircus (hī'drösër'kŭs) n. [Gk. hydor, water; kirkos, circle.] The hydrocoelic ring surrounding the mouth in Echinoderms (zool.).

hydrocladia (hī'dröklăd'iă) $n$. plu. [Gk. hydor, water; klados; short.] The secondary branches of a hydrocaulis (zool.).

hydrocoel (hî'drösël) n. [Gk. hydor, water ; koilos, hollow.] The watervascular system in the Echinoderms (zool.).

hydrocyst (hî'drösǏst) $n$. [Gk. hydor, water ; kystis, bladder.] A dactylozooid (zool.).

hydroecium (hïdrē'shǐŭ) $\boldsymbol{n}$. [Gk. hydor, water; oikos, house.] A closed tube at the upper end of a Siphonophore ; an infundibulum (zool.).

hydroid (hî'droid) n., a. [Gk. hydor, water; eidos, resemblance.] A tracheid (bot.); pert. or similar to the genus hydra; the polyp form of a Hydrozoan (zool.).

hydrolysis (hīdrŏl'ìsĩs) $n$. [Gk. hydor, water; lyein, to dissolve.] $\mathrm{De}$ composition of a chemical compound by the addition of water (phys.). hydrome (hī'drōm) n. [Gk. hydor, water; mestos, full.] Any tissue that conducts water (bot.).

hydromegatherm ( ${ }^{\prime}{ }^{\prime}$ drömëg'ăthĕrm) n. [Gk. hydor, water; mega, great; therme, heat.] A plant which must have both moisture and heat to develop fully (bot.).

hydrophilous (hīdrŏf'illŭs) a. [Gk. hydor, water; philein, to love.] Pollinated through the agency of water (bot.).

hydrophyllium (hī'dröfîl'ium) $n$. [Gk. hydor, water; phyllon, leaf.] One of leaf-like transparent bodies arising above and partly covering the sporosacs in a Siphonophore (zool.).

hydrophyte (hī'dröfït) $n$. [Gk. hydor, water; phyton, plant.] An aquatic plant.

hydrophyton (hīdrŏf'ìtŏn) n. [Gk. hydor, water; phyton, plant.] A complete hydroid colony, rootlike organ, stem and branches (zool.).

hydroplanula (hī'dröplăn'ūlă) n. [Gk. hydor, water; L. planus, flat.] A stage in the larval history of a Coelenterate between a planula and an actinula (zool.).

hydropolyp (hī'dröpŏlíp) n. [Gk. hydor, water; F. polype, polyp.] A polyp of a hydroid colony; a hydrula (zool.).

hydropore (hī'dröpōr) n. [Gk. hydor, water ; poros, opening.] The opening into the right hydrocoel in the echinoderm larvae (zool.).

hydrorhiza (hî'drörî'ză) $n$. [Gk, hydor, water; rhiza, root.] The creeping root-like portion of the coenosarc of a hydroid colony (zool.).

hydrosome (hi'drösōm) n. [Gk. hydor, water ; soma, body.] The conspicuously hydra-like stage in a coelenterate life-history (zool.).

hydrospire (hī'dröspīr) n. [Gk. hydor, water; L. spira, coil.] The folds on the stereom of blastoids; respiratory structures ( $p a l$.).

hydrostome (hî'dröstōm) n. [Gk. hydor, water ; stoma, mouth.] The mouth of a hydroid polyp (zool.).

hydrotaxis (hī'drötǎk'sǐs) $n$. [Gk. hydor, water ; taxis, arrangement.] The response of certain small 
organisms or of certain organs to the stimulus of water (biol.).

hydrotheca (hî̀'dröthē'kă) n. [Gk. hydor, water; theke, cup.] The cup-like structure into which the polyp may withdraw, found in many Coelenterates; a product of the ectoderm (zool.).

hydrotropism (hīdrŏt'röpĭzm) n. [Gk. hydor, water; trepein, to turn.] Hydrotaxis.

hydrula (hī'droolă) n. [Gk. hydor, water.] A hypothetical simple polyp (zool.).

hygrophilous (hīgrơf'ílŭs) a. [Gk. hygros, wet; philein, to love.] Inhabiting moist or marshy places (bot.).

hygrophyte (hī'gröfīt) n. [Gk. hygros, wet; phyton, plant.] A plant which lives and thrives under conditions of plentiful moisture (bot.).

hygroplasm (hīgröplăzm) $n$. [Gk. hygros, wet; plasma, something moulded.] The more liquid part of protoplasm; $c f$. stereoplasm (biol.).

hygroscopic (hī'gröskŏp'îk) a. [Gk. hygros, wet; skopein, to regard.] Sensitive to moisture (bot.).

hylophagous (hīlŏf'ăgŭs) a. [Gk. hyle, wood; phagein, to eat.] Eating wood; $a p p l$. certain insects (zool.).

hylophyte (hī'löfīt) n. [Gk. hyle, wood; phyton, plant.] A plant growing in woods (bot.).

hylotomous (hīlŏt'ömŭs) a. [Gk. hyle, wood; temnein, to cut.] Woodcutting; $a p p l$. certain insects (zool.).

hymen (hïmĕn) $n$. [Gk. hymen, membrane.] A thin fold of mucous membrane situated at the orifice of the vagina (anat.).

hymenial (hīmē'nŭl) a. [Gk. hymen, skin.] Pert. hymenium (bot.).

hymeniferous (hï'mĕnĭf'ĕrŭs) $a$. [Gk. hymen, skin ; L. ferre, to carry.] Having a hymenium (bot.).

hymenium (hî'mé'nĭŭm) n. [Gk. hymen, skin.] The outermost layer of a mushroom lamellae, or similar fungus, consisting of barren cells or paraphyses and basidial cells (bot.).

hymenophore (hî́měnöfōr) n. [Gk. hymen, skin; pherein, to carry.] The hymen portion of the sporophore of a fungus (bot.).

hymenopterous (hïměnŏp'tĕrŭs) $a$. [Gk. hymen, skin; pteron, wing.] Having membranous wings; appl. certain insects (zool.).

hyobranchial (hî'öbrăng'kuăl) a. [Gk. $\Upsilon$; brangchia, gills.] Pert. gills and hyoid (zool.).

hyoepiglottic (h'ööěpiglŏt'ìk) a. [Gk. $\Upsilon$; epi, upon; glotta, tongue.] Connecting the hyoid and the epiglottis (anat.).

hyoglossal (hï'öglŏs'ăl) a. [Gk. r; glossa, tongue.] Pert. tongue and hyoid (anat.).

hyoid (hî'oid) a. [Gk. hyoeides, Yshaped.] Pert. or designating a bone or series of bones lying at the base of the tongue and developed from the hyoid arch of the embryo (anat.).

hyoideus (hīoid'ěŭs) $n$. [Gk. hyoeides, Y-shaped.] A nerve which supplies the mucosa of the mouth and the muscles of the hyoid region (anat.).

hyomandibular (hî̀ömăndǐb'ūlăr) $a$. [Gk. $\Upsilon$; L. mandibulum, jaw.] Pert. hyoid and the mandible; pert. dorsal segment of the hyoid arch in fishes; $n$., the dorsal segment itself of the hyoid arch in fishes (zool.).

hyomental (hīöoměn'tăl) a. [Gk. $\Upsilon$; L. mentum, chin.] Pert. hyoid and chin (anat.).

hyoplastron (hî'öplăs'trŏn) $n$. [Gk. $\Upsilon$; F. plastron, breast-plate.] The second lateral plate in the plastron of Chelonians (zool.).

hyosternum (hī'östër'nŭm) n. [Gk. $\Upsilon$; sternon, breast.] The hyoplastron (zool.).

hyostylic (hî́östîl'î) a. [Gk. $\Upsilon$; stylos, pillar.] Having the jaw articulated to the skull by the agency of the hyomandibular or corresponding part (zool.).

hyothyroid (hî́thîrroid) $a$. [Gk, $\Upsilon$; thyreos, shield; eidos, like.] Pert. the hyoid and the thyroid cartilages of the larynx; appl. structures associated with them (zool.).

hypallelomorph (hípălěl'ömôrf) $n$. [Gk. hypo, under; allelon, of one 
another; morphe, shape.] Allelomorphs which under certain conditions are themselves compound (biol.).

hypanthium (hĭpăn'thǐŭm) $n$. [Gk. hypo, under; anthos, flower.] Any enlargement of the torus (bot.).

hypanthodium (hĭp'ănthō'diŭm) $n$. [Gk. hypo, under; anthodes, like flowers.] An inflorescence with a concave capitulum on the walls of which the flowers are arranged (bot.).

hypantrum (hĭpăn'trŭm) n. [Gk. hypo, under; antron, cave.] A notch on the vertebrae of certain reptiles for articulation with the hyposphene ( $p a l$.).

hypapophysis (hĭp'ăpǒf'ĩsı̆s) $n$. [Gk. hypo, under; apo, upon; phyein, to grow.] A ventral process on a vertebra (anat.).

hyparterial (híp'ârtē'rĭla a. [Gk. hypo, under; L. arteria, channel. Situated below an artery; $a p p l$. branch of the right bronchus (anat.).

hypaxial (hı̌păk'sı̌ăl) a. [Gk. hypo, under; L. axis, axis.] Ventral, or below the vertebral column; $a p p l$. muscles (zool.).

hyperapophysis (hīpěrăpŏf'ísĭs) $n$. [Gk. hyper, above; apo, from; phyein, to grow.] A postero-lateral process of the dorsal side of a vertebra (zool.).

hyperchromasy (hīpĕrkrō'măsǐ) $n$. [Gk. hyper, above ; chroma, colour.] A relatively superabundant supply of chromatin to cytoplasm in a cell (biol.).

hyperchromatosis (hî'pĕrkrō'mătō'sǐs) n. [Gk. hyper, above; chroma, colour.] The excess of nuclear substance in a cell just previous to division (zool.).

hypercoracoid (hīpěrkŏr'ăkoid) $a$. [Gk. hyper, above; korax, crow ; eidos, like.] Pert. or designating the upper bone at the base of a pectoral fin in Fishes (zool.).

hypermetamorphosis (hî́pěrmět'ămôr'fösǐs) $n$. [Gk. hyper, above ; meta, after; morphe, shape.] A protracted and thoroughgoing metamorphosis (zool.).

hyp perparasite (hī'pĕrpăr'ăsīt) $n$. [Gk. hyper, above ; para, beside ; sitos, food.] A parasite which is parasitic on or in another parasite (biol.).

hyperpnoea (hïpěrpnē'ă) n. [Gk. hyper, above ; pnoe, breath.] Rapid breathing due to an insufficient supply of oxygen (phys.).

hypersensitivity (hīperrsěn'sǐtǐv'ítǐ) $n$. [Gk. hyper, above; L. sentive, to feel.] A condition of being unduly sensitive to any drug ( $p h y s$.).

hypertely (hīpĕr'těli) $n$. [Gk. hyper, above; telos, end.] Any imitation in colour or pattern which has overshot the mark (zool.).

hypertonia (hî́pěrtō'nǐă) n. [Gk. hyper, above; tonos, tone.] Excessive tonicity (phys.).

hypertrophy (hīpěr'tröfĩ) n. [Gk. hyper, above ; trophe, nourishment.] An excessive growth or development (biol.).

hypha (hïfă) $n$. [Gk. hyphe, web.] The thread-like element of the vegetative mycelium of a Fungus (bot.).

hyphasma (hīfăz'mă) $n$. [Gk. hyphas$m a$, thing woven.] A barren mycelium (bot.).

hyphodrome (hî'födrōm) n. [Gk. hyphe, web; dromein, to run.] Running throughout the tissues; $a p p l$. thick leaves where the veins are not visible from the surface (bot.).

hypnocyst (hǐp'nösǐst) n. [Gk. hypnos, sleep; kystis, bladder.] A cyst in which the contained organism simply rests (zool.).

hypnody (hǐp'nödǐ) $n$. [Gk. hypnodia, sleepiness.] The long resting period passed by certain larval forms (zool.).

hypnogenic (hǐp'nöjĕn'îk) a. [Gk. hypnos, sleep; genos, offspring.] Sleep-producing; $a p p l$. influences or localities which tend to produce hypnosis (phys.).

hypnosperm (hǐp'nöspěrm) n. [Gk. hypnos, sleep; sperma, seed.] A hypnospore (bot.).

hypnosporangium(hǐp'nöspörăn'jǐŭm) n. [Gk. hypnos, sleep; sporos, seed; anggeion, vessel.] A sporangium containing resting spores (bot.). 
hypnospore (hĭp'nöspōr) $n$. [Gk. hypnos, sleep; sporos, seed.] A resting spore; a zygote that remains in a quiescent condition during winter (bot.).

hypoarion (hīpöărínŏn) n. [Gk. hypo, under; oarion, little egg.] A small lobe below the optic lobes of most Teleosts (zool.).

hypobasal (hīpöbā'săl) n. [Gk. hypo, under; L, basis, base.] The lower segment of a developing ovule (bot.).

hypoblast (hīpöblăst) $n$. [Gk. hypo, under; blastos, bud.] The inner germ layer in a gastrula (emb.).

hypoblastic (hî'pöblăs'tĩk) $a$. [Gk. hypo, under ; blastos, bud.] Pert. or derived from the inner layer; endodermal (biol.).

hypobranchial (h'́pöbrăng'kiăl) $a$. [Gk. hypo, under ; brangchia, gills.] Pert, the lower or fourth segment of the branchial arch (anat.).

hypocentrum (hï'pösĕn'trŭm) $n$. [Gk. hypo, under; kentron, centre.] A transverse cartilage that arises below the nerve cord and forms part of the vertebral centrum (zool.).

hypochilium (hī'pökìl'ǐŭ) n. [Gk. hypo, under; cheilos, lip.] The lower portion of the lip of an orchid (bot.).

hypochondrium (hî'pökŏn'driŭm) $n$. [Gk. hypo, under ; chondros, cartilage.] A region below the epigastric and above the lumbar (anat.).

hypochordal (hīpökôr'dăl) a. [Gk. hypo, under ; chorde, string.] Below the notochord (anat.).

hypocleidium (hî'pöklî'diŭm) n. [Gk. hypo, under; kleis, key.] The interclavicle.

hypocone (hīpökōn) n. [Gk, hypo, under; konos, cone.] The posterointernal cusp of an upper molar (zool.).

hypoconid (hïpökö'nǐd) $n$. [Gk. hypo, under; konos, cone.] The posterobuccal cusp of a lower molar (zool.).

hypoconulid (hī'pökŏn'ülìd) $n$. [Gk. hypo, under; konos, cone.] The postero-mesial cusp of a lower molar (zool.).

hypocoracoid (hî'pökŏr'ăkoid) a. [Gk. hypo, under ; korax, crow ; eidos, like.] Pert. the lower bone at the base of the pectoral fin in Fishes (zool.).

hypocotyl (hî'pökŏt'îl) $n$. [Gk. hypo, under; kotyle, hollow.] That portion of the stem below the cotyledons in an embryo (emb.).

hypocotyledonary (hĩ'pökǒt'îlé'dŏnărì) a. [Gk, hypo, under; kotyle, hollow.] Below the cotyledons (bot.).

hypocrateriform (hî'pökrătĕr'ifôrm) $a$. [Gk. hypo, under; krater, cup; L. forma, shape.] Having a gamopetalous corolla with a long narrow tube, and the limbs at right angles to the tube (bot.).

hypodactylum (hīpödăk'tǐlŭm) $n$. [Gk. hypo, under ; daktylos, digit.]

The under surface of a bird's toes (zool.).

hypoderma (hî́pödĕr'mă) $n$. [Gk. hypo, under; derma, skin.] The tissue just under the epidermis in plants.

hypodermal (hïpöděr'măl) a. [Gk. hypo, under ; derma, skin.] Pert. the hypoderma or hypodermis (biol.).

hypodermalia (hípöděrmă'liă) $n$. [Gk. hypo, under; derma, skin.] Sponge spicules situated just below the derma or skin (zool.).

hypodermic (hî'pödër'mǐk) a. [Gk. hypo, under; L. dermis, skin.] Pert. the parts just under the skin (zool.).

hypodermis (hîtpödĕr'miss) $n$. [Gk. hypo, under; L. dermis, skin.] The cellular layer lying beneath and secreting the cuticle of the Annulata, Arthropoda, etc. ; the hypoblast (zool.) ; hypodema (bot.).

hypodicrotic (hîpödīkrŏt'ík) $a$, [Gk. hypo, under ; di, two; krotein, to beat.] Exhibiting the phenomenon of having two arterial beats for the one cardiac (phys.).

hypogastric (hî́pögăs'trĭk) $a$. [Gk. hypo, under; gaster, belly.] Pert. the lower median region of the abdomen (anat.).

hypogastrium (hî́pögăs'trǐŭ) $n$. [Gk. hypo, under; gaster, belly.] The lower median region of the abdomen (anat.). 
hypogeal (hī'pöjē'ăl) a. [Gk. hypo, under ; gaia, earth.] Subterranean ; $a p p l$. stems, etc. (bot.).

hypogenesis (hî̀pöjĕn'ěsĭs) $n$. [Gk. hypo, under; genesis, origin.] Development without alternation of generations occurring (biol.).

hypogenous (hīpŏj'ěnŭs) a. [Gk. hypo, under; genos, birth.] Growing on the lower surface of anything (bot.).

hypogeous (hî́pöjē'üs) a. [Gk. hypo, under; ge, earth.] Growing or maturing under the earth (bot., zool.).

hypoglossal (hīpöglǒs'ăl) n. [Gk. hypo, under; glossa, tongue.] The twelfth paired cranial nerve, distributed to the base of the tongue (anat.).

hypoglottis (hî'pöglŏt'ĩs) $n$. [Gk. hypo, under; glotta, tongue.] The under part of the tongue (anat.); a division of the labium of beetles (zool.).

hypognathous (hïpögnâ'thŭs, hĭpŏg' năthŭs) a. [Gk. hypo, under ; gnathos, jaw.] Having the lower jaw slightly longer than the upper (zool.).

hypogynium (hîpöjǐn'iuum) n. [Gk. hypo, under; gyne, female.] That structure which supports the ovary in such plants as sedges (bot.).

hypogynous (hīpŏj'inŭs) $a$. $[\mathrm{Gk}$. hypo, under; gyne, female.] Inserted below the gynoecium, and not adherent; $c f$. perigynous (bot.).

hypohyal (hī'pöhïăl) n. [Gk. hypo, under; hyoeides, Y-shaped.] The hyoid element lying between the ceratohyal and the basihyal (anat.).

hypoischium (hî'pöĭs'kiŭm) n. [Gk. hypo, under ; ischion, hip.] A small bony rod passing backwards from the ischiadic symphysis and supporting the ventral cloacal wall (zool.).

hypomere (hīpömēr) n. [Gk. hypo, under; meros, part.] The lower or lateral plate zone of the coelomic pouches (emb.).

hypomeron (hīpŏm'ĕrŏn) n. [Gk. hypo, under; meros, part.] The lateral inflexed side of a coleopterous prothorax (zool.). hyponasty (hî'pönăs'tĩ) n. [Gk. hypo, under; nastos, close-pressed.] The state of growth in a flattened structure in which the under surface grows more vigorously than the upper (bot.).

hyponome (hī'pönōm) n. [Gk. hyponome, underground passage.] The funnel of the Cephalopods (zool., pal.).

hyponychium (hī'pönǐk'íŭm) n. [Gk. hypo, under; onyx, nail.] The layer of epidermis on which the nail rests (anat.).

hypopetalous (hî́pöpět'ălŭs) a. [Gk. hypo, under; petalon, petal.] Having the corolla inserted below and not adherent to the gynoecium (bot.).

hypophare (hī'pöfār) n. [Gk. hypo, under; pherein, to bear.] The lower part of the sponge in which there are no chambers ; $c f$. spongophare (zool.).

hypopharyngeal (hî'pöfărǐn'jěăl, -făr' injē'ăl) a. [Gk. hypo, under; pharynx, pharynx.] Pert. or situated below or in the lower surface of the pharynx (zool.).

hypopharynx (hīpöfăriñngks) $n$. [Gk. hypo, under; pharynx, pharynx.] The lingua of many insects; in mosquitoes, an outgrowth from the base of the labium which bears the salivary groove or duct (zool.).

hypophloeodal (hî́pöflēödăl) $a$. [Gk. hypo, under; phloios, bark.] Living or growing under the bark (bot.).

hypophyllium (hỉpöfíl'ium) $n$. [Gk. hypo, under; phyllon, leaf.] A scale-like leaf below a cladophyll (bot.).

hypophysial (hî́pöfüziăl) a. [Gk. hypo, under; physis, growth.] Pert. the hypophysis (anat.).

hypophysis (hīpoof'isis) $n$. [Gk. hypo, under; physis, growth.] The pituitary body (anat.); the olfactory pit in the lancelet (zool.); the last cell of the suspensor (bot.).

hypoplastron (hî'pöplăs'trŏn) $n$. [Gk. hypo, under ; F. plastron, shield.] The third lateral bony plate in the plastron of turtles (zool.).

hypopodium (hî̀pöpō'diŭm) n. [Gk. hypo, under; podion, little foot.] 
The basal portion of any leaf, including the stalk (bot.).

hypoptilum (hīpŏp'tı̌lŭm) n. [Gk. hypo, under; ptilon, down.] The after-shaft (zool.).

hypopygium (hîpöpig'ı̆ŭ, hîpöpì'jĭŭ) $n$. [Gk. hypo, under; pyge, buttocks.] The clasping organ of a male dipterous insect (zool.).

hyporachis (hï'pörā'kĭs) $n$. [Gk. hypo, under; rhachis, spine.] The stem of the after-shaft of a feather (zool.).

hyporhachis, - see hyporachis.

hyposkeletal (hīpöskěl'ětǎl) $a$. [Gk. hypo, under; skeletos, hard.] Lying beneath or internally to the endoskeleton (zool.).

hyposphene (hî̀ pösfēn) $n$. [Gk. hypo, under; sphen, wedge.] A wedgeshaped process on the neural arch of the vertebrae of certain extinct reptiles which fits into the hypantrum (pal.).

hypostereom (hīpöstěr'ěm) n. [Gk. hypo, under; stereos, solid.] The third or inner layer of the thecal plates of a Cystid; the inner layer of the integument of a Crinoid (zool.).

hypostoma (hīpöstō'mă) n. [Gk. hypo, under ; stoma, mouth.] The fold bounding the posterior margin of the oral aperture in Crustacea ; the oral projection or manubrium of a Hydrozoan (zool.).

hypostomatous (hî́pöstŏm'ătŭs) $a$. [Gk. hypo, under; stoma, mouth.] Having the mouth placed on the lower or ventral side (zool.).

hypostome,- see hypostoma.

hypotarsus (hî́pötâr'sŭs) $n$. hypo, under ; tarsus, ankle.] 'The "calcaneum" of a bird (zool.).

hypothalamus (hī'pöthăl'ămŭs)n. [Gk. hypo, under; thalamos, chamber.] The subthalamic tegmental region and the structures forming the greater part of the floor of the third ventricle (anat.).

hypothallus (hĩ'pöthăl'ŭs) n. [Gk. hypo, under; thallus, flattened plate.] The marginal hyphal outgrowth ; a membranous case bearing sporangia (bot.).

hypothecium (hî'pöthē'šŭm, -shǐŭm) $n$. [Gk. hypo, under; theke, cup.]
The layer of dense hyphal threads below the thecium in Lichens; the upper layer of the ascoma (bot.).

hypothenar (hī'pöthē'năr) $a$. [Gk. hypo, under ; thenar, palm of the hand.] Pert. the prominent part of the palm of the hand above the base of the little finger (anat.).

hypothetical units, - the ultimate component parts of protoplasm ; ultracellular units ranking between the molecule and the cell; also called variously, physiological units, pangens, gemmules, biophores, bioblasts, somacules, idiosomes, plasomes, micellae, plastidules, inotagmata, idioblasts, biogens, gemmae, and microzymas (biol.).

hypotonic (hî'pötŏn'îk) a. [Gk. hypo, under; tonos, tension.] Appl. a solution whose osmotic pressure is less than that of serum (phys.).

hypotrichous (hīpǒt'rǐkŭs) a. [Gk. hypo, under; thrix, hair.] Pert. Infusorians in which the cilia are mainly restricted to the under surface, and often form strong setalike structures (zool.).

hypotrochanteric (hīpötrồ $\mathrm{k}^{\prime}$ ăntĕr'îk) a. [Gk. hypo, under; trochanter, runner.] Beneath the trochanter (anat.).

hypotympanic (hî́pötǐm'pănǐk) $a$. [Gk. hypo, under; L. tympanum, drum.] Situated below the tympanum ; pert. the quadrate (anat.).

hypoxanthin (hīpözắn'thĭn) $n$. [Gk. hypo, under; xanthos, yellow.] A crystalline nitrogenous substance found in muscle tissue and in some seeds (phys.).

hypozygal (hī'pözígăl) $n$. [Gk. hypo, under; zygon, yoke.] The lower ossicle of a syzygial pair bearing no pinnule (zool.).

hypselodont (hip'sělödŏnt) $a$. [Gk. hypsi, high; odous, tooth.] Hypsodont.

hypsodont (hĭp'södŏnt) a. [Gk. hypsos, height; odous, tooth.] Pert. or designating teeth with high crowns and short roots (zool.).

hypsophyll (hĭp'söfîl) n. [Gk. hypsi, high; phyllon, leaf.] Any leaf beneath the sporophylls (bot.).

hypural (hǐp'ürăl) a. [Gk. hypo, under; oura, tail.] Pert. a bony 
structure, formed by the fused haemal spines of the last few vertebrae, which supports the caudal fin in certain Fishes (zool.).

hysterogenic (hǐs'těröjĕn'îk) $a$. [Gk. hysteros, later; genos, birth.] Of later development or growth (zool.).

\section{I}

ichthyic (1k'thǐk) a. [Gk. ichthys, fish.] Pert. or characteristic of Fishes (zool.).

ichthyoid (㣙'thǐoid) a.,-ichthyic. ichthyolite (1 $\mathrm{k}^{\prime}$ thiölit) $n$. [Gk. ichthys, fish; lithos, stone.] A fossil fish or part of one (pal.).

ichthyology (îkthǐŏlöjì) n. [Gk. ichthys, fish; logos, discourse.] That part of zoology treating of fishes,

ichthyopterygia (ํ' thĭŏptěrij'ıă) $n$. plu. [Gk. ichthys, fish; pteryx, wing or fin.] Paired fish fins (zool.).

icosandrous (i'kösăn'drŭs) $a$. [Gk. eikosi, twenty; aner, man.] Having twenty or more stamens (bot.).

id (îd) $n$. [Gk. idios, distinct.] A hypothetical structural unit; the chromomere (cyt.).

idant (İ́dănt) $n$. [Gk, idios, distinct.] A unit resulting from an aggregation of ids; the chromosome (cyt.).

idioblast (İ'ı̈öblăst) n. [Gk. idios, distinct; blastos, bud.] A biophore ; an ultimate cell unit. See hypothetical units.

idiochromatin (İ'iökrō'mătǐn) $n$. [Gk. idios, distinct; chroma, colour.] Temporarily dormant generative chromatin; cf. trophochromatin $(c y t$.).

idiochromidia (íd'öökrömìd'iă) $n$. plu. [Gk. idios, distinct ; chroma, colour.] Sporetia; generative chromidia; $c f$. trophochromidia (cyt.).

iđiochromosome (Ǐd'iōkrō'mösōm) $n$. [Gk. idios, distinct ; chroma, colour ; soma, body.] An additional chromosome with a relation to sex, observed in certain germ cells - one or more may be present (cyt.).

idiomuscular (îd'iömŭs'kūlăr) a. [Gk. idios, personal; L. musculus, muscle.] Appl. contraction of a degenerated muscle artificially stimulated (phys.).

idioplasm (id'ịöplăzm) n. [Gk. idios, distinct ; plasma, something moulded.] Chromatin; the generative or germinal part of a cell ; $c f$. trophoplasm (cyt.).

idiosome (İd'iösōm) n. [Gk. idios, distinct; soma, body.] An idioblast or biophore. See hypothetical units.

idiothalamous (id'iöthăl'ămŭs) $a$. [Gk. idios, personal; thalamos, receptacle.] Appl. Lichens in which various parts are differently coloured from the thallus (bot.).

idiothermous (İd'iöthĕr'mŭs) $a$. [Gk. idios, personal; thermos, hot.] Warm-blooded; homoiothermal (zool.).

idiozome (îd'iözōm) n. [Gk. idios, distinct ; zoma, girdle.] In spermatogenesis a separated portion of archoplasm which ultimately becomes the head-cap of the spermatozoon (cyt.).

idorgan (idôr'găn) n. [Gk, idios, distinct ; organon, instrument.] A purely morphological multicellular unit which does not possess the features of a soma (biol.).

ileocaecal (1̌l'ěsöé'kăl) a. [L. ileum, groin ; caecus, blind.] Pert. ileum and caecum; $a p p l$. fossae, folds, etc. (anat.).

ileocolic (̌l'ěökŏl'ík) a. [L. ileum, groin; kolon, the gut.] Pert. ileum and colon; $a p p l$. artery, lymph gland, etc. (anat.).

ileum (̌l'ĕŭm) $n$. [L. ileum, groin.] The lower part of the small intestine (anat.).

iliac (îl'̌̌ăk) a. [L. ilia, flanks.] Pert. ilium, a pelvic bone; appl. artery, fossa, furrow, tuberosity, vein, muscle, etc. (anat.).

iliocaudal (r̂l'iökô'dăl) $a$. [L. ilia, flanks; cauda, tail.] Connecting ilium and tail; $a p p l$. muscle (anat.). iliococeygeal (riliökök'š̌jē'ăl, -kǒksǔj'ěăl) a. [L. ilia, flanks; Gk. kokkyx, cuckoo.] Pert. ilium and coccyx; $a p p l$. a muscle (anat.).

iliocostal (îl'iökös'tăl) a. [L. ilia, flanks; costa, rib.] In region of 
ilia and ribs ; $a p p l$. several muscles (anat.).

iliofemoral (1̌l'ı̈öfĕm'örăl) a. [L. ilia, flanks; femur, thigh.] Pert. the ilium and femur; $a p p l$. a ligament (anat.).

iliohypogastric (ํ' '̌öhī'pögăs'trǐk) $a$. [L. ilia, flanks; Gk. hypo, under ; gaster, belly.] Pert. ilium and lower anterior part of the abdomen; $a p p l$. a nerve (anat.).

ilioinguinal (îl'iö̌n'gwinăl) a. [L. ilia, flanks ; inguen, the groin.] In the region of ilium and groins; appl. a nerve (anat.).

iliolumbar (îl'iolülü'băr) a. [L. ilia, flanks; lumbus, loins.] In region of ilium and loins; appl. artery, ligament, vein (anat.).

iliopectineal (1̌l'iopěktǐn'ěăl) $a$. [L. ilia, flanks; pecten, crest.] Appl. an eminence marking the point of union of ilium and pubis (anat.).

iliotibial (îl'ıötǐb'řăl) a. [L. ilia, flanks; tibia, pipe.] Appl. a tract or band of muscle at the lower end of the thigh (anat.).

iliotrochanteric (11'iötrŏkăntĕr'îk) $a$. [L. ilia, flanks; Gk. trochanter, a runner.] Uniting ilium and trochanter of femur ; $a p p l$. a ligament (anat.).

llium (illiŭm) $n$. [L. ilium, flank.] That part of the hip-bone supporting the flank (anat.); the dorsal bone, articulating with the backbone, of the pelvic arch (zool.).

imaginal (ímăj'inăl) a. [L. imago, image.] Pert. an imago; appl. larval discs, patches of cells from which new organs develop (zool.).

imago (ı̆mā'gŏ) n. [L. imago, image.] The last or adult stage in insect metamorphosis; the perfect insect (zool.).

imbricate (ĭm'brǐkāt) a. [L. imbricare, to tile.] Having parts overlying each other like house-tiles; appl. scales, plates, etc. (zool.); budscales, bracts, etc. (bot.).

imitative (ĭm'îtātǐv) a. [L. imitari, to imitate.] $A p p l$. form, structure, habit, colouring, etc., assumed for protection (zool.).

immaculate (ìmăk'ūlāt) a. [L. in, not; macula, spot.] Without spots or marks of different colour. immunise (ĭm'ūnīz, ı̆mū'nīz) v. [L. immunis, free.] To render invulnerable to a toxin, usually by injecting the toxin in small quantities at short intervals, without the appearance of severe symptoms (phys.).

immunity (ĭmū'nĭť̌) $n$. [L. immunis, free from duty.] An organism's resistance, natural or acquired, to the onset of pathological conditions from infection, natural or artificial, by any of the micro-organisms (phys.).

imparidigitate (ímpăr'ídij'îtāt) $a$. impar, unequal; digitus, finger.] Having an odd number of digits on a $\operatorname{limb}(z \circ o l$.$) .$

imparipinnate (impăr'ípinn'āt) $a$. [L. impar, unequal ; pinna, wing.] Unequally pinnate; pinnate with an odd terminal leaflet (bot.).

imperfect metamorphosis,-see incomplete.

imperforate (impĕr'förāt) a. [L. in, not ; per, through ; foratus, bored.] Not pierced; $a p p l$. foraminifera shells without fine pores in addition to principal opening (zool.).

impervious (İmpĕr'viǔs) a. [L. in, not; per, through; via, way.] Not permeable (biol.); appl. nostrils with a septum between the nasal cavities (zool.).

import (im'pört) $n$. [L. importare, to bring in.] A method of foodingestion in Amoeba, food being drawn in on contact (phys.).

impregnation (Ǐm'prĕgnă'shŭn) $n$. [L. impraegnare, to fertilize.] Transference of spermatozoa from male to body of female.

impression (imprěsh'ŏn) $n$. [L. in, into; premere, to press.] An indentation mark resulting from contact of organs or pressure of one on another, as those on the surfaces of the liver, the rhomboid of the clavicle, the trigeminal of the temporal (anat.).

inantherate (innăn'thĕrāt) a. [L. in, not; Gk. antheros, flowery.] Without anthers (bot.).

inarticulate (inârtǐk'ūlāt) a. [L. in, not; articulatus, jointed.] Not segmented (biol.).

inaxon (Inăk'sŏn) n. [Gk. is, fibre ; 
axon, axis.] A nerve-cell with axiscylinder branching at a distance from it (phys.).

inbreeding,--breeding through a succession of parents belonging to the same stock, or very nearly related (biol.).

incaliculate (ĭnkălǐk'ūlāt) a. [L. in, not; caliculus, snall flower-cup.] Wanting a calicle (zool.).

incasement theory,-see preformation theory.

incised (ĭnsīzd') a. [L. incisus, cut into.] With deeply notched margin (biol.).

incisiform (ĭnsíziffôrm) a. [L. incisus, cut into; forma, shape.] Incisorshaped.

incisive (insīziv) a. [L. incisus, cut into.] Pert. or in the region of the incisors; appl. bones, foramina, fossa, canals (anat.).

incisor (ĩnsî́zŏr) a. [L. incisus, cut into.] Adapted for cutting-appl. mammalian premaxillary teeth; $n$. a crest or ridge of bone (anat.).

included (Inklood'ěd) $a$. [L. includere, to shut in.] Having stamens and pistils not protruding beyond the corolla; not exserted (bot.).

incomplete metamorphosis, -insect metamorphosis in which the young are hatched in the general adult form and develop without a quiescent stage (zool.).

incongruent (Inkŏng'grooĕnt) $a$. [L. incongruens, not suiting.] Not suitable or fitting; $a p p l$. surface of joints which do not fit properly (anat.).

incoordination (ĭn'köôr'dǐnā'shŭn) $n$. [L. in, not; cum, together; ordo, order.] Want of coordination; irregularity of movement due to loss of muscle control (phys.).

incrassate (inkrăs'āt) a. [L. incrassare, to thicken.] Thickened.

incubation (ĭn'kūbā'shŭn) $n$. [L. incubare, to lie on.] The hatching of eggs by means of heat, natural or artificial (emb́.).

incubous (in'kūbŭs) a. [L, incubare, to lie on.]. Appl. leaves so arranged that the base of each is covered by the upper portion of the next lower (bot.).

incudate (ing'kūdāt) a. [L. incus, anvil.] $A p p l$. type of Rotifer mastax with large and hooked rami and reduced mallei (zool.).

incumbent (ĭnkŭm'bĕnt) a. [L. incumbere, to lie upon.] Lying upon; bent downwards to lie along a base ; appl. cotyledons with hypocotyl applied to the back (bot.); $a p p l$. hairs or spines applied lengthwise to their base (zool.).

incurrent (Ǐnkŭr'ĕnt) a. [L. in, into ; curreve, to run.] Leading into; $a p p l$. ectoderm-lined canals of Sponges which admit water; and inhalent siphons of Molluscs. (zool.).

incurvate (inkŭr'vāt) a. [L. in, in ; curvus, bend.] Of a structure, curved inwards or bent back on itself.

incurvation (ĭn'kŭrvā'shŭn) n. [L. in, in ; curvare, to bend.] The doubling back on itself of a structure or organ, as of a spirochaete about to divide (zool.).

incus (ing'kŭs) $n$. [L. incus, anvil.] Part of a Rotifer mastax ; the anvilshaped ear ossicle of Mammals (zool.).

indeciduate (In'děsĭd'ūāt) $a$. [L. in, not; de, down; cadere, to fall. Non-caducous; with maternal part of placenta not coming away at birth (zool.).

indeciduous (Ǐn'dêsš̆d'ūŭs) $a$. [L. in, not; de, down; cadere, to fall. $]$ Persistent; not falling off at maturity; everlasting; evergreen (bot.).

indefinite (inděf'init) a. [L. in, not ; de, down; finis, end.] Not limited; not determinate; of no fixed number (bot.).

indehiscent (inn'dēhis'ĕnt) a. [L. in, not; dehiscens, gaping.] Not splitting at maturity; appl. certain fruits (bot.).

indeterminate growth,-growth of stem, branch or shoot not limited or stopped by development of a terminal bud; indefinite prolongation and subdivision of an axis (bot.).

indeterminate inflorescence,growth of a floral axis by indefinite branching because unlimited by development of a terminal bud (bot.). 
index finger, - the forefinger or digit next to the thumb.

indifferent (indiff'ěrĕnt) a. [L. in, not; dis, apart; ferre, to carry.] Undifferentiated.

indigenous (indij'ěnŭs) a. [L. in, in ; gignere, to beget.] Belonging to the locality; not imported (biol.).

indirect (ǐn'dīrěkt) a. [L. in, not ; directus, straightened.] Not by a simple method ; complicated ; $a p p l$. development, mitosis, selection, embryogeny (biol.).

individual (ǐn'dĭvĭd'ūăl) $a$. [L. in, not; dividuus, divisible.] Pert. a single example or unit, as individual variations of colour (biol.) ; n. a person or zooid of distinctive function of a hydrozoan colony (zool.).

individualism (ĭn'dǐvĭd'ūălǐzm) $n$. [L. in, not; dividuus, divisible.] Symbiosis in which the two parties together form what appears to be a single organism (biol.).

individuation (în'dǐvǐdūā'shŭn), - development of interdependent functional units, as in colony formation (biol.).

induced movement,-movement dictated and influenced by external stimulus, as plant curvature (bot.).

inductive stimulus, - an external stimulus which influences the growth or behaviour of any organism (biol.).

indumentum (ǐn'dūměn'tŭm) $n$. [L. indumentum, covering.] The plumage of birds; a hairy covering (zool.).

induplicate (indū'plīkāt) a. [L. in, in ; duplex, double.] In vernation having bud-leaves bent or rolled without overlapping ; in aestivation having bud sepals or petals folded inwards at points of contact (bot.).

induplieative (indü'plikãtǐv) a. [L. in, in; duplex, double.] Appl. vernation or aestivation with induplicate foliage or floral leaves respectively (bot.).

indusial (indü'ziăl) a. [L. induere, to put on.] Containing larval insect cases, as certain limestones (pal.); pert. the indusium (bot.).

indusiate (indū'ziāt) a. [L. induere, to put on.] Having an enveloping case, appl. insect larvae (zool.); having an indusium (bot.).

indusiform (indü'zífôrm) $a$. [L. induere, to put on ; forma, shape.] Resembling an indusium (bot.).

indusium (Iัndū'žŭm) $n$. [L. induere, to put on.] An insect larva case (zool.) ; an outgrowth of plant epiderm covering and protecting a sorus (bot.) ; the supracallosal gyrus of the olfactory lobe of the cerebrum, the indusium griseum (anat.).

induviae (Indū'viē) $n$. plu. [L.induere, to put on.] Scale-leaves, or those which remain attached to stem after withering (bot.).

induviate (indū'vǐăt) a. [L. induere, to put on.] Covered with scaleleaves or induviae (bot.).

inequilateral (ǐnĕk'wǐlăt'ěrăl) $a$. [L. in, not ; aequus, equal ; latus, side.] Having two sides unequal; having unequal portions on either side of a line drawn from umbo to gape of a bivalve shell (zool.).

inequilobate (Ǐněk'wı̌ló'bât) $a$. [L. in, not; aequus, equal ; Gk. lobos, lobe.] With lobes of unequal size (biol.).

inequivalve (iněk'wivălv) $a$. [L. in, not ; aequus, equal ; valvae, folding doors.] Having the two valves or halves of the shell unequal; $a p p l$. Mollusca (zool.).

inerm (İnĕrm') a. [L. in, not ; arma, arms.] Unarmed; without means of defence and offence (biol.).

inermous (iněr'mŭs) $a .$, -inerm.

inferior (infë'rǐrr) $a$. [L. inferior, lower.] $A p p l$. the lower placed of two, the farther down the axis; growing or arising below another organ (bot.).

inferoanterior (inn'fĕröăntē'riǒr) $a$. [L. inferus, beneath ; anterior, anterior.] Below and in front (biol.).

inferobranchiate (ĩn'fĕröbrăng'kīāt) $a$. [L. inferus, beneath ; Gk. brangchia, gills.] With gills under the margin of the mantle, as in certain Mollusca (zool.).

inferolateral (in'fĕrölăt'ěrăl) a. [L. inferus, beneath; latus, side.] Below and at or towards the side (zool.).

inferomedian (ĭn'fĕrömē' diăn) $a . \quad[\mathrm{L}$. 
inferus, beneath ; medius, middle.] Below and about the middle.

inferoposterior (Ǐn'fĕröpŏstē'rǐŏr) $a$. [L. inferus, beneath; posterior, behind.] Below and behind.

inferradial (inn'fĕrrā'dŭăl) $n$. [L. inferus, beneath; radius, radius.]

The lower part of transversely bisected radials of certain fossil Crinoids (pal.).

inflated (inflā'těd) a. [L. in, into ; flare, to blow.] Puffed out ; distended (bot.).

inflected (Inflěk'těd) a. [L. inflectere, to bend in.] Curved or abruptly bent inwards or towards the axis (biol.).

inflexed (inflĕk'sd) a.,-inflected.

infiorescence (inn'flörĕs'ěns) $n$. [L. inflorescere, to begin to blossom.] A flowering or putting forth blossoms ; the method in which flowers are arranged on an axis (bot.).

infraaxillary (Ǐn'frăăksǐlărǔ) $a$. [L. infra, below; axilla, armpit.] Branching off below the axil (bot.).

infrabasal (ĩn'frăbā'săl) n. [L. infra, below; basis, base.] One of a series of plates, perradial in position, below the basals in Crinoids (zool.). infrabranchial (ĩn'frăbrăng'kĭăl) $a$. [L. infra, below; Gk. brangchia, gills.] Below the gills; appl. part of the pallial chamber (zool.).

infracentral (in'frăsĕn'trăl) a. [L. infra, below; centrum, centre. Below a vertebral centrum (zool.). infraclavicle (in'frăklăv'îkl) n. [L. infra, below ; clavicula, little key.] A membrane bone occurring in the pectoral girdle of some Ganoids and Teleosts (zool.).

infraclavicular (ǐn'frăklăvǐk'ūlăr) $a$. [L. infra, below; clavicula, small key.] Beneath the clavicle; $a p p l$. branches of brachial plexus (anat.).

infracortical (in'frăkôr'tikăl) a. [L. infra, below; cortex, bark.] Beneath the cortex (anat.).

infracostal (ǐn'frăkŏs'tăl) a. [L. infra, below; costa, rib.] Beneath the ribs ; appl. muscles (anat.).

infradentary (ĭn'frăděn'tărī) $a$. infra, below; dens, tooth] the dentary bone (anat.). infraglenoid (in'frăglë'noid) a. [L. eidos, like.] Below the glenoid fossa ; $a p p l$. a tuberosity (anat.).

infrahyoid (in'frăhī'oid) $a$. [L. infra, below; Gk. hyoeides, Y-shaped.] Beneath the hyoid; $a p p l$. muscles (anat.).

infralabial (in'frălā'biăl) $a$. [L. infra, below ; labium, lip.] Beneath the lower lip (anat.).

inframarginal (Ǐn'frămâr'jĭnăl) a. [L. infra, below; margo, margin.] Under the margin, or marginal structure ; $a p p l$. a cerebral convolution (anat.) ; appl. certain plates on the carapace of Chelonians below the marginals; $a p p l$. the lower of two series of plates round the margin of stelleroid arms and discs (zool.).

inframaxillary (Ǐn'frămăksǐlăări) $a$. [L. infra, below; maxilla, jaw.] Situated beneath the maxilla; $a p p l$. nerves (zool.).

infraorbital (ĭn'frăôr'bǐtăl) a. [L. infra, below ; orbis, circle.] Beneath the orbit ; $a p p l$. artery, canal, foramen, groove, nerve, etc. (anat.).

infrapatellar (inn'frăpătěl'ăr) $a$. [L. infra, below ; patella, knee-cap.] $A p p l$. a pad of fat beneath the patella (anat.).

infrascapular (in'frăskăp'ūlăr) a. [L. infra, below; scapula, shoulderblade.] Beneath the scapula; $a p p l$. artery (anat.).

infraspinatous (ĭn'frăspī'nătŭs) $a$. [L. infra, below; spina, spine.] Beneath the spine; beneath the scapular spine; $a p p l$. muscle, fossa (anat.).

infraspinous, - infraspinatous.

infrastapedial (in'frăstăpē'dĭăl) $a$. [L. infra, below ; stapes, a stirrup.] Beneath the stapes of the ear; $a p p l$. a part of the columella (anat.).

infrasternal (in'frăstĕr'năl) a. [L. infra, below; Gk. sternon, breast.] Beneath the breast-bone; $a p p l$. notch at the lower end of the sternum (anat.).

infratemporal (İn'frătěm'pörăl) $a$. [L. infra, below ; temporalis, temporary.] Beneath the temporal bone ; $a p p l$. a crest or fossa (anat.).

infratrochlear (in'frătrŏk'lěăr) $a$. [L. infra, below ; Gk. trochos, wheel.] 
Beneath the trochlea ; $a p p l$. a nerve (anat.).

infructescence (ĭn'frŭktĕs'ĕns) $n$. [L. in, into; fructus, fruit.] An inflorescence matured into a fruit (bot.).

infundibular (ĭn'fündǐb'ūlăr) $a$. [L. infundibulum, funnel.] Funnelshaped; $a p p l$. an abdominal muscle (anat.); appl. a funnel-shaped corolla (bot.).

infundibuliform (inn'fŭndı̌b'ülǐfôrm) $a$. [L. infundibulum, funnel; forma, shape.] Infundibular.

infundibulum (ǐn'fündỉb'ülŭm) $n . \quad[\mathrm{L}$. infundibulum, funnel.] Any funnelshaped organ or structure; $a p p l$. part of the brain, of the ethmoid bone, of right ventricle, etc. (anat.); a cephalopod siphon; part of a bird's oviduct; the flattened stomach-like cavity of a Ctenophore, lying in the transverse plane (zool.).

infuscate (infüs'kāt) a. [L. in, into ; fuscus, dark.] Tinged to appear dark, as insect wings (zool.).

infusoriform (in'fūzō'rífôrm) a. [L. infusus, poured into; forma, shape.] Resembling an Infusorian; appl. embryonic forms of some Coelenterates (zool.).

infusorigen (ǐn'füzō'rǐjĕn) $n$. [L. infusus, poured into; genos, offspring.] A gastrula-like phase in development of certain Mesozoa (zool.).

ingest (injěst') v. [L. ingestus, taken in.] To convey food material into the alimentary canal or food-cavity (phys.).

ingestion (injěs'chŏn) $n$. [L. ingestus, taken in.] The swallowing or assumption of food-material (phys.).

ingluvies(ingloov'iěz) $n$. [L.ingluvies, crop.] The crop of a bird ; a dilatation of the oesophagus (zool.).

inguinal (ing'gwǐnăl) a. [L. inguen, the groin.] In the region of the groin (anat.).

inguinal ring, - see abdominal ring.

inguino-abdominal (ing'gwinö-ăbdŏm'inăl) $a$. In region of abdomen and groin (anat.).

inguino-cruxal (Ǐng'gwinö-kroorăl) $a$. In region of groin and leg (anat.).

inhalent (Inhä'lěnt) $a$. [L. in, into ; halare, to breathe.] Adapted for inspiring or drawing in, as terminal pores of incurrent canals in Sponges, or siphons in Molluscs (zool.).

inhibition (ǐn'hỉbǐsh'ǒn) $n$. [L. inhibere, to prohibit.] Prohibition or checking of an action already commenced (phys.).

inhibitory (inhỉb'ítörí) a. [L. inhibere, to prohibit.] Appl. nerves which control movement or secretion (phys.).

inion (in'ionn) $n$. [Gk, inion, back of head.] The external protuberance of the occipital (anat.).

ink sac,-in Sepia, a pear-shaped body in the wall of the mantle cavity which secretes a black substance, ink or sepia, the ejection of which is a means of defence (zool.). innate (Iัn'nāt) a. [L. in, in ; gnatus, born.] Basifixed; appl. anther when filament is only attached to its base (bot.).

innervation (ĭn'nĕrvā'shŭn) $n$. [L. in, into; nervus, sinew.] Nervedistribution (anat.); vital nerve force (phys.).

innominate (innoัm'innāt) a. [L. in, not; nomen, name.] Nameless; $a p p l$. various arteries and veins (anat.).

innominate bone,-the hip-bone or lateral half of the pelvic girdle (anat.).

innovation ('̌n'övā'shŭn) $n$. [L. innovare, to renew.] A growth or shoot of Mosses which develops into a new plant by the dying-off of the portion of the parent-plant behind it (bot.).

inocular (Innǒk'úlăr) a. [L. in, into ; oculus, eye.] Appl. antennae inserted close to the eye (zool.).

inogen (i'nöjĕn) $n$. [Gk. is, fibre ; genos, offspring.] A nitrogenous substance of muscle tissue (phys.).

inotagmata (înötăg'mătă) n. plu. [Gk. is, fibre; tagma, arrangement.] Ultimate hypothetical units (phys.).

inquiline (ǐn'kwilīn) $n$. [L. inquilimus, tenant.] An animal living in the home of another and getting share of its food; a partner in commensalism (zool.).

inscriptions, tendinous,-term $a p p l$. three fibrous bands crossing the rectus abdominalis muscle (anat.). 
insectivorous (in'sěktǐv'örŭs) $a$. [L. insectus, cut off ; vorare, to devour.] Insect-eating; $a p p l$. certain animals and carnivorous plants.

inserted (insĕr'tĕd) a. [L. in, in ; serere, to join.] United by natural growth.

insertion (Insĕr'shŭn) $n$. [L. insertus, joined.] Point of attachment of organs, muscles; the point on which the force of a muscle is applied (anat.).

insessorial (Ĭn'sěsō'rǐăl) a. [L. in, in ; sedere, to sit.] Adapted for perching (zool.).

insistent (ĭnsĭs'tĕnt) a. [L. insistere, to persist.] $A p p l$. hind toe of certain birds whose tip only reaches the ground (zool.).

inspiration (inspĭrā'shŭn) $n$. [L. inspirare, to inhale.] The act of drawing air into the lungs (phys.).

instaminate (instăm'innāt) a. [L. in, not ; stamen, something standing.] Not bearing stamens (bot.).

instar (ĩn'stăr) $n$. [L. instar, form.] Each stage in insect metamorphosis where a moult occurs (zool.).

insula (ĭn'sūlă) $n$. [L. insula, island.] A triangular eminence lying deeply in the lateral fissure of the temporal lobe (anat.).

integrifolious (intěg'rĭfō'liŭs) a. [L. integer, whole ; folium, leaf.] With entire leaves (bot.).

integripallial (intěg'rịăl'uăl) $a$. See integripalliate.

integripalliate (intěg'rípăl'ıāt) $a$. [L. integer, whole; pallium, mantle.] Having an unbroken pallial line ; $a p p l$. shells of Molluscs with small or no siphons (zool.).

integument (intěg'ümĕnt) $n$. [L. integumentum, covering.] A covering, investing, or coating structure or layer; an investing layer of an ovule (bot., zool.).

interacinous (in'těrăs'ínŭs) $a$. [L. inter, between; acinus, a grape.] Among the alveoli of a racemose gland (anat.).

interalveolar (in'těrălvēöolăr) $a$. [L. inter, among; alveolus, small cavity.] Among alveoli ; appl. cell islets (anat.).

interambulacral (ǐn'tĕrămbūlā'krăl) $a$.
[L. inter, between; ambulare, to walk.] Appl. area of echinoderm test between two ambulacral areas ; $n$. a plate of that area (zool.).

interambulacrum(ín'tĕrămbülā'krŭm) $n$. [L. inter, between; ambulare, to walk.] The area between two ambulacral areas (zool.).

interarticular (in'tĕrârtı̌k'uulăr) $a$. [L. inter, between ; articulus, a joint.] Between articulating parts of bones; $a p p l$. certain ligaments and fibrocartilages (anat.).

interatrial ('̌n'těrā'triăl) $a$. [L. inter, between; atrium, a hall.] Appl. a groove separating the two atria of the heart (anat.).

interauricular (în'těrôrǐk' ūlăr) $a$. [L. inter, between ; auricula, little ear.] Between the auricles of the heart (anat.).

interaxillary (ĭn'těrăksǔl'ărĭ) a. [L. inter, between; axilla, armpit.] Placed between the axils (bot.).

interbrachial (in'těrbrā'kiăl) $a$, [L. inter, between; brachium, arm.] Between arms, rays, or brachial plates (zool.).

interbranchial (in'tĕrbrăng'kĭăl) $a$. [L. inter, between; Gk. brangchia, gills.] $A p p l$. septum between successive gill slits (zool.).

interbreed ('̌n'těrbrēd') $v$. [L. inter, between; A.S. brod, brood.] To cross different varieties of plants or animals experimentally.

intercalare (ǐn'tĕrkălā'rē, -kălârā) n. [L. intercalaris, inserted.] In many Fishes and fossil Amphibia, an additional element in the neural $\operatorname{arch}(z \circ o l$.$) .$

intercalary (in'těrkăl'ărĭ, intĕr'kălărǐ) a. [L. intercalaris, inserted.] Additional ; appl. meristematic layers between masses of permanent tissue; growth elsewhere than at the growing point (bot.).

intercapitular (in'těrkăpît' ūlăr) $a$. [L. inter, between; capitulum, head.] Between the capitula; $a p p l$. veins of fingers (anat.).

intercarotid (inn'tĕrkărŏt'îd) $a$. [L. inter, between; Gk. karos, deep sleep.] Between the two carotid arteries (anat.).

intercarpal (ǐn'těrkâr'păl) a. [L. inter, between ; carpus, wrist.] Among 
or between the carpal bones; $a p p l$. joints (anat.).

intercarpellary (ın'těrkârpěl'ărǐ) $a$. [L. inter, between; Gk. karpos, fruit.] Between the carpels (bot.).

intercartilaginous (inn'těrkârtìlăj'inŭs) a. [L. inter, between; cartilago, gristle.] Within the cartilage ; $a p p l$. ossification (emb.).

intercavernous (̌n'těrkăv'ěrnŭs) $a$. [L. inter, between ; cavus, hollow.] $A p p l$. sinuses connecting the cavernous sinuses, part of the ophthalmic veins (anat.).

intercellular (ïn'tĕrsĕl'ūlăr) $a$. [L. inter, between ; cellula, little cell.] Among or between cells, as the biliary passages among the livercells (anat.).

intercentral (Ǐn'tĕrsěn'trăl) a. [L. inter, between; centrum, centre.] Uniting two centra; between two centra (anat.).

intercentrum ('in'tĕrsĕn'trŭm) n. [L. inter, between ; centrum, centre.] A second central ring in an embolomerous vertebra (zool.).

interchondral (inn'tĕrkǒn'drăl) a. [L. inter, between ; Gk. chondros, cartilage.] $A p p l$. articulations and ligaments between the costal cartilages (anat.).

interclavicle (̌n'těrklăv'îkl) $n$. [L. inter, between; clavicula, small key.] The episternum; a median ventral bone between the clavicles (zool.).

interelavicular (ĩn'tĕrklăvǐk'úlăr) $a$. [L. inter, between ; clavicula, small key.] Between the clavicles; $a p p l$. a ligament (anat.).

interclinoid (in'těrklînnoid) a. [L. inter, between; Gk. kline, bed; eidos, like.] A fibrous process joining the anterior and posterior clinoid processes (anat.).

intercolumnar (ǐn'těrkǒlŭm'năr) $a$. [L. inter, between ; columna, column.] Between columnar structures, as certain abdominal muscle fibres (anat.).

intercondyloid (inn'těrkŏn'dǔloid) $a$. [L. inter, between; Gk. kondylos, knob ; eidos, resemblance.] Between the condyles; $a p p l$. an eminence of the tibia, and fossae of the femur (anat.). intercostal (ĩn'těrkŏs'tăl) a. [L. inter, between ; costa, rib.] Between the ribs, as arteries, glands, membranes, nerves, veins, muscles (anat.).

intercostolorachial (in'těrkǒs'töbrā'kiăl) a. [L. inter, between ; costa, rib; brachium, arm.] Appl. a lateral branch of the second intercostal nerve which supplies the upper arm (anat.).

intercostohumeral (inn'tĕrkŏs'töhü'mĕrăl) $a$. [L. inter, between ; costa, rib ; humerus, the humerus.] Intercostobrachial.

intercoxal ('̌n'těrkǒk'săl) a. [L. inter, between ; coxa, the hip.] Between the coxae or first-limb joints of Arthropods (zool.).

intercrescence (Ǐn'tĕrkrěs'ěns) $n . \quad[\mathrm{L}$. inter, between ; crescere, to grow.] A growing into each other, as of tissues.

intercrural (in'tĕrkroo'răl) a. [L. inter, between; crus, the leg.] $A p p l$. tendinous fibres arching across the external oblique muscles (anat.).

intercuneiform (in'těrkūnē'îfôrm) $a$. [L. inter, between; cuneus, wedge ; forma, shape.] Connecting the three cuneiform bones of the ankle; $a p p l$. articulations and ligaments. (anat.).

interdeferential (in'těrděfěrěn'shăl) a. [L. inter, between; de, down; ferre, to carry.] Between the vasa deferentia (zool.).

interfascicular (ǐn'tĕrfăsǐk'ūlăr) $a$. [L. inter, between; fasciculus, small bundle.] Situated between the fascicles or vascular bundles (bot.).

interfemoral (inn'tĕrfĕm'örăl) $a$. [L. inter, between ; femur, thigh bone.] Between the thighs (anat.).

interfertile (Ǐn'těrfĕr'tǐl) $a$. [L. inter, between; fertilis, fertile.] Able to interbreed (biol.).

interfllamentar (inn'tĕrfillăměn'tăr) $a$. [L. inter, between; filamentum, thread.] Appl. junctions or horizontal bars connecting molluscan gill filaments (zool.).

interfllar (ĭn'tĕrfíllăr) a. [L. inter, between; filum, thread.] Appl. the ground substance of protoplasm, as opposed to the reticular (cyt.).

interfoliaceous (In'tĕrfōliā'shŭs) $a$. 
[L, inter, between ; folium, leaf.] Situated or arising between two opposite leaves (bot.).

interfoliar (In'těrfó'liăr) $a$. Interfoliaceous.

interganglionic ('̌n'těrgăngglión'îk) $a$. [L. inter, between ; Gk. gangglion, a little tumour.] Connecting two ganglia, as nerve cords or strands (anat.).

intergenital (ǐn'těrjěn'îtăl) a. [L. inter, between ; genitus, produced.] Between the genitals ; appl. certain echinoderm plates (zool.).

interglobular (Inn'tĕrglŏb'ûlăr) $a, \quad[\mathrm{~L}$, inter, between; globulus, small globe.] $A p p l$. a series of spaces towards the outer surface of dentine due to imperfect calcification (anat.).

intergular (ïn'těrgū'lăr) n. [L. inter, between ; gula, gullet.] A paired or unpaired plate in front of the gulars in Chelonia (zool.).

interhyal (ǐn'tĕrhīăl) $n$. [L. inter, between ; Gk. hyoeides, Y-shaped.] A small bone between hyomandibular and rest of hyoid of some higher vertebrates (zool.).

interlamellar (in'těrlămělăr) $a . \quad[\mathrm{L}$. inter, between ; lamella, a plate.] $A p p l$. vertical bars of tissue joining the gill lamellae of Molluscs (zool.).

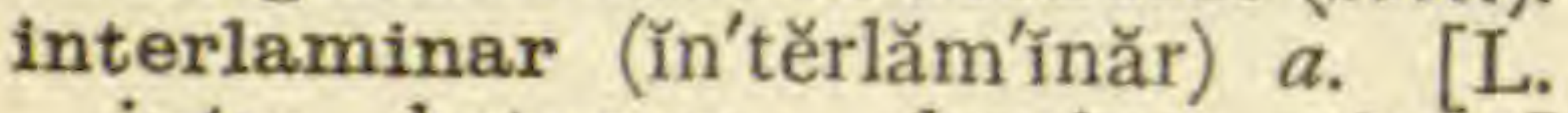
inter, between; lamina, plate.] Uniting laminae ; between laminae (anat.).

interlobular (Iñ'tĕrlŏb'ūlăr) $a . \quad[\mathrm{L}$. inter, between; lobus, lobe.] Occurring between lobes; appl. kidney arteries, etc. (anat.).

interlocular ('n'tĕrlók'úlăr) $a$. [L. inter, between; loculus, small place.] Between the loculi (bot.).

interloculus (in'tĕrlŏk'ülüs) $n, \quad[\mathrm{~L}$. inter, between ; loculus, compartment.] The space between two loculi (bot.).

intermandibular (inn'těrmăndǐb'úulăr) a. [L. inter, between; mandibulum, jaw.] Between mandibles or rami (anat.).

intermaxilla (ǐn'těrmăksīlăa) n. [L. inter, between; maxilla, jaw.] Bone between the maxillae; the premaxilla (anat.).

intermaxillary (In'těrmăksǐlărǐ)
[L. inter, between ; maxilla, jaw.] Between the maxillae; pert. the premaxillae; $a p p l$. a gland in the nasal septum of certain Amphibians and Reptiles (zool.).

intermediary (in'těrmē'duărǐ) $a$. [L. inter, between; medius, middle.] Acting as a medium; $a p p l$. nervecells receiving impulses from afferent cells and transmitting them to efferent cells (phys.).

intermediate (in'těrmé'dīăt) a. [L. inter, between; medius, middle.] Occurring between two points or parts ; $a p p l$. a nerve-mass (emb.); $a p p l$. certain areas of the brain (phys.); appl. a disc in striated muscle (anat.).

intermediate host, - the host intervening between two others in the life-history of certain parasites, as Limnaeus in the life-history of Distomum (zool.).

intermedium (ǐn'těrmē'dǔum) $n$. [L. inter, between; medius, middle.] A small bone of carpus and tarsus (anat.).

intermesenteric (Ǐn'těrměs'ěntěr'ík) $a$. [L. inter, between; Gk. mesos, middle; enteron, gut.] Occurring between the mesenteries; $a p p l$. spaces between the mesenteries in sea-anemones (zool.).

intermuscular (ĩn'těrmŭs'kūlăr) $a$. [L. inter, between; musculus, muscle.] Between or among muscle fibres (anat.).

internal (intěr'năl) a. [L. internus, within.] Located on the inner side; nearer the middle axis (biol.).

internal secretion gland,-a ductless gland, e.g. spleen (phys.).

internasal (İn'těrnā'zăl) a. [L. inter, between; nasus, nose.] Between the nostrils ; appl. septum, gland (zool.).

interneural ('̌n'těrnü'răl) $a$. [L. inter, between; Gk. neuron, nerve.] Between neural processes, arches or spines (anat.); appl. sharp bones attached to dorsal fin rays (zool.).

internodal (ĩn'těrnō'dăl) a. [L. inter, between; nodus, knot.] Pert. the part between two nodes (bot., phys.).

internode ('̌n'tĕrnōd') n. [L. inter, between; nodus, knot.] A structure between two nodes or joints ; as of 
a stem (bot.), of a nerve fibre (phys.).

internodia (ǐn'těrnō'dĭă) $n$.plu. Phalanges.

interocular ('̌n'tĕrŏk'ūlăr) $a$. [L. inter, between; oculus, eye.] Placed between the eyes (zool.).

interopercle (ĭn'tĕröpĕr'kl) $n$. [L. inter, between ; operculum, lid.] A membrane bone of the operculum of Teleostomes attached to the mandible (zool.).

interopercular bone,-the interoperculum.

interoperculum (inn'tĕröpĕr'kūlŭm). Interopercle.

interoptic (Ǐn'tĕrŏp'tîk) a. [L. inter, between ; Gk. optikos, pert. sight.] Between the optic lobes (anat.).

interorbital (In'těrôr'bĭtăl) a. [L. inter, between ; orbis, circle.] Between the orbits; $a p p l$. septum of a trophibasic skull; appl. sinus (zool.).

Interosculant (ǐn'tĕrŏs'kūlănt) a. [L. inter, between ; osculari, to kiss.] Possessing characters common to two or more groups or species (biol.).

interosseous (In'těrŏs'ěŭs) a. [L. inter, between; os, bone.] Occurring between bones; appl. arteries, membranes, muscles, nerves (anat.).

interparietal (ǐn'tĕrpări'ětăl) $a$. [L. inter, between; paries, wall.] In many vertebrates a bone arising between the parietals and supraoccipital (anat.).

interpeduncular (inn'těrpědŭng'kūlăr) a. [L. inter, between ; pedunculus, little foot.] Appl. a fossa between the cerebral peduncles; and also a ganglion (anat.).

interpetaloid (inn'těrpĕt'ăloid) a. [L. inter, between ; Gk. petalon, petal ; eidos, resemblance.] Between the petaloid areas of an echinoderm test (zool.).

interpetiolar (ǐn'tĕrpĕt'îölăr) $a$. inter, between ; petiolus, little foot.] Situated between the petioles or bases of opposite leaves (bot.).

interphalangeal (inn'tĕrfălăn'jềăl) $a$. [L. inter, between; Gk. phalanx, line of battle.] $A p p l$. articulations between successive phalanges (anat.). interplacental (Ǐn'těrplăsĕn'tăl) $a$. [L. inter, between ; placenta, flat plate.] Between placentae (bot.).

interpleural (in'tĕrploo'răl) $a$. [L. inter, between ; Gk. pleuron, side.] Between pleurae (anat.).

interpubic (in'tĕrpū'bǔk) $a$. [L. inter, between; pubis, mature.] $A p p l$. the fibrocartilaginous lamina between the pubic bones (anat.).

interradial (ǐn'těrrā'dǐăl) a. [L. inter, between; radius, radius.] Pert. an interradius (zool.).

interradium (in'těrrā'dŭŭm) $n$. [L. inter, between; radius, radius.] The area between two radii of any radially symmetrical animal (zool.).

interradius (Iัn'tĕrrā'diǔs) $n$. [L. inter, between; radius, radius.] The radius of a radiate animal halfway between two perradii (zool.).

interramal (in'tĕrrā'măl) a. [L. inter, between; ramus, branch.] Between branches or rami (biol.).

interramicorn (Ǐn'těrrăm'îkôrn) $n$. [L. inter, between; ramus, branch; cornu, horn.] A piece of a bird's bill beyond the mandibular rami forming the gonys (zool.).

interrenal (in'těrrē'năl) a. [L. inter, between; renes, kidneys.] Between the kidneys; $a p p l$. veins and adrenal organs of uncertain function in most vertebrates (zool.).

interrupted (In'těrrŭp'těd) $a$. [L. inter, between ; rumpere, to break.] Unsymmetrical; with continuity broken ; irregular (bot.).

interruptedly pinnate, - pinnate with pairs of small leaflets occurring between larger ones (bot.).

interscapular (Ǐn'tĕrskăp'ūlăr) $a$. [L. inter, between ; scapula, shoulderblade.] Between the shoulderblades; appl. feathers (zool.).

interseptal (in'tĕrsĕp'tăl) a. [L. inter, between ; septum, division.] Pert. spaces between septa or partitions.

interspicular (ĩn'těrspìk'ūlăr) $a$. [L. inter, between; spiculum, sharp point.] Occurring between spicules (zool.).

interspinal (in'těrspínăl) a. [L. inter, between ; spina, spine.] Occurring between spinous processes or between spines ; $a p p l$. bones, muscles (anat.). 
interspinous (ĭn'tĕrspīnŭs) $a$. Interspinal.

interstapedial (Ǐn'tĕrstăpē'dŭlă) a. [L. inter, between; stapes, stirrup.] Appl. a part of the columella of the ear (anat.).

intersterility (in'těrstěril'ítı̌) $n$. [L. inter, between ; sterilis, unfruitful.] Incapacity for interbreeding (biol.).

intersternal (ĭn'tĕrstĕr'năl) a. [L. inter, between ; Gk. sternon, breastplate.] Between the sterna (zool.); $a p p l$. ligaments connecting the manubrium and body of sternum (anat.).

interstitial (in'těrstǐsh'ăl) $a$. [L. inter, between; sistere, to set.] Occurring in interstices or spaces; $a p p l$. cells within tissues.

intertemporal (ĭn'těrtĕm'pörăl) $n$. [L. inter, between ; temporalis, temporary.] A paired membrane bone, part of the sphenoid complex, fusing with the alisphenoids (zool.).

intertentacular (in'tĕrtěntăk'ūlăr) $a$. [L. inter, between; tentaculum, a feeler.] Between the tentacles; $a p p l$. a ciliated tube opening at the base of the tentacles and connecting coelom and the exterior, found in the Molluscoida (zool.).

intertidal (ĭn'tĕrtī'dăl) a. [L. inter, between; A.S. tid, time.] Appl. shore animals and plants living between high- and low-water marks (biol.).

intertrochanteric (in'tĕrtrökăntĕr'îk) a. [L. inter, between; Gk. trochanter, a runner.] Between the trochanters; $a p p l$. crest, and line (anat.).

intertrochlear (inn'tĕrtrǒk'lě̆r) $a$. [L. inter, between; Gk. trochos, wheel.] $A p p l$. an ulnar ridge fitting into a groove of the humerus (anat.).

interventricular (in'těrvěntrīk' ülăr) $a$. [L. inter, between ; ventricula, small cavity.] Between the ventricles; $a p p l$. a foramen (anat.).

intervertebral (in'těrvěr'těbrăl) $a$. [L, inter, between; vertebra, vertebra.] Occurring between the vertebrae; $a p p l$. fibrocartilages, foramina, veins, discs (anat.).

intervillous (inn'těrvǐl'ŭs) a. [L. inter, between; villi, hairs.] $A p p l$. the spaces in the trophoblastic network filled with maternal blood (emb.); occurring between villi (anat., zool.).

interzonal (ĭn'tĕrzō'năl) $a$. [L. inter, between; zona, belt.] Between two zones; appl. spindle fibres uniting groups of daughter chromosomes in the anaphase of mitosis (cyt.).

interzooecial (ı̆n'těrzōē'shǔăl) a. [L. inter, between ; zoon, animal ; oikos, house.] Occurring among zooecia (zool.).

intestinal (intěs'tĭnăl) a. [L. intestinus, internal.] Pert. the intestines; $a p p l$. arteries, glands, villi, etc. (anat.).

intestine (intěs'tĭn) $n$. [L. intestimus, internal.] That part of the alimentary canal from pylorus to anus, or the part corresponding to this in lower forms (zool.).

intextine (intĕk'stǐn) $n$. [L. intus, within; exter, without.] An inner membrane of an extine (bot.).

intima (Ǐn'tĭmă) $n$. [L. intimus, innermost.] The innermost lining membrane of a part or organ (anat.).

intine (in'tinn) $n$. [L. intus, within.] The inner covering membrane of a pollen grain (bot.).

intrabiontic (in'trăbīŏn'tǐk) a. [L. intra, within ; Gk. bios, life ; onta, being's.] Appl. a process of selection occurring in a living unit (phys., biol.).

intracapsular (Ǐn'trăkăp'sūlăr) $a$. [L. intra, within; capsula, small chest.] Contained within a capsule, as the protoplasm of Radiolarians (biol.).

intracardiac (ǐn'trăkâr'dǐăk) $a$. [L. intra, within ; Gk. kardia, heart.] Within the heart (zool., anat.).

intracartilaginous (In'trăkâr'tịlăj'inŭs) a. [L. intra, within; cartilago, gristle.] Inside the cartilage ; appl. ossification (emb.).

intracellular (Inn'trăsěl'ūlăr) a. [L. intra, within; cellula, little cell.] Within the cell (biol., phys.).

intracortical (in'trăkôr'tǐkăl) $a$. [L. intra, within ; cortex, rind.] Uniting parts of the brain cortex, or within it (anat.).

intrafascicular (in'trăfăsǐk'ūlăr) $a$. [L. intra, within; fasciculus, little bundle.] Within a vascular bundle (bot.).

intrafoliaceous (ĩn'trăfōliā'shŭs) $a$. 
[L. intra, within ; folium, leaf.] $A p p l$. stipules encircling the stem and forming a sheath; $c f$. ochrea (bot.).

intrafusal (in'trăfü'săl) $a$. [L. intra, within; fusus, poured.] $A p p l$. fasciculi and fibres connected respectively with neurotendinous and neuromuscular spindles (anat.).

intraglobular (inn'trăglŏb'ūlăr) $a$. [L. intra, within ; globus, globe.] Occurring within a globule or corpuscle (phys.).

intrajugular (ǐn'trăjoog'ūlăr) $a$. [L. intra, within; jugulum; throat.] $A p p l$. a bony spicule or process in the middle of the jugular notch (anat.).

intralamellar (inn'trălăměl'ăr) $a$. [L. intra, within ; lamella, thin plate.] Within a lamella; $a p p l$, the trama of gill-bearing Fungi (bot.).

intralobular (ĭn'trălŏb'ūlăr) $a$. [L. intra, within ; lobulus, small lobe.] Occurring within lobules; appl. veins draining the liver lobules (anat.).

intramembranous (inn'trămĕm'brănŭs) a. [L. intra, within; membrana, film.] $A p p l$. bone developed in membrane (anat.).

intramolecular (in'trămǒlěk'ūlăr) $a$. [L. intra, within; F. molécule, small particle.] Appl. plant respiration from the splitting up of complex substances within the cell (bot.).

intranuclear (inn'trănū'klě̌r ) $a$. [L. intra, within; nucleus, kernel.] Within the nucleus; $a p p l$. spindles, fibres, etc. (cyt.).

intraparietal (In'trăpăríětăl) $a$. [L. intra, within; paries, wall.] Enclosed within the walls of an organ ; within the parietal lobe, as sulcus, fissure, etc. (anat.).

intrapetalous (in'trăpĕt'ălŭs) a. [L. intra, within; Gk. petalon, petal.] Situated in a petaloid area, in Echinoderms (zool.).

intrapetiolar (inn'trăpĕt'iölăr) $a$. [L. intra, within ; petiolus, little foot.] Within the petiole base expansion (bot.),

intrapleural (in'trăploo'răl) a. [L. intra, within ; Gk. pleuron, side.] Within the thoracic cavity.

intraselection (in'trăsělěk'shŭn) $n$.
[L. intra, within; selectus, chosen.] Selection within an organ of cells fittest to survive.

intrastelar (in'trăstē'lăr) a. [L. intra, within; stele, pillar.] Within the stele of a stem or root; appl. ground tissue, bundles, etc. (bot.).

intratarsal (in'trătâr'săl) a. [L. intra, within ; tarsus, ankle.] Within the tarsus; $a p p l$. joint of reptilian limb between the rows of tarsal bones (zool.).

intrathyroid (in'trăthī'roid) a. [L. intra, within; Gk. thyreos, shield ; eidos, like.] Appl. a cartilage joining the laminae of the thyroid cartilage during infancy (anat.).

intrauterine (in'trăū'těrīn) $a$. [L. intra, within; uterus, womb.] Developing or passed within the uterus (emb.).

intravaginal (Ǐn'trăvăj'ínăl) a. [L. intra, within ; vagina, sheath.] Within the vagina (zool.); contained within a sheath, as grass branches (bot.).

intravascular (inn'trăvăs'kūlăr) $a$. [L. intra, within; vasculum, small vessel.] Within the blood-vessels (anat.).

intraventricular (in'trăvĕntrǐk'ūlăr) a. [L. intra, within ; ventriculus, small cavity.] Appl. the caudate nucleus of the corpus striatum, seen within the ventricle of the brain; within a ventricle (anat.).

intravesical (in'trăvěs'íkăl) $a$. [L. intra, within; vesica, bladder.] Within the bladder (anat.).

intravitelline (inn'trăvĩtěl'în) a. [L. intra, within ; vitellus, egg-yolk.] Within the yolk of an egg (emb.).

intraxylary (in'trăzì'lărî) $a$. [L. intra, within; Gk. xylon, wood.] Within the wood or xylem (bot.).

intrinsic (intrīn'sìk) a. [L. intrinsecus, inwards.] Appl. inner muscles of tongue; opp. extrinsic (anat.).

introitus (intrō'itŭs) n. [L. intro, within; ire, to go.] An opening or orifice (anat.).

intromittent ('̌n'trömìt'ĕnt) a. [L. intro, within ; mittere, to send.] Adapted for inserting; $a p p l$. male copulatory organs (zool.).

introrse (intrôrs') a. [L. intro, within ; versus, turned.] Turned inwards 
or towards the axis; of anthers, opening on the side next the pistil (bot.).

introvert (in'trövěrt) $n$. [L. intro, within; vertere, to turn.] That which is capable of involution, as the anterior region of the body of certain zooids, of certain Annulates, the mouth extremity of certain Molluscs (zool.); v. to turn, bend, or draw inwards (biol.).

intussusception (ǐn'tŭssŭsĕp'shŭn) $n$. [L. intus, within; suscipere, to receive.] Growth in surface-extent or volume by intercalation of particles among those already present (biol.).

inulase (inn'ūlās) $n$. [L. inula, the plant elecampane.] A ferment of plants which acts on inulin (bot.).

inulin (Ǐn'ülīn) $n$. [L. inula, the plant elecampane.] A form of starch found in plant-cell sap (bot.).

invaginate (ĭnvăj'ināt) v. [L. in, into ; vagina, sheath.] To involute or draw into a sheath; appl. the insinking of a wall of a cavity or vessel apparently reducing the original cavity and leaving a new cavity or groove visible on the exterior (zool., bot.).

invagination (invăj'înā'shŭn) $n$. [L. in, into ; vagina, sheath.] Involution; introversion ; gastrula-formation by infolding of the blastula wall (zool.).

invertase (Invĕr'tās) n. [L. invertere, to turn into.] A ferment of plants which acts on cane sugar (bot.).

invertebrate (invěr'těbrāt) $a$. [L. in, not ; vertebra, joint.] Back-boneless; without spinal column.

investing bones,-membrane bones.

investment (invěst'měnt) $n$. [L. in, in ; vestire, to clothe.] The outer covering of a part, organ, animal, or plant.

involucel (ĩnvǒl'ūsěl) $n$. [Dim. of L. involucrum, covering.] The small bracts at the base of a secondary umbel; a partial involucre (bot.).

involucellate (Invvơl' '̌sěllāat) $a$. [Dim. of L. involucrum, covering.] Bearing involucels (bot.).

involucral (inn'vǒlū'krăl) a. [L. involucrum, covering.] Pert. or like an involucre (bot.).

involuerate (in'vǒlu'krāt) a. [L. in- volucrum, covering.] Bearing involucres (bot.).

involucre (In'vŏlü'kër) n. [L. involucrum, covering.] Bracts at the base of chief branches of compound umbels (bot.).

involucrum (in'vŏlū'krŭm) $n$. [L. involucrum, covering.] In Hydromedusae, the protective cup into which nematocysts can be spirally retracted ; the metanotum of Orthoptera (zool.); an involucre (bot.). involuntary (invǒl'ǔntărǐ) a. [L. in, not ; voluntas, a wish.] Not under control of the will; appl. certain plain unstriped muscles, as of the alimentary canal, and to their movements (phys.).

involute (iัn'vǒlūt) a. [L. involutus, rolled up.] Of leaves, having the edges rolled inwards at each side (bot.); of shells, closely coiled (zool.).

involution (ĭn'vŏlū'shŭn) $n$. [L. involvere, to roll up.] Appl. forms that have become deformed in structure owing to unfavourable conditions, but not to such an extent as to be incapable of recovery if the conditions improve ; as the so-called "latent bodies" in the Haemoflagellate life - history (zool.).

iodothyrin (īō'döthī'run ) n. [Gk. iodes, violet; thyreos, shield.] An iodine compound in the colloid material of the thyroid gland (phys.).

iridial angle, - the filtration angle of the eye ; an angular recess at the anterior surface of the attached margin of the eye (anat.).

iridocytes (ir'ǐdösīts) n. plu. [L. iris, rainbow; Gk. kytos, hollow.] Guanin granules, bodies or plates, of which the reflecting tissue of the skin of Fishes is composed; iridescent cells in the integument of Sepia (zool.).

iridomotor (ǐr'ídömō'tŏr) a. [L. iris, rainbow ; movere, to move.] Connected with the movements of the iris (phys.).

iris (i'ris) n. [L. iris, rainbow.] A thin, circular, contractile disc suspended in the aqueous humour of the eye between the cornea and lens (anat.). 
irritability ('ir'ítăbil'ítì) $n$. [L. irritare, to provoke.] Power of receiving external impressions or stimuli, and reacting to them, inherent in living matter (phys.).

irritant (ir'itănt) $n$. [L. irritare, to provoke.] An external stimulus which provokes a response (phys.).

ischiadic ('̌s'kiăd'ĩk) $a$. Ischial.

ischial ( Is'kiăl) a. [Gk. ischion, a hip.] Pert. or in the region of the hip; $a p p l$. artery, vein (anat.).

ischiocapsular (Ǐs'kïökăp'sūlăr) $a$. [Gk. ischion, hip ; L. capsula, little chest.] $A p p l$. a ligament joining the capsular ligament and the hip (anat.).

ischiocavernous ('̌s'kiökăv'ĕrnŭs) $a$. [Gk. ischion, hip ; L. cavus, hollow.] Appl. muscle between the hip and the corpora cavernosa (anat.).

ischiopodite (ǐs'kiŏp'ödīt) n. [Gk. ischion, hip; pous, foot.] The proximal joint of the walking legs of certain Crustacea, or of the maxillipedes (zool.).

ischiopubic (is'kiöpü'bǐk) a. [Gk. ischion, hip ; L. pubis, adult.] Appl. a gap or fenestra between the ischium and pubis (anat.).

ischiopubis (1̌s'kiöpū'bǐs) $n$. [Gk. ischion, hip; L. pubis, adult.] The ischium of Pterodactyls, the pubis being excluded from the acetabulum; a fused ischium and pubis (zool.).

ischiorectal (is'kiörĕk'tăl) a. [Gk. ischion, hip ; L. rectus, straight.] Pert. ischium and rectum; appl. fossa and muscles (anat.).

ischium (is'kiŭm) n. [Gk. ischion, hip.] The ventral and posterior bone of each half of the pelvic girdle of Mammals ; an ischiopodite (zool.).

isidiferous (î́sǐdĭf'ĕrŭs) a. [Gk. isis, plant; L. ferre, to bear.] Bearing isidia (bot.).

isidioid (isid'ioid) a. [Gk. isis, plant ; eidos, like.] Like an isidium (bot.).

isidium (issid'ium) $n$, isidia (išrd'iă) plu. [Gk. isis, plant.] Coral-like soredia on the surface of some Lichens (bot.).

isidophorous (î́sĩdŏf'örŭs) $a$. [Gk. isis, plant ; pherein, to bear.] Isidiferous. islets of Langerhans,-spherical or oval bodies scattered throughout the pancreas, concerned in the metabolism of sugar in the body (phys.).

isobilateral symmetry,-the quality of leaves whose upper and lower surfaces are similar (bot.).

isocarpous (i'sökâr'pŭs) a. [Gk. isos, equal ; karpos, fruit.] Having carpels and perianth divisions equal in number (bot.).

isocercal (i'sösĕr'kăl) a. [Gk. isos, equal; kerkos, tail.] With vertebral column ending in median line of caudal fin (zool.).

isochela (i'sökē'lă) n. [Gk. isos, equal; chele, claw.] A chela with two parts equally developed (zool.).

isocytic (''sösìt'îk) a. [Gk. isos, equal; kytos, hollow.] With all cells equal (biol.).

isodactylous (î́södăk'tǔlŭs) a. [Gk. isos, equal; daktylos, finger.] Having all the digits of equal size (zool.).

isodiametric (î'södiămět'rǐk) a. [Gk. isos, equal ; dia, through ; metron, measure.] With cells or other structures of equal diameter (bot.).

isodont (i'södŏnt) a. [Gk. isos, equal; odous, tooth.] Having teeth all equal (zool.).

isodynamic (i'södĭnăm'îk) $a$. [Gk. isos, equal ; dynamis, power.] Of equal strength; appl. foods (phys.).

isogamete (i'sögămèt') n. [Gk. isos, equal ; gamos, marriage.] One of a pair of equal gametes, not differentiated from one another.

isogamous (īsŏgămŭs) a. [Gk. isos, equal; gamos, marriage.] Having the gametes alike (bot.).

isogamy (īsŏğămì) n. [Gk. isos, equal ; gamos, union.] Sexual union, or union of similar gametes (biol.).

isogenetic (î́söjĕnĕt'îk) a. [Gk. isos, equal ; genos, offspring.] Arising from the same or a similar origin (biol.).

isogenous (īsŏj'ěnŭs) $a$. Isogenetic. isognathous (īsǒg'năthŭs) a. [Gk. isos, equal; gnathos, jaw.] Having both jaws alike (zool.).

isomastigote (î'sömăs'tĭgōt) $a$ [Gk. isos, equal; mastix, whip.] Having 
the flagella of equal length (zool.).

isomere (i'sömër) n. [Gk. isos, equal; meros, part.] A homologous structure or part (zool.).

isomerous (īsŏm'ĕrŭs) a. [Gk. isos, equal; meros, part.] Having equal numbers of different parts; appl. flowers with the same number of parts in each whorl (bot.).

isomorphic (i'sömôr'fìk) a. [Gk. isos, equal ; morphe, shape.] Superficially alike (biol.).

isomorphism (i'sömôr'fĩzm) $n$. [Gk. isos, equal ; morphe, shape.] Apparent similarity of individuals of different race or species (biol.).

isomorphous (i'sömôr'füs) $a$. Isomorphic.

isopedine (îsŏp'ědïn) $n$. [Gk. isopedos, level.] A layer of compact bony material in certain fish scales (zool.).

isopetalous (î'söpět'ălǔs) a. [Gk. isos, equal ; petalon, petal.] Having similar petals (bot.).

isophytoid (î́,söfíttoid) a. [Gk. isos, equal; phyton, plant.] An "individual" or part of a compound plant not differentiated from the rest (bot.).

isopodous (îsŏp'ödŭs) a. [Gk. isos, equal ; pous, foot.] Having the legs alike and equal (zool.).

isopogonous (i'söpög'önŭs) a. [Gk. isos, equal; pogon, beard.] Of feathers having the two webs equal and similar (zool.).

isospore (i'söspōr') n. [Gk. isos, equal; sporos, seed.]. An agamete produced by schizogony; opp, anisospore (zool., bot.).

isosporous (îsŏs'pörŭs) a. [Gk. isos, equal; sporos, seed.] Having spores of one kind only (bot.).

isostemonous (î́söstěm'önŭs) $a$. [Gk. isos, equal ; L. stamen, standing.] Having stamens equal in number to that of sepals and petals (bot.).

isotely (isŏt'élí) $n$. [Gk. isos, equal ; telos, end.] The close resemblance in a homologous character, feature, or organ which has undergone subsequent modifications on a similar line although it may be in widely divergent groups (zool., bot.).

isotomy (īsŏt'ömĩ) n. [Gk. isos, equal ; temnein, to cut.] Bifurca- tion constantly repeated in a regular manner, as in crinoid brachia (zool.).

isotonic (i'sötŏn'îk) a. [Gk. isos, equal ; tonos, tone.] Of equal tension (phys.).

isotonicity (î'sötönǐs'îtĩ) $n$. [Gk. isos, equal ; tonos, tone.] Normal tension under pressure or stimulus (phys.).

isotropous (issŏt'röpŭs) a. [Gk. isos, equal ; trepein, to turn.] Not influenced in any one direction more than another (bot.); without predetermined axes, as in eggs (zool.).

isotropy (isŏt'röpĭ) $n$. [Gk. isos, equal ; trepein, to turn.] Absence of predetermined axes in eggs. (emb.).

isozoic ( $\overline{1}^{\prime}$ sözō'îk) a. [Gk. isos, equal ; zoon, animal.] Inhabited by similar forms of animal life (biol).

isozooid (î'sözōoid) $n$. [Gk. isos, equal ; zoon, animal ; eidos, like.] A zooid similar to the parent stock (zool.).

isthmiate ('̌s'miāt) a. [Gk. isthmos, neck.] Connected by an isthmuslike part.

isthmus ('̌s'mŭs) n. [Gk. isthmos, neck.] A narrow structure connecting two larger parts, as those of aorta, acoustic meatus, limbic lobe, thyroid, etc. (anat.).

iter ('̈́t'ĕr) $n$. [L. iter, way.] A passage or canal, as those of the middle ear, brain, etc. ; an aqueduct (anat.).

ivory (i'vörì) $n$. [L. ebur, ivory, through French.] Dentine of teeth, usually that of the elephant's tusks and similar structures, formed from the odontoblasts.<smiles>[C]1[CH]CCC1</smiles>

Jacobson's cartilage, - a special cartilage formed in the nose region, supporting Jacobson's organ.

Jacobson's organ, - a diverticulum of the olfactory organ in many vertebrates, often developing into an epithelium-lined sac which opens into the mouth. 
jaculator (jăk'ūlātoŏr) n. [L. jaculatus, thrown.] A placental process, usually hook-shaped, of certain fruits (bot.).

jaculatory (jăk'ūlătörì) $a$. [L. jaculatorius, throwing.] Darting out; capable of being emitted (zool.).

jaculatory duct, - a portion of the vas deferens in many animals, which is capable of being protruded (zool.).

jaculiferous (jăk'ūliff'ěrŭs) $a$. [L. jaculum, a dart ; ferre, to carry.] Bearing dart-like spines.

jaw (jô) n. [Akin to chaw, chere.]

A structure of vertebrates supported by bone or cartilage, naked or sheathed in horn, or bearing teeth or horny plates, forming part of the mouth, and helping to open or shut it; in invertebrates, a similarly placed structure.

jaw-bone,- the mandible.

jaw-foot, - a maxillipede of Arthropods (zool.).

jecorin (jĕk'örĭn) $n$. [L. jecur, liver.] A lecithin-like phosphorized substance present in many of the organs of the body in minute quantities, and soluble in ether (phys.).

jejunum (jējoon'ŭm) n. [L. jejunus, empty.] The part of the small intestine stretching from the duodenum to the ileum (anat.).

jelly of Wharton, - the mucoid tissue found in connection with the vessels of the umbilical cord (anat.).

jubate (joob'āt) a. [L. jubatus, maned.] With mane-like growth (zool.).

jugal (joog'ăl) $n$. [L. jugum, yoke.] The malar bone, between maxilla and squamosal.

jugate (joog'āt) a. [L. jugum, yoke.] Having pairs of leaflets (bot.); furnished with a jugum (zool.).

jugular (joog'ūlăr, jŭg-) $a$. [L. jugulum, a collar-bone.] Pert. neck or throat; $a p p l$. ventral fish-fins beneath and in front of pectoral fins (zool.).

jugulum (joog'ūlŭm, jŭg-) n. [L. jugulum, collar-bone.] The foreneck region of a bird's breast; in Insects, the jugum of the wing (zool.). jugum (joog'ŭm) n. [L.jugum, yoke.] A pair of opposite leaflets; a ridge on the mericarp of umbelliferous plants (bot.) ; a small forewing lobe of a very few moths with no frenulum (zool.) ; the union of the small sphenoidal wings in the first year after birth (anat.).

juice (joos) $n$. [L.jus, mixture.] The fluid contained in animal flesh or plant structure (phys.).

Jurassic (joorăs'îk) a. [Jura mountains.] Occurring in the middle Secondary rock-system, the eighth of the thirteen systems (pal.).

\section{K}

kakogenesis (kăk'öjĕn'ěsĭs) $n$. [Gk. kakos, bad; genesis, descent.] Inability to hybridize (biol.).

kalidium (kălĭd’ưum) n. [Dim. Gk. kalia, a hut.] A form of sporocarp (bot.).

kalymmocytes (kălĭm'ösîts) n. plu. [Gk. kalymma, covering; kytos, cell.] In Ascidians, certain folliclecells which migrate into the egg after maturation (zool.).

karyaster (kărǐăs'tër) n. [Gk. karyon, nucleus ; aster, star.] A star-shaped group of chromosomes (cyt.).

karyenchyma (kăr'íng'kìmă) $n$. [Gk. karyon, nucleus; engchyma, infusion.] Nuclear sap (cyt.).

karyogamy (kăr'ioğ'ămî) n. [Gk. karyon, nucleus; gamos, union.] Union and interchange of nuclear material (cyt.).

karyokinesis (kăr'iökǐnē'sǐs) $n$. [Gk. karyon, nucleus ; kinein, to change.] Indirect cell-division; mitosis (cyt.).

karyolymph (kăr'iölìmf') n. [Gk. karyon, nucleus ; L. lympha, water.] Nuclear sap (cyt.).

karyolysis (kăr'iol'ísǐs) $n$. [Gk. karyon, nucleus; lyein, to loosen.] Supposed dissolution of the nucleus in mitosis (cyt.).

karyomicrosome (kăr'iömï'krösōm) $n$, [Gk, karyon, nucleus; mikros, small ; soma, body.] A nuclear granule $(c y t$.), 
karyomite (kăr'ömīt') n. [Gk. karyon, nucleus; mitos, thread.] A chromosome (cyt.).

karyomitome (kăr'iömĭtōm') n. [Gk. karyon, nucleus ; mitoma, network.] Nuclear network of fibres (cyt.).

karyomitosis (kăr'îomĭtō'sĭs) $n$. [Gk. karyon, nucleus; mitos, thread.] Indirect nuclear division (cyt.).

karyon (kăr'ionn) n. [Gk. karyon, nucleus.] The cell-nucleus (cyt.).

karyophans (kăr'iöfănz') n. plu. [G,k. karyon, nucleus; phainein, to appear.] Microsomes or nucleuslike granules surrounded by an ovoid matrix, which form the spironeme and axoneme in stalk of Infusoria (cyt.).

karyoplasm (kăr'iöplăzm) $n$. [Gk. karyon, nucleus ; plasma, something moulded.] The nucleoplasm or nuclear substance $(c y t$.).

karyorhexis (kăr'iörěk'sǐs) $n$. [Gk. karyon, nucleus ; rexis, breaking.] Fragmentation of the nucleus (cyt.).

karyosome (kăr'ïösōm) n. [Gk. karyon, nucleus; soma, body.] One of the nucleoli of the "net-knot" type; a chromosome; a special aggregation of chromatin in the resting nucleus; the cell-nucleus itself ; $c f$. plasmosome (cyt.).

karyota (kărīótă) n. plu. [Gk. karyon, nucleus.] Nucleated cells.

karyotheca (kăr'öthē'kă) n. [Gk. karyon, nucleus ; theke, covering.] The nuclear membrane (cyt.).

katabolism (kătăb'ölǐzm) n. [Gk. kata, down ; ballein, to throw.] The destructive processes of metabolism (phys.).

kataphoric (kătăfơr'ik) a. [Gk, kata, down; pherein, to carry.] Appl. passive action, the result of lethargy (phys.).

kataplexy (kăt'ăplěk'sĩ) n. [Gk. kata, down; plessein, to strike.] Condition of an animal feigning death (phys.).

katastate (kătăs'tāt) n. [Gk. kata, down; stasis, state.] Any product of katabolic activity of protoplasm (phys.).

kathodic (kăthŏd'îk) a. [Gk. kathodos, descent.] Not arising in conformation to the genetic spiral; appl. leaves (bot.). kation (kătî́ŏn) n. [Gk. kata, down ; ienai, to go.] A positively charged ion which moves towards the kathode or negative pole; $o p p$. anion (phys.).

keel (kēl) $n$. [A.S. ceol, ship.] The carina or breast-bone of flying birds (zool.); the boat-shaped structure formed by the two anterior petals of the Leguminosae (bot.).

keraphyllous (kěráf'ílŭs) $a$. [Gk. keras, horn; phyllon, leaf.] Appl. layer of a hoof between the horny and sensitive parts.

keratin (kěr'ătǐn) n. [Gk. keras, horn.] An insoluble substance forming the basis of epidermal structures such as horns, nails (zool.).

keratinization (kĕrăt'innǐzä'shŭn) $n$. [Gk. keras, horn.] State of becoming horny; $a p p l$. cells of epiderm developing in a horny material (zool.).

keratogenous (kěrătǒj'ěnŭs) a. [Gk. keras, horn ; gignesthai, to produce.] Horn-producing (zool.).

keratoid (kĕr'ătoid) a. [Gk. keras, horn; eidos, resemblance.] Horny; resembling horn (zool.).

keratose (kěr'ătōs) a. [Gk. keras, horn.] Having horny fibres in their skeleton, as certain Sponges (zool.).

kernel (kër'nĕl) $n$. [A.S. cyrnel, a small grain.] The inner part of a seed containing the embryo (bot.).

kidney (kĭd'nǐ) n. [M.E. kidnere, kidney.] A urine-secreting organ (anat.).

kinaesthetic (kin'ěsthět'ik) a. [Gk. kinein, to move ; aisthesis, perception.] Pert. sense of muscular effort ; motorial ; appl. sense, area (phys.).

kinesodic (kin'êsŏd'îk) a. [Gk. kinesis, movement; odos, way.] Conveying motor impulses (phys.).

kinetic (kǐnět'îk) a. [Gk. kinein, to move.] Appl. energy employed in producing or changing motion (phys.); appl. division centre in cell-division (cyt.).

kinetoblast (kinē'töblăst) n. [Gk. kinein, to move; blastos, bud.] The outer ciliated investment of aquatic larvae with special locomotor properties (zool.). 
kinetogenesis (kinē'töjĕn'ěsǐs) $n$. [Gk. kinein, to move; gignesthai, to produce.] The evolution theory that animal structures have been produced by animal movements (biol.).

kinetonucleus (kĭnē'tönū'klěŭs) $n$. [Gk. kinein, to move; L. nucleus, kernel.] The secondary nucleus, in forms such as Trypanosomes, in close connection with the flagellum and undulating membrane; cf. trophonucleus (cyt.).

kinetoplasm (kǐnē'töplăzm) n. [Gk. kinein, to move; plasma, something formed.] An iron-containing nucleo-protein forming a source of energy to Nissl granules of nerve-cells (phys.).

kinoplasm (kinnöplăzm) n. [Gk. kinein, to move; plasma, something formed.] The substance of which attraction-sphere, astral rays, and spindle-fibres consist; archoplasm (cyt.).

klasma-plates (klăs'mă-plāts) n. plu. [Gk. klasma, fragment; L. platus, flat.] Small parts of compound ambulacral plates separated by growth pressure in certain Echinoids (zool.).

kleistogamous (klīstŏg'ămŭs) a. [Gk. kleistos, closed; gamos, marriage.] Fertilized in closed flowers (bot.).

knee (nē) $n$. [A.S, cneore, knee.] The joint between femur and tibia $(z \circ o l$.$) ; a root-process of certain$ swamp-growing trees (bot.).

knot (nǒt) $n$. [A.S. cnotta, a knot.] In wood, the base of a branch surrounded by new layers of wood and hardened by pressure (bot.); in nuclear-meshwork, the small particles of chromatin where the meshes cross (cyt.).

\section{L}

labellate (lăběl'ât) a. [L. labellum, small lip.] Furnished with labella or small lips (bot., zool.).

labelloid (lăbĕl'oid) a. [L. labellum, small lip; Gk. eidos, resemblance.] Like a labellum.

labellum (lăběl'ŭm) n. [L. labellum, small lip.] The lower petal, morphologically posterior, of an orchid (bot.) ; a small lobe beneath the labrum in certain insects; one of the proboscis lobes in certain insects (zool.).

labia (lā'bră) n.plu. [L. labium, lip.] Lip-like structures (anat.).

labia cerebri,- the margins of the hemispheres of the brain overlapping the corpus callosum (anat.).

labia majora, - the outer lips of the vulva (anat.).

labia minora, - the inner vulvular lips (anat.).

labial (lā'bǐăl) a. [L. labium, lip.] Pert. or resembling a lip (zool.).

labial palp,- - the lobe-like structure near the mouth of a mollusc; the jointed appendage on the labium of Insects (zool.).

labiate (lā'blāt) a. [L. labium, lip.] Lip-like; possessing lips or thickened margins (zool.); having the limb of the calyx or corolla so divided that the one portion overlaps the other (bot.).

labiatiflorous (lā'biātĭflō'rŭs) a. [L. labium, lip ; flos, flower.] Having the corolla divided into two liplike portions (bot.).

labidophorous (lăb'ídŏf'örŭs) a. [Gk. labis, forceps; pherein, to carry.] Possessing pincer-like organs (zool.).

labiella (lā'bièl'ă) $n$. [L. Labium, lip.] One of the mouth organs of Myriapods (zool.).

labiodental (lā'biödĕn'tăl) $a$. [L. labium, lip; dens, tooth.] Pert. lip and teeth; $a p p l$. to an embryonic lamina (emb.).

labium (lä'biŭm) n. sing. of labia; the fused second maxillae of Insects (zool.).

labral (lā'brăl) a. [L. labrum, lip.] Pert. a labrum (sool.).

labrum (lắ'brŭm) n., labra (lă̌bră) plu. [L. labrum, lip.] The anterior lip of Insects, Crustaceans, and certain other Arthropods; the outer margin of the mouth of a gastropod shell (zool.).

labyrinth (lăb'irrinth) $n$. [L. laby. rinthus, labyrinth.] The complex internal ear, bony or membranous ; the portions of kidney cortex with 
the uriniferous tubules (anat.) ; the tracheal tympanum (zool.).

labyrinthodont (lăb'îrin'thödǒnt) $a$. [Gk. labyrinthos, labyrinth; odous, a tooth.] Having teeth with great complexity of dentine arrangement (zool.).

laccate (lăk'āt) a. [It. lacca, varnish.] Appearing as if varnished (bot.).

lacerated (lăs'ĕrătěd) $a$. [L. lacerare, to tear.] Having the margin or apex deeply cut into irregular lobes (bot., zool.).

lacertiform (lăsĕr'tǐfôrm) a. [L. lacerta, lizard; forma, shape.] Having the shape of a lizard (zool.).

\section{lachrymal, - see lacrimal.}

lacinia (lăsĭn'iă) $n$. [L. lacinia, flap.] Segment of an incised leaf (bot.); internal endopodite of labium of Insects (zool.).

laciniate (lăsin'íāt) a. [L. lacinia, flap.] Irregularly incised, as petals ; fringed (bot.).

lacinula (lăsin'ūlă) n. [L. lacinia, flap.] Small lacinia (bot., zool.); the inflexed sharp point of the petal (bot.).

lacinulate (lăsin'ūlāt) $a$. [L. lacinia, flap.] Having lacinulae (bot., zool.).

lacrimal (lăk'rĭmăl) a. [L. lacrima, tear.] Pert. or situated near the lacrimal organ; $a p p l$. bone, duct, papillae, sac, etc. (anat.).

lacrimonasal (lăk'rĭmönāizăl) a. [L. lacrima, tear; nasum, nose.] Pert. the lacrimal and nasal bones or duct (anat.).

lacrimose (lăk'rimōs) a. [L. lacrima, tear.] Bearing tear-shaped appendages, as the gills of certain Fungi (bot.).

lactalbumin (lăk'tălbū'mìn) n. [L. lac, milk; albumin, albumin.] An albumin found in milk (phys.).

lactase (lăk'tãs) $n$. [L. lac, milk.] An enzyme found in the animal body forming glucose, etc., from lactose (phys.).

lactation (lăktä'shŭn) $n$. [L. lac, milk.] Secretion of milk in the mammary glands (zool.).

lacteals (lăk'tê̌ălz) n. plu. [L. lac, milk.] Thechyliferous orlymphatic vessels of the smallintestine (anat.); ducts which carry latex (bot.). lactescent (lăktěs'ĕnt) $a$. [L. lactescere, to turn to milk.] Producing milk (zool.); yielding latex (bot.).

lactic (lăk'tı̌k) a. [L. lac, milk.] Pert. milk; appl. bacilli (phys.).

lactiferous (lăktíf'ěrŭs) $a$. [L. lac, milk ; ferre, to carry.] Forming or carrying milk (zool.); carrying latex (bot.).

lactochrome (lăk'tökrōm) n. [L. lac, milk; Gk. chroma, colour.] A colouring matter of a nitrogenous nature supposed to be in milk (phys.).

lactoglobulin (lăk'töglŏb'ūlǐn) $n$. [L. lac, milk ; globulus, dim. of globus, globe.] The specific proteid of milk, insoluble in water (phys.).

lactoproteid (lăk'töprō'těìd) $n$. [L. lac, milk; Gk. protos, first ; eidos, resemblance.] Any of the milk proteids (phys.).

lacuna (lăkư'nă) $n$. [L. lacuna, cavity.] A space between cells; a sinus (zool.) ; a urethral follicle ; a cavity in bone (anat.); a small cavity or depression on the surface in Lichens (bot.).

lacunar (lăkū'năr) a. [L. lacuna, cavity.] Having or resembling lacunae (zool., anat.).

lacunose (lăkư'nōs) a. [L. lacuna, cavity.] With numerous cavities (zool., bot.).

lacunosorugose (lăk'ūnōsöroo'gōs) a. [L. lacuna, cavity; rugosus, wrinkled.] Having deep furrows or pits, as some seeds and fruits (bot.).

lacustrine (lăkŭs'trìn) a. [L. lacus, lake.] Pert. or being in or beside lakes (bot., zool.).

laeotropic (lēeötrŏp'ík) a. [Gk. laios, left ; trepein, to turn.] Inclined, turned, or coiled to the left (zool.).

laeotropous (lēŏt'röpŭs). Laeotropic.

lagena (lăgên'ă, lăjēénă) n., lagenae (lăgề'nā, lăjēn'è) plu. [L. lagena, flask.] An outgrowth of the sacculus, the terminal portion of the cochlea (zool.).

lageniform (lăgếnĭfôrm, lăjếnífôrm) a. [L. lagena, flask ; forma, shape.] Shaped like a flask (zool.).

lagopodous (lăgŏp'ödŭs) $a$. [Gk. lagos, hare; pous, foot.] Possessing hairy or feathery feet (zool.). 
Lamarckian (lămârk'iăn) a. [F. Lamarck, biologist.] Of or pert. the theories put forward by Lamarck (biol.).

Lamarckism (lămârk'ízm) n. [F. Lamarck, biologist.] The evolution theory of Lamarck, embodying the principle that acquired characteristics are transmissible (biol.).

lambda (lăm'dă) $n$. [Gk. $\Lambda$, lambda.] The junction of the lambdoid and sagittal sutures (anat.).

lambdoid (lăm'doid) a. [Gk. $\Lambda$, lambda; eidos, resemblance.] Ashaped; appl. a cranial suture (anat.).

lambdoidal,-lambdoid.

lamella (lăměl'ă) n. [L. lamella, a small plate.] Any thin plate-like structure (anat., zool.); the gill of an Agaric (bot.).

lamellar (lăměl'ăr) a. [L. lamella, a small plate.] Composed of, or possessing thin plates (zool., bot.).

lamellate (lăměl'āt). Lamellar.

lamellibranchiate (lăměl'ibrăng'kiāt) a. [L. lamella, thin plate; Gk. brangchia, gills.] Having platelike gills on each side; with bilaterally compressed symmetrical body, like a bivalve (zool.).

lamellicorn (lăměl'îkôrn) a. [L. lamella, plate; cornu, horn.] Having antennal joints expanded into flattened plates (zool.).

lamelliferous (lăm'élifférŭs) a. [L. lamella, plate; ferre, to carry.] Having small plates or scales (zool.).

lamelliform (lăměl'ifôrm) a. [L. lamella, plate; forma, shape.] Platelike (zool.).

lamellirostral (lăměl'irors'trăl) $a$. [L. lamella, plate; rostrum, beak.] Having the inner edges of the bill bearing lamellar-like ridges (zool.).

lamellose (lăměl'ōs, lăm'ělōs), lamellar. lamina (lăm'ĩnă) n. [L. lamina, plate.] A thin layer, or scale ; one of the thin plate-like expansions of sensitive tissue which fit into the grooves on the inside of the horse-hoof (sool.); the blade of the leaf (bot.).

laminar (lăm'innăr) a. [L. lamina, plate.] Consisting of plates or thin layers (bot., zool.). laminiform (lămìn'ífôrm) a. [L. lamina, plate ; forma, shape.] Laminar. laminiplantar (lăm'iniñulăn'tăr) $a$. [L. Lamina, plate ; planta, sole of foot.] Having the scales of the metatarsus meeting behind in a smooth ridge (zool.).

laminous (lăm'ínŭs) $a$. [L. lamina, plate.] Laminar.

lanate (lẵn'ãt) a. [L. Lana, wool.] Woolly (zool.); covered with short hair-like processes giving a woolly appearance to the surface (bot.).

lance-linear (lăns'-lin'ěăr) $a$. [L. lancea, lance; linea, line.] Between lanceolate and linear in form; $a p p l$. leaves (bot.).

lance-oblong (lăns'-ŏb'lŏng) a. [L. lancea, lance ; oblongus, oblong.] Oblong with tapering ends; appl. leaves (bot.).

lanceolate (lăn'sěölāt) a. [L. lanccola, little lance.] Broad at base and tapering to the point ; lance-shaped (bot., zool.).

lance-oval (lăns'-ōvăl) a. [L, lancea, lance; ovalis, oval.] Something between lanceolate and oval (bot.).

lance-ovate (lăns'-ó'vāt) a. [L. lancea, lance; ovalis, oval.] Something between lanceolate and ovate (bot.).

lancet-plates,-special plates supporting the water-vascular vessels of Blastoids (zool.).

Langerhans,-see islets of Langerhans.

languet, languette (lăng'gwĕt) $n$. [F. langue, tongue.] A process on the branchial sac of Ascidians (zool.).

laniary (lăn'iărì) $a$. [L. laniare, to tear in pieces.] Term $a p p l$. to canine tooth (zool.).

lantern, - see Aristotle's lantern (zool.).

lanthanin (lăn'thăniัn) n. [Gk, lanthanein, to conceal.] Oxychromatin.

lanuginous (lănūjinnŭs)a. [L. lanugo, wool.] Woolly (bot., sool.).

lanugo (lănū'gô) $n$. [L. lanugo, wool.] The downy covering on a foetus, shed early in life (anat.).

lapidicolous (lăp'ídīk'ölús) a. [L. lapis, stone ; colere, to cultivate.] $A p p l$. animals that live under stones (zool.). 
lappaceous (lăpā'shŭs) a. [L. lappa, bur.] Prickly (bot.).

lappet (lăp'ĕt) n. [M.E. lappe, a loose hanging part.] One of the paired lobes extending downwards from the distal end of the stomodaeum in jelly-fish; the lobes of a seaanemone gullet; the wattle of a bird (zool.).

larva (lâr'vă) n. [L. larva, ghost.] An embryo which becomes selfsustaining and independent before it has assumed the characteristic features of its parents (zool.).

larval (lâr'văl) a. [L. larva, ghost.] Pert. or in the larval stage (zool.).

larviform (lâr'vifôrm) a. [L. larva, ghost ; forma, shape.] Shaped like a larva (zool.).

larvigerous (lârvij'ĕrŭs) a. [L. larva, ghost ; gerere, to bear.] Coarctate (zool.).

larviparous (lârvĭp'ărŭs) a. [L. larva, ghost; parere, to produce.] Producing live larvae (zool.).

larvivorous (lârvǐv'örŭs) $a$. [L. larva, ghost ; vorare, to devour.] Larvaeating (sool.).

larvule (lâr'vūl) $n$. [L. larvula, small larva.] Young larva (zool.).

laryngeal (lărĭn'jě̌l, lăr'ínjē'ăl) $a$, [Gk, larynx, upper part of windpipe.] Pert. or near the larynx; $a p p l$. artery, vein, nerve, etc. (anat.).

laryngotracheal (lărĭng'götrā'kěăl, lărĭn'jö-) a. [Gk, $\operatorname{larynx}$, windpipe; L. trachea, trachea.] Pert. larynx, and trachea; $a p p l$. embryonic tube (emb.).

larynx (lă̌r'ínks) n., larynges (lărĭn'jĕ̌z) plu. [Gk. larynx, the larynx.] The organ of voice in most vertebrates, with the exception of birds (zool.).

lasso-cells,-filamented hemispherical cells investing the tentacles of Ctenophores, which adhere to foreign bodies (zool.).

latebra (lăt'ěbră) $n$. [L. latebra, hiding-place.] The bulb of the flask-shaped mass of white yolk in eggs (emb.).

latebricole (lătěb'rìkōl) a. [L. latebra, hiding-place ; colere, to cultivate.] Inhabiting holes.

latent (lä'těnt) a. [L. latere, to lie hid.] Lying dormant but capable of development under favourable circumstances; appl. buds (bot.) ; resting stages (zool.); characteristics (biol.).

latent bodies, - the resting stage of certain Haemoflagellates (zool.).

lateral (lăt'ĕrăl) $a$. [L. latus, side.] Pert. or situated at a side (zool.); or at a side of an axis (bot.).

lateral chain theory, - see side chain theory (phys.).

lateral line, - a longitudinal line at each side of the body of Fishes marking the position of supposedly sensory cells connected together, and with the pneumogastric nerve (zool.).

lateral mesenteries, - the mesenteries ofZoantharia, excluding the directive or dorsal and ventral pairs (zool.).

laterigrade (lăt'ĕrĭgrād) a. [L. latus, side; gradus, step.] Walking sideways, as a crab (zool.).

laterinerved (lăt'ěriněrvd') $a$. [L. latus, side; nervus, sinew.] With lateral veins (bot.).

latex (lắ'těks) $n$. [L. latex, fluid.] A milky fluid found in some plants (bot.).

laticiferous (lăt'ísĭf'ĕrŭs) $a$. [L. latex, fluid ; ferre, to carry.] Conveying latex; $a p p l$. cells, tissue, vessels (bot.).

latiplantar (lăt'íplăn'tăr) $a$. [L. latus, side ; planta, sole of foot.] Having the hinder tarsal surface rounded (zool.).

latirostral (lăt'ǐrŏs'trăl) a. [L. latus, broad; rostrum, beak.] Broadbeaked (zool.).

latiseptate (lăt'îsĕp'tāt) $a, \quad[\mathrm{~L}$. latus, broad; septum, septum.] Having a broad septum in the silicula (bot.).

Laurer-Stieda canal, - a canalleading from the junction of the oviduct and vitelline duct to open externally on the dorsal surface in Trematodes (zool.).

laurinoxylon (lôr'inŏk'sǐlŏn) n. [L. laurus, laurel ; Gk. xylon, wood.] Any fossil wood.

law of acceleration,--the generalization that organs of greater importance develop more quickly (emb.).

$\operatorname{lax}($ lăks) a. [L. laxus, loose.] Loose, as $a p p l$. panicle (bot.). 
layer of Langhans, - see cytotrophoblast.

leader (lë'dër) n. [A.S. laedan, to lead.] Highest shoot or part of trunk of a tree (bot.).

leaf (lēf) $n$. [A.S. leaf, leaf.] An expanded outgrowth of a stem, usually green (bot.).

lechriodont (lěk'rioödŏnt') a. [Gk. lechrios, slantwise; odous, tooth.] With vomerine and pterygoid teeth in a row which is nearly if not quite transverse (zool.).

lecithalbumin (lěs'îthălbū'mīn) $n$. [Gk. lekithos, egg-yolk; L. albumen, white of egg.] A substance, consisting of albumin and lecithin, said to exist in various organs in the body (phys.).

lecithin (lës'îthĭn) n. [Gk, lekithos, egg-yolk.] A phosphorized fat of cell-protoplasm (phys.).

lecithoblast (lěs'ithöblăst) $n$. [Gk. lekithos, egg-yolk; blastos, bud.] In developing eggs, the yolk-containing blastomeres (emb.).

lecithocoel (lěs'ǐthösēl) $n$. [Gk. lekithos, egg-yolk ; koilos, hollow.] The segmentation cavity of holoblastic eggs (emb.).

legume (lěgūm', lěg'üm) n. [L. legumen, pulse.] A dehiscent onecelled, two-valved carpel, as pod of pea or bean (bot.).

legumin (lěgū'min) $n$. [L. legumen, pulse.] A proteid found in the seeds of the Leguminosae (bot.).

lemniscus (lěmnǐs'kŭs) $n$. [Gk. lemniskos, fillet.] One of paired club-shaped organs at base of the acanthocephalan proboscis (zool.) ; a fillet of fibres on each side of the cerebral peduncles (anat.).

lens (lĕnz) $n$. [L. lens, lentil.] A transparent part of the eye which focusses rays of light on the retina; the crystalline lens (anat.); the modified portion of the cornea in front of each element of a compound eye (zool.).

lenticel (lěn'tǐsěl) $n$. [L. lens, lentil.] Ventilating pore in Angiosperm stems (bot.).

lenticular (lěntǐk'ūlăr) a. [L. lenticula, dim. of lens, lentil.] Shaped like a double convex lens (bot., zool.). lenticular (lěntǐk'ūlăr) $n$. The tip of the incus articulating with the stapes, which is often ossified as a separate unit (anat.).

lenticulate (lěntîk'ūlāt) $a$. [L. lens, lentil.] Meeting in a sharp point ; depressed, circular, and frequently ribbed (zool.).

lentiform (lěn'tǐfôrm) a. [L. lens, lentil ; forma, shape.] Lenticular.

lentigerous (lĕntřj'ěrŭs) a. [L. lens, lentil ; gerere, to bear.] Furnished with a lens (zool.).

lentiginose (lěntǐj'inōs) a. [L. lentigo, from lens, lentil.] Freckled; speckled; bearing numerous small $\operatorname{dots}(z \circ o l .$, bot.).

lentiginous (lěntǐj'innus). Lentiginose. lepidodendroid (lěp'îdöděn'droid) $a$. [Gk. lepis, scale; dendron, tree ; eidos, like.] Pert. lepidodendron; having scale-like leaf-scars (pal.).

lepidophyte (lěp'ídöfīt) n. [Gk. lepis, scale; phyton, plant.] A fossil plant of the fern family (pal.).

lepidopterous (lěp'ídŏp'těrŭs) $a$. [Gk. lepis, scale; pteron, wing.] Pert. the Lepidoptera, i.e. having wings covered with minute over-lapping scales (zool.).

lepidote (lěp'î̀ōt) a. [Gk, lepis, scale.] Covered with minute scales (bot.).

lepidotic (lěp ĩdǒt'îk) a. [Gk. lepis, scale.] $A p p l$. an acid found in wings of some Lepidoptera (phys.).

lepidotrichia (lěp'îdötrǐk'iă) n. plu. [Gk. lepis, scale; thrix, hair.] In Teleostomi, bony dermal fin-rays, probably modified scales (zool.).

lepospondylous (lěp'öspǒn'dǐlŭs) $a$. [Gk. lepos, husk; sphondylos, vertebra.] Having amphicoelous, or hour-glass shaped, vertebrae (zool.).

leptocephaloid (lěp'tökĕf'ăloid, -sěf-) a. [Gk. leptos, slender; kephale, head; eidos, resemblance.] Resembling or having the shape of a Leptocephalus (zool.).

leptocercal (lěp'tösěr'kăl) a. [Gk. leptos, slender; kerkos, tail.] With long slender tapering tail, as some Fishes (zool.).

leptodactylous (lěp'tödăk'tǐlŭs) $a$. [Gk, leptos, slender; daktylos, finger.] Having small or slender digits (zool.). 
leptodermatous (lěp'tödĕr'mătŭs) $a$. [Gk. leptos, slender; derma, skin.] Thin-skinned; $a p p l$. various thecae (bot.).

leptodermic (lěp'tödĕr'mǐk). Leptodermatous.

leptodermous (lěp'tödĕr'mǔs). Leptodermatous.

leptome (lěp'tōm) n. [Gk. leptos, slender.] Vascular tissue of plant stems ; phloem ; bast (bot.).

leptophloem '(lěp'töfló'ěm) n. [Gk. leptos, slender; phloios, smooth bark.] Rudimentary bast tissue (bot.).

leptophyllous (lěp'töfǔl'ŭs) $a$. [Gk. leptos, slender; phyllon, leaf.] With slender leaves (bot.).

leptosporangiate (lěp'töspörăn'jiāt) $a$, [Gk. leptos, slender ; sporos, seed ; anggeion, vessel.] With sporogenous tissue developing from outer cell of periclinal division; $o p p$. eusporangiate (bot.).

leptostroterate (lěp'töstrŏt'ěrāt) $a$. [Gk. leptos, slender; strotos, covered.] With ambulacral plates narrow and crowded together, as in certain Stelleroidea (zool.).

leptoxylem (lěp'tözílěm) $n$. [Gk. leptos, slender; xylon, wood.] Rudimentary wood tissue (bot.).

leptus (lëp'tŭs) n. [Gk. leptos, small.] The six-legged larva of mites (zool.).

lethal (lē'thăl) $\alpha$. [L. letum, death.] Of a parasite, fatal or deadly in relation to a particular host (zool.).

leuceine (lū'sěin, lū'sěēn, loo-) n. [Gk. leukos, white.] An aminoacid formed during the decomposition of proteids (phys.).

leucine (lū'sēn, lū'sin, loo-) n. [Gk. leukos, white.] A white nitrogenous substance found as a constituent of various tissues and organs (phys.).

leucite (lü'sît, loo-) n. [Gk. leukos, white.] A colourless plastid (bot.).

leucoblast (lữ'köblăst, loo-) n. [Gk. leukos, white; blaslos, bud.] A colourless blood-corpuscle in development $(e m b$.).

leucocarpous (lū'kökâr'pŭs, loo-) a. [Gk. leukos, white; karpos, fruit.] With the fruit white (bot.).

leucocyan (lü'kösí'ăn, loo-) n. [Gk. leukos, white ; kyanos, dark blue.] A pigment found in certain Algae (bot.).

leucocyte (lū'kösīt, loo-) n. [Gk. leukos, white; kytos, hollow.] An amoebocyte; a colourless bloodcorpuscle (anat.).

leucocytogenesis (lū'kösī'töjĕn'ěsiss, loo-) n. [Gk, leukos, white ; kytos, hollow ; gignesthai, to produce.] Leucocyte formation (phys.).

leucoplastids (lī'köplăs'tỉdz, loo-) $n$. plu. [Gk. leukos, white; plastos, formed.] Colourless plastids from which amylo-, chloro-, and chromoplastids arise (bot.).

leucoplasts (lū'köplăsts, loo-) $n$. plu. [Gk. leukos, white; plastos, formed.] Colourless granules of plant cytoplasm which may develop into chromatophores or amyloplasts (bot.).

levator (lěvắtŏr) $n$. [L. levare, to raise.] A name given to muscles serving to raise an organ or part (anat.).

Leydig's duct,- the Wolffian duct (emb.).

Leydig's organs,-minute organs on the antennae of Arthropods, supposed to be organs of smell (zool.). liana (liăn'ă) $n$. [L. ligare, to bind.] Any luxuriant woody climber of tropical or semi-tropical forests (bot.).

liber (li'bĕr) $n$. [L. liber, inner bark.] Bast (bot.).

lichenism (li'kĕnǐzm) n. [Gk. leichen, liverwort.] Symbiotic relationship between Fungi and Algae (bot.).

lichenoid (li'kěnoid) a. [Gk. leichen, liverwort; eidos, resemblance.] Resembling a Lichen (bot.).

lichenology (lî'kěnǒl'öjǐl) n. [Gk. leichen, liverwort; logos, discourse.] The study of Lichens (bot.).

Lieberkühn's erypts, - tubular glands of the intestines (anat.).

lien (I'̈̌ěn, lé'ěn) $n$. [L. lien, spleen.] Spleen.

lienal (lìénăl) a. [L. lien, spleen.] Pert. spleen; $a p p l$. artery, vein, nerve plexus (anat.).

lienculus (liěn'kūlŭs) $n$. [L. lien, spleen.] An accessory spleen (anat.).

lienogastric (liēénögăs'trìk, lēā'nö-) a. 
[L. lien, spleen ; gaster, stomach.] Pert. spleen and stomach; appl. artery supplying spleen and parts of stomach and pancreas (anat.).

life-cycle - the various phases through which an individual species passes to maturity (biol.).

ligament (líg ăměnt) $n$. [L. ligamentum, bandage.] A strong fibrous band of tissue connecting two or more moveable bones (anat.).

ligneous (ling'něǔs) a. [L. lignum, wood.] Woody; of the nature of wood (bot.).

lignescent (lígněs'ĕnt) a. [L. lignescere, to become woody.] Developing the characters of woody tissue (bot.).

lignicolous (lígnik'ölŭs) a. [L.lignum, wood ; colere, to cultivate.] Growing on wood (bot.).

lignification (lǐg'nǔfikā'shŭn) $n$. [L. lignum, wood; facere, to form.] Wood-formation, the thickening of plant cell-walls by the deposition of lignin (bot.).

lignin (lìg'nēn, líg'nǐn) $n$. [L. lignum, wood.] The substance which, modified by cellulose, causes the thickening of plant cell-walls, and so forms wood (bot.).

lignivorous (lignniv'örŭs) a. [L. lignum, wood ; vorare, to devour.] Eating wood; $a p p l$. various Insects (zool.).

lignocellulose (lĭg'nösěl'ūlōs) $n$. [L. lignum, wood ; cellula, little cell.] The essential constituent of woody tissue, lignin and cellulose combined (bot.).

lignose (lig'nōs) n. [L. lignum, wood.] A variety of cellulose (bot.).

ligula (líg'ûlă) n. [L. ligula, little tongue.] A band of white matter in the wall of the fourth ventricle (anat.); a process on the wall of the mouth of Insects ( $(\mathrm{ool}$.).

ligulate (lìg'ūlāt) a. [L. ligula, little tongue.] Having or pert. ligules ; strap-shaped, as the ray flowers of Compositae (bot.).

ligule (lig' $\mathbf{u} 1$ ) $n$. [L. ligula, little tongue.] A membranous appendage at the junction of blade and petiole ; a supra-sporangial scale in Selaginella (bot.); one of the lobes of the annelidan parapodium (zool.). ligulifiorous (lĭg'úlífō'rŭs) a. [L. ligula, little tongue; flos, flower.] Having ligulate flowers only (bot.).

limacel (lim'ăsěl) n. [L. limax, slug.] The concealed vestigial shell of slugs (zool.).

limaciform (limăsífôrm) a. [L. limax, slug ; forma, shape.] Like a slug (zool.).

limacine (lìm'ăsĭn) $a$. [L. limax, slug.] Pert. or resembling a slug (zool.).

limb (lím) $n$. [A.S. lim, limb.] Branch ; arm ; leg ; wing.

limbic (lím'bǐk) a. [L.limbus, border.] Bordering ; appl. a cerebral lobe (anat.).

limbous (lím'bŭs) a. [L. limbus, border.] Appl. overlapping sutures (anat.).

limbus (lïm'bŭs) n. [L. limbus, border.] Any border if distinctly marked off by colour or structure (zool., bot.).

limicolous (limik'ölŭs) a. [L. limus, mud; colere, to dwell.] Living in mud (zool., bot.).

limivorous (lĭmǐv'örŭs) a. [L. limus, mud; vorare, to devour.] Mud-eating; appl. certain aquatic animals which swallow mud (zool.).

limnetic (lĭmnět'îk) a. [Gk. limne, marsh.] Living in marshes; pert. organisms of marshy habitat (bot., zool.).

limnophilous (límnǒf'ilŭs) a. [Gk. limne, marsh ; philein, to love.] Living in fresh-water marshes; $a p p l$. snail, etc. (sool.).

limnoplankton (lím'nöplăng'ktŏn) $n$. [Gk. limne, marsh; plangktos, wandering.] The floating animal and plant life in fresh-water ponds and marshes ; $c f$. haliplankton.

line (lin) n. [A.S. line, cable.] A line; anatomical term, such as nuchal, temporal line (anat.).

linea (linn'ěă) n. [L. linea, line.] A line, which see.

linear (lǐn'ěăr) a. [L. linea, line.] Thread-like (bot., zool.).

linear-ensate (lǐn'eăr-ěn'sāt) a. [L. linea, line ; ensis, sword.] Between linear and ensiform in shape ; $a p p l$ leaves (bot.).

linear - lanceolate (lǐn'ěăr-lăn'sēölāt) a. [L. linea, line ; lanceola, small 
lance.] Between linear and lanceolate in shape; $a p p l$. leaves (bot.).

linear-oblong (linn'eăr-ŏb'lŏng) $a$. [L linea, line ; oblongus, long across.] Between linear and oblong in shape ; $a p p l$. leaves (bot.).

linellae (liněl'ē) $n$. plu. [L. linella, fine thread.] A system of filaments in certain Sarcodina holding together the xenophya (zool.).

lineolate (lĭn'ěolät) a. [L. linea, line.] Marked by fine lines or striae (bot., zool.).

lingua (ling'gwă) $n$. [L. lingua, tongue.] The floor of the mouth in mites ; the hypopharynx of insects ; a tongue or tongue-like structure (zool.).

lingual (ling'gwăl) a. [L. lingua, tongue.] Pert.tongue; appl. radula of Molluscs (zool.); appl. artery, gyrus, nerve, vein (anat.).

lingula (lìng'gūlă) $n$. [L. lingula, little tongue.] A small tongue-like process of bone or other tissue, as of cerebellum or sphenoid (anat.).

linin (línin) $n$. [L. linum, flax.] The substance of the achromatinic reticulum of a cell-nucleus (cyt.).

Linnaean (lǐnē'ăn) a. [L. Linnaeus, Swedish naturalist.] Pert, or designating the system of classification established by Linnaeus (biol.).

lip (lipp) n. [A.S. lippa, lip.] One of the fleshy folds round the mouth; a lip-like structure, such as labia, labella, etc. (zool., anat.).

lip cell, - a sporangium cell at the point of dehiscence (bot.).

lipase (líp'ās) n. [Gk. lipos, fat.] An enzyme, lipolytic in action, found in blood and in various organs, and also in various seeds ( $p$ hys.).

lipochrome (līp'ökrōm) n. [Gk. lipos, fat ; chroma, colour.] A pigment found in some Polychaetes (zool.), and in some plants (bot.).

lipogastry (lip'ögăs'trǐ) n. [Gk. leipesthai, to be lacking; gaster, belly.] Temporary obliteration of the gastral cavity, as in some Sponges (zool.).

lipogenous (lịpój'ěnŭs) a. [Gk. lipos, fat ; gignesthai, to produce.] Fatproducing (bot., zool.).

lipoid (lip'oid) a. [Gk. lipos, fat; eidos, resemblance.] Any fatty substance, such as lecithin, cholesterin, found in cells (phys.).

lipolytic (líp'ölit'îk) a. [Gk. lipos, fat ; lyein, to reduce.] Capable of dissolving fat ; fat-reducing (phys.).

lipomerism (lípŏm'ĕrǐzm) $n$. [Gk. leipesthai, to be lacking; meros, part.] Suppression of segmentation, or coalescence of segments, as in Crustaceans (zool.).

lipostomy (lǐpŏs'tömǐ) $n$. [Gk. leipesthai, to be lacking; stoma, mouth.] Temporary obliteration of the mouth or osculum (zool.).

lipoxenous (līpŏk'sĕnŭs) a. [Gk. leipesthai, to be lacking; xenos, host.] Leaving the host before completion of development, as in case of certain parasites (bot.).

lipped (lipt) $a$. [A.S. lippa, lip.] Labiate (bot.).

lirella (lǐrěl'ă) $n$. [L. lira, furrow.] A linear apothecium of Lichens (bot.).

lissencephalous (liss'ěnkĕf'ălŭs, -sĕf-) a. [Gk, lissos, smooth; engkephalon, brain.] Having few or no convolutions on the brain (zool.).

lissoflagellate (liss'öflăj'ělāt) $a$. [Gk. lissos, smooth ; L. flagellum, whip.] Having no collar surrounding the base of the flagellum (zool.).

lithite (lith'it) n. [Gk. lithos, stone.] A calcareous secretion found in connection with the ear, or with otocysts, lithocysts, and tentaculocysts, the supposed auditory organs of many invertebrates (anat., zool.).

lithocysts (lïth'ösǐsts) n. plu. [Gk. lithos, stone; kystis, bladder.] Minute sacs or grooves, containing lithites, found in various invertebrates; the marginal sense-organs of certain Coelenterates (zool.).

lithodesma (lǐth'öděs'mă) n. [Gk. lithos, stone; desma, bond.] A small plate, shelly in nature, found in certain bivalves (zool.).

lithodomous (lïthŏd'ömǔs) a. [Gk. lithos, stone; demein, to build.] Living in rocks (zool.).

lithogenous (lithŏj'ěnŭs) a. [Gk. lithos, stone; gignesthai, to produce.] Rock-forming, or rockbuilding, as certain corals (zool.). lithophagous (lithŏf'ăgŭs) $a, \quad[\mathrm{Gk}$. 
lithos, stone; phagein, to eat.] Stone-eating, as Birds; rockburrowing, as Molluscs (zool.).

lithophilous (lïthŏf'ílŭs) $a$. [Gk. lithos, stone; philein, to love.] Growing on stones or rocks (bot.).

lithophyll (lǐth'öfřl) $n$. [Gk. lithos, stone ; phyllon, leaf.] A fossil leaf, or leaf-impression (pal.).

lithophyte (lïth'öfīt) $n$. [Gk. lithos, stone; phyton, plant.] A plant growing on rocks or in rocky places (bot.).

lithotomous (lĭthŏt'ömŭs) a. [Gk. lithos, stone; temnein, to cut.] Stoneboring, as certain Molluscs (zool.).

littoral (lit'örăl) a. [L. littus, seashore.] Growing or living at or near the sea-shore (biol.).

liver (lǐ'ër) $n$. [A.S.lifer, liver.] A bilesecreting gland of vertebrates (zool.).

liver-pancreas, - an organ in Molluscs and Crustaceans combining the functions of the liver and pancreas (zool.).

lobate (lō'bāt) a. [Gk. lobos, lobe.] Divided into lobes.

lobe (lōb) $n$. [Gk. lobos, lobe.] A flap-like structure on the toes of certain birds (zool.) ; any rounded projection of an organ.

lobed (lōbd) a. [Gk. lobos, Iobe.] Having the margin cut up into rounded divisions by incisions which reach less than half-way to the mid-rib (bot.).

lobopodia (lö'böpō'dĭă) n. plu. [Gk. lobos, lobe; pous, foot.] Blunt pseudopodia of Protozoa (zool.).

lobose (lō'bōs) a. [Gk. lobos, lobe.] Having lobes, or divided up into lobes (bot., zool.).

lobular (lǒb'ūlăr) a. [Gk. lobos, lobe.] Like or pert. small lobes (anat.).

lobulate (lǒb'ūlāt) a. [Gk. lobos, lobe.] Divided into small lobes.

lobule (lŏb'ūl) n. [Gk. lobos, lobe.] A small lobe (anat.).

lobulus (lŏb'ūlŭs). Lobule.

lobus (lō'bŭs). Lobe.

localization (lō'kălǐzā'shŭn) n. [L. locus, place.] The state of being localized (phys.).

localization of function,-reference to different parts of the brain as communicating centres of the various senses (phys.).

localization of sensation, -identifica- tion on surface of body of exact spot affected (phys.).

locellus (lōsĕl'ŭs) $n$. [L. locellus, from locus, place.] A small compartment of an ovary (bot.).

locomotor rods, - hooked or knobbed rods for crawling, on the ventral surface of certain round-worms (zool.).

locular (lǒk'ūlăr) a. [L. loculus, from locus, place.] Containing, or composed of loculi (bot., zool.).

loculate (lǒk'ūiāt). Locular.

loculicidal (lǒk'ūlǐsídăl) a. [L. locus, place ; caedere, to cut.] Dehiscent dorsally down the middle of the carpels (bot.).

loculus (lŏk'ùlŭs) n., loculi (lǒk'ūlī, lŏk'ūlē), plu. [L. loculus, from locus, place.] A small chamber or cavity ; the cavities between the septa in certain Coelenterates; a chamber of a foraminiferal shell (zool.); one of the cavities of an ovary (bot.).

lodicule (lŏd'îkūl) $n$. [L. lodicula, coverlet.] A scale at the base of the ovary in grasses supposed to represent a perianth (bot.).

loma (lō'ma) n. [Gk. loma, fringe.] A thin membranous flap forming a fringe round an opening (zool.). lomastome $\left(1 \bar{o}^{\prime} \mathrm{măs} \mathrm{ōm}^{\prime}\right) n$. [Gk. loma, fringe; stoma, mouth.] Having the margin of the lip recurved or reflected (zool.).

loment (lö'mĕnt) $n$. [L. lomentum, mixture of bean and rice meal.] A legume or pod constricted between the seeds (bot.).

lomentaceous (lō'měntā'shŭs) $a$. [L. lomentum, bean meal.] Pert. or resembling a loment, or having loments (bot.).

lomentum (Iōměn'tŭm). Loment.

longicorn (lŏn'jîkôrn) a. [L. longus, long; cornu, horn.] Having long antennae ; appl. certain beetles (zool.).

longipennate (lŏn'jĭpěn'āt) $a$. [L. longzes, long ; penna, wing.] Having long wings, or with long feathers (zool.).

longirostral (lŏn'jĭrŏs'trăl) a. [L. longus, long; rostrum, beak.] With a long beak (zool.).

longitudinal (lŏn'jītü'dĩnăl) a. [L. longus, long.] Running lengthwise or along the line of axis; appl. muscle, nerve, etc. (anat.). 
lophiostomate (lṓfiöstō'māt) a. [Gk. lophion, small crest ; stoma, mouth.] With crested conceptacle-opening (bot.).

lophobranchiate (lờ'föbrăng'kiāt) $a$. [Gk. lophos, crest ; brangchia, gills.] With tufted gills (zool.).

lophocalthrops (lố'fökăl'thrŏps) $n$. [Gk. lophos, crest ; A.S. coltraeppe, a kind of thistle.] A sponge spicule with all the rays crested or branched (zool.).

lophocercal (lö́fösër'kăl) $a$. [Gk. lophos, crest ; kerkos, tail.] Having a rayless caudal fin like a ridge round the end of the vertebral column (zool.).

lophodont (lö́födŏnt) a. [Gk. lophos, crest ; odous, tooth.] Having transverse ridges on the cheek-teeth grinding surface (zool.).

lophophore (lố'föfōr) n. [Gk. lophos, crest; pherein, to carry.] An oval tentacle-supporting organ in Polyzoa and Brachiopods (zool.).

lophoselenodont (lốfösělē'nödŏnt) $a$. [Gk. lophos, crest ; selene, moon; odous, tooth.] Having the cheek teeth ridged with crescentic cuspid ridges on the grinding surface (zool.).

lophosteon (lơ̆'fơs'těŏn) $n$. [Gk. lophos, ridge; osteon, bone.] The keelridge of a sternum (zool.).

lophotriaene (lớfötrīēe n) n. [Gk. lophos, ridge; triaina, trident.] Lophocalthrops.

lophotrichous (lǒfŏt'rǐkŭs) a. [Gk. lophos, ridge ; thrix, hair.] Having long whip-like flagella (bot., zool.).

lophs (lŏfs) n. plu. [Gk. lophos, ridge.] Crests which may connect the cones in teeth and so form ridges (zool.).

loral (lō'răl) a. [L. lorum, thong.] Pert. or situated at the lore (zool.).

lorate (lō'rāt) a. [L. lorum, thong.] Strap-shaped (bot.).

lore (lōr) $n$. [L. lorum, thong.] The space between bill and eyes in birds (zool.).

lorica (lŏr'ikă) n. [L. Iorica, corselet.] A protective external case found in Rotifers and Infusorians (zool.).

loricate (lŏr'íkāt) a. [L. lorica, corselet.] Covered with protective shell or scales (zool.).

lorication moment,-the occasion of the deposition of silica for an entire skeleton at one time (zool.).

lorum (lō'rŭm) $n$. [L. lorum, thong.] The piece of the under jaw on which the submentum lies in certain Insects (zool.).

loxodont (lǒk'södŏnt) a. [Gk. loxos, oblique ; odous, tooth.] Having molar teeth with shallow grooves between the ridges (zool.).

luciferase (loosíf'ěrās) $n$. [L. lux, light ; ferre, to carry.] An oxidizing enzyme which acts on luciferine, causing luminosity in certain animals (phys.).

luciferine (loosif'ĕrĭn) $n$. [L. lux, light; ferre, to carry.] The substance oxidized by luciferase, causing luminosity; it appears to have some of the properties of proteins (phys.).

lumbar (lŭm'băr) a. [L. lumbus, loin.] Pert. or near the region of the loins; $a p p l$. artery, vein, vertebra, plexus, gland (anat.).

lumbocostal (lŭm'bökŏs'tăl) a. [L. lumbus, loin; costa, rib.] Pert. loins and ribs ; appl. arch (anat.).

lumbosacral (lüm'bösā'krăl) a. [L. lumbus, loin; sacrum, sacred. Pert. loins and sacrum; $a p p l$. nerve-plexus, trunk (anat.).

lumbriciform (lŭmbrǐs'ifôrm) $a$. [L. lumbricus, earth-worm; forma, shape.] Like a worm (zool.).

lumbricoid (lŭm'brikoid). Lumbriciform.

lumen (lū'měn, loo-) n. [L. lumen, light.] The cavity of a tubular part or organ (anat.).

luminous organs,--specializedorgans for the production of light, found in fireflies, deep-sea fishes, glowworms, etc. (zool.).

lunar (lū'năr, loo-) a. [L. luna, moon.] Appl. carpal bone; also called semilunar and intermedium ; lunate (zool.).

lunare (lūnār'ê, loonâ'rā) n. [L. luna, moon.] The lunar bone (anat.).

lunate (lū'nāt, Ioo-) a. [L. luna, moon.] Somewhat crescent-shaped (zool.).

lung (lŭng) $n$. [A.S. lunge, lung.] The paired or single respiratory organ of air-breathing higher animal forms (zool.). 
lung-book, - the respiratory organ of Scorpionids, formed like a purse with numerous compartments (zool.).

lunular (lū'nūlăr, loo-) a. [L. lunula, small moon.] Marked with crescent-shaped marking (zool.).

lunulate (lū'nūlāt, loo-). Lunular.

lunule (lū'nūl, loo-) n. [L. lunula, small moon.] A crescent-shaped marking (zool.).

lunulet (lū'nūlět, loo-) n. [L. lunula, small moon.] A small lunule (zool.).

lupulin (lū'pūlǐn, loo'pūlín) $n$. [L. lupus, a hop.] The resinous glandular scales of hops (bot.); an organic compound, bitter and acrid, obtained from these (phys.).

lutein (lü'těin, loo-) n. [L. luteus, orange-yellow.] The yellow pigment of egg-yolk (phys.).

lychnidiate (liknì'iât) a. [Gk. lych. nis, phosphorescent gem.] Luminous (zool.).

lymph (limf) n. [L. lympha, water.] An alkaline colourless fluid contained in the lymphatic vessels (anat., pliys.).

lymph heart, - a contractile expansion of a lymph vessel where it opens into a vein, found in many of the vertebrates (zool.).

lymphatic (lĭmfăt'ik) a. [L. lympha, water.] Pert. or conveying lymph (anat.).

1ymphocyte (lím'fösīt) n. [L. lympha, water; Gk. kytos, hollow.] A colourless corpuscle found in blood and lymph (phys.).

1ymphogenic (lim'föjĕn'îk) a. [L. lympha, water; Gk. gignesthai, to produce.] Produced in the lymphglands (phys.).

1ymphogenous (limfŏj'ěnŭs) a. [L. lympha, water; Gk. gignesthai, to produce.] Lymph-forming (phys., anat.).

lymphoid (lim'foid) a. [L. lympha, water ; Gk. eidos, resemblance.] $A p p l$. retiform tissue with meshes largely occupied by lymph corpuscles ; adenoid (phys.).

lyophil (lì'öfîl) a. [Gk. lyein, to loose ; philos, loving.] Appl. solutions which, after evaporation to dryness, go readily into solution again on the addition of a fluid; $c f$. lyophobe (phys.).

lyophobe (lî́ö́fōb) a. [Gk. lyein, to loose; phobos, fear.] Appl. solutions which, after evaporation to dryness, remain as a solid; of. lyophil (phys.).

lyotropie (liötrŏp'ik) a. [Gk. lyein, to loose ; trope, a turning.] Appl. solutions which are dependent on changes in the solvent itself (phys.).

lyra (li'ră) $n$. [Gk. lyra, lyre.] Triangular part of the corpus callosum, marked with lines as a lyre (anat.).

lyrate (lī'rāt) a. [Gk. lyra, lyre.] Lyre-shaped; appl. certain leaves (bot.).

lysactinic (līsăktǐn'îk) a. [Gk. lysis, a loosing; aktis, ray.] Of Stelleroidea, having the podia limited to the lower half of the body instead of continued to the apical plates; cf. desmactinic (zool.).

lysigenous (līsīj'ěnŭs) a. [Gk. lysis, loosing ; gignesthai, to produce.] $A p p l$. formation of tissue cavities caused by the degeneration and breaking down of cell-walls in the centre of the mass (bot.).

lysin (li'sin) n. [Gk. lysis, loosing.] Any substance capable of destroying bacteria (phys.).

lysogenesis (lī'söjěn'ěsǐs) n. [Gk. lysis, loosing ; gignesthai, to produce.] The action of lysins (phys.).

1ysogenous (lissŏj'ěnŭs). Lysigenous. lyssa (lís'ă) n. [Gk. lyssa, madness.] A vermiform structure of cartilage, muscle, and connective tissue, under the tongue of Mammals (anat.).

lytta (lìt'ă) $n$. [Gk. lytta, madness.] A cartilaginous or fibrous rod lying in the tongue of Carnivores (zool.).

\section{M}

macerate (măs'ĕrāt) v. [L. macerare, to soften.] To wear away or to isolate the parts of a tissue or organ (zool.) ; to soften and wear away by digestion or other means (phys.).

machopolyp (măk'öpǒl'ĩp) $n$. [Gk. 
mache, fight; polys, many ; pous, foot.] A nematophore of certain Hydromedusae provided with cnidoblasts or adhesive globules (zool.).

macrandrous (măkrăn'drŭs) a. [Gk. makros, large ; aner, man.] Having large male plants or elements (bot.).

macrobiotic (măk'röbīŏt'îk) a. [Gk, makros, large; bios, life.] Longlived; life-prolonging (biol.).

macroblast (măk'röblăst) n. [Gk. makros, large; blastos, bud.] A large cell or corpuscle (zool.).

macrocarpous (măk'rökâr'pŭs) $a$. [Gk. makros, large ; karpos, fruit.] Producing large fruit (bot.).

macrocephalous (măk'rökĕf'ălŭs, -sěf-) a. [Gk. makros, large; kephale, head.] Having the cotyledons thickened (bot.); big-headed (anat.).

macrocnemic (măk'rökně'mǐk) $a$. [Gk. makros, large ; kneme, tibia.] Appl. Zoanthidae having the sixth protocneme or primary pair of mesenteries perfect (zool.).

macroconidium (măk'rökŏnĭd'iŭm) $n$. [Gk. makros, large; konis, dust.] A large asexual spore or conidium (bot.).

macroconjugant (măk'rökŏn'joogănt) n. [Gk. makros, large; L. conjugare, to unite.] The large individual of a conjugating pair, as the ordinary sedentary Vorticellan to which the motile microconjugant or individual attaches itself (zool.).

macrocyst (măk'rösǐst) $n$. [Gk. makros, large; kystis, bladder.] A large reproductive cell of certain Fungi ; a large cyst or case, as for spores (bot.).

macrocytase (măk'rösī'tās) n. [Gk. makros, large ; kytos, hollow.] The enzyme of macrophages or endothelial cells (phys.).

macrodactylous (măk'rödăk'tǐlŭs) $a$. [Gk. makros, large ; daktylos, finger.] With long digits (zool.).

macrodont (măk'rödŏnt) a. [Gk. makros, large ; odous, tooth.] With large teeth (anat.).

macrogamete (măk'rögămēt') $n$. [Gk. makros, large; gametes, spouse.] The larger of two conjugants, usually considered as equivalent to the ovum or female conjugant (zool.).

macrogametocyte (măk'rögămē'tösīt) n. [Gk. makros, large ; gametes, spouse; kytos, hollow.] Themothercell of a macrogamete, considered female; term used mainly in connection with Protista (biol.).

macrogamy (măkrŏg'ămǐ) n. [Gk. makros, large ; gamos, marriage.] Syngamy between full-grown individuals of a species, as in Actinophrys (zool.).

macroglossate (măk'röglǒs'āt) $a$. [Gk. makros, large; glossa, tongue.] Furnished with a large tongue.

macrognathic (măk'rögnăth'ík) $a$. [Gk. makros, large ; gnathos, jaw.] Having specially developed jaws (zool.).

macrogonidium (măk'rögŏnĭd'ium) $n$. [Gk. makros, large ; gone, generation.] A large gonidium (bot.).

macromere (măk'römēr) n. [Gk. makros, large ; meros, part.] In the cleavage of telolecithal eggs, one of the larger cells of the lower hemisphere (emb.).

macromerozoite (măk'röměr'özō'ît) $n$. [Gk. makros, large; meros, part ; zoon, animal.] One of the many divisions produced by the macroschizont stage of a Sporozoan (zool.).

macromesentery (măk'röměs'ĕntĕrǐ) n. [Gk. makros, large; mesos, middle ; enteron, gut.] One of the larger complete mesenteries of an Anthozoan (zool.).

macromyelon (măk' römï'ělŏn) $n$. [Gk. makros, large; myelos, marrow.] The medulla oblongata (anat.).

macront (măk'rŏnt) n. [Gk. makros, large; ons, being.] The larger of two sets of cells formed after schizogony in Neosporidia, the macront giving rise to macrogametes (zool.).

macronucleus (măk'rönū'klěŭs) $n$. [Gk. makros, large; L. nucleus, kernel.] The larger of two nuclei in a cell, usually supposed to be of a vegetative or somatic nature (zool.).

macrophage (măk'röfăjj) n. [Gk. makros, large ; phagein, to eat.] A large phagocyte or endothelial 
cell possessing the enzyme macrocytase (phys.).

macrophyllous (măk'röfíl'ŭs) $a$. [Gk. makros, large ; phyllon, leaf.] Having elongated leaves or leaflets (bot.).

macropodous (măkrŏp'ödŭs) a. [Gk. makros, large ; pous, foot.] Having a long stalk, as a leaf or leaflet; having the hypocotyl large in proportion to the rest of the embryo (bot.).

macropterous (măkrŏp'tĕrŭs) a. [Gk. makros, large ; pteron, wing.] With unusually large fins or wings (zool.).

macroschizogony (măk'röshǐzŏg'önĩ) n. [Gk. makros, large ; schizein, to cleave; gone, generation.] Method of multiplication of the macroschizonts (zool.).

macroschizont (măk'röshǐz'ŏnt) $n$. [Gk. makros, large; schizein, to cleave.] A stage in the life-cycle of -certain Haemosporidia developed from a sporozoite, and giving rise to a number of macromerozoites (zool.).

macroscopic (măk'röskŏp'îk) a. [Gk. makros, large ; skopein, to view.] Visible to the naked eye.

macrosepalous (măk'rösếp'ălŭs) $a$. [Gk. makros, large ; sepalon, sepal.] With specially large sepals (bot.).

macroseptum (măk'rösěp'tŭm) $n$. [Gk. makros, large; L. septum, division.] A primary or perfect septum of the Anthozoa (zool.).

macrosmatic (măk'rŏsmăt'îk) a. [Gk. makros, large; osme, smell.] With well-developed sense of smell (phys.).

macrosomatous (măk'rösŏmm'ătŭs) $a$. [Gk. makros, large ; soma, body.] Possessing an abnormally large body.

macrosporangiophore (măk'röspörăn'jiöfōr) n. [Gk. makros, large ; sporos, seed; anggeion, vessel; pherein, to bear.] A structure bearing a macrosporangium (bot.). macrosporangium (măk'röspörăn'jŭŭ)n. [Gk. makros, large; sporos, seed; anggeion, vessel.] A sporangium developing macrospores or megaspores (bot.).

macrospore (măk'röspōr) n. [Gk. makros, large; sporos, seed.] A large anisospore or gamete of Sarcodina (zool.); one of the larger spores of heterosporous plants (bot.). macrosporophore (măk'röspō'röför) $n$. [Gk. makros, large ; sporos, seed; pherein, to bear.] A leafy lobe developing macrosporangia (bot.). macrosporophyll (măk'röspō'röfîl) $n$. [Gk. makros, large ; sporos, seed; phyllon, leaf.] Macrosporophore. macrosporozoite (măk'röspō'rözō'it) $n$. [Gk. makros, large ; sporos, seed; zoon, animal.] A larger endogamous sporozoite of Sporozoa (zool.).

macrostomatous (măk'röstŏm'ătŭs) $a$. [Gk. makros, large ; stoma, mouth.] With very large mouth.

macrostylospore (măk'röstîllöspōr) $n$. [Gk. makros, large ; stylos, pillar ; sporos, seed.] A large spore-like stalked body (bot.).

macrostylous (măk' röstî'lŭs) $a$. [Gk. makros, large ; stylos, pillar.] With long styles (bot.).

macrotherm (măk'röthĕrm) n. [Gk. makros, large; therme, heat.] A tropical plant; a plant requiring heat and moisture (bot.).

macrotous (măkrō'tŭs)'a. [Gk.makros, large; ous, an ear.] With large ears (zool.).

macrotype (măk' rötīp) n. [Gk. makros, large; L. typus, a type.] A modified arrangement of Anthozoan mesenteries containing more macromesenteries than the normal microtype (zool.).

macrozoogonidium (măk'rözō'ögŏnĭd'iŭm) n. [Gk. makros, large ; zoon, animal ; gone, generation.] A large zoogonidium (bot.).

macrozoospore (măk'rözōöspōr) $n$. [Gk. makros, large; soon, animal ; sporos, seed.] A large motile spore.

macula (măk'ūlă) n., maculae (măk' ùlā) plu. [L. macula, spot.] A spot or patch of colour; a small pit or depression; a tubercle (anat.).

macula lutea,-the yellow spot of the retina, an oval yellowish area in the centre of the posterior part of the retina at the point of most perfect vision (anat.). 
maculate (măk'ūlāt) a. [L. macula, spot.] Spotted.

maculation (măk'ūlā'shŭn) n. [L. macula, spot.] The arrangement of the spots on a plant or animal (biol.).

maculiferous (măk'ūlǐf'ěrŭs) a. [L. macula, spot; ferre, to bear.] Spotted.

maculose (măk'ūlōs). Maculate.

madrepore (măd'rěpōr) $n$. [F. madrépore-from L. mater, mother; Gk. poros, friable stone.] A branching stony Coral ; the plate at the external opening of the stone canal in Echinoderms (zool.).

madreporic (măd'rěpǒr'ík) $a$. $[\mathrm{F}$. nadrépore, madrepore.] Pert. a madrepore or madreporite ; $a p p l$. body, plate, tubercle, canal (zool.).

madreporic canal,-see stone canal. madreporite (măd'rĕpō'rīt, mădrĕp'örīt) $n$. [F.madrépore, madrepore. $]$ A flat circular or pentagonal perforated plate marked by grooves, lying at the end of an interambulacral area in many, or free between two ambulacral areas in other Echinoids, or between the rays in the Asteroids ; a modified genital plate (zool.).

maggot (măg'ŏt) n. [M.E. magot, a grub.] The most lowly organized, completely worm-like, insect larva withoutappendages or distinct head (zool.).

mala (mắlă) n., malae (mắlā) plu. [L. mala, the cheek.] Part of the maxilla of some Insects, of the mandible of certain Myriapods; part of the exterior of the lower jaw of Birds (zool.).

malacoid (mălăkoid) a. [Gk. malakos, soft.] Soft in texture.

malacology (măl'ăkŏl'öjīi) n. [Gk. malakos, soft ; logos, discourse.] The department of zoology dealing with Molluscs.

malacophilous (măl'ăkŏf'ilŭs) a. [Gk. malakos, soft; philein, to love.] Pollinating through the agency of Gastropods (bot.).

malacopterous (măl'ăkŏp'těrŭs) $a$. [Gk. malakos, soft ; pteron, wing.] Soft-finned (zool.).

malacostracous (măl'ăkŏs'trăkŭs) $a$.
[Gk. malakos, soft ; ostrakon, shell.] Soft-shelled (zool.).

malar (mā'lăr) a. [L. mala, cheek.] Pert. or in the region of the cheek ; $n$. the zygomatic bone (anat.).

male (māl) n. [L. mas, a male.] Pert.

male or a masculine organism; $a p p l$. organs of reproduction, as the testes (zool.); or fertilizing organs of flowers, as stamens (bot.); symbol of.

male pronucleus, - the nucleus of the spermatozoon.

malleate (măl'ễa ) $a . \quad$ [L. malleus, hammer.] Hammer-shaped; appl. a type of trophi of Rotifer gizzard (zool.).

malleoincudal (măl'ě̆ön'küdăl) $a$. [L. malleus, hammer; incus, anvil.] Pert. malleus and incus of the ear (anat.).

malleolar (mălēölăr) $n$. [L. dim. of malleus, hammer.] The vestigial fibula of Ruminants ; $a$., pert. or in the region of the malleolus ; $a p p l$. arteries, folds, sulcus (anat.).

malleolus (mălë'ölŭs) n. [L. dim. of malleus, hammer.] Median and lateral malleolus, the lower extremity prolongations of tibia and fibula respectively (anat.).

malleoramate (măl'éörắmât) $a$. [L. malleus, hammer ; ramus, branch.] Appl. type of trophi with looped manubrium and toothed incus in Rotifer gizzard (zool.).

malleus (măl'ěŭs) $n$. [L. malleus, hammer.] A part of the Rotifer mastax or gizzard; one of the chain of auditory ossicles of Mammals ; one of the Weberian ossicles of Fishes (zool.)

Malpighian (mălpiğiăn) $a$. [After Malpighi, of Pisa.] Discovered by or named after Malpighi.

Malpighian body, or corpusele,-in spleen, a nodular mass of lymphoid tissue ensheathing the smaller arteries; in the kidney, a tuft or glomerulus of convoluted capillary blood-vessels enclosed in a dilatation of the uriniferous tubule (anat., zool.).

Malpighian layer, - the basal layer of the epidermis next to the true skin (anat.).

Malpighian tubes, - slender thread- 
like excretory tubes leading into the posterior part of the gut of Insects.

Malpighian tuft, - see Malpighian corpuscle.

maltase (môl'tās) n. [A.S. mealt, malt.] A plant ferment which converts malt-sugar into grape-sugar (bot.).

maltose (môl'tōs) n. [A.S. mealt, malt.] Malt-sugar (phys.).

mamelon (măm'ĕlŏn) $n$. [L. mamilla, nipple.] A small pimple-like structure in the centre of a tubercle of an Echinoid interambulacral plate (zool.).

mamilla (mămil'ă) $n$. [L. mamilla, nipple.] A nipple (anat., zool.).

mamillary process or tubercle, - the superior tubercle connected with the transverse processes of the lower thoracic vertebrae (anat.).

mamillate (măm'ílāt) a. [L.mamilla, nipple.] Studded with small protuberances.

mamma (măm'ă) $n$. [L. mamma, the breast.] The milk-secreting organ of Mammals, functionless in the male (zool.).

mammal (măm'ăl) $n$. [L. mamma, the breast.] An animal of the class of higher vertebrates of which the females suckle the young (zool.).

mammary ('năm'ărī) a. [L. mamma, the breast.] Pert. the breast ; appl. arteries, veins, glands, tubules (anat.).

mammiferous (mămíf'ĕrŭs) $a$. [L. mamma, the breast ; ferre, to bear.] Developing mammae ; milk-secreting; mammalian (zool.).

mandible (măn'dỉbl) $n$. [L. mandibulum, jaw.] The lower jaw of vertebrates, either a single bone or composed of a number ; or generally, either jaw ; a paired appendage connected with the mouth in Arthropods.

mandibular (măndỉb'ūlăr) $a$. [L. mandibulum, jaw.] Pert. the jaw ; $a p p l$. arch, canal, foramen, fossa, nerve, notch (anat.).

mandibulate (măndīb'ūlāt) $a$. [L. mandibulum, jaw.] Having a lower jaw ; having functional jaws ; having mandibles (zool.).

mandibuliform (măndib'úlífôrm) $a$.
[L. mandibulum, jaw; forma, shape.] Resembling, or used as a mandible; $a p p l$. certain insect maxillae (zool.). mandibulo-hyoid (măndǐb'ūlö-hīoid) a. [L. mandibulum, jaw ; Gk. hyoeides, $\mathrm{Y}$-shaped.] In the region of the mandible and hyoid (anat.).

mandibulo-maxillary (măndỉb'ülömăk'sǔlărĭ, -măksı̌l'-) $a$. [L. mandibulum, jaw; maxilla, jaw.] Pert. maxillae and mandibles of Arthropods (zool.).

manducation (măn'dūkā'shŭn) $n$. [L. manducare, to chew.] Chewing; mastication (phys.).

manicate (măn'îkāt) a. [L. manicatus, sleeved.] Covered with entangled hairs or matted scales (bot.).

manna (măn'ă) n. [Gk. manna, manna.] The hardened exudation of the bark of certain trees (bot.) ; honey-dew secreted by certain Coccidae (zool.).

mantle (măn'tl) $n$. [L. mantellum, a cloak.] The outer soft fold of integument next the shell of Molluscs; a pallium; a sheath of spongoblast cells; the body-wall of Ascidians (zool.).

mantle cavity, - a space between the mantle and body proper (zool.).

mantle cell, - a cell of the tapetum or investing tissue of a sporangium (bot.).

mantle fibres, - the spindle fibres of a fully formed spindle (emb.).

mantle layer,-a layer of the embryonic medulla spinalis representing the future gray columns (emb.).

mantle lobes,-dorsal and ventral flaps of the mantle in bivalves (zool.).

manual (măn'ūăl) n. [L. manus, hand.] A wing-quill borne on the manus or hand of Birds ; a primary feather (zool.).

manubrial (mănū'briăl) a. [L. manubrium, handle.] Pert. a manubrium; handle-shaped (zool.).

manubrium (mănū'brǐŭm) $n$. [L. mamubrium, handle.] A cell projecting inwards from the shield of an antheridial globule of Thallophytes (bot.) ; a hypostome or conical elevation at the distal end of a Hydrozoan polyp ; the clapper-like portion hanging down from the 
under surface of Medusae (zool.); the handle-like part of the malleus of the ear ; the anterior part of the sternum (anat.).

manus (mắ'nŭs) $n$. [L. manus, hand.] The hand, or part of the fore-limb corresponding to it, as found in vertebrates from Amphibia upwards (zool.).

manyplies,- the omasus or psalterium, the third chamber of the stomach of Ruminants-so-called from its folded structure (zool.).

marcescent (mărsĕs'ěnt) $a$. [L. marcescere, to wither.] Withering but not falling off; $a p p l$. a calyx or corolla persisting after fertilization (bot.).

marginal (mâr'jĭnăl) a. [L. margo, edge.] Pert. at or near the margin, edge, or border; $a p p l$. a form of nervation (bot.); $a p p l$. a convolution of the frontal lobe (anat.).

marginal organ or vesicle,-a lithocyst (zool.).

marginal plates,-the system of plates round the margin of a Chelonian carapace (zool.).

marginalia (mâr'jīnắlǐă) $n$. plu. [L. margo, edge.] Prostalia or defensive spicules on the body surface round the osculum (zool.).

marginate (mâr'jĭnāt) a. [L. margo, edge.] Having a distinct margin in structure or colouring.

marginicidal (mâr'jǐnǐsídăl) $a, \quad[\mathrm{~L}$. margo, edge ; caedere, to cut.] Dehiscing by line of union of carpels (bot.).

marginiform (mâr'jinnifôrm) a. [L. margo, edge ; forma, shape.] Like a margin or border in appearance or structure.

marginirostral (mâr'jĭnĭrŏs'trăl) $a$. [L. margo, edge ; rostrum, beak.] Forming the edges of a bird's bill (zool.).

marmorate (mâr'mörät) a. [L. marmor, marble.] Of marbled appearance.

marrow (măr $\left.{ }^{\prime} \overline{)}\right) n$. [M.E. marow, pith.] The connective tissue filling up the cylindrical cavities in the bodies of long bones, and the spaces of the cancellous tissue, differing in composition in different bones. marsupial (mârsū'puăl) a. [L. marsupium, a pouch.] Pert. a marsupium; pouch-bearing, as a kangaroo; $a p p l$. certain bones in connection with the pelvic girdle in certain Mammals.

marsupium (mârsū'pŭŭ) $n$. [L. marsupium, pouch.] Any pouchlike structure in which the young of an animal complete their development, such as the abdominal pouch of Marsupials ; the gill cavities of bivalves; a recess formed by diverging spines and a supporting membrane in Stelleroids; the structure protecting the acrocyst in Sertularians (zool.).

masked (măs'kd) a. [F. masque, a mask.] Personate, as appl. corolla (bot.).

masseter (măsē'tĕr) n. [Gk. masseter, one that chews.] The muscle which raises the lower jaw and assists in chewing (anat.).

masseteric (măs'ětĕr'îk) a. [Gk. masseter, one that chews.] Pert. or near the masseter muscle of the cheek; $a p p l$. artery, vein, nerve (anat.).

massula (măs'ūlă) $n$. [L. massa, mass.] A mass of microspores in a sporangium of certain Pteridophytes ; a massed group of microspores in Orchids (bot.).

mastax (măs'tăks) n. [Gk. mastax, the mouth.] The gizzard of Rotifers (zool.).

mast cells (Mastzellen of Ehrlich), spheroid or ovoid cells of soft protoplasm, very granular, numerous in parts where fat is being laid down. mastication (măs'tǐkā'shŭn) $n$. [L. masticare, to chew.] Process of chewing food with the teeth till reduced to small pieces or a pulp (phys.).

masticatory stomach,- the gastric mill or stomodaeal apparatus of Crustaceans for grinding and straining food material (zool.).

mastigium (măstĭj'iŭm) n. [Gk. mastigion, little whip.] A defensive posterior lash of certain insect larvae (zool.).

mastigobranchia (măs'tĭgöbrăng'kǐă) n. [Gk. mastigion, little whip ; brangchia, gills.] The epipodite of 
adult Decapoda, a bilobed membranous lamina extending upwards between the gills (zool.).

mastoid (măs'toid) a. [Gk. mastos, breast; eidos, resemblance.] Nippleshaped; $a p p l$. a process of the temporal bone, also cells, foramen, fossa, notch (anat.).

mastoideosquamous (măstoid'ěöskwā'mŭs) a. [Gk. mastos, breast ; eidos, like ; L. squama, scale.] Pert. mastoid and squamous parts of the temporal bone (anat.).

mastoidohumeralis (măstoid'öhūmĕrắliss) a. [Gk. mastos, breast ; eidos, like; L. humerus, the humerus.] A muscle of certain quadrupeds connecting mastoid and humerus (zool.).

masto-occipital (măs'tö-ŏksĭp'îtăl) $a$. [Gk. mastos, breast; L. occiput, the occiput.] Pert. occipital bone and the mastoid process of the temporal (anat.).

mastoparietal (măs'töpărīětăl) $a$. [Gk. mastos, breast ; L. paries, wall.] Pert. the parietal bone and the mastoid process of the temporal (zool.).

mastotympanic (măs'tötı̌mpăn'îk) $a$. [Gk. mastos, breast; tympanon, drum.] Appl. part of the tympanic cavity's boundary in certain Reptiles (zool.).

matrix (mắtrìks) n. [L. mater, mother.] The ground substance of connective tissue; the part beneath the body and root of the nail ; the uterus (anat.); the body upon which a Lichen or Fungus grows (bot.).

mattula (măt'ūlă) $n$. [L. matta, mat.] The fibrous network covering the petiole bases of palms (bot.).

maturation (măt'ūrā'shŭn) n. [L. maturus, ripe.] The completion of germ-cell development, consisting of the reduction of the chromatin, usually visible in the polar body formation (cyt.).

maxilla (măksilă) n. [L. maxilla, jaw.] The jaw ; part of the upper jaw beyond the premaxilla; an appendage of most Arthropods posterior to the mandible, modified in various ways in adaptation to function and requirements (zool.). maxillary (măksìl'ărì) a. [L. maxilla, jaw.] Pert. or in the region of the maxilla or jaw ; $a p p l$. artery, nerve, process, sinus, tuberosity, vein (anat.).

maxillary glands,-paired renal organs opening at the base of the maxilla in Crustacea (zool.).

maxilliferous (măk'sillif' ĕrŭs) a. [L. maxilla, jaw ; ferre, to carry.] Bearing maxillae (zool.).

maxilliform (măksîl'ífôrm) $a$. [L. maxilla, jaw ; forma, shape.] Like a maxilla (zool.).

maxillipede (măkšilineēd) $n$. [L. maxilla, jaw ; pes, foot.] An appendage, in one, two, or three pairs, posterior to the maxillae in Arthropods (zool.).

maxillodental (măksil'ödĕn'tăl) $a$. [L. maxilla, jaw ; dens, tooth.] Pert. jaws and teeth (anat.).

maxillojugal (măksill'öjoo'găl) a. [L. maxilla, jaw; jugum, yoke.] Pert. jaw and jugal bone (anat.).

maxillomandibular (măksǐlöomăndíb'ülăr) $a$. [L. maxilla, jaw ; mandibulum, jaw.] Appl. arch forming the jaws of primitive Fishes; pert. maxilla and mandible (anat.).

maxillopalatal (măksil'öpăl'ătăl) $a$. [L. maxilla, jaw ; palatus, the palate.] Pert. jaw and palatal bones; $a p p l$. a maxillary process of Birds (zool.).

maxillopharyngeal (măksil'öfărĭn'jěăl) a. [L. maxilla, jaw ; Gk. pharynx, gullet.] Pert. lower jaw and pharynx (anat.).

maxillo-premaxillary (măkšrl'ö-prě'măksīl'ărí) a. [L. maxilla, jaw ; pre, before.] Pert. the whole of the upper jaw; appl. jaw when maxilla and premaxilla are fused (anat.).

maxilloturbinal (măksinl'ötŭr'bǐnăl) $a$. [L. maxilla, jaw ; turbo, whorl.] Pert. maxilla and the turbinals; $n$., a bone arising from the lateral wall of the nasal cavity which supports the sensory epithelium (anat.).

maxillula (măksìl'ûlă) $n$. [L. dim. of maxilla, jaw.] A first maxilla in Crustacea when there are more pairs than one (zool.).

meatus (mēā'tŭs) n. [L. meatus, a 
passage.] A passage or channel, as the acoustic or auditory, and the nasal meatus (anat.).

Meckelian cartilage or rod. [After Meckel, German anatomist.] The lower jaw of lower vertebrates, and in the higher the axis round which the membrane bones of the jaw are arranged and formed (anat.).

Meckel's rod or cartilage,-Meckelian rod or cartilage.

meconidium (měk'önìd'îŭm) $n$. [Gk. mekon, poppy.] Sessile or pedicellate extracapsular medusae usually lying on the top of the gonangium of certain Hydroids (zool.).

media (mē'diă) $n$. [L. medius, middle.] A middle structure, such as a layer of tissue, a central nervure (anat., zool.); as a plu., substances of various kinds, such as bouillon, in which cultures are grown (biol.).

mediad (mē'diăd) adv. [L. medius, middle.] Towards but not quite in the middle line or axis (anat.).

medial (mé'diăl) a. [L. medius, middle.] Situated in the middle.

median (mē'diăn) a. [L. medius, middle.] Lying or running in the axial plane; intermediate; middle.

mediastinal (mē'diăs'tǐnăl, -ăstî'năl) a. [L. mediastinus, a servant.] Pert. or in the region of the mediastinum; $a p p l$. cavity, arteries, glands, pleura (anat.).

mediastinum (mē'dǐăs'tĭnŭm, -ăstī'nŭm) $n$. [L. mediastinum, servant.] The space between the right and left pleura in and near the median sagittal chest plane; an incomplete vertical septum of the testis (anat.).

mediodorsal (mē'diödôr'săl) a. [L. medius, middle ; dorsum, the back.] In the dorsal middle line.

mediopalatine (mē'diöpăl'ătî́n) a. [L. medius, middle; palatus, palate.] Between the palatal bones; $a p p l$. a cranial bone of some Birds (zool.).

mediopectoral (mē'dioöpěk'törăl) $a$. [L. medius, middle ; pectus, breast.] $A p p l$, the middle part of the sternum (anat.).

mediostapedial (mē'diöstăpē'diăl) $n$. [L. medius, middle ; stapes, stirrup.] Pert. that portion of the columella auris of certain animals external to the stapes (anat.). mediotarsal (mê'diötâr'săl) a. [L. medius, middle; tarsus, ankle.] Between the tarsal bones.

medioventral (mē'diövĕn'trăl) a. [L. medius, middle ; venter, the belly.] In the middle ventral line.

medithorax (mē'dĭthō'răks) $n$. [L. medius, middle; Gk. thorax, the breast.] The middle part of the thorax; the mesothorax of Insects (zool.).

medium (mē'dǐŭ) n., media (mē'dǐă) plu. [L. medius, middle.] Any of the structures through which a force acts, as the refracting media of the eyebulb (anat.); any of the more or less solid substances in which cultures are reared or tissues are propagated (phys.).

medulla (mědŭlă) n. [L. medulla, marrow, pith.] Marrow of bones ; the central part of an organ or tissue (anat.); the pith or central portion of a stem (bot.).

medulla oblongata,- the posterior portion of the brain continuous with the medulla spinalis, or spinal cord (anat.).

medullary (mĕdǔl'ărĭ) a. [L. medulla, pith.] Pert. or in the region of the medulla; $a p p l$. axis, artery, lamina, membrane, bone, spaces (anat.).

medullary canal or cavity, - the hollow cylindrical portion of a long bone containing marrow (anat.); the neurocoel (emb.).

medullary groove, - a groove on the surface of the medullary plate, bounded by folds which, growing up, coalesce and convert the groove into a canal ; the neurocoel (emb.).

medullary keel, - a downward growth towards the archenteron, the rudiment of the central nervous system in the development of certain primitive vertebrates (emb.).

medullary layer,-a thick subcortical layer of the thallus of some Lichens (bot.).

medullary plate, - the plate-like formation of ectoderm cells bordering the blastopore of early embryo; the earliest rudiment of the nervous system (emb.).

medullary rays, - a number of strands of connective tissue extending be 
tween the pith and the pericycle (bot.).

medullary sheath, - a ring of protoxylems round the pith of certain stems (bot.); a layer of white glistening material surrounding the axis cylinder of a medullated nerve-fibre (zool.).

medullated (mědŭlāttěd) $a$. [L. medulla, pith.] Provided with a medullary sheath.

medullated nerve-fibres, - the fibres of the white part of the brain and spinal cord, consisting of an axiscylinder or neuraxis of primitive fibrillae, surrounded by medullary sheath, which is in turn covered by a delicate membrane, the neurilemma (anat.).

medullispinal (mědŭl'íspī'năl) a. [L. medulla, pith; spina, the spine.] Of the spinal cord.

medusa (mědū'să) $n$. [Gk. Medousa, one who rules.] A jelly-fish (zool.). medusiform (mědū'sí fôrm) $a$. [Gk. Medousa, Medusa; L. forma, shape.] Like a medusa or jelly-fish. medusoid (mědū'soid) n. [Gk. Medousa, Medusa; eidos, like.] A medusa-like free-swimming gonophore of Hydrozoa (zool.) ; a., like a jelly-fish or medusa (zool.).

medusome (mědū'sōm) n. [Gk. Medousa, Medusa; soma, body.] A name given to the medusoid stage in the life-history of Obelia (zool.).

megagamete (měg'ăgămēt) n. [Gk. megas, large ; gametes, a spouse.] A rounded cell regarded as an ovum or its equivalent; developed from a megagametocyte after a process akin to maturation (zool.).

megagametocyte (měg'ăgămē'tösît) n. [Gk. megas, large; gametes, a spouse; kytos, hollow.] A cell developed from a merozoite, and itself giving rise to a megagamete, frequently requiring transference to another host before its development can proceed (zool.).

megakaryocyte (měg'ăkăríiosit) $n$. [Gk. megas, large ; karyon, nut ; kytos, hollow.] A giant-cell of marrow with one large annular lobulated nucleus, containing a number of nucleoli (anat.). megalaesthetes (měg'ălěs'thēts) n. plu. [Gk. megalon, great ; aisthetikos, perceptive.] Sensory organs, sometimes in the form of eyes in the Placophora (zool.).

megaloblast (mĕg'ălöblăst) $n$. [Gk. megalon, great ; blastos, bud.] A large erythroblast (anat.).

megalogonidium (mĕg'ălögŏnĭd'ium) n. [Gk. megalon, great ; gonos, offspring.] A large gonidium (bot.). megalopa (měg'ălópă). Megalops.

megalopic (měg'ălŏp'îk) a. [Gk. megalon, great; ops, eye.] $\mathrm{Be}-$ longing to the megalops stage (zool.).

megalopore (měg'ălöpōr) n. [Gk. megalon, great ; poros, a channel.] A pore in the dorsal plates in Chiton for placing a megalaesthete in direct communication with the exterior (zool.).

megalops (měg'ălŏps) n. [ Gk megalon, great ; ops, eye.] A larval stage of certain Crustaceans, as crabs, conspicuous by large stalked eyes (zool.).

megalospheric (měg'ălösfěr'ík) $a$. [Gk. megalon, great; sphaira, a globe.] Of polythalamous Foraminifer shells, having a megalosphere or large initial chamber (zool.).

megamere (mĕg'ămēr) n. [Gk. megas, large; meros, part.] One of the large cells formed after the primary divisions of a developing ovum (emb.).

meganucleus (měg'ănū'klěŭs) n. [Gk. megas, large ; L. nucleus, kernel.] The larger nucleus, or vegetative nucleus, of the Infusoria (zool.).

megasclere (měg'ăsklēr) $n$. [Gk. megas, large ; skleros, hard.] A skeletal spicule of the general supporting framework, as opp. a microsclere (zool.).

megaspheric (měg ăsfěr'ik). Megalospheric.

megasporangium (měg'ăspörăn'jiŭm) n. [Gk. megas, large; sporos, seed; anggeion, vessel.] A macrospore-producing sporangium (bot.).

megaspore (měg'ăspōr) n. [Gk. megas, great ; sporos, seed.] A larger-sized spore of dimorphic forms in reproduction by sporeformation (zool.); the larger spore 
of heterosporous plants, regarded as female; the embryo sac-cell of a seed plant (bot.).

megasporophyll (měg'ăspō'röfül) $n$. [Gk. megas, great; sporos, seed; phyllon, leaf.] A spore-bearing leaf developing megasporangia (bot.).

megatherm (měg'ăthĕrm) $n$. [Gk. megas, great; therme, heat.] A tropical plant (bot.).

megazooid (měg'ăzōoid) $n$. [Gk. megas, great ; zoon, animal ; eidos, like.] The larger zooid resulting from binary or other fission (zool.).

megazoospore (měg'ăzō'öspōr) $n$. [Gk. megas, great ; zoon, animal ; sporos, seed.] A large zoospore, as in the reproduction of certain Radiolaria (zool.) ; a zoogonidium of certain Algae (bot.).

Meibomian glands,-glands of the eyelid with a sebaceous secretion (anat.).

meiophylly (mīoöfil'î) $n$. [Gk. meion, smaller; phyllon, leaf.] The suppression of one or more leaves in a whorl (bot.).

meiostemonous (mī'östĕm'önŭs) $a$. [Gk. meion, smaller; stemon, a spun thread.] Having fewer stamens than petals or sepals (bot.).

meiotaxy (mî́ötăk'sĩ) n. [Gk. meion, smaller ; taxis, arrangement.] Suppression of a whorl or a set of organs (bot.).

meiotic (mīot'îk) a. [Gk. meion, smaller.] $A p p l$. reduction division, which see ; also maiotic (cyt.).

Meissner's plexus, - a gangliated plexus of nerve fibres in the submucous coat of the small intestine (phys.).

melanin (mĕl'ănĭn) n. [Gk. melas, black.] Black or dark-brown pigment, as of the retina ; cf. haemozoin (phys.).

melanism (mĕl'ănĭzm) $n$. [Gk. melas, black.] Excessive development of black pigment in skin or bodycovering (biol.).

melanocyte (mĕlănösīt) $n$. [Gk. melas, black; kytos, hollow.] A black pigmented lymphocyte (phys.).

melanospermous (měl'ănöspěr'mŭs) $a$. [Gk. melas, black; sperma, seed.] $A p p l$. seaweeds with dark-coloured spores (bot.). melanotic (mĕlănŏt'îk) a. [Gk. melas, black.] Having black pigment unusually developed.

melliferous (mělif'ĕrŭs) a. [L. mel, honey; ferre, to carry.] Honeyproducing (bot.).

melliphagous (mělíf'ăgŭs) a. [L. mel, honey; Gk. phagein, to eat.] Feeding on honey (zool.).

mellisugent (mĕl'ísū'jĕnt) $a$. [L. mel, honey; sugere, to suck.] Honeysucking (zool.).

mellivorous (mëlǐ̀'örŭs) a. [L. mel, honey; vorare, to devour.] Feeding on honey (zool.).

member (mĕm'bĕr) $n$. [L. membrum, a member.] A limb or organ of the body (zool.); a well-defined part or organ of a plant (bot.).

membrana (měmbrắnă) $n$. [L. membrana, a membrane.] A thin film, skin or layer of tissue covering a part or organ of animal or plant ; or a thin skin-like covering of cells or unicellular organisms (biol.).

membranaceous (mĕm'brănā'shŭs) $a$. [L. membrana, membrane.] Of the consistency or having the structure of a membrane (biol.).

membrane (měm'brān), -a membrana, which see.

membrane bone,-a bone developing directly from membrane without passing through a cartilage stage (anat.).

membranella (mĕm'brănĕl'ă) $n$. [L. membrana, membrane.] A flapping or swinging membrane formed by fusion of rows of cilia, found among the Protozoa (zool.).

membraniferous (měm'brănĭf'ěrŭs) $a$. [L. membrana, membrane; ferre, to carry.] Enveloped in or bearing a membrane.

membranoid (mĕm'brănoid) $a$. [L. membrana, membrane; Gk. eidos, like.] Resembling membrane.

membranous (měm'brănŭs) a. [L. membrana, membrane.] Resembling or consisting of membrane ; pliable and semitransparent.

membranous cranium,-a mesenchymal investment enclosing the whole brain (emb.).

membranous labyrinth, - the internal ear, separated from the bony cavi- 
ties by perilymph, and itself containing endolymph (anat.).

membranous vertebral column,a continuous sheath of mesoderm, enveloping notochord and neural tube (emb.).

membranula (mĕmbrăn'ūlă) $n$. [L. dim. of membrana, membrane.] A concrescence of cilia, as in certain Infusoria (zool.).

membranule (mĕm'brănūl) $n$. [L. dim. of membrana, membrane.] A small opaque space, in some dragon-flies' wings, lying close to the body of the insect in the anal area of the wing (zool.).

Mendelian,-pert. law, factor or character which behaves according to the results of Mendel's experiments.

Mendelism, - a law or rule governing the inheritance of characters in plants and animals discovered by Gregor Mendel. This principle deals with the inheritance of "unit characters," the presence or absence of one or other of a pair of contrasting characters. It also shows that the offspring of organisms with a pair of contrasting characters will be produced in a definite ratio. From this law we are able to get a more correct and scientific definition of "purity of a breed." It may be extended to deal with groups of characters.

meningeal (měn'înjē'ăl, mĕnĭn'jê̌ăl) $a$. [Gk., meninx, a membrane.] Pert. or in the region of the meninges; $a p p l$. artery, vein, nerve (anat.).

meninges (měnǐn'jèz) $n$. plu. [Gk. meninx, a membrane.] The three membranes enclosing the brain and spinal cord, from without inwardsthe dura mater, arachnoid and pia mater (anat.).

meningosis (měn'ingō'sĭs) n. [Gk. meninx, a membrane.] Attachment by means of membranes.

meningo-spinal (měniัng'gö-spínăl) $a$. [Gk. meninx, a membrane; L. spina, spine.] Pert. the spinal cord membranes (anat.).

meniscus (mĕnĭs'kŭs) n., menisci (měnı̌s'kī) plu. [Gk. meniskos, a little moon.] Interarticular fibrocartilages found in joints exposed to violent concussion, such as wrist and knee joints (anat.).

mensa (měn'să) $n$. [L. mensa, a table.] The chewing surface of a tooth.

menstruation (měn'strooā'shŭn) $n$. [L. mensis, a month; struere, to flow.] A monthly discharge from the female reproductive organs, chiefly in higher mammals (zool.).

mental (mĕn'tăl) a. [L. mentum, chin.] Pert. or in the region of the chin; appl. foramen, nerve, spines, tubercle, muscle (anat.); pert. the mentum of insects; appl. scale or plate of fish and of reptile (anat.).

mentigerous (měntij'ěrŭs) a. [L. mentum, chin; gerere, to carry.] Supporting or bearing the mentum (zool.).

mentomeckelian (měn'töměkē'liăn) $a$, [L. mentum, chin; Ger. Meckel, comparative anatomist.] $A p p l$. a cartilage bone present in a few lower vertebrates at either side of the union of the two halves of the lower jaw (zool.).

mentum (mĕn'tŭm) n. [L. mentum, chin.] The chin (anat.); an undivided mouth-part of Insects, continuous with submentum or gula and posterior to labial palps and palpigers; a projection between the head and foot of some Gastropods (zool.).

mericarp (měr'ikârp) n. [Gk. meros, part; karpos, fruit.] A one-seeded indehiscent part of a schizocarp (bot.).

meridional canal,-in Ctenophores, a canal extending upwards and downwards beneath a swimming-plate, into which the adradial canals open (zool.).

merism (měrizm) n. [Gk. meros, part.] "A repetition of homologous parts."

merismatic (měr'izmăt'ík) a. [Gk. merismos, a partition.] Dividing or separating into cells or segments ; consisting of meristem, as merismatic tissue (bot.).

merismoid (měriz'moid) a. [Gk. merismos, partition; eidos, like.] With branched pileus (bot.). merispore (měr'ispōr) n. [Gk, meros, 
part ; sporos, seed.] A segment or spore of a multicellular spore-body (bot.).

meristele (mĕr'ístēl) $n$. [Gk. meros, part; stele, pillar.] A separate part of a monostelic stem passing outwards from stele to leaves; the branch of a stele supplying a leaf (bot.).

meristem (mĕr'ǐstěm) n. [Gk. meristes, a divider.] Tissue formed of cells all capable of division, as found at growing points ; merismatic or meristematic tissue (bot.). meristematic (měr'ístĕmăt' ik) $a$. [Gk. meristes, a divider.] Pert. or consisting of meristem; appl. tissue, cells of growing point ; merismatic (bot.).

meristic (měrǐs'tǐk) a. [Gk. meristes, a divider.] Segmented; divided off into parts (bot.).

meristic variation,-changes in the number of parts or segments, and in the geometrical relations of the parts; $c f$. substantive variation (biol.).

meristogenetic (mĕris'töjĕnĕt'îk) $a$. [Gk. meristes, a divider; genesis, descent.] Developing from meristem (bot.).

merithallus (měrǐthăl'ŭs) $n$. [Gk. meros, part; thallos, young shoot.] An internode (bot.).

mermaid's purse, - the horny floating or fixed egg-envelope of skates and sharks (zool.).

meroblastic (měr'öblăs'tı̌k) $a$. [Gk. meros, part; blastos, bud.] Appl. ova which undergo only partial segmentation or cleavage in development (zool.) ; developing from part of the oosphere only (bot.).

merocerite (měrŏs'ěrīt) $n$. [Gk. meros, thigh; keras, horn.] The fourth segment of crustacean antennae (zool.).

merocyte (měr'ösīt) $n$. [Gk. meros, part; kytos, hollow.] A nucleus lying in the yolk, directly below the blastoderm in a meroblastic ovum (cyt.).

merogastrula (měr'ögăs'troolă) $n$. [Gk. meros, part ; dim. of gaster, stomach.] The gastrula formed from a meroblastic ovum (zool.).

merogenesis (mềr'öjĕn'ěsiss) $n$. [Gk. meros, part ; gignesthai, to produce.] Formation of parts ; segmentation. merognathite (měr'ögnăth'ît) $n$. [Gk. meros, thigh; gnathos, jaw.] The fourth segment of a crustacean mouth-part (zool.).

merogony (měrŏg'önǐ) $n$. [Gk. meros, part ; gone, generation.] Development of normal young of small size, from part of an egg, in which there was no female pronucleus (zool.).

meroistic (mĕröös'tǐk) a. [Gk. meros, part.] $A p p l$, certain insect ovaries which produce vitelligenous cells in addition to ova (zool.).

meromorphosis (mêr'ömôr'fösĭs) $n$. [Gk. meros, part; morphosis, change.] Regeneration of a part when the new part is less than that lost (zool.).

meront (měrŏnt') n. [Gk. meros, part; ons, being.] A uninucleate schizont-stage in Neosporidia succeeding the planont-stage, which multiplies by fission (zool.).

meroplankton (měr'öplăng'ktŏn) $n$. [Gk. meros, part; plangktos, wandering.] Plankton living only part-time near the surface (bot., zool.).

meropodite (mērŏp'ödīt') n. [Gk, meros, thigh; pous, foot.] The fourth segment of a thoracic appendage in the Crustacea (zool.).

meros (mē'rŏs) $n$. [Gk. meros, thigh.] The fourth segment of a crustacean appendage (zool.).

merosomatous (měr'ösŏm'ătŭs) $a$. [Gk. meros, part ; soma, body.] $A p p l$. ascidiozooids divided into two regions, thorax and abdomen (zool.).

merosome (měr'ösōm) n. [Gk. meros, part; soma, body.] A body segment, somite, or metamere (zool.). merosthenic (mē'rǒsthěn'îk) a. [Gk. meros, thigh; sthenos, strength.] With unusually developed hindlimbs (zool.).

merotomy (mếrŏt'ömǐ) $n$. [Gk. meros, part ; temnein, to cut.] Segmentation or division into parts (zool.).

merozoite (mêrr'özō'ît) $n$. [Gk. meros, part ; zoon, animal.] A cell, the division-product of a schizont in Sporozoa (zool.).

merozoon (měr'özōón) n. [Gk. meros, 
part; zoon, animal.] A fragment of a unicellular animal containing part of the macronucleus, obtained by artificial division (zool.).

merrythought, - the furcula of birds, formed by the coalescence of clavicles (zool.).

merus (mē'rŭs) $n$. [Gk. meros, thigh.] Meros, which see.

mesamoeboid (mĕs'ămē'boid) cells,nucleated cells of the blood islands from which blood corpuscles are derived (emb.).

mesarch (měs'ârik) a. [Gk. mesos, middle ; arche, beginning.] $A p p l$. xylem having metaxylem developing in all directions from the protoxylem, characteristic of ferns ; having the protoxylem surrounded by metaxylem (bot.).

mesaxonic (měs'ăksŏn'îk) $a$. [Gk. mesos, middle; axon, axis.] With the line dividing the foot, passing up the middle digit (zool.).

mesencephalon (měs'ěnkĕf'ălŏn, -sĕf-) n. [Gk. mesos, middle; en, in ; kephale, head.] The mid-brain, comprising corpora quadrigemina (bigemina) and cerebral peduncles (anat.).

mesenchyma (měsĕng'kĭmă) $n$. [Gk. mesos, middle; engchein, to pour in.] A mass of tissue, intermediate between ectoderm and endoderm of a gastrula (emb.).

mesenchyme (měsěng'kīm). Mesenchyma.

mesenterial (měs'ěntē'rŭăl, měz'ěntē'rĭăl) a. [Gk. mesos, middle ; enteron, gut.] Pert. a mesentery; appl. filaments of Actinozoa (zool.).

mesenteric (měs'ěntěr'ik, mĕz'ěntěr'ik) a. [Gk. mesos, middle ; enteron, gut.] Pert. a mesentery; $a p p l$. artery, glands, nerves, veins (anat.). mesenteriole (měs'ěntēriōol, měz' ěnté'riōl) $n$. [L. dim. of mesenterium, a mesentery.] A fold of peritoneum derived from the mesentery, retaining the vermiform appendix in position (anat.).

mesenterium (měs'ěntē'rĭum, měz' ěnté'rưum) $n$. [L. mesenterium, a mesentery.] A mesentery.

mesenteron (měsĕn'těrŏn) n. [Gk. mesos, middle ; enteron, gut.] The main digestive cavity of Actinozoa and otherCoelenterates; the portion of the alimentary canal lined by endoderm (zool.).

mesentery (měs'ěntěrĭ, mĕz'ěntĕrĭ) $n$. [L. mesenterium, a mesentery.] A peritoneal fold serving to hold the viscera in position: there are three, the mesentery proper, the transverse mesocolon, and the sigmoid mesocolon (anat.) ; a muscular partition, complete or incomplete, extending inwards from the bodywall in Coelenterates (zool.).

mesepimeron (měs'ěpĭm'ĕrŏn) n. [Gk. mesos, middle ; epi, upon; meros, part.] The epimeron of the mesothorax of an insect (zool.).

mesethmoid (měsěth'moid) a. [Gk. mesos, middle ; ethmos, sieve ; eidos, like.] Between the two ectethmoid bones; $a p p l$. ethmoid plate of cranium when it ossifies (anat.); a median cranial bone of vertebrates (zool.).

mesiad (mé'zlăd) adv. [Gk. mesos, middle.] Towards or near the middle plane.

mesial (mếžăl) $a$. [Gk. mesos, middle.] In the middle vertical or longitudinal plane.

mesian (mé'žăn) a. [Gk. mesos, middle.] Mesial.

mesoarium (měs'ōă'rŭum) $n$. [Gk. mesos, middle ; oarion, a small egg.] A mesovarium.

mesobenthos (měs'öbĕn'thŏs) $n$. [Gk. mesos, middle; benthos, depths.] The animal and plant life of the sea-bottom when the depth is between 100 fathoms and 500 fathoms (zool., bot.).

mesoblast (mềs'öblăst) $n$. [Gk. mesos, middle; blastos, bud.] The mesoderm or middle layer of an embryo (emb.).

mesoblastema (měs'öblăstếmă). Mesoblast.

mesoblastic (mềs'öblăs'třk) a. [Gk. mesos, middle ; blastos, bud.] Pert. or developing from the middle layer (emb.).

mesobranchial (měs'öbrăng'kǐăl) $a$. [Gk. mesos, middle; brangchia, gills.] Pert. the middle gill-region, as in Crustacea (zool.).

mesobronchus (mě̀s'öbrŏng'kŭs) $n$. [Gk. mesos, middle; brongchos, 
wind-pipe.] In birds, the main trunk of a bronchus in the lung beyond the ventricle : it gives rise to secondary bronchi (zool.).

mesocaecum (měs'ösē'kŭm) n. [Gk. mesos, middle; L. caecus, blind.] The mesentery connected with the caecum (anat.).

mesocardium (měs'ökâr'diŭm) $n$. [Gk. mesos, middle ; kardia, the heart.] An embryonic mesentery binding the heart to the pericardial walls $(e m b$.$) ; part of the pericardium$ enclosing veins (venous $\mathrm{m}$.) or aorta (arterial m.) (anat.).

mesocarp (mê̌s'ökârp) $n$. [Gk. mesos, middle ; karpos, fruit.] The middle layer of the pericarp or coat of a fruit (bot.).

mesocentrous (měs'ösěn'trŭs) $a$, [Gk. mesos, middle ; L. centrum, a centre.] Ossifying from a median centre (anat.).

mesochilium (měs'ökill'ium) $n$. [Gk. mesos, middle; cheilos, a lip.] The middle portion of the labellum of orchids (bot.).

mesocoel (měs'ösēl) n. [Gk. mesos, middle; koilos, hollow.] 'The second of three main parts of the coelom of Molluscs (zool.).

mesocolic (mê̌s'ökǒl'ik) a. [Gk. mesos, middle ; kolon, the large intestine.] Pert. the mesocolon; appl. lymph glands (anat.).

mesocolon (mềs'ökōlŏn) n. [Gk. mesos, middle ; kolon, the large intestine.] A mesentery or fold of peritoneum attaching the colon to the dorsal wall of the abdomen (anat.).

mesocoracoid (měs'ökŏr'ăkoid) $a$. [Gk, mesos, middle ; korax, crow ; eidos, resemblance.] Situated between hyper- and hypo-coracoid; $a p p l$. a middle part of the coracoid arch of certain Fishes (zool.).

mesocycle (mếs'ösīkl) $n$. [Gk, mesos, middle; kyklos, a circle.] A layer of tissue between xylem and phloem of a monostelic stem; part of the conjunctive tissue of the stele (bot.).

mesoderm (měs'öděrm) $n$. [Gk, mesos, middle ; derma, skin.] The mesoblast or embryonic layer lying between the ectoderm and endoderm (emb.). mesodermal (měs'ödĕr'măl) $a$. [Gk. mesos, middle ; derma, skin.] Pert. derived or developing from mesoderm (emb.).

mesodesm (měs'ödězm) $n$. [Gk. mesos, middle ; desma, bond.] Part of the mesocycle (bot.).

mesodont (mếs'ödŏnt) a. [Gk. mesos, middle; odous, tooth.] Appl. stagbeetles having a medium development of mandible projections (zool.).

mesogaster (měs'ögăs'tĕr) n. [Gk. mesos, middle ; gaster, belly.] The mesentery proper, or fold of peritoneum supporting the stomach (anat.).

mesogastric (mês'ögăs'trǐk) a. [Gk. mesos, middle; gaster, belly.] Pert. a mesogaster or mesogastrium; pert. the middle gastric region (anat.).

mesogastrium (měs'ögăs'trǐum) n. [Gk. mesos, middle ; gaster, belly.] The mesentery connecting stomach with dorsal abdominal wall in the embryo (emb.); the middle abdominal region (anat.).

mesogloea (mềs'öglē'ă) $n$, [Gk. mesos, middle; gloia, glue.] An intermediate non-cellular layer in Sponges and Coelenterates (zool.).

mesognathion (měs'ögnăth'îon) $n$. [Gk. mesos, middle; gnathos, jaw.] The lateral segment of the maxilla, bearing the lateral incisor (anat.).

mesohepar (měs'öhē'păr) n. [Gk. mesos, middle ; L. hepar, liver.] The mesentery supporting the liver (anat.).

mesohydrophytic (mềs'öhī'dröfît'ik) a. [Gk. mesos, middle; hydor, water; phyton, plant.] Growing in temperate regions but requiring much moisture (bot.).

mesolecithal (měs'ölěs'îthăl) $a$. [Gk. mesos, middle; lekithos, yolk of egg.] Appl. eggs with yolk in the centre (emb.).

mesology (mêsǒl'öjĩ) n. [Gk. mesos, middle; logos, discourse.] Bionomics; the relation between organism and environment.

mesomere (měs'ömēr) $n$. [Gk. mesos, middle ; meros, part.] The middle zone of the coelomic pouches in the embryo; a mesoblastic somite or protovertebra (emb.). 
mesometrium (měs'ömë'trǔŭm) $n$. [Gk. mesos, middle ; metra, uterus.] The mesentery of uterus and connecting tubes (anat.).

mesomitosis (mềs'ömîtō'sǐs) $n$. [Gk. mesos, middle; mitos, thread. Mitosis within the nuclear membrane, without co-operation of cytoplasmic elements ; $c f$. metamitosis (emb.).

mesomyodian (měs'ömīō'dĭăn) $a$. [Gk. mesos, middle; mys, a muscle.] $A p p l$. birds with muscles of syrinx attached to middle of bronchial semi-rings (zool.).

meson (mếs'ŏn, měz'ŏn) $n$. [Gk. mesos, middle.] The central plane, or region of it (zool.).

mesonephric (měs'önëf'rǐk) a. [Gk. mesos, middle; nephros, kidney.]

Pert. mesonephros, or mid-kidney; $a p p l$. duct, tubules (zool.).

mesonephridium (měs'öněfrĭd'ǐŭm) $n$. [Gk. mesos, middle; nephros, kidney.] A nephridium or excretory organ of certain invertebrates, derived from mesoblast (zool.).

mesonephros (mê̌s'öněf'rŏs) $n$. [Gk. mesos, middle; nephros, kidney.] The intermediate part of the excretory organ in vertebrate embryos -it becomes the functional kidney in lower Craniata, it atrophies in the higher forms (zool.); the Wolffian body (anat.).

mesonotum (měs'önō'tŭm) n. [Gk. mesos, middle; noton, the back.] The dorsal part of an insect mesothorax (zool.).

mesoparapteron (měs'öpărăp'tĕrŏn) $n$. [Gk. mesos, middle ; para, beside ; pteron, wing.] The small sclerite of the mesothorax of insects (zool.). mesopetalum (mê̌s'öpět'ălŭm) n. [Gk. mesos, middle; petalon, a petal.] The labellum or lip of an orchid (bot.).

mesophragma (měs'öfrăg'mă) $n$. [Gk. mesos, middle ; phragma, a fence.] A chitinous piece descending into interior of insect body with postscutellum for base (zool.).

mesophryon (měsŏf'riŏn) $n$. [Gk. mesos, middle ; ophrys, an eyebrow.]

The elevated median head-region of Trilobites (pal.).

mesophyll (měsöfill) $n$. [Gk. mesos, middle; phyllon, leaf.] The internal parenchyma of a leaf (bot.).

mesophyte (měs'öfīt) $n$. [Gk. mesos, middle; phyton, plant.] A plant thriving in temperate climates with a normal amount of moisture (bot.). mesoplankton (měs'öplăng'ktŏn) $n$. [Gk. mesos, middle; plangktos, wandering.] Floating animal and plant life from a hundred fathoms downwards.

mesoplast (měs'öplăst) $n$. [Gk. mesos, middle ; plastos, moulded.] A cell nucleus (cyt.).

mesoplastron (měs'öplăs'trŏn) $n$. [Gk. mesos, middle ; F. plastron, breastplate.] A plate between hyo- and hypo-plastron of certain Turtles (zool.).

mesopleuron (měs'öploo'rŏn) $n$. [Gk. mesos, middle; pleura, side.] A lateral part of an insect mesothorax (zool.).

mesopodial (měs'öpō'dĭăl) a. [Gk. mesos, middle; pous, foot.] Pert. a mesopodium (bot., zool.).

mesopodium (mê̌s'öpō'diŭm) $n$. [Gk. mesos, middle; pous, foot.] The leaf-stalk or petiole region of a leaf (bot.); the middle part of a molluscan foot (zool.).

mesopraescutum (mễs'öprēskū'tŭm) n. [Gk. mesos, middle; L. prae, before ; scutum, a shield.] The praescutum of mesothorax in Insects (zool.).

mesopterygium (měs'ŏptĕríj'iŭm) $n$. [Gk. mesos, middle; pterygion, a little wing or fin.] The middle of three basal pectoral fin-cartilages in recent Elasmobranchs (zool.).

mesopterygoid (měs'ŏptěr'igoid) $n$. [Gk, mesos, middle ; pteryx, a wing; eidos, resemblance.] The middle of three pterygoid bone elements of Teleosts; the ectopterygoid (zool.). mesorchium (měsốr'kǐŭ) n. [Gk. mesos, middle; orchis, a testicle.] The mesentery supporting the testis, attached to dorsal abdominal wall in mammalian embryos; suspensory in adult Fishes (zool.).

mesorectum (měs'örěk'tŭm) $n$. [Gk. mesos, middle ; L. rectus, straight.] The mesentery supporting the rectum (anat.).

mesorhinal (mềs'örin'năl) a. [Gk, 
mesos, middle; rhis, nose.] Between the nostrils (zool.).

mesorhinium (měs'örĭn'îum) $n$. [Gk. mesos, middle; rhis, nose.] The internarial surface region of a bird's bill (zool.).

mesosalpinx (měs'ösăl'pĭngks) $n$. [Gk. mesos, middle ; salpingx, a trumpet.] The portion of supporting ligament stretching from uterine tube to the level of the ovary (anat.).

mesoscapula (měs'öskăp'ūlă) $n$. [Gk. mesos, middle ; L. scapula, shoulderblade.] The scapular spine (anat.).

mesoscutellum (měs'öskūtěl'ŭm) $n$. [Gk. mesos, middle; L. scutellum, a small shield.] The scutellum of insect's mesothorax (zool.).

mesoscutum (měs'öskū'tŭm) $n$. [Gk. mesos, middle ; L. scutum, a shield.] The scutum of insect's mesothorax (zool.).

mesosoma (měs'ösō'mă)n. [Gk. mesos, middle ; soma, body.] The middle part of the body; the praeabdomen of Arthropods, or anterior broader part of abdomen (zool.).

mesosperm (mĕs'öspĕrm) $n$. [Gk. mesos, middle ; sperma, seed.] The integument investing the nucellus of an ovule (bot.).

mesospore (mềs'öspōr) $n$. [Gk. mesos, middle; sporos, seed.] The intermediate of three spore coats; a resting-spore stage (bot.).

mesosporium (měs'öspö'rǔm). Mesospore.

mesostate (mĕs'östāt) $n$. [Gk. mesos, middle; stasis, a standing.] An intermediate stage in metabolism (phys.).

mesostereom (měs'östĕr'ěŏm) $n$. [Gk. mesos, middle ; stereos, solid.] The middle layer of thecal plates of Cystidea (zool.).

mesosternebra (měs'östĕr'něbră) $n$. [Gk. mesos, middle ; sternon, breastbone.] A part of the developing mesosternum (emb.).

mesosternum (měs'östĕr'nŭm) $n$. [Gk. mesos, middle ; L. sternum, breastbone.] The middle part of the sternum of vertebrates; the gladiolus (anat.); the sternum of the mesothorax of Insects (zool.).

mesostethium (mềs'östē'thǐŭ) $n$.
[Gk. mesos, middle; stethos, the chest.] A mesosternum (zool.).

mesostylous (měs'östìllŭs) $a$. [Gk. mesos, middle ; stylos, pillar.] Having styles of intermediate length ; $a p p l$. heterostylous flowers (bot.).

mesotarsal (měs'ötâr'săl) a. [Gk. mesos, middle; L. tarsus, anklejoint.] Pert. a mesotarsus of an Insect (zool.).

mesotarsus (měs'ötâr'sŭs) $n$. [Gk. mesos, middle; L. tarsus, anklejoint.] A middle-limb tarsus of insects (zool.).

mesothecium (měs'öthē'š̌ŭ, -shǐŭm) n. [Gk. mesos, middle ; theke, cup.] The middle investing layer of an anther-sac (bot.).

mesothelium (mềs'öthẽ'liŭm) $n$. [Gk. mesos, middle; thele, nipple.] Mesoderm bounding the primitive coelom and giving rise to muscular and connective tissue (anat.).

mesotherm (měs'öthĕrm) $n$. [Gk. mesos, middle; therme, heat.] A plant thriving in a moderate heat (bot.).

mesothoracic (měs'öthörăs'îk) a. [Gk. mesos, middle ; thorax, chest.] Pert. or in the region of the mesothorax ; $a p p l$. a spiracle of Insects (zool.).

mesothorax (měs'öthō'răks) n. [Gk. mesos, middle ; thorax, chest.] The middle segment of the thoracic region of Insects (zool.).

mesotriaene (měs'ötrīēn) n. [Gk. mesos, middle ; triaina, a trident.] An aberrant type of triaene spicule (zool.).

mesotrochal (mĕsŏt'rökăl) a. [Gk. mesos, middle; trochos, wheel.] Appl. an annulate larva with circlet of cilia round the middle of the body (zool.).

mesotympanic (měs'ötĭmpăn'îk) $a$. [Gk. mesos, middle; tympanon, a drum.] The symplectic; one of the bones in the suspensory apparatus of the lower jaw in Fishes (zool.).

mesovarium (mềs'övã'rŭum) $n$. [Gk. mesos, middle; L. ovarium, an ovary.] The mesentery of the ovary; suspensory mesentery of Fishes (zool., anat.).

mesoventral (měs'övĕn'trăl) a. [Gk. 
mesos, middle ; L. venter, belly.] In the middle ventral region.

Mesozoic (měs'özō'ik) n. [Gk. mesos, middle; zoe, life.] The middle or secondary group of rock-systems (pal.).

metabiosis (mět'ăbīō'š̃s) n. [Gk. meta, after ; bios, life.] Condition in which one organism lives only after another has prepared its environment and died (biol.).

metabolic (mĕt'ăbŏl'îk) $a$. [Gk. meta, after; ballein, to throw.] Changeable; appl. chemical changes occurring in living organism; metamorphosing (biol.).

metabolin (mětăb'ölĭn) $n$. [Gk. metabole, change.] A product of metabolism (phys.).

metabolism (mětăb'ölǐzm) n. [Gk. metabole, change.] The chemical change, constructive and destructive, occurring in living organisms (biol.).

metabranchial (mĕt'ăbrăng'kĭăl) $a$. [Gk. meta, after; brangchia, gills.] Pert. or in the region of the posterior gill region (zool.).

metacarpal (mèt'ăkâr'păl) $a$. meta, after; L. carpus, the wrist.] Pert. the metacarpus ; $a p p l$. bones, articulations, etc. (anat.).

metacarpophalangeal (mĕt'ăkâr'pöfălăn'jěăl) a. [Gk, meta, after ; L. carpus, wrist; Gk, phalanx, series.] $A p p l$. the articulations between metacarpals and phalanges (anat.).

metacarpus (mĕt'ăkâr'pŭs) n. [Gk. meta, after; L. carpus, wrist.] The skeletal part of the hand between wrist and fingers, consisting of five cylindrical bones (anat.).

metachromatinic grains, - chromatoid bodies found in cells very similar to chromatin in properties and characteristics (cyt.).

metachrosis (mět'ăkrō'sis) n. [Gk. meta, after ; chrosis, colouring.] Ability to change colour by expansion of pigment cells, as in some Fishes and Reptiles (zool.).

metacneme (mět'ăknēm) n. [Gk. meta, after; kneme, the tibia.] A secondary mesentery of Zoantharia (zool.). metacoel (mĕt’ăsēl) n. [Gk. meta, after; koilos, hollow.] The third and posterior part of the coelom of Molluscs (zool.).

metacone (mět'ăkōn) n. [Gk. meta, after ; konos, cone.] The posteroexternal cusp of an upper molar (zool.)

metaconid (mĕt'ăkō'nìd)n. [Gk.meta, after; konos, cone ; eidos, resemblance.] The postero-internal cusp of a lower molar (zool.).

metaconule (mĕt'ăkō'nūl) n. [Gk. meta, after; konos, cone.] The posterior secondary cusp of an upper molar (zool.).

metacoracoid (mět'ăkŏr'ăkoid) $n$. [Gk. meta, after; korax, crow ; eidos, resemblance.] The posterior part of the coracoid (zool.).

metacromion (mět'ăkrō'miǒn) $n$. [Gk. meta, after ; akros, summit ; omos, shoulder.] A posterior branchprocess of the acromion-process of the scapular spine (zool.).

metadiscoidal (mět'ădiskoid'ăl) $a$. [Gk. meta, after ; diskos, a quoit ; eidos,resemblance.] Appl. placenta in which the villi areat first scattered and later restricted to a disc, as in man and monkey (zool.).

metadromous (mětăd'römŭs) a. [Gk. meta, after; dromos, a running.] With primary veins of a segment arising from the upper side of the midrib (bot.).

metaesthetism (mětěs'thĕtĩzm) $n$. [Gk. meta, after; aisthetos, perceptible by the senses.] The doctrine that "consciousness is a product of the evolution of matter and force."

metagastric (mět'ăgăs'trǐk) a. [Gk. meta, after; gaster; belly.] Pert. the posterior gastric region (zool.). metagastrula (mět'ăgăs'troolă) $n$. [Gk. meta, after; gaster, belly.] A modified form of gastrula (zool.).

metagenesis (mět'ăjěn'ěsis) n. [Gk. meta, after; genesis, descent.] Alternation of generations, which see. metakinesis (mětăkǐñe'sı̌s) n. [Gk. meta, after ; kinein, to move.] The middle stage of mitosis, during which the chromosomes are grouped in the equatorial plate (cyt.).

metaloph (mět'ălǒf) n. [Gk. meta, 
after; lophos, a crest.] The posterior crest of a molar, uniting metacone, metaconule, and hypocone (zool.).

metamere (mět'ămēr) $n$. [Gk. meta, after; meros, part.] A body segment (zool.).

metameric (mět'ămĕr'ík) $a$. [Gk.meta, after ; meros, part.] Pert. metamerism or segmentation (zool.).

metamerism (mětăm'ěrǐzm) $n$. [Gk. meta, after ; meros, part.] The condition of a body divided up into segments more or less alike; segmentation; zonal symmetry (zool.).

metamerized (mětăm'ěrǐzd) $a$. [Gk, meta, after; meros, part.] Segmented (zool.).

metamitosis (mět'ămĭtō'sĭs) $n$. [Gk. meta, after; mitos, thread.] Mitosis in which cytoplasmic and nuclear elements are both affected; $c f$. mesomitosis.

metamorphosis (mět'ămôr'fösĭs) $n$. [Gk. meta, beyond ; morphe, form.] Change of form and structure undergone by an animal from embryo to adult stage, as in Insects (zool.); interference with normal symmetry in flowers (bot.) ; internal chemical change (phys.).

metamps (mĕtămp's, mē'tămps) $n$. plu. [Gk. meta, after; morphe, form.] Different forms of the same species, as in certain Sponges (zool.). metanauplius (mět'ănôp'liŭs) $n$. [Gk. meta, after; L. nauplius, a kind of shell-fish.] The larval stage of Crustacea succeeding the nauplius stage (zool.).

metanephric (mět'ăněf'rǐk) $a$. [Gk. meta, after; nephros, a kidney.] Pert. or in the region of the hindkidney (emb.).

metanephros (mĕt'ănĕf'rŏs) $n$. [Gk. meta, after; nephros, a kidney.] The organ arising behind the mesonephros and replacing it as the functional kidney of fullydeveloped amniotes (zool.).

metanotum (mèt'ănō'tŭm) $n$. meta, after; noton, back.] notum or tergum of the metathorax of Insects (zool.).

metanucleus (mĕt'ănū'klê̌us) n. [Gk. meta, after; L. nucleus, a kernel.] A term appl. by Haecker to the egg-nucleus after its extrusion from the germinal vesicle (cyt.).

metapeptone (mět'ăpěp'tōn) $n$. [Gk. meta, after; peptos, cooked.] A product of the action of gastric juice on albumins (phys.).

metaphase (mět'ăfāz) n. [Gk. meta, after; phainein, to appear.] The stage in mitosis in which the chromosomes are split up in the equatorial plate (cyt.).

metaphery (mětăf'ěrì) $n$. [Gk. meta, beyond; pherein, to bear.] Displacement of organs (bot.).

metaphloem (mět'ăflōe ěm) n. [Gk. meta, after; phloos, bark.] The phloem of secondary xylem (bot.).

metaphragma (mĕt'ăfrăg'mă) $n$. [Gk. meta, after; phragma, a fence.] An internal metathoracic septum in Insects (zool.).

metaphyte (mět'ăfï) $n$. [Gk. meta, after; phyton, plant.] A multicellular plant (bot.).

metaplasia (mĕt'ăplā'zuă) $n$. [Gk. meta, after; plasis, moulding.] Conversion of tissue from one form to another, as in ossification (phys.).

metaplasis (mětăp'lăsǐs) $n$. [Gk. meta, after; plasis, moulding.] The mature period in the life of an individual (phys.).

metaplasm (mět'ăplăzm) n. [Gk. meta, after; plasma, something moulded.] The lifeless ingredients of protoplasm, as $o p p$. to the living material (cyt.).

metaplastic (mĕt'ăplăs'tǐk) $a$. [Gk. meta, after; plastos, moulded.] Pert. metaplasia or metaplasm (cyt.).

metaplastic bodies, - grains or granules of protoplasm which are stages or products of metabolism and not true protoplasm (cyt.).

metapleural (mět'ăploo'răl) a. [Gk. meta, after ; pleura, a side.] Posteriorly and laterally situated; pert. a metapleure or metapleuron (zool.).

metapleure (mĕtăploor) $n$. [Gk. meta, after; pleura, a side.] An abdominal or ventro-lateral fold of integument of certain of the lowest vertebrates (zool.).

metapleuron (mět'ăploor'ŏn) $n$. [Gk. 
meta, after; pleura, a side.] The pleuron of an insect metathorax (zool.).

metapneustic (mět'ăpnū'stǐk) $a$ [Gk. meta, after ; pneuma, breath.] $A p p l$. insect larvae with only the terminal pair of spiracles (zool.).

metapodeon (mět'ăpō'děŏn) $n$. [Gk. meta, after; pous, foot.] That part of an insect's abdomen behind the petiole or podeon (zool.).

metapodeum (mět'ăpō'dêum). Metapodeon.

metapodial (mět'ăpō'diăl) a. [Gk. meta, after; pous, foot.] Pert. a metapodeon or metapodium (zool.). metapodium (mět'ăpō'diŭm) $n$. [Gk. meta, after; pous, foot.] The posterior portion of a molluscan foot; the portion of the foot between tarsus and digits; in four-footed animals, the metacarpus and metatarsus (zool.).

metapolar cells, - the second circlet of cells of the polar cap of the rhombogen of Rhombozoa.

metapophysis (mět'ăpŏf'išss) $n$. [Gk. meta, after; apo, from; phyein, to grow.] A prolongation of a vertebral articular process developed in certain vertebrates (zool.); the mammillary process (anat.).

metapore (mět'ăpōr) n. [Gk. meta, after; poros, a channel.] The medial aperture in the roof of the fourth ventricle of the brain; Magendie's foramen (anat.).

metapostscutellum (mèt'ăpōstskūtěl'ŭm) $n$. [Gk. meta, after; L. post, after; scutellum, a small shield.] The post-scutellum of an insect metathorax (zool.).

metapraescutum (mĕt'ăprēskū'tŭm) n. [Gk. meta, after; L. prae, before; scutum, shield.] The praescutum of an insect meta-thorax (zool.).

metapterygium (mět'ăptěríj'iŭm) $n$. [Gk. meta, after; pterygion, a little wing.] The posterior basal fincartilage or bone, either pectoral or pelvic, of recent Elasmobranchs (zool.).

metapterygoid (mět'ăptěr'ígoid) $n$. [Gk, meta, after; pteryx, wing; eidos, resemblance.] The posterior of three pterygoid elements in certain lower vertebrates (sool.). metarachis (mĕt'ărăk'ĩs) $n$. [Gk. meta, after ; rhachis, a spine.] The face of Pennatulacea which coincides with the sulcar aspect of the terminal zooid, otherwise the so-called dorsal surface (zool.).

metascutellum (mět'ăskūtěl'ŭm) $n$. [Gk. meta, after; L. scutellum, a small shield.] The scutellum of an insect metathorax (zool.).

metascutum (mět'ăskū'tŭm) n. [Gk. meta, after; L. scutum, shield.] The scutum of an insect metathorax (zool.).

metasitism (mět'ăsĭt'izm) $n . \quad[\mathrm{Gk}$. meta, after ; sitos, food.] The acquisition of a cannibalistic mode of life (zool.).

metasoma (mĕt'ăsō'mă) n. [Gk. meta, after ; soma, body.] The posterior body-region of Arachnids (zool.).

metasomatic (mět'ăsömăt'îk) a. [Gk. meta, after; soma, body.] Pert. or situated in the metasoma (zool.). metasperm (mět'ăspĕrm) $n$. [Gk. meta, after ; sperma, seed.] A plant having seeds in a closed ovary ; an angiosperm (bot.).

metastasis (mětăs'tăsǐs) n. [Gk. meta, after ; stasis, standing.] Metabolism; transference of function from one organ to another (phys.).

metastatic (mĕt'ăstăt' $\mathrm{k}$ ) life-history that of certain Trematodes in which the young form after entering the intermediate host, metamorphoses into the adult, after which the intermediate host is swallowed by the final host (zool.).

metasternum (mět'ăstěr'nŭm) $n$. [Gk. meta, after; sternon, breast-bone.] The sternum of insect metathorax ; the posterior sternal part of Anura ; the xiphoid or ensiform process, the posterior part of the sternum of higher vertebrates (zool.).

metasthenic (mět'ăsthěn'îk) $a$. [Gk. meta, after; sthenos, strength.] With well-developed posterior part of the body (zool.).

metastigmate (mět'ăstǐg'māt) a. [Gk. meta, after ; stigma, mark.] Having posterior tracheal openings or stigmata, as in Mites (zool.).

metastoma (mět'ăstō'mă) n. [Gk. meta, after; stoma, mouth.] The twolobed lower lip of Crustacea (zool.). 
metatarsal (mĕt'ătâr'săl) $a$. [Gk. meta, after ; L. tarsus, the ankle.] In the region of the tarsus; $a p p l$. arteries, veins, etc. ; pert. the metatarsal bones (zool., anat.).

metatarsophalangeal (mět'ătâr'söfălăn'jě̆l) a. [Gk. meta, after; L. tarsus, ankle ; Gk. phalanx, troop.] $A p p l$. articulations between the metatarsus and phalanges of the foot (anat.).

metatarsus (mět'ătâr'sŭs) $n$. [Gk. meta, after; L. tarsus, ankle.] The part of the foot between the ankle and toes (anat.).

metathalamus (mĕt'ăthăl'ămŭs) $n$. [Gk meta, after; thalamos, chamber.] The geniculate bodies of the brain (anat.).

metathorax (mět'ăthō'răks) $n$. $[\mathrm{Gk}$. meta, after; thorax, the chest.] The posterior segment of the thorax of Insects (zool.).

metatrophic (mět'ătrŏf'ǐk) a. [Gk. meta, after ; trophe, nourishment.] Living on decaying organic matter (bot.).

metaxylem (mět'ăzīlěm) $n$. [Gk. meta, after; xylon, wood.] Secondary xylem with thick walled cells (bot.).

metazoaea (mět'ăzō'ěă) $n$. [Gk. meta, after; zoe, life.] A larval stage of Crustacea between zoaea and megalopa stages (zool.).

metazoon (mět'ăzōoón) $n$. [Gk. meta, after; zoon, animal.] A multicellular animal (zool.).

metencephalon (mĕt'ěnkĕf'ălŏn, -sĕf-) n. [Gk. meta, after; en, in ; kephale, head.] The hind-brain or cerebellum.

metenteron (mětěn'tĕrŏn) $n$. [Gk. meta, after; enteron, gut.] An intermesenteric chamber of a seaanemone or other Coelenterate (zool.).

metepimeron (mět'ěpim'ěrŏn) $n$. [Gk. meta, after ; epi, upon ; meros, part.] The epimeron of an insect metathorax (zool.).

metepisternum (mět'ěpistěr'nŭm) $n$. [Gk. meta, after ; epi, upon ; sternon, breast-bone.] The episternum of an insect metathorax (zool.).

methaemoglobin (měthé' möglō'bĭn) $n$. [Gk. meta, after; haima, blood; L. globus, a globe.] A product of blood decomposition (phys.).

metochy (mĕt'ökǐ) n. [Gk. metoche, a sharing.] The relationship between a neutral guest insect and its host (zool.).

metoecious (měté'shŭs) a. [Gk. meta, after; oikos, a house.] Metoxenous or heteroecious (bot.).

metope (mět'öpē) n. [Gk. metopon, forehead.] The middle frontal portion of a Crustacean (zool.).

metopic (mětŏp'ik) a. [Gk. metopon, forehead.] Pert. the forehead; $a p p l$. the frontal suture (anat.).

metosteon (mětŏs'těŏn) $n$. [Gk. meta, after; osteon, bone.] A posterior sternal ossification in birds (zool.).

metovum (mětō'vŭm) n. [Gk. meta, after; L. ovum, an egg.] An eggcell surrounded by nutritive material (cyt.).

metoxenous (mĕtŏk'sĕnŭs) a. [Gk. meta, after ; xenos, a guest.] Parasitic on different hosts at different stages in life-history (bot.).

micella (misĕl'ă) $n$. [L. dim. of mica, morsel.] An ultimate supra-molecular unit of a cell. See hypothetical units.

micraesthetes (mỉkrěs'thëts) $n$. plu. [Gk. mikros, small ; aesthetikos, perceptive.] The smaller sensory organs of Placophora (zool.).

microbe (mī'krōb) n. [Gk. mikros, small; bios, life.] A bacterium ; a micro-organism.

microbiology (mī'kröbīŏl'öjǐ) n. [Gk. mikros, small ; bios, life ; logos, discourse.] Bacteriology.

microcalthrops (mî'krökăl'thrŏps) $n$. [Gk. mikros, small ; A.S. coltraeppe, a kind of thistle.] A primitive tetraxon, or euaster with four persistent rays (zool.).

microcentrum (mī'krösěn'trŭm) $n$. [Gk. mikros, small ; L. centrum, centre.] The dynamic centre of a cell composed of centrosomes (cyt.).

microconjugant (mī'krökŏn'joogănt) $n$. [Gk. mikros, small; L. conjugare, to unite.] A motile ciliated freeswimming conjugant or gamete which attaches itself to a macroconjugant and fertilizes it (sool.).

microconidium (míkrökŏnĭd'iŭm) $n$. 
[Gk. mikros, small ; konis, dust.] A comparatively small conidium (bot.).

microcyst (mík krösǐst) n. [Gk. mikros, small ; kystis, bladder.] A restingspore stage of slime Fungi (bot.).

microcytase (mî'krösī'tăs) $n$. [Gk. mikros, small ; kytos, hollow.] The enzyme of microphages or smaller leucocytes (phys.).

microcytes (mīkrösīts) n. plu. [Gk. mikros, small; kytos, hollow.] Blood-corpuscles about half the size of erythrocytes, numerous in diseased conditions (phys.).

microdont (mî'krödŏnt) a. [Gk. mikros, small; odous, a tooth.] With comparatively small teeth (zool.).

microgamete (mī'krögămēt') $n$. [Gk. mikros, small ; gametes, a spouse.] The smaller of two conjugant gametes, regarded as male (zool.).

microgametocyte (mî'krögămē'tösīt) n. [Gk. mikros, small; gametes, a spouse; kytos, hollow.] A cell developed from a merozoite in certain Protozoa, and giving rise to a microgamete (zool.).

microgamy (mīkrŏg'ămĩ) n. [Gk. mikros, small; gamos, marriage.] Syngamy between the smallest individuals, produced by fission or gemmation, as in Foraminifers (zool.).

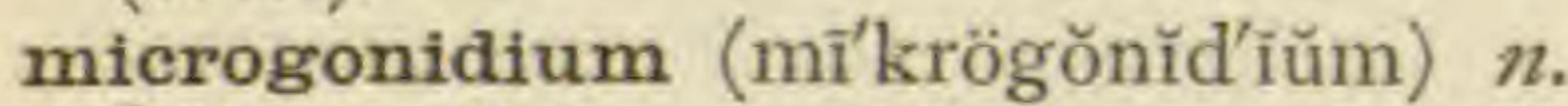
[Gk. mikros, small; gonos, offspring.] A comparatively small gonidium (bot.); a male gamont or gametocyte (zool.).

micromere (mî'krömēr) n. [Gk. mikros, small; meros, part.] A cell of the upper or animal hemisphere in meroblastic and other eggs (emb.).

micromerozoite (mīkröměr'özōit) $n$. [Gk. mikros, small ; meros, part ; zoon, animal.] A cell derived from a microschizont and developing into a gametocyte in Haemosporidia (zool.).

micromesentery (mī'kröměs'ěntěrí) $n$. [Gk, mikros, small ; mesos, middle ; enteron, gut.] A secondary incomplete mesentery in Zoantharia (zool.).

mieron (mì'krŏn) $n$. [Gk. mikros, small.] One-thousandth part of a millimetre, symbol $\mu$, used in measurement of diameters of corpuscles, etc. (phys.).

micront (mī'krŏnt) n. [Gk. mikros, small; ons, being.] A small cell formed by schizogony, itself giving rise to microgametes in $\mathrm{Neo-}$ sporidia (zool.).

micronucleus (mí'krönū'klě̌s) $n$. [Gk. mikros, small ; L. nucleus, a kernel.] The smaller nucleus of many Protozoa, lying in close proximity to the meganucleus (zool.).

micro-organism (mī'krö-ôr'gănĭzm) $n$. [Gk. mikros, small; organon, an instrument.] A microscopic organism ; a bacterium or microbe.

microphages (mī'kröfä'jĕz) $n$. plu. [Gk. mikros, small; phagein, to eat.] Leucocytes possessing the enzyme microcytase (phys.).

microphagocyte (mīkröfăg'ösīl) $n$. [Gk. mikros, small; phagein, to eat ; kytos, hollow.] A microphage or small phagocyte of blood (phys.).

microphyllous (mī'kröfíl'ǔs) $a$. [Gk. mikros, small ; phyllon, leaf.] With small leaves (bot.).

microphyte (mi'kröfït) $n$. [Gk. mikros, small; phyton, plant.] A microscopic plant (bot.).

microphytology (míkröfítŏl'öjĩ) $n$. [Gk. mikros, small ; phyton, plant ; logos, discourse.] The science of microphytes; vegetable bacteriology (bot.).

micropodous (mīkrŏp'ödŭs) a. [Gk. mikros, small; pous, foot.] With rudimentary or small foot or feet.

micropore (mī'kröpōr) n. [Gk. mikros, small; poros, a channel.] A small pore in a Chiton shell containing a sense-organ (zool.).

micropterism (mikkrŏp'těrǐzm) $n$. [Gk. mikros, small ; pteron, wing.] Condition of having unusually small wings, as in some insects (zool.).

micropterous (mīkrŏp'tĕrŭs) a. [Gk. mikros, small; pteron, a wing.] Having small hind wings invisible till tegmina are expanded, as in some insects; with small or rudimentary fins (zool.).

micropyle (mî'kröpīl) $n$. [Gk. mikros, small ; pyle, a gate.] The aperture for admission of pollen-tube at the 
ovule apex (bot.); the aperture in the egg-membrane for admission of spermatozoon; a pore in the spongin-coat of Sponges for escape of gemmules (zool.).

micropyle apparatus, - raised processes or porches, sometimes of very elaborate structure, developed round the micropyle of certain insect eggs (zool.).

microrhabdus (mī'krörăb'dŭs) $n$. [Gk. mikros, small; rhabdos, a rod.] A minute monaxon or rod-like spicule (zool.).

microschizont (mī'kröshízŏnt) $n$. [Gk. mikros, small; schizein, to cut.] A male schizont of certain Protozoa (zool.).

microsclere (mï'krösklēr) n. [Gk. mikros, small ; skleros, hard.] One of sponge spicules found lying scattered freely in the tissues (zool.).

microseptum (mī'krösěp'tŭm) $n$. [Gk. mikros, small; L. septum, partition.] An incomplete mesentery of Zoantharia (zool.).

microsmatic (mî'krŏsmăt'ik) a. [Gk. mikros, small ; osme, smell.] With feebly-developed sense of smell (phys.).

microsome (mī'krösōm) n. [Gk. mikros, small ; soma, body.] The granule of protoplasm as opposed to the ground-substance $(c y t$.$) .$

microsphere (mī'krösfēr) n. [Gk. mikros, small; sphaira, a globe.] The initial chamber of Foraminifera when very small (zool.).

microspheric (mī'krösfĕr'ı̄k) a. [Gk. mikros, small; sphaira, a globe.] $A p p l$. Foraminifera when the initial chamber of the shell is small (zool.).

microsporangium (mî'kröspörăn'jưum) n. [Gk. mikros, small; sporos, seed ; anggeion, vessel.] A sporangium bearing a number of microspores (bot.).

microspore (mīkröspōr) n. [Gk. mikros, small; sporos, seed.] The spore developed in a microsporangium of heterosporous plants (bot.); a smaller anisospore of Sarcodina (zool.).

microsporophore (mī'kröspō'röfōr) $n$. [Gk. mikros, small ; sporos, seed; pherein, to bear.] A microsporangium (bot.).

microsporophyll (mī'kröspō'röfill) $n$. [Gk. mikros, small ; sporos, seed ; phyllon, leaf.] A microsporangiumbearing leaf (bot.).

microsporozoite ( $\mathrm{mi}^{-} \mathrm{kröspō}$ rözō'ît) $n$. [Gk. mikros, small ; sporos, seed; zoon, animal.] A smaller endogenous sporozoite of Sporozoa (zool. $)$.

microstome (mín'kröstōm) n. [Gk. mikros, small; stoma, mouth.] A small opening or orifice (zool.).

microstylospore (mî'kröstīllöspōr) $n$. [Gk. mikros, small ; stylos, pillar; sporos, a seed.] A comparatively small stylospore (bot.).

microstylous (mī'kröstī'lŭs) a. [Gk. mikros, small ; stylos, pillar.] Having short styles; appl. heterostylous flowers (bot.).

microtherm (mī'kröthĕrm) $n$. [Gk. mikros, small; therme, heat.] A plant of the north temperate zone (bot.).

microtype (mî́krötīp) n. [Gk. mikros, small; L. typus, type.] The normal arrangement of mesenteries in Anthozoa (zool.).

microzooid (mî'krözōoid) $n$. [Gk. mikros, small ; zoon, animal ; eidos, resemblance.] A free-swimming motile ciliated bud of Vorticella and other Protozoa (zool.).

microzoospore (míkrözōöspōr) $n$. [Gk. mikros, small ; zoon, animal ; sporos, seed.] A small planogamete (bot.); a small anisospore of Radiolarians (zool.). microzyma (míkrözímă) $n$. [Gk.
mikros, small ; zyme, leaven.] A biophore or idioblast, a hypothetical ultimate unit (biol.).

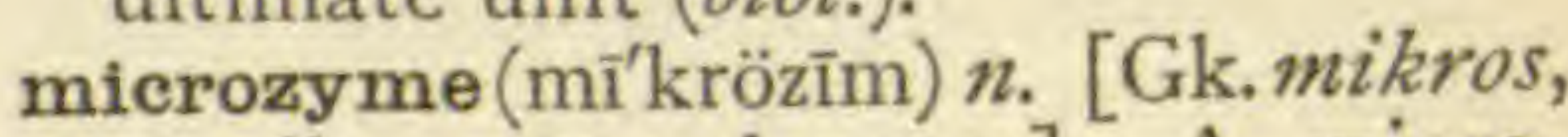
small; zyme, leaven.] A microorganism of fermenting or decomposing liquids (phys.).

mid-body,-a cell plate or group of granules in the equatorial region of the spindle in the anaphase of mitosis (cyt.).

mid-brain, - the middle zone of the primitive or embryonic brain ; the mesencephalon of adults, consisting of the cerebral peduncles, the corpora quadrigema, and the aqueductus Sylvii (anat.). 
mid-rib, - the large central vein of a leaf, the continuation of the petiole (bot.).

midriff (mid'rĭf) $n$. [A.S. mid, middle ; hrif, the belly.] The diaphragm or muscular partition between the thoracic and abdominal cavities (anat., zool.).

Miescher's tubes, - see Rainey's tubes.

migration (mígrā'shŭn) $n$. [L. migrare, to transfer.] Change of habitat, according to climate or food-supply, observable chiefly in birds, also in reindeer, bats, certain fishes, etc. (zool.).

migratory cell, - an amoeboid cell or leucocyte of the blood.

miliary (mil'iărĭ) a. [L. milium, millet.] Of granular appearance ; small and numerous (zool.).

milk-teeth, - the first dentition of Mammals, shed soon after or before birth.

milt (milt) $n$. [A.S. milte, the spleen.] The spleen.

milt (milt) n. [A corruption of milk, due to confusion with milt, the spleen.] The soft roe, or male generative organ of Fishes.

mimetic (mimět'ik) a. [Gk. mimetikos, imitative.] Appl. animals and plants which practise mimicry (biol.).

mimic (mim'îk) v. [Gk. mimikos, imitating.] To assume, usually for protection, the habits, colour, or structure of another organism (zool.).

mimicry (mim'ı̌krǐ) $n$. [Gk. mimikos, imitative.] Assumption of resemblance in colour or structure as a means of self-protection (biol.).

mine (mīn) n. [L. minare, to conduct.] A tunnel or gallery constructed by an insect (sool.).

minimus (mín'ĩmŭs) $n$. [L. minimus, least.] The fifth digit of hand or foot.

Miocene (mî'ösēn) a. [Gk. meion, less; kainos, recent.] Appl. the eleventh of the thirteen rocksystems, and belonging to the Cainozoic or Tertiary group (pal.).

miostemonous, - meiostemonous (bot.).

miracidium (mirrăsĭd'iŭm) n. [Gk. dim. of meirakion, a stripling.] The ciliated embryo or youngest stage in the life-history of a Trematode (zool.).

mitochondria (mî̀tökŏn'drŭă) $n$, plu. [Gk. mitos, thread; chondros, grain.] Ergastoplasmic granulations of protozoan protoplasm; spheroplasts (zool.); a rounded mass of granules or fibrils near the nucleus of pancreas cells (anat.).

mitochondrial sheath, - an envelope containing mitochondrial granules sheathing the spiral thread of a spermatozoan body or connecting piece (emb.).

mitome (mî́tōm) n. [Gk. mitos, thread.] The reticulum of cellprotoplasm, as opposed to groundsubstance (biol.).

mitoschisis (mîtŏs'kǐsǐs) n, [Gk. mitos, thread; schizein, to cleave.] Indirect nuclear division; mitosis (cyt.).

mitosis (mîtō'sĭs) n. [Gk, mitos, thread.] Indirect or karyokinetic nuclear division, with chromosomeformation, spindle-formation, and with or without centrosome activity, and final reduction of the chromosomes (cyt.).

mitosome (mit'ösōm) n. [Gk. mitos, thread; soma, body.] A body arising from the spindle-fibres of secondary spermatocytes, eventually said to form the connecting piece and tail envelope of the spermatozoon (zool.).

mitotic (mǐtŏt'ík) a. [Gk. mitos, thread.] Pert. or produced by mitosis; $a p p l$. division, figure, phase (biol.).

mitra (mītră) $n$. [L. mitra, headband.] A helmet-shaped part of calyx or corolla; the mitriform pileus of certain Fungi (bot.).

mitral cells,-pyramidal cells with thick basal dendrites, found in the molecular layer of the olfactory bulb (anat.).

mitral valve,- the bicuspid valve, guarding the left auriculo-ventricular orifice of the heart (anat.).

mitriform (mit'rífôrm) a. [L. mitra, head-band; forma, shape.] Mitreshaped,

mixipterygium (mik'sĭptěrī'iŭm) $n$. 
[Gk. mixis, mixing; pterygion, a little wing or fin.] The clasper of male Elasmobranchs, the medial lobe of the pelvic fin (zool.).

mixotrophic (mǐk'sötrŏf'îk) a. [Gk. mixis, mixing; trephein, to nourish.] Combining holophytic with saprophytic nutrition (zool.); obtaining part of the nourishment from an outside source; partly parasitic (bot.).

modiolus (mödíölŭs) n. [L. modiolus, a small measure.] The conical central axis of the cochlea of the ear (anat.).

molar (mō'lăr) a. [L. molere, to grind.] Adapted for grinding, as $a p p l$. teeth; $a p p l$. certain buccal glands (anat.).

molecular hypothesis, - the supposition that muscle and nerve are composed of molecules or particles, like the molecules of a magnet, with positive and negative surfaces (phys.).

molecular layer,-the external layer of the cortex of cerebrum and cerebellum; a layer of the olfactory bulb (anat.).

molluscoid (mǒlŭs'koid) a. [L. molluscus, soft ; Gk. eidos, like.] Resembling a Mollusc ; characteristic of a Mollusc (zool.).

monacanthid (mŏn'ăkăn'thĭd) $a$. [Gk. monos, alone ; akantha, thorn.] With one row of ambulacral spines, as certain Starfishes (zool.).

monactinal (mŏnăk'tinnăl) $a$. [Gk. monos, alone; aktis, ray.] $A p p l$. a monactine or single-rayed spicule (zool.).

monactinellid (mŏnăk'tinněl'íd) $a$. [Gk. monos, alone ; aktis, ray.] Containing uniaxial spicules only, as certain Sponges (zool.).

monad (mốnăd) $n$. [Gk. monas, a unit.] A primitive organism or organic unit; a flagellula form of Protozoan (biol.).

monadelphous (mŏnăděl'fŭs) $a$. [Gk. monos, single ; adelphos, brother.] Having the stamens united into one bundle by union of their filaments (bot.).

monadiform (mŏnăd'ífôrm) a. [Gk. monas, a unit; L. forma, shape.] Like a flagellate Protozoan (zool.). monandrous (mŏnăn'drŭs) $a$. [Gk. monos, alone; aner, male.] Having only one stamen (bot.).

monarch (mŏn'ărk) a. [Gk. monos, alone; arche, beginning.] With only one protoxylem (bot.).

monaster (mŏnăs'tër) $n$. [Gk. monos, alone; aster, star.] The astral arrangement of the $\mathbf{V}$-shaped chromosomes at the end of the prophase of mitosis (cyt.).

monaxial (mŏnăk'sĭlal) a. [Gk. monos, alone; axon, axis.] Having one line of axis ; uniaxial (biol.); having the inflorescence developed on the primary axis (bot.).

monaxon (mŏnăk'sŏn) $n$. [Gk. monos, alone; axon, axis.] A type of spicule built upon a single axis (zool.).

monaxonic (mŏn'ăksŏn'îk) a. [Gk. monos, alone; axon, axis.] Elongate; appl. types of Protozoa with one long body-axis (zool.).

monembryonic (mŏnĕm'brion'îk) $a$. [Gk. monos, alone ; embryon, foetus.] Producing a single embryo at a time (bot.).

monergic (mŏnĕr'jík) a. [Gk. monos, alone; energos, active.] Having one energid; consisting of one nucleated cell (bot.).

monilicorn (mŏnĭl'íkôrn) a. [L. monile, necklace ; cornu, horn.] Having antennae with appearance of a chain of beads (zool.).

moniliform (mŏnil'ífôrm) a. [L. monile, necklace; forma, shape.] Constricted at regular intervals, giving the appearance of a chain of beads; $a p p l$. the nucleus of certain Infusoria (zool.) ; with contractionsand expansionsalternately, as the branches of certain roots (bot.).

monimostylic (mŏn'ímöstǐllik) $a$. [Gk. monimos, fixed; stylos, pillar.] Having the quadrate united to the squamosal, and sometimes to other bones, as in certain Reptiles; $c f$. streptostylic (zool.).

monocardian (mŏn'ökâr'diăn) a. [Gk. monos, alone; kardia, heart.] Having one auricle and ventricle (zool.).

monocarp (mŏn'ökârp) n. [Gk. monos, alone; karpos, fruit.] A monocarpic plant (bot.). 
monocarpellary (mŏn'ökârpĕl'ărǐ) $a$. [Gk. monos, alone; karpos, fruit.] Containing a single carpel (bot.).

monocarpic (mŏn'ökâr'pīk) $a$. [Gk. monos, alone; karpos, fruit.] Dying after bearing fruit once (bot.).

monocarpous (mŏn'ökâr'pŭs) a. [Gk. monos, alone ; karpos, fruit.] Having one ovary developed from the gynoecium (bot.).

monocephalous (mŏn'ökĕf'ălŭs, -sěf-) a. [Gk. monos, alone; kephale, head.] With one capitulum only (bot.).

monocercous (mŏn'ösĕr'kŭs) $a$. [Gk. monos, alone; kerkos, tail.] With one flagellum, as certain Protozoa (zool.).

monocerous (mŏnŏs'ĕrŭs) a. [Gk. monos, alone; keras, horn.] Having only one horn (zool.).

monochasium (mŏn'ökā'ziŭm) n. [Gk. monos, alone ; chasis, division.] A cymose inflorescence with main axes producing only one branch each (bot.).

monochlamydeous (mŏn'öklămĭd'ěŭs) a. [Gk. monos, alone; chlamys, cloak.] Apetalous; having calyx but no corolla (bot.).

monociliated (mŏn'ösil'îâtěd) a. [Gk. monos, alone; L. cilium, lash.] Having one flagellum (zool.).

monoclinous (mŏn'öklînŭs) a. [Gk. monos, alone; kline, couch.] Having both stamens and pistil in each flower (bot.).

monocotyledonous (mŏnökŏt'île'dönŭs) a. [Gk. monos, alone ; kotyledon, a cup-shaped hollow.] Having one cotyledon or embryolobe (bot.).

monocrepid (mŏn'ökrěp'îd) a. [Gk. monos, alone ; krepis, foundation.] $A p p l$. a desma formed by secondary silica deposits on a monaxial spicule (zool.).

monocule (mŏn'ökūl) n. [Gk. monos, alone; L. oculus, eye.] A oneeyed animal, as certain Insects and Crustacea (zool.).

monocyclic (mŏn'ösìk'lik) a. [Gk. monos, alone; kyklos, circle.] Having one whorl or circular structure (biol.).

monodactylous (mŏn'ödăk'tillŭs) $a$. [Gk. monos, alone ; daktylos, finger.] With one digit only (zool.). monodelphous,-monadelphous.

monodont (mŏn'ödŏnt) a. [Gk. monos, alone; odous, tooth.] Having one persistent tooth; $a p p l$. the narwal with one tusk ten or twelve feet long (zool.).

monoecious (mŏnē'shŭs) $a$. [Gk. monos, single; oikos, house.] With male and female flowers on the same plant; with sex organs on one gametophyte (bot.); hermaphrodite (zool.).

monogamous (mŏnŏg'ămŭs) a. [Gk. monos, single; gamos, marriage. Consorting with one mate only (zool.).

monoganglionic (mŏn'ögăng'glǐonnìk) a. [Gk. monos, alone; gangglion, a little tumour.] Having a single ganglion (zool.).

monogastric (mŏn'ögăs'trǐk) a. [Gk. monos, single; gaster, stomach.] With only one gastric cavity (zool.).

monogenesis (mŏn'öjĕn'ěsǐs) $n$. [Gk. monos, alone; genesis, descent.] Asexual reproduction; the theory of the development of all organisms from a single cell (biol.).

monogenetic (mŏn'öjěnět'ik) a. [Gk. monos, alone; genesis, descent.] Reproducing asexually; direct, as appl. reproduction (biol.).

monogenic,-monogenetic.

monogenous (mŏnŏj'ĕnŭs) a. [Gk. monos, alone; genos, offspring.] Asexual, as appl. reproduction (biol.).

monogonoporous (mŏn'ögönŏp'örŭs) a. [Gk. monos, alone; gonos, offspring; poros, channel.] Having one genital pore common to both male and female organs, as in certain Turbellarians (zool.).

monogony (mŏnŏg'önĩ) $n$. [Gk. monos, alone; gonos, offspring.] Non-sexual schizogony; asexual reproduction (biol.).

monogynoecial (mŏn'öjīnē'shǐăl) $a$. [Gk. monos, alone; gyne, female ; oikos, house.] Developing from one pistil (bot).

monogynous (mŏnŏj'ínŭs) a. [Gk. monos, alone ; gyne, female.] Having one pistil only (bot.) ; consorting with one female mate, of male animals (zool.). 
monohybrid (mŏn'öhī'brĭd) $n$. [Gk. monos, alone ; L. hybrida, mongrel.] A hybrid offspring of parents differing in one character (biol.).

monokaryon (mŏn'ökăr'ı̆on) $n$. [Gk. monos, alone; karyon, nut.] A nucleus with a single centriole (cyt.).

monolophous (mŏn'ölöf'ŭs) a. [Gk. monos, alone;lophos, crest.] Appl. spicules with one ray forked or branched like a crest (zool.).

monomastigate,-monomastigote.

monomastigote (mŏn'ömăs'tǐgōt) $a$. [Gk. monos, alone ; mastis, whip.] Having a single flagellum, as certain Protozoa (zool.).

monomeniscous (mŏn'ömĕnǐs'kŭs) $a$. [Gk. monos, alone; meniskos, a small moon.] Having an eye with only one lens (zool.).

monomeric (mŏn'ömĕr'îk) a. [Gk. monos, alone; meros, part.] Pert. one segment; derived from one part (biol.).

monomerosomatous (mŏn'ömĕr'ösŏm'ătŭs) a. [Gk. monos, alone ; meros, part ; soma, body.] Having bodysegments all fused together, as in certain Insects (zool.).

monomerous (mǒnŏm'ĕrŭs) a. [Gk. monos, alone ; meros, part.] Consisting of one part only; appl. flower-whorls (bot.).

monomial (mŏnō'miăl) a. [Gk. monos, alone; L. nomen, name.] Appl. a name or designation consisting of one term only; $c f$. binomial (biol.).

monomorphic (mŏn'ömôr'fîk) $a$. [Gk. monos, alone ; morphe, form.] Developing with no or very slight change of form from stage to stage, as in certain Protozoa and Insects; cf. polymorphic (zool.); producing spores of one kind only (bot.).

monont (mŏn'ŏnt) n. [Gk. monos, alone.] A single individual reproducing without conjugation, as $o p p$. sporont or zygote (zool.).

mononuclear (mŏn'önü'klê̆ăr) $a$. [Gk. monos, alone; L. nucleus, kernel.] With one nucleus only (biol.).

mononychous (mŏn'önīk'üs) a. [Gk. monos, alone; onyx, claw.] Having a single claw (zool.).

monopetalous (mŏn'öpět'ălŭs) $a$. [Gk. monos, alone; petalon, petal.] Hav- ing one petal only; having petals united all round (bot.).

monophagous (mŏnŏf'ăgŭs) $a$. [Gk. monos, alone; phagein, to eat.] Subsisting on one kind of food; $a p p l$. Sporozoa living permanently in a single cell (zool.).

monophyletic (mơn'öfílĕt'îk) $a$. [Gk. monos, alone; phyle, tribe.] Derived from a single common parent form (biol.).

monophyllous (mŏn'öfíl'ŭs) a. [Gk. monos, alone; phyllon, leaf.] Having one leaf only; unifoliate; having a one-piece calyx (bot.).

monophyodont (mŏn'öfí̄ödŏnt) $a$. [Gk. monos, alone; phyein, to produce; odous, tooth.] Having only one set of teeth, the milk dentition being absorbed in foetal life or absent altogether (zool.).

monoplacid (mŏn'öplăs'ĩd) a. [Gk. monos, alone ; plakous, a flat cake.] With one plate only, of any particular kind (biol.).

monoplacula (mŏn'öplăk'ülă) $n$. [Gk. monos, alone; plax, a flat plate.] A single-layered placula (biol.).

monoplastic (mŏn'öplăs'tǐk) $a$. [Gk. monos, alone; plastos, formed.] Persisting in one form (biol.).

monopodial (mŏn'öpō'dǐăl) $a$. [Gk. monos, alone ; pous, foot.] Branching from one main or primary axis acropetally (bot.).

monopodium (mǒn'öpō'diŭm) $n$. [Gk. monos, alone; pous, foot.] A single main or primary axis from which all main lateral branches develop, as in the pine (bot.).

monopyrenous (mơn'öpî̀ēénŭs) $a$. [Gk. monos, alone ; pyren, kernel.] Single-stoned, as a fruit (bot.).

monorhinal (mŏn'örin'năl) a. [Gk. monos, alone ; rhis, nose.] Having only one nostril, as the Cyclostomes (zool.).

monosepalous (mŏn'ösěp'ălŭs) $a$. [Gk. monos, alone ; sepalon, sepal.] Having a single sepal; having all sepals united into one (bot.).

monosiphonic (mŏn'ösîfŏn'îk) a. [Gk. monos, alone ; siphon, a small pipe.] Having the tubes of a hydrocaulus distinct from one another, as in certain Hydromedusae (zool.).

monosiphonous (mŏn'ösi'fönŭs) $a$. 
[Gk. monos, alone ; siphon, a small pipe.] Having a single central tube in the filament, as in certain red Algae (bot.).

monospermous (mŏn'öspĕr'mŭs) $a$. [Gk. monos, alone ; sperma, seed.] One-seeded (bot.).

monospermy (mŏn'öspĕr'mĩ) $n$. [Gk. monos, alone; sperma, seed.] Normal fertilization by the entrance of one sperm only into an ovum (emb.).

monospondylic (mŏn'öspŏndǐl'ík) $a$. [Gk. monos, alone; sphondylos, a vertebra.] $A p p l$. vertebrae without intercentra (zool.).

monosporangium (mŏn'öspörăn'jiŭum) n. [Gk. monos, alone; sporos, seed; anggeion, vessel.] A sporangium producing simple spores (bot.).

monospore (mŏn'öspōr) $n$. [Gk. monos, alone; sporos, seed.] A simple or undivided spore (bot.).

monosporous (mŏnŏs'pörŭs) a. [Gk. monos, alone ; sporos, seed,] Having only one spore or a simple spore (biol.).

monostachyous (moัn'östăk'rŭs) $a$. [Gk. monos, alone ; stachys, a cornear.] With only one spike (bot.).

monostele (mŏn'östēl) n. [Gk. monos, alone; stele, column.] An axis stele when only one is the direct continuation of the plerome (bot.).

monostelie (mŏn'östĕl'îk) a. [Gk. monos, alone; stele, column.] Having a single stele or central cylinder running through the whole axis (bot.).

monostichous (mŏnǒs'tíkŭs) $a$. [Gk. monos, alone ; stichos, row.] Arranged in one row (zool.); along one side of an axis (bot.).

monostigmatous (mǒn'östíg'mătŭs) $a$. [Gk. monos, alone ; stigma, mark.] With one stigma only (bot.).

monostylous (mǒn'östílŭs) a. [Gk. monos, alone; stylos, pillar.] Having one style only (bot.).

monosy (mǒn'ösĩ) n. [Gk. monos, alone.] The separation of parts normally fused (biol.).

monosymmetrical (mŏn'ösǔmět'rǐkăl) a. [Gk. monos, alone; syn, with ; metron, measure.] Having only one plane of bilateral symmetry (bot.). monothalamic (mŏn'öthălămik) $a$. [Gk. monos, alone; thalamos, chamber.] Appl. fruits formed from single flowers; having one gynoecium (bot.).

monothalamous (mŏn'öthălămŭs) $a$. [Gk. monos, alone; thalamos, chamber.] Unilocular; single chambered; appl. shells of Foraminifers and other Protozoa (zool.). monothecal (mŏn'öthē'kăl) a. [Gk. monos, alone; theke, box.] Having one loculus; single-chambered (bot.).

monothelious (mǒn'öthē'lǐus) $a$. [Gk. monos, alone; thelys, female.] $A p p l$. a female consorting with more than one male (biol.).

monotocous (mŏnŏt'ökŭs) a. [Gk. monos, alone; tokos, offspring.] Having one at a birth (biol.).

monotrochous (mǒnŏt'rökŭs) $a$. [Gk. monos, alone; trochos, wheel.] Having a single-piece trochanter, as in most stinging Hymenoptera (zool.).

monotrophic (mŏn'ötrŏf'ik) a. [Gk. monos, alone ; trophe, nourishment.] Subsisting on one kind of food (biol.).

monotype (mŏn'ötīp) n. [Gk. monos, alone; L. typus, type.] A single type which constitutes a species or genus (biol.).

monozoic (mŏn'özōîk) a. [Gk. monos, alone; zoon, animal.] Appl. archispores forming only one sporozoite on liberation from the cyst ; producing one sporozoite only (biol.).

monticolous (mŏntik'ölŭs) $a$. [L. mons, mountain ; colere, to inhabit.] Inhabiting mountainous regions (biol.).

morphalaxis (môr'fălăk'sǐs) n. [Gk. morphe, form ; L. laxare, to release.] Transformation of one part directly into another, in regeneration of parts (zool.).

morphology (môrfǒl'öjĩ) n. [Gk. morphe, form ; logos, discourse.] The science of the form and structure of plants or animals, as distinct from consideration of the functions.

morphon (mô'foun) n. [Gk. morphe, form.] A definitely formed individual, as opp. a bion (biol.). 
morphosis (môr'fösĭs, môrfō'sĭs) $n$. [Gk. morphosis, a forming.] The manner of development of part or organism (biol.).

morphotic (môrfót'ìk) a. [Gk. morphosis, a forming.] Tissue-building (phys.).

morula (môr'ūlă) $n$. [L. morum, a mulberry.] A solid cellular globular mass, the first result of ovum segmentation; the stage in development preceding the gastrula stage (emb.).

morulation (môrülā'shŭn) $n$. [L. morum, a mulberry.] Morulaformation by segmentation (emb.).

morulit (môr'ūlìt) $n$. [L. morum, a mulberry.] Nucleolus or karyosome (cyt.).

motor (mō'tŏr) a. [L. movere, to move.] Pert. or connected with movement; appl. nerves (anat., phys.).

motor areas, - areas of the brain where motion is supposed to be correlated (phys.).

motor end-plates, - the terminal expansions of nerves in muscle fibres (anat.).

motor neurons, - nerve cells with appendages and branches, concerned in the regulation of movement (anat.).

motor oculi, - the third cranial nerve (anat.).

motorium (mötō'rǐŭm) $n$. [L. movere, to move.] Motor areas; the part of the nervous system where the motorial sense is localized (phys.).

moult (mōlt)v. [L. mutare, to change.] To cast or shed periodically the outer covering, whether of feathers, hair, skin, or horns (zool.).

mouth part, - a head or mouth appendage of Arthropods or Insects (zool.).

mucific (mūsĭf'îk) a. [L. mucus, mucus ; facere, to make.] Mucussecreting (phys.).

muciform (mü'sífôrm) a. [L. mucus, mucus ; forma, shape.] Resembling mucus (phys.).

mucigen (mū'sǐjĕn) n. [L. mucus, mucus; Gk. genos, offspring.] The substance of certain granules in the cells of mucous membrane (phys.). mucilage (mū'sǐlāj) n. [L. mucus, mucus.] A substance produced in cell-walls of certain plants due to changes in the cellulose or pectose constituents, causing exudations of gum when degeneration of the cellwall is excessive (bot.).

mucilage cell, - a cell which secretes mucilage (bot.).

mucilaginous ' (mū'sǐlăj'ínŭs) $a$. [L. mucus, mucus.] Pert. containing, resembling, or composed of mucilage; $a p p l$. certain glands of joints (anat.) ; appl. cells, ducts, canals, slits (bot.).

mucin (mū'sin) $n$. [L. mucus, mucus.] A glucoproteid of mucus (phys.).

mucinogen (mūsinn'öjěn) $n$. [L. mucus, mucus; Gk. genos, offspring.] A substance producing mucin by reaction of alkalies (phys.).

muciparous (mūsīp'ărŭs) a. [L. mucus, mucus; parere, to beget.] Mucus-secreting (phys.).

mucocutaneous (mū'kökūtā'něŭs) $a$. [L. mucus, mucus; cutis, skin.] Pert. skin and mucous membrane (anat.).

mucodermal (mū'ködĕr'măl) a. [L. mucus, mucus; Gk. derma, skin.] Pert. skin and mucous membrane (anat.).

mucoid (mū'koid) a. [L. mucus, mucus; Gk. eidos, like.] Pert. or caused by mucus or mucilage; $a p p l$. degeneration (bot.); tissue (anat.).

mucosa (mūkō'să) n. [L. mucus, mucus.] A mucous membrane (anat.).

mucoserous (mū'kösē'rŭs) a. [L. mucus, mucus; serum, whey.] Secreting mucus and body fluid (phys.).

mucous (mü'kŭs) a. [L. mucus, mucus.] Secreting, containing, or pert. mucus ; $a p p l$. glands, sheaths, tissue (anat.).

mucro (mū'krō) n. [L. mucro, a sharp point.] A stiff or sharp point abruptly terminating an organ (biol.).

mucronate (mū'krönāt) a. [L. mucro, a sharp point.] Abruptly terminated by a sharp spine; mucroniferous.

mucronulate (mūkrŏn'ūlāt) a. [L. 
mucro, a sharp point.] Tipped with a small mucro.

mucronule (mū'krönūl) $n$. [L. mucro, a sharp point.] A small mucro.

muculent (mü'kūlěnt) a. [L. mucus, mucus.] Mucoid ; containing mucus; mucilaginous (bot.).

mucus (mū'kŭs) n. [L. mucus, mucus.] The slimy, glairy substance secreted by mucous membrane (phys.).

Müllerian (mülë'rǐăn) $a$. [Joh. Müller, German anatomist, and other Müllers.] Appl. eminence, fibres (anat.); corpuscles (bot.); larva (zool.).

Mullerian ducts,-ducts arising on the lateral aspects of the Wolffian ducts (emb.).

multangular (mŭltăng'gūlăr) a. [L. multus, many; angulus, angle.] $A p p l$. two carpal bones, the greater and lesser multangulum, respectively the trapezium and the trapezoid (anat.).

multiarticulate (mŭl'tǐârtǐk'ūlāt) $a$. [L. multus, many ; articulus, joint.] With many articulations; manyjointed (zool.).

multicamerate (mǔl'tǐkăm'ĕrāt) $a$. [L. multus, many; camera, chamber.] Multilocular ; with many chambers. multicapsular (mŭl'tǐkăp'sūlăr) $a$. [L. multus, many; capsula, a little chest.] With many capsules (bot.).

multicarinate (mŭl'tǐkăr'ĩnāt) $a . \quad[\mathrm{L}$. multus, many; carina, keel.] Having many keels.

multicellular (mŭl'tǐsěl'ūlăr) $a$. [L. multus, many; cella, storeroom. $]$ Many-celled; consisting of more than one cell (biol.).

multicentral (mŭl'tǐsěn'trăl) $a$. [L. multus, many; centrum, centre.] With more than one centre of growth or development (biol.).

multicipital (mŭl'tísíp'ítăl) a. [L. multus, many; caput, head.] With many heads or branches arising from one point (bot.).

multicostate (mǔl'tỉkǒs'tāt) a. [L. multus, many; costa, rib.] With many ribs or veins (bot.); with many ridges (zool.).

multicuspid (mŭl'tǐkŭs'píd) $a$. [L. multus, many ; cuspis, spear-head.] With several cusps or tubercles; appl. molar teeth (anat.). multidentate (mŭl'tíděn'tāt) a. [L. multus, many; dens, tooth.] With many teeth, or indentations (biol.). multidigitate (mǔl'tĭdĭj'ítāt) $a$. [L. multus, many; digitus, finger.] Many-fingered (zool.).

multifid (mŭl'tífíd) a. [L. multus, many ; fidus, cleft.] Having many clefts or divisions (bot.).

multiflagellate (mǔl'tĭflăj'ělāt) $a$. [L. multus, many; flagellum, whip.] Furnished with several or many flagella; polymastigote (zool.).

multiflorous (mŭl'tĭfló'rŭs) a. [L. multus, many; flos, flower.] Bearing many flowers (bot.).

multifoliate (mǔl'tífōliât) a. [L. multus, many; folium, leaf.] With many leaves (bot.).

multifoliolate (mǔl'tǐfō'lïölāt) $a$. [L. multus, many; foliolum, a small leaf.] With many leaflets (bot.).

multiganglionate (mŭl'tigăng'glioonāt) a. [L. multus, many; [Gk. gangglion, a small tumour.] With several or many ganglia (anat.).

multigyrate (mǔl'tĭjī'rãt) a. [L. multus, many; gyrus, circle.] With many gyri; tortuous (biol.). multijugate (mŭl'tijoog'āt) a. [L. multus, many; jugum, yoke.] Having many pairs of leaflets (bot.).

multilaminate (mǔl'tílăm'innāt) $a$. [L. multus, many ; lamina, plate.] Composed of several or many laminae (biol.).

multilobate (mǔl'tìlō'bāt) a. [L. multus, many; lobus, lobe.] Composed of many lobes.

multilobulate (mŭl'tǐlǒb'úlāt) $a$. [L. multus, many; lobulus, a small lobe.] Having many lobules.

multilocular (mŭl'tǐlǒk'ūlăr) a. [L. multus, many ; loculus, chamber.] Having many cells or chambers.

multinervate (mǔl'tǐněr'vāt) a. [L. multus, many; nervus, sinew.] With many nerves or nervures (zool.).

multinodal (mŭl'tĭnồdăl) $a$. [L. multus, many ; nodus, knot.] With many nodes (bot.).

multinomial (mǔl'tĭnō'miăl) a. [L. multus, many; nomen, name.] Appl. a name or designation com- 
posed of several names or terms ; cf. binomial (biol.).

multinucleate (mǔl'tĭnū'klễt) $a$. [L. multus, many; nucleus, kernel.] With several or many nuclei $(c y t$.$) .$ multinucleolate (mŭl'tĭnū'klěölāt) $a$. [L. multus, many; nucleolus, a small kernel.] With more than one nucleolus (cyt.).

multiovulate (mưl'tîō'vūlāt) a. [L. multus, many; ovum, egg.] With several or many ovules (bot.).

multiparous (mŭltǐp’ărŭs) a. [L. multus, many; parere, to beget.] Bearing several, or more than one, at a birth (zool.) ; developing several or many lateral axes (bot.).

multiple corolla,- a corolla with two or more whorls of petals (bot.).

multiple fission,-repeated division ; division into a large number of parts or spores (biol.).

multipolar (mŭl'tịpōlăr) a. [L. multus, many; polus, an axisend.] Appl. nerve-cells with many dendrites or branching processes (anat.).

multiradiate (mǔl'tĭrā'dīāt) a. [L. multus, many; radius, ray.] Manyrayed.

multiramose (mŭl'tĭrăm'ōs) a. [L. multus, many; ramus, branch.] Much branched.

multiseptate (mǔl'tǐsěp'tāt) $a$. [L. multus, many; septum, partition.] Having numerous septa or partitions.

multiserial (mŭl'tǐsē'rǐăl) a. [L. multus, many; series, row.] Arranged in several or many rows.

multispiral (mŭl'tǐspīirăl) a. [L. multus, many; spira, coil.] With many coils or whorls.

multistaminate (mŭl'tǐstăm'înāt) $a$. [L. multus, many; stamen, something standing.] Having several or many stamens (bot.).

multisulcate (mǔl'tǐsŭl'kāt) $a$, [L. multus, many; sulcus, furrow.] Much furrowed.

multitentaculate (mŭl'tǐtěntăk'ūlāt) a. [L. multus, many; tentaculum, feeler.] Having many tentacles $(z \circ o l$.).

multituberculate (mŭl'tǐtūbĕr'kūlāt) a. [L. multus, many; tuberculum, a small hump.] Having several or many tubercles or small prominences.

multituberculy (mŭl'tǐtūběr'kūlǐ) $n$.

[L. multus, many; tuberculum, a small hump.] The theory that molar teeth are derived from forms with a number of tubercles (zool.).

multivalve (mŭl'tívălv) n. [L.multus, many; valvae, folding-doors.] A shell composed of more valves or pieces than two (zool.).

multivincular (mǔl'tǐvǐng'kūlăr) $a$. [L. multus, many; vinculum, chain.] $A p p l$. the hinge of bivalve shells when it has several ligaments (zool.).

multivoltine (mŭl'tǐvŏl'tĭn) a. [L. multus, many; It. volta, turn.] Having more than one brood in a year; $a p p l$. silkworms (zool.).

multocular (mǔltǒk'ūlăr) a. [L. multus, many; oculus, eye.] Many-eyed.

multungulate (mŭltŭng'gūlāt) $a$. [L. multus, many; unguis, hoof.] Having the hoof in more than two parts (zool.).

muricate (mü'rǐkãt) a. [L. muricatus, full of sharp points.] Formed with sharp points; covered with short sharp prickles (biol.).

muriform (mü'rüfôrm) a. [L. murus, wall ; forma, shape.] Like a brick wall; $a p p l$. a variety of parenchyma so arranged, occurring in medullary rays of Dicotyledons and in corky formations (bot.).

muscicoline (mŭsǐk'ölî̀n) a. [L. muscus, moss ; colere, to inhabit.] Living or growing among mosses (biol.).

muscicolous,-muscicoline.

muscle (mŭs'l) n. [L. musculus, muscle.] A mass of contractile fibres with motorial function; the fleshy part of the body, composed of muscular tissue (phys.).

muscle-banners, - folds or plaits of mesogloea on the sulcar aspects of Anthozoan mesenteries, supporting the retractor muscles (zool.).

muscoid (mŭs'koid) a. [L. muscus, moss ; Gk. eidos, resemblance.] Mossy.

muscous,-muscoid, 
muscular (mŭs'kūlăr) a. [L. musculus, muscle.] Pert. or consisting of muscle; $a p p l$. sense, excitability (phys.), stomach (zool.), fibres, process, tissue, triangle (anat.).

musculature (mŭs'kūlắtūr) $n$. [L. musculus, muscle.] The system or arrangement of muscles as a whole (zool.).

musculocutaneous (mŭs'kūlökūtā'něus) a. [L. musculus, muscle ; cutis, skin.] Pert. muscles and skin; $a p p l$. veins and nerves of leg and arm supplying muscles and skin (anat., zool.).

musculophrenic (mŭs'kūlöfrĕn'îk) $a$. [L. musculus, muscle ; Gk. phren, midriff.] Supplying diaphragm and body-wall muscles ; $a p p l$. an artery (anat.).

musculospiral (mŭs'kūlöspĩ'răl) $a$. [L. musculus, muscle; spira, coil.] $A p p l$. a nerve which passes spirally down the humerus (anat.).

mutation (mūtā'shŭn) $n$. [L. mutare, to change.] Gradual variation towards a definite change of structure; discontinuous variation; the theory of De Vries that new forms, differing sufficiently to constitute a new variety, arise spontaneously and remain true (biol.).

muticous (mū'tǐkŭs) a. [L. muticus, maimed.] Without defensive structures, as clawless, toothless, blunt (zool.).

mutilation (mū'tĩlāshŭn) $n$. [L. mutilare, to maim.] Loss of an essential part of a structure ; amputation (zool.).

mutualism (mū'tūălǐzm) n. [L. mutuus, exchanged.] A form of symbiosis in which both parties derive advantage without sustaining injury (biol.).

myarian (mīärĭăn) a. [Gk. mys, muscle.] Appl. classification according to musculature (biol.).

mycele,-mycelium.

mycelioid (mīsē'líoid) a. [Gk. mykes, mushroom; eidos, resemblance. Like mycelium.

mycelium (mīsē'lǔum) n. [Gk. mykes, fungus.] The network of filamentous cells forming the typical vegetative structure of Fungi (bot.).

mycetogenetic (mīséttöjĕnět'îk) $a$.
[Gk. mykes, fungus ; genesis, descent.] Produced by a Fungus.

mycetogenic, - mycetogenetic.

mycetoid (mīsē'toid) a. [Gk. mykes, fungus; eidos, resemblance.] Fungoid ; fungus-like.

mycetology,-mycology.

mycetophagous (mī'sētǒf'ăgŭs) $a$. [Gk. mykes, fungus; phagein, to eat.] Fungivorous; feeding on Fungi (zool.).

mycoderm ( $\mathrm{mi}^{\prime}$ ködĕrm) $n$. $[\mathrm{Gk}$. mykes, fungus; derma, skin.] A bacterium of alcoholic fermentation. mycology (mīkŏl'öjī) n. [Gk. mykes, fungus; logos, discourse.] The department of botany dealing with Fungi.

mycoplasm (mī'köplăzm) $n$. [Gk. mykes, fungus ; plasma, form.] A parasitic substance of cereal seeds which may give rise to a rust Fungus (bot.).

mycorhiza (mī'körī'ză) n. [Gk. mykes, fungus; rhiza, root.] Association of a fungus with the roots of a higher plant, with mutual benefit (bot.).

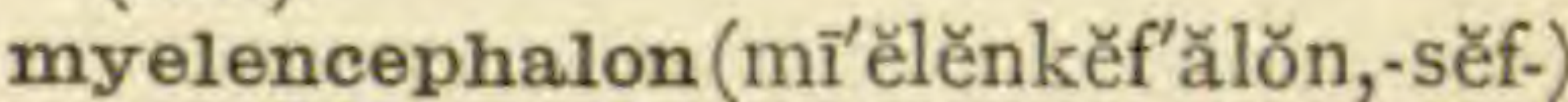
n. [Gk. myelos, marrow; en, in ; kephale, head.] The posterior part of the hind-brain (emb.); the medulla oblongata; brain and spinal cord generally (anat.).

myelin (míělin) n. [Gk. myelos, marrow.] A highly refracting fatty material forming the medullary sheath of nerve fibres (anat.).

myelination (mî'ělǐnä'shŭn) $n$. [Gk. myelos, marrow.] Acquisition of a medullary sheath (anat.).

myelinization,-myelination.

myelocoel (míélösēl) $n$. [Gk. myelos, marrow; koilos, hollow.] The spinal cord canal (anat.).

myelocyte (mícélösīt) $n$. [Gk. myelos, marrow ; kytos, hollow.] An amoeboid marrow cell, resembling a lymphoid corpuscle (anat.).

myeloid (míěloid) a. [Gk. myelos, marrow; eidos, resemblance.] Like marrow in appearance or structure (anat.).

myelon (mīělŏn) n. [Gk. myelos, marrow.] The spinal cord of vetebrates (zool.).

myeloplast (míělöplăst) $n$. [Gk, 
myelos, marrow ; plastos, formed.] A leucocyte of bone marrow.

myeloplax (mî́ëlöplăks) n. [Gk. myelos, marrow; plax, something flat.] A giant-cell of marrow and blood-forming organs, sometimes multinucleate, but in most cases multinucleolate (anat.).

mylohyoid (mîllöhï'oid) a. [Gk. myle, mill; hyoeides, $\mathrm{Y}$-shaped.] In the region of hyoid bone and posterior part of mandible; $a p p l$. artery, groove, muscle, nerve (anat.).

myoalbumin (mî'öălbü'minn) n. [Gk. mys, muscle ; L. albumen, white of egg.] An albumin product of muscle (phys.).

myoblast (mî́öblăst) n. [Gk. mys, muscle; blastos, bud.] A cell which develops into muscle fibre (emb.).

myocardium (mīö ôkấdǐŭm) n. [Gk. mys, muscle ; kardia, heart.] The muscular walls of the heart (anat.). myochrome (mīö ökrōm) $n$. [Gk, mys, muscle ; chroma, colour.] A musclepigment.

myocoel (mī'ösēl) n. [Gk, mys, muscle ; koilos, hollow.] Part of the coelom enclosed in a myotome (emb.).

myocomma (mīöŏkŏm’ă) $n$. [Gk. mys, muscle; komma, a clause.] A myoseptum or ligamentous connection between successive myotomes $(e m b$.).

myocyte (míösìt) $n$. [Gk. mys, muscle; kytos, hollow.] A contractile layer of ectoplasm of Gregarines; a contractile cell (zool.).

myodome (mī'ödōm) n. [Gk. mys, muscle ; L. domus, house.] A chamber containing the eye-muscles in some Teleosts (zool.).

myodynamic (mîöìñăm'ík) a. [Gk. mys, muscle ; dynamis, power.] Pert. muscular force or contraction (phys.).

myoepicardial (mīöěpīkâr'dǐăl) $a$. [Gk. mys, muscle; epi, upon; kardia, heart.] Appl. a mantle, consisting of the mesocardium walls, destined to form the muscular and epicardial walls of the heart (emb.).

myoepithelial (mî́öŏpĭthē'liăl) $a$. [Gk. mys, muscle ; epi, upon; thele, nipple.] Pert. muscle and epithelium (anat.); appl. epithelium cells with contractile outgrowths, as in Coelenterates (zool.).

myofibrillae (mī'öfībrì'ê) $n$. plu. [Gk. mys, muscle; L. fibrilla, a small fibre.] Contractile fibrils of muscular tissue (anat.).

myoglobulin (míöglŏb'ūlǐn) $n$. [Gk. mys, muscle ; L. globulus, a small globe.] A globulin of muscle (phys.). myohaematin (mīöhēe'mătĭn) $n$. [Gk. mys, muscle ; haima, blood.] A pigment of muscular tissue (phys.). myoid (míoid) a. [Gk. mys, muscle ; eidos, resemblance.] Resembling or composed of muscular fibres (anat.). myolemma (mî́ölěm’ă) n. [Gk. mys, muscle; lemma, skin.] The sheath of muscle fibre ; sarcolemma.

myology (mīǒl'öjīi) n. [Gk. mys, muscle ; logos, discourse.] The department of anatomy dealing with muscles.

myomere (mī'ömēr) n. [Gk. mys, muscle ; meros, part.] A musclesegment of Arthropods, divided off by connective tissue insertions; a myocomma (zool.).

myoneme (mīöönēm) $n$. [Gk. mys, muscle; nema, thread.] A minute contractile fibril of Protozoa (zool.).

myoneure (mī'önūr) n. [Gk. mys, muscle; neuron, nerve.] A motorial nerve-cell (phys.).

myonicity (mî́önšsîtǐ) n. [Gk. mys, muscle.] The contracting power of muscular tissue (phys.).

myophan (mīöfăn) $n$. [Gk. mys, muscle; phainein, to appear.] The contractile layer of Protozoa (zool.). myophore (mīöfōor) n. [Gk. mys, muscle ; pherein, to bear.] A structure adapted for muscle attachment (zool.).

myophrisk (mīöfrǐsk) n. [Gk. mys, muscle; phrix, ripple.] A myoneme or contractile element of Protozoa (zool.).

myopolar (míöpōllăr) a. [Gk. mys, muscle; polos, an axle-end.] Pert. muscular polarity (phys.).

myoproteid (mî́oprō'tểid) $n$. [Gk. mys, muscle; protos, first.] A globulin-like substance of fish muscle (phys.).

myoseptum (míösěp'tŭm) n. [Gk. mys, muscle ; L. septum, partition.] A myocomma, which see. 
myosin (mī'ösĭn) $n$. [Gk. mys, muscle.] A globulin of dead muscular tissue (phys.).

myotasis (mīŏt'ăsĭs) n. [Gk. mys, muscle ; tasis, tension.] Muscular tension or tonicity (phys.).

myotome (mî̄ötōm) n. [Gk. mys, muscle ; tome, a cutting.] One of a series of hollow cubes formed in the early vertebrate embryo $(e m b$. $)$; a muscular metamere of primitive vertebrates and segmented invertebrates (zool.).

myotonia (mïötōnǐă) n. [Gk. mys, muscle ; tonos, tension.] Muscular tension or tonicity (phys.).

myrmecophagous (mirměkŏf'ăgŭs) $a$. [Gk. myrmex, ant; phagein, to eat.] Ant-eating (zool.).

myrmecophile (mir'měköfíl) $n$. [Gk. myrmex, ant; philos, loving.] A guest insect in a nest of ants (zool.).

myrmecophyte (mür'měköfît) $n$. [Gk. myrmex, ant ; phyton, plant.] A myrmecophilous plant, or one that benefits from ant inhabitants and has special adaptations for housing them (bot.).

myrosin (mǐr'ösǐn) n. [Gk. myron, unguent.] An enzyme of mustard seeds, acting upon glucosides (bot.). myxamoeba (mǐk'sămē'bă) n. [Gk. myxa, slime ; amoibe, change.] A mycetozoan spore in the amoebula stage (zool.).

myxoflagellate (mīk'söflăj'ělāt) $n$. [Gk, myxa, slime; L. flagellum, whip.] A flagellula or zoospore, the stage in mycetozoan development following the myxamoeba, and which multiplies by fission (zool.).

myxopodium (mǐk'söpō'dŭum) $n$. [Gk. myxa, slime ; pous, foot.] A slimy pseudopodium (zool.).

myxopterygium,--mixipterygium.

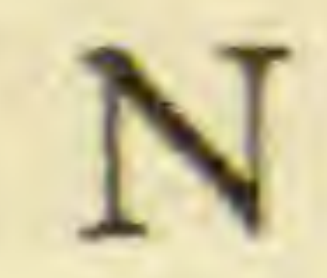

nacreous (nā'krěŭs) a. [Ar. nakir, hollowed.] Yielding or resembling mother-of-pearl (zool.).

nacrine (nā'krĭn) n. [Ar. nakir, hollowed.] Mother-of-pearl colour (zool.). naevose (nā'vōs, nē'vōs) a. [L. naevus, spot.] Freckled; spotted with congenital marks (zool.).

nail (nāl) n. [A.S. naegel, nail.] The terminal horny plate of finger or toe (zool.).

nail bone, - the terminal bone of finger or toe.

nanism (năn'ĩzm) n. [Gk. nanos, dwarf.] Dwarfishness.

na noplankton (nắn'öplăng'ktŏn) n. [Gk. nanos, dwarf; plangktos, wandering.] Microscopic plankton.

napiform (nā'pĭfôrm) a. [L. napus, turnip; forma, shape.] Turnipshaped; $a p p l$. roots (bot.).

narcotic (nârkŏt'ík) n. [Gk. narke, numbness.] A drug which produces unconsciousness (zool.).

nares (nā'rēz, nâ'rĕz) $n$. plu. [L. nares, nostrils.] Nostrils (zool.).

nares, anterior, - the openings of the olfactory organ to the exterior (zool.).

nares, posterior,- the openings of the olfactory organ into the pharynx or throat (zool.).

narial (nā'ruăl) a. [L. nares, nostrils.] Pert. the nostrils (zool.).

narial septum, - the partition between the nostrils (zool.).

naricorn (nâr'ikôrn) $n$. [L. nares, nostrils; cornu, horn.] The terminal horny part of nostril of Turbinares (zool.); nasal scale (anat.).

nariform (nâr'ifôrm) a. [L. nares, nostrils; forma, shape.] Shaped like nostrils (zool.).

nasal (nā'zăl) a. [L. nasus, nose.] Pert. the nose (zool.).

nasion (nä'ziŏn) $\boldsymbol{n}$. [L. nasus, nose.] The middle of the nasofrontal suture (anat.).

Nasmyth's membrane, - a transparent sheet of membrane over the enamel of the crown of a mammalian tooth (phys.).

nasoantral (nā'zöăn'trăl) a. [L. nasus, nose; antrum, cavity.] Pert. nose and maxillary cavity (anat.).

nasobuccal (nā'zöbǔk'ăl) a. [L. nasus, nose; bucca, cheek.] Pert. nose and cheek (anat.); pert. nose and mouth cavity (zool.).

nasocillary (nā'zösîl'iărì) a. [L. nasus, 
nose ; cilia, eyelashes.] - Appl. nasal nerve off which the ciliary nerves branch (anat.).

nasofrontal (nā'zöfrŭn'tăl) a. [L. nasus, nose ; frons, forehead.] $A p p l$. part of the superior ophthalmic vein in nose and forehead region (anat.).

nasolabial (nā'zölā'bŭăl) a. [L. nasus, nose ; labium, lip.] Pert. nose and lip ; appl. muscle (anat.).

nasolacrimal (nā'zölăk'rĭmăl) a. [L. nasus, nose ; lacrima, tear.] Appl. a duct from the lacrimal sac to the meatus of the nose (anat.).

nasomaxillary (nā'zömăksǐlărǐ) $a$. [L. nasus, nose; maxilla, jaw.] Pert. nose and jaw (anat.).

nasooptic (nā'zöŏp'tǐk) a. [L. nasus, nose ; Gk. optikos, relating to sight.] $A p p l$. a furrow, an embryonic groove between nasal and maxillary processes (emb.).

nasopalatal (nā'zöpălătăl) $a$. nasus, nose; palatus, palate.] $A p p l$. a canal between the nose and palate (anat.).

nasopalatine (nā'zöpăl'ătîn) a. [L. nasus, nose; palatus, palate.] Pert. nose and palate (anat.).

nasopharyngeal (nā'zöfărĭn'jēeăl) $a$. [L. nasus, nose; Gk, pharyngx, gullet.] Pert. the nose and pharynx (anat.).

nasopharynx (nā'zöfắr'íngks) $n$. [L. nasus, nose ; Gk. pharyngx, gullet.] That part of pharynx continuous with posterior nares (anat.).

nasoturbinal (nā'zötŭr'bǐnăl) a. [L. nasus, nose ; turbo, wheel.] Appl. outgrowths from the lateral wall of the nasal cavity increasing the area of sensory surface (zool.).

nasus (nā'zŭs) n. [L. nasus, nose.] The nose; the clypeus of an insect's head (zool.).

natal (nā'tăl) a. [L. nates, buttocks.] Connected with the buttocks (anat.).

natant (nā'tănt) a. [L. natare, to swim.] Floating on the surface of water (zool., bot.).

natatorial (nă'tătó'riăl) a. [L. natare, to swim.] Formed or adapted for swimming (zool.).

natatory (nắt tătŏrì) $a$. See natatorial. nates' (nằ'těz) n. plu. [L. nates, but- tocks.] Buttocks (anat.); umbones (zool.).

native (nā'tĩv) a. [L. gnatus, born.] $A p p l$. animals and plants which originated in the district or area in which they live, not those imported thereinto (biol.).

natural selection, - the processes occurring in nature resulting in the survival of the fittest and the elimination of the individuals less adapted to their surroundings (biol.). nauplius (nốplĭŭs) $n$. [L. nauplizus, a shell-fish.] The earliest larval stage of entomostracan Crustaceans (zool.).

nautiliform (nôtǐl'ífôrm) a. [L. nautilus, nautilus; forma, shape.] Shaped like a nautilus shell (zool.).

navel (nā'věl) n. [A.S. nafele, navel.] Place of attachment of the umbilical cord (emb.).

navicular (năvǐk'úlăr) a. [L. navis, ship.] Boat-shaped.

naviculare (năvǐk'ūlārě) $n$. [L. navis, ship.] The scaphoid radiale of the mammalian carpus (anat.).

nebenkern (nā'bĕnkĕrn) $n$. [Ger. neben, near; kern, kernel.] An extra-nuclear chromatinic body in the spermatia (cyt.).

nebenkörper (nā'běnkër'pĕr) $n$. [Ger. neben, near ; körper, body.] 'A body surrounded by oil-drops at the hinder pole of Pyrodinium, perhaps the seat of luminosity (zool.).

necrogenous (někrŏj'ennŭs) a. [Gk. nekros, dead ; genos, offspring.] Living or developing in dead bodies (zool.).

necrophagous (někrǒf'ăgŭs) a. [Gk. nekros, dead; phagein, to eat.] Feeding on dead bodies (zool.).

necrophilous (někrǒf'îlŭs) $a$. [Gk. nekros, dead; philein, to love.] Feeding on dead bodies (zool.).

nectar (něk'tăr) n. [Gk.nektar, nectar.] The sweet substance secreted by special glands, the nectaries, in flowers (bot.).

nectar gland,- - see nectary.

nectar guides,-the series of markings on the petals of flowers, pointing apparently to the easiest way to reach the nectar, and at the same time ensuring that the insect visitor will cause cross-fertilization (biol.). 
nectariferous (něk'tărif'ěrŭs) a. [Gk. nektar, nectar ; L. ferre, to carry.] Producing or having nectar-secreting structures (bot.).

nectarivorous (něk'tărǐv'örŭs) $a$. [Gk. nektar, nectar; $\mathrm{L}$. vorare, to devour.] Nectar-sipping; appl. to certain Insects (zool.).

nectary (něk'tărĭ) n. [Gk. nektar, nectar.] A group of sub-epidermal cells of no definite position in a flower, secreting a sweet substance ; a nectar gland (bot.).

nectocalyx (něk'tökä'líks) n., nectocalyces (něk'tökä'lǐsēz) plu. [Gk. nektos, swimming; kalyx, cup.] A modifiedmedusiform person adapted for swimming purposes found as part of a Siphonophore colony (zool.).

nectocyst (něk'tösĭst) n. [Gk. nektos, swimming; kystis, bladder.] The cavity of a nectocalyx (zool.).

nectophore (něk'töfōr) n. [Gk. nektos, swimming; pherein, to carry.] A nectocalyx; that portion of the common coenosarc on which the nectocalyces are borne (zool.).

nectopod (něk' töpǒd) n. [Gk. nektos, swimming; pous, foot.] An appendage modified for swimming (zool.).

nectosac (něk'tösăk) n. [Gk. nektos, swimming; L. saccus, sac.] A nectocyst (zool.).

nectosome (něk'tösōm) n. [Gk. nektos, swimming; soma, body.] The upper or swimming part of a Siphonophore (zool.).

nectozooid (něk'tözōoid) n. [Gk. nektos, swimming; zoon, animal; eidos, resemblance.] A nectocalyx (zool.).

negative tropism, - a tendency to move away from a source of stimulus (phys.).

nekton (něk'tǒn) n. [Gk. nektos, swimming.] The organisms swimming about the surface of the sea (biol.).

nemathecium (něm'ăthē'sǐŭ, nĕm'ăthê'shĭŭm) n. [Gk. nema, thread ; theke, box.] A protuberance on the thallus of Thallophytes (bot.).

nematoblast (něm'ătöblăst) $n$. [Gk. nema, thread; blastos, bud.] Spermatocyte.

nematocalyx (něm'ătökä'liks) $n$. [Gk. nema, thread; kalyx, cup.] The "Guard-polyp" of a Plumularian, carrying nematocysts (zool.).

nematocyst (nĕm'ătösǐst) $n$. [Gk. nema, thread; kystis, bladder. A stinging cell (zool.).

nematogene (něm’ătöjēn) $n$. [Gk. nema, thread; genos, birth.] Appl. the phase of Dicyema when its vermiform embryos escape from the parent by perforating the body wall (zool.).

nematogone (něm'ătögōn) $n$. [Gk. nema, thread ; gonos, offspring.] A thin-walled propagative cell in certain Mosses (bot.).

nematophore (něm'ătöfōr) n. [Gk. nema, thread; pherein, to carry.] A nematocalyx (zool.).

nematophorous (nĕm'ătŏf'örŭs) $a$. [Gk. nema, thread; phercin, to carry.] Pert. a nematophore (zool.).

nematozooid (něm'ătözō'oid) $n$. [Gk. nema, thread; zoon, animal ; eidos, resemblance.] A defensive zooid in a Hydrozoan (zool.).

nemorose (nĕm'örōs) a. [L. nemus, woodland with pasture.] Inhabiting open woodland places (bot.).

Neo-Darwinism, - a revival of Darwin's doctrine of natural selection as the chief factor in evolution, and of non-transmissibility of acquired characters.

neogamous (nēŏg'ămŭs) a. [Gk. neos, young; gamos, marriage.] $A p p l$. forms of Protozoa exhibiting precocious association of gametocytes (zool.).

Neo-Lamarckism, - a revival of Lamarck's doctrine of evolution, that inherited acquired characters formed the inception of specific differences.

Neolithic (nē'ölith'îk) a. [Gk. neos, young; lithos, stone.] Pert. that age following on the Palaeolithic (pal.).

neomorph (nēéömôrf) n. [Gk, neos, young; morphe, form.] A structural variation from type (biol.).

neomorphosis (nē'ömôr'fösĩs) $n$. [Gk. neos, young; morphosis, change.] Regeneration in the case where the new part is unlike anything in the body (biol.).

neonychium (nēönìkiŭm) $n$. [Gk. 
neos, new ; onyx, nail.] A soft pad enclosing each claw of the embryo of all unguiculate vertebrates and of some other mammals, probably to prevent the tearing of the foetal membranes during movements of the embryo; also found in the chick (zool.).

neopallium (nēöpăl'íum) n. [Gk. neos, young; L. pallium, cloak.] In the mammalian brain, a definite area of pallium for impressions of tactile, visual, and other senses (anat.).

neoteinia (nēétīíniă) n. [Gk. neos, young; teinein, to stretch.] The state of having development arrested to prolong immaturity (biol.).

neoteinic (nē'ötî'nı̌k) a. [Gk. neos, young; teinein, to stretch.] $A p p l$. substitution royalties of termites which remain undeveloped in certain respects (zool.).

neoteny (nēŏt'ĕnĭ) n. [Gk. neos, young; teinein, to stretch.] The retention of larval characters beyond the normal period, or the occurrence of adult characteristics in the larva, exemplified in Amphibia (zool.).

Neotropical (nēöötrŏp'íkăl) a. [Gk. neos, young; trepein, to turn.] Pert. or designating a zoogeographical region consisting of South America, the Antilles, and tropical North America.

Neozoic (né'özō'ik) a. [Gk. neos, young ; $z o e$, life.] Pert. the period from the Mesozoic to the present day ( $p a l$. ).

nephric (něf'rik) a. [Gk. nephros, kidney.] Pert. the kidney (anat.).

nephridial (něfrĭd'iăl) a. [Gk. nephros, kidney.] Nephric, usually $a p p l$. the small excretory tubules in the kidney (anat.) ; also pert. the excretory organ or nephridium of Invertebrates (zool.).

nephridiopore (něfríd'iöpōr) n. [Gk. nephros, kidney; poros, passage. The externalopening of a nephridium (zool.).

nephridium (něfrìd'iŭm) $n$. [Gk. nephros, kidney.] Any excretory organ ; usually the excretory organ of Invertebrates (zool.).

nephrocytes (něf'rösīts) $n$. plu. [Gk. nephros, kidney; kytos, hollow.] Cells in Sponges which secrete waste and then migrate to the surface of the body to discharge (zool.).

nephrodinic (nĕf'rödǐn'ík) $a$. [Gk. nephros, kidney; odis, labour.] Having one duct, serving for both excretory and genital purposes (zool.).

nephrogonaduct (nĕf'rögŏn'ădŭkt) $n$. [Gk. nephros, kidney; gonos, offspring; L. ducere, to lead.] Excretory and genital duct in one (zool.).

nephroid (něf'roid) a. [Gk, nephros, kidney; eidos, resemblance.] Kidney-shaped (anat., zool.).

nephrolytic (něf'rölìt'ík) a. [Gk. nephros, kidney ; lyein, to dissolve.] Pert. or designating enzymatic action destructive to the kidneys (phys.).

nephropore (nĕf'röpōr) $n$. [Gk.nephros, kidney; poros, passage.] A nephridiopore (zool.).

nephros (něf'rǒs) n. [Gk. nephros, kidney.] A kidney; usually the functional portion of a kidney (anat.).

nephrostome (něf'röstōm) n. [Gk. nephros, kidney; stoma, mouth.] The opening of a nephridial tubule into the coelom or body cavity (zool.).

nephrotome (něf'rötōm) n. [Gk. nephros, kidney; temnein, to cut.] That part of a somite developing into an embryonic excretory organ (emb.).

nervated (něr'vātĕd) a. [L. nervus, sinew.] Having nerves or veins (bot.).

nervation (něrvā'shŭn) $n$. [L. nervus, sinew.] The disposition of nerves in a leaf (bot.).

nerve (nĕrv) $n$. [L. nervus, sinew.] One of the numerous grey fibrous cords connecting the brain with all other parts of the body (anat.); the vein of an insect wing (zool.); a vein (bot.).

nerve eanal,-a canal for passage of nerve to the pulp of a tooth (anat.). nerve cell, - a cell characteristic of brain and nerve tissue (anat.).

nerve centre,-a collection of nerve cells associated with one particular function (phys.). 
nerve eminence,- - a superficial group of cells in some Fishes, acting as a sense organ and connected with the lateral line system (zool.).

nerve ending, - the terminal distal portion of a nerve, modified in various ways (anat.).

nerve fibres, - the thread-like structures of which nerves are composed (anat.).

nerve pentagon,- - the five-sided nerve ring round the mouth of Echinoderms (zool.).

nervimotion (něr'vimō'shŭn) $n$. [L. nervus, sinew ; movere, to move.] Motion due to direct stimulus from nerves (phys.).

nervous (nĕr'vŭs) a. [L. nervus, sinew.] Pert. or designating nerves; $a p p l$. tissue composed of nerve fibres (anat.).

nervous system,- - the brain, spinal cord, nerves and all their branches taken collectively (anat.).

nervule (nĕr'vūl) $n$. [L. dim. of nervus, sinew.] A branch or terminal portion of a nervure of an insect wing (zool.).

nervuration (něr'vürā'shŭn) $n$. [L. nervus, sinew.] Disposition of nervures (zool.).

nervure (nĕr'vūr) n. [L. nervus, sinew.] One of the rib-like structures which support the membranous wings of Insects, branches of the tracheal system (zool.); a vein (bot.). nervus lateralis (něr'vŭs lăt'ĕrăl'ìs) $n$. [L. nervus, sinew ; lateralis, pert. the side.] A branch of the vagus nerve in Fishes connecting the sensory "lateral line" with the brain (anat.).

net-knots,-karyosomes.

netted-veined, - with veins in the form of a network (bot.).

nettling-cells, - the stinging cells in Hydra and its allies (zool.).

neurad (nū'răd) adv. [Gk. neuron, nerve.] Dorsally (anat.).

neural (nū'răl) a. [Gk. neuron, nerve.] Pert. or closely connected with nerves (anat.).

neural arch, - the arch formed on the dorsal surface of a vertebral centrum, by the neural plates and neural spine, for the passage of the spinal cord (anat.). neural canal,- the canal formed by the neural arches (anat.).

neural plates,- the lateral members of a neural arch (anat.) ; the median row, usually of eight bony plates, in the carapace of a turtle (zool.).

neurapophysis (nūr'ăpǒf'isišs) $n$. [Gk. neuron, nerve; $a p o$, from ; phyein, to grow.] The spinous process of a vertebra (anat.).

neuraxis (nūrăk'sis) $n$. [Gk. neuron, nerve; L. axis, axle.] The central cylinder of a medullated nervefibre (anat.).

neuraxon (nürăk'sŏn) n. [Gk. neuron, nerve; axon, axle.] Neuraxis.

neurenteric (nūr'ěntĕr'ík, nūrěn'těrǐk) a. [Gk. neuron, nerve; enteron, gut.] Pert. the neurocoele and enteric cavity (anat.).

neurenteric canal, - a short canal connecting the posterior end of the central canal of the spinal cord with the posterior end of the enteric cavity (emb.).

neuric (nū'rǐk) a. [Gk. neuron, nerve.] Neural.

neuricity (nūrǐs'îtǐ) $n$. [Gk. neuron, nerve.] Property peculiar to nerves (phys.).

neurility (nūrưl'îtǐ) n. [Gk. neuron, nerve.] The stimuli-transmitting capacity of nerves (phys.).

neuroblast (nū'röblăst) n. [Gk. neuron, nerve; blastos, bud.] Special epithelial cells from which nerve cells are formed (emb.).

neurocentral (nū'rösěn'trăl) a. [Gk. neuron, nerve ; L. centrum, centre.] $A p p l$. two vertebral synchondroses persisting during the first few years of life (anat.).

neurocirrus (nū'röšrr'ŭs) n. [Gk. neuron, nerve; L. cirrus, curl.] The cirrus of the neuropodium of a polychaet Annelid (zool.).

neurocoel (nū'rösēl) n. [Gk, neuron, nerve; koilos, hollow.] The cavity of the central nervous system (anat.).

neurocyte (nü'rösĩt) n. [Gk. neuron, nerve ; kytos, hollow.] Nerve cell (anat.).

neurodendron(nū'röděn'drŏn) $n$. [Gk. neuron, nerve; dendron, tree.] A dendrite.

neuro-epithelium (nū'rö-ěpĭthē'liǔm) n. [Gk. neuron, nerve ; epi, upon; 
thele, nipple.] The superficial layer of cells where specialized for a senseorgan (anat.).

neuroflbrils (nū'röfi'́brìlz) n. plu. [Gk. neuron, nerve; L. fibrilla, fine fibre.] Exceedingly fine fibres of which a medullated nerve fibre is composed; also present in nerve cells, and believed to be the conductors of nerve impulses (anat.).

neurogenesis (nū'röjën'ěsiss) n. [Gk. neuron, nerve; gignesthai, to produce.] Nerve production (phys.).

neuroglia (nư'röglē'ă, nūrǒg'liă) $n$. [Gk. neuron, nerve; glia, glue.] A peculiar tissue, composed of cells and fibres, supporting the nerve cells and nerve fibres (anat.).

neuroid (nū'roid) a. [Gk. neuron, nerve; eidos, resemblance.] Like a nerve (anat.).

neurokeratin (nū'rökĕr'ătĭn) $n$. [Gk. neuron, nerve; keras, horn.] The keratin of nervous tissue (phys.).

neurolemma (nū'rölěm’ă) n. [Gk. neuron, nerve; lemma, skin.] The delicate tubular sheath of a nerve (anat.).

neurology (nūrŏl'öjīi) n. [Gk. neuron, nerve; logos, discourse.] That part of anatomy dealing with the details of the nervous system.

neuromasts (nü'römăsts) n. plu. [Gk. neuron, nerve ; mastos, knoll.] Groups of sensory cells in the lateral line of Fishes (zool.).

neuromere (nū'römēr) n. [Gk.neuron, nerve; meros, part.] A spinal segment, a division of convenience not structural (anat.).

neuromuscular (nū'römŭs'kūlăr) $a$. [Gk. neuron, nerve; L. musculus, muscle.] Pert. nerve and muscle (anat).

neuron (nü'rŏn) $n$. [Gk. neuron, nerve.] The nerve-cell with its outgrowths (anat.); also neurone.

neuroneme (nū'rönēm) $n$. [Gk. neuron, nerve; nema, thread.] A nerve fibril running parallel to a myoneme in an Infusorian (zool.).

neuronephroblast (nü'rönëf'röblăst) n. [Gk. neuron, nerve; nephros, kidney; blastos, bud.] One of cells derived from one of the megameres in the segmenting egg of Clepsine, which later give rise to part of the germinal bands from which the nerve cord and the nephridia develop (zool.).

neurophags (nū'röfăgz) $n$. plu. [Gk. neuron, nerve; phagein, to eat.] Phagocytic cells that encroach upon and destroy nerve-cells in old age (phys.).

neurophane (nū'röfān) $a$. [Gk. neuron, nerve; phainein, to appear.] Nervous, sensory; $a p p l$. supposed nervous fibrils of Ciliata (zool.).

neuropodium (nū'röpō'dǐŭm) n. [Gk. neuron, nerve; pous, foot.] The ventral lobe of a polychaetan parapodium (zool.).

neuropodous (nūrŏp'ödŭs) a. [Gk. neuron, nerve ; pous, foot.] "Having limbs directed towards the neural side" (zool.).

neuropore (nū'röpōr) $n$. [Gk. neuron, nerve; poros, passage.] The anterior opening of the neurocoel to the exterior (emb.).

neuropterous (nūrŏp'těrŭs) a. [Gk. neuron, nerve; pteron, wing.] Having wings with a network of nervures (zool.).

neuroskeleton (nū'röskěl'ětŏn) $n$. [Gk. neuron, nerve; skeletos, dried up.] Endoskeleton (sool.).

neurosynapse (nū'rösìnăps') $n$. [Gk. neuron, nerve; synapsis, union.] Junction of nerve-cells through terminal arborizations or cell processes (anat.).

neurotendinous (nū'rötěn'dĭnŭs) $a$. [Gk. neuron, nerve ; tenon, tendon.] Concerning nerves and tendons (anat.).

neurotrophic (nū'rötrŏf'îk) a. [Gk. neuron, nerve ; trephein, to nourish.] Nourishing the nervous system (phys.).

neurotropism (nûrǒt'röpǐzm) n. [Gk. neuron, nerve; trepein, to turn.] The attraction exerted by nervous tissue upon developing nerve tissue (phys.). neuter (nü'têr) a. [L. neuter, of neither sex.] Sexless,

neutral (nū'trăl) $a$. [L. neuter, neuter.] Neither male nor female (zool.).

neutrophil (nü'tröfil) a. [L. neuter, neuter; Gk. philein, to love.] Designating granules of white blood corpuscles, which stain only with neutral stains (cyt.). 
neutrophilic, - neutrophil.

nictitant (nìk'tĭtănt) a. [L. nictare, to wink.] $A p p l$. an ocellus with central lunate spot (zool.).

nictitating membrane, - the third eyelid, a transparent membrane which assists in keeping the eye clean (zool.).

nidamental (nĭd'ămĕn'tăl) $a$. nidus, nest.] Appl. glands which secrete material for an egg-covering (zool.).

nidation (nĭdā'shŭn) $n$. [L. nidus, nest.] The renewal of the uterus lining between menstrual periods (phys.).

nidicolous (nǐdřk'ölŭs) a. [L. nidus, nest ; colere, to cultivate.] Living in the nest for a time after hatching (zool.).

nidifugous (nĭdĭf'ūgŭs) $a$. [L. nidus, nest ; fugere, to flee.] Leaving the nest soon after hatching (zool.).

nidulus (nĭd'ülŭs) $n$. [L. dim. of nidus, nest.] The nucleus from which a nerve originates (anat.).

nidus (nï'dŭs) $n$. [L. nidus, nest.] A nest; a nest-like hollow (zool.) ; a nucleus (anat.) ; a cavity for the development of spores (bot.).

nidus hirundinalis (hĭrŭn'dĭnắlĭs) $n$. A fossa of the cerebellum (anat.).

nigrescent (nigrěs'ĕnt) a. [L. nigrescere, to turn black.] Approaching to black in colour (zool.).

nipple (nǐp'l) $n$. [Dim. of A.S. nib, for neb, nose.] Mamma ; teat (anat., zool.).

Nissl's granules,-angular particles found in the cytoplasm of nerve cells (phys.).

nisus formativus (nī'sŭs fôrmătî vŭs) $n$. [L. niti, to strive ; formare, to form.] The tendency to reproduce. nitid (nît'id) a. [L. nitidus, shining.] Glossy.

nitidous (nit'idŭs) a. [L. nitidus, shining.] Glossy.

nitrobacteria (ni'tröbăktē'riă) n. plu. [L. nitrum, natron; bacterium, bacterium.] The nitric bacteria of the soil (bot.).

nitrogen (nĩ'tröjën) n. [Gk. nitron, soda; genos, descent.] An elementary gas composing four-fifths of the volume of the atmosphere (phys.). nitrogenous (nītrŏj'ĕnŭs) a. [Gk. nitron, soda;genos, descent.] Pert. or containing nitrogen.

nitrogenous equilibrium, - equilibrium of body maintained by equality of income and output of nitrogen (phys.).

nitrophilous (nītrŏf'îlŭs) a. [Gk. nitron, soda; philein, to love.] Thriving in nitrogenous soils (bot.). noctilucent (nŏk'tīloo'sĕnt, $-\mathrm{lu}^{\prime}-$ ) $a$. [L. nox, night ; lux, light.] Phosphorescent (biol.).

nocturnal (nŏktŭr'năl) a. [L. nox, night.] Seeking food and moving about at night, and not in the day-time (zool.).

nodal (nō'dăl) a. [L. nodus, knob.] Pert. a node (bot., zool.).

node (nōd) $n$. [L. nodus, knob.] The knob or joint of a stem at which leaves arise (bot.).

nodose (nō'dōs) a. [L. nodus, knob.] Having the intermediate and terminal joints thicker than the remainder; having knots or swellings (zool., bot.).

nodular (nŏd'ūlăr) a. [L. nodulus, dim. of nodus, knob.] Pert. a nodule or knot (bot., zool.).

nodule (nǒd'ūl) $n$. [L. nodulus, dim. of nodus, knob.] A small knoblike structure.

noduliferous (nǒd'ūlif'ěrŭs) $a$. [L. nodus, knob; ferre, to carry.] Bearing a nodule; appl. roots of leguminous plants (bot.).

nodulus (nŏd'ūlŭs) $n$. [L. nodulus, dim. of nodus, knob.] A nodule.

nodus (nö'dŭs) $n$. [L. nodus, knob.] A knob or node.

nomenclature (nō'měnklā'tūr, nömĕn'klătūr) $n$. [L. nomen, natne; calare, to call.] System of naming plants, animals, organs, etc.

norma (nôr'mă) n. [L. norma, rule.] View of the skull as a whole from certain points (anat.).

normal (nôr'măl) a. [L. norma, rule.] Consistent with type or standard. normoblasts (nôr'möblăsts) n. plu. [L. norma, rule; Gk. blastos, bud.] Erythroblasts, which see.

nostrils (nǒs'trìlz) n. plu. [A.S. nosthyrl, nostril.] The external openings of the nose (anat.). notochordal (nō'tökôr'dăl) a. [Gk. 
noton, back; chorde, cord.] Pert. or enveloping the notochord; $a p p l$. sheath, tissue, etc. (anat.).

notocirrus (no'tössür'ŭs) $n$. [L. notum, back; cirrus, curl.] The cirrus of the notopodium of a polychaet Annelid (zool.).

notonectal (nō'töněk'tăl) a. [Gk. noton, back; nektos, swimming.] Appl. Notonectidae, which swim back downwards (zool.).

notopodium (nō'töpō'díum) n. [Gk. noton, back; pous, foot.] The dorsal lobe of a polychaetan parapodium (zool.).

nototribe (nō'tötrīb) a. [Gk. noton, back; tribein, to rub.] Appl. flowers whose anthers and stigma touch the back of insects as they enter the calyx, a device for securing cross-fertilization (bot.).

notum (nō'tŭm) n. [L. notum, back.] The dorsal portion of an insect segment ; tergum (zool.).

nucellus (nūsĕl'ŭs) $n$. [L. dim. of nux, nut.] The central region and chief part of an ovule (bot.).

nuchal (nū'kăl) a. [L.L. mucha, spinal marrow.] Appl. two sense organs regarded as olfactory, on the prostomium of Chaetopoda (zool.).

nuchal cartilage, - a thin shieldshaped plate on the posterior surface of the neck of Sepia (zool.).

nuciferous (nūsíf'ěrŭs) a. [L. nux, nut ; ferre, to carry.] Nut-bearing (bot.).

nucivorous (nūsǐv'örŭs) a. [L. nux, nut ; vorare, to devour.] Nuteating (zool.).

nuclear (nū'klĕ̌r) a. [L. nucleus, kernel.] Pert. the nucleus (bot., zool.).

nuclear disc, - a star-like structure formed by the chromosomes in the equator of the spindle during mitosis (cyt.).

nuclear membrane, - the delicate membrane bounding a nucleus, formed from the surrounding cytoplasm (cyt.).

nuclear plate, - the equatorial plate (cyt.).

nuclear spindle,-a barrel-shaped structure formed of a number of fine fibrils in the cytoplasm sur- rounding the nucleus, a stage in mitosis (cyt.).

nucleate (nü'klěāt) a. [L. nucleus, nucleus.] Having a nucleus (cyt.).

nucleation (nūklê̌ă'shŭn) $a$. [L. nucleus, kernel.] Nucleus formation (cyt.).

nucleic (nū'klěik) a. [L. nucleus, kernel.] Pert. an acid containing phosphorus, found in some nuclei (phys.).

nucleiform (nü'klēîfôrm) a. [L. nucleus, kernel; forma, shape.] Shaped like a nucleus (cyt.).

nuclein (nū'klě̆n) $n$. [L, nucleus, kernel.] One of the chemical compounds found in nuclei, similar to protein but with the addition of phosphorus ( $p h y s$. .).

nucleochylema (nū'klëökīlē'mă) n. [L. mucleus, kernel; Gk. chylos, juice.] The ground substance of a cell-nucleus (cyt.).

nucleohyaloplasm (nū'klěöhīălöplăzm) $n$. [L. nucleus, kernel ; Gk. hyalos, glass ; plasma, something moulded.] The semi-fluid groundsubstance of a nucleus (cyt.).

nucleolar (nūklē'ölăr) $a$. [L. nucleus, kernel.] Pert. a nucleolus (cyt.).

nucleolus (nūklē'ölŭs) $n$. [L. nucleolus, dim. of nucleus, little kernel.] A rounded mass of pure plastin occurring in a nucleus (cyt.).

nucleomicrosomes (nü'klëömíkrösōmz) n. plu. [L. nucleus, kernel ; Gk. mikros, small; soma, body.] Nuclear chromatin granules (cyt.).

nucleoplasm (nū'klěoöplăzm) n. [L. nucleus, kernel ; Gk. plasma, something moulded.] Reticular nuclear substance ; $c f$. eytoplasm (cyt.).

nucleoproteid (nü'klě̈öpō'tě̀d) $n$. [L. nucleus, kernel ; Gk. protos, first ; eidos, resemblance.] A nuclein with much albumin (phys.).

nucleus (nū'klěus) $n$. [L. nucleus, kernel.] A complex spheroidal mass essential to the life of a cell (cyt.).

nuculanium (nū'kūlā'nǐum) $n$. [L. nucula, small nut.] A fleshy fruit like a grape (bot.).

nudibranchiate (nū'dǐbrăng'kīât) $a$. [L. nudus, naked; Gk. brangchia, gills.] Having gills not covered by a protective shell or membrane (zool.). 
nudicaudate (nū'dìkôd'āt) a. [L. nudus, naked; cauda, tail.] Having a tail not covered by hair or fur (zool.). nudicaulous (nū'dỉkôl'ŭs) $a$. [L. nudus, naked; caulis, stem.] $A p p l$. stems without leaves (bot.).

nudiflorous (nū'dĭfló'rŭs) $a$. [L. nudus, naked ; flos, flower.] Having flowers without glands or hairs (bot.).

nummulation (nŭm'ūlā'shŭn) $n$. [L. nummus, coin.] The tendency of red blood corpuscles to adhere together like piles of coins (phys.).

nummulitic (nŭm'ülìt'îk) a. [L. nummus, coin.] Like or pert. a Nummulite (zool., pal.).

nuptial flight,- the flight taken by the queen bee when fertilization takes place (zool.).

nurse cells,-single cells or layers of cells attached to or surrounding an egg-cell, probably for elaboration of its food-material (cyt.).

nurse generation, - an asexual budding generation of some Tunicates, in which the phorozooids act as foster parents to the later formed buds, the gonozooids (zool.).

nut (nŭt) $n$. [A.S. knutu, nut.] A dry, hard, indehiscent one-celled fruit (bot.).

nutation (nūtā'shŭn) n. [L. nutare, to nod.] Curvature or change of position in organs of a growing plant (bot.).

nutlet (nŭt'lět) $n$. [Dim. of nut.] The stone formed in drupaceous fruits (bot.).

nutricism (nū'trǐsǐzm) $n$. [L. nutrix, nurse.] Symbiotic relationship with all the benefit to one partner (biol.). nutrition (nütrǐsh'ün) n. [L. mutrix, nurse.] The ingestion and assimilation of food materials of animals and plants (phys.).

nutritive (nü'tritiv) a. [L. nutrix, nurse.] Concerned in the function of nutrition; $a p p l$. yolk, polyp, zooid, plasma.

nyctipelagie (nīk'tǐpělăj'îk) a. [Gk. nyktios, nightly; pelagos, the sea.] Rising to the surface of the sea only at night (zool.).

nyetitropism (nǐktǐt'röpizm) n. [Gk. nyktios, nightly ; trepein, to turn.] Tendency of certain leaves to curve upwards at night (bot.). nymph (nimf) $n$. [Gk. nymphe, bride.] A stage following the larval in insect metamorphosis (zool.).

nymphae (nim'fē) n. plu. [Gk. nymphe, bride.] The labia minora (anat.).

\section{$\mathrm{O}$}

oar-feathers, - the wing feathers used in flight in Birds (zool.).

obcompressed (ŏb'kŏmprĕst') a. [L. $o b$, towards ; comprimere, to compress.] Flattened in a vertical direction (bot.).

obcordate (ŏbkôr'dāt) a. [L. ob, against; cor, the heart.] Heartshaped; appl. leaves which have the stalk attached to the apex of the heart (bot.).

obdiplostemonous (ŏbdǐplöstěm'önŭs) a. [L. $o b$, against ; Gk. diploos, double ; stemon, a warp.] With the outer series of stamens opposite the petals (bot.).

obelion (öbëliǒn) n. [Gk. obelos, a spit.] The point between the two foramina on the interparietal suture (anat.).

obex (ō'běks) $n$. [L. obex, an obstacle.] A triangular layer of grey matter above the calamus in the roof of the fourth ventricle (anat.).

obimbricate (ŏbĭm'brìkāt) a. [L. ob, in the way ; imbrex, a tile.] With regularly overlapping scales, with the overlapping ends downwards (bot.).

oblanceolate (ŏblăn'sěoualāt) $a$. [L. ob, reversely; lancea, a spear.] Inversely lanceolate (bot.).

obligate or obligatory parasites, parasites which are limited to one mode of life, and cannot exist independently of a host ; $c f$. facultative (biol.).

oblique'(öblēk')a. [L. obliquus, bent.] Placed obliquely; $a p p l$. certain muscles (anat.); asymmetrical (bot.). obliquus (öblë'kwŭs) a. [L. obliquus, bent.] Oblique; $a p p l$. muscles (anat.).

obliterate (ǒblìt'ěrât) $a . \quad[\mathrm{L} . o b$, reversely; litera, a letter.] Indistinct or profuse ; $a p p l$. markings on insects (zool.). 
obovate (ŏbō'vāt) a. [L. $o b$, reversely ; ovum, an egg.] Egg-shaped, with the narrow end attached to the stalk (bot.).

obovoid (ŏbō'void) a. [L. $o b$, against ; ovum, an egg ; Gk. eidos, shape.] Inversely ovoid; roughly eggshaped, with the narrow end downwards (bot.).

obsolescence (ŏbsölěs'ĕns) n. [L. obsolescere, to wear out.] The gradual reduction and consequent disappearance of an organism (biol.) ; a blurred portion of a marking on any animal (zool.).

obsolete (ŏb'sölēt) a. [L. obsolescere, to wear out.] Wearing out or disappearing ; $a p p l$. any character that is becoming less and less distinct in each succeeding generation (biol.).

obturator (ŏb'tūrắtŏr) a. [L.obturare, to close.] Pert. any structure in the neighbourhood of the obturator foramen (anat.).

obturator foramen, - an oval foramen between ischium and pubis (zool.).

obtusilingual (ŏbtūsǔling'gwăl) $a$. [L. obtundere, to make blunt; lingua, a tongue.] Short-tongued (zool.).

o bumbrate (ǒbŭm'brāt) $a$. [L. obumbrare, to overshadow.] With some structure overhanging the part so as to conceal it partially (zool.).

obverse (ŏb'vĕrs, ŏbvĕrs') $a$. [L. obvertere, to turn round.] With the base narrower than the apex (bot.).

obvolute (ŏb'völūt) a. [L. obvolvere, to wrap round.] Overlapping; $a p p l$. leaves when half of one leaf is wrapped round half of another similar leaf (bot.).

obvolvent (ǒbvǒl'věnt) $a$. [L. obvolvere, to wrap round.] Bent downwards and inwards; $a p p l$. wings, elytra of insects, etc. (zool.).

occipital (ǒksǐp'ítăl) a. [L. occiput, back of the head.] Pert. the back part of the head or the occipital bones (anat., sool.).

oceipitalia (ŏk'sípitắlǐă) n. plu. [L. occiput, back of the head.] The group of parts of the cartilaginous brain case forming the back part of the head (zool.). occiput (ŏk'sĭpoot, ŏk'sĭpŭt) $n$. [L. occiput, back of the head.] The occipital region of the skull (anat.); the back of an insect's head (zool.).

occlude (ŏklood') v. [L. occludere, to shut in.] To absorb (phys.).

occlusor (ŏkloo'sŏr) a. [L. occludere, to shut in.] Appl. muscles of an operculum or movable lid (zool.).

ocellate (ösěl'āt) a. [L. ocellus, a little eye.] Like an eye or eyes; $a p p l$. markings on many animals (zool.).

ocellated (ösěl'ātěd, ŏs'ělātěd) $a$. [L. ocellus, a little eye.] Having ocelli; having eye-like spots or markings (zool.).

ocellation (ŏs'ělā'shŭn) $n$. [L. ocellus, a little eye.] Condition of having ocelli, or of having ocellate markings; ocellate marking (zool.).

ocelliferous (ŏs'ělif'ěrŭs) a. [L. ocellus, a little eye ; ferre, to bear.] Ocellated, which see.

ocellus (ösěl'ǔs) n., ocelli (ösěl'î, ösěl'ē) plu. [L. ocellus, a little eye.] A simple single eye or eyespot found in many of the lower animals; an eye-like marking as seen in many Insects (zool.).

ochrea, ocrea (ǒk'rě̌ă, ō'krěă) $n$. [L. ocrea, a greave.] A tubular sheathlike expansion at the base of the petiole (bot.) ; a sheath (zool.).

ocreaceous (ök'rěă'shŭs) a. [L. ocrea, agreave.] Ocrea-like; $a p p l$.various structures in plants and animals.

ocreate (ök'rễāt) a. [L. ocrea, a greave.] Having an ocrea (bot.); booted, sheathed (zool.).

octactine (ǒktăk'tĭn) $n$. [Gk. okta, eight; aktis, a ray.]. A type of sponge spicule with eight rays, a modification of a hexactine (zool.).

octamerous (ŏktăm'ĕrŭs) $a$. [Gk. okta, eight; meros, a part.] Appl. organs or parts of organs when arranged in eights; $a p p l$. parts of whorls of certain plants (bot.) ; $a p p l$. parts of certain Alcyonaria (zool.).

octandrous (ŏktăn'drŭs) a. [Gk. okta, eight; aner, a man.] Having eight stamens (bot.).

octant (ŏk'tănt) $n$. [L. octo, eight.] One of the eight cells formed by 
the division of the fertilized ovule in plants (bot.); one of the units in the eight-celled stage in the segmentation of the ovum (zool.). octogynous (ŏktŏj'inŭs) a. [Gk. okta, eight; gyne, a woman.] Having eight pistils (bot.).

octopetalous (ŏk'töpĕt'ălŭs) a. [Gk. okta, eight ; petalon, a petal.] Having eight petals (bot.).

octopod (ŏk'töpŏd) a. [Gk. okta, eight; pous, a foot.] Having eight feet or arms (zool.).

octoradiate (ŏk'törā'dīăt) a. [L. octo, eight; radius, a spoke.] Having eight rays or arms (zool.).

octosepalous (ŏk'tösě̀p'ălŭs) $a$. [Gk. okta, eight; sepalon, a sepal.] Having eight sepals (bot.).

octosporous (ŏk'töspō'rŭs, ǒktǒs'pörŭs) a. [Gk. okta, eight; sporos, a seed.] Having eight spores (bot.).

octostichous (ǒktǒs'tǐkŭs) a. [Gk. okta, eight; stichos, a row.] Having the leaves in eights, as in phyllotaxis (bot.).

octozoic (ŏk'tözōîik) a. [Gk. okta, eight; zoon, an animal.] Appl. a spore of Gregarines, containing eight sporozoites (zool.).

ocular (ŏk'ülăr) a. [L. oculus, an eye.] Pert. or perceived by the eye.

ocular 1obe,- the projecting thoracic lobe in some beetles (zool.).

ocular plates, - the plates at the end of the ambulacral areas in sea urchins (zool.).

oculate (ơk'ūlāt) a. [L. oculus, an eye.] Having eyes, or having eyelike spots (zool.).

oculiferous (ŏk'úliff'ěrŭs), oculigerous (ŏk'ülij'ěrŭs) a. [L. oculus, eye ; ferre, gerere, to carry.] Bearing eyes (sool.).

oculofrontal (ŏk'úlöfrŭn'tăl) $a$. [L. oculus, eye ; frons, forehead.] Pert. region of forehead and eye.

oculomotor (ŏk'ülömō'tŏr) a. [L. oculus, eye ; movere, to move.] Causing the movements of the eyeball; appl. the third cranial nerve (anat., zool.).

oculonasal (ŏk'ūlönāzăl) a. [L.oculus, eye; nasus, nose.] Pert. eyeandnose. oculus (ŏk'úlŭs) n. [L. oculus, eye. The eye (anat., zool.); a leaf-bud in a tuber (bot.). odontoblast (ödŏn'töblăst) $n$. [Gk. odous, a tooth; blastos, a bud.] One of the columnar cells on the outside of the pulp that form the dentine (zool.).

odontoclast (ödŏn'töklăst) $n$. [Gk. odous, a tooth ; klan, to break.] One of the large multinucleate cells that absorb the roots of the milk teeth (zool.).

odontogeny (ödǒntǒj'ěnǐ) n. [Gk. odous, tooth; genos, offspring.] The origin and development of teeth.

odontoid (ödŏn'toid) a. [Gk. odous, tooth ; eidos, form.] Tooth-like ; pert. the odontoid process.

odontoid process, - a tooth-like peg on the axis round which the atlas rotates, - it is the centrum of the atlas, which has first become free and finally fused with the axis (anat., zool.).

odontophore (ödŏn'töfōr) $n$. [Gk. odous, tooth; pherein, to carry.] The radula or tooth-bearing organ in Molluscs; a structure over which the radula slides (zool.).

odontoplast (ödŏn'töplăst) $n$. [Gk. odous, tooth ; plastos, moulded.] An odontoblast cell (anat.).

odontostomatous (ödŏn'töstŏm'ătǔs) a. [Gk. odous, tooth; stoma, mouth.] Having tooth-bearing jaws.

oecoid (e'tkoid) $n$. [Gk. oikos, a house.] The stroma of a blood corpuscle (anat.).

oecology (ēköl'öjĩ) n. [Gk. oikos, house; logos, discourse.] Bionomics, which see.

oedematin (ēděm'ătĭn) $n$. [Gk, oidema, a swelling.] The microsomes of the ground substance of the nucleus (cyt.).

oenocyte (è'nösīt) n. [Gk. oinos, wine; kytos, hollow.] One of the large cells from the clusters which surround the trachea and fat body of Insects (zool.).

oesophageal (êsǒf'ăjēéăl) a. [Gk. oisophagos, the gullet.] Pert. or near the oesophagus, as ganglia (sool.).

oesophagus (ěsǒf'ăgŭs) n. [Gk, oisophagos, the gullet.] That part of the alimentary canal between the pharynx and the stomach, or part equivalent thereto (zool.). 
oestrual (ế'strooăl) a. [Gk, oistros, gadfly.] Pert. oestrus (phys.); also oestrous.

oestruation (ē'strooā'shŭn) n. [Gk. oistros, gadfly.] State of being under sexual desire; rut (phys.).

oestrus (e'strŭs) n. [Gk. oistros, gadfly.] The sexual heat of animals ; rut (phys.).

offset, - a short prostratebranch which takes root at the apex and develops new individuals (bot.).

offshoot,-a lateral shoot from a main stem (bot.).

oidium (ōìd'̌um) $n$. [Gk. oon, an egg.] The conidial stage of some of the mildews (bot.).

oikoplast (oik'öplăst) n. [Gk. oikos, house; plastos, moulded.] One of the large glandular ectoderm cells which form the gelatinous layer of Appendicularians (zool.).

oilgland, - the uropygial gland in Birds; a gland which secretes oil (zool.).

oleaginous (ŏl'ěă'ǐnŭs) a. [L. olea, oil.] Pert. oil ; containing oil; producing oil (biol.).

olecranon (ölěk'rănŏn) n. [Gk. olene, elbow.] A large process at the upper end of the ulna (zool.).

oleiferous (ölěif' ěrŭs) $a$. [L. oleum, oil ; ferre, to carry.] Producing oil (bot.).

olein (óliě̀n) $n$. [L. oleum, oil.] A fat found in animal and vegetable tissues and liquid at ordinary temperatures (phys.).

oleocyst (ólễösist) $n$. [L. oleum, oil ; Gk. kystis, bladder.] A diverticulum of the nectocalyx (zool.).

olfactory (ôlfăk'tŏrǐ) a. [L. olere, to have a smell ; facere, to make.] Pert. associated with, or designating the structures associated with the sense of smell.

olfactory lobe, - a smali lobe projecting from the anterior lower margin of the cerebral hemispheres (anat.). olfactory pit, - any olfactory organ of the nature of a small pit or hollow (zool.) ; the depression which later forms the nasal passage (emb.). oligacanthous (ŏl'rigăkăn'thŭs) $a$. [Gk. oligos, few ; akantha, a spine.] Bearing few spines (zool.).

oligandrous (ŏl'igăn'drŭs) a. [Gk. oligos, few ; aner, man.] Having few stamens (bot.).

oligocarpous (ŏl'igökâr'pŭs) $a$. [Gk. oligos, few ; karpos, fruit.] Having few carpels (bot.).

oligocene (ŏl'igösēn') a. [Gk. oligos, few; kainos, recent.] $A p p l$. a tertiary period between Eocene and Miocene (pal.).

oligodynamic (ŏl'ígödinăm'îk) $a$. [Gk. oligos, few ; dynamis, power.] Caused by small or minute forces (bot.).

oligomerous (ŏl'ígŏm'ĕrŭs) a. [Gk. oligos, few ; meros, a part.] Having one or more of the whorls with fewer members than the rest (bot.).

oligonephrous (ŏl'ĭgöněf'rŭs) $a$. [Gk. oligos, few ; nephros, a kidney.] Having few Malpighian tubules; appl. Insects (zool.).

oligospermous (ŏl'igöspěr'mŭs) $a$. [Gk. oligos, few ; sperma, a seed.] Bearing few seeds (bot.).

oligostemonous (ŏl'igöstĕm'önŭs) $a$. [Gk. oligos, few ; stemon, a stamen.] Having few stamens (bot.).

oligotaxy (ŏl'ígötăk'sǐ) n. [Gk. oligos, few ; taxis, arrangement.] Diminution in the number of whorls (bot.).

oligotokous (ŏl'ígŏt'ökŭs) $a$. [Gk. oligos, few ; tokos, offspring.] Bearing few young (zool.).

oliva (ŏlî́vă), olive (ŏl'ǐv) $n$. [L. oliva, olive.] A prominence on each side of the anterior end of the medulla just below the pons (anat.). olivary (ŏl'ivărǐ) a. [L. oliva, olive.] Pert. the oliva, or olivary body (anat.).

omasum (ömã'sŭm) $n$. [L. omasum, paunch.] The psalterium or third division of a ruminant's stomach (zool.).

omental (ömĕn'tăl) a. [L. omentum, a fold.] Pert. the omentum or omenta (anat.).

omentum (ömĕn'tŭm) $n$. [L.omentum, a fold.] A fold of the peritoneum either free or acting as the connecting link between viscera, etc. (anat.).

ommateum (ŏm'ăté'ŭm) n. [Gk. omma, the eye.] Any compound eye (zool.).

ommatidium (ŏm'ătĭd’úŭ) $n$. [Gk. omma, eye.] One of the com- 
ponent elements of a compound eye (zool.).

ommatoids (ŏm'ătoidz) n. plu. [Gk. omma, eye ; eidos, form.] Two or four light-coloured spots on the last abdominal segment of Pedipalpi, - of disputed function (zool.). ommatophore (ŏm'ătöfōr) n. [Gk. omma, eye ; pherein, to bear.] Any movable process bearing an eye (zool.).

omnivorous (ŏmnív'örŭs) $a$. [L. omnis, all; vorare, to devour.] Eating both animal and vegetable tissue (zool.).

omohyoid (o'möhīoid) a. [Gk. omos, shoulder; hyoeides, Y-shaped.] Pert. shoulder and hyoid; appl. a muscle (anat.).

omoideum (ömoid'ěum) n. [Gk. omos, shoulder; eidos, shape.] The pterygoid bone in a Bird's skull (zool.).

omosternum (ō'möstĕr'nŭm) $n$. [Gk. omos, shoulder; sternon, breast.] One of the elements of the Amphibian sternum (zool.).

omphalic (ŏmfăl'rk) a. [Gk. omphalos, navel.] Pert. the umbilicus (anat.). omphaloid (ŏm'făloid) a. [Gk. omphalos, navel; eidos, like.] Like a navel; having an umbilicus (zool.).

omphaloidium (ŏm'făloid'iŭm) $n$. [Gk. omphalos, navel; eidos, like.] The scar at the hilum of a seed, or the hilum itself (bot.).

omphalomesaraic (ŏm'fălöměs'ărā'îk), - omphalomesenteric, which see.

omphalomesenteric (ŏm'fălömĕs'ĕntĕr'ik) a. [Gk. omphalos, navel; mesenteron, mid-gut.] Pert. umbilicus and mesentery ; appl. veins, ducts (anat.).

onchosphere (ŏng'kösfēr) n. [Gk. ongkos, hook; sphaira, a globe.] The larval stage of a tapeworm preceding the cysticercus stage; the proscolex or six-hooked embryo stage of Cestoidea; also oncosphere (zool.).

ontocyele (ŏn'tösīkl) n. [Gk. on, being; kyklos, a circle.] Evolution which in its later stages tends to produce forms exactly like those in the early stages (biol.). ontogenesis (ŏn'töjěn'ěsǐs) $n$. [Gk. on, being; genesis, descent.] The life-history of a single individual (biol.).

ontogenetic (ŏn'töjěnět'îk) a. [Gk. on, being ; genesis, descent.] Pert. ontogeny, or the development of the individual (biol.).

ontogeny (ŏntŏj'ěnì) $n$. [Gk. on, being ; genos, birth.] Ontogenesis, which see.

onychium (önǐk'iŭm) n. [Gk. onyx, a nail.] The layer below the nail (anat.); a pulvillus; in some spiders a special false articulation at the end of the tarsus to bear the claws (zool.).

onychogenic (ŏn'îköjěn'îk) a. [Gk. onyx, nail; genos, offspring.] Capable of producing a nail or a naillike substance; $a p p l$. a material occurring in nail matrix and cells forming the fibrous substance and cuticula of hairs (phys.).

ooblastema (óōblăstè'mă) n. [Gk. oon, egg; blastos, bud.] The egg after fertilization (zool.).

oocyte (ōōsīt) n. [Gk. oon, egg; kytos, hollow.] An egg before the formation of the first polar body $(e m b$.$) ; in Protozoa a stage in the$ supposedly female conjugant before it prepares for fertilization (zool.).

ooecium (ōē'shĭŭm) n. [Gk. oon, egg ; oikos, house.] An ovicell (zool.).

oogamete (óōgămēt') n. [Gk. oon, egg; gamos, marriage.] An oosphere of Sporozoa (zool.).

oogamous (ōŏgămŭs) a. [Gk, oon, egg ; gamos, marriage.] Having sexually differentiated gametes (bot.). oogenesis (ō'ōjĕn'ěsīs) n. [Gk. oon, egg ; genesis, descent.] Formation, development, and maturation of the egg (biol.).

oogloea (ónglē'ă) n. [Gk. oon, egg ; gloia, glue.] Egg cement (zool.).

oogonial (ó'ogō'niăl) a. [Gk. oon, egg ; gonos, descent.] Pert. the oogonium.

oogonium (ō'ōgō'nǐum) n. [Gk. oon, egg ; gonos, offspring.] The female reproductive organ in certain Thallophytes (bot.); the mother egg-cell (biol.).

ooid (óoid) a. [Gk. oon, egg; eidos, form.] Egg-shaped. 
ookinesis (ō'ōkĭnē'sĭs) $n$. [Gk. oon, egg; kinein, to move.] The karyokinetic stages of the nucleus in the maturation and fertilization of the egg (biol.).

ookinete (óōkǐnēt') n. [Gk. oon, egg ; kinein, to move.] The motile worm-shaped stage of the zygote in certain Protozoa (zool.).

oolemma (ōōlěm’ă) n. [Gk. oon, egg ; lemma, a husk.] The vitelline membrane of an egg (emb.).

oophore (óōför) n. [Gk. oon, egg ; pherein, to bear.] Oophyte, which see.

oophoridium (o'ōöörĭd'̌ŭm) $n$. [Gk. oon, egg; pherein, to bear.] The megasporangium in certain plants (bot.).

oophyte (ōōfīt) $n$. [Gk. oon, egg ; phyton, a plant.] The sexual generation in such plants as the liverwort; the gametophyte (bot.).

ooplasm (o'ōplăzm) n. [Gk. oon, egg ; plasma, something moulded.] The cytoplasm of an egg; the yolk or cell substance of an egg (emb.).

oopod (o'ōpŏd) $n$. [Gk. oon, egg; pous, foot.] Any of the component parts of a sting or ovipositor (zool.).

oosperm (ōōspěrm) $n$. [Gk. oon, egg; sperma, seed.] A fertilized egg.

oosphere (ōōsfêr) n. [Gk. oon, egg ; sphaira, globe.] An egg before fertilization ; a female gamete (zool.).

oospore (ō'ōspōr) n. [Gk. oon, egg ; sporos, seed.] The zygote or fertilized egg-cell (bot.); the encysted zygote in certain Protozoa (zool.).

oostegite (ōŏs'tĕgīt) n. [Gk, oon, egg ; stege, roof.] A plate-like structure on the basal portion of a thoracic limb in certain Crustaceans, which forms or helps to form a receptacle for the egg (zool.).

oostegopod (o'ōstĕg'öpŏd) n. [Gk. oon, egg ; stege, roof; pous, foot.] A thoracic foot bearing an oostegite (zool.).

ootheca (ō'ōthē'ka) n. [Gk. oon, egg ; theke, a case.] A sporangium (bot.); an egg-case, as in Insects (zool.).

ootocoid (ōŏt'ökoid) a. [Gk.oon, egg ; tokos, offspring; eidos, form.] Giving birth to the young at a very early stage,'andithen carrying them in a marsupium I(zool.). ootocous (ōŏt'ökŭs) a. [Gk. oon, egg ; tokos, offspring.] Egg-laying (zool.). ootype (óotīp) $n$. [Gk. oon, egg; type, place.] The part of the oviduct where the shell is formed; the shell-gland of Turbellarians and Trematodes (zool.).

ooze $(\mathrm{oOz}) n$. [A.S. $w \overline{o s}$, juice.] A soft deposit found over large areas of the floor of the ocean.

oozooid (ó'ōzó'oid) $n$. [Gk. oon, egg ; zoon, animal; eidos, form.] Any individual developed from an egg.

opercle (öpĕr'kl) n. [L. operculum, a lid.] The posterior bone of a fish operculum (zool.).

operculate (öpĕr'kūlāt) $a$. [L. operculum, a lid.] Having a lid, as in the capsule of Mosses (bot.) ; having a covering for the gills, as in most Fishes (zool.).

operculiferous (öpĕr'kūlĭf'ěrŭs) $a$. [L. operculum, a lid; ferre, to bear.] Operculate.

operculiform (öpĕr'kūlǐfôrm' ${ }^{\prime}$ a. [L. operculum, a lid; forma, shape.] Lid-like (biol.).

operculigenous (öpĕr'külǐj'ěnŭs) $a$. [L. operculum, lid ; Gk. genos, offspring.] Producing or forming a lid (zool.).

operculum (öpĕr'kūlŭm) $n$. [L. oper culum, a lid.] A lid or flap, as in the capsules of Mosses (bot.); any of the convolutions covering the island of Reil (anat.); the lid-like structure seen in the Gastropods ; the movable plates in the shell of a Barnacle; the first pair of abdominal appendages in Limulus; the gill-cover of Fishes; the small plate covering the opening of a lung book in Spiders (zool.).

ophiopluteus (ŏf'iöploot'ěus) $n$. [Gk. ophis, serpent ; L. pluteus, shed.] The pluteus larva of an Ophiuran (zool.).

ophryon (ŏf'rǐŏn) n. [Gk. ophrys, brow.] The point of junction of the median line of the face with a line across the narrowest part of the forehead (anat.).

opisthion (öpis'thǐon) $n$. [Gk. opisthe, behind.] The median point of the posterior margin of the foramen magnum (anat.).

opisthocoelous (öpis'thösē'lǔs) $a$. [Gk. 
opisthe, behind; koilos, hollow.] Having the centrum concave behind ; $a p p l$. vertebrae (anat.).

opisthodetic (öprss'thödět'îk) $a$. [Gk. opisthe, behind; detos, bound.] Lying posterior to the beak; $a p p l$. ligaments in some bivalve shells (zool.).

opisthoglossal(öpiss'thöglŏs'ăl) $a$. [Gk. opisthe, behind; glossa, tongue.] Having the tongue fixed in front, free behind (zool.).

opisthognathous (öpis'thögnầth'ŭs) $a$. [Gk, opisthe, behind ; gnathos, jaw.] Having retreating jaws (zool.).

opisthotic (ŏp'îsthŏt'ik) a. [Gk. opisthe, behind; ous, the ear.] Pert. the inferior posterior bony element of the otic capsule (zool.). opisthure (ŏp'îsthūr') n. [Gk. opisthe, behind; oura, a tail.] The projecting tip of the vertebral column (zool.).

opponens (ŏpō'nĕnz) a. [L. opponere, to oppose.] Pert. muscles which cause the digits to approach one another (anat.).

opposite (ŏp'özit) a. [L. opponere, to oppose.] Pert. leaves which are opposed, or placed opposite one another at the same level on opposite sides of the stem (bot.).

opsonic (ŏpsŏn'îk) a. [Gk. opsonein, to cater.] Pert. or affected by opsonin (phys.).

opsonin (ŏpsō'nìn) $n$. [Gk. opsonein, to cater.] A constituent of blood which helps the phagocytes to destroy invading bacteria (phys.).

optic (ŏp'tik) a. [Gk. opsis, sight.] Pert. vision.

optic lobes, - that part of the brain which supplies the eyes.

optic thalami, - see thalami.

opticociliary (ŏp'tǐkösı̌l'iărĩ) a. [Gk. opsis, sight ; L. cilia, eyelashes.] Pert. optic and ciliary nerves (anat.).

opticopupillary (ŏp'tîköpü'pilărǐ) $a$. [Gk. opsis, sight; L. pupilla, pupil of eye.] Pert. optic nerve and pupil (anat.)..

optimum (ŏp'tĭmŭm) n. [L. optimus, best.] The most suitable degree of heat, etc., for the full development of the organism concerned (biol.); the point at which the best response can be obtained (phys.). optocoel (ŏp'tösēl) n. [Gk. opsis, sight ; koilos, hollow.] The cavity in the optic lobes of the brain (anat.).

optogram (ŏp'tögrăm) n. [Gk. opsis, sight; graphein, to write.] The image impressed on the retina by the action of light on the visual purple (phys.).

ora serrata, - the wavy border of the retina, where the nervous elements cease (anat.).

oral (o'răl) a. [L. os, mouth.] Pert. or belonging to the mouth; on the side on which the mouth lies.

orbicular (ôrbǐk'ülăr) a. [Gk. orbis, an orb.] $A p p l$. the eye muscles (anat.). orbicularis (ôrbǔk'ūlắrǐs) a. [L, orbis, an orb.] Appl. a muscle whose fibres surround an opening (anat.).

orbiculate (ôrbìk'ūlāt) a. [L. orbis, orb.] Nearly circular in outline; $a p p l$. leaves (bot.).

orbit (ôr'bǔt) $n$. [L. orbita, a circuit.] The bony cavity in which the eye is situated (anat.); the skin round the eye of a bird; the hollow in the arthropod cephalothorax in which the eye-stalk rises (zool.).

orbital (ôr'bĭtăl) a. [L. orbita, circuit.] Pert. the orbit.

orbitomalar (ôr'bǐtömā'lăr) a. [L. orbita, circuit; mala, the cheek.] Pert. orbit and malar bone (anat.).

orbitonasal (ôr'bĭtönā'zăl) a. [L. orbita, circuit; nasus, nose.] Pert. the orbit and the nasal portions of the adjoining bones (anat.).

orbitosphenoid (ôr'bìtösfé'noid) $a$. [L. orbita, circuit; Gk. sphen, a wedge ; eidos, form.] Pert. paired cranial elements lying between presphenoid and frontal (zool.).

order (ôr'dër) $n$. [L. ordo, order.] Any group of organisms closely allied, ranking between the family and the class (biol.).

ordinate (ôr'dinnāt) a. [L.ordo, order.] Having the markings or ornamentation arranged in rows (zool.). ordinatopunctate (ôr'dīnā'töpŭng'ktāt) a. [L. ordo, order; punctum, a prick.] Indicating the serial presence of dots, etc. (zool.).

ordovician (ôr'dövišshăn) a. [L. Ordovices, people of Wales.] Lower Silurian (pal.). 
organ (ôr'găn) $n$. [Gk. organon, an implement.] Any part or structure of an organism adapted for a special purpose (biol.).

organ of Corti, - -see Corti's organ.

organellae (ôr'gănĕl'ê) n. plu. [Gk. organon, an instrument.] The various parts of a cell (cyt.).

organic (ôrgăn'îk) a. [Gk. organon, an instrument.] Pert., derived from, or showing the peculiarities of a living organism (biol.).

organific (ôr'gănif'îk) a. [Gk. organon, instrument; L. facere, to make.] Producing an organism; making an organized structure (biol.).

organism (ôr'gănizm) n. [Gk, organon, instrument.] Any living animal or plant; anything capable of carrying on the processes of life (biol.).

organized (ôr'gănīzd) a. [Gk. organon, instrument.] Exhibiting the characteristics of, or behaving like an organism (biol.).

organogen (ôrgăn'öjĕn) n. [Gk. organon, instrument ; genos, offspring.] Any of the four elements C., H., O., N. (phys.).

organogenesis (ôrgăn'öjĕn'ěsĭs) $n$. [Gk. organon, instrument; genesis, descent.] The formation and development of organs (biol.).

organography (ôr'gănŏg'răfĩ) $n$. [Gk. organon, instrument; graphein, to write.] The description of the organs in any living organism (biol.).

organoleptic (ôr'gănölěp'tîk) a. [Gk. organon, instrument ; lambanein, to take hold of.] Capable of being impressed, or of making an impression (phys.).

organonomy (ôr'gănŏn'ömǐ) $n$. [Gk. organon, instrument ; nomos, law.] The laws that deal with life or living organisms (biol.).

organonymy (ôr'gănŏn'ìmì) $n$. [Gk. organon, instrument ; onyma, name.] The nomenclature of organs (biol.).

organophyly (ôr'gănŏf'îlí) n. [Gk. organon, instrument; phylon, a tribe.] The phylogeny of organs (biol.).

organotrophic (ôr'gănötrŏf'ik) a. [Gk. organon, instrument; trephein, to nourish.] Pert. the formation and nourishment of organs (biol.).

organule (ŏr'gănūl) n. [Gk. organon, instrument.] Any of the cells or elements of an organism (biol.).

orgasm (ôr'găzm) $n$. [Gk. organ, to swell.] Any immoderate excitement ; turgescence of any organism (phys.).

orientation (ón'rǔntā'shŭn) $n$. [L. oriens, rising.] The alteration in position shown by various protoplasmic bodies in the cell under various stimuli (phys.).

orifice (ŏr'ifǐs) $n$. [L. os, mouth ; facere, to make.] A mouth or aperture; the opening of a tube, duct, etc.

original (örĭj'inăl) a. [L. origo, origin.] Pert. the beginning; $a p p l$. the wild species from which the cultivated have been derived (biol.).

ornis (ôr'nis) $n$. [Gk. ornis, a bird.] The bird fauna of a region (zool.).

ornithic (ôrnìth'ik) a. [Gk. ornis, a bird.] Pert. Birds (pal.).

ornithichnite (ôr'nǐthìk'nīt) n. [Gk. ornis, bird; ichnos, a tract.] The fossil track or foot-prints of a Bird (pal.).

ornithine (ôr'nĭthĭn) $n$. [Gk. ornis, bird.] An organic substance found in the excreta of Birds (phys.).

ornithocopros (ôr'nĭthökŏp'rŏs) $n$. [Gk. ornis, bird; kopros, dung.] The dung of Birds.

Ornithogaea (ôr'nǐthöjë'ă) n. [Gk. ornis, bird; gaia, land.] The zoographical region which includes New Zealand (zool.).

ornithology (ôr'nìthŏl'öjī) n. [Gk. ornis, bird; logos, discourse.] The branch of Zoology dealing with Birds.

ornithophilous (ôr'nĭthŏf'îlŭs) a. [Gk. ornis, bird ; philein, to love.] Birdloving; $a p p l$. flowers that are pollinated through the agency of Birds (bot.).

oroanal (öröä'năl) a. [L. os, mouth; anus, anus.] Serving as mouth and anus (zool.).

oronasal (órönā'zăl) a. [L. os, mouth; nasus, nose.] Pert. or designating the groove that connects the mouth and nose (zool.). 
orthoenteric (ôr'thöĕn'těrik) $a$. [Gk. orthos, straight ; enteron, intestine.] Having the alimentary canal stretched out along the ventral body surface ; $a p p l$. certain Tunicates (zool.).

orthogenesis (ôr'thöjĕn'ěsǐs) $n$. [Gk. orthos, straight; genesis, descent.] Variation which, irrespective of natural selection or external forces, gradually produces a new and distinct type (biol.).

orthopterous (ôrthŏp'tĕrŭs) $a$. [Gk. orthos, straight; pteron, wing.] Having straight folded posterior wings (zool.).

orthospermous (ôr'thöspĕr'mŭs) $a$. [Gk. orthos, straight ; sperma, seed.] With straight seeds (bot.).

orthostichous (ôrthŏs'tìkŭs) a. [Gk. orthos, straight; stichos, a row.] $A p p l$. a fin skeleton when the peripheral somactids are parallel as in Cladoselache (pal.).

orthostichy (ôrthŏs'tĩkĩ) n. [Gk. orthos, straight; stichos, a row.] The vertical line on which a row of leaves or scales is found; the arrangement of the leaves or scales in this row (bot.).

orthotriaene (ôr'thötrīēn) $n$. [Gk. orthos, straight ; triaina, a trident.] A triaene with cladi directed outwards at right angles to the shaft (zool.).

orthotropism (ôrthŏt'röpǐzm) n. [Gk. orthos, straight; trope, a turning.] Growth in a vertical line (bot.).

orthotropous (ôrthŏt'röpŭs) $a$. [Gk. orthos, straight; trope, a turning.] Having the chalaza, hilum, and micropyle in a straight line; appl. ovules (bot.).

os (ð̌s) $n$. [L. os, a bone.] A bone.

osculant (ós'kūlănt) a. [L. osculans, kissing.] Closely adherent ; intermediate in character between two groups (biol.).

oscular (ŏs'kūlăr) a. [L, osculum, a small mouth.] Pert. an osculum.

osculate (ŏs'kūlāt) v. [L. osculare, to kiss.] To have characters intermediate between two groups (biol.). osculiferous (ŏs'kūlif'ěrŭs) a. [L. osculum, a small mouth; ferre, to bear.] Having oscula (zool.). osculum (ŏs'kūlŭm) n. [L. osculum, a small mouth.] An excurrent opening in a Sponge (zool.).

osmeterium (ŏs'mĕtē'rǔŭm) n. [Gk. osme, smell.] A forked protrusible organ borne on the first thoracic segment of the larva of many butterflies, and emitting an offensive smell (zool.).

osmosis (ŏsmō'šs) $n$. [Gk. othein, to push.] A diffusion which takes place between two miscible fluids through a permeable membrane (phys.).

osmotic (ŏsmŏt'î) a. [Gk. othein, to push.] Pert. osmosis (phys.).

osphradium (ŏsfrā'diŭm) n. [Gk. osphradion, strong scent.] A sense organ associated with the visceral ganglia in Molluscs, olfactory in function (zool.).

ossa triquetra,- the Wormian bones (anat.).

ossein .(ǒs'ěñ $n$. [L. osseus, bony.] The organic base of bone (phys.).

osseous (ŏs'ěŭs) a. [L. osseus, bony.] Composed of or resembling bone (zool.).

ossicle (ŏs'íkl) $n$. [L.os, bone.] Any small bone; one of those in the sclerotic; one of those in the gastric mill of Crustacea; a plate of a sea-urchin's test (sool.).

ossicular (ŏš̌k'ūlăr) a. [L. os, bone.] Pert. ossicles.

ossiculum (ǒsǐk'ūlŭm) n. [L. $o s$, bone.] An ossicle; a lithodesma (zool.); a pyrene (bot.).

ossification (ŏs'ifikā'shŭn) $n$. [L. os, bone ; facere, to make.] The formation of bone; the replacement of cartilage by bone (anat.).

ossify (ŏs'ifî) v. [L. os, bone ; fieri, to become.] To change to bone (anat.).

osteoblast (ŏs'tê̌öblăst) $n$. [Gk. osteon, bone; blastos, bud.] A bone-forming cell (emb.).

osteoclast (ŏs'tểỏklăst) $n$. [Gk. osteon, a bone; klan, to break.] A cell which absorbs or breaks up bony tissue (emb.).

osteocomma (os'tě̈kŏm'ă) n. [Gk. osteon, bone; komma, piece.] A segment of the vertebral skeleton (sool.).

osteocranium (ŏs'těökrā'nǐŭm) $n$. [Gk. osteon, bone ; kranion, skull.] 
The bony skull as distinguished from the cartilaginous or chondrocranium (zool.).

osteodentine (ǒs'těeodĕn'tĭn) $n$. [Gk. osteon, bone; L. dens, a tooth.] A variety of dentine which closely approaches bone in structure (zool.). osteodermis (ŏs'těödĕr'mis) $n$. [Gk. osteon, bone ; derma, skin.] A dermis which is more or less ossified; a bony dermal plate (zool.).

osteogen (ŏs'těöjĕn') $n$. [Gk. osteon, bone ; genos, offspring.] The tissue which alters and forms bone (phys.). osteogenesis ((ŏs'těöjĕn'ěš̌s) $n$. [Gk. osteon, bone; genesis, descent.] Bone formation (emb.).

osteogenetic (ǒs'těöjĕnět'ǐk) $a$. [Gk. osteon, bone; genesis, descent.] Pert, or causing the formation of bone (emb.).

osteogenic (ǒs'tě̈jën'îk) a. [Gk. osteon, bone; genos, offspring.] Bone-producing (phys.).

osteoid (ŏs'těoid) a. [Gk. osteon, bone; eidos, form.] Bone-like (anat.).

osteology (ŏs'těǒl'öjî́) $n$. [Gk. osteon, bone ; logos, discourse.] That part of anatomy that deals with the structure, nature, and development of bones.

osteoplastic (ŏs'těöplăs'tǐk) a. [Gk. osteon, bone; plastos, moulded.] Producing bone ; $a p p l$. certain cells (emb.).

osteoporosis (ǒs'těöpörō'sĭs) $n$. [Gk. osteon, bone ; poros, a pore.] The absorption of bone, resulting in a porous structure ( $\not h y s$. .).

ostiolar (ŏs'tiölăr) a. [L. ostiolum, a little door.] Pert. an ostiole (biol.).

ostiolate (ŏs'tiölât) a. [L. ostiolum, little door.] Provided with ostioles (biol.).

ostiole (ŏs'tiōl) n. [L. ostiolum, little door.] The opening of a conceptacle, of a perithecium, of a stoma, of an anther sac (bot.); the inhalent aperture of a Sponge (zool.). ostium (ŏs'tŭm) n., ostia (ŏs'tiă) plu. [L. ostium, a door.] Any mouthlike opening; the openings of the Fallopian tubes; the opening in the crustacean heart by means of which the blood enters the heart from the pericardium ; the opening from flagellate canal into paragastric cavity in Sponges (zool.).

otic (ö'tik) a. [Gk. ous, the ear.] Pert. the region of the auditory capsule (anat.).

otidium (ötĭd'ı̆um) n. [Gk. ous, ear.] The otocyst of a Mollusc (zool.).

otoconium (o'tökō'nĭum) $n$. [Gk. ous, ear ; konia, grain of sand.] One of the minute particles found in the internal ear (anat.).

otocrypt (o'tökrūpt) $n$. [Gk. ous, ear ; kryptos, hidden.] An open invagination of the integument of the foot in certain Molluscs (zool.).

otocyst (ó'tösǐst) n. [Gk. ous, ear ; kystis, bladder.] A sac containing fluid and otoliths, supposed to be auditory (zool.).

otolith (o'tölïth) n. [Gk. ous, ear ; lithos, stone.] The calcareous particle or plate-like structure found in the ear or the auditory organ of many animals (zool.).

otoporpae (ö'töpör'pẽ) n. plu. [Gk. ous, ear ; porpe, a brooch.] Stripes of cnidoblasts on the exumbrella of Hydromedusae (zool.).

oval (o'văl) a. [L.ovum, egg.] Eggshaped; pert. an egg.

ovalbumin (ō'vălbū'min) $n$. [L. ovum, egg; albumen, white of egg.] The chief constituent of white of egg (phys.).

ovarian (övā'rǐăn) a. [L. ovarium, an ovary.] Pert. an ovary.

ovariole (övăr'ioll) $n$. [L. ovarium, ovary.] The ovarian tube of an Insect; the tubes which together form the ovary (zool.).

ovarium (övā'rium) $n$. [L. ovarium, ovary.] An ovary.

ovary (o'vărǐ) $n$. [L. ovarium, ovary.] The essential female reproductive organ (zool.); an enlarged portion of the pistil or gynoecium (bot.).

ovate ('̄'vāt) a. [L. ovum, egg.] Egg-shaped.

ovate-acuminate, - appl. an ovate lamina with a very sharp point; appl. leaves (bot.).

ovate-ellipsoidal,-ovate, approaching ellipsoid; $a p p l$. leaves (bot.).

ovate-lanceolate, -having a form of lamina intermediate between ovate and lanceolate (bot.). 
ovate-oblong, - having an oblong lamina with one end narrower than the other (bot.).

ovenchyma (övěng'kimă) $n$. [L. ovum, egg; Gk. engchyma, infusion.] A connective tissue with ovoid-shaped cells (emb.).

ovicell (ó'vǐsěl) $n$. [L. ovum, egg; cellula, a cell.] A dilatation of the zooecium, serving as a brood pouch (zool.).

oviduct (o'vǐdŭkt) $n$. [L. ovum, egg; ducere, to lead.] The tube which carries the eggs from the ovary to the exterior; the Muillerian duct; the tube may or may not be attached to the ovary (zool.).

oviferous (övif'ěrŭs) $a$. [L. ovum, egg; ferre, to carry.] Serving to carry the eggs (zool.).

oviform (ó'vîfôrm) a. [L.ovum, egg ; forma, shape.] Egg-shaped.

ovipaxity (óvǐpăr'itĩ) n. [L. ovum, egg ; parere, to bring forth.] Condition of being oviparous (zool.).

oviparous (övĭp'ărŭs) a. [L. ovum, egg; parere, to bring forth.] Producing eggs; egg-laying ; $c f$. viviparous (zool.).

oviposit (o'́vipŏz'it) v. [L. ovum, egg; ponere, to place.] To lay eggs; $a p p l$. Insects (zool.).

ovipositor (o'vǐpŏz'îtŏr) $n$. [L. ovum, egg ; ponere, to place.] A specialized structure in Insects for placing the eggs in a suitable place; a tubular extension of the genital orifice in Fishes (zool.).

ovisac (ō'visăk) $n$. [L. ovum, egg; saccus, a bag.] An egg-capsule (zool.).

ovism (ō'vǐm) $n$. [L. ovum, egg.] The theory held by the Ovists that the egg contained the germ with the germs of all future generations within it (biol.).

ovist (o'vǐst) $n$. [L. ovum, egg.] A supporter of the Ovism theory (biol.). ovocentre (o'vösĕn'tër) $n$. [L. ovum, egg ; centrum, a centre.] The eggcentrosome during fertilization (emb.).

ovogenesis (ō'vöjĕn'ěsĭs) $n$. [L.ovum, egg ; Gk. genesis, descent.] Oogenesis, which see.

ovoid (o'vvoid) a. [L. ovum, egg ; Gk. eidos, form.] Egg-shaped. ovomucoid (ō'vömü'koid) $n$. [L. ovum, egg ; mucus, mucus ; Gk. eidos, form.] A mucoid found in eggs (phys.).

ovotestis (ō'vötěs'tǐs) $n$. [L. ovum, egg; testis, testicle.] The hermaphroditic reproductive gland of certain Gastropods (zool.).

ovoviviparous (ō'vövǐvĭp'ărŭs) a. [L. ovum, egg ; vivus, living ; parere, to bring forth.] Pert. forms which produce an egg with a definite shell, which yet hatch out internally (zool.).

ovulate (öv'ūlāt) a. [L. ovum, egg.] Containing an egg or ovule (bot., zool.).

ovule (ō'vūl) $n$. [L.ovum, egg.] The megasporangium of a seed-plant (bot.); any small egg or egg-like structure (zool.).

ovuliferous (ō'vūliff'ĕrŭs) a. [L. ovum, egg ; ferre, to carry.] Ovuleproducing ; containing ovules (bot.). ovuliferous scales,-stout scales, each bearing two ovules, developed on bract scales (bot.).

ovum (ó'vŭm) $n$. [L. ovum, egg.] A female germ cell (biol.).

oxea (ŏk'sěă) $n$. [Gk. oxys, sharp.] A sponge spicule, rod-shaped and sharp at both ends (zool.).

oxeote (ŏk'sěōt) a. [Gk. oxys, sharp.] Like an oxea; in the form of a simple rod; $a p p l$. sponge spicules (zool.).

oxidize,-oxydize.

oxyaster (ǒk'šăs'tër) n. [Gk. oxys, sharp; aster, a star.] A stellate sponge spicule with sharp-pointed rays (zool.).

oxychromatin (ǒk'sǐkrō'mătĭn) $n$. [Gk. oxys, sharp ; chroma, colour.] Linin (emb.).

oxydactyl (ǒk'sǐdăk'tǐl) a. [Gk. oxys, sharp; daktylos, a finger.] Having slender tapering digits (zool.).

oxydase (ŏk'sĭdãs) $n$. [Gk. oxys, sour.] An enzyme which promotes oxydation (phys.).

oxydiact (ơk'sìdíăkt) a. [Gk. oxys, sharp; di, two; aktis, ray.] Having three rays of which only two are fully developed; $a p p l$. sponge spicules (zool.).

oxydize (ǒk'sĭdiz) v. [Gk. oxys, acid.] To combine with more oxygen; to 
increase the oxygen content of the blood (phys.).

oxygnathous (ŏk'signâ̄th'ŭs) $a$. [Gk. oxys, sharp ; gnathos, jaw.] Having more or less sharp jaws (zool.).

oxyhaemoglobin (ǒk'sihê'möglō'bĭn) n. [Gk. oxys, acid; haima, blood; L. globus, a globe.] Hæmoglobin combined with oxygen, as found in arterial blood (phys.).

oxyhexactine (ǒk'sǐhěksăk'tĭn) $n$. [Gk. oxys, sharp; hex, six ; aktis, ray.] A hexactine with rays ending in sharp points (zool.).

oxyhexaster (ŏk'sĩhěksăs'tër) $n$. [Gk. oxys, sharp; hex, six ; aster, star.] A hexaster with rays ending in sharp points (zool.).

oxyntic (ŏkš̆n'tik) a. [Gk. oxyein, to make acid.] Secreting acid; appl. cells, glands (phys.).

oxytropism (ǒksǐt'röpizm) n. [Gk. oxys, acid; trope, a turning.] The tendency of numerous organisms to be attracted by oxygen (phys.).

oxytylote (ǒk'sitî'lōt) n. [Gk. oxys, sharp; tylos, a knob.] A slender, straight sponge spicule, sharp at one end, knobbed at the other (zool.).

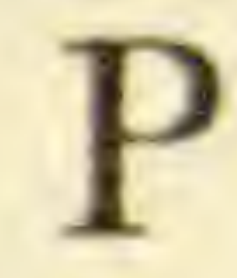

$\mathbf{P}_{1}$, - denoting the first parental generation, $\mathrm{P}_{2}$ the grandparents, etc., in the law of Mendel. See $\mathbf{F}_{1}$.

Pacinian bodies or corpuscles,-distal nerve-endings, consisting of lamellated connective-tissue capsule with a core of nucleated protoplasmic cells containing the ramifications of a single medullated nerve-fibre (anat.).

paedogenesis (pē'döjĕn'ěsis) $n$. [Gk. pais, child; genesis, descent.] Breeding while still in the young or larval state, as Axolotl, certain Diptera (zool.).

paired fins, - the pectoral and pelvic fins of fishes; dorsal, anal, and caudal fins are unpaired.

Palaeobotany (păl'ềbŏt'ănǐ) $n$. [Gk. palaios, ancient ; botane, a plant.] The botany of fossil plants or plant impressions. palaeogenetic (păl'ěöjĕnět'ík) a. [Gk. palaios, ancient; genesis, descent.] $A p p l$. atavistic features fully developed, which are usually characteristically embryonic (biol.).

Palaeontology (păl'ěŏntǒl'öjī) $n$. [Gk. palaios, ancient ; ons, being ; logos, discourse.] The science of past organic life based on fossils and fossil impressions.

Palaeozoic (păl'ěözōîn)a. [Gk.palaios, ancient ; zoon, animal.] Appl. the Primary or earliest of the three groups of rock-systems (pal.).

Palaeozoology (pẫl'ěözōǒl'öjī) $n$. [Gk. palaios, ancient ; zoon, animal; logos, discourse.] The zoology of fossil animals and animal impressions.

palama (păl'ămă) n. [Gk. palame, the palm.] Foot-webbing of aquatic birds.

palamate,-palmate.

palatal (păl'ătăl) a. [L. palatum, palate.] Pert. the palate; palatine; $a p p l$. bone, sinus, etc. (anat.).

palate (păl'ăt) $n$. [L. palatum, palate.] The roof of the mouth (anat.); an insect epipharynx (zool.); a projection of the lower lip of a personate corolla (bot.).

palatine (păl'ătĭn) a. [L. palatum, palate.] Pert. or in the region of the palate; $a p p l$. artery, bone, foramen, etc. (anat.).

palatoglossal (păl'ătöglŏs'ăl) a. [L. palatum, palate; Gk. glossa, tongue.] Pert. palate and tongue; $a p p l$. a muscle (anat.).

palatonasal (păl'ătönā'zăl) a. [L. palatum, palate; nasus, nose.] Pert. palate and nose (anat.).

palatopharyngeal (păl'ătöfărĭn'jĕăl) $a$. [L. palatum, palate; Gk. pharyngx, pharynx.] In the region of palate and pharynx; appl. a muscle (anat.).

palatopterygoid (pălătöptĕr'ígoid) $a$. [L. palatum, palate; Gk. pterygion, little wing; eidos, resemblance.] In the region of or pert. palate and pterygoid (anat.).

palatoquadrate (păl'ătökwôd'rāt) $a$. [L. palatum, palate; quadratus, squared.] Connecting palatine and quadrate; $a p p l$. the dorsal cartilage of the mandibular arch (anat.). 
palea (pắlěă) $n$. [L. palea, chaff.] One of little bracts on the florets of Compositae (bot.).

paleaceous (pălễă'shŭs) a. [L. palea, chaff.]. $A p p l$. a capitulum furnished with small scaly bracts or paleae (bot.).

paliform (pā'lífôrm) a. [L. palus, a stake; forma, shape.] Like an upright stake.

palingenesis (păl'ínjĕn'ěsiss) $n$. [Gk. palin, anew; genesis, descent.] Abrupt metamorphosis; the rebirth of ancestral characters (biol.).

palisade tissue, - the general ground tissue of many foliage leaves, so called from the palisade-like arrangement of their elongated cells (bot.).

pallet (păl'ět) $n$. [L. pala, a spade.] A shelly plate on a bivalve siphon (zool.).

pallial (păl'iăl) a. [L. pallium, mantle.] Pert. the molluscan pallium or mantle; appl. line, groove, sinus, muscles (zool.).

palliate (păl'iât) a. [L. pallium, mantle.] Having a mantle or similar structure (zool.).

palliopedal (păl'ı̈öpěd'ăl) a. [L. pallium, mantle; pes, foot.] Pert. molluscan mantle and foot.

pallium (păl'ǐum) n. [L. pallium, mantle.] A mollusc or brachiopod mantle; a portion of the cerebral wall (zool.).

palmar (păl'măr) a. [L. palma, palm of the hand.] Pert. the palm of the hand; $a p p l$. aponeurosis, nerve, muscle (anat.).

palmaria (pălmä'riă) n. plu. [L. palmaris, pert. the palm.] The third brachials of Crinoids (zool.).

palmate (păl'māt) a. [L.palma, palm of the hand.] Appl. leaves divided into lobes arising from a common centre (bot.); having anterior toes webbed, as in most aquatic Birds (zool.).

palmatifid (pălmăı'ífid) a. [L.palma, palm of the hand; findere, to cleave.] $A p p l$. leaves divided into lobes to about the middle, at acute angles to each other (bot.).

palmatilobate (pălmăt'ílótbāt) $a$. [L. palma, palm; lobus, a lobe.] Palmate with rounded lobes and divisions half-way to the base (bot.).

palmatipartite (pălmăt'ípâr'tīt) $a$. [L. palma, palm ; partitus, divided.] Palmate with the divisions more than half-way to the base (bot.).

palmatisect (pălmăt'isěkt) $a$. [L. palma, palm; sectus, cut.] Palmate with the divisions nearly to the base (bot.).

palmella (pălmělă $n$. [Gk. palmos, a quivering.] A stage of certain Algae, consisting of groups of rounded cells in a jelly-like mass (bot.).

palmitin (păl'mĭtĭn) n. [Gk. palma, palm-tree.] A compound of fatty acid and glycerine found in adipose tissue (phys.).

palmula (păl'mülă) $n$. [L. palma, palm.] A terminal lobe or process between the paired claws of insect feet (zool.).

palp,-see palpus.

palpacle (păl'păkl) n. [L. palpare, to feel.] The tentacle of a dactylozooid or palpon of Siphonophora (zool.).

palpal (păl'păl) a. [L. palpare, to stroke.] Pert. a palpus.

palpate (păl'pāt) a. [L. palpare, to stroke.] Provided with a palpus or palpi (zool.).

palpebra (păl'pěbră) n. [L. palpebra, an eyelid.] An eyelid.

palpebral (păl'pěbrăl) a. [L. palpebra, an eyelid.] Pert. the eyelids; appl. arteries, ligament, nerves (anat.); $a p p l$. a lobe or buttress on which the eye of Trilobites rests (zool.).

palpifer (păl'pŭfĕr) $n$. [L. palpare, to feel ; ferre, to carry.] A maxilla lobe bearing the palpus of Insects (zool.).

palpiform (păl'püfôrm) a. [L. palpare, to feel ; forma, shape.] $\mathrm{Re}$ sembling a palpus or insect-feeler (zool.).

palpiger (păl'pijĕr) n. [L. palpare, to feel; gerere, to bear.] The support of a labial palpus in Insects (zool.).

palpocil (păl'pösỉl) n. [L. palpare, to touch; cilium, a lash.] A stiff sensory filament attached to the sense cells of Hydromedusae (zool.).

palpon (păl'pŏn) $n$. [L. palpare, to 
feel.] A hydrocyst or dactylozooid of Siphonophores (zool.).

palpulus (păl'pūlŭs) $n$. [L. palpare, to feel.] A small palpus or feeler. palpus (păl'pŭs) n., palpi (păl'pī, păl'pē) plu. [L. palpare, to feel.] The labial feelers of Insects; sensory appendages on the prostomium of polychaet worms, on mandibles of Crustacea, etc. (zool.).

paludicole (pălü'dỉkōl) a. [L. palus, a marsh ; colere, to inhabit.] Living in ponds and streams.

palule (păl'ūl) n. [L. palus, a stake.] An unattached calcareous process of Corals ; a small palus (zool.).

palus (pă̌lŭs) n., pali (pā'lī, păl'êe) plu. [L. palus, a stake.] A series of small pillars projecting upwards from the theca-base towards the stomodaeum of madrepore Corals (zool.).

pampiniform (pămpinn'îfôrm) a. [L. pampinus, a tendril ; forma, shape.] Tendril-like (biol.); appl. a convoluted vein plexus of the spermatic cord (anat.).

pancreas (păn'krěăs) n. [Gk. pan, all ; kreas, flesh.] A compound racemose gland at the posterior abdominal wall of most vertebrates.

pancreatic (pănkrěăt'ik) a. [Gk. pan, all; kreas, flesh.] Pert. the pancreas; $a p p l$. artery, duct, vein (anat.).

pancreaticoduodena1,-pert. pancreas and duodenum ; $a p p l$. artery, glands, veins (anat.).

panduriform (păndū'rǐfôrm) a. [L. pandura, a three-stringed lute; forma, shape.] Fiddle-shaped; appl. leaves (bot.).

pangamic (păngăm'îk) a. [Gk. pan, all; gamos, union.] $A p p l$. indiscriminate mating.

pangen (păn'jĕn) n. [Gk. pan, all ; genos, offspring.] Biophore; see hypothetical units.

pangenesis (pănjěn'ěsĭs) $n$. [Gk. pan, all; genesis, descent.] The gemmule theory, that hereditary characteristics are carried by germs from individual body cells (biol.).

paniele (păn'îkl) n. [L. panicula, a tuft on plants.] A tuft or bunch of flowers or seeds, close or scattered; a compound raceme (bot.). paniculate (pănǐk'ūlāt) a. [L. panicula, a tuft.] Having the flowers arranged in panicles (bot.).

panmeristic (păn'mĕrǐs'tǐk) a. [Gk. pan, all; meros, part.] Appl. an ultimate protoplasmic structure of independent units (biol.).

panmixia (pănmǐk'siă) n. [Gk. pan, all ; mixis, a mixing.] Indiscriminate interbreeding consequent on suspension of the influence of natural selection.

pansporoblast (pănspō'röblăst) $n$. [Gk. pan, all ; sporos, seed ; blastos, bud.] A cell-complex of Neosporidia producing sporoblasts and spores; an archespore (zool.).

papilionaceous (păpîl'íŏnă'shŭs) $a$. [L. papilio, a butterfly.] Resembling a butterfly; $a p p l$. a fivepetal corolla, one enlarged posterior, two united anterior forming a keel, and two lateral, the wings or alae (bot.).

papilla (păpǐl’ă) $n$. [L. papilla, a pimple.] A glandular hair with one secreting cell above the epidermis level (bot.); an accessory adhesive organ with retractile tip, of some Trematodes; a conical dermal structure on Birds, the beginning of a feather (zool.); one of various small projections of the corium of the tongue, and eminences on the skin (anat.).

papillary (păpǐlărǐ) a. [L. papilla, a pimple.] Pert. papillae; appl. a dermal layer with papillae (anat.). papillate (păpı̌l'āt) a. [L. papilla, a pimple.] Covered by papillae; papillose; like a papilla (biol.); $a p p l$. petals with external cells projecting slightly above the surface (bot.).

papilliform (păpìl'ífôrm) a. [L. papilla, a pimple; forma, shape.] Like a papilla in shape.

papillose,-papillate.

pappiferous (păpĭf'ĕrŭs) $a . \quad[\mathrm{Gk}$. pappos, an old man; L. ferre, to carry.] Pappus-bearing (bot.).

pappose (păp'ös, păpōs') a. [Gk. pappos, an old man.] Having the limb of the calyx developed as a tuft of hairs or bristles ; downy, or covered with feathery processes (bot.). 
pappus (păp'ŭs) n. [Gk. pappos, an old man.] A circle or tuft of bristles, hairs, or feathery processes in place of the limb of a calyx (bot.).

papulae (păp'ūlē) $n$. plu. [L. papula, a pimple.] Dermal gills; the soft skin of Asteroids raised up into finger-like processes with respiratory function (zool.).

papyraceous (păpirā'shŭs) a. [L. papyrus, the papyrus-tree.] of papery texture (bot.).

parabasal (părăbā'săl) a. [Gk. para, beside; basis, base.] $A p p l$. a striated apparatus surrounding the calyx of certain Protozoa (zool.).

parabasalia (păr'ăbăsā'liă) n. plu. [Gk. para, beside; basis, base.] The basalia of Crinoids when a circlet of perradial infrabasalia occurs beneath them (zool.).

parablast (părăblăst) $n$. [Gk. para, beside; blastos, bud.] The yolk of meroblastic eggs; $a p p l$. the large nuclei of cells laden with yolkgranules, in the development of higher Mammals (emb.),

parabranchia (părăbrăng'kiă) $n$. [Gk. para, beside; brangchia, gills.] A much plumed mollusc osphradium or organ of smell (zool.).

parabronchi (părăbrŏng'kī) n. plu. [Gk. para, beside ; brongchos, windpipe.] The tertiary lung tubes of Birds, their terminations being embedded in the lung mesenchyme (zool.).

paracentral (părăsěn'trăl) a. [Gk. para, beside ; L. centrum, centre.] Situated at or near the centre ; $a p p l$. lobule, gyrus, fissure (anat.).

parachordal (părăkôr'dăl) $a$. [Gk. para, beside ; chorde, a cord.] Appl. paired horizontal cartilage plates formed on each side of the chondrocranium (emb.).

parachromatin (părăkrō'mătĭn) $n$. [Gk. para, beside ; chroma, colour.] Achromatic nuclear substance giving rise to spindle-fibres (cyt.).

parachute (părăshoot) $n$. [L.parare, to prepare; F. chute, a fall.] A special structure, such as an aril, a caruncle, a wing, of seeds enabling them to be wafted away, and so aiding in dispersal (bot.). paracme (pârăk'mē)n. [Gk. parakme, decadence.] The decline of a species or race after reaching the highest point of development (biol.).

paracoel (părăsēl) n. [Gk. para, beside ; koilos, hollow.] The lateral ventricle, or cavity of the cerebral hemisphere (anat.).

paracondyloid (părăkŏn'dilloid) $a$. [Gk. para, beside ; kondylos, a knob; eidos, resemblance.] $A p p l$. a process of the occipital occurring beside the condyles of some mammals (zool.).

paracone (păr'ăkōn) n. [Gk. para, beside; konos, a cone.] The antero-external cusp of an upper molar tooth.

paraconid (părăkō'nĭd) n. [Gk. para, beside ; konos, cone.] The anterointernal cusp of a lower molar tooth.

paracorolla (păr'ăkörŏlăă) n. [Gk. para, beside; L. corolla, a small crown.] A corolla appendage (bot.).

paracyst (păr'ăsǐst) n. [Gk. para, beside; kystis, a bladder.] The antheridium of Pyronema (bot.).

paraderm (păr'ădĕrm) n. [Gk. para, beside; derma, skin.] The delicate limiting membrane of a pronymph (zool.).

paradidymis (părădĭd'ímǐs) $n . \quad[\mathrm{Gk}$. para, beside ; didymos, a testicle.] A small collection of convoluted tubules anterior to the lower part of the spermatic cord (anat.).

parafibula (părăfīb'ūlă) $n$. [Gk. para, beside; L. fibula, a buckle.] An accessory element outside the fibula at its proximal end, seen in some Lacertilia and young Marsupials (zool.).

paraflagellum (păr'ăflăjěl'ŭm) $n$. [Gk. para, beside ; L. flagellum, a whip.] A subsidiary flagellum (zool.).

paraganglia (părăgăng'gliă) $n$. flu. [Gk. para, beside ; ganglion, swelling.] Scattered remains or rudiments of ganglia left along the aorta when the suprarenal ganglion has been formed (phys.).

paragaster (părăgăs'tĕr) n. [Gk. para, beside; gaster, stomach.] A central cavity of Heterocoela into which gastric ostia open (zool.). 
paragastric (părăgăs'trǐk) a. [Gk. para, beside; gaster, stomach.] Pert. a paragaster ; $a p p l$. passages or cavities in the branches of a Sponge; $a p p l$. paired blind canals from the infundibulum to the oral cone of Ctenophores (zool.).

paragastrula (părăgăs'troolă) $n$. [Gk. para, beside ; gaster, stomach.] The stage of the amphiblastula of a Sponge when the flagellated cells are invaginated into the dome of rounded cells (zool.).

paragenesia (părăjěnē'sĭă) $n$. [Gk. para, beside; genesis, descent.] Hybrids' fertility with the parent species but not inter se (biol.).

paraglossa (părăglŏs'ă) n. [Gk.para, beside; glossa, tongue.] A process on each side of the ligula of Insects (zool.).

paraglycogen (părăglì'köjën) $n$. [Gk. para, beside ; glykos, sweet ; genos, production.] Reserve food-material stored in protoplasm-grains of Gregarines (zool.).

paragnatha (părăgnā'thă) $n$. plu, [Gk. para, beside; gnathos, jaw.] Paired, delicate, unjointed processes between maxilla and mandible of certain Crustacea (zool.).

paragnathous (păr'ăgnăth'ŭs) $a$. [Gk. para, beside; gnathos, jaw.] With mandibles of equal length ; appl. Birds.

paraheliotropism (păr'ăhēlǐŏt'röpǐzm) n. [Gk, para, beside; helios, sun; trope, a turning.] Tendency of plants to turn the edges of their leaves to too brilliant an illumination to save their surfaces (bot.).

parahormone (păr'ăhôr'mōn) n. [Gk. para, beside; ormao, I arouse to activity.] A substance which acts like a hormone but is a product of the ordinary metabolism of cells ; e.g., the sensibility of a nerve to carbon dioxide (phys.).

paralinin (părălì'nīn) n. [Gk. para, beside; L. linum, a linen thread.] Nuclear ground-substance (cyt.).

parallelinervate, parallelodrome,$a p p l$. leaves with veins or nerves parallel (bot.).

paramastigote (părămăs'tigōt) $a$. [Gk. para, beside ; mastis, a whip.] Having one long principal flagellum and a short accessory one, as certain Mastigophora (zool.).

paramastoid (părămăs'toid) $a$. [Gk. para, beside ; mastos, breast ; eidos, resemblance.] Beside the mastoid; $a p p l$. the two paroccipital processes of the exoccipitals (zool.).

paramere (părămēr) $n$. [Gk. para, beside ; meros, part.] Half of a bilaterally symmetrical structure.

parametrium (părămět'riŭm) $n$. [Gk. para, beside; metra, uterus.] Fibrous tissue partly surrounding the uterus (anat.).

paramitome (părămítöm) $n$. [Gk. para, beside; mitos, a thread.] The interfilar substance of protoplasm (cyt.).

paramylum (părămīilŭm) n. [Gk. para, beside; amylon, starch.] A substance allied to starch, occurring in Protozoa (phys.).

paranephric (părăněf'rǐk) a. [Gk. para, beside; nephros, kidney.] Beside the kidney; $a p p l$. a fatty body behind the renal fascia (anat.).

paranephros (părăněf'rŏs) $n$. [Gk. para, beside; nephros, kidney.] An adrenal body.

paranuclein (părănū'klě̆in) $n$. [Gk. para, beside ; L. nucleus, a kernel.] The substance of a true nucleolus (cyt.).

paranucleus (părănū'klěŭs) $n$. [Gk. para, beside ; L. nucleus, a kernel.] A micronucleus; a spherical mass of mitochondria (cyt.).

paraphysis (părăf'isĩs) $n$. [Gk. para, beside; physis, growth.] A slender filamentous epidermal outgrowth occurring among sporogenous organs (bot.); a non-nervous outgrowth on the top of the brain of nearly all Vertebrates (zool.).

parapineal (părăpinnēăl) $a$. [Gk. para, beside ; L. pinea, a pinecone.] $A p p l$. an eye-like epiphysis of lampreys, the pineal body of other Vertebrates (zool.).

paraplasm (părăplăzm) $n$. [Gk. para, beside ; plasma, something moulded.] The vegetative or less active part of cell substance (cyt.).

parapodium (părăpō'dĭŭm) $n$. [Gk. para, beside; pous, a foot.] A paired process on the bodysegments of Polychaets (zool.). 
parapolar (părăpō'lăr) a. [Gk. para, beside; polos, a pivot.] Beside the pole ; $a p p l$. the first two trunk cells in the development of Rhombozoa (zool.).

parapophysis (păr'ăpŏf'ǐsǐs) n. [Gk. para, beside; apo, from; physis, growth.] A transverse process arising from a vertebra centrum.

parapteron (părăp'tĕrŏn) n. [Gk. para, beside; pteron, a wing.] The tegula or shoulder-lappet or scapula of an insect mesothorax (zool.).

parapterum,-parapteron.

parapyles (părăpīlz) n. plu. [Gk. para, beside; pyle, a gate.]. Two accessory openings in certain developing Radiolarians (zool.).

paraquadrate (părăkwôd'rāt) $n$. [Gk. para, beside; L. quadratus, squared.] The squamosal, a hammer-shaped investing bone supporting the suspensorium, externally (zool.).

pararectal (părărĕk'tăl) a. [Gk. para, beside; L. rectus, straight.] Beside the rectum; appl. fossa, lymph glands (anat.).

parasite (păr'ăsīt) $n$. [Gk. para, beside ; sitos, food.] An organism living with or within another to its own advantage in food or shelter (biol.).

parasitic (părăsǐt'ík) a. [Gk. para, beside; sitos, food.] Appl. an organism living at the expense of another, and in or on it (biol.).

parasitic castration,- - castration caused by the presence of a parasite, as in certain male crabs infested by Sacculina (biol.).

parasitism (păr'ăsītǐzm) n. [Gk. para, beside ; sitos, food.] A form of symbiosis in which one symbiont, the parasite, receives advantage to the detriment of the other, the host (biol.).

parasitology (păr'ăsītǒl'öjī) n. [Gk. para, beside ; sitos, food; logos, discourse.] The science treating of parasites, especially those affecting human beings.

parasphenoid (părăsfēénoid) n. [Gk. - para, beside ; sphen, wedge ; eides, like.] A membrane bone forming the floor of the cranium in certain Reptiles (zool.).

parastemon (părăstē'mŏn) n. [Gk. para, beside ; stemon, a warp.] 1 A sterile stamen (bot.).

parasternum (părăstĕr'nŭm) $n$. [Gk. para, beside ; sternon, the breast.] The sum-total of the abdominal ribs of certain Reptiles (zool.).

parastichy (părăs'tikì) n. [Gk. para, beside; stichos, row.] A secondary spiral in phyllotaxis (bot.).

parately (părăt'ělî) n. [Gk. para, beside; telos, end.] Evolution from unrelated material to that of type, but resulting in superficial resemblance (biol.).

parathyroid (părăthīroid) a. [Gk. para, beside; thyreos, a shield.] Beside the thyroid; appl. small brownish-red glands (anat.).

paratonic (părătŏn'îk) a. [Gk. para, beside; tonos, pitch.] Stimulating; $a p p l$. the influence of light on growing plants (bot.).

paravesical (părăvĕs'îkăl) a. [Gk. para, beside; vesica, bladder.] Beside the bladder; $a p p l$. a fossa (anat.).

paraxial (pârăk'šăl) a. [Gk. para, beside; L. axis, axle.] Alongside the axis ; $a p p l$. a medial column of mesoderm (emb.).

parencephalon (pâr'ěnkĕf'ălŏn, -sěf-) n. [Gk. para, beside ; engkephalon, brain.] One of paired cerebral hemispheres.

parenchyma (părĕng'kĭmă) $n$. [Gk. para, beside ; engchyma, infusion.] The soft, succulent tissue commonest in plants (bot.); the groundwork tissue of organs (zool.).

parenchymalia (părĕng'kīmā'liă) $n$. plu. [Gk. para, beside ; engchyma, infusion.] Spicules of the parenchyma of Hexactinellids (zool.).

parenchymatous (părěngkî̀m'ătŭs) $a$. [Gk. para, beside; engchyma, infusion.] Pert. or found in parenchyma ; $a p p l$. a kind of cell (bot.).

parenchymula (părěngkĭm'ūlă) $n$. [Gk. para, beside; engchyma, infusion.] A flagellate sponge larva with cavity filled with gelatinous connective tissue (zool.).

parental generation,-see $\mathbf{F}_{1}, \mathbf{P}_{1}$.

parhomology (pâr'hömǒl'öji) $n$. [Gk. para, beside ; homos, alike ; logos, discourse.] Apparent similarity of structure (biol.). 
paries (pắriěz) n. [L. paries, wall.] The central division of a compartment of Cirripedia (zool.).

parietal (pări’ětăl) a. [L.paries, wall.] Pert. or forming part of the wall of an organ or structure; $a p p l$. cells, membrane, lobe (zool.); layer (bot.).

parietal bone, - a paired bone of the roof of the skull.

parietomastoid (părî̀ĕtömăs'toid) $a$. [L. paries, wall ; Gk. mastos, breast.] Connecting mastoid with parietal; $a p p l$. a suture (anat.).

parieto-occipital (părí'ětö-ǒksīp'ítăl) $a$. [L. paries, wall ; occiput, back part of the head.] Appl. a fissure between parietal and occipital lobes of the cerebrum (anat.).

parietotemporal (părî'ětötĕm'pörăl) $a$. [L. paries, wall ; temporalis, temporary.] Pert. parietal and temporal regions; $a p p l$. an artery (anat.).

paripinnate (păr'ǐpin'āt) a. [L. par, equal; pinna, a wing.] Pinnate without a terminal leaflet (bot.).

paroceipital (părŏksĭp'ítăl) $a$. [Gk. para, beside; L. occiput, back of the head.] $A p p l$, ventrally-directed processes of the exoccipitals (zool.).

paroecious (părē'shŭs) a. [Gk.para, beside ; oikos, a house.] With antheridium and archegonium close to one another; paroicous (bot.).

parolfactory (păr'ôlfăk'törĩ) $a$. [Gk. para, beside; L. olfactorius, olfactory.] Appl. an area and sulcus adjoining the olfactory trigone of the rhinencephalon (anat.).

paronychia (păr'önik'iă) n. plu. [Gk. para, beside ; onyx, nail.] Bristles on the pulvillus of an insect foot (zool.).

paroophoron (păr'öŏf'örŏn) $n$. [Gk. para, beside ; oon, egg ; pherein, to bear.] A few scattered rudimentary tubules, remnants of the Wolffian body in the female (anat.).

parosteal (părŏs'těăl) $a$. [Gk. para, beside; osteon, bone.] $A p p \bar{l}$. abnormal bone formations.

parosteosis (păr'ǒstễo'sǐs) n. [Gk. para, beside; osteon, bone.] Bone formation in tracts normally purely fibrous.

parotic (părŏt'ík) n. [Gk. para, beside; ous, ear.] A process formed by' fusion of exoccipital and opisthotic in adult lizards (zool.).

parotid glands, - paired salivary glands opening into the mouth cavity of Mammals; in some Amphibians large swellings on the side of the head formed of aggregated cutaneous glands, sometimes poisonous (zool.).

parovarium (păr'ōvā'rŭŭm) n. [Gk. para, beside ; L. ovarium, ovary.] A small collection of tubules anterior to the ovary, the remnant in the adult of the embryonic mesonephros (zool.).

parthenogenesis (pâr'thĕnöjĕn'ěsĭs) $n$. [Gk. parthenos, virgin; genesis, descent.] Reproduction without fertilization by a male element (biol.).

parthenogenetic (pâr'thĕnöjĕnět'ík) $a$. [Gk. parthenos, virgin; genesis, descent.] Appl. plants or animals developed from seed or ovum without fertilization by pollen or spermatozoon (biol.).

parthenogonidia (pâr'thĕnögönǐd'iă) n. plu. [Gk. parthenos, virgin; gonos, offspring.] Zooids of a protozoan colony, with the function of asexual reproduction (sool.).

parthenosperm (pâr'thĕnöspĕrm) $n$. [Gk. parthenos, virgin; sperma, seed.] A sperm produced without fertilization (bot.).

parthenospore (pâr'thĕnöspōr) n. [Gk. parthenos, virgin; sporos, seed.] A spore produced without fertilization (bot.).

partial involucre,-see involucel.

partial segmentation, - see meroblastic.

partial umbel, - see umbellule.

partite (pâr'tīt) a. [L. partitus, divided.] Divided nearly to the base (bot.).

parumbilical (păr'ŭmbil'îkăl) a. [Gk. para, beside ; umbilicus, the navel.] Beside the navel; $a p p l$. small veins from the anterior abdominal wall to the portal and iliac veins (anat.). patagial (pătā'jiăl) a. [L. patagium, a border.] Pert. a patagium.

patagiate (pătā'jīāt) $a$. [L.patagium, a border.] Furnished with a patagium.

patagium (pătā'jĭŭm) $n$. [L.patagium, 
a border.] The membranous expansion between fore and hind limbs of bats and flying squirrels and foxes; the similar expansion on a bird's wing; a tegula, or dorsal process of the prothorax of certain Lepidoptera (zool.).

patella (pătěl'ă) $n$. [L. patclla, a small pan.] The knee-cap (zool.); a rounded apothecium of Lichens (bot.).

patellar (pătĕlăr) a. [L. patella, a small pan.] Pert. a patella.

patelliform (pătěl'ifôrm) $a$. [L.patella, a small pan; forma, shape.] Shaped like a patella; pan-shaped; like a bordered disc.

patent (păt'ěnt) a. [L. patens, lying open.] Spreading widely; expanded (biol.).

pathetic (păthět'ík) a. [Gk, pathos, feeling.] Appl. the trochlear nerve and the superior oblique muscle of the eye (anat.).

pathogenic (păth'öjěn'ík) a. [Gk. pathos, suffering ; genos, offspring.] Disease-producing ; $a p p l$. a parasite in relation to a particular host (biol.).

patina (păt'ínă) n. [L. patina, a dish.] Circles of plates round the calyx of Crinoids (zool.).

patulent (păt'ūlěnt), patulous (păt'ūlǔs) a. [L. patulus, standing open.] Spreading open; expanding (biol.).

paturon (pătü'rŏn) n. [Gk. patein, to trample on.] The basal joint of arachnid chelicerae, used for crushing and expressing the fluids of insects (zool.).

paulospore (pôl'öspōr) n. [Gk. paula, rest; sporos, seed.] A resting or winter stage in development, as a cyst; a stage of suspended development (biol.).

paunch (pônsh) n. [L. pantex, the paunch.] The rumen, an expansion of the oesophagus, the first stomach of ruminants (zool.).

pavement epithelium,- simple squamous epithelium of flat, nucleated scales, fitting together like mosaic (phys.).

paxilla (păksı̌l’ă) n. [L. paxillus, a peg.] A thick plate supporting calcareous pillars, the summit of each covered by a group of small spines, - a structure of certain Stelleroids (zool.).

paxillar (păksǐlăr) a. [L. paxillus, a peg.] Pert. a paxilla.

paxilliform (păksỉlífôrm) a. [L. paxillus, a peg; forma, shape.] Shaped like a paxilla.

paxillus, - a paxilla.

pearl (pĕrl) n. [F. perle, a pearl.]

In the shells of some Mussels, an abnormal growth formed with a grain of foreign matter or a minute organism for nucleus and many thin layers of nacre surrounding it (zool.). pectase (pěk'tās) n. [Gk, pektos, congealed.] An enzyme of plants which forms vegetable jelly.

pecten (pěk'tĕn) n. [L. pecten, a comb.] Any comb-like structure ; a process of the inner retinal surface in Reptiles, expanded into a folded quadrangular plate in Birds; the stridulating organ of certain Arachnids (zool.).

pectic (pěk'tiki) a. [Gk, pektos, congealed.] $A p p l$. acids and bodies consisting of pectase, pectin, pectose (bot.).

pectinal (pěk'tĭnăl) a. [L. pecten, comb.] Pert. a pecten.

pectinate (pěk'tĭnāt) a. [L. pecten, comb.] Comb-like; pectiniform; $a p p l$. leaves (bot.), a ligament of the iris (anat.), certain gills, pedicellariae of Asteroids, a septum between the corpora cavernosa (zool.).

pectineal (pěktīn'ěăl) a. [L. pecten, comb.] Appl. a process of the pubis of Birds; appl. a ridge-line on the femur and the muscle attached thereto (anat.).

pectinellae (pěk'tǐněl'ē) $n$. plu. [L. pectinella, a small comb.] Transversely-planted, comb-like membranellae constituting the adoral ciliary spiral of some Infusoria (zool.).

pectinirhomb (pěk'tĭnĭrŏmb') n. [L. pecten, comb ; Gk. rhombos, a magic wheel.] A type of stereom-folding in Cystidea (zool.).

pectoral (pěk'törăl) a. [L. pectus, breast.] Pert. the chest; in the chest region; $a p p l$. arch, girdle, fins, limbs : (zool.). 
pectoralis major and minor,-outer and inner chest muscles connecting the ventral chest wall with shoulder and humerus (zool.).

pectus (pěk'tŭs) $n$. [L. pectus, breast.] The chest or breast region.

pedal (pĕd'ăl) a. [L.pes, foot.] Pert. the foot or feet; $a p p l$. cords, ganglia.

pedate (pěd'āt) a. [L. pes, foot.] Pedatipartite.

pedatipartite (pědăt'îpâr'tīt) $a$. [L. pes, foot; partitus, divided.] Appl. a variety of palmate leaf with cymose branching of the third order (bot.).

pedatisect (pědăt'ĩsěkt) $a$. [L. pes, foot; sectus, cut.] In pedate arrangement, and with divisions nearly to the midrib (bot.).

pedicel (pěd'ísěl) n. [L. pediculus, a small foot.] A small, short footstalk of leaf, flower, fruit, or sporangium (bot.); the foot-stalk or stem of a stationary and fixed organism (zool.).

pedicellariae (pěd'îsělăríîe) $n$. plu. [L. pediculus, a small foot.] Minute pincer-like structures studding the surface of certain Echinoderms (zool.).

pedicellate (pěd'ísĕl'ât) $a$. [L. pediculus, a small foot.] Supported by a pedicel; $a p p l$. Hymenoptera with stalked abdomen; $c f$. pseudo-sessile (zool.).

pedicellus (pěd'ísěl'ǔs) $n$. [L. pediculus, a small foot.] A short footstalk (bot.); the second joint of insect antennae (zool.).

pediele (pĕd'ŕkl) $n$. [L. pediculus, a small foot.] A, short stem (bot.); a backward-projecting vertebral process (anat.); the narrow stalk uniting thorax with abdomen in Arachnids (zool.).

pedipalpus (pěd'ǐpăl'pŭs) $n$. [L. pes, foot; palpare, to feel.] In Arachnids, the second cephalothoracic paired appendage, variously a pincer-like claw, a simple or leglike appendage, a chelate structure (zool.).

peduncle (pědŭng'kl) $n$. [L. pedunculus, a small foot.] A stem or stalk, supporting flower or fruit (bot.); a band of white fibres joining differ- ent parts of the brain (anat.); the stalk of Brachiopods and Barnacles ; the link between thorax and abdomen in Insects and Arachnids (zool.).

pedunculate (pědŭng'kūlāt) $a$. [L. pedunculus, a small foot.] Growing on or having a peduncle (biol.); $a p p l$. the primordial cerebral lobe of Hymenoptera (zool.).

pelagic (pělăj'îk) a. [L. pelagus, the open sea.] Ocean-inhabiting.

pelasgic (pělăs'jīk) a. [L. Pelasgus, a Pelasgian.] Moving from place to place.

pellicle (pěl'íkl) n. [L. pellicula, a small skin.] The delicate protective investment of Protozoa ; any filmy protective covering (biol.).

pellions (pěl'ǐnz) n. plu. [Gk. pella, a cup.] Ring of plates supporting the suckers of Echinoids; rosettes (zool.).

pelma (pĕl'mă) n. [Gk. pelma, sole.] The sole of the foot.

peloria (pělō'riă) n. [Gk. pelorios, monstrous.] Condition of abnormal regularity ; a modification of structure from irregularity to regularity (bot.).

peloric (pělŏr'ik) a. [Gk. pelorios, monstrous.] $A p p l$. a flower which, normally irregular, becomes regular (bot.).

pelta (pěl'tă) n. [Gk. pelte, a shield.] The shield-like apothecium of certain Lichens (bot.).

peltate (pěl'tāt) a. [Gk. pelte, a shield.] Shield-shaped; fastened to the stalk at a point within the margin, as a leaf (bot.).

pelvic (pěl'vik) a. [L. pelvis, a basin.] Pert. or situated at or near the pelvis; $a p p l$. girdle, cavity, fin, limbs, plexus (zool.).

pelvis (pěl'vis) n. [L. pelvis, a basin.] In Vertebrates the bony cavity formed by the pelvic girdle along with the coccyx and sacrum; the expansion of the ureter at its junction with the kidney (anat.) ; the basal portion of the cup of Crinoids (zool.).

pen (pěn) $n$. [L. penna, a feather.] A leaf midrib (bot.); the skeletal part of a cuttlefish (zool.).

pendulous (pěn'dūlŭs) a. [L. pen- 
dere, to hang.] Bending downwards from the point of origin; overhanging; appl.ovules, branches, flowers (bot.).

penial setae, - paired needle-like chitinoid bodies at the anus of a round-worm, which also serves as reproductive aperture (zool.).

penicillate (pěn'issủlāt) a. [L. penicillum, a painter's brush.] Penicilliform ; pencil-shaped ; tipped with hairs; having a structure like a camel-hair brush.

penis (pē'nǐs) $n$. [L. penis, a penis.] The male copulatory organ.

pennaceous (pĕnā'shŭs) $a$. [L. penna, feather.] Penniform ; like a plume or feather.

pentacapsular (pĕn'tăkăp'sülăr) $a$. [Gk. pente, five ; L. capsula, a capsule.] With five capsules (bot.).

pentacarpellary (pěn'tăkârpěl'ărí) $a$. [Gk. pente, five ; karpos, fruit.] With five carpels (bot.).

pentachenium (pěn'tăkē'nŭŭm) $n$. [Gk. pente, five ; $a$, not ; chainein, to gape.] A form of schizocarp with five carpels (bot.).

pentacoceous (pěn'tăkǒk'ŭs) a. [Gk. pente, five ; kokkos, kernel.] With five seeds or carpels (bot.).

pentacrinoid (pěn'tăkrī'noid) $a$. [Gk. pente, five; krinon, a lily ; eidos, resemblance.] Resembling a Pentacrinus; $a p p l$. a larval stage of Feather-stars, the fixed stalked stage like a Pentacrinus (zool.).

pentactinal (pĕntăk'tĭnăl) $a$. [Gk. pente, five; aktis, ray.] Five-rayed; five-branched.

pentacyelic (pĕn'tăsî̉k'lik) a. [Gk. pente, five ; kyklos, a circle.] Arranged in five whorls (bot.).

pentadactyl (pěn'tădăk'tîl) a. [Gk. pente, five ; daktylos, a finger.] Having all four limbs normally terminating in five digits.

pentadelphous (pěn'tăděl'füs) $a$. [Gk. pente, five; adelphos, brother.] Having five clusters of more or less united filaments (bot.).

pentafld (pěn'tăfid) a. [Gk. pente, five; L. findere, to cleave.] In five divisions or lobes (bot.).

pentagonal (pěntăg'önăl) $a$. [Gk. pente, five; gonia, angle.] Appl. the symmetry of a pentamerous flower ; quinary ; having five angles (bot.).

pentagynous (pěntăj'inŭs) $a$. [Gk. pente, five; gyne, a woman.] Having five styles (bot.).

pentamerous (pěntăm'ĕrŭs) a. [Gk. pente, five; meros, part.] Composed of five parts; in whorls of five or a multiple of five (bot.).

pentandrous (pěntăn'drŭs) $a$. [Gk. pente, five; andros, male.] Having five stamens (bot.).

pentapetalous (pěn'tăpĕt'ălŭs) $a$. [Gk. pente, five; petalon, a petal.] Having five petals (bot.).

pentapterous (pěntăp'těrŭs) a. [Gk. pente, five; pteron, wing.] With five wings, as some fruits (bot.).

pentasepalous (pěn'tăsěp'ălŭs) $a$. [Gk. pente, five ; sepalon, sepal.] Having five sepals (bot.).

pentastichous (pěntăs'tĩkŭs) a. [Gk. pente, five; stichos, a row.] Arranged in five vertical rows (bot.).

pepo (pë'pö) n. [Gk. pepon, melon.] An inferior one-celled, manyseeded pulpy fruit (bot.).

pepsin (pěp'siñ) n. [Gk. pepsis, a digesting.] An enzyme secreted by the stomach (phys.).

peptic (pěp'tîk) a. [Gk. pepsis, a digesting.] Relating to or promoting digestion; appl. pepsinsecreting glands of the stomach (anat.).

peptonephridia (pěp'tönëfrĭd'iă) n.plu. [Gk. pepsis, digestion; nephros. kidney.] The anterior nephridia of Oligochaets which function as digestive glands (zool.).

peraeopods, - pereiopods.

percurrent (pěrkưr'ěnt) a. [L. percurrens, running through.] Extending throughout the entire length, or from base to apex (bot.). pereion (pěríŏon) n. [Gk, peraioun, to convey.] The thorax of Crustacea (zool.).

pereiopods (pěrīöpŏdz) n. plu. [Gk. peraioun, to convey; pous, foot.] The locomotory thoracic limbs of Malacostraca ; trunk-legs (gool.).

perennation (pĕr'ěnā'shün) $n$. [L. per, through; annus, a year.] Condition of living for a number of years (bot.).

perennial (pěrěn'iăl) a. [L per, 
through; annus, year.] Persisting through the year or for a number of years (bot.).

perennibranchiate (pěrěn'îbrăng'kīāt) a. [L. per, through ; annus, year; Gk. brangchia, gills.] Having gills persisting throughout life, as certain Amphibians (zool.).

perfoliate (pĕrfō'liāt) $a$. [L. per, through; folium, leaf.] $A p p \hat{l}$. a leaf with basal lobes so united as to appear as if the stem ran through it (bot.).

perforate (pĕr'förāt) a. [L. perforare, to bore through.] Having holes or pores, as Corals, Foraminifers (zool.); $a p p l$. certain areas of the brain perforated by small bloodvessels (anat.).

perforator (pěr'förā'tŏr) $n$. [L. perforare, to bore through.] A barbed spear-like head and process of some spermatozoa, as of Salamander (zool.).

perhydridase (pěrhī'drĭdās) $n$. [L. per, through; Gk. hydor, water.] An enzyme which causes the activation of perhydride hydrogen (phys.).

perianth (pĕr'iănth) n. [Gk. peri, round; anthos, flower.] A floral envelope ; the external floral whorls, including calyx and corolla (bot.).

periblast (pĕr'ı̉blăst) $n$. [Gk. peri, round; blastos, a bud.] The outside layer, epiblast, or blastoderm of an insect embryo (emb.).

periblastic (pěrǐblăs'tǐk) a. [Gk, peri, round; blastos, a bud.] Pert. the periblast; superficial, as appl. segmentation (emb.).

periblastula (pěr'íblăs'tūlă) $n$. [Gk. peri, round; blastos, bud.] A blastula resulting from periblastic segmentation (emb.).

periblem (pĕr'̂blěm) n. [Gk. peri, round; blema, a coverlet.] Layers of ground or fundamental tissue between dermatogen and plerome of growing points (bot.).

peribranchial (pěr'íbrăng'kŭăl) $a$. [Gk. peri, round; brangchia, gills.] Around the gills; appl. a type of gemmation and an atrial cavity in Ascidians; $a p p l$. circular spaces surrounding basal parts of papulae of Asteroids (zool.). pericardiac (pěr'îkâr'dǐăk), pericardial (pěr'íkâr'dǐăl) a. [Gk. peri, round; kardia, heart.] Pert. the pericardium; surrounding the heart; appl. cavity, septum (anat.). pericardium (pěr'ǐkâr'diŭm) n. [Gk. peri, round; kardia, heart.] The cavity containing the heart; the membrane enveloping the heart (anat.).

pericarp (pĕr'ikârp) n. [Gk. peri, round; karpos, fruit.] The ovary walls of fruits (bot.).

pericentral (pěr'isěn'trăl) a. [Gk. peri, round; L. centrum, centre.] Round or near the centre; $a p p l$. auxiliary cells (bot.).

perichaetium (pěr'ikë'shǐum) $n$. [Gk. peri, round; chaite, loose hair.] One of the membranes enveloping the archegonia of Mosses (bot.).

perichondrium (pĕr'íkôn'driŭm) $n$. [Gk. peri, round; chondros, cartilage.] A fibrous membrane that covers cartilages (anat.).

perichordal (pĕr'îkôr'dăl) a. [Gk, peri, round; chorde, a cord.] Enveloping or near the notochord (zool.).

perichylous (pěr'îkílŭs) a. [Gk. peri, round; chylos, juice.] With waterstorage cells outside the chlorenchyma (bot.).

pericladium (pĕr'íklā'dĭŭm) n. [Gk. peri, round; klados, a branch.] The lowermost clasping portion of a sheathing petiole (bot.).

periclinal (pěr'iklī'năl) a. [Gk. peri, round; kleiein, to surround.] $A p p l$. the system of cells parallel to the surface of the apex of a growing point (bot.).

periclinium (pĕr'îklĭn'iŭm) n. [Gk. peri, round; kline, a bed.] The involucre of a composite flower (bot.).

pericranium (pěr'îkrā'nĭŭm) n. [Gk. peri, round; kranion, skull.] The fibrous membrane investing the skull (anat.).

pericycle (pěr'isīíkl) n. [Gk. peri, round; kyklos, a circle.] The external layer of the stele (bot.).

peridental (pĕr'îdĕn'tăl) a. [Gk. peri, round; L. dens, tooth.] Investing a tooth; $a p p l$. a membrane, or the periosteum of a root (anat.). 
periderm (pĕr'îdĕrm) n. [Gk. peri, round; derma, skin.] The outer layer of bark (bot.); the external cuticular layer of Hydrozoa (zool.).

peridesm (pĕr'ídězm) n. [Gk. peri, round; desme, a bundle.] Tissue surrounding a vascular bundle (bot.). peridesmium (pěr'íděz'miŭm) $n$. [Gk. peri, round; desmos, a band.] Tissue surrounding a ligament (anat.).

peridial (pĕrì'iăl) a. [Gk. peridion, a small wallet.] Pert. a peridium (bot.).

perididymis (pěr'ǐdĭd'ímĭs) $n$. [Gk. peri, round; didymos, a testicle.] The fibrous covering of the testis (anat.).

peridiolum (pěrĭd’ölŭm) n. [Gk. peridion, a small wallet.] A small peridium or collection of spores enclosed within the peridial covering (bot.).

peridium (pĕrĭd'iŭm) $n$. [Gk. peridion, a small wallet.] The coat investing the sporophore of Fungi ; the outer covering of a puff-ball (bot.).

peridural (pĕr'ídū'răl) a. [Gk. peri, round; L. durus, hard.] Appl. the perimeningeal space at a later stage of development (emb.).

perienteric (pěr'iěn'těrik) a. [Gk. peri, round; enteron, the gut.] Surrounding the enteron (zool.).

perienteron (pĕr'ǐ̌n'tĕrŏn) $n$. [Gk. peri, round; enteron, gut.] A cavity surrounding the enteron or visceral cavity (emb.).

perifoliary (pĕr'ı́fóllĭ̌rì) a. [Gk. peri, round; L, folium, a leaf.] Round a leaf margin (bot.).

perigastric (pěr'igăs'trǐk) a. [Gk. peri, round; gaster, stomach.] Surrounding the viscera; $a p p l$. the abdominal cavity.

perigastrula (pĕr'igăs'troolă) $n$. [Gk. peri, round; gaster, stomach.] The gastrula resulting after superficial segmentation (emb.).

perigonium (pěr'igō'nǐum) n. [Gk. peri, round ; gone, generation.] A floral envelope or perianth; the involucre round thot.); a gonotheca (zool.). perigynium (pěr'ijīn'ǐum) n. [Gk. peri, round ; gyne, a female.] The fruit-investing utricle of the genus
Carex; the membranous perianth of Mosses (bot.).

perigynous (pěrij'ínŭs) a. [Gk. peri, round; gyne, female.] Having sepals, petals, stamens round the gynoecium, not underneath; $c f$. hypogynous (bot.).

perigyny (pĕrìj'inì) $n$. [Gk. peri, round; gyne, a female.] Arrangement in a perigynous manner.

perihaemal (pěr'îhē'măl) $a$. [Gk. peri, round; haima, blood.] Appl. the blood-vascular system of canals and spaces of Echinoderms; $a p p l$. dorsal outgrowths of the third bodycavity of Enteropneusta (zool.).

perilymph (pěr'îlìmf) $n$. [Gk. peri, round; L. lympha, water.] A fluid separating the membranous from the osseous labyrinth of the ear (anat.).

perimedullary (pěr'ìmědŭl'ărǐ) $a$. [Gk. peri, round; L. medulla, the marrow.] Surrounding the pith of a stem ; appl. a zone (bot.).

perimeningeal (pěr'íměnin'jě̌leăl) $a$.

[Gk. peri, round ; meningx, a membrane.] $A p p l$. a space between the endorhachis and the meninx primitiva or spinal cord envelope (emb.).

perimysium (pěr'imì̌íŭm) n. [Gk. peri, round; mys, a muscle.] Connective tissue binding numbers of fibres into bundles and muscles, and continuing into the tendons; alternatively, appl. only to fasciculi envelopes ; cf. epimysium (anat.).

perinaeal (pĕr'inēéăl) a. [Gk. perinaion, the part between anus and scrotum.] Pert. the perinaeum; $a p p l$. artery, body, nerve (anat.).

perinaeum (pĕr'inné'ŭm) n. [Gk. perinaion, the part between anus and scrotum.] A surface of the body limited by the scrotum in front, the buttocks behind, and laterally by the medial side of the thigh (anat.). perinephrium (pěr'iněf'riŭm) $n$. [Gk. peri, round; nephros, kidney.] The enveloping tissue of the kidney (anat.).

perineurium (pěr'inū'rǐŭm) n. [Gk. peri, round ; neuron, a nerve.] The tubular sheath of a small bundle of nerve fibres (anat.).

perinium (pěrīn'ium) n. [Gk. peri, round; is, a fibre.] An epispore, 
or microspore-coating of certain Pteridophytes (bot.).

periodicity (périödïs'itī) n. [Gk.peri, round; odos, a way.] The fulfilment of functions at regular periods or intervals; rhythm (biol.).

perioesophageal (pěr'î̄'sŏfăjē'ăl) $a$. [Gk. peri, round; oisophagos, gullet.] Surrounding the oesophagus ; $a p p l$. a nerve ring (zool.).

periosteum (pěr'iǒs'těum) n. [Gk. peri, round; osteon, bone.] The connective membranous tissue investing the surface of bones (anat.).

periostracum (pěr'iǒs'trăkŭm) $n$. [Gk. peri, round; ostrakon, shell.] The chitinous external layer of most Mollusc shells (zool.).

periotic (pěr'iōt'îk) n. [Gk. peri, round; ous, ear.] A cranial bone enclosing parts of the membranous labyrinth of the internal ear (anat.).

peripetalous (pĕr'ipĕt'ălŭs) $a$. [Gk. peri, round; petalon, a leaf.] Surrounding petals or a petaloid structure (bot.).

peripharyngeal (pĕr'ifărĭn'jěăl) $a$. [Gk. peri, round ; pharyngx, gullet.] Encircling or surrounding the pharynx; $a p p l$. the cilia of Ascidians (zool.).

peripheral (pěrĭf'ĕrăl) a. [Gk. peri, round; pherein, to bear.] Distant from the centre; near the circumference ; $a p p l$. end-organs of nerves, nervous system (anat.).

peripherical (pĕr'ífĕr'ikăl) a. [Gk. peri, round; pherein, to bear.] $A p p l$. an embryo more or less completely surrounding the endosperm in the seed (bot.).

periphery (pěríf'ěrī) n. [Gk. peri, round; pherein, to bear.] The boundary outline of a surface or part.

periphysis (pĕrĭf'isiss) n. [Gk. peri, round; physis, growth.] In certain Fungi, a filament branching from a hymenium without asci (bot.).

periplasm (pěr'ı̌plăzm) $n$. [Gk. peri, round; plasma, something moulded.] The region of an oogonium outside the oosphere, in Fungi (bot.).

periplast (pĕríplăst) n. [Gk. peri, round; plastos, moulded.] The attraction-sphere (cyt.); the ectoplasm of flagellates; the firm cuticle of certain Mastigophora; intercellular substance of tissues (zool.).

peripneustic (pěr'ípnū'stǐk) a. [Gk. peri, round ; pneustikos, pert. breathing.] Having stigmata arranged along the sides of the body, normal in insect larvae (zool.).

periproct (pĕr'̌̌prŏkt) $n$. [Gk. peri, round; proktos, anus.] The surface immediately surrounding the anus of Echinoids (zool.).

perisarc (pĕr'isârrk) $n$. [Gk. peri, round; sarx, flesh.] The tough outer membrane of Hydrozoa (zool.). periscleral (pĕr'îsklē'răl) $a$. [Gk. peri, round; skleros, hard.] Appl. a lymph-space external to the sclera of the eye (anat.).

perisome (pěr'ǐsōm) n. [Gk. peri, round; soma, body.] A body-wall; the integument of Echinoderms (zool.).

perisperm (pĕr'íspĕrm) n. [Gk. peri, round; sperma, seed.] The remains of the nucellus of an ovule when it is not all absorbed during development of the embryo (bot.).

perispore (pěr'ispōr) n. [Gk. peri, round; sporos, seed.] A sporecovering; the mother cell in Algae spores (bot.).

peristalsis (pĕr'îstăl'sĭs) n. [Gk. peri, round; stellein, to place.] Movement of the digestive tract, by which food is digested and absorbed, by means of involuntary muscles (phys.).

peristaltic (pěr'isstăl'tı̌k) a. [Gk. peri, round; stellein, to place.] Appl. the movement by which food is digested, forced along the alimentary canal (phys.).

peristethium (pěr'istếthĭŭm) n. [Gk. peri, round; stethos, breast.] An insect mesosternum.

peristome (pěr'ístōm) n. [Gk. peri, round; stoma, mouth.] The region surrounding the mouth; used in connection with Mosses (bot.), Vorticella, Actinozoa, Annulates, Insects (zool.).

perisystole (pěr'ísı̌s'tölē) $n . \quad[\mathrm{Gk}$. peri, round; systole, a drawing together.] The interval elapsing between diastole and systole of the heart (phys.).

perithecium (pĕr'ithē'shřŭm) $n$. [Gk. 
peri, round; theke, a case.] A flask-shaped cavity with terminal ostiole in stroma of Fungi (bot.).

peritoneal (pĕr'ítönē'ăl) a. [Gk. peri, round; teinein, to stretch.] Pert. the peritoneum ; appl. cavity, fossa, membrane (anat.).

peritoneum (pĕr'îönē'ŭm) n. [Gk. peri, round; teinein, to stretch.] A serous membrane partly applied against the abdominal walls, partly reflected over the contained viscera (anat.).

peritreme (pĕr'ítrēm) n. [Gk. peri, round; trema, a hole.] The margin of a shell-opening; the small plate perforated by the spiracle-opening in Insects (zool.).

peritrichous (pěr'ítrił'ŭs) a. [Gk. peri, round; thrix, hair.] Having the adoral band of cilia arranged in a spiral as in Vorticella (zool.).

peritrochium (pĕr'itrō'kiŭm) n. [Gk. peri, round; trochos, a wheel.] A ciliary band; a circularly ciliated larva (zool.).

peritrophic (pěr'ítrǒf'îk) a. [Gk. peri, round ; trophe, food.] $A p p l$. a fold of membrane in the latter part of the intestine of Insects (zool.).

perivascular (pěr'ĩvăs'kūlăr) $a$. [Gk. peri, round; L. vasculum, a small vessel.] Surrounding the bloodvessels; $a p p l$. lymph channels (anat.).

perivisceral (pěr'ǐvis'ěrăl) a. [Gk. peri, round; L. viscera, bowels.] Surrounding the viscera; appl. the body cavity.

perivitelline (pĕr'ĩvitěl'ín) a. [Gk. peri, round; L. vitellus, yolk of egg.] Surrounding the yolk of an egg.

permanent cartilage,-cartilage which remains unossified throughout life ; opp. temporary (sool.).

permanent teeth, - the set of teeth developed after the milk or deciduous dentition; the second set of most, the third set of some, the first set of other Mammals.

permanent tissue,-tissue consisting of cells which have completed their period of growth and subsequently change little till they lose their protoplasm and die (bot.).

Permian (pěr'miăn) a. [Perm, E.
Russia.] The sixth rock-system of the primary group (pal.).

peronate (pěr'önāt) $a$. [L. peronatus, rough - booted.] Covered with woolly hairs; powdery or mealy externally (biol.).

peroneal (pĕrönē'ăl) a. [Gk. perone, the fibula.] Pert. or lying near the fibula ; appl. artery, nerve (anat.).

peroneotibial (pěr'önē'ötǐb'ı̌la $a$. [Gk. perone, fibula; L. tibia, the tibia.] In the region of fibula and tibia; $a p p l$. certain muscles (anat.).

peronium (pěrō'nĭŭm) n. [Gk. perone, a fibula.] In Trachomedusae, one of the mantle-rivets, or cartilaginous processes ascending from the disc margin towards the centre (zool.).

peroral (pĕrō'răl) $a$. [L. per, through ; os, mouth.] Appl. a membrane of Infusoria formed by concrescence of rows of cilia (zool.).

peroxidase (pĕrŏk'sĭdâs) $n$. [L. per, through; Gk. oxys, sharp.] An enzyme which causes the activation of peroxide oxygen (phys.).

perradius (pĕr'rā'drŭs) $n$. [L. per, through ; radius, a radius.] One of four primary radii of Coelenterates (zool.).

persistent (pĕrsǐs'tĕnt) a. [L. per, through; sistere, to be fixed.] Remaining attached till maturation, as a corolla (bot.); appl. organs or parts in the adult which normally disappear with larval stage or youth, as gills (zool.).

person (pĕr'sŏn) n. [L. persona, a person.] An individual or zooid of a colony (zool.).

personate (pěr'sönāt) a. [L. personatus, masked.] Appl. a corolla of two lips, closely approximated and with a projection of the lower closing the throat of the corolla (bot.).

perspiration (pěr'spirā'shŭn) $n$. [L. per, through ; spirare, to breathe.] Exudation or excretion through the pores of the skin (phys.).

pertusate (pěrtū'sāt) a. [L. pertusus, thrust through.] Pierced at the apex (bot.).

perula (pěr'ūlă, pěr'oolă) n. [Gk. pera, a wallet.] A leaf-bud scale (bot.).'

pervalvar (pĕrvăl'văr) a. [L. per, through; valvae, folding-doors.] 
Dividing a valve longitudinally (bot.).

pervious (pĕr'viŭs) $a$. [L. per, through ; via, a way.] Perforated; permeable (biol.) ; appl. nostrils with no septum between the nasal cavities (zool.).

pes (pěz) $n$. [L. pes, foot.] A foot or foot-like structure; as certain parts of the brain, branches of the facial nerve (anat.).

pessulus (pĕs'ülŭs) $n$. [L. pessulus, a bolt.] An internal skeletal element in the syrinx of some Birds.

petal (pět'ăl) $n$. [Gk. petalon, a petal.] One of the separate parts of a corolla (bot.).

petaliform (pětăl'ûfôrm) a. [Gk. petalon, petal; L. forma, shape.] Petal-shaped ; petal-like ; petaloid ; petaline.

petalled (pĕtăld) a. [Gk. petalon, a petal.] With petals; petaliferous; opp. apetalous (bot.).

petalody (pĕtăl'ödǐ) n. [Gk. petalon, petal ; eidos, resemblance.] Conversion of other parts of a flower into petals (bot.).

petaloid (pět'ăloid) a. [Gk. petalon, petal ; eidos, resemblance.] Like a petal (biol.); appl. the ambulacral areas of certain Echinoderms (zool.). petaloideous (pět'ăloid'ěŭs) $a$. [Gk. petalon, petal ; eidos, resemblance.] Petaloid; appl. monocotyledons with coloured perianth (bot.).

petasma (pĕtăz'mă) n. [Gk. petasma, anything spread out.] A complicated membranous plate on the inner side of the peduncle with interlocking coupling hooks, an apparatus of certain Crustacea (zool.).

petiolar (pět'iölăr) a. [L. petiolus, a little foot.] Pert. having, or growing on a small stalk (bot.).

petiolate (pět'iölāt) a. [L. petiolus, a small foot.] Growing on a petiole (bot.) ; having thorax and abdomen connected by a petiole (zool.).

petiole (pĕt'iōl) n. [L. petiolus, a small foot.] The foot-stalk of a leaf (bot.); a slender stalk connecting thorax and abdomen in Insects (zool.).

petiolule (pět'īōlūil) $n$. [L. petiolus, a small foot.] The foot-stalk of a leaflet of a compound leaf (bot.). petrohyoid (pĕt'röhīoid) a. [Gk. petros, stone ; hyoeides, $\mathrm{Y}$-shaped.] Pert. hyoid and petrous part of temporal (anat.).

petromastoid (pět'römăs'toid) $a$. [Gk. petros, stone ; mastos, breast.] Pert. the mastoid process and the petrous portion of the temporal (anat.).

petrooccipital (pět'röŏksı̆p'ítăl) $a$. [Gk. petros, stone ; L. occiput, back of the head.] Pert. occipital and petrous part of temporal ; $a p p l$. a fissure (anat.).

petrosal (pĕtrō'săl) a. [Gk. petros, stone.] Solidly bony; appl. a sphenoidal process, a ganglion of the glossopharyngeal, to nerves and sinus in the region of the petrous portion of the temporal bone (anat.); $a p p l$. the otic bones of Fishes (zool.). petrosphenoidal (pět'rösfê̌noid'ăl) $a$. [Gk. petros, stone ; sphen, wedge.] Pert. sphenoid and petrous part of temporal ; $a p p l$. a fissure (anat.).

petrosquamosal (pĕt'röskwămō'săl) $a$. [Gk. petros, stone; L. squama, scale.] Pert. squamosal and petrous part of temporal; $a p p l$. sinus and suture (anat.).

petrotympanic (pět'rötı̌mpăn'1̂k) $a$. [Gk. petros, stone; tympanon, drum.] Pert. tympanum and petrous portion of temporal; $a p p l$. a fissure (anat.).

petrous (pĕt'rŭs) a. [Gk. petros, stone.] Very hard or stony ; $a p p l$. a pyramidal portion of the temporal bone wedged in between sphenoid and occipital; also a ganglion on its lower border (anat.).

Peyer's patches, - oval patches of aggregated lymph follicles on the intestine walls (zool.).

phacella (făsěl'ă) $n$. [Gk. phakelos, a bundle of faggots.] A delicate filament with mesogloea core, and supplied with stinging capsules, occurring in rows in the stomach of certain Coelenterates (zool.).

phacoid (făk'oid) a. [Gk. phako, a lentil; eidos, resemblance.] Lentilshaped.

phaeism (fé̀izm) n. [Gk. phaios, dusky.] Duskiness; $a p p l$. the colouring of butterflies.

phaeochrome (fétökrōm) n. [Gk. 
phaios, dusky; chroma, colour.] Chromaphil.

phaeochrous (fēŏk'rŭs) a. [Gk. phaios, dusky; chros, colour.] Of dusky colour.

phaeodium (fēō'dĭŭm) $n$. [Gk. phaios, dusky; eidos, resemblance.] In certain Protozoa, an aggregation of food and excretory substances forming a mass round the central capsule aperture (zool.).

phaeophyll (féööf îl') n. [Gk. phaios, dusky; phyllon, a leaf.] The colouring matter of brown Algae (bot.).

phagocyte (făg'ösīt) n. [Gk. phagein, to eat; kytos, hollow.] A colourless blood-corpuscle which tends to take in and destroy foreign particles (phys.).

phagocytosis (făg'ösītōsǐs) n. [Gk. phagein, to eat; kytos, hollow.] The ingestion and destruction of microparasites by phagocytes (phys.).

phagolysis(făgôl'ísǐs) $n$. [Gk. phagein, to eat ; lysis, a loosing.] Dissolution of phagocytes (phys.).

phalange (fălănj') $n$. [Gk, phalangx, line of battle.] A bundle of stamens united by filaments (bot.).

phalangeal (fălăn'jěla $a$. [Gk. phalangx, line of battle.] Pert. the phalanges; appl. bones, processes of Corti's rods, etc. (anat.).

phalanx (făl'ăngks) n., phalanges (fălăn'jëz) plu. [Gk. phalangx, line of battle.] Segments of the digits of Vertebrates.

phallus (făl'ŭs) n. [Gk. phallos, penis.] A penis.

phanerocodonic (făn'ĕröködŏn'îk) $a$. [Gk. phaneros, manifest; kodon, a bell.] Appl. detached and freeswimming zooids of a hydroid colony (zool.).

phanerogam (fănĕrögăm) n. [Gk. phaneros, manifest; gamos, union.] A phaenogam or plant with conspicuous flowers; $c f$. oryptogam (bot.).

phanerogamous (fănĕrŏg'ămŭs) $a$. [Gk. phaneros, manifest: gamos, union.] $A p p l$. plants with flowers containing pistils and stamens (bot.).

pharyngeal (fărĭn'jěăl, făr'injéčăl) $a$.
[Gk. pharyngx, gullet or windpipe.] Pert. the pharynx; appl. artery, membrane, nerve, tonsil, tubercle, veins (anat.).

pharyngobranchial (fărĭng'göbrăng' kiăl) a. [Gk. pharyngx, gullet ; brangchia, gills.] Pert. pharynx and gills; $a p p l$. certain bones of Fishes (zool.).

pharyngopalatine (fărĭng'göpăl'ătǐn) a. [Gk. pharyngx, gullet; L. palatus, palate.] Pert. pharynx and palatine; $a p p l$. arch and muscle (anat.).

pharynx (fắr'ǐngks) $n$. [Gk. pharyngx, gullet or windpipe.] A musculomembranous tube extending from the under surface of the skull to the level of the sixth cervical vertebra (anat.); the gullet or anterior part of the alimentary canal following the buccal cavity (zool.).

phelloderm (fěl'öděrm) $n$. [Gk. phellos, cork; derma, skin.] The secondary parenchymatous subereous cortex of trees, formed on the inner side of the cork-cambium (bot.).

phellogen (fěl'öjĕn) $n$. [Gk. phellos, cork ; gene, production.] The cork cambium of tree stems, arising as a secondary meristem (bot.).

philtrum (fil'trŭm) n. [Gk. philiron, a philtre.] The depression on the upper lip beneath the septum of the nose (anat.).

phlebenterism (flěběn'tĕrĭzm) n. [Gk. phleps, vein; enteron, intestine.] Condition of having branches of the intestine extending into other organs, as arms or legs (zool.).

phleboedesis (flěbē'děsis) $n$. [Gk. phleps, vein; oidein, to swell.] Condition of having the circulatory system cavity so distended and insinuated as to diminish the coelom, especially so in Molluscs (zool.).

phloem (flō'ěm) n. [Gk. phloios, smooth bark.] The soft bast of vascular bundles, consisting of sieve-tube tissue (bot.).

phloem parenchyma, - thin-walled parenchyma associated with the sieve-tubes of phloem (bot.).

phloem sheath, - the pericycle, together with the inner layer of a 
bundle sheath where the latter consists of two layers (bot.).

phloeoterma (flëöötĕr'mă) $n$. [Gk. phloios, bark; terma, end.] Endodermis ; innermost layer of cortex (bot.).

pholidosis (föl'îdō'šs) $n$. [Gk. pholis, scale.] Scale arrangement of scaled animals.

phonation (fönä'shŭn) n. [Gk. phone, sound.] Of Insects, sound production.

phoranthium (förăn'thĭŭm) n. [Gk. pherein, to bear; anthos, flower.] The receptacle of composite plants (bot.).

phorozooid (förözōoid) n. [Gk. pherein, to bear; zoon, animal; eidos, resemblance.] Foster forms of Doliolum buds, never sexually mature but set free with gonozooids attached to a ventral outgrowth (zool.).

phosphene (fŏs'fēn) $n$. [Gk. phos, light; phainein, to show.] A light impression on the retina due to stimulus other than rays of light (phys.).

phosphorescence (fŏs'förĕs'ĕns) $n$. [Gk. phosphoros, bringing light.] The state of being luminous without sensible heat; common in marine Protozoa, some Copepods, and the majority of deep-sea animals.

photodynamics (fō'tödǐnăm'îks) $n$. [Gk. phos, light ; dynamis, strength.] The study of the effects of lightstimulation on plants (bot.).

photogen (fö'töjën) n. [Gk. phos, light; gene, production.] The lightproducing organ of certain Polychaets (zool.).

photogenic (fó'töjën'ı̂k) a. [Gk. phos, light ; gene, production.] Lightproducing ; phosphorescent.

photopathy (fötŏpăthĩ) n. [Gk. phos, light ; pathos, feeling.] Response to light stimulus (bot.).

photophilous (fötǒf'ílŭs) a. [Gk. phos, light ; philos, loving.] Seeking and thriving in strong light (bot.).

photophore (fö'töför) n. [Gk. phos, light; pherein, to bear.] A phosphorescent organ of Fishes (zool.).

photophygous (fötǒf'ígŭs) a. [Gk. phos, light; phyge,flight.] Avoiding strong light (biol.). photospheres (fö'tösfērz) n. plu. [Gk. phos, light; sphaira, a globe.] Luminous organs of certain Crustacea (zool.).

photosynthesis (fō'tösǐn'thěš̌s) $n$. [Gk. phos, light ; synthesis, a putting together.] Carbon assimilation (biol.).

phototaxis (fót'tötăk'sǐs) $n$. [Gk. phos, light ; taxis, an arrangement.] Response to the stimulus of light (phys.).

phototonus (fō'tötō'nŭs) n. [Gk.phos, light; tonos, a stretching.] Sensitiveness to light; the condition of a plant or plant organ induced by light (bot.).

phototropism (fötŏt'röpízm) n. [Gk. phos, light ; trope, a turning.] The tendency shown by most plants to turn their growing parts towards the greater light (bot.).

phragma (frăg'mă) $n$. [Gk.phragma, a fence.] A spurious dissepiment; a septum (bot.) ; a thoracic partition in Insects (zool.).

phragmocone (frăg'mökōn) n. [Gk. phragma, fence; konos, a cone.] In Belemnites and other Molluscs, a cone divided internally by a series of septa perforated by a siphuncle (pal.).

phrenic (frĕn'îk) a. [Gk. phren, diaphragm.] Pert. or in the region of the diaphragm; $a p p l$. artery, nerve, plexus, vein (anat.).

phrenicocolic (frěn'íkökǒl'̌̌lk) a. [Gk. phren, diaphragm; kolon, part of intestine.] Appl. a ligament, consisting of a fold of peritoneum from left colic flexure to diaphragm(anat.). phrenicocostal (frěn'îkökŏs'tăl) $a$. [Gk. phren, diaphragm; L. costa, rib.] $A p p l$. a narrow slit or sinus between the costal and diaphragmatic pleurae (anat.).

phrenicolienal (frěn'îköliē'năl) a. [Gk. phren, diaphragm ; L. lien, spleen.] $A p p l$. a ligament forming part of the peritoneum reflected over the spleen and extending to the diaphragm (anat.).

phrenicopericardiac (frĕn'íköpër'íkâr' diăk) a. [Gk. phren, diaphragm; peri, round; kardia, heart.] Appl. a ligament extending from diaphragm to pericardium (anat.). 
phycochrome (fī'kökrōm) n. [Gk. phykos, seaweed; chroma, colour.] The colouring matter of blue-green Algae (bot.).

phycocyanin (fín'kösīănĭn) n. [Gk. phykos, seaweed; kyanos, dark blue.] The pigment of blue-green Algae (bot.).

phycoerythrin (fî́köĕr'ïthrĭn) $n$. [Gk. phykos, seaweed; erythros, red.] The colouring matter of red Algae (bot.).

phycology (fīkŏl'öjǐ) $n$. [Gk. phykos, seaweed; $\log o s$, discourse.] The part of Botany dealing with Algae.

phycophaein (fi'köfé'in) n. [Gk. phykos, seaweed; phaios, dusky.] The pigment of brown Algae (bot.). phycoxanthin (fīközăn'thĭn) n. [Gk. phykos, seaweed; xanthos, yellow.] The buff-coloured substance of diatoms (bot.).

phylactocarp (filăk'tökârp) $n$. [Gk. phylaktikos, guarding ; karpos, fruit.] A modification of the hydrocladium in Hydromedusae for the protection of the gonophore (zool.).

phylephebic (fî́lěfé'bìk) a. [Gk. phylon, a race ; ephebeia, manhood.] $A p p l$. the adult stage in race history (biol.).

phyletic (fīlět'ík) a. [Gk. phylon, race.] Pert. a phylum or race (biol.).

phyllade (fillād) n. [Gk. phyllas, foliage.] A reduced scale-like leaf (bot.).

phyllary (fil'ărǐ) n. [Gk. phyllon, leaf.] One of the bracts of the involucres of Compositae (bot.).

phyllidia (filìd'iă) n. plu. [Gk. phyllidion, a little leaf.] Four outgrowths from the side of the scolex of Cestoidea ; bothridia (zool.).

phyllobranchia (fíl'öbrăng'kiă) $n$. [Gk. phyllon, leaf ; brangchia, gills.] A gill consisting of numbers of lamellae or thin plates (zool.).

phyllocladium (fíl'öklä'diŭm) $n$. [Gk. phyllon, leaf; klados, sprout.] A green flattened or rounded stem functioning as a leaf, as in Cactus (bot.).

phyllocyst (fillösist) $n$. [Gk. phyllon, leaf; kystis, bladder.] The rudimentary cavity of a hydrophyllium or protective medusoid (zool.). phyllode (fril'öd) n. [Gk. phyllon, leaf ; eidos, resemblance.] A winged petiole with flattened surfaces placed laterally to the stem, functioning as a leaf (bot.).

phyllody (fill'ödǐ) $n$. [Gk, phyllon, leaf; eidos, resemblance.] The metamorphosis of an organ into a foliage leaf (bot.).

phyllogenetic (fril'öjĕnĕt'îk) $a$. [Gk. phyllon, leaf; genesis, descent.] Producing or developing leaves (bot.).

phylloid (fíl'oid) a. [Gk. phyllon, leaf; eidos, resemblance.] Leaf-like. phyllomania (fíl'ömā'niă) n. [Gk. phyllon, leaf; mania, madness.] Abnormal leaf-production (bot.).

phyllomorphosis (fíl'ömôr'fösis) $n$. [Gk. phyllon, leaf; morphe, form.] Phyllody; variation of leaves at different seasons (bot.).

phyllophagous (fillớf'ăgŭs) $a$. [Gk. phyllon, leaf; phagein, to eat.] Feeding on leaves (zool.).

phyllophore (fîl'öfōr) $n$. [Gk. phyllon, leaf; pherein, to bear.] The terminal bud or growing point of palms.

phyllophorous (fillŏf'örŭs) a. [Gk. phyllon, leaf; pherein, to bear.] Bearing or producing leaves (bot.).

phyllopode (fîl'öpōd) $n$. [Gk. phyllon, leaf; pous, foot.] A sheathing leaf of Isoetes (bot.).

phyllopodium (fîl'öpō'dřŭm) n. [Gk. phyllon, leaf; pous, foot.] The axis of a leaf (bot.).

phyllopodous (fillŏp'ödŭs) $a \quad[\mathrm{Gk}$. phyllon, leaf; pous, foot.] Having leaf-like swimming-feet, as in Branchiopods and Cladocera (zool.).

phylloptosis (fillǒptō'sǐs) n. [Gk. phyllon, leaf; ptosis, a falling.] The fall of the leaf (bot.).

phyllospondylous (fillöspơn'dillŭs) $a$. [Gk. phyllon, leaf; sphondylos, vertebra.] $A p p l$. vertebrae consisting of hypocentrum and neural arch, both contributing to the hollow transverse process, as in Stegocephals (zool.).

phyllotaxis (fîl'ötăk'sís) n. [Gk. phyllon, leaf; taxis, arrangement.] The system of leaf-arrangement on an axis or stem (bot.).

phylloxanthin,- - see xanthophyll. 
phyllozooid (fíl'özō'oid) n. [Gk. phyllon, leaf; zoon, animal.] A shield-shaped medusoid of protective function; a hydrophyllium of Hydromedusae (zool.).

phylogenesis, - phylogeny.

phylogenetic (fílöjënět'îk) a. [Gk. phylon, race; genesis, descent.] Pert. race-history; appl. reproductive cells as $o p p$. autogenetic or body cells (biol.).

phylogeny (fīlŏj'ěnǐ) n. [Gk. phylon, race; genesis, descent.] The history of the development of a species or race, as $o p p$. ontogeny, that of the individual (biol.).

phylogerontic (fílöjërŏn'tǐk) $a$. [Gk. phylon, race; geron, an old man.] $A p p l$. the decadent stage in racehistory (biol.).

phylon (fíl'lŏn), phylum (fíl'lŭm) $n$. phyla (fî́lă) plu. [Gk. phylon, a race or tribe.] A group of animals or plants constructed on a similar general plan; a division in classification (biol.).

phyloneanic (fīilönēăn'îk) a. [Gk. phylon, race; neanikos, youthful.] $A p p l$. the youthful stage in racehistory (biol.).

phylonepionic (fílönĕp'ín̆nǐ) $a$. [Gk. phylon, race; nepios, infant.] Appl. the post-embryonic stage in racehistory (biol.).

physicist (füz'Isist) $n$. [Gk. physikos, physical.] An upholder of the theory that vital phenomena are explicable on a physico-chemical basis (biol.).

physiogeny (fižŏj'ĕnĩ) $n$. [Gk. physis, nature; gene, production.] The development of vital activities (Haeckel).

physiological zero,-see zero.

physiology (fíz'iol'öjī) n. [Gk. physis, nature; logos, discourse.] The study of functions and activities of organisms.

physoclistous (físöklǐs'tŭs) a. [Gk. physa, bladder; kleiein, to close.] Having no channel connecting swim-bladder and digestive tract, as in most Teleosts (zool.).

physodes (fï'sōdz) n. plu. [Gk. physa, a bubble.] Spindles of phoroglucin contained in the plasmodium of certain Sarcodina (zool.). physostomous (fīsŏs'tömŭs) a. [Gk. physa, a bladder; stoma, mouth.] Having swim-bladder and digestive tract connected throughout life by the pneumatic duct, as in Ganoids (zool.).

phytobiology (fî́töbīŏl'öjī) n. [Gk. phyton, plant ; bios, life ; logos, discourse.] The life-history of plants. phytochemistry (fítökĕm'istrī) $n$. [Gk. phyton, plant; chymeia, an infusion.] The chemistry of plant life.

phytogenesis (fí'töjěn'ěsĭs), $n$. [Gk. phyton, plant; genesis, descent.] The development of plants.

phytogeography (fí'töjēŏg'răfĩ) $n$. [Gk. phyton, plant; ge, earth ; graphein, to write.] Geographical distribution of plants.

phytoid (fî̀toid) a. [Gk. phyton, plant; eidos, resemblance.] Plantlike.

phytology (fītŏl'öjī) n. [Gk. phyton, plant ; logos, discourse.] Botany.

phytoma (fíto'mă) n. [Gk. phyton, plant.] Vegetative plant-substance (bot.).

phytomer (fít'ömĕr) n. [Gk. phyton, plant; meros, part.] A structural unit of a plant ; a bud-bearing node (bot.).

phytomorphic (fítömôr'fìk) a. [Gk. phyton, plant; morphe, form.] With plant-like structure.

phyton (fî́tŏn) $n$. [Gk. phyton, plant.] A rudimentary plant; a phytomer (bot.).

phytonomy (fītŏn'ömǐ) n. [Gk. phyton, plant; nomos, law.] The laws of origin and development of plants.

phytophagous (fitǒf'ăgŭs) a. [Gk. phyton, plant; phagein, to eat.] Feeding on plants; herbivorous (zool.).

phytophilous (fitŏf'ílŭs) a. [Gk. phyton, plant; philos, loving.] Plant-eating (zool.).

phytophysiology (fî́töfíz'́ölööjì) $n$. [Gk. phyton, plant ; physis, nature ; logos, discourse.] Plant physiology, a branch of Botany.

phytoplasm (fî́töplăzm) n. [Gk. phyton, plant; plasma, something moulded.] The protoplasm of plants (bot.).

pia mater (pé'ă măt'ĕr, pīă mā'těr) $n$. 
[L. pia mater, kind mother.] A delicate highly vascular membrane investing brain and spinal cord (anat.).

pigment (pĭg'mĕnt) n. [L. pingere, to paint.] Colouring matter in plants or animals.

pigment cell, - a chromatophore or cell containing colouring matter (biol.).

pigmentation (pĭg'mĕntā'shŭn) $n$. [L. pingere, to paint.]. Disposition of colouring matter in an organ or organism (biol.).

pileated (pil'ễätěd) a. [L. pileus, a felt cap.] Crested; appl. Birds (zool.).

pileolated (pǔl'ěölā'těd) $a$. [L. pileolus, a small cap.] Furnished with a small cap or caps.

pileolus (pilléëölŭs) $n$. [L. pileolus, a small cap.] A small pileus.

pileorhiza (pil'ě̈öríză) n. [L. pileus, a cap; Gk. rhiza, root.] A rootcovering; a root-cap (bot.).

pileum (püleǔm) $n$. [L. pileum, a cap.] The top of the head region of a bird.

pileus (pı̌l'ěus) $n$. [L. pileus, a felt cap.] The umbrella-shaped structure of a mushroom (bot.), or of a jelly-fish (zool.).

pilidium (pílìd'ium) n. [Gk, pilidion, a small cap.] The characteristic helmet-shaped larva of Nemertines (zool.).

pilifer (pïl'ífĕr) n. [L. pilus, hair ; ferre, to carry.] Part of the labrum of Lepidoptera (zool.).

piliferous (pĭlif'ěrŭs) a. [L. pilus, hair ; ferre, to carry.] Bearing or producing hair (biol.); appl. the outermost layer of a root or epiblema which gives rise to roothairs (bot.).

pilose (pî́lōs) a. [L. pilus, hair.] Hairy.

pilus (pî'lŭs) n. [L.pilus, hair.] One of slender hair-like structures covering some plants (bot.).

pinacocytes (pǐn'ăkösīts) n.plu. [Gk. pinax, a tablet; kytos, hollow.] The flattened plate-like cells of the dermal epithelium of Sponges (zool.).

pincers, - prehensile claws, as of lobster ; chelae of Insects; chelicerae of Arachnids (zool.). pinealis (pǐnēălı̌s) $n$. [L. pinea, a pine-cone.] An upgrowth from the roof of the midbrain of Vertebrates ; the pineal body or gland or eye.

pinna (pin'ă) $n$. [L. pinna, a feather.] A leaflet of a pinnate leaf (bot.) ; the outer ear; a bird's feather or wing ; a fish-fin (zool.).

pinnate (pin'āt) $a$. [L. pinna, a feather.] Divided in a feathery manner; with lateral processes ; of a compound leaf, having leaflets on each side of an axis or midrib (bot.).

pinnatifid (pinăt'ífid) a. [L. pinna, feather; findere, to cleave.] $\mathrm{Appl}$. leaves lobed about half-way to the midrib (bot.).

pinnatilobate (pinăt'īlōbāt) $a$. [L. pinna, feather; Gk. lobos, a lobe.] With leaves pinnately lobed (bot.). pinnation (piัnă'shŭn) n. [L. pinna, feather.] Pinnate condition (bot.).

pinnatipartite (pinăt'ípâr'tīt) $a$. [L. pinna, feather; partitus, divided.] With leaves lobed three-quarters of the way to the midrib (bot.).

pinnatiped (pinăt'ípěd) $a$. [L. pinna, feather; pes, foot.] Having lobed feet, as certain Birds.

pinnatisect (pinnăt'ǐsěkt) a. [L. pinna, feather; sectus, cut.] With leaves lobed almost down to the base or midrib (bot.).

pinnatodentate (pinăt'öděn'tāt) $a . \quad[\mathrm{L}$. pinna, feather; dens, tooth.] Pinnate, with toothed lobes (bot.).

pinnatopectinate (pinăt'öpěk'tinnāt) $a$. [L. pinna, feather ; pecten, a comb.] Pinnate, with pectinate lobes (bot.).

pinniform (pǐn'îfôrm) a. [L. pinna, feather; forma, shape.] Feathershaped or fin-shaped (biol.).

pinninervate (pĭn'iněr'vāt) a. [L. pinna, feather; nervus, a sinew.] With veins disposed like parts of a feather (bot.).

pinnule (pin'ûl) $n$. [L. pinna, feather.] A secondary leaflet of a bipinnate leaf (bot.) ; in Crinoids, one of the side-branches, two rows of which fringe the arms (zool.).

pinulus (pin'ūlŭs) n. [L. pinulus, a small fir.] A spicule resembling a fir-tree owing to the development of numerous small spines from one radial ray (zool.). 
piscicolous (pǐsǐk'ölŭs) a. [L. piscis, fish ; colere, to inhabit.] Living within fishes, as certain parasites (zool.).

pisciform (pǐs'ûfôrm) a. [L. piscis, fish; forma, shape.] Shaped like a fish.

piscivorous (pǐsı̌v'örŭs) a. [L.piscis, fish; vorare, to devour.] Fisheating.

pisiform (pī'sǐfôrm) a. [L. pisum, a pea ; forma, shape.] Pea-shaped; $a p p l$. a carpal bone (zool.).

pisohamate (pī'söhăm'āt) a. [L. pisum, pea; hamus, a hook.] Appl. a ligament connecting pisiform and hamate bones (anat.).

pisometacarpal (pī'sömět'ăkâr'păl) $a$. [L. pisum, pea ; Gk. meta, beyond ; L. carpus, wrist.] $A p p l$. a ligament connecting the pisiform bone with the fifth metacarpal (anat.).

pistil (pis'tǐl) n. [L. pistillum, a pestle.] The seed-bearing organ of a flower, consisting of ovary and stigma (bot.).

pistillate (pis'tǐlāt) a. [L. pistillum, a pestle.] Bearing pistils or female reproductive organs (bot.).

pistillidium (pistîlíd'ium) n. [L. pistillum, a pestle.] The female sexual organ of Bryophytes, Pteridophytes, and Gymnosperms (bot.).

pistillody (piss'tǐlödĩ) $n$. [L. pistillum, a pestle ; Gk. eidos, resemblance.] The conversion of any organ of a flower into carpels (bot.).

pistillum (pǐstǐl'ưm) n. [L. pistillum, a pestle.] A mass of muscle in a chitinous tube in the aurophore of a medusoid colony (zool.).

pit (pït) $n$. [A.S. pyt, a pit.] A depression formed in the course of cell-wall thickening in plant tissue (bot.); an embryonic olfactory depression (emb.).

pitcher (pìt'shër) n. [L.L. picarium, a beaker.] A modification of a leaf for insect-catching purposes, as the pitcher-shaped leaf of Nepenthes (bot.).

pith (pith) n. [A.S.pitha, pith.] The medulla or central region of a dicotyledonous stem (bot.).

pituitary (pìtūîtărĭ) $a$. [L. pituita, phlegm.] Appl. a body or hypo- physis of the hypothalamus of the brain (anat.).

pivot joint, - a trochoid joint, or one in which the movement is limited to rotation (phys.).

placenta (plăsěn'tă) n. [L. placenta, a flat cake.] The ovule-bearing part of the carpel (bot.); in eutherian Mammals, a double vascular spongy structure formed by interlocking of foetal and maternal tissue in the uterus, and in which maternal and foetal blood are in close proximity, allowing nutritive and respiratory elements to pass from the former to the latter by osmosis.

placental (plăsĕn'tăl) a. [L. placenta, a flat cake.] Pert. a placenta or similar structure; $a p p l$. Mammals which develop a placenta.

placentate (plăsĕn'tāt) $a$. [L.placenta, a flat cake.] Having a placenta developed (biol.).

placentation (plăs'ěntā'shŭn) $n$. [L. placenta, a flat cake.] The manner in which seeds are attached to the pericarp, whether axile, central, marginal, or parietal (bot.).

placentiferous, placentigerous, - placentate.

placochromatic (plăk'ökrömăt'îk) $a$. [Gk. plax, a plate ; chroma, colour.] With plate-arrangement of chromatophores (cyt.).

placoid (plăk'oid) a. [Gk. plax, a plate; eidos, resemblance.] Platelike ; $a p p l$. the hard scales or dermal teeth on the external surface of Elasmobranchs (zool.).

placula (plăk'ūlă) $n$. [Gk. plax, plate. A flattened blastula with small segmentation cavity, an embryonic stage of Urochords (emb.).

plagiotropic (plā'jǐötrŏp'ik) a. |Gk. plagios, oblique ; trope, a turning.] Obliquely inclined; $a p p l$. roots and branches (bot.).

plagiotropism (plā'jǐot'röpǐzm) $n$. [Gk. plagios, oblique ; trope, a turning.] Tendency to incline from the vertical line (bot.).

plagiotropous (plā'jǐot'röpŭs) a. [Gk. plagios, oblique ; trope, a turning.] Obliquely inclined; appl. the asymmetrical polar cap of Rhombozoa (zool.).

planiform (plā'nífôrm) a. [L.planus, 
level ; forma, shape.] With nearly flat surface; $a p p l$. certain articulation surfaces.

plankton (plăngk'tŏn) $n$. [Gk. plangktos, wandering.] The animal and plant life floating through water, including animals with weak locomotory power (biol.).

planoblast (plăn'öblăst) $n$. [Gk. planos, wandering; blastos, bud.] A free-swimming hydroid individual (zool.).

planogamete (plăn'ögămēt') n. [Gk. planos, wandering; gamete, a spouse.] A ciliated motile protoplast or microzoospore of Algae (bot.).

planont (plăn'ŏnt) n. [Gk. planos, wandering.] The initial amoebulastage of Neosporidia (zool.).

planta (plăn'tă) $n$. [L. planta, sole of the foot.] The sole of the foot; the first tarsal joint of Insects.

plantar (plăn'tăr) a. [L. planta, sole of the foot.] Pert. the sole of the foot; $a p p l$. arteries, ligaments, muscles, nerves, veins (anat.).

plantigrade (plăn'tigrầd) $a . \quad[\mathrm{L}$. planta, sole of the foot; gradus, a step.] Walking with the whole sole of the foot touching the ground.

plantula (plăn'tūlă) n. [L. plantula, a small sole.] The empodium or pulvillus of Insects (zool.).

planula (plăn'ūlă) n. [L. planus, flat.] The ovoid young freeswimming larva of Coelenterates (zool.).

planum (plắn'üm) n. [L. planus, flat.] A plane or area ; $a p p l$. certain cranial bone surfaces (anat.).

plasma (plăz'mă) $n$. [Gk. plasma, something formed.] The "liquid tissue " of body fluids through which leucocytes and corpuscles are disseminated; protoplasm generally (biol.).

plasmatic (plăzmătîk) $a$. [Gk. plasma, something formed.] Pert. plasma ; protoplasmic (biol.).

plasmatoparous (plăz'mătŏp'ărŭs) $a$. [Gk. plasma, something formed; L. parere, to beget.] Developing a mycelium directly upon germination instead of zoospores, as the grape mildew and other Plasmopara (bot.). plasmocyte (plăz'mösīt) 1, n. [Gk. plasma, something formed; kytos, hollow.] A leucocyte (phys.).

plasmodial (plăzmō'diăl) $a$. [Gk. plasma, a mould; eidos, form.] Pert. a plasmodium.

plasmodiocarp (plăzmō'diökârp') $n$. [Gk. plasma, a mould ; eidos, form ; karpos, fruit.] A modification of a plasmodium in some slime Moulds (bot.).

plasmodium (plăzmō'dǐŭm) n. [Gk. plasma, a mould; eidos, form.] A collection of amoeboid masses without nuclear fusion; the naked protoplasm of Myxomycetes (biol.). plasmogamy,-plastogamy.

plasmolysis (plăzmŏl'išs) $n$. [Gk. plasma, a mould ; lysis, a loosing.] The withdrawal of water from plant protoplasm, causing contraction of cell walls (bot).

plasmosome (plăz'mösōm) n. [Gk. plasma, a mould; soma, body.] The true nucleolus ; $c f$. karyosome (cyt.).

plasmotomy (plăzmŏt'ömĩ) n. [Gk. plasma, a mould; tome, a cutting.] Division of a plasmodium by cleavage into two or more multinucleate parts (biol.).

plasome (plăs'ōm) n. [Gk. plasma, a mould ; soma, body.] An ultimate vital unit; a biophore. See hypothetical units.

plastic (plăs'tík) a. [Gk. plastos, formed.] Formative; appl. substances used in forming or building up tissues or organs; appl. force which gives matter definite form (phys.).

plastid (plăs'tĩd) n. [Gk. plastos, formed.] A cell-body other than nucleus or centrosome (cyt.).

plastidogen organ, - the axial organ of Echinoderms (sool.).

plastidule (plăs'tǐdūl) n. [Gk. plastos, formed.] The ultimate vital unit; a plasome or biophore. See hypothetical units.

plastin (plăs'tiñ) n. [Gk. plastos, formed.] A substance found in the reticulum of cells $(c y t)$.

plastodynamia (plăs'tödínămíră) $n$. [Gk. plastos, formed; dynamis, power.] Plastic or formative force (phys.). 
plastogamy (plăstŏg'ămĭ) n. [Gk. plastos, formed; gamos, marriage.] Union of distinct protozoan individuals with fusion of cytoplasm but not of nuclei (zool.).

plastral (plăs'trăl) a. [F.plastron, a breast-plate.] Pert. a plastron.

plastron (plăs'trŏn) $n$. [F. plastron, a breast-plate.] The ventral bony shield of Tortoises and Turtles; some other corresponding structures (zool.).

plate (plāt) n. [L. platus, flat.] A flat, broad, plate-like structure or surface ; a lamina, scale, disc, etc.

platydactyl (plăt'ídăk'tǐl) $a$. [Gk. platys, flat; daktylos, a finger.] With flattened-out fingers and toes, as certain tailless Amphibians (zool.).

platysma (plătǐz'mă) $n$. [Gk. platysma, a flat piece.] A broad sheet of muscle beneath the superficial fascia of the neck (anat.).

plectonephridia (plěk'töněfrĭd'iă) $n$. plu. [Gk. plektos, twisted; nephros, kidney.] Nephridia of diffuse type formed of networks of fine excretory tubules lying on the body-wall and septa of certain Oligochaetes ; plectonephria, nephridia (zool.).

pleiocyclic (plínösìk'lìk) a. [Gk. pleion, more ; kyklos, circle.] Living through more than one cycle of activity, as a perennial plant (bot.).

pleiomerous (plīom'ěrŭs) $a$. [Gk. pleion, more ; meros, part.] Having more than the normal number of parts, as of petals or sepals (bot.).

pleiophyllous (plì'öfil'ŭs) a. [Gk. pleion, more; phyllon, leaf.] Having more than the normal number of leaves or leaflets (bot.).

pleiotaxy (plīötăk'sí) n. [Gk. pleion, more ; taxis, arrangement.] A multiplication of whorls, as in double flowers (bot.).

pleomorphous (plēömôr'fús) a. [Gk. pleon, more ; morphe, form.] Polymorphous; having two or more distinct forms occurring in one lifecycle (biol.).

pleon (plëŏn) n. [Gk. pleein, to sail.] The abdominal region of Crustaceans (zool.).

pleopod (plë'öpŏd) n. [Gk. pleein, to sail; pous, foot.] An abdominal appendage or swimming-leg of Crustaceans (zool.).

plerocestoid (plĕr'ösĕs'toid) n. [Gk. pleros, full ; kestos, girdle ; eidos, form.] A metacestode, or sexless encysted stage of a cestoid worm (zool.).

plerome (plër'ōm) n. [Gk. pleroma, completion.] The core or central part of an apical meristem (bot.).

pleura (plooră) n. [Gk. pleura, a side.] A serous membrane lining the thoracic cavity and investing the lung (anat.).

pleural (ploor'ăl) a. [Gk. pleura, a side.] Pert. a pleura or pleuron; as pleural ganglia (zool.).

pleuralia (ploorắliă) n. plu. [Gk. pleura, a side.] Defensive spicules scattered over the general surface of the body (zool.).

pleurapophysis (ploor'ăpŏf'issıs) $n$. [Gk. pleura, a side; apo, from ; physis, growth.] A lateral vertebral process or true rib (zool.).

pleurite (ploor'it) n. [Gk. pleura, a side.] A pleuron.

pleurobranchiae (ploor'öbrăng'kiẽ) $n$. plu. [Gk. pleura, a side ; brangchia, gills.] Pleurobranchs, or gills springing from the lateral walls of the thorax of certain Arthropods (zool.).

pleurocarpous (ploor'ökâr'pŭs) a. [Gk. pleura, a side; karpos, fruit.] Appl. Mosses with fructification on lateral branches (bot.).

pleurocentrum (ploor'ösěn'trŭm) $n$. [Gk. pleura, a side; L. centrum, a centre.] A lateral element of the centrum of many Fishes and fossil Amphibians (zool.).

pleurocerebral (ploor'ösĕr'ěbrăl) $a$. [Gk. pleura, a side ; L. cerebrum, brain.] Pert. pleural and cerebral ganglia, in Molluscs (zool.).

pleurodont (ploor’ödŏnt) a. [Gk. pleura, side; odous, tooth.] Having teeth fixed by their sides to the lateral surface of the jaw ridge, as in some Lizards (zool.).

pleuron (ploor'ón) n., pleura (ploor'ă), plu. [Gk. pleuron, a side.] The external lateral pieces of the body segments of Arthropods; the lateral extensions of Crustacean shells (zool.). 
pleuropedal (ploor'öpěd'ăl) $a$. [Gk. pleura, a side; L. pes, foot.] Pert. pleural and pedal ganglia of Molluscs (zool.).

pleuroperitoneum (plooröperr' itönē'ŭm) n. [Gk. pleura, side ; peri, round; teinein, to stretch.] Pleura and peritoneum combined, the body-lining membrane of animals without diaphragm (zool.).

pleuropodium (ploor'öpō'diŭm) $n$. [Gk, pleura, a side; pous, foot.] A lateral glandular process of the abdomen of some Insects (zool.).

pleurosteon (ploorŏs'těŏn) n. [Gk. pleura, side; osteon, bone.] The lateral process of the sternum in young Birds, afterwards the costal process (zool.).

pleurotribe (ploor'ötrīb) a. [Gk. pleura, side; tribein, to rub.] Appl. flowers whose anthers and stigma are so placed as to rub the sides of insects entering them, - a device for securing cross-pollination (bot.). pleurovisceral (ploor'övǐs'ěrăl) $a$. [Gk. pleura, side ; L. viscera, intestines.] Pert. pleural and visceral ganglia of Molluscs (zool.).

plexiform (plěk'sǐfôrm) a. [L.plexus, interwoven; forma, shape.] Entangled or complicated; like a network; $a p p l$. layers of the retina (anat.).

plexiform gland,-the axial organ of Echinoderms (zool.).

plexus (plěk'sŭs) $n$. [L. plexus, interwoven.] A network of interlacing blood-vessels or nerves (anat.).

plica (pli'kă) n. [L. plicare, to fold.] A fold of skin or membrane (anat.).

plicate (plǐk'āt) a. [L. plicare, to fold.] Folded like a fan, as a leaf $(b \circ t$.$) ; folded or ridged (zool.).$

pliciform (plís'ifôrm) a. [L. plicare, to fold; forma, shape.] Resembling a fold; disposed in folds.

pluma (ploom'ă) n. [L. pluma, a feather.] A contour feather of birds. plumage (ploom'āj) n. [L. pluma, feather.] The entire covering of feathers of a bird.

plumate (ploom'àt) a. [L. pluma, feather.] Plume-like in arrangement.

plume (ploom) n. [L. pluma, feather.] A feather, or feather-like structure. plumicome (ploom'îkōm) n. [L. pluma, feather ; coma, hair.] A spicule with plume-like tufts (zool.).

plumicorn (ploom'îkôrn) $n$. [L. pluma, feather ; cornu, horn.] A horn-like tuft of feathers on a bird's head.

plumigerous (ploomij'ěrŭs) a. [L. pluma, feather; gerere, to carry.] Feathered.

plumiped (ploom'ípěd) $n$. [L. pluma, feather; pes, foot.] A bird with feathered feet.

plumose (ploom'ōs) a. [L. pluma, feather.] Feathery; having feathers; feather-like; $a p p l$. a type arrangement of skeletal fibre in Sponges.

plumula, - a plumule.

plumulaceous,-plumulate.

plumulate (ploom'ūlāt) a. [L. plumula, a small feather.] Downy; with a downy covering.

plumule (ploom'ül) n. [L. plumula, a small feather.] A primary bud which develops the primary axis of a stem (bot.); the androconia of numerous butterflies; a downfeather (zool.).

pluriaxial (ploor'răk'šăl) a. [L. plus, more; axis, axle.] Having flowers developed on secondary shoots (bot.).

plurilocular (ploor'îlǒk'ūlăr) a. [L. plus, more ; loculus, a little place.] Having two or more loculi.

pluripartite (ploor'îpâr'tit) a. [L. plus, more; partitus, divided.] With many divisions, lobes, or partitions.

pluriserial (ploor'isēériăl) a. [L. plus, more; series, a row.] Arranged in two or more rows.

plurivalent (ploorǐv'ălěnt, ploor'ivā'lěnt) a. [L. plus, more; valere, to be worth.] $A p p l$. a chromatin-rod with more than one chromosome (cyt).

pluteal (ploot'ěăl) a. [L. pluteus, a shed.] Pert. a pluteus.

pluteus (ploot'ěus) $n$. [L. pluteus, a shed.] The free-swimming larva of Echinoids and Ophiuroids (zool.).

pneumatic (nūmăt'îk) a. [Gk. pneuma, air.] Appl. bones of birds penetrated by canals connected with the respiratory system (zool.).

pneumaticity (nümătǐs'îtî) n. [Gk. pneuma, air.] State of having air 
cavities, as in the bones of flying birds (zool.).

pneumatized (nü'mătīzd) a. [Gk. pneuma, air.] Furnished with air cavities.

pneumatocyst (nū'mătösǐst) n. [Gk. pneuma, air ; kystis, a bladder.] The air-bladder or swim-bladder of Fishes (zool.).

pneumatophore (nū'mătöfōr) n. [Gk. pneuma, air ; pherein, to bear.] The air-sac or float of Siphonophores (zool.) ; an air-bladder of marsh or shore-plants (bot.).

pneumatopyle (nū'mătöpīl) n. [Gk. pneuma, air; pyle, gate.] One of the pores of a pneumatophore, opening above to the exterior in certain Siphonophores (zool.).

pneumogastric (nū'mögăs'trìk) $a$. [Gk. pneuma, air ; gaster, stomach.] $A p p l$. the tenth cranial nerve, supplying heart, lungs, and viscera (anat.).

pneumotaxis (nū'mötăk'sǐs) n. [Gk. pneuma, air ; taxis, arrangement.] Reaction to the stimulation of carbon dioxide in solution; $c f$. aerotaxy (phys.).

pod (pǒd) n. [M.E. pod, a bag.] A superior, one-celled, one- or manyseeded fruit of two valves; a husk (bot.).

podal (pō'dăl) a. [Gk, pous, a foot.] Pert. feet; pedal.

podeon (pō'dê̌ŏn) $n$. [Gk. pous, foot.] The petiole or slender middle part of the abdomen of Hymenoptera uniting propodeon and metapodeon (zool.).

podetiiform (pǒdē'shĩfôrm) a. [Gk. pous, foot; L. forma, shape.] Resembling a podetium (bot.).

podetium (pǒdē'shiumm) n. [Gk, pous, foot.] A stalk-like elevation from the thallus of some Lichens (bot.).

podeum, - a podeon.

podex (pô'děks) $n$. [L. podex, rump.] The region about the anus,

podical (pŏd'îkăl) a. [L. podex, rump.] In the anal region; $a p p l$, a pair of small hard plates beside the anus of Arthropods (zool.).

podite (pöd'ît) $n$. [Gk. pous, foot.] A Crustacean walking leg.

podium (pō'diŭm) $n$. [Gk, pous, foot.] A foot or footlike structure (biol.). podobranchiae (pǒdöbrăng'kīē) $n$. plu. [Gk. pous, foot; brangchia, gills.] Podobranchs or foot-gills, springing from the coxopodites of the thoracic appendages of certain Arthropods (zool.).

podocephalous (pŏdökěf'ălŭs, -sĕf-) a. [Gk. pous, foot; kephale, head.] Having a head of flowers on a long stalk (bot.).

podoconus (pŏd'ökō'nŭs) n. [Gk. pous, foot; konos, cone.] A conical mass of endoplasm connecting the central capsule with the disc of Sarcodina (zool.).

podocyst (pŏd'ösǐst) $n$. [Gk. pous, foot; kystis, bladder.] A pedal sinus or caudal vesicle in certain Gasteropods (zool.).

pododerm (pŏd'öděrm) n. [Gk. pous, foot; derma, skin.] The dermal layer of a hoof, within the horny layer (zool.).

podogynium (pǒd'öjĭn'íŭm) n. [Gk. pous, foot; gyne, a female.] A stipe supporting the gynoecium (bot.).

podomere (pŏd'ömēr) n. [Gk. pous, foot ; meros, part.] A limb segment of Arthropods (zool.).

pođophthalmite (pǒd'ŏfthăl'mīt) $n$. [Gk. pous, foot ; ophthalmos, eye.] In Crustaceans, the eyestalk segment farthest from the head (zool.).

podotheca (pŏd'öthē'kă) n. [Gk. pous, foot; theke, a box.] A foot covering, as of Birds or Reptiles.

pogonion (pögō'nı̆n) n. [Gk, pogonion, little beard.] The most prominent point of the chin as represented on the mandible (anat.).

poikilothermal (poǐk'ilöthĕr'măl) $a$. [Gk. poikilos, various; thermos, heat.] $A p p l$. cold-blooded animals, or those whose temperature varies with that of the surrounding medium; cf. homoiothermal (phys.).

poikilothermous,-poikilothermal.

poisers,-halteres, which see.

polar (pō'lăr) a. [Gk. polos, a pivot.] In the region of the end of an axis; at a pole.

polar body, - one of two cells divided off from the ovum during maturation, before the germ-nuclei fuse (cyt.).

polar nuclei,-a nucleus remaining at each end of an angiosperm em- 
bryo, which later form the secondary nucleus (bot.).

polar plates, - two narrow ciliated areas produced in the transverse plane, part of the equilibrium apparatus of certain Coelenterates (zool.).

polar rays, - astral rays, as opp. spindle-fibres $(c y t$.).

polar rings, - two ring-shaped cytoplasmic masses near the ovum poles formed after union of the germnuclei (cyt.).

polarity (pölăr'ítǐ) n. [Gk. polos, a pivot.] The tendency of plants to develop from the poles, roots downwards, stems upwards (bot.); the tendency of any ovum to place itself with its axis corresponding to that of the mother (emb.).

pole plates, - the end-plates or achromatic masses at the spindle poles in Protozoa mitosis (cyt.).

Polian vesicles, - interradial vesicles opening into the ring-vessel of the ambulacral system of most Starfishes and Holothurians (zool.).

polioplasm (pŏl'̌öplăzm) n. [Gk. polios, gray; plasma,form.] Spongioplasm.

pollen (pǒl'ěn) $n$. [L. pollen, fine flour.] The male fertilizing element of seed plants (bot.).

pollen tube, - a tubular process developed from pollen grains after attachment to the stigma (bot.).

pollex (pǒl'ěks) $n$. [L. pollex, thumb.] The thumb, or innermost digit of the normal five in the anterior limb (zool.).

pollination (pŏlínāshŭn) $n$. [L. pollen, fine flour.] Fertilization in flowers ; transference of pollen from stigma to ovule (bot.).

polliniferous (pǒlinnif́ĕrŭs) $a . \quad[\mathrm{L}$. pollen, fine flour; ferre, to carry.] Pollen-bearing (bot.); adapted for transferring pollen $(z \circ o l$.).

pollinium (pơlin'îum) $n$. [L. pollen, fine flour.] An agglutinated pollen mass of Orchids and some other plants (bot.).

pollinodium (pŏl'ĩnō'diŭm) n. [L. pollen, fine flour; Gk. eidos, form.] A club-shaped branch of mycelium, the antheridium of certain Fungi (bot.). pollinoid (pŏlinnoid) n. [L. pollen, fine flour; Gk. eidos, form.] A male gamete or spermatium (bot.). polocytes (pōllösīts) n. plu. [Gk. polos, axis; kytos, hollow.] Polar bodies (cyt.).

polyadelphous (pǒl'ıădĕl'fŭs) a. [Gk. polys, many; adelphos, brother.] Having stamens united by filaments into more than two bundles (bot.).

polyandrous (pǒl'̌ăn'drŭs) a. [Gk. polys, many; andros, male.] Having twenty or more stamens (bot.).

polyandry (pǒl'iăn'drǐ) n. [Gk. polys, many; andros, male.] Condition of a female consorting with several males; as in some Fishes (biol.).

polyarch (pǒlînârk) a. [Gk. polys, many; arche, beginning.] Appl. a root having many xylem bundles united to form a plate in wood tissue (bot.).

polyaxon (pơl'řăk'sŏn) n. [Gk. polys, many; axis, an axis.] A type of spicule laid down along numerous axes (zool.).

polycarp (pǒlíkârp) n. [Gk. polys, many; karpos, fruit.] One of the gonads of some Ascidians distributed over the inner surface of the mantle (zool.).

polycarpellary (pŏl'îkârpěl'ărǐ) $a$. [Gk. polys, many ; karpos, fruit.] With compound gynoecium (bot.).

polycarpic,-polycarpous.

polycarpous (pơllíkâr'pŭs) a. [Gk. polys, many ; karpos, fruit.] With numerous carpels ; $a p p l$. perennials (bot.).

polycercous (pŏl'issěr'kŭs) $a$. [Gk. polys, many; kerkos, tail.] Appl. bladderworms developing several cysts, each with a head (zool.).

polychasium (pǒl'íkā'žŭm) $n$. [Gk. polys, many; chasis, division.] A cymose branch system when more than two branches arise about the same point (bot.).

polycotyledon (pǒlíkŏtĭlédŏn) $n$. [Gk. polys, many; kotyledon, a hollow vessel.] A plant with more than two embryo lobes (bot.).

polycotyledonary (pǒl'îkơttílédönărǐ) a. [Gk. polys, many ; kotyledon, a hollow vessel.] Having the placenta in many divisions or cotyledons (zool.). 
polycotyledonous (pǒl'îkŏtǐlē'dönŭs) a. [Gk. polys, many; kotyledon, a hollow vessel.] Having more than two cotyledons or seed lobes, as the fir embryo (bot.).

polycotyledony (pŏl'̌k kŏtǐlë'dönǐ) $n$. [Gk. polys, many; kotyledon, a hollow vessel.] A great increase in the number of cotyledons (bot.). polyerotism (pǒlǐk'rötǐzm) $n$. [Gk. polys, many; krotos, a beating.] Condition of having several secondary elevations in the pulse curve (phys.).

polycyclic (pǒl'ísǐk'lǐk) a. [Gk. polys, many; kyklos, a circle.] Having many whorls or ring structures (biol.).

polycystid (pǒl'ǐsǐs'tǐd) a. [Gk. polys, many ; kystis, a bladder.] Septate; partitioned off (biol.).

polydactylism (pǒl'ídăk'tillǐzm) $n$. [Gk. polys, many; daktylos, a finger.] Condition of having an excessive number of fingers or toes (zool.).

polyembryony (pǒl'ǐm̌m'brǐnini) $n$. [Gk. polys, many; embryon, a foetus.] Instance of a zygote giving rise to more than one embryo (bot.).

polyenergid (pŏl'ǐn'ěrjĭd) a. [Gk. polys, many; energos, active.] $A p p l$. nuclei with more than one centriole (cyt.).

polygamous (pŏlĭgămŭs) a. [Gk. polys, many ; gamos, union.] Bearing male, female, and hermaphrodite flowers (bot.); consorting with more than one mate (zool.).

polygamy (pǒlĭg'ămǐ) n. [Gk. polys, many ; gamos, union.] Condition of having staminate, pistillate, and hermaphrodite flowers upon the same individual (bot.); condition of having more than one mate at a time (zool.).

polygenetic (pǒl'íjěnět'îk) $a$. [Gk. polys, many; genesis, descent.] Derived from two sources ; sexually produced (biol.).

polygenic,-polygenetic.

polygoneutic (pŏl'ígŏnü'tǐk) a. [Gk. polys, many ; goneuein, to beget.] Rearing more than one brood in a season (zool.).

polygynoecial (pǒl'íjinnē'shrăl) a. [Gk. polys, many; gyne, woman; oikos, house.] Having multiple fruits formed by united gynoecia (bot.). polygynous (pŏlǐj'inǔs) a. [Gk.polys, many; gyne, female.] Consorting with more than one female at a time (zool.) ; with many styles (bot.). polykaryon (pŏl'îkăr'ǐñ) $n$. [Gk. polys, many; karyon, nut.] A polyenergid nucleus; a nucleus with more than one centriole (cyt.). polymastigote (pŏl'immăs'tĭgōt) $a$. [Gk. polys, many ; mastix, whip.] Having flagella arranged in a tuft (zool.).

polymastism (pŏl'ĩmăs'tĭzm) n. [Gk. polys, many ; mastos, breast.] Occurrence of more than the normal number of mammae.

polymerisation (pŏlimmĕr'1̌zāshŭn) $n$. [Gk. polys, many; meros, part.] The uniting together of a number of molecules in a liquid with chemical combination (phys.).

polymerous (pǒlĭm'ěrŭs) a. [Gk. polys, many ; meros, part.] Consisting of many parts or members (bot.).

polymorphism (pŏl'̌môr'fizm) $n$. [Gk. polys, many ; morphe, form.] Occurrence of different forms of individuals in the same species; occurrence of different forms, or different forms of organs, in the same individual at different periods of life (biol.).

polymorphonuclear (pǒl'ǐmôr'fönū'klěăr) a. [Gk.polys, many; morphe, form; L. nucleus, kernel.] Appl. leucocytes with multipartite nuclei connected by fine threads of chromatin (cyt.).

polymorphous (pŏlinmôr'fưs) a. [Gk. polys, many; morphe, form.] Assuming various forms or shapes (biol.).

polynucleate (pǒl'innū'klěāt) a. [Gk, polys, many; L. nucleus, kernel.] Containing several or many nuclei (cyt.).

polyp (pǒl'îp) n. [L. polypus, polyp.] A simple Actinozoon, as a seaanemone; a separate zooid of an Actinozoan colony (zool.).

polyparium (pǒl'ĩpä'rǐŭ) n. [L. polypus, polyp.」 The common base and connecting tissue of a colony of polyps (zool.).

polypary, - a polyparium. 
polypetalous (pǒl'îpět'ălŭs) a. [Gk. polys, many ; petalon, leaf.] Having separate, free, or distinct petals (bot.).

polyphagous (pǒlïf'ăgŭs) $a$. [Gk. polys, many; phagein, to eat.] Eating many and various kinds of food ; of Sporozoa, passing different phases of life-history in different cells (biol.).

polyphyletic (pǒl'ífílět'îk) a. [Gk. polys, many; phylon, race.] Convergent, as appl. a group; combining characteristics of more than one ancestral type through independent acquisition (biol.).

polyphyllous (pǒl'îfil'ǔs) $a$. [Gk. polys, many; phyllon, leaf.] Manyleaved (bot.).

polyphyodont (pǒl'îfi'ödŏnt) a. [Gk. polyphyes, manifold ; odous, tooth.] Having many successive sets of teeth.

polypide (pŏlípīd) n. [L. polypus, a polyp.] An individual or person of a zooid colony (zool.).

polypite,-a polypide.

polyplastic (pŏl'íplăs'tǐk) a. [Gk. polys, many; plastos, formed.] Capable of assuming many forms (biol.). polypod (pǒl'ipŏd) a. [Gk. polys, many; pous, foot.] Furnished with many feet or legs.

polypoid (pǒl'ipooid) a. [L. polypas, polyp; Gk, eidos, form.] Polyplike.

polyprotodont (pǒl'íprō'tödŏnt) $a$. [Gk. polys, many; protos, first ; odous, tooth.] With four or five incisors on each side of the upper jaw, and one or two fewer on the lower-as in the Tasmanian Devil (zool.).

polyrhizal (pŏl'înízăl) a. [Gk. polys, many; rhiza, root.] With many roots or rootlets (bot.).

polysepalous (pǒl'isěp'ălŭs) a. [Gk. polys, many; sepalon, a sepal.] Having free or distinct sepals (bot.). polysiphonic (pǒl'îsifŏn'îk) $a$. [Gk. polys, many; siphon, a tube.] Appl. a hydromedusa stem consisting of several hydrocauli bound together (zool.).

polysomitic (pǒl'ǐsömǐt'îk) a. [Gk. polys, many; soma, body ; temnein, to cut.] Having many body- segments; formed from fusion of the primitive body segments (zool.). polyspermous (pǒl'isspěr'mŭs) $a$. [Gk. polys, many; sperma, seed.] Having many seeds (bot.).

polyspermy (pŏl'ispĕr'mĭ) n. [Gk. polys, many; sperma, seed.] Entry of several sperms into one ovum (biol.).

polysporous (pǒl'ǐspō'rŭs) a. [Gk. polys, many; sporos, seed.] Manyseeded; many-spored (bot.).

polystachyous (pǒl'ǐstăk'iưs) a. [Gk. polys, many; stachys, an ear of corn.] With numerous spikes (bot.). polystelic (pǒlinstělîk) a. [Gk. polys, many ; stele, a post.] With several steles (bot.).

polystely (pŏl'ístē'lì) n. [Gk. polys, many ; stele, a post.] Arrangement of axial vascular tissue in several steles, each containing more than one vascular bundle (bot.).

polystemonous (pǒl'ĩstěm'önŭs) $a$. [Gk. polys, many; stemon, a warp.] Having the stamens more than double the number of petals or sepals (bot.).

polystichous (pǒl'ĩstîk'ŭs) a. [Gk. polys, many; stichos, a row.] Arranged in numerous rows or series.

polystomatous (pŏl'îstŏm'ătŭs) $a$. [Gk. polys, many; stoma, mouth.] Having many pores, mouths, or openings; many-mouthed, as Discomedusae and Sponges (zool.).

polystomium (pǒl'îstō'mĭum) n. $[\mathrm{Gk}$. polys, many; stoma, mouth.] A suctorial mouth of Discomedusae (zool.).

polystylar (pǒl'ı̌stîllăr) a. [Gk. polys, many; stylos, pillar.] Many. styled (bot.).

polysymmetrical (pǒl'ǐsǐmět'rǐkăl) $a$, [Gk. polys, many; syn, with ; metron, measure.] Divisible through several planes into bilaterally symmetrical portions (bot.).

polythalamous (pǒl'îthăl'ămŭs) $a$. [Gk. polys, many; thalamos, a chamber.] Aggregate or collective, as $a p p l$. fruits (bot.); $a p p l$. shells made up of many chambers formed successively (zool.).

polythely (pŏl'íthē'lî) n. [Gk. polys, 
many ; thele, a nipple.] Polymastism.

polytocous (pŏlitt'ökŭs) $a$. [Gk. polys, many; tokos, offspring.] Prolific.

polytomous (pŏlít'ömŭs) $a$, [Gk. polys, many; tome, a cutting.] Having more than two secondary branches (bot.).

polytrichous (pǒl'îtrìk'ǔs) a. [Gk. polys, many ; thrix, hair.] Having the body covered with an even coat of cilia, as certain Infusorians (zool.).

polytrochal (pŏl'îtrō'kăl, pŏlít'rökăl) $a$. [Gk. polys, many ; trochos, wheel.] Having several circlets of cilia between mouth and posterior end, as in certain Annulates (zool.).

polytrochous,- polytrochal.

polytrophic (pǒl'îtrŏf'îk) a. [Gk. polys, many ; trophe, nourishment.] Nourished by more than one organism or substance (biol.).

polyzoarium (pǒl'ǐzöä'rĭŭm) n. [Gk. polys, many ; zoon, animal.] The skeletal system of a Polyzoan colony ; the colony itself (zool.).

polyzoie (pŏlíiōî̉ ) a. [Gk. polys, many; zoon, animal.] Appl. a colony of many zooids; $a p p l$. a spore containing many sporozoites (zool.). pome (pōm) n. [L. pomum, apple.] An inferior, indehiscent, two or more celled fleshy fruit (bot.).

pomum Adami, - the prominent ridge of the thyroid cartilage in the front of the neck, more pronounced in males (anat.).

pons (pŏnz) n. [L. pons, bridge.] A structure connecting two parts, as the pons Varolii of the cerebellum (anat.).

pontal, pontic, pontile, pontine,pert. a pons or the pons Varolii (anat.).

ponticulus (pŏntǐk'ūlŭs) $n$. [L. ponticulus, a small bridge.] A vertical ridge on the auricular cartilage (anat.).

popliteal (pŏplìt'ěăl, pŏp'lǐtēeăl) $a$. [L. poples, the ham.] Pert. the region behind and above the kneejoint ; $a p p l$. artery, glands, nerve, vein, muscle (anat.).

pore (pōr) n. [Gk, poros, channel.] A minute opening or interstice, as of the skin, of a stone. poricidal (pō'rǐsīdăl) a. [Gk. poros, channel ; L. caedere, to cut.] Dehiscing by valves or pores, as the poppy order (bot.).

poriferous (pörif'ĕrŭs) a. [Gk. poros, channel; L. ferre, to bear.] Furnished with numerous openings or pores.

poriform (pō'rífôrm) a. [Gk. poros, channel; L. forma, shape.] Resembling a pore.

porocyte (pō'rösīt) n. [Gk, poros, channel; kytos, hollow.] A perforated cell of Porifera (zool.).

porogam (pō'rögăm) n. [Gk. poros, channel; gamos, union.] A plant whose pollen-tube enters the ovule by the micropyle; $\not p p$. chalazogam (bot.).

porogamy (pörŏgămǐ) n. [Gk. poros, channel ; gamos, union.] Entrance of a pollen-tube into the ovule by the micropyle to secure fertilization (bot.).

porophyllous (pō'röfil'ǔs) $a$. [Gk. poros, channel; phyllon, leaf.] Appl. leaves with numerous transparent spots (bot.).

porta (pōr'tă) n. [L. porta, a gate.] A gate-like structure, as the transverse fissure of the liver (anat.).

portal (pör'tăl) a. [L. porta, gate.] $A p p l$. a system of veins draining the abdominal part of the alimentary canal, spleen, pancreas, and gallbladder (anat.).

portio (pōr'tǐō, pōr'shrō) n. [L.portio, portion.] A part or portion of a nerve, blood-vessel, etc. (anat.).

postabdomen (pōst'ăbdō'mĕn) $n$. [L. post, after; abdomen, belly.] In Scorpions, themetasoma or posterior narrower five segments of the abdomen (zool.).

postanal (pōstā'năl) a. [L. post, after ; anus, vent.] Situated behind the anus (zool.).

postaxial (pōstăk'šăl) a. [L. post, after;'axis, axle.] On the posterior side of the axis; as on the fibular side of the leg (anat.).

postbranchial (pōstbrăng'kǐăl)a. [L. post, after; Gk. brangchia, gills.] Behind the gill-clefts; appl. a structure arising in the pharynx (zool.).

postcardinal (pōstkâr'dīnăl) $a$. [L. 
post, after; Gk. kardia, heart.] Behind the region of the heart; $a p p l$. a dorsal vein (anat.).

postcava (pōstkä'vă) n. [L. post, after ; cavus, hollow.] The inferior or dorsal vena cava of vertebrates above fishes; the postcaval vein (zool.).

postcentral (pōstsěn'trăl) a. [L. post, after; centrum, centre.] Behind the central region; $a p p l$. a cerebral sulcus (anat.).

postcentrum (pōstsĕn'trŭm) $n$. [L. post, after; centrum, centre.] The posterior part of the vertebral centrum of certain vertebrates (zool.).

postclavicle (pōstklăv'îkl) n. [L. post, after ; claviculum, a small key.] A membrane bone occurring in the shoulder girdle of some higher Ganoids and Teleosts (zool.). postclitellian (pōst'klïtěl'iăn) a. [L. post, after ; clitellae, a pack-saddle.] Situated behind the clitellum (zool.).

postclival (pōstklî'văl) a. [L. post, after; clivus, a hill.] Appl. a fissure behind the clivus of the cerebellum (anat.).

postclypeus (pōstklīp'ěŭs) n. [L. post, after; clypeus, shield.] The posterior part of the clypeus of an Insect (zool.).

postdicrotic (pōst'dīkrŏt'îk) a. [L. post, after; Gk. dis, twice ; krotein, to beat.] $A p p l$. a secondary wave of a pulse, or that succeeding the dicrotic (phys.).

postembryonic (pōst'ĕmbrǐŏn'îk) a. [L. post, after; Gk. embryon, a foetus.] Pert. the age succeeding the embryonic (biol.).

posterior (pōstē'riŏr) a. [L. posterior, later.] Situated behind or dorsally; behind the axis; superior or next the axis (bot.).

posterolateral (pōs'těrölăt'errăl) $a$. [L. posterior, later; latus, side.] Placed posteriorly and towards the side; appl. arteries (anat.).

posteromedial (pōs'těrömē'dǐăl) $a$. [L.posterior, later; medius, middle.] Placed posteriorly and medianly ; appl. arteries (anat.).

postfrontal (pöstfrŭn'tăl) a. [L. post,
after ; frons, forehead.] Appl. a bone occurring behind the orbit of some vertebrates, articulating with the frontal (zool.).

postfurca (pōstfŭr'kă) n. [L. post, after; furca, fork.] A posterior sternal furca of an Insect (zool.).

postganglionic (pōst'găng'glǐon'îk) $a$. [L. post, after; Gk. gangglion, tumour.] Appl. fibres that leave the ganglion; $c f$. preganglionic (anat.).

postglenoid (pōstglēnoid) a. [L. post, after; Gk. glene, socket.] Behind the glenoid fossa; $a p p l$. a small process (anat.).

posthepatic (pōst'hěpăt'îk) $a$. [L. post, after; hepar, liver.] Appl. the latter part of the alimentary canal, that from the liver to the end (emb.).

posticous (pŏs'tǐkŭs) a. [L. posticus, behind.] On the outer or posterior surface ; extrorse (biol.).

postminimus (pōstmǐn'îmŭs) $n$. [L. post, after ; minimus, smallest.] A rudimentary additional digit occurring occasionally in Amphibia and Mammals (zool.).

postnodular (pōstnŏd'ūlăr) $a$. [L. post, after; nodulus, a small knot.] $A p p l$. a cerebellar fissure between nodule and uvula (anat.).

postorbital (pōstôr'bìtăl) a. [L. post, after; orbis, circle.] Behind the orbit; appl. a bone forming part of the posterior wall of the orbit (zool.).

postotic (pōstǒt' îk) a. [L. post, after ; Gk. ous, ear.] Behind the ear; $a p p l$. a system of nerves (anat.).

postparietal (pōst'părícĕtăl) a. [L. post, after; paries, wall.] Appl. paired bones sometimes occurring between parietals and interparietals (zool.).

postpatagium (pōst'pătā'jŭŭm) $n . \quad[\mathrm{L}$. post, after ; patagium, border.] In Birds, a small fold of skin extending postaxially between upper arm and trunk (zool.).

postpermanent (pōstpěr'mănĕnt) $a$. [L. post, after ; permanens, remaining.] $A p p l$. traces of a dentition succeeding the permanent in man.

postpubic (pōstpü'bǐk) a. [L. post, after; pubis, mature.] At the posterior end of the pubis; $a p p l$. 
processes of the pubis parallel to the ischium (zool.).

postpyramidal (pōst'pirămiñuăl) $a$. [L. post, after ; pyramis, pyramid.] Behind the pyramid; $a p p l$. a cerebellar fissure (anat.).

postscutellum (pōst'skūtěl'ŭm) n. [L. post, after; scutellum, a small shield.] A projection under the mesoscutellar lobe of Insects, the base of the mesophragma (zool.).

postsphenoid (pōstsfē'noid) $n$. [L. post, after; Gk. sphen, wedge.] The posterior part of the sphenoid (emb.).

post-temporal (pōst-těm'pörăl) a. [L. post, after ; temporalis, temporary.] Behind the temporal bone; $a p p l$. bone and fossa (anat.).

post-trematic (pōst-trěmăt'ík) $a$. [L. post, after; Gk. trema, a hole.] $A p p l$. nerves running in the posterior wall of the first gill cleft to the pharynx (zool.).

postzygapophysis (pōst'zīgăpŏf'íš̌s) $n$. [L. post, after; Gk. zygon, yoke; apo, from; physis, growth.] An articular process on the posterior face of the neural arch for articulation with the succeeding vertebra (anat.).

potential (pötĕn'shăl) a. [L. potens, powerful.] Latent, as appl, characteristics (biol.).

pouch (powch) n. [O.F. pouche, bag.] A bag-like structure; a sac or bladder, as the pharyngeal pouches (emb.) ; a marsupial pouch (zool.); a pod (bot.).

powder-down feathers, - those which do not develop beyond the early stage, and which disintegrate at the tip into powder (zool.).

praeabdomen (prā'-, prē'ăbdō'měn) $n$. [L. prae, before; abdomen, belly.] The anterior, broader part of the abdomen of Scorpions (zool.).

praeauricular (prâ'-, prê'ôriłk'ülăr) $a$. [L. prae, before ; auricula, a small ear.] $A p p l$. a sulcus at the anterior part of the auricular surface of the hip-bone (anat.).

praeaxial (prā-, prēăk'sǐăl) a. [L. prae, before; axis, axle.] On the anterior border or surface.

praecentrum (prä-, prēsěn'trŭm) $n$. [L. prae, before ; centrum, centre.]
The anterior part of the vertebral centrum of certain lower vertebrates (zool.).

praecoces (prā-, prēkō'sê̌z) $n$, plu. [L. prae, before ; coquere, to cook.] Newly-hatched birds able to take care of themselves; $c f$. altrices (zool.).

praecostal (prā-, prēkŏs'tăl) $a$. [L. prae, before; costa, rib.] Appl. short spurs on the basal portion of the hind wing of Lepidoptera (zool.). praecrural (prā-, prēkroor'ăl) a. [L. prae, before ; crus, leg.] On the anterior side of leg or thigh (anat.). praecuneus (prā-, prēkū'něŭs) $n$. [L. prae, before; cuneus, wedge.] The quadrate lobe of the cerebrum (anat.).

praemaxilla (prã'-, prē'măksịlă) $n$. [L. prae, before; maxilla, jaw.] The anterior portion of the upper jaw ; the os incisivum (anat.).

praemorse (prä'-, prē'môrs) a. [L. praemorsus, bitten off.] With irregular and abrupt termination, as if bitten off (bot.).

praeoccipital (prā'-, préǒóksı̌n'îtăl) $a$. [L. prae, before; occiput, back of the head.] $A p p l$. an indentation or notch anterior to the occipital pole of the cerebral hemispheres (anat.).

praeoral (prā-, prēō'răl) a. [L. prae, before; os, mouth.] Pert. the part of the body of a larva anterior to the mouth; $a p p l$. process, loop, lobe, ciliated rings (zool.).

praepubic (prā-, prēpū'bìk) a. [L. prae, before; pubes, mature.] On the anterior part of the pubis ; $a p p l$. the elongated processes of the pubis of certain vertebrates (zool.).

praepuce (prā'-, prē'püs) n. [L. praeputium, the foreskin.] That part of the integument of the penis which leaves the surface at the neck and becomes folded upon itself; the foreskin.

praeputial (prā-, prēpū'shřăl) a. [L. praeputium, the foreskin.] Pert. the praepuce; appl. glands, sac (anat.).

praeputium,- the praepuce.

praescutum (prā-, prēskū'tŭm) $n$. [L. prae, before ; scutum, shield.] 
The anterior part of the notum of an insect thoracic ring (zool.).

praesphenoid (prā-, prēsfē'noid) $n$. [L, prae, before ; Gk. sphen, wedge.] The anterior part of the sphenoid (emb.).

praesternal (prā-, prēstěr'năl) $a$. [L. prae, before ; sternum, breast-bone.] $A p p l$. the jugular notch, on the superior border of the sternum (anat.).

preaxial (prēăk'siăl) a. [L. prae, before; axis, axle.] In front of the axis.

precava (prēkā'vă) n. [L. prae, before; cavus, hollow.] The anterior vena cava; the precaval vein (zool.).

precentral (prēsěn'trăl) a. [L. prae, before ; centrum, centre.] Anteriorly to the centre; $a p p l$. a sulcus parallel to the central sulcus of the cerebrum (anat.).

prechordal (prēkôr'dăl) a. [L. prae, before ; Gk. chorde, a cord.] Anteriorly to the notochord or spinal cord ; $a p p l$. part of the base of the skull (emb.).

precipitin (prēsīp'ítĭn) $n$. [L. praeceps, headlong.] A precipitate developed in blood serum (phys.).

preclival (prēklī'văl) a. [L. prae, before; clivus, hill.] Appl. a fissure in front of the clivus of the cerebellum (anat.).

precoracoid (prēkŏrăkoid) n. [L. prae, before; Gk. korax, crow.] An anterior ventral bone of the pectoral girdle of higher vertebrates (zool.).

predelineation (prê'dēlině̌à'shŭn) $n$. [L. prae, before; de, down; linea, a line.] Formation and individualization of the various physiological molecules in definite areas and substances of the undevelopedegg, the theory of germinal localization (biol.).

predentary (prēděn'tărī) $n$. [L. prae, before; dens, tooth.] A bone at the tip of the jaw of many Dinosaurs (pal.).

preepistome (prēěp'îstōm) n. [L. prae, -before; Gk. epi, upon ; stoma, mouth.] A plate covering the basal portion of the epistome of 1 certain Arachnids (zool.).

prefloration (prétflörā'shün) n. [L. prae, before; flos, flower.] The arrangement of floral leaves in a flower-bud (bot.).

prefoliation (prē'föliă'shŭn) n. [L. prae, before; folium, leaf.] The arrangement of foliage leaves in the bud stage (bot.).

preformation theory, - the theory of evolution according to which it was supposed that each ovum of an animal contained a miniature adult, and that nourishment only was required to develop it into the perfect form (biol.).

prefrontal (prēfrŭn'tăl) a. [L. prae, before; frons, forehead.] Appl. a bone anterior to the frontal bone of certain vertebrates; $a p p l$. paired plates or scales anterior to the frontal scale in some Reptiles (zool.). preganglionic (prēgăng'gliŏn'ik) a. [L. prae, before ; Gk. gangglion, a tumour.] Appl. the (usually) medullated fibres from the spinal cord to the sympathetic cell station (anat.).

preglobulin (prēglǒb'ūlín) n. [L. prae, before ; globulus, a small globe.] A compound proteid of white blood corpuscles (phys.).

prehallux (prēhăl'ŭks) $n$. [L. proe, before; hallex, the great toe.] A rudimentary additional digit on the hind limb, in some Amphibia and Mammals (zool.).

prehalteres (prēhăl'tĕrĕz) $n$.plu. [L. prae, before; Gk. halter, a weight.] The squamae of Diptera (zool.).

prehaustorium (prē'hôsstō'rừm) $n$. [L. prae, before; haurire, to drink.] A rudimentary root-like sucker (bot.).

prehensile (prēhěn'sĭll) a. [L. prehendere, to seize.] Adapted for catching hold, as a suctorial tentacle (zool.).

prehepatic (prē'hěpăt'îk) a. [L. prae, before; hepar, liver.] Appl. that part of the digestive tract anterior to the liver (emb.).

prelacteal (prèlăk'těal) a. [L. prae, before; lac, milk.] Pert. a dentition which may occur previous to the milk dentition (emb.).

prelocalization (prēlō'kălizā'shŭn) $n$. [L. prae, before; locus, place.] The theory that certain portions of 
the ovum are predestined to develop into certain organs or parts (biol.). premaxilla (prē'măksill'ă) n. [L. prae, before; maxilla, jaw.] A paired bone anterior to the maxilla in most vertebrates (zool.).

premaxillary (prē'măksĭl'ărǐ) a. [L. prae, before; maxilla, jaw.] Anterior to the maxillae; pert. the premaxilla (zool.).

premedian (prēmē'diăn) a. [L. prae, before; medius, middle.] Anterior to the middle of a body or part ; $a p p l$. a vein in front of the median vein of certain insect wings (zool.).

premolar (prēmō'lăr) a. [L. prae, before; mola, mill.] Appl. the teeth developed between canines and molars, the bicuspid teeth (zool.).

prenasal (prēnā'zăl) a. [L. prae, before; nasus, nose.] A bone developed in the septum in front of the mesethmoid in certain Mammals (zool.).

preocular (prēŏk'ülăr) a. [L. prae, before; oculus, eye.] In front of the eye ; as antennae, scales (zool.).

preopercle,-preoperculum.

preoperculum (prēöpër'kūlŭm) n. [L. prae, before ; operculum, cover.] The anterior membrane bone of the operculum or gill-cover (zool.). preoral (prēō'răl) a. [L. prae, before ; $o s$, mouth.] Situated in front of the mouth; appl. cilia, etc. (zool.).

preorbital (prēôr'bităl) a. [L. prae, before; orbis, circle.] Anterior to the orbit; $a p p l$. a membrane bone of Teleosts (zool.).

prepatagium (prēpătā'jüŭm) n. [L. prae, before; patagium, border.] The alar membrane, or fold of skin extending between upper arm and forearm of Birds (zool.).

preplacental (prēplăsěn'tăl) a. [L. prae, before ; placenta, a flat cake.] Occurring before placenta formation or development (emb.).

prepollex (prēpöl'ěks) $n$. [L. prae, before; pollex, thumb.] A rudimentary additional digit occurring sometimes preaxially to the thumb digit of certain Amphibians and Mammals (zool.).

prepotency (prēpötěnsĩ) n. [L. prae, before; potens, powerful.] The fertilization of a flower by pollen from another flower in preference to pollen from its own stamens, when both are offered simultaneously (bot.) ; capacity of one parent to transmit more characteristics to the offspring than the other parent (biol.).

prepotent (prēpō'těnt) a. [L. prae, before; potens, powerful.] Transmitting the majority of characteristics (biol.); $a p p l$. a flower exhibiting a preference for cross-pollination (bot.).

prepubis (prēpü'bĭs) n. [L. prae, before ; pubes, mature.] Part of the pelvic girdle of certain Reptiles, anterior to the pubis (zool.).

prepyramidal (prē'pirăm'ǐdăl) $a . \quad$ [L. prae, before ; pyramis, pyramid.] In front of the pyramid; $a p p l$. a cerebellar fissure (anat.).

presphenoid (prēsfēnoid) n. [L. prae, before; Gk. sphen, wedge.] In many vertebrates, a cranial bone anterior to the basisphenoid (zool.).

pressor (prěs'ŏr) a. [L. pressare, to press.] Appl. nerve-fibres which, when stimulated, cause a rise of arterial pressure (phys.).

pressure (prěsh'ŭr) n. [L. pressare, to press.] Tension in plant tissue caused by the turgidity of the cells (bot.).

presternal (prēstěr'năl) a. [L. prae, before; sternum, breast - bone.] Situated in front of the sternum or breast-bone; pert. the anterior part of the sternum (zool.).

presternum (prēstĕr'nŭm) n. [L. prae, before ; sternum, breast-bone.] The manubrium, or anterior part of a sternum (zool.).

pretrematic (prē'trĕmăt'îk) a. [L. prae, before ; Gk. trema, hole.] $A p p l$. nerves running in the anterior wall of the first gill cleft to the pharynx (zool.).

prevertebral (prēvĕr'těbrăl) a. [L. prae, before ; vertebra, a vertebra.] Pert. or situated in the region in front of the vertebral column; $a p p l$. a portion of the base of the skull (emb.) ; appl. ganglia of the sympathetic system (zool.).

prezygapophysis (prēzîgăpŏf'išsis) $n$. [L. prae, before ; Gk. zygon, yoke ; 
apo, from; physis, growth.] A process on the anterior face of the neural arch for articulation with the vertebra in front (anat.).

prickle (prik'l) $n$. [A.S. prica, a point.] A pointed process arising through epidermal tissue (bot.).

prickle cells, - cells of the deeper layers of stratified squamous epithelium: they have short, fine, marginal, connecting fibrils (anat.).

primary (prīmărĩ) a. [L. primus, first.] First; principal ; original ; $a p p l$. axis, feathers, meristem, root, wood (biol.).

primaxil (prīmăk'sĩl) n. [L. primus, first; axilla, armpit.] The first axillary arm of a Crinoid (zool.).

primibrachs (prî'mibrăks) n.plu. [L. primus, first; brachia, arms.] In Crinoids, all brachials up to and including the first axillary (zool.).

primine (prîmin) $n$. [L. primus, first.] The external integument of an ovule; occasionally $a p p l$. the first-formed or internal coat (bot.).

primite (prĭm'ît) $n$. [L. primus, first.]

The first of any pair of individuals of a catenoid colony in the pseudoconjugation of Gregarinida, in which the protomerite of one (the satellite) becomes attached to the deutomerite of another (the primite) (zool.).

primitive (prim'itǐv) a. [L.primitivus, early.] Of earliest origin; appl. groove, knot, streak, aorta, palate, ventricle (emb.).

primordial (prīmôr'dĭla $a$. [L. primordium, a beginning.] Primitive ; original; first commenced; appl. ova (emb.), cell, utricle (bot.).

primordium (prīmôr'dǔum) $n$. [L. primordium, a beginning.] Original form; a structure when first indicating assumption of form; anlage (emb.).

priodont (príödŏnt) a. [Gk. prion, saw; odous, tooth.] Saw-toothed; appl. stag-beetles with smallest development of mandible projections (zool.).

prismatic (prizmăt'îk) a. [L.prisma, prism.] Like a prism; $a p p l$. leaves (bot.) ; consisting of prisms, as the prismatic layer of shells (zool.). proamnion (prōăm'niŏn) n. [Gk. pro, before; amnion, a vessel for receiving blood.] An area of blastoderm in front of the head of early embryos of higher vertebrates (emb.).

proangiosperm (prōăn'jīöspĕrm) $n$. [Gk. pro, for ; anggeion, vessel ; sperma, seed.] A fossil type of angiosperm (bot.).

proatlas (prōăt'lăs) $n$. [Gk. pro, before; Atlas.] A median bone intercalated between atlas and skull in certain Reptiles (zool.).

proboscidiform (prō'bǒsĭd'ifôrm) $a$. [Gk. proboskis, trunk; L. forma, shape.] Proboscis-like; appl. Infusorians with tentacles on a proboscis-like process (zool.).

proboscis (prōbŏs'ís) n. [Gk. proboskis, trunk.] A trunk-like process of the head, as of Insects, Annelids, Nemerteans, Elephants (zool.).

procambial strand, - a longitudinal strand of elongated cells near the periphery of the plerome of a vascular bundle; a desmogen strand (bot.).

procambium (prökăm'bǐŭ) n. [L. pro, before; L.L. cambium, nutriment.] The tissue from which vascular bundles are developed (bot.).

procarp (prō'kârp) n. [Gk. pro, for ; karpos, fruit.] The female organ of red Seaweeds, a one or more celled structure containing no differentiated oosphere (bot.).

process (prō'sěs) $n$. [L. pro, forth ; cedere, to go.] An outgrowth, prolongation, projection, or eminence of any structure.

processus, - a process.

prochorion (prōkō'riŏn) n. [Gk. pro, before; chorion, skin.] An enveloping structure of the blastodermic vesicle preceding formation of a chorion (emb.).

prochromatin (prōkrō'mătǐn) $n . \quad[\mathrm{Gk}$. pro, for ; chroma, colour.] Plasmosome substance (cyt.).

procoelous (prōsēllús) a. [Gk. pro, before; koilos, hollow.] With concave anterior face, as vertebral centra (zool.).

procoracoid (prōkŏr'ăkoid) $n$. [Gk. pro, before; korax, crow.] An 
anteriorly directed process from the glenoid fossa of Urodeles (zool.). procryptic (prōkrǐp'tǐk) a. [Gk. pro, for; kryptos, hidden.] With coloration adapted for concealment (zool.). proctal (prŏk'tăl) a. [Gk. proktos, anus.] Anal; appl. fish fins (zool.).

proctodaeum (prŏk'tödē'ŭm) n. [Gk. proktos, anus; odos, a way.] The latter part of the embryonic alimentary canal; formed by anal invagination ; a similar ectodermlined part in certain invertebrates (zool.).

procumbent (prōkŭm'běnt) $a$. [L. pro, forward ; cumbens, lying down.] Prostrate ; trailing on the ground; appl. stems (bot.).

prodentine (prōdèn'tín) n. [L. pro, before ; dens, tooth.] A layer of uncalcified matrix capping tooth cusps before the formation of dentine (anat.).

proembryo (prōĕm'brïö) n. [Gk. pro, for; embryon, a foetus.] An embryonic structure preceding the true embryo; the first results of spore segmentation (bot.).

progamete (prō'gămēt') \%. [Gk. pro, before; gamos, union.] A structure giving rise to gametes by abstriction, in certain Fungi (bot.).

progamic (prōgăm'îk) a. [Gk. pro, before; gamos, union.] Appl. brood-division for gamete production (zool.).

progeotropism (prōjjēōt'röpǐzm) $n$. [Gk. pro, for ; ge, earth; trope, a turning.] Positive geotropism(bot.).

proglottides (prōglŏt'ìděz) $n$. plu. [Gk. pro, for ; glotta, tongue.] The propagative body-segments of a tapeworm, formed by strobilization from the neck (zool.); sing. proglottis.

prognathous (prōgnằth'ŭs) a. [Gk. pro, forth; gnathos, jaw.] Having prominent or projecting jaws.

prohydrotropism (prōhīdrŏt'röpĭzm) n. [Gk. pro, for; hydor, water; trope, a turning.] Positive hydrotropism (bot.).

projectile (prōjēk'tîl) a. [L. pro, forth; jacere, to throw.] Protrusible; that can be thrust forward (zool.). projection (prōjěk'shŭn) $n$. [L. pro, forth; jacere, to throw.] The referring of stimulations to endorgans of sense by means of the connecting projection nerve-fibres (phys.).

proleg (prō'lĕg) $n$. [L. pro, for ; M.E. leg, a leg.] An unjointed abdominal appendage of arthropod larvae (zool.).

proliferate (prōlif'ěrāt) v. [L. proles, offspring ; ferre, to bear.] To reproduce repeatedly (biol.).

proliferation (prōlǐf'ěrā'shŭn) $n . \quad[\mathrm{L}$. proles, offspring ; ferre, to bear.] Prolification; increase by frequent and repeated reproduction of any kind (biol.).

proliferous (prōliff'ĕrŭs) a. [L. proles, offspring ; ferre, to bear.] Multiply. ing quickly (biol.); appl. bud-bearing leaves; developing supernumerary parts abnormally (bot.).

promitosis (prōminto'sĭs) n. [Gk. pro, for ; mitos, thread.] A simple type of mitosis exemplified in nuclei of protokaryon type (cyt.).

promontory (prŏm'ŏntörǐ) $n$. [L. pro, forth; mons, mountain.] A prominence or projection, as of the cochlea (anat.).

promorphology (prō'môrfŏl'öjī) $n$. [Gk. pro, for ; morphe, form ; logos, discourse.] Morphology from the geometrical standpoint.

promuscis (prōmŭs'ís) $n$. [L. pro. muscis, a proboscis.] The proboscis of Hemiptera (zool.).

promycelium (prō'mīsē'liŭm) n. [Gk. pro, for ; mykes, mushroom.] The mycelium developed from a zygospore, itself giving rise to a sporangium (bot.).

pronate (prō'nāt) a. [L. pronare, to bend forward.] Prone; inclined (biol.).

pronation (prönā'shŭn) n. [L. pronare, to bend forward.] The act by which the palm of the hand is turned downwards by means of pronator muscles ; $c f$. supination (phys.).

pronephric (prōněf'rīk) a. [Gk. pro, before; nephros, kidney.] Pert. or in the region of the pronephros; $a p p l$. duct, tubules (emb.).

pronephros (prōněf'rŏs) $n$. [Gk. pro, before; nephros, kidney.] The 
head-kidney of embryonic life, arising from mesomeric somites, functional for a time in lower vertebrates, later replaced by mesoor meta-nephros (emb.).

pronotum (prōnō'tŭm) n. [Gk. pro, before; noton, back.] The dorsal part of the prothorax of Insects (zool.).

pronucleus (prōnū'klěŭs) n. [L. pro, before ; nucleus, kernel.] The eggnucleus or sperm-nucleus during fertilization (emb.).

pronymph (prṓnìmf) n. [L. pro, before; nympha, a maid.]. The stage in the metamorphosis of Diptera preceding the nymph stage (zool.).

proostracum (prōŏs'trăkŭm) n. [Gk. pro, for; ostrakon, a testacean shell.] The horny pen of a decapod dibranchiate shell or Belemnite (pal.).

prootic (prōōt'îk) n. [Gk. pro, before ; ous, ear.] The anterior bone of the otic capsule in vertebrates (zool.).

propagative (prŏp'ăgā'tǐv) $a$. [L. propagare, to propagate.] Reproductive; $a p p l$. a cell, a phase, an individual of a colony (biol.).

propagulum (prŏpăg'ūlüm) $n$. [L. propagare, to propagate.] A bud or shoot capable of developing into an adult (bot.).

propatagium,- - a prepatagium.

prophase (prō'fāz) n. [Gk. pro, before ; phasis, appearance.] The preparatory changes, the first stage in mitosis (cyt.).

prophloem,--protophloem.

prophototropism (prō'fötŏt'röpǐzm) $n$. [Gk. pro, for ; phos, light ; trope, a turning.] Positive phototropism (bot.).

prophyllum (prōfîl'üm) n. [Gk. pro, for; phyllon, leaf.] A small bract (bot.).

propleuron (prōploor'ŏn) n. [Gk. pro, before; pleura, side.] A lateral plate of the prothorax of Insects (zool.).

propodeon (prōpō'děŏn) $n$. [Gk. pro, before; pous, foot.] An abdominal segment of Hymenoptera in front of the petiole or podeon; otherwise the median segment, Latraille's segment, etc. (zool.). propodeum,-propodeon.

propodite (prō'pödìt) n. [Gk. pro, before; pous, foot.] In Malacostraca, the segment of a foot sixth from the body (zool.).

propodium (prôpō'dium) n. [Gk. pro, before; pous, foot.] The small anterior part of a Molluscan foot (zool.).

propterygium (prō'tĕrij'iŭum, prŏp'těrij'iŭm) n. [Gk. pro, before ; pterygion, a little wing.] The foremost of three basals supporting the pectoral fin of Elasmobranchs (zool.).

propulsive pseudopodium, - in some Neosporidia, a pseudopodium developed posteriorly which by its elongation pushes the body forward (zool.).

propupa (prōpū'pă) n. [L. pro, before; pupa, a puppet.] A stage in insect metamorphosis preceding the pupa stage (zool.).

propygidium (prō'pǐjìd'ium) n. [Gk. pro, before ; pyge, the rump.]. The dorsal plate anterior to the pygidium in Coleoptera (zool.).

prorachis (prōrăk'iss) n. [Gk. pro, before; rhachis, spine.] The face of Pennatulacea which is sterile and coincides with the asulcar aspect of the terminal zooid (zool.).

proscapula (prōskăp'ūlă) $n$. [L. pro, before; scapula, shoulder-blade.] The clavicle (zool.).

proscolex (prōskólěks) n. [Gk. pro, before; skolex, worm.] A rounded cyst with fluid-filled cavity, a stage in the development of the Tapeworm (zool.).

prosecretin (prō'sēkrē'tǐn) n. [L. pro, before; secretus, separated.] The precursor of secretin ( $p$ hys.).

prosencephalon (prös'énkěf'ălŏn, -sĕf-) n. [Gk. pro, before; engkephalon, brain.] The telencephalon, or forebrain (anat.).

prosenchyma (prösĕng'kĭmă) n. [Gk. pros, near; engchyma, infusion.] Tissue of prosenchymatous cells.

prosenchymatous (prös'ěngkǐm'ătŭs) a. [Gk. pros, near; engchyma, infusion.] $A p p l$. elongated pointed cells, with thin or thick cell-walls, in plant tissue (bot.).

prosethmoid (prösěth'moid) n. [Gk. pros, near; ethmos, sieve.] An 
anterior cranial bone of Teleosts (zool.).

prosiphon (prōsīfŏn) n. [Gk. pro, for ; siphon, tube.] A spout-like prolongation of the edges of the mantle-flaps of certain Molluscs (zool.).

prosocoel (prös'ösēl) n. [Gk. pros, near; koilos, hollow.] A narrow cavity in the epistome of Molluscoidea, the first main part of the coelom (zool.).

prosodetic (prös'ödět'îk) a. [Gk. prosodos, advance.] Anterior to the beak; $a p p l$. certain bivalve ligaments (zool.).

prosodus (prös'ödŭs) $n$. [Gk.prosodos, advance.] A delicate canalicule between chamber and incurrent canal in some Sponges (zool.).

prosoma (prōsō'mă) n. [Gk. pro, before ; soma, body.] The anterior part of the body; a cephalothorax (zool.).

prosopyle (prös'öpill) n. [Gk. proso, forward; pyle, gate.] The aperture of communication between adjacent incurrent and flagellate canals in some Sponges (zool.).

prostalia (prŏstā'liă) n. plu. [L. pro, forth; stare, to stand.] Projecting spicules of Hexactinellids (zool.).

prostate (prǒs'tāt) a. [L. pro, before ; stare, to stand.] Appl. a gland placed around the commencement of the male urethra in the pelvic cavity (anat.).

prostatic (pröstăt'îk) a. [L. pro, before; stare, to stand.] Pert. the prostate gland; $a p p l$. duct, nerve, sinus, utricle (anat.).

prostemmate (prōstěm'āt) a. [Gk. pro, before; stemma, wreath.] $A p p l$. an ante-ocular structure or organ of some Collembola, of doubtful function (zool.).

prostemmatic,-prostemmate.

prosternum (prōstěr'nŭm) $n$.

[L. pro, before ; sternum, breast-bone.] The ventral part of the prothorax of Insects (zool.).

prosthion (prŏs'thiŏn) $n$. [Gk. prosthios, foremost.] The alveolar point; the middle point of the upper alveolar arch (anat.).

prostomiate (prōstōmiāt) a. [Gk. pro, before; stoma, mouth.] Having a portion of the head in front of the mouth (zool.).

prostomium (prōstō'mǔum) n. [Gk. pro, before; stoma, mouth.] In Worms and Molluscs, the part of the head anterior to the mouth (zool.).

prostrate (prŏs'trāt) a. [L. prostratus, thrown down.] Procumbent; trailing on the ground (bot.).

protandrism (prōtăn'drizm) $n$. [Gk. protos, first ; andros, male.] Protandry; sometimes exclusively in zoological application (biol.).

protandrous (prōtăn'drŭs) a. [Gk. protos, first; andros, male.] Exhibiting protandry (biol.).

protandry (prōtăn'drǐ) $n$. [Gk. protos, first ; andros, male.] Condition of hermaphrodite plants and animals where the male elements mature and are shed before the female elements mature (biol.).

protegulum (prōtěg'ūlŭm) n. [L. pro, before; tegulum, a covering.] The semicircular or semielliptical embryonic shell of Brachiopods (zool.). proteid (prō'těrid) n. [Gk. protos, first; eidos, resemblance.] The nitrogenous material of plant cells ; albuminous substance; a term subject to varying restrictions in different authors (phys.).

protein (prō'tê̌in) n. [Gk. protos, first.] Albuminous substance; a nitrogenous compound of cell protoplasm; the sum-total of nitrogen present in protoplasm; a term of variable application (phys.).

proteolytic (prō'těölìt'îk) a. [Gk. protos, first; lysis, a loosing.] $A p p l$. ferments which change proteins into proteoses and peptones, as pepsin, trypsin (phys.).

proteose (prōtễō) n. [Gk. protos, first.] The first cleavage product of the action of hydrolysis on a protein molecule (phys.).

proterandric (prō'tĕrăn'drìk) a. [Gk. proteros, earlier; andros, male.] $A p p l$. hermaphroditism in which ovaries and testes are functional at different times (biol.).

proterandrous,- - protandrous.

proteranthous (prō'tĕrăn'thŭs) $a$. [Gk. proteros, earlier; anthos, flower.] Flowering before foliage leaves appear (bot.). 
proteroglyph (prō'těröglif́) a. [Gk. proteros, earlier ; glyphein, to carve.] 1 Having the specialized fang teeth permanently erect; opp. soleno-

-.. glyph (zool.).

proterogyny,-protogyny.

prothallium, - prothallus.

prothalloid (prōthăl'oid) a. [Gk. pro, before ; thallos, young shoot ; eidos, form.] Like a prothallium (bot.).

prothallus (prōthăl'ŭs) n. [Gk. pro, before; thallos, young shoot.] A small, thin, fleshy mass developed from spores of ferns, itself producing antheridia and archegonia (bot.).

protheca (prōthë'kă) n. [Gk. pro, before; theke, a box.] The rudiment of coral formation ; the basal part of the coral calicle (zool.).

prothorax (prōthōrăks) n. [Gk. pro, before ; thorax, breast.] The anterior thoracic segment of Arthropods (zool.).

prothrombin (prōthrŏm'bin) n. [Gk. pro, before; thrombos, clot.] Thrombogen (phys.).

prothyalosome (prōthīălösōm) $n$. [Gk. pro, before; hyalos, glass; soma, body.] The area surrounding the germinal spot in the germinal vesicle $(e m b$.$) .$

protista (prōtís'tă) n. plu. [Gk. protistos, first of all.]. The assemblage of simple and primitive living beings from which animals and plants arise (biol.).

protobasidium (prō'töbăsid'iưm) $n$. [Gk. protos, first ; basidion, a small pedestal.] A basidium producing a mycelium of four cells from each of which a sporidium is developed by abstriction (bot.).

protoblast (prō'töblăst) $n$. [Gk.protos, first; blastos, bud.] A naked cell, devoid of membrane; the first or single-cell stage of an embryo; the internal-bud stage in the life-history of Neosporidia (zool.).

protocercal (prō'tösĕr'kăl) a. [Gk. protos, first; kerkos, tail.] Having the caudal fin divided into two equal lobes; diphycercal, the primitive form of caudal fin (zool.).

protocerebrum (prō'tösěr'ěbrŭm) $n$. [Gk. protos, first; L. cerebrum, brain.] The anterior pair of ganglionic centres of Crustacea (zool.). protocnemes (prō'töknēmz) n. plu. [Gk. protos, first; kneme, a wheelspoke.] The six primary pairs of mesenteries of Zoantharia (zool.).

protoconch (prōttökŏngk) $n$. [Gk. protos, first; konche, shell.] The larval shell of Molluscs, indicated by the cicatrix on the adult shell (zool.).

protocone (prō'tökōn) n. [Gk. protos, first; konos, cone.] The inner cusp of an upper jaw molar (anat.).

protoconid (prō'tökō'nìd) n. [Gk. protos, first; konos, cone ; eidlos, form.] The external cusp of a lower jaw molar (anat.).

protoconule (prō'tökō'nūl) $n_{幺}$ [Gk. protos, first ; konos, cone.] An anterior intermediate cusp of an upper jaw molar (anat.).

protocranium (prō'tökrā'nǐŭm) $n$. [Gk. protos, first; kranion, skull.] A name sometimes given to the posterior part of the epicranium of Insects (zool.).

protoepiphyte (prō'töěp'ífīit) n. [Gk. protos, first ; epi, upon; phyton, plant.] A plant growing upon another and getting all its nourishment from that other (bot.).

protogenic (prō'töjĕn'îk) a. [Gk. protos, first ; genos, offspring.] Persistent from the beginning of development onwards (biol.).

protogynous (prōtŏj'innŭs) a. [Gk. protos, first; gyne, woman.] Having female elements mature before male (biol.).

protogyny (prōtŏj'ínǐ) n. [Gk. protos, first ; gyne, woman.] Condition of hermaphrodite plants and animals in which female elements mature and are spent before maturation of male elements (biol.).

protokaryon (prō'tökăr'iŏn) n. [Gk. protos, first; karyon, nut.] A simple or primitive nucleus consisting of a mass of chromatin suspended in nuclear sap, as in small limax Amoebae (cyt.).

protoloph (prō'tölŏf) n. [Gk. protos first ; lophos, crest.] The anterior transverse crest of upper jaw molars (anat.).

protomala (prō'tömā'lă) n. [Gk. protos, first; L. mala, cheek.] A myriapod mandible (zool.). 
protomerite (prōtŏm'ĕrīt) $n$. [Gk. protos, first; meros, part.] The anterior part of the medullary protoplasm of adult Gregarines; $c f$. deutomerite (zool.).

protomonostelic (prō'tömŏn'östěl'îk) a. [Gk. protos, first ; monos, alone ; stele, column.] Appl. a stem or root with a protostele or central cylinder (bot.).

protonema (prō'tönē'mă) n. [Gk. protos, first ; nema, thread.] The germination structure of Mosses, from which the moss plant buds (bot.).

protonematoid (prō'töněm'ătoid) $a$. [Gk. protos, first; nema, thread; eidos, form.] Like a protonema (bot.).

protonephridial (prō'töněfrĭd'ǐăl) $a$. [Gk. protos, first ; nephros, kidney.] $A p p l$. the excretory water-vascular system of Flat-worms (zool.).

protopepsia (prō'töpĕp'siă) n. [Gk. protos, first ; pepsis, a digesting.] Solution and alteration of foodmaterial accomplished in the digestive tract ( $p$ hys.).

protophloem (prōtöffō'ěm) n. [Gk. protos, first ; phloios, tree-bark.] The first phloem elements of a vascular bundle (bot.).

protophyte (prō'töfìt) n. [Gk. protos, first ; phyton, plant.] A unicellular vegetable organism or primitive plant (bot.).

protoplasm (prō'töplăzm) n. [Gk. protos, first ; plasma, form.] Cell substance; cytoplasm and karyoplasm (cyt.).

protoplasmic (prō'töplăz'mǐk) a. [Gk. protos, first ; plasma, form.] Pert. or consisting of protoplasm (biol.).

protoplast (prō'töplăst) n. [Gk, protos, first; plastos, formed.] An energid; a living uninucleate primitive protoplasmic unit (biol.).

protopođite (prōtŏp'ödīt) n. [Gk. protos, first ; pous, foot.] The basal segment of a typical crustacean limb (zool.).

protospore (prō'töspōr) n. [Gk.protos, first; sporos, seed.] A spore of the first generation; a myceliumproducing spore (bot.).

protostele (prō'töstēl) n. [Gk. protos, first; stele, column.] The concentric bundle or central cylinder of vascular tissue of most roots and some stems (bot.).

prototheca (prō'töthē'kă) n. [Gk. protos, first; theke, box.] A skeletal cup-shaped plate at the aboral end of a coral embryo, the first skeletal formation (zool.).

prototroch (prō'tötrŏk) n. [Gk. protos, first ; trochos, wheel.] A pre-oral circlet of cilia of a trochosphere or trochelminth larva (zool.).

prototrophic (prō'tötrŏf'îk) a. [Gk. protos, first ; trophe, nourishment.] Nourished from one supply or in one manner only; appl. bacteria (biol.).

prototype (prōtötīp) n. [Gk. protos, first; typos, model.] An original type species or example; an ancestral form (biol.).

protovertebrae (prō'tövĕr'těbrē) $n$. plu. [Gk. protos, first; L. vertebra, a vertebra.] A series of primitive segments in a vertebrate embryo, once thought to be the beginnings of vertebrae (emb.).

protoxylem (prō'tözīlěm) n. [Gk. protos, first; xylon, wood.] Primary. xylem lying next the pith of stems (bot.).

protozoaea (prō'tözō'ēă) n. [Gk. protos, first; zoon, animal.] A stage in the life-history of certain Arthropods succeeding the free-swimming nauplius (zool.).

protozoology (prōtözōōl'öjǐ) n. [Gk. protos, first ; zoon, animal; logos, discourse.] The department of Zoology dealing with the simplest animal organisms.

protozoon (prō'tözō'ŏn) $n$. [Gk. protos, first ; zoon, animal.] A unicellular animal organism (zool.).

protractor (prōtrăk'tŏr). n. [L. pro, forth; tractus, drawn out.] A muscle which draws out or extends a part (anat.).

protriaene (prō'triēn) n. [Gk. pro, before; triaina, trident.] A triaene with anteriorly-directed branches (zool.).

proventriculus (prō'vĕntrik'üŭŭs) $n$. [L. pro, before; ventriculus, a small stomach.] In Insects, the digestive chamber anterior to the stomach; in Worms, that anterior to the 
gizzard; in Birds, the glandular stomach anterior to the gizzard (zool.).

provineulum (prōving'kūlŭm) $n$. [L. pro, before; vinculum, a chain.] A primitive hinge of young stages of certain Lamellibranchia (zool.).

proximal (prŏk'simmăl) a. [L. proximus, next.] Nearest the body or centre ; opp. distal (biol.).

pruinose (proo'ínōs) a. [L. pruina, hoar-frost.] Covered with whitish particles or globules; covered by bloom (bot.).

psalterium (sôlté'rǐŭm, săl-) n. [L. psalterium, a psalter.] The third stomach of Ruminants, the omasus, or manyplies (zool.); the lyra, a thin triangular lamina joining lateral portions of the fornix (anat.).

psammophilous (sămŏf'ílŭs, psăm-) $a$. [Gk. psammos, sand; philos, loving.] Thriving in sandy places (bot.).

psammophyte (săm'öfît, psăm-) n. [Gk. psammos, sand; phyton, plant.] A plant growing in dry, sandy ground (bot.).

pseudambulacrum (sū'dămbūlā'krŭm, psū-) n. [Gk. pseudes, false; L. ambulare, to walk.] A term for the lancet-plate, with adhering sideplates and covering plates of Blastoidea (zool.).

pseudannual (sūdăn'üăl, psū-) $n$. [Gk. pseudes, false; L. annus, year.] A plant which completes its growth in one year but provides a bulb or other means of surviving winter (bot.).

pseudaposematic (sūdăp'ösĕmăt'îk, psū-) a. [Gk. pseudes, false ; apo, from; sema, sign.] Imitating the warning coloration or other protective features of hurtful animals (biol.).

pseudaxis (sūdăk'sǐs, psū-) n. [Gk. pseudes, false; axis, axle.] An apparent main axis (bot.).

pseudhaemal (sūdhē'măl, psū-) $a$. [Gk. pseudes, false; haima, blood.] $A p p l$. the vascular system of certain Worms and Echinoderms (zool.).

pseudholoptic (sư'dhölŏp'tìk, psū-) $a$. [Gk. pseudes, false; holos, whole ; optikos, relating to sight.] Inter- mediate between holoptic and dichoptic, conditions in the eyes of Diptera (zool.).

pseudimago (sü'dĭmā'gö, psū-) $n$. [Gk. pseudes, false ; L. imago, image.] A stage between pupa and imago in the metamorphosis of certain Insects (zool.).

pseudoalveolar (sū'döălvē'ölăr, psū-) a. [Gk. pseudes, false ; L. alveus, a hollow.] $A p p l$. a structure of cytoplasm containing starch grains or deutoplasm spheres (cyt.).

pseudoaquatic (sư'döăkwăt'ik, -kwôt-, psū-) a. [Gk. pseudes, false; L. aqua, water.] Thriving in moist ground (bot.).

pseudobrachium (sū'döbrā'kĭŭm, psū-) n. [Gk. pseudes, false; brachion, arm.] The kind of arm formed from elongated pterygials of the pectoral fin of Pediculates (zool.).

pseudobranchia (sū'döbrăng'kǐă, psū-) n. [Gk. pseudes, false ; brangchia, gills.] An accessory gill of some Fishes, not respiratory in function (zool.).

pseudobulb (sū'döbŭlb, psū-) n. [Gk. pseudes, false ; L. bulbus, bulb.] A thickened internode of Orchids for storage of water and reserves (bot. $)$.

pseudobulbil (sū'döbǔl'būl, psū-) n. [Gk. pseudes, false ; L. bulbus, bulb.] An outgrowth of some Ferns, a substitute for sporangia (bot. .).

pseudobulbous (sū'döbül'bǔs, psū-) $a$. [Gk. pseudes, false ; L. bulbus, bulb.] Adapted to xerophytic conditions through development of pseudobulbs (bot.).

pseudocarp (sū'dökârp, psū-) n. [Gk. pseudes, false; karpos, fruit.] A false fruit, or one in which other parts than the ovary assist in formation (bot.).

pseudocentrous (sư'dösĕn'trŭs, psū-) $a$. [Gk. pseudes, false; L. centrum, centre.] $A p p l$. vertebrae composed of two pairs of arcualia meeting and forming a suture laterally ( $p a l$.$) .$

pseudochromatin,- prochromatin (cyt.).

pseudoconch (sū'dökŏngk, psū-) $n$. [Gk. pseudes, false ; kongche, shell.] A structure developed above and behind the true concha in Crocodiles (zool.). 
pseudocone (sū'dökōn, psū-) n. [Gk. pseudes, false; konos, cone.] A soft gelatinous cone occurring in numbers in some insect eyes (zool.).

pseudoconjugation (sū'dökǒnjoogā'shŭn, psū-) n. [Gk. pseudes, false ; L. cum, with ; jugum, yoke.] Conjugation of Sporozoa in which two individuals, temporarily and without true fusion, join end to end, protomerite to deutomerite, or side to side (zool.).

pseudocostate (sū'dökŏs'tāt, psū-) $a$. [Gk. pseudes, false; L. costa, rib.] False-veined; having a marginal vein uniting all others (bot.).

pseudocyst (sū'dösĭst, psū-) n. [Gk. pseudes, false; kystis, bladder.] A residual protoplasmic mass which swells and ruptures, liberating spores of Sporozoa (zool.).

pseudodeltidium (sū'döděltǐd'iuum, psū-) n. [Gk. pseudes, false ; delta, D.] A plate partly or entirely closing the deltidial fissure in the ventral valve of certain Testicardines (zool.).

pseudoderm (sū'dödĕrm, psū-) n. [Gk. pseudes, false; derma, skin.] A kind of covering or skin of certain compact sponges, formed also towards the pseudogastric cavity (zool.).

pseudodont (sū'dödǒnt, psū-) $a$. [Gk. pseudes, false ; odous, tooth.] Having false or horny teeth, as Monotremes (zool.).

pseudofoliaceous (sū'döfōliâ'shŭs, psū-) a. [Gk, pseudes, false; L. folium, leaf.] With expansions resembling leaves (bot.).

pseudogaster (sū'dögăs'tĕr, psū-) $n$. [Gk. pseudes, false; gaster, stomach.] An apparent gastral cavity of certain Sponges, opening to the exterior by a pseudoosculum and having the true oscula opening into itself (zool.).

pseudogastrula (sū'dögăs'troolă, psü-) n. [Gk. pseudes, false; gaster, stomach.] The stage of Sycon development when the archaeocytes become completely enclosed by the flagellate cells (zool.).

pseudoheart, - the axial organ of Echinoderms (zool.). pseudomanubrium (sū'dömănū'brǐŭm, psū-) n. [Gk. pseudes, false; L. manubrium, handle.] The manubrium considered as a process of the subumbrella where the former contains the gastric cavity - in certain Trachylinae (zool.).

pseudometamerism (sū'dömĕtăm' ĕrìzm, psū-) n. [Gk. pseudes, false ; meta, between ; meros, part.] Apparent serial segmentation; an approximation to metamerism, as in certain Flat-worms (zool.).

pseudomonocotyledonous (sü'dömŏn'ökŏtîlē'dönŭs, psū-) a. [Gk. pseudes, false ; monos, alone ; kotyledon, a cup-like hollow.] With two cotyledons coalescing to appear as one (bot.).

pseudomonocyclic (sū'dömŏn'ösĭk'lǐk, psū-) a. [Gk. pseudes, false ; monos, alone; kyklos, circle.] Appl. Crinoids with infrabasals absent in adults but present in the young or in near ancestors (zool.).

pseudonavicella (sū'dönăvǐsěl'ă, psū-) n. [Gk. pseudes, false; L. navicella, small boat.] A small boat-shaped spore containing sporozoites, in Sporozoa (zool.).

pseudonuclein,-paranuclein (cyt.). pseudonucleoli (sū'dönūklēölī, psū-) n. plu. [Gk. pseudes, false; L. nucleus, kernel.] Knots or granules in nuclear reticulum not true nucleoli (cyt.).

pseudonychium (sū'dönǐk'iŭm, psü-) $n$. [Gk. pseudes, false ; onyx, claw.] A lobe or process between claws of Insects (zool.).

pseudoosculum (sü'döŏs'kūlŭm, psū-) n. [Gk. pseudes, false; L. osculum, small mouth.] The exterior opening of a pseudogaster (zool.).

pseudoparenchyma (sü'döpărĕng'kĭmă, psū-) n. [Gk. pseudes, false : para, beside ; engchyma, infusion.] A tissue-like collection of hyphae resembling parenchyma (bot.).

pseudoperculum (sū'döpěr'kūlŭm, psū-) n. [Gk. pseudes, false; L. operculum, lid.] A structure resembling an operculum or closing membrane (zool.).

pseudoperianth (sū'döpĕr'iănth, psū-) n. [Gk. pseudes, false; peri, round; anthos, flower.] An archegonium- 
investing envelope of certain Liverworts (bot.).

pseudoperidium (sū'döpěrìd'ǐŭm, psū-)

n. [Gk. pseudes, false; peridion, small wallet.] The aeciospore envelope of certain Fungi (bot.).

pseudoplasmodium (sū'döplăzmō'diŭm, psū-) n. [Gk. pseudes, false ; plasma, form.] An aggregation of amoebulae without fusion of their protoplasmic bodies (zool.).

pseudopodiospore (sūdöpō'diöspōr, psū-) n. [Gk. pseudes, false ; pous, foot; sporos, seed.] An amoebula or amoeboid swarm-spore which moves by means of pseudopodia (zool.).

pseudopodium (sū'döpō'diŭm, psū-) $n$. [Gk. pseudes, false ; pous, foot.] A blunt protrusion of ectoplasm serving for locomotion and prehension in Protozoa (zool.); in certain Mosses, the sporogonium-supporting pedicel (bot.).

pseudopore (sū'döpōr, psū-) n. [Gk. pseudes, false; poros, channel.] A small orifice between outermost tube and intercanal system of certain Sponges (zool.).

pseudopupa (sū'döpū'pă, psū-) n. [Gk. pseudes, false; L. pupa, puppet.] The semi-pupa or coarctate stage of certain insect larvae (zool.).

pseudoramose (sū'dörā'mōs, psū-) a. [Gk. pseudes, false; L. ramus, branch.] Having false branches (bot.).

pseudoramulus (sū'dörăm'ūlŭs, psū-) $n$. [Gk. pseudes, false; L. ramulus, small branch.] A spurious branch of certain Algae (bot. ).

pseudo-reduction, - the preliminary division of chromatin-rods preceding the formation of tetrads and the actual reduction in maturation (cyt.).

pseudorhabdites (sū'dörăb'dīts, psū-) n. plu. [Gk. pseudes, false; rhabdos, rod.] Granular masses of formed secretion produced by gland-cells of Rhabdocoelida (zool.).

pseudoscolex (sū'döskō'lëks, psū-) $n$. [Gk. pseudes, false ; skolex, worm.] Modified anterior proglottides of certain Cestoids where the true scolex is absent (zool.).

pseudoseptate (sū'dösěp'tầt, psū-) $a$.
[Gk. pseudes, false; L. septum, division.] Apparently, but not morphologically, septate (bot.).

pseudosessile (sū'dösěs'îl, psū-) $a$. [Gk. pseudes, false ; L. sedere, to sit.] $A p p l$. the abdomen of petiolate Insects when the petiole is so short that the abdomen is close to the thorax ; $c f$. pedicellate (zool.).

pseudosperm (sū'döspěrm, psū-) $n$. [Gk. pseudes, false; sperma, seed.] A false seed or carpel (bot.).

pseudospore (sū'döspōr, psū-) n. [Gk. pseudes, false; sporos, seed.] A teliospore or winter-spore of certain Rusts (bot.).

pseudostoma (sū'döstō'mă, psū-) $n$. [Gk. pseudes, false ; stoma, mouth.] A temporary mouth; a mouth-like opening; a pseudoosculum (zool.).

pseudovarium (sū'dövā'rǐŭm, psū-) $n$. [Gk. pseudes, false ; L. ovarium, ovary.] An ovary producing pseudova (zool.).

pseudovitellus (sū'dövĭtěl'ǔs, psū-) $n$. [Gk. pseudes, false ; L. vitellus, eggyolk.] A cellular double-string structure of Aphidae, a supposed substitute for absent Malpighian tubes (zool.).

pseudovum (südō'vŭm, psū-) $n$. [Gk. pseudes, false ; L. ovum, egg.] An ovum that can develop without fertilization; a parthenogenetic ovum; the earlier condition of the viviparously-produced Aphidae (zool.).

pseudozoaea (sū'dözō'êă, psū-) n. [Gk. pseudes, false; zoon, animal.] A larval stage of Stomatopods, socalled from its resemblance to the zoaea stage of Decapods (zool.).

psoas (sō'ăs, psō-) n. [Gk. psoa, loins.] Name of two loin muscles (anat.).

psorosperms (sō'röspěrmz, psō-) $n$. plu. [Gk. psora, itch ; sperma, seed.] Sporozoa; parasitic organisms generally (biol.).

pteridology (těr'idǒl'öjĭ, ptěr-) n. [Gk. pteris, fern ; logos, discourse.] The branch of Botany dealing with ferns. pteridophyte (tĕr'idöfit, ptĕr-) $n$. [Gk. pteris, fern ; phyton, plant.] A plant of the fern group (bot.).

pterion (těr'iǒn, ptĕr-) n. [Gk. pteron, wing.] The point of junction of 
parietal, frontal, and great wing of sphenoid (anat.).

pterocarpous (tĕr'ökâr'pŭs, ptĕr-) $a$.

[Gk. pteron, wing; karpos, fruit.]

With winged fruit (bot.).

pteroid (těr'oid, ptěr-) a. [Gk. pteris, fern ; eidos, resemblance.] Like a fern (bot.).

pteropaedes (tĕr'öpē'dĕz, ptĕr-) $n$. plu. [Gk. pteron, wing; pais, child.] Birds able to fly when newly hatched (zool.).

pteropegum (těr'öpē'gŭm, ptĕr-) $n$. [Gk. pteron, wing; pegos, firm.] An insect's wing socket (zool.).

pteropodium (těr'öpō'diŭm, ptěr-) $n$. [Gk. pteron, wing; pous, foot.] A winged foot, as of certain bats (zool.). pterospermous (tĕr'öspĕr'mŭs, ptěr-) a. [Gk. pteron, wing; sperma, seed.] With winged seeds (bot.).

pterostigma (tĕr'östĭg'mă, ptĕr-) $n$.

[Gk. pteron, wing; stigma, mark.] An opaque cell on certain insect wings (zool.).

pterotheea (tĕr'öthē'kă, ptĕr-) n. [Gk. pteron, wing; theke, a case.] The wing-case of pupae (zool.).

pterotic (těrồt'îk, ptěr-) $n$. [Gk. pteron, wing; ous, ear.] A cranial bone overlying the horizontal semicircular canal of the ear (zool.).

pterygial (těrij'íăl, ptĕr-) a. [Gk. ptery $x$, wing.] Pert. a wing or fin ; $a p p l$. a bone supporting a fin-ray (zool.).

pterygiophore (těrī'iöōōr, ptĕr-) $n$. [Gk. pteryx, wing ; pherein, to bear.] One of a row of cartilaginous rays forming the skeleton of median fins (zool.).

pterygium (těrij'ı̌ŭm, ptĕr-) $n$. [Gk. pteryx, wing.] A prothoracic process of weevils; a vertebrate limb (zool.).

pterygobranchiate (těr'ígöbrăng'kiāt, ptěr-) a. [Gk. pteryx, wing; brangchia, gills.] Having spreading or feathery gills, as certain Crustaceans (zool.).

pterygoda (těr'ígōdă, ptěr-) n. plu. [Gk. pteryx, wing; eidos, resemblance.] The tegulae of an Insect (zool.).

pterygoid (těr'igoid, ptër-) n. [Gk. pteryx, wing; eidos, form.] A cranial bone (zool.); $a$, wing-like; $a p p l$. the wing-like processes of the sphenoid, also canal, fissure, fossa, plexus, muscles (anat.).

pterygomandibular (tĕr'igömăndíb'ūlăr, ptĕr-) a. [Gk. pteryx, wing ; L. mandibulum, jaw.] Pert. pterygoid and mandible; appl. a tendinous band of the buccopharyngeal muscle (anat.).

pterygomaxillary (těr'ĭgömăkšllărǐ, ptĕr-) a. [Gk. pteryx, wing; L. maxilla, jaw.] Appl. a fissure formed by divergence of the maxilla from the pterygoid process of the sphenoid (anat.).

pterygopalatal, - pterygopalatine.

pterygopalatine (těr'ígöpăl'ătǐn, ptěr-) a. [Gk. pteryx, wing; L. palatus, palate.] Pert. the region of pterygoid and palatal cranial bones; $a p p l$. canal, fossa, groove (anat.).

pterygoquadrate (těr'igökwôd'rāt, ptěr-) a. [Gk. pteryx, wing; L. quadratus, squared.] Appl. a cartilage constituting the dorsal half of the mandibular arch of certain Fishes (zool.).

pterygospinous (těr'ígöspīnnŭs, ptĕr-) a. [Gk. pteryx, wing; L. spina, spine.] $A p p l$. a ligament stretching from lateral pterygoid plate to spinous process of sphenoid (anat.). pterylae (tĕr'ilē, ptĕr-) n. plu. [Gk. pteron, feather; yle, a wood.] The feather tracts of a bird's body, or the areas on which feathers spring, as distinguished from the unfeathered areas or apteria (zool.).

pterylosis (těrǐlō'š̌s, ptěr-) $n$. [Gk. pteron, feather; yle, a wood.] Arrangement of pterylae and apteria in Birds (zool.).

ptilinum (tîli'nŭm, ptǐl-)n. [Gk.ptilon, feather.] A head-vesicle or bladderlike expansion of the head of a fly emerging from the pupa, useful for rupturing the hard covering, introverted when the insect is mature; found in about one-half of the Diptera (zool.).

ptyalin (tīălǐn, ptī-) $n$. [Gk. ptyalon, saliva.] A digestive ferment of saliva (phys.).

ptyxis (tik'sis, ptik-) $n$. [Gk. ptyxis, a folding.] The form in which young leaves are folded or rolled on themselves in the bud (bot.). 
puberty (pū'bĕrtǐ) $n$. [L. pubertas, adult state.] Sexualmaturity ( $p$ hys.). puberulent (pūbĕr'ülěnt) $a$. [L.pubes, adult.] Covered with down or fine hair (bot.).

pubes (pü'bëz) $n$. [L. pubes, adult.] The pubic region (anat.).

pubescence (pū'běs'ěns) n. [L. pubescere, to become mature.] Downy or hairy covering on some plants and certain insects (biol.).

pubescent (püběs'ěnt) $a$. [L. pubescere, to become mature.] Covered with soft hair or down (bot.).

pubic (pū'bǐk) a. [L. pubes, mature.] In the region of the pubes; $a p p l$. arch, ligament, tubercle, vein (anat.).

pubis (pū'bǐs) $n$. [L. pubes, mature.] The anterior part of the hip-bone, consisting of body and ramus (anat.); the antero-ventral portion of the pelvic girdle (zool.).

pudendal (pūděn'dăl) a. [L. pudere, to be ashamed.] In the region of the pudendum ; $a p p l$. artery, cleft, nerve, veins (anat.).

pudendum (püdĕn'dŭm) n. [L.pudere, to be ashamed.] The vulva, or externals of the female organs of generation (anat.).

pudic,-pudendal.

pullulation (pǔl'ūlā'shŭn) $n$. [L. pullulare, to sprout.] Gemmation; reproduction by vegetative budding, as in yeast cells (bot.).

pulmobranchia (pŭl'möbrăng'kiă) $n$. [L. pulmo, lung; Gk. brangchia, gills.] A gill-like organ adapted to air-breathing conditions; a lung book, as of Spiders (zool.).

pulmogastric (pŭl'mögăs'trìk) a. [L. pulmo, lung; gaster, stomach.] Pert. lungs and stomach (anat.).

pulmonary (pŭl'mönărì) a. [L.pulmo, lung.] Pert. lungs; $a p p l$. artery, ligament, valves, veins, pleura (anat.).

pulmonary cavity or sac, - the mantlecavity of Molluscs without ctenidia : it functions as a lung (zool.).

pulmones (pǔlmōnê̌z) $n$. plu. pulmo, lung.] Lungs (anat.).

pulp (pŭlp) $n$. [L. pulpa, fruit-pulp.] The dental papilla; the soft mass of splenic tissue (zool.); the soft, fleshy part of a fruit (bot.), pulsating vacuole, - a contractile vacuole.

pulse (pŭls) n. [L. pulsus, beaten.] The beat or throb observable in the arteries, due to the action of the heart (phys.).

pulse wave, - a wave of increased pressure over the arterial system, started by the ventricular systole (phys.).

pulsellum (pŭlsĕl'ŭm) n. [L. pulsus, beaten.] A flagellum situated at the posterior end of a protozoan body (zool.).

pulvillar (pŭlvǐl'ăr) a. [L. pulvillus, a little cushion.] Pert. or at a pulvillus of an Insect (zool.).

pulvilliform (pǔlvǐl'îfôrm) a. [L. pulvillus, a small cushion; forma, shape.] Like a small cushion.

pulvillus (pŭlvǐl'ŭs) n. [L. pulvillus, small cushion.] A free pad or membrane under each claw of Diptera (zool.).

pulvinar (pŭlvìnnăr) $n$. [L. pulvinus, cushion.] An angular prominence on the optic thalamus (anat.); $a$. cushion-like ; pert. a pulvinus (bot.).

pulvinate (pǔl'vinnât) $a$. [L.pulvinus, cushion.] Cushion-like; having a pulvinus (biol.).

pulvinulus (pŭlvĭn'ūlŭs) n. [L. pulvinus, cushion.] A pulvillus.

pulvinus (pŭlvĩ'nŭs) $n$. [L. pulvinus, cushion.] A cellular swelling at the junction of axis and leaf-stalk (bot.).

pulviplume (pŭl'viploom) $n$. [L. pulvis, powder ; pluma, feather.] A powder-down feather (zool.).

punctate (pŭng'ktāt) a. [L.punctum, point.] Dotted ; having the surface covered with small holes or dots (biol.).

punctulate (pŭng'ktūlāt) a. [L. punctum, point.] Covered with very small dots or holes (biol.).

punctum (pŭng'ktŭm) n. [L. punctum, point.] A minute dot, point, or orifice ; as puncta lacrimalia, puncta vasculosa (anat.); the apex of a growing point (bot.).

puncture (pŭng'ktūr) n. [L.punctura, prick.] A small round surface depression (biol.).

pupa (pü'pă) n. [L. pupa, puppet.] The third or chrysalis stage of 
insect life; the stage in insect metamorphosis preceding the imago or adult (zool.).

pupal (pū'păl) a. [L. pupa, puppet.] Pert. the pupa stage (zool.).

puparium (pūpā'riumm) n. [L. pupa, puppet.] A coarctate pupa ; the pupal instar, exemplified in the blow-fly (zool.).

pupiform (pứpífôrm) a. [L. pupa, puppet; forma, shape.] Pupashaped ; pupa-like.

pupigerous (pūpij'ĕrŭs) a. [L. pupa, puppet ; gerere, to bear.] Containing a pupa (zool.).

pupil (pü'pil) n. [L. pupilla, the pupil of the eye.] The aperture of the iris through which rays pass to the retina (anat.).

pupillary (pūpịlărĭ, pū'pūlărǐ) a. [L. pupilla, pupil of the eye.] Pert. the pupil of the eye ; appl. a membrane (anat.).

pupiparous (pūpı̌p'ărŭs) a. [L. pupa, puppet ; parere, to beget.] Bringing forth young already developed to the pupa stage, as certain parasitic Insects (zool.).

Purkinje, cells of,-an incomplete stratum of flask - shaped cells between the two layers of the grey matter of the cerebellum (anat.).

pustule (pŭs'tūl) n. [L. pustula, pimple.] A blister-like prominence (bot.).

pusules (pŭs'ūlz) n. plu. [L. pus, matter.] Non-contractile vacuoles consisting of two sacs containing watery fluid, each emptying by its own duct, found in many Dinoflagellates (zool.).

putamen (pūtä'měn) $n$. [L. putamen, pod.] The hard endocarp or stone of some fruits (bot.); the lateral part of the lentiform nucleus of the cerebrum (anat.); the shell membrane of a bird's egg (zool.).

pyenidiophore (pǐknìd'iofōor) $n$. [Gk. pyknos, dense ; pherein, to bear.] A conidiophore producing pycnidia (bot.).

pyenidiospore (p̌̌knǐd'iöspōr) n. [Gk. pyknos, dense; sporos, seed.] The spore produced by pycnidia (bot.).

pyenidium (pìknìd'ium) n. [Gk. pyknos, dense.] A small flask-shaped organ or spermogonium containing slender filaments which form pycnidiospores or spermatia by abstriction, $-\mathrm{a}$ stage in the lifehistory of wheat rust (bot.).

pyenium,-a pycnidium.

pyenoconidium, pyenogonidium, pycnospore, - varieties of pycnidiospore (bot.).

pygal (pí'găl) $a$. [Gk. pyge, the rump.] Situated at or pert. the posterior end of the back; $a p p l$. certain plates of the chelonian carapace (zool.).

pygidium (pījĭd'iŭm) $n$. [Gk. pyge, rump.] A caudal shield covering the abdomen of certain Arthropods ; the terminal uncovered abdominal segment of a beetle (zool.).

pygochord (pī'gökôrd) n. [Gk. pyge, rump; chorde, cord.] A ventral median ridge-like outgrowth of the intestinal epithelium in certain Enteropneusta (zool.).

pygostyle (pī'göstīl) n. [Gk. pyge, rump; stylos, column.] An upturned compressed bone at the end of the vertebral column of Birds, formed by fusion of the four or more hindmost vertebrae (zool.).

pylocyte (pīlösīt) n. [Gk. pylon, gateway ; kytos, hollow.] A porecell at the inner end of a small funnel-shaped depression, the porocyte of certain Sponges (zool.).

pylome (pīlōm') n. [Gk. pyloma, gate.] In certain Sarcodina, an aperture for emission of pseudopodia and reception of food (zool.). pyloric (pīlŏr'ík) a. [Gk. pyloros, gate-keeper.] Pert. or in the region of the pylorus ; $a p p l$. artery, antrum, glands, orifice, valve, vein (anat.).

pylorus (pīlórŭs) n. [Gk. pyloros, gate-keeper.] The lower orifice of the stomach, communicating with the duodenum (anat.).

pyramid (pürămĭd) n. [L. pyramis, a pyramid.] A conical structure, protuberance, eminence; a piece of the dental apparatus of Echinoids (zool.); appl. parts of brain, temporal bone, vestibule (anat.).

pyramidal (pirăm'ídăl) $a$. [L.pyramis, a pyramid.] Conical; like a pyramid; $a p p l$. a carpal bone, brain cells, lobes, processes, muscle (anat.). pyrene (pî́rēn, pīrēn') n. [Gk. pyren, 
a fruit-stone.] A fruit-stone or kernel (bot.).

pyrenin (pīrénñn) n. [Gk. pyren, a fruit-stone.] The substance of a true nucleolus, paranuclein (cyt.).

pyrenocarp (pīrē'nökârp) n. [Gk. pyren, a fruit-stone; karpos, fruit.] A form of ascocarp; a fleshy fruit with stone or hard kernel (bot.).

pyrenoid (pīrěnoid) $n$. [Gk. pyren, a fruit-stone; eidos, form.] A colourless plastid of lower plants, a centre of starch formation (bot.).

pyriform (pī'rífôrm) a. [L. pyrum, pear;forma, shape.] Pear-shaped; appl. a muscle (anat.), an organ of a larval Mollusc, and a vestigial sac of a male Nautilus (zool.).

pyxidium (pǐksĭd'ǐm $n$. [Gk. pyxis, box.] A pyxis, or capsular fruit which dehisces transversely (bot.).

\section{Q}

quadrate (kwŏd'rāt) n. [L.quadratus, squared.] The bone with which the lower jaw articulates in Birds, Reptiles, Amphibians, and Fishes; one of the lobes of the liver (anat.). quadratojugal (kwǒdrā'töjoo'găl) n. [L. quadratus, squared; jugum, yoke.] Membranous bone connecting the quadrate and jugal bones (anat.).

quadrato - mandibular (kwŏdrā'tömăndỉb'ūlăr) $a$. [L. quadratus, squared; mandibulum, jaw.] Pert. quadrate and mandibular.

quadratus (kwǒdrā'tŭs) $n$. [L. quadratus, squared.] The name of several muscles, e.g. quadratus femoris (anat.).

quadriceps (kwŏd'rĭsĕps) $n$. [L. quattuor, four ; caput, head.] Muscle in front of the thigh extending the lower leg and divided up into four portions at its upper end (anat.).

quadrifarious (kwödrífá'ríŭs) a. [L. quadrifarius, fourfold.] In four rows; proceeding from all the sides of a branch (bot.).

quadrifid (kwǒd'rǐfid) a. [L. quattuor, four ; findere, to cleave.] Deeply cleft into four parts (bot.). quadrifoliate (kwŏd'rĭfō'liāt) a. [L. quattuor, four; folium, leaf.] $A p p l$. compound palmate leaf, consisting of four leaflets arising at a common point (bot.).

quadrigeminal bodies (kwŏd'rỉjěm'inăl). See corpora quadrigemina. quadrijugate (kwŏd'rijoo'gāt) a. [L. quattuor, four; jugum, yoke.] Appl. pinnate leaf having four pairs of leaflets (bot.).

quadrilocular (kwŏd'rǐlǒk'ülăr) a. [L. quattuor, four; loculus, small space.] Having four loculi or chambers, as the ovary of certain plants (bot.). quadrimaculate (kwŏd'rǐmăk'ūlāt) $a$. [L. quattuor, four; macula, spot.] Having four spots (zool.).

quadrinate (kwǒd'rĭnāt) a. [L. quattuor, four.] See quadrifoliate.

quadripennate (kwŏd'rīpěn'āt) a. [L. quattuor, four; penna, wing.] With four wings.

quadritubercular (kwŏd'rĭtūběr'kūlăr) a. [L. quattuor, four ; tuberculum, a small hump.] $A p p l$. teeth with four tubercles (anat.).

quadrumanous (kwŏdroom'ănŭs) $a$. [L. quattuor, four ; manus, hand.' Having hind-feet, as well as front feet, constructed like hands, as most Primates except man (anat.).

quađrupedal (kwŏd'roopē'dăl, kwǒdroop'ědăl) a. [L. quattuor, four ; pes, foot.] Appl. the habitual attitude of four-footed animals (anat.).

quaternary (kwǒtĕr'nărĩ) a. [L. quaterni, four each.] Appl. flower symmetry when there are four parts in a whorl (bot.).

quaternate (kwǒtěr'nāt) a. [L. quaterni, four each.] Appl. leaves growing in fours from one point (bot.).

queen,- the reproductive female in colonies of social Hymenoptera.

quill (kwil) n. [M.E. quille, feather.] The calamus of a feather (zool.).

quill feathers, - the feathers of the wings (remiges) and tail (rectrices) of a Bird.

quinary (kwīnărǐ) a. [L. quini, five each.] $A p p l$. flower symmetry when there are five parts in a whorl (bot.). quinate (kwi'nāt) a. [L. quini, five each.] $A p p l$. five leaflets growing from one point (bot.). 
quincuncial (kwĭnkŭn'shăl) a. [L. quinque, five; uncia, twelfth part.] Arranged in quincunx.

quincunx (kwin'kŭngks) n. [L. quinque, five; uncia, twelfth part.] Arrangement of five petals or leaves, of which two are exterior, two interior, and the fifth partly exterior, partly interior (bot.).

quinquecostate (kwĭn'kwëkǒs'tāt) $a$. [L. quinque, five; costa, rib.] Having five ribs on the leaf (bot.).

quinquefarious (kwǐn'kwěfā'rǐŭs) $u$. [L. quinque, five.] In five directions or parts (bot.).

quinquefid (kwin'kwëfĩd) a. [L.quinque, five; findere, to cleave.] Cut into five parts as far as the middle (bot.)

quinquefoliated (kwĭn'kwëf ó'līātĕd) $a$. [L. quinque, five; folium, leaf.] With five leaves (bot.).

quinquepartite (kwin'kwëpâr'tīt) $a$. [L. quinque, five; pars, part.] Divided into five parts.

quinquetubercular (kwǐn'kwëtūbĕr' kūlăr) a. [L. quinque, five ; tuberculum, a small hump.] Appl. molar teeth with five tubercles (anat.).

\section{$\mathrm{R}$}

race (rās) $n$. [F. race, race, family.] A permanent variety (bot.); a particular breed (zool.).

racemation (răs'ĕmā'shŭn) $n$. [L. racemus, a bunch.] A cluster, as of grapes (bot.).

raceme (răsēm') $n$. [L. racemus, a bunch.] An inflorescence having a common axis and stalked flowers in acropetal succession, as the hyacinth (bot.).

racemed (răsē'md) a. [L. racemus, a bunch.] Growing in the form of a raceme (bot.).

racemiferous (răsēmĭf'ěrŭs) $a$. [L. racemus, a bunch ; ferre, to carry.] Bearing racemes (bot.).

racemiform (răsē'mifôrm) $a$. [L. racemus, a bunch ; forma, shape.] In the form of a raceme (bot.).

racemose (răs'émōs) a. [L. racemus, a bunch.] Bearing flowers in clusters (bot.); appl. glands with many branches whose shape suggests a raceme (anat.).

racemule (răs'ĕmūl) $n$. [L. racemulus, a small bunch.] A small raceme (bot.).

racemulose (răsĕm'ūlōs) a. [L. racemulus, a small bunch.] In small clusters (bot.).

rachial (rā́kuăl) a. [Gk, rhachis, spine.] Pert. a rachis.

rachidial (răkĭd'ǐăl) a. [Gk. rhachis, spine.] Pert. a $\mathrm{r}$ chis.

rachiform (rā'kifôr n)a. [Gk. rhachis, spine; L. forma, shape.] In the form of a rachis.

rachilla (răkỉlă) n. [Gk. rhachis, spine.] A small rachis (bot.).

rachiodont (răk'iödŏnt') a. [Gk. rhachis, spine; odous, tooth.] Appl. egg-eating Snakes with much developed hypophyses of the anterior thoracic vertebrae, which function as teeth (zool.).

rachiostichous (rā'kǐŏs'tǐkŭs) a. [Gk. rhachis, spine; stichos, row.] Having a succession of somactids as the axis of the fin skeleton, as in Dipnoans (zool.).

rachis (rā'kǐs) $n$. [Gk. rhachis, spine.] The spinal column (anat.); the stalk or axis (bot.); the shaft of a feather (zool.).

rachitomous (răkĭt'ömŭs) $a$. [Gk. rhachis, spine.] Temnospondylous, which see.

radial (rā'diăl) a. [L. radius, a ray.] Pert. the radius; pert. the ray of an Echinoderm; appl. the plates supporting the oral disc of Crinoids (zool.); appl. leaves or flowers growing out like rays from a centre (bot.). As noun, an endoskeletal support of fins in Fishes.

radial symmetry, - arrangement of similar parts round a median vertical axis, as in Jellyfish (zool.).

radiale (ră'dǐăl'lē) n. [L. radius, a ray.] A carpal bone in Mammals (zool.).

radiate (rā'dīāt) a. [L. radius, a ray.] Radially symmetrical.

radiate-veined,-veined in a palmate manner (bot.).

radiatiform (rä'duăt'îfôrm) a. [L. radius, ray ; forma, shape.] With radiating marginal florets (bot.). 
radical (răd'ikăl) a. [L. radix, root.] Arising from the root close to the ground, as basal leaves (bot.).

radicant (răd'ikănt) a. [L. radicari, to take root.] With roots developing from the stem (bot.).

radicel (răd'ísĕl) $n$. [L. radix, root.] A small root (bot.).

radiciflorous (rădǐs'íflórŭs) $a$. [L. radix, root; flos, flower.] With flowers arising at the extreme base of the stem (bot.).

radiciform (rădis'ífôrm) a. [L. radix, root; forma, shape.] Resembling a root (bot.).

radicivorous (răd'ís̆vivörŭs) a. [L. radix, root; vorare, to devour.] Root-eating (zool.).

radicle (răd'îkl) $n$. [L. radix, root.] A small root (bot.).

radicolous (rădík'ölŭs) a. [L. radix, root ; colere, to inhabit.] Inhabiting roots (biol.).

radicose (răd'îkōs) a. [L. radix, root.] With large root (bot.).

radicular (rădǐk'ūlăr) a. [L. radix, root.] Pert. a radicule or radicle (bot.).

radicule (răd'ikūl) $n$. [L. radix, root.] A rootlet.

radiculose (rădǐk'ūlōs) a. [L. radix, root.] Having many rootlets (bot.). radiocarpal (rā'diökâr'păl) $a$. [L. radius, ray ; carpus, wrist.] Pert. radius and wrist (zool.).

radiosymmetrical (rā'diösǐmět'rǐkăl) a. [L. radius, ray; Gk. syn, with ; metron, measure.] Having similar parts similarly arranged round a central axis (biol.).

radioulnar (rā'diöŭl'năr) a. [L. radius, ray; ulna, elbow.] Pert.radius and ulna (zool.).

radius (rä'diŭs) $n$. [L. radius, ray.] A bone of the arm or fore-limb between humerus and carpals, often fused with the ulna; one of the plates of Aristotle's lantern; an insect wing-vein (zool.).

radix (răd'íks, rä'dīks) $n$. [L. radix, root.] A root (bot.).

radula (răd'ülă) $n$. [L. radere, to scrape.] A short and broad strip of membrane with longitudinal rows of chitinous teeth found in the mouth of most Gastropods (zool.).

radulate (răd'ūlāt) a. [L. radere, to scrape.] Having a radula or rasping organ (zool.).

raduliferous (răd'ūliff'ĕrŭs) $a$. [L. radere, to scrape ; ferre, to carry.] Radulate (zool.).

raduliform (rădū'lifồrm) a. [L. radere, to scrape ; forma, shape.] Like a radula or flexible file (zool.).

Rainey's corpuscles, - the spores of Sarcocystis, an elongated Sporozoan found in voluntary muscle fibres (phys.).

Rainey's tubes, - a name given to elongated sacs found in the substance of voluntary muscle, which are adult stages of Dolichosporidia, Sporozoa (phys.).

raker,-see gill rakers.

ramal (rā'măl) a. [L. ramus, a branch.] Belonging to branches; originating on a branch (bot.).

ramate (ră'māt) a. [L. ramus, a branch.] Branched (bot.).

ramelose (răm'ělôs) a. [L. ramus, a branch.] Having small branches (bot.).

ramentaceous (răm'ĕntā'shŭs) $a . \quad$ [L. radere, to scrape.] Like a ramentum ; covered by ramenta (bot.).

ramentiferous (răm'ěntíf'ĕrŭs) $a$. [L. radere, to scrape ; ferre, to carry.] Bearing ramenta (bot.).

ramentum (răměn'tŭm) $n$. [L. radere, to scrape.] One of the brown scale-like structures found on fern leaves (bot.); plu. ramenta, elongated membranous hairs, epidermal outgrowths (bot.).

rameous (rä'měŭs) a. [L. ramus, a branch.] Branched (bot.).

ramicorn (răm'ǐkôrn) a. [L. ramus, branch; cormu, horn.] Having branched antennae, as some Insects (zool.).

ramiferous (rămíf'ĕrŭs) a. [L. ramus, branch ; ferre, to bear.] Branched (bot.).

ramification (răm'if îkā'shŭn) $n$. [L. ramus, a branch ; facere, to make.] Branching; a branch of a tree, nerve, artery, etc.

ramiflorous (răm'iffó'rŭs) a. [L. ramus, branch; flos, flower.] Having flowers on the branches (bot.).

ramiform (răm'ifôrm) a. [L. ramus, branch; forma, shape.] Branchlike. 
ramigerous (rămij'ěrŭs) a. [L. ramus, branch ; gerere, to carry.] Bearing branches (bot.).

ramiparous (rămị 'ărŭs) $a$. [L. ramus, branch; parere, to beget.] Producing branches (bot.).

ramose (răm'ōs) a. [L. ramus, branch.] Much branched (bot.).

ramule (răm'ūl) n. [L. ramulus, small branch.] A small branch (bot.).

ramuliferous (răm'ülíf'ĕrŭs) $a . \quad[\mathrm{L}$. ramulus, small branch; ferre, to bear.] Bearing small branches (bot.).

ramulose (răm'ūlōs) a. [L. ramulus, small branch.] With many small branches (bot.).

ramulous (rằm'ülŭs) $a$. [L. ramulus, small branch.] With small branches (bot.).

ramulus (răm'ūlŭs), ramuscule (rămŭs'kūl) n. [L. ramus, branch.] A small branch (bot.).

ramus (rā'mŭs) n., rami (rā'mī) plu. [L. ramus, a branch.] Any branchlike structure; part of the chewing apparatus of Rotifers; the barbs of feathers; the lower jaw or mandible of Vertebrates (zool.).

ranine (rā'nīn) a. [L. rana, a frog.] Pert. the under surface of the tongue (anat.).

ranivorous (rănìv'örŭs) a. [L. rana, frog ; vorare, to devour.] Feeding on frogs (zool.).

Ranvier's nodes, - constrictions or interruptions of the medullary sheath of a nerve fibre (phys.).

raphe (rấfề) $n$. [Gk. rhaphe, a seam.] A seam-like suture, as the junction line of some fruits (bot.); the perineal line (anat.).

raphides (răf'idĕz) n.plu. [Gk.rhaphis, a needle.] Minute crystals found in plant cells (bot.).

raphidiferous (răf'idìf'ěrŭs) $a$, [Gk. rhaphis, a needle; L. ferre, to carry.] Containing raphides (bot.).

raptatory (răp'tătörì) a. [L. raptere, to rob.] Preying (zool.).

raptorial (răptō'riăl) a. [L. raptere, to rob.] Appl. birds of prey (zool.).

rasorial (răzốriăl) $a$. [L. radere, to scratch.] Adapted for scratching or scraping, as fowls (zool.). rastellus (răstĕl'ŭs) $n$. [L. radere, to rasp.] A group of teeth in arachnid chelicera (zool.).

ratite (răt'ît) a. [L. ratis, raft.] Having an unkeeled sternum; $o p p$. carinate (zool.).

rattle (răt'I) n. [M.E. ratelen, to clatter.] The sound-producing series of horny joints at the end of a rattlesnake's tail (zool.).

ray (rā) n. [L. radius, a ray.] One of the bony spines supporting fins ; a division of a radiate animal, as an arm of an Asteroid (zool.).

reaction time, - the time required between stimulus and response ( $p h y s$.). read (rêd), - the abomasum or fourth stomach of ruminants (zool.).

reagent (rēā'jĕnt) n. [L. re, again ; agere, to do.] One who acts in response to a given stimulus ( $p h y s$.). recapitulation theory, - the theory that ontogeny tends to recapitulate phylogeny, that the individual lifehistory reproduces certain stages in the life-history of the race; biogenetic law; von Baer's law (biol.). receptacle (rêsěp'tăkl) n. [L. recipere, to receive.] An organ used as a repository; the peduncle of a racemose inflorescence; the torus or thalamus of a flower; the terminal disc of Mosses (bot.).

receptacular (rēsěptăk'ūlăr) a. [L. recipere, to receive.] Pert. a receptacle of any kind.

receptaculum (rêsěptăk'ülŭm) $n . \quad[\mathrm{L}$. recipere, to receive.] A receptacle of any kind.

receptaculum chyli, - the cavity in the lower part of the thoracic duct (anat.).

receptaculum ovorum, - an internal sac in the earthworm in which ova are collected (zool.).

receptaculum seminis, - a female organ for the reception of spermatozoa (zool.).

receptive spot, - the point in an oosphere at which the sperm enters (emb.).

receptor (rēsĕp'tŏr) n. [L. recipere, to receive.] The part of a cell which combines with outside molecules, - side chain theory (phys.).

recess (rēsěs') n. [L. recessus, withdrawn.] A niche, sinus, cleft, or 
hollow space; as omental, optic, pineal recess (anat.).

recessive (rēsěs'ìv) a. [L. recessus, withdrawn.] Appl.Mendelian characters. See Mendelism (biol.).

reciprocal hybrids, - two hybrids, one descended from the male of one species and the female of another, the other from a female of the first and a male of the second (biol.).

reclinate (rěk'lināt) a. [L. reclinare, to lean.] Curved downwards from apex to base; $a p p l$. an ovule suspended from a funiculus (bot.).

reclining (rēklì'nìng)a. [L. reclinare, to lean.] Leaning over; not perpendicular (bot.).

recrudescence (rēkrooděs'ěns) $n$. [L. re, again; crudescere, to become hard.] A state of breaking out into renewed freshness or active growth (bot.).

rectal (rěk'tăl) a. [L. rectus, straight.] Pert. the rectum.

rectal gland,-a small vascular sac of unknown significance near the end of the gut in Fishes (zool.).

rectigradations (rěk'tĭgrădā'shŭnz) $n$. plu. [L. rectus, straight; gradus, a step.] "The origin of new cusps or cuspules which appear determinately, definitely, orthogenetically in both the upper and lower teeth, quite independently in different orders of mammals, and separated perhaps by vast intervals of time" (Osborn).

rectinerved (rěk'tĭnĕrvd) a. [L.rectus, straight; nervus, a nerve.] With veins or nerves straight (bot.).

rectipetality (rěk'tǐpětăl'ítī) $n$. [L. rectus, straight; petere, to seek.] Tendency to rectilinear growth (bot.).

rectirostral (rěk'tĭrŏs'trăl) $a$. [L. rectus, straight ; rostrum, a beak. Straight-beaked (zool.).

rectiserial (rěk'tísē'riăl) a. straight ; series, row.] Arranged in vertical rows (bot:).

rectivenous (rěk'tĭvē'nŭs) a. [L. rectus, straight; vena, a vein.] With straight veins (bot.).

rectogenital (rěk'töjĕn'ítăl) a. [L. rectus, straight ; genitalia, genitals.] Pert. rectum and genital organs (anat.). rectouterine (rěk'tö $\bar{u}^{\prime}$ těrīn) a. [L. rectus, straight; uterus, womb.] $A p p l$. the posterior ligaments of the uterus (anat.).

rectovesical (rěk'tövěs'îlkăl) $a$. [L. rectus, straight; vesica, bladder.] Pert. rectum and bladder (anat.).

rectricial (rěktrǐsh'ăl) a. [L. regere, to rule.] Pert. the rectrices (zool.). rectrix (rěk'trǐks) n., rectrices (rěk'trǐsěz) plu. [L. regere, to rule.] The stiff tail feathers of a bird, used in steering (zool.).

rectum (rěk'tŭm) $n$. [L. rectus, straight.] The posterior terminal part of the alimentary canal (zool.). rectus (rěk'tŭs) $n$. [L.rectus, straight.] A name for a rectilinear muscle, as rectus femoris, the thigh muscle (anat.).

recurrent (rēkŭr'ĕnt) a. [L. re, back ; currere, to run.] Returning or reascending towards the origin (anat.).

recurrent sensibility, - sensibility shown by the motor roots of the spinal cord due to sensory fibres of the sensory roots (phys.).

recurved (rếkŭrvd) $a$. [L. re, back ; curvus, bent.] Bent backwards (bot.).

recurvirostral (rēkŭr'vĭrŏs'trăl) a. [L. re, back ; curvus, curved ; rostrum, beak.] With beak bent upwards (zool.).

red body, - see rete mirabile.

red corpuscle, - a coloured blood corpuscle of vertebrates, containing haemoglobin (phys.).

red glands,-see rete mirabile.

red nucleus, - a collection of nerve cells in the tegmentum of the midbrain (anat.).

red spots,-see rete mirabile.

redia (rē'diă) $n$. [It. scientist Redi.] A larval stage in the development of Distomum (zool.).

reduction (rēdŭk'shŭn) $n$. [L. reductus, reduced.] The halving of the number of chromosomes in germ-nuclei during maturation; meiotic division (cyt.).

reduplicate (rēdū'plikāt) a. [L. $r e$, again ; duplicare, to repeat.] $A p p l$. aestivation in which the margins turn outwards at the points of contact (bot.). 
reduviid (rědü'vĭd) $a$. [L. reduvia, a hang nail.] Appl. eggs of certain Insects, protected by micropyle apparatus with porches (zool.).

reflected (rēflěk'tĕd) $a$. [L. reflectere, to turn back.] Turned or folded back on itself (anat.).

reflex (rē'flěks) a. [L. reflectere, to turn back.] Involuntary; $a p p l$. reaction to stimulus (phys.).

reflex action,-the simplest expression of the principles according to which the nervous system acts. Elements that appreciate stimuli and elements that react to stimuli are switched on to one another, without direct appeal to the brain, by means of a subsidiary nerve centre, the result being so-called involuntary action (phys.).

reflexed (rē'flěksd) $a$. [L. reflectere, to turn back.] Curved or turned backwards.

refracted (rēfrăk'těd) a. [L. re, back; frangere, to break.] Bent backwards at an acute angle.

regeneration (rêjēn'ěrâ'shŭn) $n$. [L. re, again; generare, to beget.] The renewal of a portion of the body which has been lost (biol.).

regma '(rěg'mă) n. [Gk. regma, fracture.] A seed-vessel the valves of which open by an elastic movement (bot.).

Reissner's membrane, - the membrana vestibularis, stretching from the lamina spiralis ossea to the outer cochlear wall of the ear (anat.).

rejuvenescence (rē'joověněs'ĕns) $n$. [L. re, again ; juvenescere, to grow young.] A renewal of youth; in cells, renewed life and vigour following on conjugation and interchange and fusion of nuclear and protoplasmic material (cyt.).

remiges (rĕm'ijě̀z) $n$. plu. [L. remex, a rower.] The large feathers or quills of a bird's wing, comprising primaries and secondaries (zool.).

remiped (rĕm'îpěd) $n$. [L. remus, oar; pes, foot.] Having feetadapted for rowing motion (zool.).

ren (rĕn) $n$, renes (rĕn'ěz) plu. [L. ren, kidney.] The kidneys.

renal (rểnăl) a. [L. ren, kidney.] Pert. kidneys. renal portal,-appl. a system of circulation in which some of the returning blood passes through the kidneys (zool.).

renes,-see ren.

reniform (rĕn'ifôrm) a. [L. ren, kidney; forma, shape.] Shaped like a kidney (biol.).

renopericardial (rē'nöpĕr'íkâr'dĭăl) $a$. [L. ren, kidney; Gk, peri, round; kardia, heart.] Appl. a narrow ciliated canal connecting kidney and pericardium in higher Molluscs (zool.).

repand (rēpănd') a. [L. repandus, bent backwards.] Appl. a leaf with undulated margin (bot.).

repandodentate (rēpăn'dödĕn'tāt) $a$. [L. repandus, bent backwards ; dens, a tooth.] Varying between undulated and toothed (bot.).

repent (rëpěnt) a. [L. repere, to crawl.] Creeping along the ground; $a p p l$. ground creepers (bot.).

replicate (rĕp'likaät) a. [L. re, back ; plicare, to fold.] Doubled over on itself (biol.).

replicatile (rĕplìk'ătǐl) a. [L. re, back; plicare, to fold.] Appl. wings which are folded back on themselves when at rest (zool.).

replum (rěp'lŭm) $n$. [L. replum, a bolt.] The longitudinal division between the valves of some pericarps, as in some Legumes; a placental dissepiment (bot.).

reproduction (rē'prödŭk'shŭn) $n$. [L. re, again; pro, forth; ducere, to lead.] The process by means of which the race is continued, whether sexual or through cell-rupture, celldivision, budding, spore-formation, conjugation, or parthenogenesis (biol.).

reproductive (rē'prödŭk'tĭv) a. [L. re, again ; pro, forth ; ducere, to lead.] Appl. organs concerned in reproduction (biol.).

reptile (rěp'tīl) $n$. [L. repere, to crawl.] An animal that crawls along the ground or close to the ground, as serpents, lizards, etc. (zool,).

reptilian (rěptỉlıăn) a. [L. repere, to creep.] Pert. reptiles (zool.).

reptiloid (rěp'tīloid) a. [L. repere, to crawl; Gk. eidos, form.] With 
the characteristics of a Reptile (zool.).

reservoir (rĕz'ĕrvwôr) $n$. [L. reservare, to keep back.] A non-contractile space discharging into the gullet of Mastigophora (zool.).

resilium (rěsǐl'iŭm) $n$. [L. resilire, to leap back.]. The horny flexible hinge of a bivalve (zool.).

respiration (rěs'pĭrā'shŭn) $n$. [L. re, again; spirare, to breathe.] The process of interchange of oxygen and carbonic acid taking place between an organism and its surrounding medium (phys.).

respiratory heart, - a name given to the auricle and ventricle of the right side of the heart where there is no direct communication between right and left sides; $o p p$. systemic heart (zool.).

restiform (rěs'tifôrm) a. [L. restis, a rope ; forma, shape.] Having the form or appearance of a rope ; $a p p l$. two bodies of nerve fibres on the medulla oblongata (anat.).

resupinate (rēsü'pīnāt) a. [L. resupinare, to bend back.] So twisted that the various parts are upside down (bot.).

resupination (rēsū'pinā'shŭn) $n$. [L. resupinare, to bend back.] Inversion (bot.).

rete (ré'tē) $n$. [L. rete, a net.] A net or network.

rete Malpighii, - the Malpighian layer or deeper portion of the epidermis, from the stratum granulosum inwards (anat.).

rete mirabile, - a network of bloodvessels, chiefly arterial, in the swimbladder of Fishes and in Mammals, also called red body, red glands, red spots.

rete mucosum, - the Malpighian layer or rete Malpighii.

retecious (rětë'shŭs) a. [L. rete, a net.] In the form of a network.

retial (rë'tiăl, rë'shǐăl) a. [L. rete, net.] Pert. a rete (anat.).

reticle (rět'ikl) $n$. [L. reticulum, a small net.] A reticulum.

reticular (rětǐk'ūlăr) a. [L. reticulum, a small net.] Having interstices like network; pert. a reticulum; $a p p l$. tissue.

reticulate (rětík'ülāt) a. [L. reticulum, a small net.] Appl. network nervation of leaf or insect wing.

reticule (rět'îkül) $n$. Reticulum.

reticulose (rětǐk'ūlōs) a. [L. ret. iculum, a small net.] Of network formation.

reticulum (rětīk'ūlŭm) n. [L. reticulum, a small net.] The honeycomb bag or second stomach of a Ruminant ; the delicate network of cell protoplasm (zool.); the crossfibres about the base of the petioles in palms (bot.).

retiform (rē'tífôrm) a. [L. rete, net; forma, shape.] In the form of a network.

retina (rět'ină) $n$. [L. rete, net.] The retiform membrane of the eye which receives the impressions, resulting in the sense of vision (anat., zool.).

retinaculum (rět'ĩnăk'ūlŭm) $n$. [L. retinere, to retain.] A small glandular mass to which an orchid pollinium adheres at dehiscence (bot.); a band which holds parts closely together (anat.); a minute hooked prominence holding the egg-sac in position in Cirripedes; a structure linking together the fore and hind wings of some Insects along with the frenulum (zool.).

retinal (rět'inăl) a. [L. rete, a net.] Pert. the retina (anat.).

retinerved (rět'ínĕrvd) a. [L. rete, a net; nervus, a sinew.] Having reticulate veins or nerves (bot.).

retinophore (rět'innöfōr) n. [L. rete, net; Gk. pherein, to bear.] A crystal cell in the ommatidium of Arthropods (zool.).

retinula (rětĭn'ülă) $n$. [L. rete, net.] A group of elongated cells, the innermost element of an arthropod ommatidium.

retractile (rētrăk'tǐl) a. [L. retractus, withdrawn.] $A p p l$. a part or organ that may be drawn inwards, as feelers, claws, etc. (zool.).

retractor (rētrăk'tǒr) n. [L. retrahere, to draw back.] A muscle which by contraction withdraws the part attached to it, as retractor penis (zool.).

retrobulbar (rềt'röbŭl'băr) $a$. [L. retro, backwards; bulbus, a ball.] Posterior to the eyeball (anat.). 
retrocaecal (rět'rösē'kăl) a. [L. retro, backwards ; caecus, blind.] Behind the caecum; $a p p l$. fossae additional to the caecal fossa (anat.).

retrofract (rět'röfrăkt) $a$. [L. retro, backwards ; fractus, broken.] Bent backwards at an angle (bot.).

retrogression (rět'rögrěsh'ŭn) $n$. retro, backwards; gradus, a step.] A step from superior to inferior type in the development of an individual or race (biol.).

retrogressive (rě̆t'rögrĕs'iv) $a$. [L. retro, backwards; gradus, a step.] Degenerating ; assuming characteristics of a lower type (biol.).

retrolingual (rět'rölïng'gwăl) $a$. [L. retro, backwards; lingua, a tongue.] Behind the tongue; $a p p l$. a gland (zool.).

retromorphosis (rět'römôr'fösĭs) $n$. [L. retro, backwards; Gk. morphe, form.] Development with a degenerating tendency (biol.).

retropharyngeal (rět'röfărǐn'jěăl) $a$. [L. retro, backwards; Gk. pharyngx, pharynx.] Behind the pharynx; appl. a space, lymph glands (anat.).

retropubic (rět'röpū'bǐk) a. [L. retro, backwards; pubes, of ripe age.] $A p p l$. a pad or mass of fatty tissue behind the pubic symphysis (anat.). retrorse (rētrôrs') a. [L. retro, backwards; vertere, to turn.] Turned or directed backwards.

retroserrate (rět'rösĕr'āt) $a$. [L. retro, backwards; serra, a saw.] Toothed, with teeth directed backwards.

retroserrulate (rětt'rösĕr'ūlāt) $a$. [L. retro, backwards; serra, a saw.] With small retrorse teeth.

retrouterine (rět'röü'tĕrīn) $a . \quad[\mathrm{L}$. retro, backwards; uterus, womb.] Behind the uterus (anat.).

retroverse (rět'rövĕrs') $a$. [L. retro, backwards; vertere, to turn.] Retrorse.

retroversion (rět'rövĕr'shŭn) $n$. [L. retro, backwards ; vertere, to turn.] State of being reversed or turned backwards.

retuse (rētūs') a. [L. retusus, beaten back.] Obtuse with a broad shallow notch in the middle; $a p p l$. leaves (bot.).

revehent (rēvēhĕnt, rĕv'ěhĕnt) $a$. [L. revehens, carrying back.] In the renal portal system, $a p p l$. vessels carrying blood back from the excretory organs (zool.).

reversed (rēvěr'sd) $a$. [L. re, back ; vertere, to turn.] Inverted (bot.); $a p p l$. a spiral shell whose turns are directed sinistrally (zool.).

reversion (rēvěr'shŭn) $n$. [L. re, back; vertere, to turn.] Atavișm; a return in a greater or less degree to some ancestral type (biol.).

reversionary (rēvěr'shŏnărī) a. [L. re, back; vertere, to turn.] Appl. atavistic characteristics (biol.).

revert (rēvĕrt') v. [L. re, back ; vertere, to turn.] To exhibit ancestral features; to hark back (biol.).

revolute (rěv'ölüt) a. [L. revolvere, to roll back.] Rolled backwards from the margin upon the under surface, as some leaves (bot.).

rhabdite (răb'dīt) $n$. [Gk. rhabdos, a rod.] One of the short rod-like bodies in the epidermal cells in Polycladida; a gonapophysis (zool.). rhabdocrepid (răb'dökrěp'íd) $a$. [Gk. rhabdos, a rod; krepis, a foundation.] Appl. a desma with uniaxial crepis, in sponge spicules (zool.).

rhabdoid (răb'doid) $a$. and $n$. [Gk. rhabdos, a rod; eidos, resemblance.] Rod-like ; any rod-shaped body.

rhabdolith (răb'dölïth) $n$. [Gk. rhabdos, rod; lithos, stone.] A calcareous rod found in some Protozoa, strengthening the walls (zool.).

rhabdome (răb'dōm) n. [Gk, rhabdos, a rod.] A refractive rod composed of rhabdomeres enclosed by the retinula cells of an arthropod ommatidium (zool.).

rhabdomere (răb'dömēr) $n$. [Gk. rhabdos, a rod; meros, a part.] The refracting element in the retinula (zool.).

rhabdopod (răb'döpŏd) $n$. [Gk. rhabdos, rod; pous, foot.] An element of the clasper of some male Insects (zool.).

rhabdosphere (răb'dösfēr) n. [Gk. rhabdos, rod; sphaira, a globe.] Aggregated rhabdoliths found in deep-sea calcareous oozes (zool.).

rhabdus (răb'dŭs) n. [Gk. rhabdos, a rod.] A rod-like spicule (zool.). rhachis,-see rachis. 
rhachitomous, - see rachitomous. rhagon '(răg'ŏn) $n$. [Gk. rhax, a berry.] A bun-shaped type of Sponge with apical osculum and large gastral cavity (zool.).

rhamphoid (răm'foid) a. [Gk. rhamphos, a beak; eidos, resemblance.] Beak-shaped.

rhamphotheca (răm'föthē'kă) $n$. [Gk. rhamphos, a beak; theke, a case.] The horny sheath of a bird's beak (zool.).

rheotaxis (rēeötăk'sǐs) n. [Gk, rhein, to flow; taxis, arrangement.] $\mathrm{Re}_{-}$ sponse to the stimulus of a water current (bot.).

rheotropic (rēötrŏp'îk) a. [Gk. rhein, to flow ; trope, a turning.] Responding to current stimulus (bot.).

rheotropism (rēŏt'röpǐzm) n. [Gk. rhein, to flow; trope, a turning.] Mechanical response, positive or negative, to the influence of a water current (bot.).

rhinal (rínăl) a. [Gk. rhis, nose.] Of or pert. the nose.

rhinencephaion (rî́nĕnkĕf'ălŏn, -sĕf-) n. [Gk. rhis, nose; engkephalon, brain.] The olfactory lobe of the brain (zool.).

rhinion (rĭn'ionn) $n$. [Gk, rhis, nose.] The most prominent point at which the nasals touch (anat.).

rhinocoel (rînösēl) n. [Gk. rhis, nose; koilos, hollow.] A cavity in the olfactory lobe of the brain (zool.).

rhinophore (rī'nöfōr) n. [Gk. rhis, nose; pherein, to bear.] A process on the aboral side of the eye of certain Molluscs with a supposed olfactory function (zool.).

rhinotheca (rínöthē'kă) n. [Gk. rhis, nose ; theke, a case.] The sheath of the upper jaw of a Bird (zool.).

rhipidate (rǐp'idāt) a. [Gk. rhipis, a fan.] Fan-shaped.

rhipidium (rīpid'ím) n. [Gk. rhipis, a fan.] A fan-shaped inflorescence (bot.), or colony of zooids (zool.).

rhipidostichous (rĭp'ĩdŏs'tíkŭs) $a$. [Gk. rhipis, a fan; stichos, a row.] Appl. fan-shaped fins (zool.).

rhizanthous (rīzăn'thŭs) a. [Gk. rhiza, a root; anthos, a flower.] Producing a root, and a flower apparently straight from it (bot.).

rhizautoicous (rî́zôtoik'ŭs) a. [Gk. rhiza, root; autos, self; iikos, house.] With antheridial and archegonial branches coherent (bot.).

rhizine (rízin) n. [Gk. rhiza, a root.] A rhizoid (bot.).

rhizocarp (rī'zökârp) n. [Gk. rhiza, root; karpos, fruit.] A perennial herb (bot.).

rhizocarpous (rízökâr'pŭs) a. [Gk. rhiza, root; karpos, fruit.] Having perennial roots and annual stems (bot.).

rhizocaul (rízökôl) n. [Gk. rhiza, root; L. caulis, stem.] The rootlike horizontal portion of a Zoophyte (zool.).

rhizocorm (rízökôrm) n. [Gk, rhiza, root; kormos, a log.] An underground stem like a single-jointed rhizome, popularly a bulb (bot.).

rhizogenic (rīzöjěn'ík), rhizogenous (rīzŏj'ěnŭs) $a$. Root-producing ; arising from endodermic cells, not developed from the pericycle (bot.).

rhizoid (rízoid) $n$. [Gk. rhiza, root ; eidos, resemblance.] A root-like outgrowth of many Mosses and Thallophytes (bot.).

rhizomatous (rīzŏm’ătŭs) a. [Gk. rhizoma, a root.] Of the nature of a rhizome (bot.).

rhizome (rízōm) n. [Gk. rhizoma, a root.] A thick stem partly along and partly under the ground, sending out shoots above and roots below (bot.).

rhizomorph (rīzömôrf) n. [Gk. rhiza, root; morphe, form.] A root-like hypha of certain Fungi (bot.).

rhizomorphous (rîzömôr'füs) a. [Gk. rhiza, root; morphe, form.] In the form of a root ; root-like (bot.).

rhizophagous (rīŏf'ăgŭs) $a$. [Gk. rhiza, root; phagein, to eat.] Living on roots (zool.).

rhizophore (rízöför) $n$. [Gk. rhisa, root; pherein, to bear.] A naked branch which grows down into the soil and develops roots from its apex (bot.).

rhizophorous (rizŏf'örŭs) a. [Gk. rhisa, root; pherein, to bear.] Root-bearing (bot.).

rhizoplast (rízöplăst) n. [Gk. rhiza, root; plastos, moulded.] One or more root-like processes connecting 
the basal granule with the nucleus in certain Protozoa (zool.).

rhizotaxis (rí'zötăk'siss) $n$. [Gk. rhiza, root; taxis, arrangement.] Root arrangement (bot.).

rhodophane (rō'döfān) n. [Gk. rhodon, rose; phainein, to show.] Chromophane; the red oil globule found in the retina of Marsupials, Birds, Reptiles, Fishes (phys.).

rhodophyll (rō’döfil) $n$. [Gk. rhodon, rose; phyllon, a leaf.] The red colouring matter of red Algae (bot.). rhodopsin (rōdŏp'šn) n. [Gk. rhodon, rose ; opsis, sight.] A temporary reddish-purple pigment in the retinal rods; visual purple ( $p h y s$.$) .$ rhombencephalon (rômb'ěnkëf'ălŏn, -sĕf-) n. [Gk. rhombos, magic wheel; engkephalon, brain.] The hind-brain.

rhombic (rôm'bǐk) a. [Gk. rhombos, magic wheel.] Appl. lip and grooves of brain at the rhomboid fossa (emb.).

rhombogen (rôm'böjĕn) n. [Gk. rhombos, magic wheel; genos, offspring.] A phase of the parent form in the life cycle of some Mesozoa (zool.).

rhomboid (rôm'boid) a. [Gk, rhombos, magic wheel; eidos, form.] Rhombus-shaped; appl. fossa, sinus, ligament (anat.).

rhomboideus, major and minor,parallel muscles connecting the scapula with the spinal column (anat.).

rhomboid - ovate, - something between rhomboid and oval in shape. rhopalium (rōpālliŭm) n. [Gk. rhopalon, a club.] A marginal sense organ of Discomedusae (zool.).

rhynchocoel (rĭng'kösēl) n. [Gk. rhyngchos, snout; koilos, hollow.] In Nemertines, the cavity whose contracting muscular walls evert the proboscis (zool.).

rhynchodaeum (rĭng'ködē'ŭm) $n$. [Gk. rhyngchos, snout; odaios, pert. a way.] The precerebral region of a Nemertine (zool.).

rhynchodont (rīng'ködǒnt) a. [Gk. rhyngchos, snout ; odous, tooth.] With a toothed beak (zool.).

rhynchophorous (ringkŏf'örŭs) $a$.
[Gk. rhyngchos, beak; pherein, to bear.] Beaked.

rhynchostome (ring'köstōm) $n$. [Gk. rhyngchos, snout; stoma, mouth.] The anterior terminal pore of Nemertines through which the proboscis is everted (zool.).

rhythm (rithm) n. [Gk. rhythmos, measured motion.] Regularity of movement, as seen in heart pulsation (phys.), or movement of telegraph plant leaves (bot.).

rib (rib) $n$. [A.S. ribb, a rib.] One of the curved bones of the thorax articulating with the spine and either free at the other end or connected with the sternum (anat., $z o o l$.$) ; the central vein of a leaf$ (bot.).

rictal (rı̌k'tăl) a. [L. rictus, mouth aperture.] Pert. the mouth gape of a Bird.

rigor (rı̆g'or $\mathrm{r}) n$. [L, rigor, stiffness.] The rigid state of plants when they are not sensitive to stimuli (bot.); a state of rigidity.

rigor mortis, - the stiffening of the body after death, due to myosinformation, and lasting till the commencement of decomposition (biol.).

rima (rímă) n. [L. rima, a cleft.] A cleft or fissure (anat.).

rimate (ri'māt) a. [L. rima, a cleft.] Having fissures.

rimiform (rî́mǐfôrm) a. [L. rima, a cleft; forma, shape.] In the shape of a narrow fissure.

rimose ( $\left.\mathrm{r}^{\prime} \mathrm{m} \overline{\mathrm{s}} \mathrm{s}\right)$ a. [L. rima, a cleft.] Having many clefts or fissures.

rimulose (rim'ūlōs) a. [L. rimula, a small cleft.] Having many small clefts.

rind (rî̀nd) $n$. [A.S. rinde, bark of a tree.] The outer skin or cortex (bot.).

ring canal, $-\mathrm{a}$ circular canal running close to and parallel with the umbrella margin in Hydrozoa (zool.).

ring cell, - a thick-walled cell of the sporangium annulus of Ferns (bot.). ring vessel, - a structure in the head of Cestodes which unites the four longitudinal excretory trunks (zool.).

ringed bark, - the bark of a tree where the formations of phellogen 
are cylindrical; $o p p$. scale bark (bot.).

ringent (rĭn'jěnt) a. [L. ringi, to open the mouth wide.] Having the lips, as of a corolla, or valves, separated by a distinct gap (bot., zool.).

ringless, $-a p p l$. Ferns without an annulus (bot.).

riparial (rịpā'ruăl), riparian (rǐpā'rǔăn), riparious (rǐpā'riǔs) a. [L. ripa, a river bank.] Frequenting, growing on, or living on the banks of streams or rivers (bot., zool.).

ripe (rī) $a$. [A.S. ripe, fit for reaping.] Having seeds mature and ready for germination (bot.).

risorius (rǐsō'rǔus) n. [L. risus, laughter.] A cheek muscle stretching from over the masseter muscle to the corner of the mouth (anat.).

rivose ( $\overline{r i}^{-1} v \bar{s}$ ) a. [L. rivus, a stream.] Marked with irregularly winding furrows or channels.

rivulose (rǐv'ūlōs) a. [L. rivulus, a rivulet.] Marked with sinuate narrow lines or furrows (bot.).

rod epithelium, - epithelium consisting of apparently striated cells (phys.).

rod fibre,- - the fibre with which a rod of the retina is connected internally (anat.).

rod fructification, - fructification occurring in basidiomycetous Fungi by means of rod-like gonidia from a hyphal branch (bot.).

rod granule,-the nucleus of a rod fibre (anat.).

rodent (rö'dënt) $n$. [L. rodere, to gnaw.] An animal with a habit of gnawing or nibbling, as a rabbit.

rods and cones, - the nerve-epithelium layer of the retina (anat.).

root (root) n. [A.S. wyrt, a root.] The descending portion of a plant, fixing the plant in the soil, and absorbing nourishment (bot.).

root absorption,-osmosis (bot.).

root borer, - a larval form or Insect which bores into the roots of plants (zool.).

root cap,-a protective cap of tissue at the apex of a root (bot.).

root cell,- the clear colourless base of one of the Algae attaching the thallus to its substratum (bot.). root climber, - a plant which climbs by means of roots developed from the stem (bot.).

root hairs, - unicellular epidermal outgrowths from roots, of protective and absorbent function (bot.).

root leaf, - a basal leaf (bot.).

root parasitism, - a condition exhibited by semi-parasitic plants, the roots of which penetrate the roots of neighbouring plants and draw from them elaborated food material (bot.).

root pocket, - a sheath containing a root, especially of aquatic plants (bot.).

root pressure,- the force by which water is made to rise in the axial stele of a plant, a main factor in the transport of water through the plant (bot.).

root process, - a branched colourless structure fixing an Alga thallus to soil (bot.).

root sheath, - an orchid velamen (bot.); that part of a hair follicle continuous with the epidermis (anat.).

root stalk, - a rhizome (bot.); the root-like horizontal portion of Hydrozoa (zool.).

root tubercle, - a small swelling on a legume root, caused by Bacteria (bot.).

rootlet, - an ultimate branch of a root (bot.).

rosaceous (rōzā'shŭs) a. [L. rosa, a rose.] With five petals arranged in a circle ; formed like a rose (bot.).

rosellate (rözĕl'āt) a. [L. rosa, a rose.] Arranged like rosettes.

Rosenmuiller's (rō'zĕnmül'ěrz) organ, -a uterine rudimentary organ homologous with the epididymis (anat.).

rosette (rōzĕt') $n$. [L. rosa, a rose.] A cluster of leaves arising in close circles from a central axis (bot.); a thin plate formed by the coalescence of the basals of a larval Crinoid; a large ciliated funnel leading out of the anterior sperm reservoir of the Earthworm (sool.).

rosette organ, - in certain Ascidians, the ventral complex stolon from which buds are constricted off (zool.). 
rosette plate,-five interradial basal plates united together in Crinoids (zool.).

rostel (rŏs'tĕl) $n$. [L. rostellum, dim. of rostrum, a beak.] A rostellum. rostellar (rǒstěl'ăr) a. [L. rostellum, a small beak.] Pert. a rostellum. rostellate (rŏstĕl'āt) a. [L. rostellum, a small beak.] Furnished with a small beak.

rostelliform (rŏstěl'îfôrm) $a$. [L. rostellum, a small beak; forma, shape.] Shaped like a small beak. rostellum (rǒstěl'ŭm) $n$. [L. rostellum, a small beak.] A small rostrum; a projecting structure developed from one of the stigmatic surfaces of the orchid flower (bot.); a rounded prominence, furnished with hooks, on the head of a Tapeworm (zool.); a beaked-shaped process (anat.).

rostral (rǒs'trăl) a. [L. rostrum, a beak.] Pert. a rostrum.

rostrate (rǒs'trāt) a. [L. rostrum, a beak.] Beaked.

rostriform (rŏs'trĭfôrm), rostroid (rŏs'troid) a. [L. rostrum, a beak ; forma, shape; Gk. eidos, resemblance.] Beak-shaped.

rostrulate (rŏs'troolāt) a. [L. rostrulum, a small beak.] Like a rostrulum.

rostrulum (rŏs'troolŭm) $n$. [L. rostrulum, a small beak.] A small rostrum.

rostrum (rŏs'trŭm) n. [L. rostrum, a beak.] A beak or beak-like process; the projecting process between the eyes of a Crayfish; a median ventral plate at the base of the capitulum of Cirripedes; etc. (zool.).

rosular (rŏz'ūlăr), rosulate (rŏz'ūlāt) a. [L. rosa, a rose.] Arranged in rosettes.

rot (rŏt) $n$. [A.S. rotian, to rot.] Decay; decomposition; disease caused by Fungi or Bacteria (bot.) ; a parasitic disease causing emaciation (zool.).

rotate (rötāt') a. [L. rota, a wheel.] Shaped like a wheel; with flat and spreading parts (bot.).

rotation (rötā'shŭn) n. [L. rota, a wheel.] Turning as on a pivot, as limbs (phys.) ; circulation, as of cell sap (bot.). rotator (rötā'tŏr) $n$. [L. rota, a wheel.] A muscle which allows of circular motion (anat.).

rotatores spinae,-paired muscles, one on each side of the spine, each arising from a transverse process of a vertebra and inserted into the vertebra next above (anat.).

rotiform (rō'tĭfôrm) a. [L. rota, a wheel; forma, shape.] Wheelshaped ; circular.

rotula (rǒt'ūlă) $n$. [L. rotula, a small wheel.] One of five radially-directed bars bounding the circular aperture of the oesophagus of a Sea-urchin (zool.); the patella or kneecap (anat.).

rotular (rŏt'ūlăr) a. [L. rotula, a small wheel.] Pert. the rotula.

rotuliform (rǒtū'lífôrm) a. [L. rotula, a small wheel; forma, shape.] Shaped like a small wheel.

rotundifolious (rötŭn'dĭfō'lǐus) a. [L. rotundus, 'round ; folium, a leaf.] With rounded leaves (bot.).

rouleaux (rool'ō, rool'ōz) n. plu. [F. rouleau, a wheel.] Formations like piles of coins into which red blood corpuscles tend to aggregate when blood is at rest (phys.).

rubiginose (roobij'inōs), rubiginous (roobij'inŭs) a. [L. rubigo, rust.] Of a brownish-red tint; with the colour of rust; affected by rust parasites (bot.).

ruderal (rood'ěrăl) a. [L. rudus, débris.] Growing among rubbish or débris (bot.).

rudimentary (rood'ímĕn'tărǐ) a. [L. rudimentum, a first attempt.] In an imperfectly developed condition; at an early stage of development ; arrested at an early stage; vestigial, in certain authors (biol.).

ruff (rŭf) $n$. [A.S. reafan, to reave.] A neck fringe of hair or feathers (zool.).

ruga (roog'ă) $n$. [L. ruga, a wrinkle.] A fold or wrinkle, as the folds of the mucous membrane of certain organs (anat.).

rugate (roog'āt), rugose (roog'ōs), rugous (roog'uัs) a. [L. ruga, a wrinkle.] Wrinkled; with many wrinkles on the surface.

rugulose (roog'ūlōs) a. [L. ruga, a wrinkle.] Finely wrinkled. 
rumen (room'ĕn) $n$. [L. rumen, the throat.] The paunch or first cavity of a ruminant's stomach (zool.).

ruminant (room'innănt) $n$. [L. rumen, throat.] An animal which returns and re-chews what has been swallowed (zool.).

ruminate (room'ināt) a. [L. rumen, the throat.] Having a mottled appearance through the infolding of the tegmen; having mottled albumen; $a p p l$. such seeds as the betel-nut (bot.).

rumination (room'īnāshŭn) $n$. [L. rumen, the throat.] The act of ruminant animals in returning the food from the first stomach to the mouth in small quantities for thorough mastication and insalivation (phys.).

runcinate (rŭn'sĭnāt) a. [L. runcina, a plane.] Appl. a pinnate leaf when the divisions point downwards, as in the dandelion (bot.).

runner (rŭn'ër) $n$. [A.S. rinnan, to run.] A slender prostrate stem which roots at the nodes, as in the strawberry (bot.).

rupestrine (roopĕs'trin), rupicoline (roopik'ölǐn), rupicolous (roopik' ölŭs) $a$. [L. mupes, rock ; colere, to inhabit.] Growing or living on rocks.

ruptile (rŭp'tǐl) a. [L. rumpere, to break.] Bursting in an irregular manner (bot.).

rust (rŭst) n. [A.S. rust, redness.] A destructive parasite whose mycelium lives in the intercellular spaces of higher plants, as wheat rust (bot.).

rut (rŭt) n. [M.E. mutien, to rut.] The season when deers mate and copulate.

\section{S}

sabuline (săb'ūlǐn) a. [L. sabulum, sand.] Sandy.

sabulose,-sabuline.

sac (săk) n. [L. saccus, a sack.] A sack, bag, or pouch.

saccate (săk'āt) a. [L. saccus, a sack.] Pouched; $a p p l$. a calyx of which two lateral sepals are expanded into little sacs or pouches; gibbous (bot.).

sacciferous (săksĭf'ěrŭs) a. [L. saccus, a sack ; ferre, to bear.] Furnished with a sac.

sacciform (săk'sǐfôrm) a. [L. saccus, a sack; forma, shape.] Like a sack or pouch.

sacculate (săk'ūlāt) a. [L. sacculus, a little bag.] Provided with little sacs.

sacculus (săk'ūlŭs) n. [L. sacculus, a small sack.] A saccule or small sac ; the lower part of the vestibule of the ear (anat.).

saccus (săk'ŭs) $n$. [L. saccus, a sack.] A sac-like structure,-as saccus vasculosus, saccus endolymphaticus of the brain (anat.).

sacral (sā'krăl) a. [L. sacer, sacred.] Pert. the sacrum.

sacrocaudal (sā'krökôd'ăl) a. [L. sacer, sacred; cauda, tail.] Pert. sacrum and tail region (zool.).

sacrococcygeal (sā'krökŏksij'éăl) $a$. [L. sacer, sacred; Gk. kokkyx, cuckoo.] Pert. sacrum and coccyx. sacrolumbar (sā'krölŭm'băr) a. [L. sacer, sacred; lumbus, loin.] Pert. sacral and lumbar regions.

sacrospinal (sā'kröspînăl) a. [L. sacer, sacred; spina, spine.] Pert. sacral region and spine.

sacrovertebral (sā'krövĕr'těbrăl) a. [L. sacer, sacred ; vertebra, a joint.] Pert. sacrum and vertebrae.

sacrum (sā'krŭm) n. [L. sacer, sacred.] The os sacrum or bone forming the termination of the vertebral column, usually consisting of several fused vertebrae (anat.).

sagittal (săjĭtăl, săj'ítăl) a. [L. sagitta, an arrow.] Appl. the suture between the parietals (anat.). sagittal section,- - section or division in the median longitudinal plane (anat.).

sagittate (săjìt'āt, săj'itāt) a. [L. sagitta, arrow.] Shaped like the head of an arrow, as a leaf (bot.).

sagittocyst (săjĭt'ösǐst) $n$. [L. sagitta, arrow; Gk. kystis, bladder.] A cyst or capsule in Turbellarians containing a single spindle (zool.).

saliva (sălî'vă) $n$. [L. saliva, spittle.] A fluid secreted by the mouth glands, which aids mastication and 
is the first digestive juice to attack food (phys.).

salivary (sălĩvărǐ) a. [L. saliva, spittle.] Pert. saliva, or connected with it in any way (phys.); $a p p l$. glands which secrete saliva (anat.). salivation (săl'ivā'shŭn) $n$. [L. saliva, spittle.] The flow of saliva into the mouth, especially an increased flow ( $p$ hys.).

salpingian (sălpìn'jiăn) a. [Gk. salpingx, a trumpet.] Pert. the Eustachian or the Fallopian tube (anat.).

salpingopalatine,-pert. Eustachian tubes and palate (anat.).

salpinx (săl'pĭngks) $n$. [Gk. salpingx, a trumpet.] Eustachian or Fallopian tube (anat.).

salsuginous (sălsứ'jinnŭs) $a$. [L. salsugo, saltness.] Growing in soil impregnated with salts (bot.).

saltatorial (săltătō'rǔăl) a. [L. saltare, to leap.] Adapted for, or used in, leaping or dancing; $a p p l$. limbs of jumping Insects.

saltatory, - saltatorial.

saltigrade (săl'tĭgrād) a. [L. saltare, to leap ; gradus, a step.] Moving by leaps, as some Insects.

samara (sămā'ră) n. [L. samara, the seed of the elm.] A winged in. dehiscent fruit, as in elm and ash (bot.).

samaroid (săm'ăroid) a. [L. samara, seed of elm; Gk. eidos, form.] Samariform; resembling a samara (bot.).

sanguicolous (sănggwǐk'ölŭs) $a$. [L. sanguis, blood ; colere, to inhabit.] Living in the blood of animals (zool.).

sanguiferous (sănggwiff'ĕrŭs) a. [L. sanguis, blood; ferre, to carry.] Conveying blood, as arteries, veins (phys.).

sanguivorous (sănggwǐv'örŭs) a. [L. sanguis, blood ; vorare, to devour.] Living on blood (zool.).

sanidaster (săn'idăs'tër) n. [Gk. sanidion, a panel ; aster, star. ] A slender rod-like spicule with spines at intervals (zool.).

saphena (săfếnă) n. [Gk. saphenes, clear.] A conspicuous vein of the leg, extending from the knee to the foot (anat.). saphenous (săfē'nŭs) $a$. [Gk. saphenes, clear.] Pert. the internal or external saphena (anat.).

sapropelic (săp'röpěl'̛́k) a. [Gk. sapros, rotten ; pelos, mud.] Living among the débris of bottom ooze.

saprophyte (săp'röfît) $n$. [Gk. sapros, rotten ; phyton, plant.] An organism which lives on dead and decaying organic matter; a saprophytic organism.

saprozoic (săp'rözō'ík) a. [Gk. sapros, rotten; zoon, animal.] $A p p l$. an animal organism which lives on dead or decaying organic matter (zool.)

sarcenchyma (sârkěng'kĭmă) $n$. [Gk. sarx, flesh ; engchyma, infusion.] Parenchyma in which the groundsubstance is granular and not abundant (biol.).

sarcocarp (sâr'kökârp) n. [Gk. sarx, flesh ; karpos, fruit.] The fleshy or pulpy part of a fruit (bot.).

sarcocyte (sâr'kösīt) n. [Gk. sarx, flesh; kytos, hollow.] The middle layer of Gregarine ectoplasm (zool.).

sarcode (sâr'kōd) $n$. [Gk. sarx, flesh.] The body protoplasm of a Protozoan (cyt.).

sarcoderm (sâr'ködĕrm) n. [Gk. sarx, flesh; derma, skin.] The fleshy layer between a seed and the external covering (bot.).

sarcodic (sârkǒd'îk) a. [Gk. sarx, flesh.] Pert. or resembling protoplasm (biol.).

sarcodictyum (sâr'ködǐk'tuŭm) n. [Gk. sarx, flesh ; diktyon, a net.] The second or network protoplasmic zone of Radiolarians (zool.).

sarcogenic (sâr'köjĕn'ík) a. [Gk. sarx, flesh; genos, offspring.] Flesh-producing (biol.).

sarcoid (sâr'koid) a. [Gk. sarx, flesh ; eidos, form.] Fleshy, as sponge tissue (zool.).

sarcolemma (sâr'kölĕm’ă) n. [Gk. sarx, flesh; lemma, skin.] The tubular sheath of a muscle fibre (anat.).

sarcoma (sârkō'mă) n. [Gk. sarx, flesh.] A fleshy excrescence (bot.). sarcomatrix (sârkömā'trǐks) n. [Gk. sarx, flesh; L. matrix, womb.] The fourth protoplasmic zone of a Radiolarian, the seat of digestion and assimilation (zool.). 
sarcomere (sâr'kömēr) n. [Gk. sarx, flesh; meros, part.] A transverse line subdividing the sarcostyle (phys.).

sarcophagous (sârkŏf'ăgŭs) a. [Gk. sarx, flesh; phagein, to eat.] Subsisting on flesh (zool.).

sarcoplasm (sâr'köplăzm) $n$. [Gk. sarx, flesh; plasma, something moulded.] The longitudinal interstitial reticulum of muscular tissue (phys.).

sarcosoma (sâr'kösō'mă) n. [Gk. sarx, flesh; soma, body.] The fleshy portion of the body as opp. the skeletal (zool.).

sarcosperm (sâr'köspĕrm) n. [Gk. sarx, flesh; sperma, seed.] Sarcoderm (bot.).

sarcostyle (sâr'köstīl) n. [Gk. sarx, flesh; stylos, a pillar.] A fibril or muscle column of muscular tissue (phys.); a dactylozooid column (zool.).

sarcotheca (sâr'köthē'kă) n. [Gk. sarx, flesh; theke, a box.] The sheath of a hydrozoan sarcostyle (zool.).

sarcous (sâr'kŭs) a. [Gk. sarx, flesh.] Pert. flesh or muscle tissue (zool.).

sarmentaceous (sârmĕntā'shŭs) $a$. [L. sarmentum, a twig.] Having slender prostrate stems or runners (bot.).

sarmentose, sarmentous, - sarmentaceous.

sarmentum (sârmĕn'tŭm) n. [L. sarmentum, a twig.] The slender stem of a climber or runner (bot.).

sarothrum (sârō'thrŭm) $n$. [Gk. sarotron, a broom.] An enlarged hairy tarsal joint of a bee, the pollen brush (zool.).

sartorius (sârtō'riusu) $n$. [L. sartor, a tailor.] A thigh muscle which enables the legs to be bent inwards (anat.).

satellite (săt'ělìt) $n$. [L. satelles, an attendant.] The second of any pair of individuals of a catenoid colony in pseudoconjugation of Gregarinida ; $c f$. primite (zool.).

saurian (sôr'ǐăn) a. [Gk. sauros, a lizard.] Resembling a lizard ( $p a l$.$) .$ saurognathous (sôr'ögnā'thưs) $\alpha$. [Gk. sauros, lizard ; gnathos, jaw.] With a saurian arrangement of jaw-bones (zool.), sauroid (sòroid) a. [Gk. sauros, lizard ; eidos, form.] Resembling a saurian (zool.).

saxicavous (săk'sǐkä'vǔs) a. [L. saxum, rock; cavus, hollow.] Appl. rock-borers, as some Molluscs (zool.).

saxicoline (săksı̌k'ölǐn) a. [L. saxum, rock; colere, to inhabit.] Living or growing among rocks (bot., zool.).

scaberulous (skăbĕr'ūlŭs) $a$. [L. scaber, rough.] Somewhat rough.

scabrate (skăb'rāt) a. [L. scaber, rough.] Rough with a covering of stiff hairs, scales, or points (bot.).

scabrous, - scabrate.

scala (skā'lă) $n$. [L. scala, a ladder.] Any of three ladder-like canals in the cochlea of the ear (zool.).

scalariform (skălăr'ífôrm) a. [L. scala, ladder; forma, shape.] Laddershaped; $a p p l$. vessels or tissues having bars like a ladder (bot.).

scale (skāl) n. [A.S. sceala, a shell, husk.] A flat, small, platelike external structure, dermal or epidermal ; a bony, horny, or chitinous outgrowth (zool.); the bract of a catkin, being of a scaly nature; the ligule of certain flowers; a modification of a stellate hair on certain leaves (bot.).

scale bark,-bark in irregular sheets or patches, due to irregular or dipping formation of phellogen (bot.).

scale lear, - a bud-protecting cataphyllary leaf (bot.).

scalene (skālēn') a. [Gk. skalenos, uneven,] Pert. any of the scalene muscles (anat.).

scalenus (skālē'nŭs) n. [Gk, skalenos, uneven.] One of three neck muscles used in bending the head,--scalenus posticus, medius, anticus (anat.).

scalp (skălp) n. [M.E. scalp.] The skin and subcutaneous tissues of the surface of the head where hair grows (anat.).

sealpella (skălpèl'ă) n. plu. [L. scalpellum, a scalpel.] Paired pointed processes, parts of the maxillae of Diptera (zool.).

scalpriform (skăl'prǐfôrm) a. [L. scalprum, a chisel; forma, shape.] Chisel-shaped, as certain teeth (zool., anat.). 
scandent (skăn'dĕnt) a. [L. scandere, to climb.] Climbing by stem-roots or tendrils (bot.).

scansorial (skănsō'rǔăl) a. [L. scandere, to climb.] Formed or adapted for climbing (zool.).

scape (skāp) $n$. [Gk. skapos, stalk.] A flower-stalk arising at or under the ground; a radical peduncle, as hyacinth (bot.); a structure formed by the two basal segments of the antennae of Diptera (zool.).

scapha (skä'fă) n. [Gk. scaphe, a boat.] The narrow curved depression between helix and antihelix of the ear (anat.).

scaphium (skā'fĭum) n. [Gk. scaphe, boat.] A process of the ninth (copulatory) segment of male Lepidoptera (zool.).

scaphocerite (skăf'ösēérīt) n. [Gk. skaphe, boat; keras, horn.] The scale-like exopodite of the second antenna of Decapods (zool.).

scaphognathite (skăfögnâth'īt, skăfŏg'năthīt) n. [Gk. skaphe, boat; gnathos, jaw.] The exopodite of the second maxilla of Decapods, regulating the flow of water through the respiratory chamber (zool.).

scaphoid (skăf'oid) a. [Gk. skaphe, boat ; eidos, form.] Shaped like a boat; $a p p l$. a carpal and a tarsal bone (anat.).

scapholunar (skăf'ölü'năr) a. [Gk. skaphe, boat; L.luna, moon.] Pert. scaphoid and lunar carpal bones, or those bones fused (anat., zool.).

scapiform (skā'pǐfôrm) a. [Gk. skapos, stalk; L. forma, shape.] Scapoid; resembling a scape (bot.). scapose (skā'pōs) a. [Gk. skapos, stalk.] Consisting of or in the form of a scape (bot.).

scapula (skăp'ūlă) n. [L. scapula, shoulder-blade.] The shoulderblade; name given to various structures suggestive of a shoulderblade, as tegula, patagium, mesothoracic pleuron, fore-leg trochanter of certain Insects ; in Crinoids, the proximal plate of a ray that has an articular facet for the arms (zool.).

scapular (skăp'ūlăr) a. [L. scapula, shoulder-blade.] Pert. the scapula. scapulars, - scapular feathers of birds. scapus (skā'pŭs) n. [L. scapus, stem, stalk.] A scape (bot.); the stem of a feather (zool.).

scarfskin (skârf'skĭn) $n$. [A.S. sceorfa, scurf.] The cuticle or epidermis (anat.).

scarious (skā'rŭŭs) a. [F. scarieux, membranous.] Thin, dry, membranous (bot.); scaly or scurfy (zool.).

schindylesis (skĭn'dīlē'sĭs) $n$. [Gk. schindylesis, a fissure.] Articulation in which a thin plate of bone fits into a cleft or fissure, as that between vomer and palatines (anat.). schizocarp (shǐz'ökârp, skǐ-) $n$. [Gk. schizein, to cleave ; karpos, fruit.] A dry seed-vessel which splits into two or more one-seeded carpels (bot.).

schizochroal (shǐzökrōăl, skǐ-) a. [Gk. schizein, to cleave; chros, bodysurface.] With lenses separate and cornea not continuous; $a p p l$. certain trilobite eyes ( $p a l$.$) .$

schizocoel (shî́z'ösēl, skî̀-) n. [Gk. schizein, to cleave; koilos, hollow.] A body-cavity formed by splitting of the mesoblast into layers (emb.).

schizogamy (shǐzŏg'ămì, skǐ-) $n$. [Gk. schizein, to cleave; gamos, marriage.] Fission into a sexual and a nonsexual zooid in some Polychaets (zool.).

schizogenesis (shǐz'öjĕn'ěsǐs, skĭ-) $n$. [Gk. schizein, to cleave; genesis, descent.] Reproduction by means of fission (biol.).

schizogenetic (shǐz'öjĕnět'îk, skǐ-) $a$. [Gk. schizein, to cleave; genesis, descent.] Reproducing by means of fission (biol.); appl. resin ducts in young stems of ivy; $a p p l$. spaces formed by delamination of adjacent cell walls (bot.).

schizognathous (shĭzŏg'năthŭs, skĭ-) a. [Gk. schizein, to cleave ; gnathos, jaw.] $A p p l$. the arrangement of jaws when the vomer is small and pointed in front and maxillopalatines do not unite with each other and the vomer, as in the Pigeon (zool.).

schizogony (shî̉ŏg'önĭ, skî-) $n$. [Gk. schizein, to cleave ; gonos, offspring.] A kind of multiple fission in Protozoa (zool.). 
schizokinete (shǐz'ökīnēt', skī-) $n$. [Gk. schizein, to cleave; kinetos, movable.] A motile vermicule stage in the life-history of Haemosporidiae (zool.).

schizont (shĭzŏnt', skǐ-) $n$. [Gk. schizein, to cleave; ons, being.] A trophozoite stage of parasitic Sporozoa, reproducing in the host by multiple fission (zool.).

schizontocytes (shǐzŏn'tösîts, skĭ-) $n$. plu. [Gk. schizein, to cleave; ons, being ; kytos, hollow.] Cytomeres into which a schizont divides, and which themselves divide into clusters of merozoites (zool.).

schizopelmous (shŭz'öpěl'mŭs, skĭ-) $a$.

[Gk. schizein, to cleave; pelma, sole of the foot.] With two separate flexor tendons connected with the toes, as in some Birds (zool.).

schizopod stage,--that stage in the development of a Decapod larva when it resembles an adult Mysis in having exopodite and endopodite to all the thoracic limbs (zool.).

schizorhinal (shî̀'örínăl, skī-) $a$. [Gk. schizein, to cleave ; rhis, nose.] Having the external narial opening elongated, and the posterior border angular or slit-like (zool.).

schizostele (shǐ̌löstēl, skì-) n. [Gk. schizein, to cleave; stele, a post.] One of a number of strands formed by division of the plerome of a stem (bot.).

schizostely (shľ̈'östē'lí, skî-) n. [Gk. schizein, to cleave; stele, a post.] The condition of a stem in which the plerome gives rise to a number of strands, each composed of one vascular bundle ; astely (bot.).

schizothecal (shî̀zöthē'kăl, skì-) $a$. [Gk. schizein, to cleave; theke, a case.] Having scale-like horny tarsal plates (zool.).

schizozoite (shǐz'özō'it, skī-) n. [Gk. schizein, to cleave; zoon, animal.] A merozoite formed from each segment of a dividing schizont (zool.).

Schwann's sheath, - a delicate but tough membrane outside the medullary sheath of a nerve fibre; the primitive sheath ( $p$ hys.).

sciatic (siăt'ik) a. [Gk. ischion, hipjoint.] Pert. the hip region; $a p p l$. artery, nerve, etc. (anat.). scion (sìŏn) n. [F. scion, shoot.] A branch or shoot for grafting purposes (bot.).

selera (sklē'ră) n. [Gk. skleros, hard.] A firm unyielding membrane forming five-sixths of the fibrous tunic of the eyeball, the cornea forming the anterior sixth (anat.).

scleratogenous layer, - a strand of fused sclerotomes formed along the neural tube, later surrounding the notochord (emb.).

sclere (sklēr) n. [Gk. skleros, hard.] A skeletal structure; a sponge spicule (zool.).

sclerenchyma (sklĕrĕng'kĭmă) $n$. [Gk. skleros, hard; engchyma, infusion.] The hard tissue of coral (zool.) ; tissue of thickened and of hard cells of vessels (bot.).

sclerite (sklë́rït) n. [Gk. skleros, hard.] A calcareous plate or spicule (zool.).

sclerobase (sklě́röbās) n. [Gk. skleros, hard; basis, base.] The calcareous axis of Alcyonaria (zool.). scleroblast (sklếröblăst) $n$. [Gk. skleros, hard; blastos, a bud.] A sponge cell from which a sclere develops (zool.).

sclerocauly (sklê̌r'ökôl'î) n. [Gk. skleros, hard ; kaulos, stalk.] Condition of excessive skeletal structure in a stem (bot.).

sclerocorneal (sklĕr'ökôr'něăl) $a$. [Gk. skleros, hard; L.cornea, the cornea.] Pert. cornea and sclerotic (anat.).

scleroderm (sklěrrööĕrm) $n$. [Gk. skleros, hard; derma, skin.] An indurating integument; the skeletal part of Corals (zool.).

sclerodermatous (sklêr'öděr'mătŭs) $a$. [Gk. skleros, hard; derma, skin.] Having an external skeletal structure (zool.).

sclerodermite (sklěr'ödĕr'mït) $n$. [Gk. skleros, hard; derma, skin.] The hard outer covering of an arthropod segment (zool.).

sclerogen (sklěr'öjĕn) $n$. [Gk. skleros, hard ; genos, offspring.] Woody tissue in plant cells (bot.).

sclerogenie (sklêrr'öjĕn'îk), - sclerogenous.

sclerogenous (sklěrŏj'ěnǔs) a. [Gk. skleros, hard; genos, offspring.] Secreting lignin (bot.). 
scleroid (sklě́roid) a. [Gk. skleros, hard; eidos, resemblance.] Hard; skeletal (biol.).

sclerophylly (sklê̌'röfil'í) $n$. [Gk. skleros, hard ; phyllon, leaf.] Condition of excessive skeletal structure in leaves (bot.).

scleroseptum (sklër'ösĕp'tŭm) $n$. [Gk. skleros, hard ; L. septum, a division.] A radial vertical wall of carbonate of lime in madrepore Corals.

sclerosis (sklěrō'sǐs) $n$. [Gk. skleros, hard.] Hardening by increase of connective tissue or lignin (bot.).

sclerotal (sklërō'tăl) a. [Gk. skleros, hard.] Sclerotic ; indurated ; containing lignin (bot.); pert. the sclerotic of the eye (anat.).

sclerotic (sklěrŏt'ı́k) n. [Gk. skleros, hard.] The outer layer or protective membrane of the eye (anat.).

sclerotic ossicles, - a ring of small bones round the protruded sclerotic of Birds (zool.).

sclerotioid (sklěrŏt'ĩoid) $a$. [Gk. skleros, hard; eidos, resemblance.] Pert. a sclerotium (bot.).

sclerotium (sklěrōttiŭm, -shǔum) n. [Gk. skleros, hard.] The resting, dormant, or winter stage of some Fungi when they become a mass of hardened mycelium or waxy protoplasm (bot.).

sclerotome (sklê̌r'ötōm) n. [Gk. skleros, hard; tome, a cutting.] A partition of connective tissue between two myotomes (zool.).

sclerous (sklé'rŭs) a. [Gk. skleros, hard.] Sclerotal.

scolecid (skōlěsĭd) a. [Gk. skolex, a worm.] Pert. a scolex.

scoleciform (skölěs'ífôrm) a. [Gk. skolex, worm; L. forma, shape.] Like a scolex.

scolecite (sköl'ěsīt) $n$. [Gk. skolex, worm.] A vermiform body branching from the mycelium of Discomycetes (bot.).

scolecoid (sköl'ěkoid) a. [Gk. skolex, worm; eidos, form.] Resembling a scolex.

scolex (skō'lěks) n. [Gk. skolex, worm.] The head or rounded terminal knob of a Tape-worm (zool.). scolite (skōlitt) n. [Gk. skolex, worm; lithos, stone.] A fossil worm burrow (pal.). scopa (skōpă) n. [L. scopa, brush.] A pollen brush (zool.).

scopate (skō'pāt) $a$. [L. scopa, brush.] Having a tuft of hairs like a brush (zool.).

scopiferous, - scopate.

scopiform (skō'pífôrm) a. [L. scopa, brush ; forma, shape.] Brushlike.

scopula (skŏp'ūlă) $n$. [L. scopula, a small brush.] A small tuft of hairs ; a needle-like sponge spicule with brush-like head; in climbing spiders, a tuft of club-like hairs on each foot, replacing the third claw (zool.).

scopulate (skŏp'ūlāt) a. [L. scopula, a small brush.] Like a brush.

scopuliferous (skǒp'ūliff'ĕrŭs) a. [L. scopula, a small brush; ferre, to carry.] Having a small brush-like structure.

scopuliform (skǒp'ūlífôrm) a. [L. scopula, a small brush; forma, shape.] Resembling a small brush. scorpioid (skôr'pioid) a. [Gk. skorpios, scorpion; eidos, form.] Cicinnal (bot.); resembling a scorpion; with curved tail.

scorpioid cyme,-a uniparous cymose inflorescence in which the daughteraxes are developed right and left alternately (bot.).

scrobicula (skröbỉk'ūlă) $n$. [L. scrobis, a ditch.] The smooth area round the boss of an echinoid test (zool.). scrobicular (skröbǐk'ūlăr) a. [L. scrobis, ditch.] In the region of the scrobicula.

serobiculate (skröbřk'ūlāt) a. [L. scrobis, ditch.] Marked with little pits or depressions (zool.).

scrobicule, - a scrobicula.

scrobiculus (skröbřk'ūlŭs) $n$. [L. scrobis, ditch.] A pit or depression. scrobiculus cordis, - the pit of the stomach (anat.).

serotal (skrō'tăl) a. [L. scrotum.] Pert. or in the region of the scrotum (anat.).

scrotum (skrō'tŭm) n. [L. scrotum.] The external sac containing the testicles, in Mammals.

scurf (skưrf) $n$. [A.S. scurf.] Scaly skin ; dried outer skin peeling off in scales (anat.); the scaly epidermal covering of some leaves (bot.). 
scutal (skū'tăl) a. [L. scutum, shield.] Pert. a scutum.

scutate (skü'tāt) a. [L. scutum, shield.] Protected by large scales or horny plates (zool.).

scute (skūt) $n$. [L. scutum, shield.] An external scale, as of Reptile, Fish, or scaly Insect (zool.).

scutella (skūtĕl'ă) n. [L. scutellum, a small shield.] A scutellum or shield-like structure.

scutellar (skūtěl'ăr) a. [L. scutellum, a small shield.] Pert. a scutellum. scutellate (skūtěl'āt) a. [L. scutellum, a small shield.] Shaped like a small shield.

scutellation (skū'tělä'shŭn) n. [L. scutellum, a small shield.] The method of arrangement of scales, as on tarsus of Bird (zool.).

scutelliform,-scutellate.

scutelligerous (skū'tělǐj’ěrŭs) a. [L. scutellum, a small shield; gerere, to bear.] Furnished with scutella or a scutellum.

scutelliplantar (skūtěl'íplăn'tăr) $a$. [L. scutellum, a small shield; planta, sole of foot.] Having the tarsus covered with small plates or scutella (zool.).

scutellum (skūtěl'ŭm) n. [L. scutellum, a small shield.] A tarsal scale of Birds ; the posterior part of the mesothoracic segment of an Insect (zool.); the single massive cotyledon lying next the starchy endosperm in seed of Maize; a development of part of the cotyledon which separates the embryo from the endosperm in the seed of Grasses (bot.).

scutiferous,-scutigerous.

scutiform (skū'tifôrm) a. [L. scutum, shield; forma, shape.] Shaped like a shield; $a p p l$. the floating leaf of Salvinia (bot.).

scutigerous (skūtǐj'ěrŭs) $a$. [L. scutum, shield; gerere, to bear.] Bearing a shield-like structure (zool.).

scutiped (skū'tīpěd) a. [L. scutum, shield; pes, foot.] Having the foot or part of it covered by scutella (zool.).

scutum (skūtŭm) n. [L. scutum, shield.] A shield-like plate, horny, bony, or chitinous, developed in the integument; the fornix or modified spine overhanging the aperture in some Cheilostomata (zool.).

scyphiferous (skĭfif'ěrŭs, sī-) $a$. [Gk. skyphos, cup; L. ferre, to bear.] Bearing scyphi, as some Lichens (bot.).

seyphiform (skî́f'ifôrm, sī-) a. [Gk. skyphos, cup; L. forma, shape.] Shaped like a cup (bot.).

scyphistoma (skǐfís'tömă, sī-) $n$. [Gk. skyphos, cup; stoma, mouth.] A scyphula, the scyphozoon polyp stage in the development of Aurelia (zool.).

scyphose (skǐf'ōs, sî́fōs) a. [Gk. skyphos, cup.] Scyphiform.

scyphula (skîf'ülă, sîf-) $n$. [Gk. skyphos, cup.] A scyphistoma.

scyphulus (skĭf'ūlüs, sĭ-) $n$. [Gk. skyphos, cup.] A small cup-shaped structure (bot.).

seyphus (skîf'ús, sī-) $n$. [Gk. skyphos, cup.] The cup of a Narcissus; a funnel-shaped corolla ; the cupshaped expansion of the podetium in some Lichens (bot.).

sebaceous (sěbā'shŭs) a. [L. sebum, tallow.] Containing or secreting fatty matter; $a p p l$. glands (anat.). sebiferous (sěbĭf'ěrŭs) a. [L. sebum, tallow ; ferre, to carry.] Conveying fatty matter (phys.).

sebiparous (sěbip'ărŭs) a. [L. sebum, tallow ; parere, to beget.] Secreting fatty matter (phys.).

sebum (sé'bŭm) $n$. [L. sebum, tallow.] The secretion of sebaceous glands, consisting of fatty matter and isocholesterin (phys.).

secodont (sěk'ödŏnt) a. [L. secare, to cut; Gk. odous, tooth.] Furnished with teeth adapted for cutting (zool.).

secondary (sěk'ŏndărǐ) a. [L. secundus, second.] Second in importance or in position (zool.) ; arising, not from the growing point, but from other tissue (bot.); $n$. a forearm quill-feather of a bird's wing; an insect hind-wing (zool.). secondary bud, - an axillary bud, accessory to the norinal one (bot.). secondary capitula,--six small cells rising from each capitulum of Chara (bot.).

secondary growth,-development of 
secondary meristem or cambium producing new tissue on both sides, as in woody dicotyledons (bot.).

secondary meristem, - phellogen (bot.).

secondary prothallium, - a tissue produced in the megaspore of Selaginella after the true prothallium is formed (bot.).

secondary roots, - branches of the primary root, arising within its tissue, and in turn giving rise to tertiary roots; roots arising at other than normal points of origin (bot.).

secondary spore, - a small or abjointed spore ; an ascospore (bot.).

secondary tissue, - tissue formed through phellogen, externally cork, and internally phelloderm (bot.).

secondary wood, - wood formed from cambium (bot.).

secretin (sēkrē'tĭn) $n$. [L. secernere, to separate.] A chemical substance produced in the intestinal mucous membrane whose action on the pancreas causes a copious secretion of pancreatic juice (phys.).

secretion (sēkrế'shŭn) $n$. [Li.secernere, to separate.] A substance or fluid which is separated from the blood or other cells; the process of such separation (phys.).

secretitious (sēkrētǐsh'ŭs) a. [L. secernere, to separate.] Appl. a substance or fluid secreted (phys.). secretory (sēkrē'törī) a. [L. secernere, to separate.] Performing the office of secretion (phys.).

sectile (sěk'tîl) $a$. [L, secare, to cut.] Cut into small partitions, compartments (bot.).

sectorial (sĕktō'rǔăl) a. [L. secare, to cut.] Formed or adapted for cutting, as certain teeth.

secund (sěk'ŭnd) a. [L. secundus, following.] $A p p l$. flowers or leaves arranged on one side of the stem (bot.).

secundiflorous' (sěkŭnd'iffō'rŭs) $a$. [L. secundus, following; flos, flower.] Having flowers on one side of the stem only (bot.).

secundine (sěk'ŭundĭn) $n$. [L. secundus, following.] The second coat of the ovule, lying within the primine (bot.). secundines, - the foetal membranes collectively (anat.).

secundly (sěk'ŭndlǐ) $a d v$. [L. secundus, following.] On one side of a stem or axis (bot.).

sedentary (sĕd'ĕntărĭ) a. [L. sedere, to sit.] Not free-living; $a p p l$. animals attached by a base to some substratum (zool.).

seed (sēd) $n$. [A.S. saed, seed.] A mature fruit containing an embryo ready for germination under suitable conditions (bot.); semen (anat.).

seed bud, - an ovule (bot.).

seed coat, - the testa, a thin membrane investing the seed (bot.).

seed plant, - a seed-bearing plant (bot.).

seed stalk, - the funicle (bot.).

seed vessel, - a structure containing seed, as a pod (bot.).

segment (sĕg'mĕnt) $n . \quad[\mathrm{L} . \quad s e g$ mentum, a piece cut off.] A division formed by cleavage of an ovum (emb.); a part of an animal or of a jointed appendage (zool.) ; a division of a leaf if cleft nearly to the base (bot.).

segmental (sěgmĕn'tăl) a. [L. segmentum, a part.] Of the nature of a segment; pert. a segment.

segmental arteries, - diverticula from the dorsal aortae arising in the spaces between successive somites (emb.).

segmental duct,-an embryonic duct which gives rise to Wolffian or Müllerian duct (emb.).

segmental organ, - an embryonic excretory organ (emb.).

segmental papillae, - conspicuous pigment spots by which true segments may be recognised in Leeches (zool.).

segmentation (sĕg'mĕntā'shŭn) $n$. [L. segmentum, a segment.] The division or splitting into segments or portions (biol.); cleavage of an ovum (emb.).

segmentation cavity, - the blastocoel or central cavity formed at an early stage of egg cleavage (emb.).

segmentation nucleus, - the body formed by the union of male and female pronuclei in the course of fertilization of an ovum (emb.). 
segregation (sĕgrĕgā'shŭn) $n$. [L. se, aside ; grex, flock.] In the Mendelian sense, the dissociation of characters from each other in the course of the formation of germs, the characters being called allelomorphic (biol.).

sejugous (sěj'oogŭs) a. [L. sex, six ; jugum, a yoke.] With six pairs of leaflets (bot.).

selenodont (sělē'nödŏnt) a. [Gk. selene, moon; odous, tooth.] Appl. molars when lengthened out antero-posteriorly and curved (as in sheep).

selenotropism (sělĕnŏt'röpǐzm) $n$. [Gk, selene, moon; trope, a turning.] Tendency to turn towards the moon's rays (bot.).

self-fertile, - fertile by means of its own male elements, said of a flower (bot.).

self-fertilization,-autogamy.

self-mutilation,-autotomy.

self-pollination, - transference of pollen-grains from anthers to stigmas of the same flower.

self-sterile, - not capable of fertilization by its own male elements; $a p p l$. flowers (bot.) ; appl. hermaphrodite animals (zool.).

sella turcica (sěl'ă tŭr'sǐkă) n. [L. sella, a seat; turcicus, Turkish.] A deep depression on the inner surface of the sphenoid behind the tuberculum sellae (anat.); a transverse bar formed by union of apodemes of posterior somites of certain Decapods (zool.).

sematic (sēmăt'ik) a. [Gk. sema, a sign.] Functioning as a danger signal, as certain colours or odours in animals.

semen (sē'mĕn) n. [L. semen, seed.] The fluid secreted in the testicles (zool.).

semiamplexicaul (sĕm'iămplĕk'sìkôl) a. [L. semi, half; amplecti, to embrace ; caulis, stem.] Partially surrounding the stem (bot.). semianatropous (sěm'iănăt'röpŭs) $a$. [L. semi, half; Gk. ana, up; trope, a turning.] With half-inverted ovule (bot.).

semicaudate (sěm'îkốdāt) $a$. [L. semi, half ; cauda, tail.] With the tail rudimentary (zool.). semicircular (sĕm'ísër'kūlăr) $a$ : [L semi, half; circulus, a circle.] Describing a half-circle; $a p p l$. the canals of the ear labyrinth (anat.).

semicomplete (sĕm'íkŏmplēt') $a$. [L. semi, half; completus, filled.] Incomplete; appl. metamorphosis (zool.).

semifloret (sĕm'îflörĕt) $n$. [L. semi, half; flos, flower.] A semifloscule or ray of composite flowers (bot.).

semifloseulous (sĕm'îflŏs'külŭs) $a$. [L. semi, half; flosculus, a small flower.] Having ligulate florets (bot.).

semilocular (sěm'îlŏk'ūlăr) $a$. [L. semi, half; loculus, a small place.] Appl. ovary with incomplete loculi (bot.).

semilunar (sĕm'ílū'năr, -loo-) a. [L. semi, half; luna, moon.] Halfmoon shaped ; $a p p l$. ganglia, fascia, valves (anat.); n., a carpal bone (zool.).

semimembranosus (sěm'íměm'brănō'sŭs) $n$. [L. semi, half ; membranosus, membranous.] A thigh muscle with a flat membranelike tendon at its upper extremity (anat.).

semimetamorphosis (sěm'îmětămôr' fösiss) $n$. [L. semi, half; Gk. metamorphosis, transformation.] Partial, incomplete, or semicomplete metamorphosis (zool.).

seminal (sĕm'inăl) a. [L. semen, seed.] Pert. semen; appl. the fluid of the testicles, the duct or the vesicle (zool.); appl. cotyledons (bot.).

seminal receptacle, - the spermatheca or sac in Worms or Snails which stores male elements till required (zool.).

semination (sĕm'ǐnā'shŭn) $n$. [L. semen, seed.] Dispersal of seeds (bot.).

seminiferous (sĕminif'ĕrŭs) $a . \quad[\mathrm{L}$. semen, seed;ferre, to carry.] Secreting or conveying seed or seminal fluid (zool.); bearing seed (bot.).

seminude (sĕm'inūd) $a$. [L. semi, half; nudus, naked.] With ovules or seeds exposed (bot.).

seminymph (sĕm'inimf) $n$. [L. seni, 
half; nympha, a nymph.] A condition in development of certain Insects approaching complete metamorphosis (zool.).

semiovate (sĕm'î́o'vāt) a. [L. semi, half ; ovum, egg.] Half-oval; somewhat oval.

semioviparous (sĕm'ïövĭp'ărŭs) $a$. [L. semi, half; ovum, egg ; parere, to beget.] Between oviparous and viviparous, as a Marsupial whose young are very imperfectly developed when born (zool.).

semiovoid (sěm'iō'void) a. [L. semi, half ; ovum, egg ; Gk. eidos, form.] Somewhat ovoid in shape.

semipalmate (sĕm'ípăl'māt) $a$. [L. semi, half; palma, palm of the hand.] Having toes webbed halfway down (zool.).

semiparasite (sĕm’ípăr'ăsīt) $n$. [L. semi, half; Gk. parasitos, eating beside another.] A partial parasite, as a plant which derives part only of its nutriment from its host (biol.). semipenniform (sĕm'ípĕn'ífôrm) $a$. [L. semi, half; penna, feather; forma, shape.] Appl. certain muscles bearing some resemblance to the plume of a feather (anat.).

semipermeable (sěm'ípĕr'mēăbl) $a$. [L. semi, half; per, through; meare, to pass.] Appl. a membrane which does not permit any dissolved substance to pass, although permeable to water (phys.).

semiplume (sěm'íploom) $n$. [L. semi, half; pluma, feather.] A feather with an ordinary shaft but a downy web (zool.).

semipupa (sĕm'ipü'pă) $n$. [L. semi, half; $p u p a$, a puppet.] A larval stage in the development of certain Insects (zool.).

semirecondite (sěm'írěk'ŏndīt) $a$. [L. semi, half; recondere, to conceal.] Half-concealed, as an insect's head may be by its thorax (zool.).

semisagittate (sĕm'ĩsăj'itāt) $a$. [L. semi, half; sagitta, an arrow.] Shaped like a half arrow-head.

semisaprophyte (sěm'isăp'röfit) $n$. [L. semi, half; Gk. sapros, rotten ; phyton, plant.] A plant partially saprophytic (bot.).

semispinalis (sěm'ispĭnắlis) $n$. [L. semi, half; spinalis, spinal.] A muscle of the back on each side of the spinal column, inserted into transverse and spinous processes continuously (anat.).

semitendinosus (sĕm'ǐtěn'dīnōsŭs) $n$. [L. semi, half; tendere, to stretch.] A dorsal muscle of the thigh stretching from the tuber ischii to the tibia (anat.).

semitendinous (sĕm'ítěn'dinnus) $a$. [L. semi, half; tendere, to stretch.] Half tendinous (anat.).

semituberous (sěm'îtū'bĕrŭs) $a$. [L. semi, half ; tuber, a hump.] Having somewhat tuberous roots (bot.).

senescence (sĕnĕs'ĕns) $n$. [L. senescere, to grow old.] Advancing age ; $a p p l$. condition of Protozoa after many bipartitions, which condition may be counteracted by conjugation (biol.).

senility (sěnǐl'ítǐ) $n$. [L. senilis, senile.] Senile derangement; the vital exhaustion of Protozoa (biol.).

sense organ,-an organ functional in receiving external stimulation (phys.).

sensiferous (sĕnsĭf'ĕrŭs) $a$. [L. sensus, sense; ferre, to carry.] Receiving or conveying sense impressions; sensigerous ( $p$ hys.).

sensile (sěn'sīl) a. [L. sensus, sense.] Capable of affecting a sense (phys.).

sensitive (sĕn'sĭtǐv) a. [L. sensus, sense.] Capable of receiving impressions from external objects (phys.).

sensitive plant, - a plant which droops, recoils, or closes at a touch, as Mimosa (bot.).

sensorial (sĕnsō'rǐăl) a. [L. sensus, sense.] Pert. the sensorium (phys.). sensorium (sěnsō'riŭm) $n$. [L. sensus, sense.] The seat of sensation or consciousness, supposed to be the brain; the entire nervous system (phys.).

sensory (sĕn'sörĩ) a. [L. sensus, sense.] Having direct connection with any part of the sensorium (phys.).

sentient (sěn'shǐnt) $a$. [L. sentive, to feel.] $A p p l$. cells which are sensitive and can perceive (phys.). sepal (sě́păl) n. [Gk. sepalon, a sepal, on analogy of petalon, a petal ; or 
L. sepes, a hedge.] A leaf-like division of the calyx (bot.).

sepaled (sē'păld) a. [Sepal.] Having sepals (bot.).

sepaline (sěp'ălǐn) a. [Sepal.] Like a sepal (bot.).

sepalody (sěpăl'ödř) $n$. [Sepal; Gk. eidos, form ] Conversion of petals or other parts of a flower into sepals (bot.).

sepaloid (sěp'ăloid) a. [Sepal; Gk. eidos, form.] Like a sepal (bot.).

sepalous (sěp'ălŭs) a. [Sepal.] Having sepals (bot.).

separation layer,-see absciss layer. sepicolous (sěpǐk'ölŭs) a. [L. sepes, hedge ; colere, to inhabit.] Living in hedges.

septal (sĕp'tăl) a. [L. septum, a partition.] Pert. a septum.

septal fossula, - a small primary septum which appears to lie in a pit in some fossil Corals (pal.).

septal neck, - in Nautilus, a shelly tube continuous for some distance beyond each septum as a support to the siphuncle (zool.).

septate (sěp'tāt) $a$. [L. septum, a partition.] Divided by partitions. septempartite (sĕp'těmpâr'tīt) $a$. [L. septem, seven ; pars, a part.] Appl. a leaf with seven divisions extending nearly to the base (bot.).

septenate (sěp'těnāt) a. [L. septeni, seven each.] With parts in sevens; $a p p l$. seven leaflets of a leaf (bot.).

septicidal (sěp'tĭsíddăl) a. [L. septum, division ; caedere, to cut.] Dividing through the middle of the ovary septa (bot.).

septiferous (sĕptif'ěrŭs) a. [L.septum, partition; ferre, to bear.] Having

septa (bot.). (sěp'tifōóliŭs) a. [L.
septifolious septem, seven ; folium, a leaf.] With seven leaves or leaflets (bot.). septiform (sěp'tǐfôrm) $a$. [L. septum, partition; forma, shape.] In the form of a septum.

septifragal (sěptǐf'răgăl) a. [L. septum, partition ; frangere, to break.] With slits as in loculicidal or septicidal dehiscence, but with the septa broken and the placentas and seeds left in the middle (bot.).

septomaxillary (sěp'tömăkšll'ărĭ) $a$. [L. septum, partition ; maxilla, jaw.]
Pert. maxilla and nasal septum (zool.).

septonasal (sěp'tönā'zăl) a. [L. septum, partition; nasus, nose.] Pert. the internarial septum (anat.). septulate (sěp'tūlāt) a. [L. septulum, a small septum.] Having spurious septa (bot.).

septulum (sĕp'tūlŭm) n. [L. septulum, a small septum.] A small or secondary septum (bot.).

septum (sĕp'tŭm) n. [L. septum, partition.] A partition separating into two cavities, as in fruits, chambered shells, corals (biol.).

septum narium, - the partition between the nostrils (anat.).

septum transversum, - the diaphragm (anat.).

sericate (sĕr'ikāt), sericeous (sěrǐsh'ŭs) a. [L. sericus, silken.] Covered with fine close-pressed silky hairs (bot.).

serosa (sĕro'să) $n$. [L. serum, serum.] A serous membrane (anat.); the outer larval membrane of Insects (zool.).

serosity (sěrŏs'ítǐ) n. [L. serum, serum.] The watery part of animal fluid (phys.).

serotinous (sĕrŏtĩnŭs) a. [L. serus, late.] Blooming later in the season than customary for the species (bot.).

serous (sē'rŭs) a. [L. serum, serum.] Watery; pert. serum; appl. fluid, gland (phys.).

serous alveoli,--alveoli which secrete a watery non-viscid saliva, $o p p$. mucous alveoli (phys.).

serous membrane, - a thin membrane consisting of a single layer of epithelial cells, lining some closed cavity of the body, as the pericardium, the peritoneum (anat.).

serpulite (sěr'pülīt) $n$. [L. serpula, a small snake.] The fossil tube of a Polychaet worm; appl. chalk containing fossil worm-tubes ( $p a l$. .). serra (sĕr ăa $n$. [L. serra, a saw.] Any saw-like structure.

serrate (sĕr'āt) a. [L. serra, saw.] Notched on the edge like a saw ; $a p p l$. leaves and other structures (biol.).

serrate-ciliate, - with hairs fringing toothed edges (bot.). 
serrate-dentate, - with serrate edges themselves toothed (bot.).

serratiform (sĕrăt'ifôrm) $a$. [L. serra, saw ; forma, shape.] Like a saw.

serration (sěrā'shŭn) $n$. [L. serra, saw.] Saw-like formation.

serratirostral (sĕrăt'írŏs'trăl) $a$. [L. serra, saw; rostrum, beak.] Appl. Birds with serrate bill.

serratodenticulate (sĕrăt ${ }^{\prime}$ ödĕntǐk' $\left.\mathrm{u} l a ̄ t\right)$ a. [L. serra, saw; dens, tooth.] With many-toothed serrations (bot.). serrature (sĕrătūr) $n$. [L. serra, saw.] A saw-like notch.

serratus magnus, - a muscle stretching from upper ribs to scapula (anat.).

serriferous (sĕrĭf'ěrŭs) $a$. [L. serra, saw; ferre, to carry.] Furnished with a saw-like organ or part.

serriform (sĕr'ifôrm) a. [L. serra, saw ; forma, shape.] Like a saw. serriped (sěr'ipèd) a. [L. serra, saw ; pes, foot.] With notched feet.

serrula (sěr'ūlă) $n$. [L. serrula, a small saw.] A comb-like ridge on the chelicerae of some Arachnids (zool.).

serrulate (sěr'ūlāt) a. [L. serrula, a small saw.] Like a finely-notched saw,

serrulation (sĕr'ūlā'shŭn) $n$. $\quad[\mathrm{L}$. serrula, a small saw.] A small notch.

Sertoli cells, - enlarged lining epithelium-cells connected with groups of developing spermatozoa in testes (anat.).

serum (sē'rŭm) n. [L. serum, serum.] The thin watery fluid which separates from the blood on coagulation, -it contains proteins, extractives, and salts (phys.).

serum albumin, serum globulin,two of the proteins of serum (phys.).

sesamoid (sěs'ămoid) a. [Gk. sesamon, sesame; eidos, form.] Appl. a bone developed within a tendon and near a joint, as the patella, the radial or ulnar sesamoid (anat.).

sesamoidal (sěs'ămoidăl) $a$. [L. sesamon, sesame; eidos, form.] Pert. a sesamoid bone.

sessile (sěs'il) a. [L. sedere, to sit.] Sitting directly on the base with- out support, stalk, or peduncle ; stationary, as $o p p$. free-living or motile (zool.).

seta (sē'tă) $n$. [L. seta, a bristle.] Any bristle-like structure; the chaeta of Chaetopods (zool.).

setaceous (sětā'shŭs) a. [L. seta, a bristle.] Bristle-like; set with bristles.

setiform (sē'tifŏrm) a. [L. seta, a bristle; forma, shape.] Bristleshaped; $a p p l$. teeth when very fine and closely set.

setigerous (sētřj'ěrŭs) a. [L. seta, bristle ; gerere, to bear.] Setiferous ; setiparous ; bristle-bearing. setigerous sac, - a sac, in which is lodged a bundle of setae, formed by an invagination of the epidermis in the parapodium of Chaetopods (zool.).

setirostral (sē'tĭrŏs'trăl) a. [L. setu, bristle; rostrum, beak.] Appl. Birds with beak bristles.

setobranchia (sē'töbrăng'kiă) n. [L. seta, bristle; Gk. brangchia, gills.] A tuft of setae attached to the gills of certain Decapods (zool.).

setose (sē'tōs) a. [L. seta, bristle.] Set with bristles; bristly.

setula (sět'ūlă) n. [Dim. from L. seta, bristle.] A setule; a threadlike or hair-like bristle.

setuliform (sětü'lifôrm) a. [L. seta, bristle; forma, shape.] Threadlike; like a setula or fine bristle.

setulose (sět'ūlōs) a. [L. seta, bristle.] Set with small bristles.

sex (sěks) $n$. [L. sexus, sex.] The sum of characteristics, structures, functions, by which an animal or plant is classed as male or female.

sexdigitate (sěksdíj'ítāt) a. [L. sex, six ; digitus, a finger.] With six fingers or toes (zool.).

sexfid (sěks'fid) a. [L. sex, six; findere, to cleave.] Cleft into six, as a calyx (bot.).

sexfoil (sĕks'foil) a. [L. sex, six ; folium, leaf.] A group of six leaves or leaflets round one axis (bot.).

sex-limited inheritance, - inheritance of characteristics limited by the fact that some are predominantly male and others predominantly female (biol.).

sexual (sěk'sūăl) a. [L. sexus, sex.] 
Pert. sex ; $a p p l$. reproduction, opp. asexual (biol.).

sexual cell, -an ovum or sperm.

sexual dimorphism, - stronglymarked differences, in size, colour, etc., between male and female of one species (zool.).

sexual generation, - a gamobium or medusa. - See alternation of generations.

shaft (shăft) $n$. [A.S. sceaft, a spearshaft.] A rachis; the distal part of the stem of a feather; the straight cylindrical part of a long bone (zool.).

sheath (shēth) n. [A.S. sceth, shell or pod.] A protective covering; a theca ; an investing petiole (bot.); an insect wing-cover (zool.).

shell (shĕl) $n$. [A.S. scell, shell.] The hard outer covering of animal or fruit (biol.) ; a covering, calcareous, siliceous, bony, horny, or chitinous (zool.).

shell gland, shell sac,-the organ in whose walls material for forming a shell is created.

shield (shēld) $n$. [A.S. scild, a shield.] A protecting structure such as a carapace or lorica (zool.).

shoulder blade,-the scapula.

shoulder girdle,- - the pectoral girdle, which consists of scapula, coracoid, and clavicle (anat.).

sialoid (sîăloid) a. [Gk. sialon, saliva ; eidos, resemblance.] Like saliva (phys.).

sicula (š̌k'ülă) $n$. [L. sicula, a small dagger.] A small dagger-shaped body at the end of a Graptolite, supposed to be the skeleton of the primary zooid of the colony (pal.).

side-chain theory,-Ehrlich's theory of the phenomena of immunity, viz., that toxins unite with living protoplasm by possessing the same property as that by which nutritive proteins are normally assimilated (phys.).

sieve cell, - the thin-walled elongated cell of a sieve tube (bot.).

sieve disc or plate,- the end walls of sieve cells thickened and modified to form sieve-plates (bot.).

sieve pit or pore, - a perforation of a sieve-plate (bot.). sieve tissue, - the iessential tissue of the phloem of vascular bundles (bot.).

sieve tubes or vessels,-long slender structures consisting of elongated cells placed end to end, developed in Angiosperms as lines of conduction of food (bot.).

sight (sīt) n. [A.S. siht, sight.] The visual faculty ; impressions of outward things conveyed to the brain by means of retina and optic nerves (phys.).

sigillate (š̌j'ìlāt) a. [L. sigillum, a seal.] Having seal-like markings, as certain roots (bot.).

sigma (sig'mă) $n$. [Gk. $\Sigma$, sigma.] A C-shaped sponge spicule (zool.). sigmaspire (š̆g'măspīr) n. [Gk. ¿, sigma ; L. spira, a coil.] A sigma with an additional twist (zool.).

sigmoid (sig'moid) a. [Gk. $\Sigma$, sigma ; eidos, resemblance.] Curved like a sigma; curved in two directions; appl. arteries, cavities, valves (anat.).

sigmoid flexure, - an S-shaped double curve as in a bird's neck; the Sshaped curve described by the intestine (anat.).

silicle (š̃l'îkl) $n$. [L. silicula, a little pod.] A silicula, or very short flat form of siliqua (bot.).

silicular (šllìk'ülăr) a. [L. silicula, a little pod.] Siliculose; siliculous ; like or pert. or having a silicle (bot.).

siliqua (sǐlı̌k'wă) $n$. [L. siliqua, a pod.] A long cylindrical fruit divided in two by a false septum, characteristic of the Cruciferae (bot.).

silique (š̃lēk'), -a siliqua.

siliquiform (šilik'wifôrm) a. [L. siliqua, a pod; forma, shape.] Formed like a silique (bot.).

siliquose (sîlíkwōs) a. [L. siliqua, pod.] Siliquous; bearing siliques (bot.).

simian (sı̆miăn) a. [L. simia, an ape.] Possessing the characteristics of or pert. the anthropoid apes (zool.).

simple eyes,-ocelli which occur with or without compound eyes in the adults of many Insects ; usually the only eyes possessed by larvae; eyes with only one lens (zool.). 
simulation (sĭm'ūlā'shŭn) n. [L. simulare, to simulate.] The assumption by some animals of features or structures intended to deceive enemies and so protect themselves, as the forms of leaf and stick Insects, and all the varieties of protective coloration (zool.).

sincipital (sinsǐp'îtăl) a. [L. semi, half; caput, head.] Pert. the sinciput (anat.).

sinciput (sin'sı̆pŭt) $n$. [L. semi, half ; caput, head.] The upper or fore part of the head (anat.).

sinistral (sinn'îstrăl) a. [L. sinister, left.] On the left; $a p p l$. a shell whose spiral turns in the opposite direction to dextral (zool.).

sinistrorse (sin'ístrôrs) a. [L. sinister, left; vertere, to turn.] Appl. a spiral twining towards the left; $o p p$. dextrorse (bot.).

sinuaté (šn'ūāt) a. [L. sinus, curve.] Winding ; tortuous; having a wavy indented margin, as leaves (bot.).

sinuous,-sinuate.

sinupalliate (sǐn'ūpăl'iāt) a. [L. sinus, curve; pallium, mantle.] In Molluscs, having a well - developed siphon, and so an indented pallial line ; opp. integripalliate (zool.).

sinus (sînŭs) $n$. [L. sinus, curve.]

A cavity, depression, or dilation (zool., anat.); a groove or indentation (bot.).

sinus pocularis,-uterus masculinus.

sinus rhomboidalis, - in vertebrate embryos, the posterior incompletelyclosed part of the medullary canal (emb.) ; later, a dilation of the canal in the sacral region, formed from it (anat.).

sinus venosus, - the posterior chamber of the tubular heart of the embryo $(e m b$.$) ; in lower vertebrates, a$ corresponding structure receiving venous blood and opening into the auricle (zool.); the cavity of the auricle (anat.).

sinusoid (sínŭsoid) $n . \quad$ [L. sinus, curve; Gk. eidos, resemblance.] A minute blood space in organ tissue formed from intercrescence of endodermal cells and vascular endothelium, especially in the liver, where sinusoids give rise to "capillaries" of the hepatic lobules of the adult liver (emb.).

siphon ( $\left.\mathrm{sil}^{\prime} f \circ \mathrm{n}\right) n$. [Gk. siphon, a reed or tube.] A prolongation of the mantle in Lamellibranchs into a longer and shorter tube through which the water of respiration enters and leaves the mantle cavity; a similar respiratory structure of Gasteropods, found modified also in Cephalopods; a sucking proboscis (zool.).

siphonate (sî́fönāt) a. [Gk. siphon, tube.] Furnished with a siphon or siphons (zool.).

siphonet (sî́fönĕt) n. [Gk. siphon, tube.] The honeydew tube of an Aphid (zool.).

siphonial (sīfōnuăl) a. [Gk. siphon, tube.] Pert. a siphonium.

siphonium (sifón niŭm)n. [Gk. siphon, tube.] A membranous tube connecting the air-passages of the quadrate with an air-space in the mandible (Crocodile) (zool.).

siphonogamous (sífŏnŏg'ămŭs) $a$. [Gk. siphon, tube; gamos, marriage.] Securing fertilization by a pollen tube (bot.).

siphonogamy (sī'fŏnŏg'ămǐ) n. [Gk. siphon, tube.] Fertilization by means of a pollen tube (bot.).

siphonoglyph (sî́fönöglĭf') $n$. [Gk. siphon, tube ; glyphein, to engrave.] One of two longitudinal grooves of the gullet of Sea-anemones (zool.).

siphonoplax (sífönöplăks') n. [Gk. siphon, tube; plax, a tablet.] A calcareous plate connected with the siphon of certain Molluscs (zool.).

siphonostele (sĩ'fönöstēl') n. [Gk. siphon, tube; stele, a post.] The hollow vascular cylinder of a stem, containing pith (bot.).

siphonostelic (sî'fönöstěl'îk) $a$. [Gk. siphon, tube; stele, a post.] Appl. hollow cylindrical stems, chiefly of Ferns (bot.).

siphonostomatous (sífönöstŏm'ătŭs) a. [Gk. siphon, tube; stoma, mouth.] With tubular mouth; having the front margin of the shell notched for emission of the siphon (zool.).

siphonozooid (sī́fönözōoid) $n$. [Gk. 
siphon, tube ; zoon, animal ; eidos, resemblance.] A smaller individual of certain Alcyonarian colonies, without tentacles or gonads (zool.).

siphorhinal (sî́förînăl) a. [Gk. siphon, tube; rhis, nose.] With tubular nostrils (zool.).

siphuncle (sǐfŭng'kl) $n$. [L. siphunculus, a small tube.] A siphonet; a median tube of skin, partly calcareous, connecting up all the compartments of a Nautilus shell (zool.).

siphunculate (sǐfŭng'kūlāt) a. [L. siphunculus, a small tube.] Having a siphuncle.

sitotropism (š̌tǒt'röpǐzm) n. [Gk. sitos, food; trope, a turning.] Tendency to turn in the direction of food; reaction towards the stimulating influences of food (biol.).

skeletal (skěl'ětăl) a. [Gk. skeletos, dried.] Pert. the skeleton (bot., zool.).

skeletogenous (skěl'ětŏj'ěnŭs) $a$. [Gk. skeletos, hard; genos, offspring.] $A p p l$. embryonic structures or parts which ultimately develop into parts of the skeleton (biol.).

skeleton (skěl'ětŏn) $n$. [Gk. skeletos, dried, hard.] The hard or bony framework, internal or external, which supports and protects the softer parts of the body of plant or animal.

skin (skinn) $n$. [Swed. skinn, skin.] The external covering of an animal, plant, fruit, or seed.

skin-gills, - transparent contractile outgrowths from the skin of Asteroids, with respiratory function (zool.).

skin-rings, - annular markings on the body of a Worm.

skull (skül) n. [M.E. skulle, the cranium.] The cranium, or hard and bony part of the head of a vertebrate.

slough (slŭf) $n$. [M.E. slouh, skin of a snake.] The dead outer skin cast off periodically by Snakes (zool.).

smell (směl) n. [M.E. smel, odour.] The impression produced on the expanse of the olfactory nerve by inhaled air charged with odorous matter, and therefrom communicated to the olfactory centre of the brain (phys.).

soboles (sŏb'ölězz) $n$. [L. soboles, a shoot.] A sucker or underground creeping stem (bot.).

soboliferous (sǒb'ölif'ěrŭs) a. [L. soboles, shoot; ferre, to carry.] Having shoots or running stems (bot.).

socket (sǒk'ět) $n$. [L. soccus, a sock.] A hollow into which something fits, as that of humerus or femur (anat.).

soft-rayed,-having jointed fin-rays (zool.).

soft-shelled, - appl. mud Tortoises with flat shell without horny shields and covered with soft leathery skin (zool.).

solar (sō'lăr) a. [L. sol, the sun.] Having branches or filaments like the rays of the sun (anat.).

solar plexus, - a network of nerves with some ganglia, situated behind the stomach and supplying all the abdominal viscera (anat.).

soleaform (sō'lěăfôrm) $a$. [L. solea, sandal; forma, shape.] Slippershaped.

solenia (sölē'nǔă) n. plu. [Gk. solen, a channel.] Endoderm-lined canals, diverticula from the coelentera of a zooid colony (zool.).

solenocytes (sölē'nösīts) $n$. plu. [Gk. solen, channel; kytos, hollow.] Slender club-shaped tubular flagellated cells connected with the nephridia of some Polychaets, Trochelminths, and of Amphioxus (zool.).

solenostele (sölénöstēl) n. [Gk. solen, channel; stele, a column.] A stage after the siphonostele in fernstem development (bot.).

soleus (sō'lěŭs) n. [L. solea, sole of the foot.] A flat calf muscle below the gastrocnemius (anat.).

soliped (sôl'ĩpěd) a. [L, solidus, solid; pes, foot.] Solid-hoofed, as a horse or zebra (zool.).

solitary glands or follicles, - lymphoid nodules occurring singly on the intestines; Peyer's patches (anat.).

soma (sō'mă) n. [Gk. soma, body.] 
The animal body as a whole with the exception of the germinal or reproductive cells (biol.).

somacule (sō'măkūl) n. [Gk. soma, body.] A unit of protoplasm; a biophore. See hypothetical units. somatic (sömăt'îk) $a$. [Gk. soma, body.] Pert. the purely bodily part of an animal as distinct from the germinal or reproductive cells (biol.).

somatoblast (söm'ătöblăst) $n$. [Gk. soma, body; blastos, bud.] A cell which gives rise to somatic cells; a specialized micromere in oosperm division of Annulates (emb.).

somatocyst (söm’ătösǐst) $n$. [Gk. soma, body; kystis, a bladder.] An air cavity in the pneumatophore of Siphonophores (zool.).

somatogenic (söm'ătöjĕn'îk) a. [Gk. soma, body; genos, offspring.] Developing from somatic cells (emb.).

somatome (söm'ătōm) n. [Gk. soma, body; tome, a cutting.] A somite or body segment (zool.).

somatophyte (söm'ătöfīt) n. [Gk. soma, body; phyton, plant.] A plant whose cells develop mainly into adult body tissue (bot.).

somatoplasm (söm'ătöplăzm) n. [Gk. soma, body; plasma, something moulded.] The substance of a somatic cell (biol.).

somatopleural (söm'ătöploor'ăl) $a$. [Gk. soma, body; pleura, side.] Pert. the somatopleure.

somatopleure (söm'ătöploor) $n$. [Gk. soma, body; pleura, side.] The body-wall formed by the somatic layer of the mesoblast becoming closely connected with the surface epiblast (emb.).

somite (sō'mīt) $n$. [Gk. soma, body.] A mesoblastic segment or compartment (emb.) ; a body segment of an articulate animal (zool.).

soredial (sörë'diăl) a. [Gk. soros, a pile.] Pert.orresembling a soredium (bot.).

sorediate (sörē'dīāt) a. [Gk. soros, a pile.] Bearing soredia (bot.).

soredium (sörē'dĭŭm) n. [Gk. soros, a pile.] A scale-like or globular body consisting of mycelium with some algae cells, on the thallus of some Lichens (bot.). soriferous (sörǐf'ĕrŭs) a. [Gk. soros, a pile; L. ferre, to carry.] Bearing sori (bot.).

sorosis (sörō'sis) n. [Gk. soros, a pile.] A composite fruit formed by fusion of fleshy axis and flowers, as in Pine-apple (bot.).

sorus (sō'rŭs) $n$. [Gk. soros, a pile.]

A collection of small stalked sporangia on the under surface of a fern pinnule (bot.); clusters of spores in some Sarcodina (zool.).

spadiceous (spădǐsh'ǔs)a. [L. spadix, a palm-branch.] Arranged like a spadix (bot.).

spadicifloral,-spadiceous.

spadiciform (spădǐs'îfôrm) a. [L. spadix, a palm-branch; forma, shape.] Resembling a spadix (bot.). spadicose (spä'dīkōs) a. [L. spadix, a palm-branch.] Like a spadix (bot.).

spadix (spā'dĭks) $n$. [L. spadix, a palm-branch broken off with its fruit; a nut-brown colour.] A racemose inflorescence with elongated axis, sessile flowers, and an enveloping spathe (bot.).

spasmoneme (spăz'mönēm) $n$. [Gk. spasma, a spasm ; nema, a thread.] In certain Infusorians, a stalkmuscle formed by union of longitudinal myonemes (zool.).

spathaceous (spăthä'shŭs) a. [Gk. spathe, a broad blade.] Resembling or bearing a spathe (bot.).

spathal,-spathaceous.

spathe (spāth) $n$. [Gk. spathe, a broad blade.] A large enveloping leaf, green or petaloid, protecting a spadix (bot.).

spathed (spāthd) $a$. [Gk. spathe, a broad blade.] Furnished with a spathe (bot.).

spathella (spăthĕlă) n. [Gk. spathe, a broad blade.] A small spathe surrounding a division of a palm spadix (bot.).

spathose (spā'thōs) a. [Gk. spathe, a broad blade.] With or like a spathe (bot.).

spathous,-spathose.

spathulate, - see spatulate.

spatula (spăt'ūlă) n. [L. spatula, a spoon.] A breast-bone or anchor process of certain dipterous larvae (zool.). 
spatulate (spăt'ūlāt) a. [L. spatula, spoon.] Spoon-shaped; appl. a leaf with broad, rounded apex, thence tapering to the base (bot.). spawn (spôn) n. [M.E. spawnen, to spawn.] The collection of eggs deposited by Fishes, Frogs, etc. (zool.); mycelium of certain Fungi (bot.).

species (spē'shǐez) $n$. [L. species, a particular kind.] A term used in the natural sciences to denote a group of closely-allied individuals : the division is purely artificial (biol.). specific (spěsĭf'ik) a. [L. species, a particular kind ; facere, to make.] The second name in binomial nomenclature, which see; $a p p l$. characteristics distinguishing a species (biol.).

speleology (spē'lěŏl'öjǐ) n. [Gk. spelaion, cave ; logos, discourse.] The study of cave life.

sperm (spĕrm) $n$. [Gk. sperma, seed.] The male fertilizing element; a spermatozoon (biol.).

sperm aster, - the rayed structure surrounding the centrosome (emb.).

sperm cell, - a male reproductive cell or spermatozoon.

sperm centrosome, - the end-knob of the axial filament of a spermatozoon, situated on the middle piece just at the base of the head; according to some writers, the small body at the apex of the head (cyt.).

sperm nucleus, - the nucleus of the spermatozoon; the male pro-nucleus (cyt.).

spermaduct (spĕr'mădŭkt) n. [Gk. sperma, seed; L. ducere, to lead.] A duct for conveyance of spermatozoa (zool.).

spermarium,-a spermary.

spermary (spĕr'mărì) n. [Gk. sperma, seed.] An organ in which spermatozoa or antheridia are produced (biol.).

spermatangium (spĕr'mătăn'jiŭum) $n$. [Gk. sperma, seed; anggeion, a vessel.] The antheridium of certain Algae (bot.).

spermatheca (spĕr'măthē'kă) $n$. [Gk. sperma, seed; theke, a case.]. A receptaculum seminis; a sac in the female of many invertebrates in which spermatozoa are stored till required (zool.). spermatic (spěrmăt'îk) a. [Gk. sperma, seed.] Pert. spermatozoa or testis (zool.).

spermatid (spĕr'mătĭd) n. [Gk. sperma, seed.] A cell arising by division of the secondary spermatocytes and becoming a spermatozoon (cyt.).

spermatiferous (spěrmătĭf'ěrŭs) $a$. [Gk. sperma, seed; L. ferre, to carry.] Bearing spermatia (bot.).

spermatiophore (spěrmăt'iöför) $n$. [Gk. sperma, seed ; pherein, to bear.] A spermatia-producing sporophore (bot.).

spermatium (spĕrmä'shŭŭm) $n$. [Gk. sperna, seed.] A non-motile sperm of red Algae; a small cell formed by abstrictions of filaments of spermogonia of wheat Rust (bot.). spermatize (spěr'mătīz) v. [Gk. sperma, seed.] To impregnate (biol.).

spermatoblast (spěr'mătöblăst) $n$. [Gk. sperma, seed; blastos, bud.] A spermatid; a Sertoli cell (cyt.). spermatoblastic (spĕr'mătöblăs'tīk) $a$. [Gk. sperma, seed ; blastos, bud.] Sperm-producing.

spermatocyst (spĕr'mătösǐst) $n$. [Gk. sperma, seed ; kystis, a bladder.] A seminal sac.

spermatocyte (spěr'mătösīt) $n$. [Gk. sperma, seed; kytos, hollow.] A cell arising by growth from a spermatogonium; a primary spermatocyte divides to form two secondary spermatocytes, each of which gives rise to two spermatids (cyt.).

spermatogenesis (spěr'mătöjĕn'ěsĭs) n. [Gk. sperma, seed; genesis, origin.] The process of spermformation (biol.).

spermatogenetic (spěr'mătöjĕnĕt'îk) a. [Gk. sperma, seed; genesis, descent.] Pert. sperm-formation; sperm-producing.

spermatogenic, spermatogenous, spermatogenetic.

spermatogonial (spèr'mătögō'niăl) $a$. [Gk. sperma, seed ; gonos, offspring.] Pert, a spermatogonium.

spermatogonium (spěr'mătögô'niŭm) n. [Gk. sperma, seed; gonos, offspring.] A primordial male germcell (cyt). 
spermatoid (spĕr'mătoid) a. [Gk. sperma, seed ; eidos, resemblance.] Like a sperm (biol.).

spermatomerites (spĕr'mătömē'rīts) n. plu. [Gk. sperma, seed; meros, part.] Chromatin granules formed from the sperm-nucleus (cyt.).

spermatophore (spěr'mătöfōr) $n$. [Gk. sperma, seed; pherein, to bear.] A capsule of albuminous matter containing a number of sperms (zool.).

spermatoplasm (spĕr'mătöplăzm) $n$. [Gk. sperma, seed ; plasma, something moulded.] The protoplasm of sperm cells (cyt.).

spermatoplast (spěr'mătöplăst) $n$. [Gk. sperma, seed ; plastos, moulded.] A male sexual cell (bot.).

spermatosome (spĕr'mătösōm) n. [Gk. sperma, seed; soma, body.] A spermatozoon.

spermatotheca,-a spermatheca.

spermatozeugma (spĕr'mătözū'gmă) n. [Gk. sperma, seed; zeugma, union.] The union by conjugation of two or more spermatozoa occurring in the vas deferens of some Insects (zool.).

spermatozoan (spěr'mătözō'ăn) $a$. [Gk. sperma, seed; zoon, animal.] Pert. spermatozoa.

spermatozoid (spěr'mătözō'íd) $n$. [Gk. sperma, seed ; zoon, animal ; eidos, resemblance.] An antherozoid; a free-swimming male gamete (bot.). spermatozooid,--a spermatozoid.

spermatozoon (spĕr'mătözöón) $n$. [Gk. sperma, seed; zoon, animal.] A male reproductive cell, consisting of head, middle part, and flagellum (zool.).

spermiducal glands,-glandular structures into or near which spermducts open, in many vertebrates (zool.).

spermiduct (spěr'mìdŭkt) $n$. [Gk. sperma, seed; L. ducere, to lead.] A duct for the transmission of spermatozoa (zool.).

spermocarp (spĕr'mökârp) n. [Gk. sperma, seed; karpos, fruit.] An oogonium after fertilization (bot.).

spermocentre (spĕr'mösĕn'tër) $n$. [Gk. sperma, seed; L. centrum, a centre.] The male centrosome during fertilization (cyt.). spermoderm (spĕr'mödĕrm) $n$. [Gk. sperma, seed; derma, skin.] The outer covering of a seed (bot.).

spermoduct,- same as spermaduct, spermiduct.

spermogoniferous (spĕr'mögönĭf'ĕrŭs) a. [Gk. sperma, seed; gonos, offspring; L.ferre, to carry.] Having spermogonia (bot.).

spermogonium (spěr'mögō'nǐŭm) $n$. [Gk. sperma, seed; gonos, offspring.] A capsule containing spermatia, found on certain Fungi and Lichens (bot.).

spermogonous (spĕrmŏg'önŭs) $a$. [Gk. sperma, seed; gonos, offspring.] Like or pert. a spermogonium (bot.). spermology (spěrmǒl'öjī) n. [Gk. sperma, seed; logos, discourse.] A branch of Botany treating of seeds.

spermotheca (spĕr'möthē'kă) n. [Gk. sperma, seed; theke, a case.] A chamber for storing sperms received in copulation; spermatheca (zool.). sphacelated (sfăs'ělātěd) $a$. [Gk. sphakelos, gangrene.] Dead; decayed; withered (bot.).

sphacelia (sfăsē'liă) $n$. [Gk. sphakelos, gangrene.] The gonidial stage in the development of the Fungus, producing ergot (bot.).

sphaeraphides (sfërăf'ídēz) $n$. plu. [Gk. sphaira, a globe ; rhaphis, a needle.] Conglomerate raphides; globular clusters of minute crystals in vegetable cells (bot.).

sphaerenchyma (sfërĕng'kĭmă) $n$. [Gk. sphaira, a globe ; engchyma, juice.] Tissue composed of spherical cells (biol.).

sphaeridia (sfērìd'iă) n. plu. [Gk. sphaira, globe.] Small rounded bodies, probably organs of special sense, found on Echinoderms (zool.). sphaeroid (sfëroid) a. [Gk. sphaira, globe; eidos, resemblance.] Globular, ellipsoidal, or cylindrical; $a p p l$. a colony or aggregate of individual Protozoa (zool.).

sphagnicolous (sfăgnǐk'ölŭs) a. [Gk. sphagnos, moss; L. colere, to inhabit.] Inhabiting peat mosses (bot.).

sphagnous (sfăg'nŭs) a. [Gk. sphagnos, moss.] Pert. peat moss (bot.). sphenethmoid (sfĕněth'moid) $n$. [Gk. 
sphen, a wedge; ethmos, sieve; eidos, resemblance.] The single "girdle" bone replacing the two orbitosphenoids in the Anura (zool.). sphenoethmoidal (sfé'nöĕthmoid'ăl) a. [Gk. sphen, wedge ; ethmos, sieve; eidos, like.] Pert. or in the region of sphenoid and ethmoid (anat.).

sphenofrontal (sfēénöfrŭn'tăl) a. [Gk. sphen, wedge ; L. frons, forehead.] Pert. sphenoid and frontal bones; appl. a suture (anat.).

sphenoid (sfé'noid) n. [Gk. sphen, wedge; eidos, resemblance.] A basal cranial compound bone of some vertebrates (zool.).

sphenoidal (sfēnoid'ăl) a. [Gk. sphen, wedge: eidos, resemblance.] Wedge-shaped; pert. or in the region of the sphenoid; appl. fissure, process, sinus (anat.).

sphenomandibular (sfē'nömăndǐb'ūlăr) a. [Gk. sphen, wedge; L. mandibulum, jaw.] Pert. sphenoid and mandibular (zool.).

sphenomaxillary (sfë'nömăksı̌l'ărǐ) $a$. [Gk. sphen, wedge; maxilla, jaw.] Pert. sphenoid and maxilla; appl. fissure and fossa (anat.).

sphenopalatine(sfē'nöpăl'ătîn) $a$. [Gk. sphen, wedge; L. palatus, palate.] Pert. sphenoid and palatine; appl. foramen, ganglion (anat.).

sphenoparietal (sfē'nöpăríětăl) $a$. [Gk. sphen, wedge; L. paries, a wall.] Pert. sphenoid and parietal ; $a p p l$. a cranial suture (anat.).

sphenosquamosal (sfē'nöskwămō'săl) a. [Gk. sphen, wedge; L. squama, a scale.] Appl. the cranial suture between sphenoid and squamosal (anat.).

sphenotic (sfĕnŏt'ík) n. [Gk. sphen, wedge ; ous, ear.] The post-frontal cranial bone of many Fishes (zool.). sphenoturbinal (sfé'nötŭr'binăl) $n$. [Gk. sphen, wedge; L. turbo, a whirl.] A laminar process of the sphenoid (anat.).

sphenozygomatic (sfé'nözígömătǐk) $a$. [Gk. sphen, wedge ; zygoma, a bar.] $A p p l$. the cranial suture between sphenoid and zygomatic (anat.). spheraster (sfërăs'tër) $n$. [Gk. many-rayed globular spicule (zool.). spheroidal (sfëroid’ăl) a. [Gk. sphaira, globe; eidos, resemblance.] Globularbut not perfectly spherical ; appl. glandular epithelium (anat.).

spheromere (sfétrömēr) $n$. [Gk. sphaira, globe; meros, part.] A symmetrical segment of a radiate animal (zool.).

spheroplasts (sfēéröplăsts) $n$, plu. [Gk. sphaira, globe; plastos, formed.] Chondriosomes ; bioblasts ; bodies found among granulations of protoplasm (biol.).

spherula (sfër'ūlă) n. [Gk. sphaira, a globe.] A spherule or small sphere; a small spherical spicule (zool.).

spherulate (sfĕr'ūlāt) a. [Gk. sphaira, globe.] Covered with small spheres.

sphincter (sfing'ktër) $n$. [Gk. sphinggein, to bind tightly.] A muscle which contracts or closes an orifice, as that of bladder, anus, mouth (anat.).

sphygmic (sfig'mik) a. [Gk. sphygmos, pulse.] Pert. the pulse (phys.).

sphygmoid (sfig'moid) a. [Gk. sphygmos, pulse; eidos, resemblance.] Pulsating; like a pulse (phys.).

sphygmus (sfïg'mŭs) $n$. [Gk. sphygmos, pulse.] The pulse ( $p h y s$.$) .$

spicate (spīkāt) a. [L. spica, a spike.] Spiked; arranged in spikes, as an inflorescence ; bearing spikes (bot.); with spur-like prominence (zool.).

spiciferous, - spicate.

spiciform (spi'sǐfôrm) a. [L. spica, a spike; forma, shape.] Spikeshaped.

spicigerous,- spicate.

spicose (spíkōs) a. [L. spica, a spike.] With spikes or ears, as corn (bot.).

spicula (spik'ūlă) $n$. [L. spicula, a small spike.] A small spike; a needle-like body.

spicular (spik'úlăr) a. [L. spicula, a small spike.] Pert. or like a spicule.

spiculate (spǐk'ülāt) a. [L. spicula, a small spike.] Set with spicules (zool.) ; divided into small spikes (bot.). 
spicule (spǐk'ūl) $n$. [L. spicula, a small spike.] A minute needlelike body, siliceous or calcareous, found extensively in Alcyonaria and other invertebrates (zool.); a minute-pointed process (bot.).

spiculiferous (spǐkūlíf'ĕrŭs) $a$. [L. spicula, a small spike; ferre, to carry.] Furnished with or protected by spicules (zool.).

spiculiform (spǐk'ülífôrm) a. [L. spicula, a small spike; forma, shape.] Spicule-shaped.

spiculigenous, spiculigerous, spiculose,-spiculiferous.

spiculum (spǐk'ūlŭm) $n$. [L. spicula, a small spike.] A spicular structure ; the dart of a Snail (zool.).

spike (spik) $n$. [L. spica, a spike.] An inflorescence with sessile flowers along the axis, as in Plantago (bat.).

spikelet (spīk'lět) n. [L. spica, a spike.] A secondary spike of Grasses, bearing few flowers (bot.). spinal (spi'năl) a. [L. spina, the spine.] Pert. the backbone or vertebral column; $a p p l$. foramen, ganglion, nerves (anat.).

spinal canal, - the canal containing the spinal cord, formed by the neural arches (anat.).

spinal cord,-the nervous tissue contained in the spinal or vertebral canal (anat.).

spinalis (spïnắlìs) $n$. [L. spina, spine.] Name given to muscles, as spinalis dorsi and spinalis cervicis, muscles connecting up the vertebrae (anat.).

spinate (spi'nāt) a. [L. spina, a thorn.] Spine-shaped; spine-bearing.

spindle (spin'dl) n. [A.S. spinnan, to spin.] A structure resembling a spinning-machine spindle; an elongated peduncle bearing sessile flowers (bot.); a spindle-shaped structure formed of achromatin fibres during mitosis (biol.).

spine (spin) $n$. [L. spina, the spine.] The backbone; the vertebral column; a sharp-pointed process or outgrowth as found on leaves, Echinoids, Porcupines ; the pointed process of a vertebra; the scapular ridge; a fin-ray. spinescent (spīnĕs'ĕnt) $a . \quad[$ L. spinescere, to become spiny.] Tapering ; tending to become spiny.

spiniferous (spīniff'ěrŭs) a. [L. spina, a spine; ferre, to carry.] Furnished with spines.

spiniform (spīnifôrm) a. [L. spina, spine; forma, shape.] Spineshaped.

spinigerous (spīnīj'ĕrŭs) $\alpha$. [L. spina, spine; gevere, to carry.] Spinebearing.

spinneret (spin'ërĕt) $n$. [A.S. spinnan, to spin.] In Spiders, one of the movable organs perforated by tubes connected with glands secreting liquid silk,-they arise from modifications of abdominal appendages, and lie slightly anterior to the anus (zool.).

spinnerule (spin'ërūl) $n$. [A.S. spinnan, to spin.] One of the tubes for discharging the silk solution of Spiders (zool.).

spinning glands,-glands which secrete material for webs in Spiders, and for cocoons in caterpillars.

spinose (spīnōs) a. [L. spina, a spine.] Bearing many spines.

spinous (spínŭs) a. [L. spina, a spine.] Spiny; spine-like.

spinous process, - the median dorsal spinelike process of each vertebra ; a process of the sphenoid; a process between the articular surfaces of the proximal end of the tibia (anat.).

spinulate (spin'ūlāt) a. [L. spinula, a small spine.] Covered with small spines.

spinulation (spinnūlā'shŭn) $n$. [L. spinula, a small spine.] A defensive spiny covering; state of being spinulate.

spinule (spin'úl) $n$. [L. spinula, a small spine.] A small spine.

spinulescent (spinnūlěs'ěnt) $a$. [L. spinula, a small spine.] Tending to be spiny.

spinuliferous (spinūlíf'ěrŭs) $a . \quad[\mathrm{L}$. spinula, a small spine; ferre, to bear.] Bearing small spines.

spinulose, spinulous, - spinuliferous. spiny-finned,-bearing fins with spiny rays for support.

spiny-rayed,-appl. fins supported by spiny rays, 
spiracle (spīrăkl) n. [L. spiraculum, an air-hole.] The first pharyngeal aperture or visceral cleft (emb.) ; the branchial passage between mandibular and hyoid arches in Fishes ; a lateral branchial opening in tadpoles; a nasal aperture of a Cetacean; a respiratory aperture behind the eye of Skates and Rays ; a breathing aperture of Insects (zool.).

spiracular (spirăk'ûlăr) a. [L. spiraculum, an air-hole.] Pert. a spiracle (zool.).

spiraculate (spirăk'ūlāt) $a$. [L. spiraculum, an air-hole.] Having spiracles (zool.).

spiraculiferous,-spiraculate.

spiraculiform (spirăk'úlifôrm) $a$. [L. spiraculum, an air-hole; forma, shape.] Spiracle-shaped.

spiraculum (spirăk'ūlŭm) $n$. [L.spiraculum, an air-hole.] A spiracle.

spiral (spírăl) a. [L. spira, a coil.] Winding, like a screw ; $a p p l$. leaves alternately placed; $a p p l$. flower with spirally inserted parts (bot.).

spiral, oblique, or alternating cleavage,-cleavage into unequal parts, arranged in mosaic fashion and interlocking, the upper cells being rotated to the right to alternate with the lower (cyt.).

spiral valve, - in all Fishes except Teleosts, a spiral infolding of the intestine wall, increasing the absorptive surface (zool.).

spiral vessels, - the first xylem elements of a stele, spiral fibres coiled up inside tubes and so adapted for rapid elongation (bot.). spiranthy (spirăn'thī) n. [L. spira, coil ; Gk. anthos, flower.] Displacement of flower parts through twisting (bot.).

spiraster (spirăs'tër) $n$. [L. spira, coil; aster, star.] A spiral and rayed sponge spicule (zool.).

spire (spir) $n$. [L. spira, coil.] The totality of the whorls of a spiral shell (zool.).

spireme (spírēm) n. [Gk. speirema, a coil.] That stage in mitosis when the nucleus chromatin appears in the form of a thread, continuous or segmented (cyt.).

spiricles (spîriklz) n. plu. [L. spira, coil.] Thin, coiled, thread-like outgrowths of some seed-coats (bot.).

spiriferous (spīrif'ěrŭs) a. [L. spira, a coil ; ferre, to bear.] Having a spiral structure.

spirillar (spirrilăr) a. [L. spirillum, a small coil.] Pert. a spirillum.

spirillum (spïril'ŭm) $n$. [L. spirillum, a small coil.] A thread-like Bacterium ; a motile filament in a cryptogam antheridium (bot.).

spirivalve (spírivălv) $n$. [L. spira, coil; valvae, folding doors.] A Gastropod with spiral shell (zool.). spiroid (spi'roid) a. [L. spira, coil ; Gk. eidos, resemblance.] Spirally formed.

spironeme (spi'rönēm) n. [L. spira, coil; Gk. nema, thread.] The coiling or twisting thread in an Infusorian stalk (zool.).

spirulate (spir'ūlāt) a. [L. spira, coil.] $A p p l$. any spiral structure or coiled arrangement.

splanchnic (splăngk'nǐk) a. [Gk. splangchnon, an entrail.] Pert. the viscera; $a p p l$. nerves (anat.).

splanchnocoel (splăngk'nösēl) $n$. [Gk. splangchnon, an entrail; koilos, hollow.] The cavity of the lateral plates of the embryo, persisting as the visceral cavity of the adult (emb.).

splanchnology (splăngknŏl'öjī) $n$. [Gk. splangchnon, an entrail ; logos, discourse.] The branch of Anatomy dealing with the viscera.

splanchnopleure (splăngk'nöploor) $n$. [Gk. splangchnon, an entrail; pleura, side.] The alimentary canal wall, formed from the splanchnic layer of the mesoblast and the hypoblast (emb.).

spleen (splēn) n. [Gk, splen, the spleen.] A vascular ductless organ situate beneath the diaphragm to the left of the stomach (anat.).

splenetic (splěnĕt'îk) a. [Gk. splen, spleen.] Pert. the spleen.

splenial (splē'niăl) a. [L. splenium, a patch.] Pert. the splenius muscle (anat.), or splenial bone (zool.).

splenial bone, - a membrane bone in the lower jaw of Reptiles.

splenic (splën'îk) a. [Gk. splen, the spleen.] Pert. the spleen. 
splenium (splē'nı̌ŭm) $n$. [L. splenium, a patch.] The posterior border of the corpus callosum (anat.).

splenius (splë'nŭs) $n$. [L. splenium, a patch.] A muscle of the upper dorsal region and back of the neck, in two parts the splenius capitis and splenius colli (anat.).

splenophrenic (splë'nöfrěn'îk) a. [Gk. splen, spleen; phren, midriff.] Pert. spleen and diaphragm (anat.). spondy1 (spŏn'dīl) n. [Gk. sphondylos, a vertebra.] A vertebra.

spondylous (spŏn'dĭlŭs) $a$. [Gk. sphondylos, a vertebra.] Vertebral. spondylus (spŏn'dǔlŭs) $n$. [Gk. sphondylos, a vertebra.] A spondyl or vertebra.

spongicolous (spŭnjǐk'ölŭs) $a$. [L. spongia, a sponge; colere, to inhabit.] Living in Sponges (zool.).

spongin (spŭn'jìn) n. [L. spongia, a sponge.] The material of which the skeletal fibres of a Sponge consist (zool.).

sponginblast (spŭn'jĭnblăst) $n$. [L. spongia, a sponge; Gk. blastos, a bud.] A spongin-producing cell (zool.).

spongioblasts (spŭn'jiöblăsts) $n$. plu. [L. spongia, a sponge; Gk. blastos, a bud.] Columnar epithelial cells which give rise to the skeletal framework of the spinal cord (emb.).

spongioplasm (spŭn'jiöplăzm) $n$. [L. spongia, a sponge; GK. plasma, something moulded.] The cytoplasmic threadwork of a cell; the cytoreticulum (cyt.).

spongiose (spŭn'jiōs) a. [L. spongia, a sponge.] Of a spongy texture ; spongoid ; full of small cavities.

spongoblast (spŭn'jöblăst) $n$. [L. spongia, a sponge; Gk. blastos, a bud.] A sponginblast.

spongophare (spŭn'jöfär) $n$. [L. spongia, a sponge; Gk. pherein, to bear.] The upper chamber-bearing part of a Sponge ; $c f$. hypophare.

spongy parenchyma, - loosely arranged tissue with abundant intercellular spaces on the lower side of a leaf (bot.).

spontaneous generation, - see abiogenesis.

sporadie (spörăd'îk) a. [Gk, spor- adikos, scattered.] Appl. plants confined to limited localities.

sporange (spörănj') n. [Gk. sporos, seed; anggeion, a vessel.] A sac containing spores (biol.).

sporangial (spörăn'jiăl) a. [Gk. sporos, seed; anggeion, a vessel.] Pert. a sporangium (bot.).

sporangiferous (spörănjĭf'ěrŭs) $a$. [Gk. sporos, seed; anggeion, a vessel; L. ferre, tobear.] Sporangiabearing (bot.).

sporangiform (spörăn'jüfôrm) a. [Gk. sporos, seed; anggeion, vessel; L. forma, shape.] Sporangioid; like a sporangium.

sporangiole (spörăn'jǐōl) n. [Gk. sporos, seed; anggeion, vessel.] A secondary or small few-spored sporangium (bot.).

sporangiophore (spörăn'jīöför) $n$. [Gk. sporos, seed; anggeion, vessel; pherein, to bear.] A stalk-like structure bearing sporangia (bot.).

sporangiospore (spörăn'jiöspōr) $n$. [Gk. sporos, seed ; anggeion, vessel; sporos.] A sporangium spore (bot.). sporangium (spörăn'jŭum) $n$. [Gk. sporos, seed; anggeion, vessel.] A tiny slender-stalked capsule in which spores are produced (bot.).

sporation,-see sporulation.

spore (spōr) $n$. [Gk. sporos, seed.]

A highly specialized reproductive cell of plants (bot.) ; a falciform cell of Sporozoa which bores into a mother sperm cell and emerges as an adult (zool.).

spore case, - an elliptical chitinoid case containing usually eight spores lying round a residual core, a stage in the life-history of Monocystis (zool.) ; a sporangium (bot.).

spore formation, - reproduction by encystation of germ-cells followed by division and free-cell liberation; endogenous multiplication ; sporogony; sporogenesis (biol.).

spore mother cells, - sixteen cells produced by repeated division of an archesporium, each in turn dividing into four spores (bot.).

spore sac,-a case containing spores; a sporangium (bot.).

sporetia (spörē'tiă) n. plu. [Gk. sporos, seed.] Idiochromidia ; chromidia of generative chromatin, 
sporidiferous (spörĭdĭf'ĕrŭs) a. [Gk. sporos, seed; L. ferre, to bear.] Sporidia-bearing (bot.).

sporidiole (spörĭd'iol) $n$. [Gk, sporos, seed.] A protobasidium; a sporidium arising from rust promycelium (bot.).

sporidium (spörĭd'ǔŭm) $n$. [Gk. sporos, seed.] A gonidium developed by abstriction from a gonidiophore in Fungi; spore of an ascus (bot.).

sporiferous (spörĭf'ĕrŭs) a. [Gk. sporos, seed; L. ferre, to bear.] Spore-bearing.

sporification (spō'rĭfikā̄'shŭn) $n$. [Gk. sporos, seed; L. facere, to make.] Formation of spores.

sporiparity (spō'rĭpăr'ítĩ) n. [Gk. sporos, seed; L. parere, to beget.] Reproduction by spore formation. sporiparous (spörĭpărŭs) a. [Gk. sporos, seed ; L. parere, to beget.] Reproducing by spore formation. sporoblast (spō'röblăst) $n$. [Gk. sporos, seed; blastos, bud.] An archespore; a stage in spore formation, a sporoblast giving rise to spores, and these to sporozoites. sporocarp (spō'rökârp) n. [Gk. sporos, seed; karpos, fruit.] An ascocarp; a structure formed from archicarp and investing hyphae, enclosing spored asci (bot.).

sporocyst (spö'rösǐst) n. [Gk. sporos, seed; kystis, bladder.] A stage in spore formation preceding the liberation of spores in many Protozoa; the encysted embryo stage of a Trematode after degeneration following on entry into intermediate host (zool.).

sporocyte (spō'rösīt) n. [Gk. sporos, seed; kytos, hollow.] A spore mother cell.

sporoduct (spō'rödŭkt) $n$. [Gk. sporos, seed; L. ducere, to lead.] A special apparatus for the dissemination of spores of Sporozoa (zool.).

sporogenesis,-spore formation. sporogenous (spörŏj'ĕnŭs) a. [Gk. sporos, seed; genos, offspring.] Spore-producing ; sporiparous.

sporogonial (spōrögōniăl) $a$. [Gk. sporos, seed; gonos, offspring.] Pert. a sporogonium (bot.).

sporogonium (spörögō'nĭum) $n$. [Gk. sporos, seed; gonos, offspring.] A structure developed from a fertilized oosphere of an archegonium, giving rise to asexual spores, in Mosses (bot.).

sporogony,-spore formation, following schizogony or the asexual process of reproduction (zool.).

sporoid (spō'roid) a. [Gk. sporos, seed ; eidos, like.] Like a spore.

sporont (spörŏnt') $n$. [Gk. sporos, seed; ons, being.] The gametocyte stage in the life-history of Sporozoa (zool.).

sporophore (spō'röfōr) $n$. [Gk. sporos, seed; pherein, to bear.] A vertical branch which gives rise to spores by abstriction or otherwise, in Fungi (bot.).

sporophydium (spöröfíd'íŭm) $n$. [Gk. sporos, seed; phyas, a shoot.] The sporangium of certain Thallophytes (bot.).

sporophyll (spōröfîl) $n$. [Gk. sporos, seed; phyllon, a leaf.] A sporangium-bearing leaf of Pteridophytes (bot.).

sporophyte (spöröfït) n. [Gk. sporos, seed; phyton, plant.] A stem covered with sporophylls or leaves, each bearing a sporangium, in Pteridophytes; the asexual generation of Ferns; cf. gametophyte (bot.).

sporoplasm (spō'röplăzm) n. [Gk. sporos, seed ; plasma, something moulded.] The sporozoite, binucleate amoebula, or central part of a spore.

sporosac (spō'rösăk) $n$. [Gk. sporos, seed ; L. saccus, a sack.] An ovoid pouch-like body, consisting of a gonad, a degraded reproductive zooid of a medusoid colony (zool.). sporozoite (spō'rözō'ît) $n$. [Gk. sporos, seed; zoon, animal.] A germ liberated through the dissolving of the spore-membrane of sporocysts; a phase in the life-history of Sporozoa.

sporulation (spôr'ūlāshŭn) n. [L. sporula, a small seed.] Broodformation by multiple cell-fission. spur (spŭr) n. [A.S. spora, a spur.] A calcar (zool.); a process of the anterior petal of violets functioning as a nectar receptacle (bot.). 
spuriae (spū'rīē) n. plu. [L. spurius, false.] The feathers of the alula or bastard wing (zool.).

spurious (spü'rǐŭs) a. [L. spurius, false.] Seemingly true but morphologically false; $a p p l$. dissepiment, fruit (bot.), vein, wing (zool.). squama (skwắmă) n. [L. squama, a scale.] A squame or scale; a part arranged like a scale (bot.); the antitegula of Diptera, or lobe at the base of the wing; a scalelike body attached to the second podomere of the antenna of some Crustaceans (zool.).

squamate (skwă'māt) a. [L. squama, scale.] Scaly.

squamation (skwămā'shŭn) n. [L. squama, scale.] Scale arrangement.

squamella (skwămĕlă) $n$. [L. squama, scale.] A small scale or bract; a palea (bot.).

squamellate (skwăměl'ât) a. [L. squama, a scale.] Having small scales or bracts; squamelliferous (bot.).

squamelliform (skwămĕlifôrm) $a$. [L. squama, scale ; forma, shape.] Resembling a squamella.

squamiferous (skwămĭf'ĕrŭs) $a$. [L. squama, scale; ferre, to bear.] Bearing scales.

squamiform (skwắmífôrm) a. [L. squama, scale; forma, shape.] Scale-like.

squamigerous,--squamiferous.

squamosal (skwămō'săl) n. [L. squama, scale.] A membrane bone of the vertebrate skull forming part of the posterior side wall (zool.).

squamose (skwä'mōs) a. [L. squama, a scale.] Covered with scales.

squamous (skwā'mŭs) a. [L. squama, scale.] Scaly; squamate; squamose.

squamous epithelium,-pavement epithelium.

squamula (skwăm'úlă) $n$. [L. squama, scale.] A squamule or small scale ; a minute membranous scale found in Grasses (bot.); the tegula of some Insects (zool.).

squamulate (skwăm'ūlãt) $a . \quad[\mathrm{L}$. squama, scale.] Having minute scales (bot.).

squamulose,-squamulate. squarrose (skwôr'ōs) a. [L.L. squarrosus, scurfy.] Rough with projecting scales or jags.

squarrulose (skwôr'ūlōs) a. [L.L. squarrosus, scurfy.] Tending to become squarrose (bot.).

stadium (stâ'drŭm) n. [L. stare, to stand.] A stage in development or life-history of plant or animal.

stage (stāj) $n$. [L. stare, to stand.] A period in the life-history of metamorphous animals.

staghorned (stăg'hôrnd) a. [Icèl. stiga, to mount; A.S. horn.] Having large branched mandibles, as a stag-beetle.

stagnicolous (stăgnǐk'ölŭs) a. [L. stagnum, standing water; colere, to inhabit.] Living in stagnant water.

stalk (stôk) $n$. [A.S. stel, stem.] The stem or axis supporting outgrowths (bot.); a stem-like structure in animals, as in some Alcyonaria (zool.).

stalk-cell, - the barren cell of two into which the antheridial cell of the pine divides, - the other, the generative (bot.).

stalk-eyed,--having the eyes at the end of a short stalk, as in some Crustaceans, $-o p p$. sessile-eyed.

stamen (stā'měn) $n$. [L. stare, to stand.] The male organ of a flower, consisting of stalk or filament with anther containing pollen (bot.).

staminal (stăm'ínăl) a. [L. stare, to stand.] Pert. a stamen.

staminate (stăm'ínāt) a. [L. stare, to stand.] Producing or consisting of stamens.

staminiferous (stăminĭf'ěrŭs) $a . \quad$ [L. stare, to stand; ferre, to bear.] Staminigerous; stamen-bearing. staminode (stăm'innōd) n. [L. stare, to stand ; Gk. eidos, resemblance.] Also staminodium, a foliaceous scale-like body in some flowers, derived from a metamorphosed stamen; a rudimentary stamen (bot.).

staminody (stăm'ínödĭ) $n$. [L. stare, to stand; Gk. eidos, resemblance.] The metamorphosis of flower organs into stamens (bot.).

stapes (stắpê̌z) $n$. [L.L. stapes, 
a stirrup.] The stirrup-shaped innermost bone of the middle ear (anat.); the operculum or internal end of the columella auris, fitting into and filling the fenestra ovalis in Amphibians (zool.).

stasimorphy (stăs'ímôr'fĩ) $n$. [Gk. stasis, standing; morphe, form.] A deviation in form due to arrested development (biol.).

statoblast (stăt'öblăst) n. [Gk. statos, stationary; blastos, bud.] A specialized bud or "winter-egg" of some Polyzoa, developed on the funiculus and set free on the death of the parent organism (zool.).

statocone (stăt'ökōn) n. [Gk. statos, stationary; konos, a cone.] One of the minute structures contained in a statocyst (zool.).

statocyst (stăt'ösist) n. [Gk. statos, stationary; kystis, a bladder.] A vesicle or organ found in Molluscs, Medusae, Crustacea, Worms, with the function of perception of the position of the body in space (zool.).

statolith (stăt'ölïth) n. [Gk. statos, stationary ; lithos, stone.] A structure of carbonate of lime, sand grain, or secreted substance, contained in a statocyst (zool.).

statorhab (stăt'örăb) n. [Gk. statos, stationary; rhabdos, a rod.] In Trachomedusae, a short tentacular process carrying the statolith (zool.).

steapsin (stēăp'sĭn) n. [Gk. stear, tallow; pepsis, digestion.] A digestive ferment secreted by the pancreas (phys.).

stearin (sté'ărin) $n$. [Gk. stear, tallow.] The solid part of a fat; a chief component of many fats, animal and vegetable (phys.).

stegocarpous (stěg'ökâr'pŭs) a. [Gk. stegein, to cover; karpos, fruit.] Having a capsule with operculum and peristome (bot.).

stelar system,- - of plants, the vascular and associated conjunctive tissue (bot.).

stele (stēl) n. [Gk. stele, a pillar.] A bulky strand or cylinder of vascular tissue contained in the stem and root of plants, developed from the plerome (bot.). stellar, -stellate.

stellate (stěl'āt) a. [L. stella, a star.] Astral; radiating; star-shaped; appl. leaf.

stelliform, - stellate.

stem (stěm) $n$. [A.S, stemn, a treestem.] The trunk of a tree; the main axis of a plant.

stem-cell,-in mitosis, a cell in which all the chromatin is preserved, and from which arise the germ cells; $o p p$. somatic cell (cyt.).

stemless,-without a stalk; acaulescent (bot.).

stemma (stěm'ă) n. [Gk. stemma, a garland.] A simple eye or ocellus of Arthropods; one of the ocelli of an ommatidium (zool.).

stenohaline (stěn'öhăl'ĩn) a. [Gk. stenos, narrow; halinos, marine.] $A p p l$. marine animals adaptable only to a narrow range of salinity ; cf. euryhaline (zool.).

stenopetalous (stĕn'öpět'ălŭs) a. [Gk. stenos, narrow ; petalon, a leaf.] With narrow petals.

stenophyllous (stěn'öfril'ŭs) $a$. [Gk. stenos, narrow; phyllon, leaf.] Narrow-leaved.

stenosepalous (stěn'ösěp'ălŭs) $a$. [Gk. stenos, narrow; sepalon, a sepal.] With narrow sepals.

stenostomatous (stĕn'östŏm'ătŭs) $a$. [Gk. stenos, narrow ; stoma, mouth.] Narrow-mouthed.

stephanion (stĕfắn'ionn) n. [Gk. stephanos, crown.] The point where the superior temporal ridge is crossed by the coronal suture (anat.).

stercomarium (stĕrkömā'rǐum) n. [L. stercus, dung.] The system of stercome-containing tubes of certain Sarcodina (zool.).

stercome (stěr'köm) n. [L. stercus, dung.] Faecal matter of Sarcodina protoplasm, in masses of brown granules (zool.).

stereid bundles,-bands or bundles of sclerenchymatous fibres (bot.).

stereome (stěr ěōm) n. [Gk. stereos, solid.] Sclerenchymatous and collenchymatous masses along with hardened parts of vascular bundles forming supporting tissue in plants (bot.).

stereoplasm (stěr'éöplăzm) n. [Gk. 
stereos, solid; plasma, something moulded.] The more solid part of protoplasm ( $f f$. hygroplasm); a vesicular substance filling interseptal spaces of certain Corals (zool.).

stereospondylous (stĕr'ěöspŏn'dǔlŭs) a. [Gk. stereos, solid; sphondylos, a vertebra.] Having the vertebrae each fused into one piece; $c f$. temnospondylous (zool.).

stereotaxy (stĕr'ěötăk'sĩ) n. [Gk. stereos, solid ; taxis, arrangement.] The mechanical reaction to continuous contact with a solid (phys.).

stereotropism (stěrěŏt'röpizm) $n$.

[Gk, stereos, solid; trope, a turning.]

Tendency of minute organisms to attach themselves to solid objects; thigmotaxis (phys.).

sterigma (stĕrĭg'mă) $n$. [Gk. sterigma, a support.] A slender filament arising from the basidium, and giving rise to spores by abstriction (bot.).

sterile (stĕrìl) a. [L. sterilis, barren.] Incapable of propagation; $a p p l$. a plant unable to bear fruit, a neutral flower, a seed unable to germinate (bot.).

sterilize (stĕr'ílīz) v. [L. sterilis, barren.] To render incapable of conveying infection, or of reproducing the species (phys.).

sternal (stĕr'năl) $a$. [Gk. sternon, the breast.] Pert. the sternum, or a sternite; $a p p l$. ribs united to the sternum (zool.).

sternebrae (stěr'něbrē) n. plu. [Gk. sternon, the breast; ebra, on analogy of vertebra.] Divisions of a segmented sternum or breastbone (zool.).

sternite (stěr'nìt) $n$. [Gk. sternon, the breast.] A ventral plate of an Arthropod segment, carrying legs and tracheal openings (zool.).

sternoclavicular (stěr'nöklăvik'ülăr) a. [Gk. sternon, breast ; L. claviculum, a small key.] Appl. the articulation between sternum and clavicle (anat.).

sternocostal (stĕr'nökŏs'tăl) a. [Gk. sternon, breast; L. costa, a rib.] Pert. sternum and ribs; $a p p l$. ligament, surface of heart (anat.). sternokleidomastoid (stĕr'nöklì'dömăs'toid) a. [Gk. sternon, breast ; kleis, key; mastos, breast ; eidos, resemblance.] $A p p l$. an oblique neck muscle stretching from sternum to mastoid process, also an artery in the same region (anat.).

sternoscapular (stěr'nöskăp'ūlăr) $a$. [Gk. sternon, breast ; L. scapula, shoulder-blade.] $A p p l$. a muscle connecting sternum and scapula (anat.).

sternotribe (stĕr'nötrīb) a. [Gk. sternon, breast; tribein, to rub.] $A p p l$. flowers with fertilizing elements so placed as to be brushed by the breasts of visiting Insects (bot.).

sternum (stĕr'nŭm) n. [L. sternum, the breast-bone.] The breast-bone of vertebrates, specialized in Birds with a carina for wing-muscle attachment ; the ventral plate of a typical Arthropod segment (zool.).

sterraster (stěrăs'tër) $n$. [Gk. sterros, solid; aster, star.] An aster with numerous actines soldered together by silica (zool.).

sterrula (stĕr'ūlă) n. [Gk. sterros, solid.] The solid free-swimming larva of Alcyonaria, the stage preceding the planula (zool.).

stichidium (stîkĭd'iuum) $n$. [Gk. stichos, a row.] A tetraspore receptacle of some Algae (bot.).

stigma (stĭg'mă) n., stigmata (stĭg'mătă) plu. [Gk. stigma, a pricked mark.] The portion of the pistil on which the pollen falls (bot.); spots of brilliant colour with lenslike body, the eye-spots, of some Protozoa; an Arthropod spiracle; apertures connected with the tracheae of Insects; a coloured wing spot of certain butterflies and other insects; a gill-slit of Tunicates (zool.).

stigmatic (stigmăt'ík) a. [Gk. stigma, a pricked mark.] Appl. a lid cell of an archegonium (bot.).

stigmatiferous (stĭgmătǐf'ěrŭs) $a$. [Gk. stigma, a pricked mark; L. ferre, to carry.] Stigma-bearing.

stigmatiform (stĭgmăt'ífôrm) a. [Gk. stigma, a pricked mark ; L. forma, shape.] Resembling a stigma; stigmatoid. 
stimulant (stĭm'ūlănt) $n$. [L. stimulare, to incite.] A stimulus-producing agent (phys.).

stimulation (stim'ūlā'shŭn) $n$. [L. stimulare, to incite.] Excitation or irritation of an organism or part by external influence, mechanical, chemical, etc. (phys.).

stimulose (stǐm'ūlōs) a. [L. stimulare, to incite.] Furnished with stinging hairs or cells (biol.).

stimulus (stı̌m'ūlŭs) n. [L. stimulare, to incite.] An agent which causes a body or some part of it to react when affected by it (phys.).

sting (stĭng) $n$. [A.S. stingan, to sting.] A stinging hair or cell (biol.); the spine of a sting-ray; an offensive and defensive organ for piercing, and usually also for inoculating with poison, as in the wasp (zool.).

stinging capsule, - a nematocyst.

stipe (stīp) n. [L. stipes, stock, stalk.] The stem bearing the pileus in Agarics; the stem of palms and tree ferns; the stem of fern fronds (bot.) ; a stipes (zool.).

stipel (stīpěl) $n$. [L. stipes, a stalk.] An outgrowth of leaflets resembling the stipule of a leaf-base (bot.).

stipellate (stî́pělāt) a. [L. stipes, stalk.] Bearing stipels (bot.).

stipes (stīpĕz) n. [L. stipes, stalk.] The distal part of the protopodite of the first maxilla of Insects; the peduncle of a stalked eye (zool.).

stipiform (stî́pifôrm) a. [L. stipes, a stalk; forma, shape.] Resembling a stalk or stem.

stipitate (stǐp'îāt) a. [L. stipes, a stalk.] Stalked; supported on a stalk.

stipular (stǐp'ūlăr) a. [L. stipula, a stem.] Like, pert, or growing in place of stipules (bot.).

stipulate (stịp'ūlāt) a. [L. stipula, a stem.] Furnished with stipules (bot.).

stipule (stǐp'ül) $n$. [L. stipula, a stem.] One of two foliaceous or membranaceous processes developed at the base of a leaf petiole, sometimes in tendril or spine form (bot.).

stipuliferous,-stipulate.

stipuliform (stǐp'ūlǐfôrm) a. [L. stipula, stem; forma, shape.] In the form of a stipule (bot.).

stirp (stërp), stirps (stërps) $n$. [L. stirps, root-stock.] The sum-total of germs or gemmules to be found in a newly fertilized ovum.

stock (stŏk) n. [A.S. stocc, a post.] An asexual zooid which produces sexual zooids of one sex by gemmation, as in Polychaets (zool.).

stolon (stō'lŏn) $n$. [L. stolo, a shoot.] A creeping stem or runner capable of developing rootlets and stem, and ultimately forming a new individual (bot.) ; a cylindrical stem of some Polyzoa from which individuals grow out at intervals; a horizontal tubular branch of some Coelenterates from which new zooids arise by budding ; the cadophore of Tunicates (zool.).

stolonate (stō'lŏnāt) a. [L. stolo, a shoot.] Having stolons; resembling a stolon; developing from a stolon; $a p p l$. plants and animals which develop by means of stolons (biol.).

stoloniferous (stō'lŏnĭf'ĕrŭs) a. [L. stolo, a shoot; ferre, to carry.] Bearing stolons (biol.).

stoma (stō'mă) n., stomata (stöm'ătă) plu. [Gk. stoma, mouth.] A small mouth-like orifice; minute openings in the epidermis of plants, especially on the under surface of leaves (biol.).

stomach (stŭm'ăk) n. [Gk. stomachos, throat, gullet.] The sac-like portion of the food canal beyond the gullet, in vertebrates; a corresponding part, or the entire digestive cavity, of invertebrates (zool.).

stomachic (stömăk'ik) a. [Gk. stomachos, gullet.] Pert. the stomach.

stomatal (stốm'ătăl) a. [Gk. stoma, mouth.] Pert. or like a stoma; stomatic.

stomate (stō'māt) a. [Gk. stoma, mouth.] Bearing stomata or a stoma.

stomatiferous (stǒmmătĭf'ĕrŭs) a. [Gk. stoma, mouth ; L. ferre, to carry.] Bearing stomata.

stomatogastric (stỗm'ătögăs'trǐk) $a$. [Gk, stoma, mouth ; gaster, stomach.] Pert. mouth and stomach; appl. the visceral system of nerves 
supplying the anterior part of the alimentary canal in Annulates (zool.).

stomatose, stomatous,--stomatiferous.

stomidium (stömĭd'ıum) n. [Gk. stoma, mouth.] An aperture representing the terminal pore of degenerated tentacles of many Actiniaria (zool.).

stomions (stō'mǐnz) n. plu. [Gk. stoma, mouth.] The dermal pores or ostia perforating the dermal membrane of a developing Sponge (zool.).

stomium (stō'mĩum) n. [Gk. stoma, mouth.] A group of thin-walled cells in a fern sporangium where cleavage of the capsule takes place (bot.).

stomodaeal canal,-in Ctenophores, a canal given off by each per-radial canal, and situate parallel to the stomodaeum (zool.).

stomodaeum (stöm'ödē'úm) n. [Gk. stoma, mouth ; odaios, pert. a way.] The anterior perforated depression communicating with the enteric cavity of many Coelenterates, ectoderm-lined since formed by invagination (zool.); the anterior pitted-in portion of the embryonic gut (emb.).

stone canal,- the madreporic canal, an S-shaped cylinder extending from the madreporite to near the mouth border in Echinoderms (zool.).

stone cells,- - sclerotic cells or rounded parenchymatous elements, as found in the pear (bot.).

strangulated,-constricted in places ; contracted and expanded irregularly (bot.).

strata, - plu. of stratum.

stratification (străt'îfíkä'shŭn) $n . \quad[\mathrm{L}$. stratum, layer; facere, to make.] Arrangement in layers; the superimposition of layers of epithelium cells (phys.).

stratified epithelium, - epithelium cells arranged in many superimposed layers (phys.).

stratiform (străt'ífôrm) a. [L. stratum, layer ; forma, shape.] $A p p l$. a fibrocartilage which forms a thin coating to osseous grooves, or is developed in small masses in some tendons (anat.).

stratose (străt'ós) a. [L. stratum, layer.] Arranged in layers (bot.).

stratum (strắtüm) $n$. [L. stratum, a layer.] A layer of cells, tissue, etc.

stratum compactum, - the surface layer of the decidua vera, constituting about one-fourth of the entire thickness (emb.).

stratum corneum, - the horny external layer of the epidermis (anat.).

stratum granulosum, - the superficial layer of the rete mucosum, consisting of flattened cells filled with granules of eleidin (anat.).

stratum lucidum, - the layer of cells of indistinct outline between the stratum corneum and the stratum granulosum (anat.).

stratum spongiosum, - the deeper three-fourths of the thickness of the decidua vera $(e m b$. $)$.

stratum zonale, cinereum, opticum, lemnisci, - strata of the anterior corpora quadrigemina, from the surface inwards (anat.).

streptostylic (strěp'töstîl'ík) a. [Gk. streptos, pliant ; stylos, a column.] Having the quadrate in movable articulation with the squamosal; cf. monimostylic (zool.).

stria (stríă) n., striae (strīê) plu. [L. stria, funnel, channel.] A narrow line, streak, groove, or channel.

striated (strīấtĕd) a. [L. stria, a channel.] Marked by narrow lines or grooves, usually parallel.

striated muscle, - - bundles of fibres enclosed in a sheath continuous with the tendons; voluntary muscle, the fibres of which present transverse striations (anat.).

stridulate (strīd'ūlāt) v. [L. stridere, to creak.] To make a strident sound like the characteristic song of cicadas.

stridulating organs, - a special apparatus on the metathoracic and anterior abdominal segments for producing the song of cicadas; grasshoppers, spiders, and decapod Crustacea also possess stridulating organs (zool.). 
striga (strí'gă) $n$. [L. striga, a ridge, furrow.] An upright, stiff, pointed hair or bristle (bot.).

strigate (strīgāt) a. [L. striga, a ridge.] Bearing strigae (bot.).

strigilis (strijîlilis) n. [L. stringere, to scrape.] A mechanism for cleaning the antennae, at the junction of tibia and first tarsal joint on the first leg of bees (zool.).

strigillose (strìj'îlōs) a. [L. strigilla, a small ridge.] Minutely strigose.

strigose (strĭg'ōs) a. [L. striga, a ridge.] Covered with stiff hairs (bot.); marked by small grooves or furrows (zool.).

striola (strīólă) $n$. [L. striola, a small channel.] A fine narrow line or streak.

striolate (strí'ölāt) a. [L. striola, a small channel.] Finely striate. strobila (strŏb'ílă) n. [Gk. strobilos, a fir cone.] A stage in the development of some Scyphozoa, where from a succession of annular discs the embryos take the form of a pile of discs which are separated off in turn; the jointed body of a Tape-worm (zool.).

strobilaceous (strŏb'ílāshŭs) a. [Gk. strobilos, a fir cone.] Coneshaped; pert. or having strobiles (bot.).

strobilation (strŏb'ilāshŭn) n. [Gk. strobilos, a fir cone.] Reproduction by body-segmentation into zooids, as in Coelenterates, or into proglottides, as in Worms, which develop into adult forms (zool.).

strobile (strŏb'il) n. [Gk. strobilos, a fir cone.] A strobila (zool.); a spike formed of persistent membranous bracts, each having a pistillate flower; a cone; an assemblage of sporophylls (bot.).

strobiliferous (strǒbillif'ěrŭs) a. [Gk. strobilos, a fir cone; L. ferre, to carry.] Having or producing strobiles (bot.).

strobiloid (strŏb'íloid) a. [Gk. strobilos, a fir cone; eidos, resemblance.] Strobiliform ; resembling or shaped like a strobilus or cone (bot.).

strobilus (strǒb'ílŭs) $n$. [Gk. strobilos, a fir cone.] A strobile; a cone (bot.). stroma (strō'mă) n. [Gk. stroma, something spread out for lying on.]
The transparent filmy framework of red blood corpuscles (phys.); connective tissue binding and supporting an organ; in the ovary, a soft, vascular, reticular framework in the meshes of which the ovarian follicles are imbedded (anat.); in plu. stromata, short protrusions from a sclerotium, each composed of hyphae, in which perithecia are developed, in some Thallophytes (bot.).

stromatic (strömăt'ik) a. [Gk. stroma, something spread out for lying on.] Pert., like, in the form or nature of, a stroma ; stromatiform ; stromatous.

strombuliferous (strŏmbūlif'ĕrŭs) $a$. [L. strombus, a spiral snail ; ferre, to carry.] Having spirally-coiled organs or structures (bot.).

strombuliform (strŏmbü'lifôrm) $a$. [L. strombus, a spiral snail ; forma, shape.] Spirally coiled.

strongyle (strǒn'jīl), strongylon (strŏn'jülŏn) $n$. [Gk. stronggylos, globular.] A two-rayed rod sponge spicule (zool.).

strophiolate (strốf'iölāt) $a$. [L. strophiolum, a small garland.] Having excrescences round the hilum (bot.). strophioles (strô̆f'iōlz) n. plu. [L. strophiolum, a small garland.] Small excrescences arising from various parts of a seed testa, never developed before fertilization (bot.). structural (strǔk'tūrăl) a. [L. struere, to build.] Pert. the structure or build of an organism as distinct from its function (biol.).

struma (stroom'ă) $n$. [L. struma, a scrofulous tumour.] A swelling on a plant organ (bot.).

strumiferous (stroomúf'errŭs) a. [L. struma, a scrofulous tumour ; ferre, to carry.] Having a struma or strumae (bot.).

strumiform (stroom'ifôrm) a. [L. struma, a scrofulous tumour ; forma, shape.] Cushion-like.

strumose (stroom'ōs), strumulose (stroom'ūtōs) a. [L. struma, a tumour.] Having small cushionlike swellings (bot.).

stupeous (stü'pěŭs), stupose (stū'pōs) a. [L. stupa, tow.] Tow-like; having a tuft of matted filaments. 
stupulose (stū'pūlōs) a. [L. stupa, tow.] Covered with short filaments.

stylar (stīlăr) a. [L. stilus, a pricker.] Pert. a style.

stylate (stī'lāt) a. [L. stilus, a pricker.] Having a style or styles.

style (stil) $n$. [L. stilus, a pricker.] The slender upper part of an ovary supporting the stigma (bot.); a calcareous projection from the pore tabula in some Millepora; an abdominal bristle-like process on the male of many Insects (zool.).

stylet (stî́lět) $n$. [L. stilus, a pricker.] A small, pointed bristle-like appendage (zool.).

styliferous (stīliff'ĕrŭs) a. [L. stilus, a pricker; ferre, to carry.] Having bristly appendages.

styliform (stī'lïfôrm) a. [L. stilus, a pricker ; forma, shape.] Bristleshaped.

styloglossal (stî́löglŏs'ăl) a. [Gk. stylos, pillar; glossa, tongue.] Pert. the styloglossus muscle connecting styloid process and tongue (anat.).

stylogonidium,- - see conidium.

stylohyal (stî́löhī'ăl) n. [Gk. stylos, pillar; hyoeides, $\mathrm{Y}$-shaped.] The distal part of the styloid process of the temporal bone (anat.).

stylohyoid (stî́löhïoid) a. [Gk. stylos, pillar; hyoeides, Y-shaped.] Appl. a ligament attached to the styloid process and the lesser cornu of the hyoid (anat.).

styloid (stî́loid) a. [Gk, stylos, pillar ; eidos, resemblance.] Appl. processes of the temporal bone, the fibula, the radius, the ulna (anat.).

stylomandibular (stī'lömăndỉb'ūlăr) a. [Gk. stylos, pillar; L. mandibulum, jaw.]. Appl. a strong ligament extending from the styloid process to the cervical muscle under the parotid gland (anat.).

stylomastoid (stīlömăs'toid) a. [Gk. stylos, pillar ; mastos, breast ; eidos, like.] Appl. a foramen between styloid and mastoid processes, also an artery entering that foramen (anat.).

stylomaxillary (stî́lömăkšrl'ărǐ) $a$. [Gk. stylos, pillar; L. maxilla, jaw.] Stylomandibular.

stylopharyngeus (stî'löfărĭn'jēǔs) n. [Gk. stylos, pillar; pharyngx, pharynx.] A muscle extending from the base of the styloid process downwards along the side of the pharynx (anat.).

stylopodium (stīlöpō'dŭŭm) $n$. [Gk. stylos, pillar; pous, foot.] A conical swelling surrounding the bases of the divaricating styles of Umbelliferae (bot.).

stylospore,-see conidium.

stylosporous (stīlŏs'pörŭs) $a$. [Gk. stylos, pillar; sporos, seed.] Pert. a stylospore or conidium.

stylostegium (stî'löstē'jiŭum) n. [Gk. stylos, pillar; stege, roof.] The inner corona of some milk-weed plants (bot.).

stylus (stî́lŭs) $n$. [L. stilus, a pricker.] A style; a stylet ; a simple pointed spicule ; a molar cusp (biol.).

subabdominal (sŭb'ăbdŏm'ínăl) $a$. [L. sub, under; abdomen, belly.] Nearly in the abdominal region.

subacuminate (sŭb'ăkū'minnāt) $a$. [L. sub, under ; acumen, point.] Somewhat tapering (bot.).

subaduncate (sŭb'ădŭng'kāt) $a$. [L, sub, under; aduncus, hooked.] Somewhat crooked.

subaerial (súb'āếrǐăl) a. [L. sub, under; aer, air.] Growing just above the surface of the ground (bot.).

subalpine (sŭbăl'pīn) a. [L. sub, under; alpinus, alpine.] Appl. the zone below the timber line, or to plants or animals growing or living in that zone.

subalternate (sŭb'ăltĕr'nāt) $a$. [L. sub, under; altermus, one after another.] Tending to change from alternate to opposite (bot.).

subanconeus (sŭb'ăngkönē'ús) $n$. [L. $s u b$, under; ancon, elbow.] A small muscle extending from the triceps to the elbow joint (anat.).

subapical (sŭbăp'íkăl) a. [L. sub, under ; apex, extremity.] Nearly at the apex.

subarachnoid (sŭbărăk'noid) a. [L. sub, under; Gk. arachne, spider's web; eidos, resemblance.] Appl. a cavity filled with cerebrospinal fluid between the arachnoid and the pia mater; $a p p l$. cisternae of the brain, and a longitudinal septum in the same region (anat.). 
subarborescent (sŭb'ârbŏrěs'ěnt) $a$. [L. sub, under ; arborescens, growing into a tree.] Somewhat like a tree.

subarcuate (sŭbâr'kūāt) a. [L. sub, under; arcus, a bow.] Appl. a large blind fossa in the infant skull which extends backwards under the superior semicircular canal (anat.).

subauricular (sŭb'ôrǐk'ūlăr) $a$. [L. sub, under; auricula, the ear-tip.] Below the ear (anat.).

subaxillary (sŭb'ăksı̌l'ărĭ)a. [L. sub, under; axilla, the arm-pit.] $A p p l$. outgrowths just beneath the axil (bot.).

subbasal (sŭbbā'săl) a. [L. sub, under; Gk. basis, foundation.] Situated near the base (zool.).

subbranchial (sŭbbrăng'kiăl) a. [L. sub, under; Gk, brangchia, gills.] Under the gills.

subbronchial (sŭbbrŏng'kiăl) a. [L. sub, under; Gk. brongchos, windpipe.] Below the bronchials.

subcalcareous (sǔb'kălkā'rǐŭs) $a$. [L. sub, under ; calx, lime.] Somewhat limy.

subcalcarine (sŭbkăl'kărǐn) a. [L. $s u b$, under; calcar, spur.] Under the calcarine fissure; appl. the lingual gyrus of the brain (anat.). subcallosal (sǔb'kălō'săl) a. [L.sub, under; callus, hard skin.] Appl. a gyrus below the corpus callosum (anat.).

subcampanulate (sŭb'kămpăn'ūlāt) $a$. [L. sub, under; campanula, a little bell.] Somewhat bell-shaped (bot.). subcapsular (sǔbkăp'sūlăr) $a$. [L. $s u b$, under ; capsula, a little chest.] Inside a capsule.

subcardinal (sŭbkâr'dinnăl) $a$. [L. sub, under ; cardo, hinge.] Appl. a pair of veins which develop between the mesonephroi (emb.).

subcarinate (sŭbkăriñāt) $a$. [L. sub, under; carina, keel.] Somewhat keel-shaped.

subcartilaginous (sŭb'kârtǐlăj'inŭs) $a$, [L. sub, under; cartilago, gristle.] Not entirely cartilaginous.

subcaudal (sŭbkôd’ăl) a. [L. sub, under; cauda, tail.] Situate under the tail, as a shield or plate (zool.).

subcaudate (sŭbkôd'āt) a. [L. sub, under; cauda, tail.] Having a tail-like process (zool.). subcaulescent (sǔb'kôlěs'ěnt) a. [L. sub, under; caulis, stalk.] Borne on a very short stem (bot.).

subcentral (sǔbsĕn'trăl) $a$. [L. sub, under; centrum, a centre.] Nearly central.

subchela (sŭbkē'lă) $n$. [L. sub, under; Gk. chele, claw.] A prehensile claw of which the last joint folds back on the preceding, as in Squilla (zool.).

subchelate (sŭbkē'lāt) $a$. [L. sub, under; Gk. chele, claw.] Having prehensile claws of which the last joint folds back on the preceding; having imperfect chelae (zool.).

subchordal (sŭbkôr'dăl) a. [L. sub, under ; chorda, a cord.] Under the notochord (zool.).

subcingulum (sǔbsing'gūlŭm) $n$. [L. sub, under ; cingulum, a girdle.] The lower lip part of a cingulum or girdle of Rotifers (zool.).

subclavate (sǔbklăv'āt) a. [L. sub, under ; clavus, club.] Somewhat club-shaped.

subclavian (sǔbklā'viăn) $a$, [L. sub, under ; clavis, key.] Appl. artery, vein, nerve, muscle, below the clavicle (anat.).

subcoracoid (sŭbkôr'ăkoid) a. [L. sub, under; Gk. korax, crow ; eidos, like.] Below the coracoid.

subcordate (sŭbkôr'dāt) a. [L. sub, under ; cor, heart.] Tending to be heart-shaped.

subcorneous (sŭbkôr'něus) $a$. [L. sub, under; cormu, horn.] Under a horny layer ; slightly horny (zool.).

subcortical (sŭbkôr'tîkăl) $a$. [L. $s u b$, under; cortex, bark.] Under the cortex, or cortical layer (bot.); appl. cavities under the dermal cortex of Sponges (zool.).

subcosta (sŭbkŏs'tă) $n$. [L. sub, under ; costa, rib.] The subcostal nervure of an insect wing.

subcostal (sǔbkǒs'tăl) $a$. [L. sub, under ; costa, rib.] Below the ribs; appl. zone, muscles, arteries (anat.). subcrenate (sŭbkrē'nāt) a. [L. sub, under; L.L. crena, a notch.] Tending to have rounded scallops, as a leaf margin (bot.).

subcrureal (sŭbkroor'ěăl) $a$. [L. sub, under; crus, leg.] $A p p l$. the subcrureus or articularis genu muscle, 
extending from the lower femur to the knee-joint (anat.).

subcutaneous (sŭb'kūtā'něŭs) $a$. [L. sub, under; cutis, skin.] Under the cutis or skin; $a p p l$. parasites living just under the skin; $a p p l$. the external abdominal ring (anat.). subeuticular (sŭb'kūtı̌k'ūlăr) $a$. [L. sub, under; cuticula, the cuticle.] Under the epidermis or outer skin. subcutis (sŭbkü'tĭs) $n$. [L. sub, under; cutis, skin.] A loose layer of connective tissue between the corium and the deeper tissues of the skin (anat.).

subdentate (sübdĕn'tāt) $a$. [L. sub, under; dens, a tooth.] Slightly toothed or notched (bot.).

subdermal (sŭbdĕr'măl) $a$. [L. sub, under; Gk. derma, skin.] Beneath the skin.

subdorsal (sŭbdôr'săl) $a$. [L. sub, under; dorsum, the back.] Situated dorsally or almost on the dorsal surface.

subdural (sŭbdū'răl) a. [L. sub, under; durus, hard.] $A p p l$. a potential cavity separating the spinal dura mater from the arachnoid (anat.).

subepiglottic (sŭb'ěpiglŏt'îk) a. [L. $s u b$, under ; Gk. epi, upon; glottis, mouth of the windpipe.] Beneath the epiglottis (anat.).

subepithelial (sǔb'ěpithēliăl) a. [L. $s u b$, under; Gk. epi, upon; thallein, to grow.] $A p p l$. a plexus of the cornea (anat.).

suber (sư'bër) $n$. [L. suber, cork tree.] Cork tissue (bot.).

subereous (sūbē'rěŭs) $a$. [L. suber, cork tree.] Of corky texture (bot.).

suberiferous (sūběríf'ĕrŭs) $a$. [L. suber, cork tree; ferre, to bear.] Cork-producing (bot.).

suberiflcation (sü'běrîfikā'shŭn) $n$. [L. suber, cork tree; facere, to make.] Conversion into cork tissue (bot.).

suberin (sū'bĕrĭn) $n$. [L. suber, cork tree.] The waxy substance developed in a thickened cell-wall, making it almost waterproof (bot.).

suberization (sū'běrīzä'shŭn) n. [L. suber, cork tree.] The modification of cell walls due to the formation of suberin (bot.). suberose (sū'bĕrōs) a. [L. suber, cork tree.] Having a corky, waterproof texture (bot.).

subgalea (sŭbgăl'ěă) $n$. [L. sub, under; galea, a helmet.] Part of the maxilla of Insects (zool.).

subgeniculate (sŭb'jěnǐk'ūlāt) $a$. [L. sub, under; genu, knee.] Somewhat bent.

subgenital (sŭbjĕn'ítăl) $a$. [L. sub, under; genitalis, genital.] Below the reproductive organs; $a p p l$. a shallow pit or pouch beneath the gonad in Aurelia; $a p p l$. a portico formed by the fusion of the subgenital pouches of Discomedusae (zool.).

subglenoid (sŭbglē'noid) a. [L. sub, under ; Gk. glene, socket ; eidos, form.] Beneath the glenoid cavity (anat.).

subglossal (sŭbglŏs'ăl) a. [L. sub, under; Gk. glossa, tongue.] Beneath the tongue.

subhyaloid (sǔbhīăloid) $a$. [L. sub, under; Gk. hyalos, glass ; eidos, like.] Beneath the hyaloid membrane or fossa of the eye (anat.).

subhymenial, - pert. the subhymenium.

subhymenium (sŭb'hîmê'nĭŭm) $n$. [L. sub, under; Gk. hymen, a membrane.] A layer of small cells between trama and hymenium in the gill of Agarics (bot.).

subhyoid (sübhïoid) a. [L. sub, under; Gk, hyoeides, $\mathrm{Y}$-shaped.] Below the hyoid bone at the base of the tongue (anat.).

subiculum (sŭbìk'ūlüm) $n$. [L. subiculum, an under layer.] The filamentous mycelium of certain Fungi (bot.).

subimago (sǔb'ímā'gō) $n$. [L. sub, under ; imago, an imitation.] A stage between pupa and imago in the life-history of some Insects.

subinguinal (sŭbǐn'gwĭnăl, sŭb'ĩngwī'năl) a. [L. sub, under; inguen, groin.] Situated below a horizontal line at the level of the great saphenous vein termination; $a p p l$. glands (anat.).

subjugal (sǔbjoog'ăl) $a$. [L. sub, under; jugum, yoke.] Below the jugal or cheek bone (zool.).

subjugular (sǔbjoog'ūlăr) a. [L. sub, 
under; jugulum, collar-bone.] $A p p l$. a ventral fish-fin nearly far enough forward to be jugular (zool.). sublanceolate (sŭblăn'sěoulāt) $a$. [L. $s u b$, under; lanceolatus, speared.] Tending to be narrow and to taper towards both ends (bot.).

sublaryngeal (sǔblărǐn'jěăl) $a$. [L. sub, under; Gk. laryngx, larynx.] Situate below the larynx (zool.).

sublenticular (sŭb'lĕntǐk'ūlăr) $a$. [L. sub, under; lenticula, a small lentil.] Somewhat lens-shaped.

sublingua (sŭblĭng'gwă) $n$. [L. sub, under; lingua, tongue.] A single or double projection beneath the tongue, most developed in Insectivores (zool.).

sublingual (sŭblǐng'gwăl) $a$, [L. sub, under; lingua, tongue.] Beneath the tongue; $a p p l$. gland, artery, fossa (anat.).

sublobular (sŭblŏb'ūlăr) $a$. [L, sub, under; Gk. lobos, a lobe.] Appl. veins at the base of the lobules of the liver (anat.).

sublocular (sŭblǒk'ūlăr) $a$. [L. sub, under; loculus, a little place.] Somewhat locular or cellular.

submalleate (sǔbmăl'ễt) a. [L, sub, under; malleus, a hammer.] Somewhat hammer-shaped; appl. the trophi of a rotifer mastax (zool.).

submarginal (sǔbmâr'jinăl) a. [L. sub, under; margo, margin.] Placed nearly at the margin.

submarginate (sŭbmâr'jǐnāt) a. [L. sub, under; margo, margin.] Appl. a bordering structure near a margin. submaxilla (sŭb'măksı̌l'ă) $n$. [L. sub, under; maxilla, jaw.] The mandible or lower jaw.

submaxillary (sŭb'măksīlărǐ̀) a. [L. sub, under; maxilla, jaw.] Appl. duct, ganglion, gland, triangle, beneath the lower jaw (anat.).

submedian (sŭbmé'diăn) a. [L.'sub, under; medius, the middle.] Appl. the tooth or vein next the median (zool.).

submental (sŭbmĕn'tăl) $a$. [L. sub, under; mentum, chin.] Beneath the chin; appl. artery, glands, triangle(anat.); pert. thesubmentum (zool.).

submentum (sŭbměn'tŭm) $n . \quad[$ L. sub, under; mentum, chin.] The basal part of the labium or fused second maxillae of Insects (zool.).

submerged,- -submersed.

submersed (sŭbmĕrsd') a. [L. submergere, to submerge.] Appl. plants growing entirely under water (bot.). submicron (sǔbmìk'rŏn) $n$. [L. $s u b$, under; Gk. mikros, small.] An element seen as a separate disc with the aid of an ultramicroscope, although invisible with an ordinary microscope ; cf. amicron (phys.).

submucosa (sủb'mūkō'să) $n$. [L. sub, under; mucosus, mucous.] The layer of tissue under a mucous membrane (anat.).

subnasal (sŭbnă'zăl) $a . \quad[\mathrm{L} . \quad s u b$, under; nasus, nose.] Beneath the nose (anat.).

subneural (sŭbnū'răl) $a$. [L. sub, under; Gk. neuron, nerve.] Appl. gland and ganglion of nervous system of Tunicates (zool.).

suboceipital (sŭb'ŏksịp'ítăl) a. [L. sub, under; occiput, the back part of the head.] Appl.muscles, nerve, triangle, under the occipitals of the skull (anat.).

subocular shelf,-an ingrowth from the suborbitals supporting the eyeball of Fishes.

suboesophageal (sǔbēsǒf'ăjē'ăl) $a$. [L. sub, under; Gk. oisophagos, gullet.] Below the gullet (zool.).

subopercular (sǔb'öpĕr'kūlăr) $a$. [L. sub, under; operculum, a lid or cover.] Under the operculum or gill-cover of Fishes, or the shell-lid of Molluscs (zool.).

suboperculum (sŭb'öpěr'kūlŭm) $n$. [L. $s u b$, under ; operculum, a cover.] The subopercle, one of the membrane bones of the operculum of Fishes (zool.).

suboptic (sŭbŏp'tîk) a. [L. sub, under; Gk. optikos, relating to sight.] Below the eye.

suboral (sŭbō'răl) a. [L. sub, under; os, mouth.] Below the month; near the mouth.

suborbital (sǔbôr'bĭtăl) a. [L. sub, under; orbis, a circle.] $A p p l$. structures below the orbit of the eye.

subovate (sǔbō'vāt) a. [L. sub, under; ovum, egg.] Suboval; subovoid; somewhat oval or egg-shaped. 
subpalmate (sŭbpăl'māt) a. [L. sub, under ; palma, palm of the hand.] Tending to become palmate ; $a p p l$. leaves (bot.).

subparietal (sŭb'pări'ětăl) $a, \quad$ [L. sub, under; paries, a wall.] Beneath the parietals; $a p p l$. a sulcus which is the lower boundary of the parietal lobe (anat.).

subpectinate (sŭbpěk'tināt) $a$. [L. sub, under; pecten, a comb.] Tending to be comb-like in structure.

subpedunculate (sŭb'pědŭng'kūlāt) $a$. [L. sub, under; pedunculus, a little foot.] Resting on a very short base-stalk.

subpericardial (sŭb'pĕrǐkâr'dĭăl) $a$. [L. sub, under; Gk. peri, round ; kardia, heart.] Under the pericardium, or membranous sac enclosing the heart (anat.).

subperitoneal (sŭb'pěrǐtönē'ăl) $a$. [L. sub, under; Gk. peritonaion, something stretched round.] $A p p l$. connective tissue under the peritoneum (anat.).

subpetiolar (sŭbpět'iölăr) $a$. [L. sub, under; petiolus, a little foot.] Within the petiole or leaf-stalk (bot.).

subpetiolate (sŭbpět'iölāt) $a$. [L. sub, under; petiolus, a small foot.] Almost sessile (bot.).

subpharyngeal (sŭb'fărĭn'jě̌l) $a$. [L. sub, under; Gk. pharyngx, pharynx.] Below the gullet.

subphrenic (sŭbfrĕn'î) a. [L. sub, under; Gk. phren, midriff.] Below the diaphragm (anat.).

subpial (sǔbpi'ăl) a. [L. sub, under; pia, kind.] Under the pia mater (anat.).

subpleural (sǔbploor'ăl) a. [L. sub, under; Gk. pleura, side.] Beneath the inner lining of the chest wall (anat.).

subpubic (sŭbpū'bǐk) $a$. [L, sub, under; pubes, adult.] Below the pubic region (anat.).

subpulmonary (sǔbpǔl'mönărǐ) $a, \quad[\mathrm{~L}$. sub, under; pulmo, lung.] Beneath the lungs (anat.).

subradius (sŭbrā'diŭs) $n$. [L. sub, under ; radius, a ray.] In radiate animals, a radius of the fourth order, that between adradius and perradius, or between adradius and interradius (zool.). subramose (sŭbrā'mōs) a. [L. sub, under; ramus, a branch.] Branching somewhat (bot.).

subreniform (sǔbrěn'ǐfôrm) a. [L. sub, under ; renes, kidneys ; forma, shape.] Slightly kidney-shaped (bot.).

subretinal (sŭbrĕt'inăl) $a$. [L. sub, under; rete, net.] Beneath the retina (anat.).

subrostral (sŭbrŏs'trăl) $a$. [L. sub, under; rostrum, a beak.] Below the beak (zool.).

subsacral (sŭbsā'krăl) $a$. [L. sub, under; sacrum, sacred.] Below the sacrum (zool.).

subsartorial (sŭb'sârtō'ríăl) a. [L. sub, under; sartor, a tailor.] $A p p l$. a plexus under the sartorius muscle of the thigh (anat.).

subscapular (sŭbskăp'ülăr) $a$. [L. sub, under; scapula, shoulder-blade.] Beneath the scapula; $a p p l$. artery, muscles, nerves, etc. (anat.).

subselerotic (sǔb'sklěrŏt'̌k) a. [L. sub, under; Gk. skleros, hard.] Beneath the sclerotic layer of the eye; between sclerotic and choroid (anat.).

subserous (sŭbsēérŭs) $a . \quad[L . s u b$, under; serum, whey.] Beneath a serous membrane; appl. areolar tissue (anat.).

subserrate (sŭbsĕr'āt) $a$. [L. sub, under; serra, saw.] Somewhat notched or saw-toothed (bot.).

subsessile (sŭbsĕs'il) $a$. [L. $s u b$, under; sedere, to sit.] Nearly sessile; with almost no stalk (bot.).

subsidiary cells, - additional modified epidermal cells lying outside guard-cells (bot.).

subspatulate (sǔbspăt'ūlāt) $a$. [L. sub, under; spatula, spoon.] Somewhat spoon-shaped (bot.).

subspinous (sǔbspīnŭs) $a . \quad$ [L. $s u b$, under; spina, spine.] Tending to become spiny.

substantia (sǔbstăn'shǐa) $n$. [L. substantia, substance.] Substance or matter (anat.).

substantia adamantina, eburnea, ossea,-respectively enamel, dentine, and cement or crusta petrosa of teeth (anat.).

substantia gelatinosa, - the grey matter of the spinal cord (anat.). 
substantia nigra,-a semilunar layer of grey cells of the mid-brain (anat.).

substantive variation,-changes in the actual constitution or substance of the parts ; $c f$. meristic variation (biol.).

substernal (sŭbstĕr'năl) a. [L. sub, under; sternum, breastbone.] Below the sternum (zool.).

substratose (sŭbstrā'tōs) a. [L. sub, under; stratum, a layer.] Slightly or indistinctly stratified.

substratum (sŭbstrā'tŭm) $n$. [L. sub, under; stratum, a layer.] The base to which a stationary animal or a plant is fixed (biol.).

subtectal (sŭbtĕk'tăl) a. [L. sub, under; tectum, roof.] Pert. the alisphenoid of a fish skull (zool.).

subtegminal (sǔbtěg'minăl) $a$. [L. sub, under; tegmen, a covering.] Under the tegmen or inner coat of a seed (bot.).

subtentacular canals,-two prolongations of the echinoderm coelom (zool.).

subthoracic (sŭb'thörăs'îk) a. [L. $s u b$, under; Gk. thorax, breast.] Not so far forward as to be called thoracic; $a p p l$. certain fish-fins (zool.).

subtrapezoidal (sŭb'trăpēzoid'ăl) $a$. [L. sub, under; Gk, trapezion, a small table; eidos, resemblance.] Somewhat trapezoid-shaped.

subtruncate (sŭbtrŭng'kāt) a. [L. sub, under; truncatus, maimed.] Terminating rather abruptly, as if cut off (biol.).

subtypical (sŭbtīp'ikăl) $a$. [L. sub, under; typus, image.] Deviating slightly from type.

subulate (sū'būlāt) a. [L. subula, an awl.] Awl-shaped; $a p p l$. leaves, very narrow and tapering from the base to a fine point (bot.).

subumbellate (sŭbŭm'bĕlāt) $a$. [L. $s u b$, under ; umbella, a small shade.] Tending to an umbellate arrangement, with peduncles arising from a common centre (bot.).

subumbonal (sŭb'ŭmbōnăl) $a . \quad$ [L. sub, under; umbo, boss.] Beneath or anterior to the umbo of a bivalve shell (zool.).

subumbrella (sŭb'ŭmbrěl̆ă) $n, \quad[\mathrm{~L}$. sub, under; umbra, shade.] The concave inner surface of the medusoid bell (zool.).

subuncinate (sŭbŭn'sinnāt) $a$. [L. sub, under; uncus, hook.] Having a somewhat hooked process; somewhat hook-shaped.

subungual (sŭbŭng'gwăl) $a$. [L. sub, under; unguis, a nail.] Under a nail, claw, or hoof (zool.).

subunguis (sŭbŭng'gwĭs) $n$. [L. sub, under; unguis, a nail.] The ventral scale of a claw.

subvaginal (sŭbvăjĩnăl) a. [L. sub, under; vagina, a sheath.] Within or under a sheath.

subvertebral (sŭbvĕr'těbrăl) $a$. [L. sub, under; vertebra, a joint.] Under the spinal column.

subzonal (sŭbzō'năl) $a$. [L. sub, under; zona, a belt.] Appl. a layer of cells immediately internal to the zona radiata (emb.).

subzygomatic (sǔbzígömăt'îk) a. [L. $s u b$, under; Gk. zygon, a yoke.] Under the cheek-bone.

succiferous (sŭksǐf'ěrŭs) a. [L. succus, sap; ferre, to carry.] Sap-conveying (bot.).

succise (sŭksīs') a. [L. succisus, lopped off.] Abrupt; appearing as if a part were cut off (bot.).

succubous (sŭk'ūbŭs) a. [L. sub, under; cubare, to lie down.] With each leaf covering part of that under it (bot.).

succulent (sǔk'ülěnt) a. [L. succus, sap.] With tissues full of juice or sap (bot.).

succus (sŭk'ŭs) n. [L. succus, juice, sap.] The juice of a plant ; fluid secreted by certain glands (biol.).

sucker (sŭk'ër) n. [A.S. sucan, to suck.] A stem-branch, first subterranean and then aerial, which may ultimately form an independent plant (bot.); an organ adapted for creating a vacuum, in some animals for purposes of ingestion, in others to assist in locomotion (zool.).

sucking-disc, - a disc assisting in attachment, at the end of an echinoderm tube-foot (zool.).

suctorial (sŭktō'riăl) a. [L. sugere, to suck.] Adapted for sucking; furnished with suckers ; $a p p l$. a pad of fat in relation with the buccin- 
ator, supposed to assist in sucking (zool., anat.).

sudor (sū'dǒr) $n$. [L. sudor, sweat.]

Perspiration (phys.).

sudoriferous (sū'dŏríf'ěrŭs) $a$. [L. sudor, sweat ; ferre, to carry.] Conveying, producing, or secreting sweat, $a p p l$. glands and their ducts (anat.).

suffrutex (sŭf'rootĕks) $n$. [L. sub, under; frutex, shrub.] An undershrub (bot.).

suffruticose (sŭfroot'ikōs) a. [L. sub, under; frutex, shrub.] Somewhat shrubby (bot.).

sugent (sū'jĕnt), sugescent '(sūjēs'ĕnt) a. [L. sugere, to suck.] Suctorial. sulcate (sǔl'kāt) a. [L. sulcus, furrow.] Furrowed; grooved.

sulcus (sŭl'kŭs) $n$. [L. sulcus, furrow.] A groove; $a p p l$. the cerebral grooves; those of heart, tongue, cornea, bones, etc. (anat.); a stomodaeal groove of Anthozoa; a longitudinal flagellum groove of Dinoflagellata (zool.).

summer eggs, - the thin-shelled, quickly developing eggs of some fresh-water forms laid in spring or summer ; $c f$. winter eggs (zool.).

supercarpal (sūpěrkâr'păl, soo-) $a$. [L. super, over; carpus, wrist.] Upper carpal or above the carpus (anat.).

supercilia (sūpĕrsǐl'iă, soo-) n. plu. [L. super, over; cilia, eyelids.] The eyebrows.

superciliary (sūpěrsǐl'iărĭ, soo-) $a$. [L. super, over; cilia, eyelids.] Pert. the eyebrows; above the orbit (anat.).

superciliary arches,- two arched elevations below the frontal eminences (anat.).

superficial (sūpěrfísh'ăl, soo-) $a$. [L. super, over ; facies, face.] On the surface; $a p p l$. arteries, veins, etc. (anat.).

superglottal (sūperrglŏt'ăl, soo-) $a$. [L. super, over; Gk. glottis, end of windpipe.] Above the glottis (anat.).

superior (sūpērrǐor, soo-) $a$. [L. superior, upper.] Upper; higher (anat.); growing or arising above another organ (bot.).

superparasite,-see hyperparasite, supersacral (sūpĕrsā'krăl, soo-) $a$. [L. super, over ; sacrum, sacred.] Above the sacrum (anat.).

supersphenoidal (sū'pěrsfēnoid'ăl, soo-) a. [L. super, over; Gk. sphen,wedge.] Above the sphenoid bone.

supervolute (sūpěrvǒlūt', soo-) $a$. [L. super, over; volvere, to roll.] Having a plaited and rolled arrangement in the bud (bot.).

supinate (sū'pināt) a. [L. supinus, bent backwards.] Inclining or leaning backwards (bot.).

supination (sū'pināshŭn) $n$. [L. supinus, bent backward.] Movement of the arm by which the palm of the hand is turned upwards ; $c f$. pronation (phys.).

supinator brevis and longus, - two arm muscles used in supination (anat.).

suppression (sŭprĕsh'ŭn) $n$. [L. sub, under; pressus, pressed.] The non-development of an organ or part (bot.).

supraacromial (sū'prăăkrō'mǐăl, soo-) a. [L. supra, above; Gk. akros, summit ; omos, shoulder.] Above the acromion of the shoulder-blade (anat.).

supraanal (sū'prăă'năl, soo-) $a$. [L. supra, above; anus, anus.] Suranal; above the anus or anal region.

supraangular, - see surangular.

supraauricular (sū'prăôrĭk'ülăr, soo-) a. [L. supra, above; auris, ear.] Above the auricle; $a p p l$. feathers (zool.).

suprabranchial (sū'prăbrăng'kiăl, soo-) a. [L. supra, above; Gk. brangchia, gills.] Above the gills (zool.).

suprabuceal (sū'prăbŭk'ăl, soo-) a. [L. supra, above ; bucca, cheek.] Above the cheek and mouth (zool.). supracallosal (sü'prăkălō'săl, soo-) a. [L. supra, above ; callosus, hard.] $A p p l$. a gyrus on the upper surface of the corpus callosum of the brain (anat.).

supracaudal (sū'prăkôd'ăl, soo-) $a$. [L. supra, above; cauda, tail.] Above the tail or caudal region. suprachoroid (sū'prăkō'roid, soo-) $a$. [L. supra, above; Gk. chorion, skin.] 
Over the choroid; between choroid and sclerotic (anat.).

supraclavicle (sū'prăklăv'íkl, soo-) $n$.

[L. supra, above ; clavicula, a small

key.] The supracleithrum ; a bone

of the shoulder girdle of Fishes (zool.).

supraclavicular (sū'prăklăvǐk'ūlăr, soo-) a. [L. supra, above; clavicula, a small key.] Above or over the clavicle; appl. nerves (anat.).

supracleithrum (sū'prăkli'thrŭm, soo-) n. [L. supra, above; Gk. kleithron, key.] Supraclavicle.

supracondylar (sū'prăkŏn'dillăr, soo-) a. [L. supra, above; Gk. kondylos, knob.] Above a condyle; $a p p l$. ridge and process (anat.).

supracostal (sū'prăkŏs'tăl, soo-) a. [L. supra, above; costa, a rib.] Over or externally to the ribs.

supracranial (sū'prăkrā'niăl, soo-) $a$.

[L. supra, above; Gk. kranion, skull.] Over or above the skull. supradorsal (sū'prădôr'săl, soo-) $a$. [L. supra, above; dorsum, back.] On or over the back; $a p p l$. small cartilaginous elements in connection with the primitive vertebral column (zool.).

supraglenoid (sü'prăglē'noid, soo-) $a$. [L. supra, above; Gk. glene, socket.] Above the glenoid cavity.

supraglenoid tuberosity, - a slight elevation at the apex of the glenoid cavity (anat.). suprahyoid (sū'prăhīoid, soo-) a. [L.
supra, above; Gk. hyoeides, Yshaped.] Over the hyoid bone; $a p p l$. aponeurosis, glands, muscles (anat.).

supralabial (sū'prălā'bǔl, soo-) $a$. [L. supra, above ; labium, lip.] On the lip; $a p p l$. scutes or scales (zool.).

supraloral (sū'prălō'răl, soo-) a. [L. supra, above; lorum, thong.] Above the loral region; $a p p l$. birds, snakes (zool.).

supramastoid crest, - the ridge at the upper boundary of the mastoid region of the temporal bone (anat.). supramaxillary

(sū'prămăksǔllărĭ, soo-) a. [L. supra, above; maxilla, jaw.] Pert. the upper jaw; appl. nerves (anat.).

suprameatal (sū'prămēā'tăl, soo-) $a$.
[L. supra, above ; meatus, a passage.] $A p p l$. triangle and spine over the external acoustic meatus (anat.).

supranasal (sū'prănā'zăl, soo-) a. [L. supra, above; nasus, nose.] Over the nasal bone or nose (zool.).

supraoccipital (sü'prăǒksǐp'ităl, soo-) n. [L. supra, above ; occiput, back part of the head.] A large median bone of the upper occipital region (zool.).

supraocular (sū'prăǒk'ūlăr, soo-) a. [L. supra, above; oculus, eye.] Over or above the eye ; appl. scales (zool.).

supraoesophageal (sū'prăēsŏf'ăjē'ăl, soo-) a. [L. supra, above; Gk. oisophagos, gullet.] Above or over the gullet (zool.).

supraorbital (sū'prăôr'bĭtăl, soo-) $a$. [L. supra, above; orbis, a circle.] Above the orbital cavities; $a p p l$. artery, foramen, nerve, vein, etc. (anat.).

suprapharyngeal (sū'prăfarĭn'jěăl, soo-) a. [L. supra, above; Gk. pharyngx, pharynx.] Above or over the pharynx.

suprapubic (sū'prăpū'bǐk, soo-) a. [L. supra, above; pubes, adult.] Above the pubic bone.

suprapygal (sü'prăpī'găl, soo-) a. [L. supra, above; Gk. pyge, the rump.] Above the pygal bone (zool.).

suprarenal (sū'prărē'năl, soo-) $a$. [L. supra, above; renes, kidneys.] Situated above the kidneys; $a p p l$. arteries, glands, veins, plexus (anat.).

suprarenal bodies,-adrenal bodies. suprascapula (sū'prăskăp'ūla, soo-) $n$. [L. supra, above ; scapula, shoulderblade.] An incompletely ossified extension of the scapula of Amphibians and Ophidians (zool.).

suprascapular(sū'prăskăp'ūlăr, soo-) $a$. [L. supra, above ; scapula, shoulderblade.] Above the shoulder-blade; $a p p l$. artery, ligament, nerve (anat.). suprasphenoidal (sū'prăsfēnoid'ăl, soo-) a. [L. supra, above; Gk. sphen, wedge.] Above the sphenoid bone of the skull.

supraspinal (sū'prăspīnăl, soo-) a. [L. supra, above; spina, a spine.] Above or over the spinal column; $a p p l$. a ligament (anat.). 
supraspinatous (sū'prăspīnā'tŭs, soo-) a. [L. supra, above; spina, a spine.] $A p p l$. the scapular fossa and fascia for the origin of the supraspinatus, a muscle extending from scapula to humerus head (anat.).

suprastapedial (sū'prăstăpē'dĭăl, soo-) n. [L. supra, above; stapes, a stirrup.] The part of the columella of the ear above the stapes, homologous with the mammalian incus (zool.).

suprasternal (sū'prăstĕr'năl, soo-) $a$. [L. supra, above; sternum, breastbone.] Over or above the breastbone; $a p p l$, a slit-like space in the cervical muscle (anat.).

suprastigmal (sū'prăstĭg'măl, soo-) $a$. [L. supra, above; Gk. stigma, a pricked mark.] Above a stigma or breathing-pore of Insects.

supratemporal (sū'prătěm'pörăl, soo-) a. [L. supra, above; temporalis, temporary.] Pert. the upper temporal region of the skull; $a p p l$. arch, bone, fossa (anat.).

suprathoracic (sü'prăthörăs'îk, soo-) a. [L. supra, above; Gk. thorax, breast.] Over or above the thoracic region.

supratonsillar (sū'prătŏn'sǐlăr, soo-) $a$. [L. supra, above ; tonsilis, clipped.] $A p p l$. a small depression in the lymphoid mass of a tonsil (anat.). supratrochlear (sū'prătrŏk'lěăr, soo-) a. [L. supra, above; Gk. trochlea, a pulley.] Over or above the trochlear surface; $a p p l$. nerve and foramen (anat.).

supratympanic (sū'prătǐmpăn'îk, soo-) a. [L. supra, above; Gk. tympanon, a drum.] Above the ear-drum.

sural (sü'răl) a. [L. sura, calf of the leg.] Pert. the calf of the leg; $a p p l$. arteries and nerves (anat.).

suranal,-see supraanal.

surangular (sūrăng'gūlar) n. [L. supra, above ; angulus, an angle.] The supraangular; a bone of the lower jaw of Reptiles and Birds (zool.).

surculose (sŭr'kūlōs) a. [L. surculus, a twig.] Surculous; surculigerous ; $a p p l$. plants producing suckers first underground, thence aerial and forming independent plants; bear- ing suckers (bot.); stoloniferous (zool.).

surculus (sŭr'kūlŭs) $n$. [L. surculus, a twig.] An underground shoot, ultimately aerial and independent (bot.); a sucker (zool.).

suspensor (sŭspěn'sŏr) n. [L. suspendere, to hang down.] A chain of cells developed from the hypobasal segment of an angiosperm zygote, attaching the embryo to the embryo sac; occurring in a modified form in the development of other plants (bot.).

suspensorium (sŭspěnsō'rŭŭm) $n$. [L. suspendere, to hang down.] The upper part of the hyoid arch from which the lower jaw is suspended (zool.).

suspensory (sŭspĕn'sörĭ) $a$. [L. suspendere, to hang down.] Pert. a suspensorium; serving for suspension; $a p p l$. various ligaments (anat.).

sustentacular (sǔstěntăk'ūlăr) $a$. [L. sustentaculum, a prop, support.] Supporting ; $a p p l$. connective tissue acting as a supporting framework for an organ (anat.).

sustentaculum lieni, tali,-support of the spleen, of the ankle-bone (anat.).

sustentator (sŭstěntā'tŏr) n. [L. sustinere, to sustain.] The sustentor or hooked cremaster of Lepidoptera (zool.).

sutural (sū'tūrăl, soo-) a. [L. sutura, a seam.] Pert. a suture; $a p p l$. dehiscence taking place at a suture (biol.).

sutural bones, - Wormian bones; irregular isolated bones occurring in the course of sutures, especially in the lambdoidal suture and posterior fontanelle (anat.).

suture (sū'tūr, soo-) $n$. [L. sutura, a seam.] The line of junction of two parts immovably connected; an immovable articulation of bone as in the skull (anat.); the dehiscence line (bot.).

swarm (swôrm) $n$. [A.S. swearm, swarm.] A large number of minute motile organisms viewed collectively; departure of a number of bees from one hive to form another (zool.). 
swimmerets, - paired appendages posterior to the walking-legs of Crustaceans, functional partly for swimming (zool.).

swimming bells, - nectocalyces : medusoid bell-like structures of Siphonophores with velum and radiating canals, serving to propel the colony (zool.).

swimming or swim bladder, - the air bladder of Fishes, developed as a diverticulum of the alimentary canal, - function not precisely determined (zool.).

swimming funnel, - the tube of Dibranchiates through which water is expelled from the mantle cavity, expulsion providing the means of propulsion (zool.).

swimming ovaries,-groups of ripe ova of Acanthocephala detached and floating freely in the body cavity (zool.).

swimming plates,-in Ctenophores, eight equidistant bands of ciliated comb-like plates or comb-ribs, propellers of the organism (zool.).

syconium (sīkō'nı̌ŭm) n. [Gk. sykon, fig.] A cyconus; a multiple, succulent, receptacular fruit (bot.).

symbiont (sim'bǔnt) n. [Gk. syn, with; bioun, to live.] One of the partners in symbiosis (biol.).

symbiosis (simbiō'sǐs) n. [Gk. symbioun, to live together.] A condition in which two animals, two plants, or plant and animal, live in mutually beneficial partnership (biol.).

symbiote,- symbiont.

symbiotic (simbrǒt'îk) a. [Gk. symbioun, to live together.] Living in beneficial partnership, as Clione, Dromia (biol.).

symmetrical (simět'rikăl) a. [Gk. syn, with; metron, measure.] Regularly shaped; divisible into exactly similar halves (biol.).

symmetry (sim'ětrǐ) n. [Gk. syn, with ; metron, measure.] State of divisibility into similar halves; regularity of form; similarity of structure on each side of an axis, central, dorsoventral, or anteroposterior. See bilateral and radial symmetry (biol.).

sympathetic (simpăthĕt'ík) a. [Gk. syn, with; pathos, feeling.] Appl. the system of nerves supplying the viscera and blood-vessels, and intimately connected with the spinal and some cerebral nerves (anat.); $a p p l$. coloration in imitation of surroundings (biol.).

sympetalous (sǐmpět'ălŭs) a. [Gk. syn, with ; petalon, leaf.] Having a tubular corolla formed by union of petals (bot.).

symphily (sim'fillì) $n$. [Gk. syn, with ; philein, to love.] Commensalism with mutual liking (zool.).

symphyantherous, - synantherous.

symphyllous, - gamophyllous.

symphyogenesis (sim'fiöjĕn'ěsǐs) $n$.

[Gk. symphyesthain, to grow together; genesis, descent.] Development of an organ from the union of two others.

symphysial (simfĩz'iăl) a. [Gk. symphysis, a growing together.] Symphyseal; symphysian; pert. a symphysis.

symphysis (sim'fĩsǐs) n. [Gk. symphysis, a growing together.] The line of junction of two pieces of bone separate in early life, as the pubic symphysis; a slightly movable articulation with the bony surfaces connected by fibrocartilage; $c f$. syndesmosis (anat.).

symplectic (simmplěk'tǐk) n. [Gk. syn, with; plektos, plaited.] A bone of the fish skull between quadrate and hyomandibular (zool.).

sympodial (simpō'diăl) a. [Gk. syn, with; pous, foot.] Pert. or resembling a sympodium in principle (bot.).

sympodite (šm'pödìt) n. [Gk. syn, with ; pous, foot.] The protopodite of Crustacea (zool.).

sympodium (simpō'diŭm) n. [Gk. syn, with; pous, foot.] A primary axis consisting of a line connecting the bases of consecutive branchings (bot.).

synacme (sinăk'mē) $n$. [Gk. syn, with; akme, prime.] Condition when stamens and pistils mature simultaneously; synanthesis (bot.).

synangium (sinăn'jiŭm) n. [Gk. syn, with; anggeion, a vessel.] A compound sporangium in which the sporangia are coherent, as in some Ferns (bot.). 
synantherous (sĭnăn'thĕrŭs) $a$. [Gk. syn, with; antheros, flowery.] Having anthers united to form a tube (bot.).

synanthesis,-synacme.

synanthous (sinăn'thŭs) a. [Gk. syn, with; anthos, flower.] Having flowers and leaves appearing simultaneously; having flowers united together (bot.).

synanthy (šnăn'thĭ) n. [Gk. syn, with; anthos, flower.] The adhesion of flowers usually separate (bot.).

synaposematic (sinăp'ösĕmăt'ık) $a$. [Gk. syn, with; apo, from; sema, sign.] Appl. mimicry of a more powerful species as a means of defence (biol.).

synapse (sinăps') n. [Gk. synapsis, union.] The connection of one nerve cell and another through the medium of the terminal branchings of the dendrons or axons (phys.).

synapsis (sinăp'sı̌s) $n$. [Gk. synapsis, union.] A contraction of the chromatin linin filament which usually includes the nucleolus in the chromatin mass, a stage in the reduction-division of cells (cyt.).

synaptic membrane,-a membrane intervening between the nerve-ending and the muscle fibre supplied by it, also between one neurone and the fibre connecting it with another (phys.).

synapticula (sĭnăptǐk'ūlă) n. [Gk. synaptos, united.] One of small calcareous rods connecting the septa of the mushroom-coral (zool.).

synarthrosis (šn'ârthrō'sǐs) n. [Gk. syn, with; arthron, joint.] An articulation in which bone surfaces are in almost direct contact, fastened together by connective tissue or hyaline cartilage, with no appreciable motion (anat.).

syncarp (sinn'kârp) n. [Gk. syn, with ; karpos, fruit.] A syncarpium; an aggregate fruit with united carpels (bot.).

syncarpous (sinkâr'pŭs) a. [Gk, syn, with; karpos, fruit.] Bearing a collective fruit (bot.).

synearpy (sinkâr'pĩ) n. [Gk. syn, with; karpos, fruit.] Condition of having carpels united to form a compound ovary (bot.). syncerebrum (sinsĕr'ĕbrŭm) $n$. [Gk. syn, with; L. cerebrum, brain.] A secondary brain formed by union with the brain of one or more of the ventral cord ganglia in some Arthropods (zool.).

synchondrosis (sĭn'kŏndrō'sis) $n$. [Gk. syn, with ; chondros, cartilage.] A synarthrosis in which the connecting medium is cartilage (anat.). syneraniate (šnkrā'nīāt) a. [Gk. syn, with; kranion, skull.] Having certain vertebral elements fused with the skull (zool.).

syncranterian (sĭnkrăntē'riăn) $a$. [Gk. syn, with ; kranteres, wisdom teeth.] With teeth in a continuous row (zool.).

syncryptic (sǐnkrǐp'tìk) a. [Gk. syn, with; kryptos, hidden.] Appl. animals alike though unrelated, through common protective resemblance to their surroundings (biol.).

syncytiotrophoblast, - see syncytium (emb.).

syneytium (sinnsittiŭum) n. [Gk. syn, with; kytos, hollow.] A multinucleated mass of protoplasm without differentiation into cells (biol.) ; the outer stratum of the trophoblast of the mammalian ovum, the syncytiotrophoblast (emb.).

syndactyl (sĭndăk'tīl) $a$. [Gk. syn, with; daktylos, digit.] With fused digits, as in many Birds.

syndactylism (sindăk'tǐlǐzm) n. [Gk. syn, with ; daktylos, digit.] Whole or part fusion of two or more digits (zool.).

syndesmology (sinn'děsmŏl'öjî) n. [Gk. syndesmos, a band; logos, discourse.] The branch of anatomy dealing with ligaments and articulations.

syndesmosis (sǐn'děsmō'š̌s) $n$. [Gk. syndesmos, a ligament.] A slightly movable articulation, with the bony surfaces connected by an interosseous ligament; $c f$. symphysis (anat.).

synecthry (sinněk'thrǐ) n. [Gk. syn, with; echthros, hatred.] Commensalism with mutual dislike (biol.).

synema (sinē'mă) $n$. [Gk. syn, with ; nema, thread.] The united stamen filaments of a monadelphous flower (bot.). 
synergetic (siněrjĕt'îk), synergic (sinĕr'jǐk) a. [Gk. synergos, a cooperator.] Operating together; appl. muscles which combine with "prime movers" and "fixation muscles" in movement (anat.).

synergid (sinĕr'jĭd) n., sinergidae (siněr'jĭdē) plu. [Gk. synergos, cooperating.] Two help-cells lying beside the ovum at the micropylar end of the embryo sac of an ovule (bot.).

syngamy (š̆n'gămǐ) $n$. [Gk. syn, with ; gamos, marriage.] Comprehensively, sexual union.

syngenesious (šn'jěnē'sĭŭs) a. [Gk. syn, with; genesis, descent.] Having the stamens united in a cylindrical form by the anthers (bot.).

syngenesis (sinjĕn'ěsiss) $n$. [Gk. syn, with; genesis, descent.] Sexual reproduction; the theory that the germs of all human beings, past, present, and future, were created simultaneously, and that there are germs within germs ad infinitum (biol.).

syngenetic (sĭn'jĕnĕt'îk) $a$. [Gk. syn, with ; genesis, descent.] Sexually reproduced (biol.).

syngnaths (sinn'gnâths) n. plu. [Gk. syn, with; gnathos, jaw.] Paired jaws or mouth-plates of Stelleroids (zool.).

synkaryon (sǐnkăr'ǐŏn) $n$. [Gk. syn, with; karyon, a nut.] The nucleus resulting from fusion of pronuclei in the zygote.

synochreate, - see synocreate.

synocreate (sinǒ̌k'rěãt) a. [Gk. syn, with; L. ocrea, legging.] With stipules united, enclosing the stem in a sheath (bot.).

synoecious (sinē'shŭs), synoicous (sinnoik'ŭs) a. [Gk. syn, with; oikos, house.] Having antheridia and archegonia on the same receptacle, or stamens and pistils on the same flower (bot.).

synosteosis or synostosis, - anchylosis.

synotic tectum, - a cartilaginous arch between the otic capsules representing the cartilaginous roof of higher vertebrates (emb.).

synovia (sinō'viă) n. [Gk. syn, with ; L. ovum, egg.] The thick, viscid, glairy secretion of the synovial membrane (anat.).

synovial membrane,-the inner stratum of the articular capsule, a delicate connective tissue secreting a fluid for keeping joints moist (anat.).

synoviparous (sĭn'övĭp'ărŭs) $a$. [Gk. syn, with ; L. ovum, egg ; parere, to beget.] Secreting synovia (phys.).

synpelmous (sinpĕl'mŭs) a. [Gk.syn, with; pelma, sole.] Having the two tendons to the toes united before they divide up to go to the separate digits (zool.).

synsacrum (sinsā'krŭm) n. [Gk. syn, with; L. sacrum, sacred.] A mass of fused vertebrae supporting the pelvic girdle of Birds (zool.).

synsepalous (sinsěp'ălŭs) $a$. [Gk. syn, with; sepalon, a sepal.] With calyx composed of fused or united sepals (bot.).

synspermous (sǐnspĕr'mŭs) a. [Gk. syn, with; sperma, seed.] Having several seeds united (bot.).

synsporous (sinspō'rŭs) a. [Gk. syn, with; sporos, seed.] Propagating by cell conjugation, as in Algae (bot.).

syntechnic (sintěk'nì) $n$. [Gk. syn, with; techne, skill.] Resemblance in unrelated animals, due to environment.

syntenosis (sintěnō'sǐs) n. [Gk. syn, with; tenon, sinew.] Tendinous articulation.

syringeal (sirrin'jě̆ăl) a. [Gk. syring $x$, a pipe.] Pert. the syrinx (zool.).

syringium (sǐrin'jiŭm) n. [Gk. syring $x$, a pipe.] A syringe-like organ of some Insects for the ejection of a disagreeable fluid (zool.).

syrinx (surringks) $n$. [Gk. syringx, a pipe.] The vocal organ of Birds at the base of the trachea (zool.).

systemic heart,-the heart of invertebrates, and the auricle and ventricle of the left side of the heart of higher vertebrates; $o p p$. respiratory heart.

systilius (sǐstǐl'ǔus) n. [Gk. syn, with; stylos, a column.] The columella-lid of some Mosses (bot.). systole (sǐs'tölē) $n$. [Gk. systole, a drawing together.] The contraction 
of the heart causing the circulation of the blood; contraction of any contractile cavity (phys.).

systylous (šs'tîlŭs) $a$. [Gk. syn, with ; stylos, a column.] With coherent syles; with fixed columellalid (bot.).

syzygy (šz'ijĩ) $n$. [Gk. syn, with; zygon, yoke.] A close suture of two adjacent arms, found in Crinoids ; a number of individuals, two to five, adhering to one another in strings in the association of Gregarines (zool.).

\section{$\mathrm{T}$}

tabula (tăb'ûlă) n., tabulae (tăb'ūlē) plu. [L. tabula, a table.] Horizontal partitions traversing the vertical canals of Hydrocorallina and of tabulate corals (zool.).

tabulare (tăb'ūlā'rē, tăb'ūlâ'rā) $n$. [L. tabula, a table.] A bone above each otic capsule in higher vertebrates (zool.).

tachygenesis (tăk'íjĕn'ěšss) $n$. [Gk. tachys, quick; genesis, descent.] Development with omission of certain embryonic stages, as in some Crustaceans (zool.).

tactile (tăk'tǐl) a. [L. tangere, to touch.] Appl. capsular corpuscles or cones constituting special sense end-organs (anat., zool.).

tactual (tăk'tūăl) a. [L. tangere, to touch.] Pert. the sense of touch (phys.).

taenia (tê'niă) $n$. [L. taenia, a ribbon.] A Tape-worm ; $a p p l$. a band or line of nerve and muscle (anat.).

taeniate (tếniāt) a. [L. taenia, a ribbon.] Ribbon - like; striped (zool.).

taenidium (tēnǐd'̌um) n., taenidia plu. [L. taenia, a ribbon.] Spiral threads strengthening the chitinous layer of insect tracheae (zool.).

taenioid (tếnı̌oid) a. [Gk. tainia, a ribbon; eidos, form.] Ribbonshaped; like a Tape-worm (zool.).

taenioles (tē'nīōlz) n. plu. [L. taeniola, a small ribbon.] Four longitudinal, inter-radial, gastric ridges of a scyphula (zool.). tagmata (tăg'mătă) n. plu. [Gk. tagma, a corps.] Units; parts ; segments (biol.).

talocalcaneal (tăl'ökăl'kănēeăl) a. [L. talus, ankle-bone ; calcaneum, heel.] Pert. talus or astragalus and calcaneus, or ankle-bone and heel.

talon (tăl'ŏn) $n$. [L. talus, ankle.] Claw of bird of prey; the posterior heel of a molar tooth (zool.).

taloscaphoid (tăl'öskăf'oid) a. [L. talus, heel; Gk. skaphe, a boat; eidos, resemblance.] Pert. astragalus and scaphoid bone (anat.).

talus (tắlŭs) n. [L. talus, ankle.] The ankle - bone or astragalus (anat.).

tapetal (tăpē'tăl) a. [L. tapetum, a carpet.] Pert. a tapetum; $a p p l$. cells (bot.).

tapetum (tăpē'tŭm) n. [L. tapetum, a carpet.] The outer and posterior part of the choroid; the main body of fibres of the corpus callosum (anat.); a special nutritive layer investing the sporogenous tissue of a sporangium (bot.).

taproot (tăp'root) n. [M.E. tappe, a short pipe ; A.S. wyrt, a root.] An elongated parent root with secondary roots in acropetal succession (bot.).

tarsal (târ'săl) a. [Gk. tarsos, sole of the foot.] Pert. the tarsus (zool.); $a p p l$. arteries, bones, glands (anat.).

tarsale (târsā'lē, târsâlā) n., tarsalia (tărsắliă) plu. [Gk. tarsos, sole of the foot.] Ankle-bones.

tarsi (târ'sī) n. plu. [Gk. tarsos, sole of the foot.] Two thin elongated plates of dense connective tissue helping to form and support the eyelid (anat.).

tarsometatarsal (târ'sömět'ătâr'săl) a. [Gk. tarsos, sole of the foot; meta, beyond.] Pert. an articulation of tarsus with metatarsus (anat., zool.).

tarsometatarsus (târ'sömĕt'ătâr'sŭs) $n$. [Gk. tarsos, sole of the foot ; meta, beyond.] A short straight bone of a bird's leg formed by fusion of the distal row of tarsals with the second to fifth metatarsals (zool.).

tarsophalangeal (târ'söfălăn'jě̌ăl) $a$. [Gk. tarsos, sole of the foot; phal- 
angx, line of battle.] Pert. tarsus and phalanges (zool.).

tarsus (târ'sŭs) $n$. [Gk. tarsos, sole of the foot.] The ankle-bones, usually consisting of two rows (zool.); a cartilage plate of the eyelid. See tarsi (anat.).

tartareous (târtâr'èus) a. [L.L. tartarum, an acid salt.] Having a rough and crumbling surface (bot.).

taste bud, - an end-organ of taste, consisting of a flask-shaped group of modified epithelial cells found on the tongue and adjacent parts ; a gustatory calyculus (anat.).

taxis (tăk'sis) $n$. [Gk. taxis, arrangement.] A tendency of an organism towards (positive) or away from (negative) a source of stimulus (biol.).

taxonomy (tăksŏn'ömǐ) n. [Gk. taxis, arrangement; nomos, law.] The laws of classification as applied to Natural History.

tectology (těktŏl'öjĭ) n. [Gk. tekton, a carpenter; logos, discourse.] Morphology in which an organism is considered as a group of morphological as distinct from physiological units or individuals (biol.).

tectorial (těktōórĭăl) a. [L. tectus, covered.] Covering; $a p p l$. a membrane covering the spiral organ of Corti (anat.).

tectospondylic (těk'töspŏndill'ík) $a$. [L. tectus, covered; Gk. sphondylos, a vertebra.] Having vertebrae with several concentric rings of calcification, as in some Elasmobranchs (zool.).

tectrices (těk'trĭsĕz) n. plu. [L. tectus, covered.] Wing-coverts; small feathers covering the bases of the remiges and filling gaps between them (zool.).

teeth (têth) $n$. plu. [A.S. toth, a tooth.] Hard bony growths on maxillae, premaxillae, and mandibles of Mammals; growths of similar, of chitinous, or of horny formation borne on jaws or tongue (zool.).

tegmen (tĕg'mĕn) $n$. [L. tegmen, a covering.] The integument, endopleura, or inner seed-coat (bot.); the calyx cover of Crinoids; an anterior wing of Orthoptera (zool.); a thin plate of bone over the tympanic antrum (anat.).

tegmentum (těgměn'tŭm) n. [L. tegmen, a covering.] A protective bud-scale (bot.); a tract of the midbrain (anat.).

tegula (těg'ūlă) $n$. [L. tegula, a tile.] A small flap on the mesothorax overhanging the articulation of the wings in Lepidoptera; a small lobe at the wing-base of Diptera (zool.).

tegular (těg' ūlăr) a. [L. tegula, a tile.] Pert. a tegula; consisting of a tile-like structure.

tela (té'lă) $n$. [L. tela, a web.] A web-like tissue; $a p p l$. the choroid membrane (anat.).

telarian (tělā'riăn) a. [L. tela, a web.] Web-spinning.

telegony (tělëg'önǐ) n. [Gk. tele, far; gonos, offspring.] The supposed influence of a male parent on offspring subsequent to his own, of the same female parent (biol.).

teleianthous (těl'iăn'thŭs) $a$. [Gk. teleios, complete; anthos, flower.] $A p p l$. a flower having both gynoecium and androecium (bot.).

telencephalon (těl'ěnkěf'ălŏn, -sěf-) $n$. [Gk. tele, far; engkephalon, brain.] The anterior part of the fore-brain (emb.).

teleodont (těl'ěödŏnt) a. [Gk. tele, far; odous, a tooth.] Appl. forms of Stag-beetles with largest mandible development (zool.).

teleophore (těl'ěêfōr) $n$. [Gk. teleos, complete; pherein, to bear.] A gonotheca, or transparent case enclosing medusae of Hydrozoa (zool.).

teleorganic (těl'ěŏrgăn'îk) $a,[\mathrm{Gk}$. teleos, complete ; organon, instrument.] $A p p l$. functions vital to an organism (phys.).

telescopiform (tělěskō'pífôrm) $a$. [Gk. tele, far; skopein, to view; L. forma, shape.] Having joints that telescope successively into each other.

teleutogonidium (tělū'tögŏnĭd'ium), teleutospore (tělü'töspōr) n. [Gk. teleute, completion; gonos, offspring; sporos, seed.] In the Uredineae, a winter-spore formed 
in autumn, germinating in the following spring (bot.).

teleutosporiferous (tělü'töspörĭf'ĕrŭs) a. [Gk. teleute, completion ; sporos, seed ; L. ferre, to carry.] Appl. Rusts bearing teleutospores (bot.).

teliospore,-teleutogonidium.

teliosporiferous,-teleutosporiferous.

teliostage (tělı̌östāj) n. [Gk. telos, end; L. stare, to stand.] The last summer-stage of certain Fungi in which telia are produced; the teleutoform stage (bot.).

telium (tē'liŭm) n., telia (tēelliă) plu. [Gk. telos, end.] The teleutosorus, or sorus produced in the last summer stage of certain rust Fungi (bot.).

teloblast (těl'öblăst) $n$. [Gk. telos, end; blastos, bud.] A large cell which buds forth rows of smaller cells, as in annelid embryos (emb.).

telokinesis (těl'ökĭnē'sǐs) $n$. [Gk. telos, end ; kinesis, movement.] The last stage of mitosis when daughternuclei are re-formed (cyt.).

telolecithal (těl'ölěs'îthăl) $a$. [Gk. telos, end; lekithos, yolk.] Having the yolk accumulated mainly in one hemisphere (emb.).

telolemma (těl'ölěm'ă) n. [Gk. telos, end; lemma, skin.] A capsule containing a nerve-fibre termination, in neuromuscular spindles (anat.).

telophase (těllöfāz) n. [Gk. telos, end; phasis, aspect.] Telokinesis, which see.

telotrocha (těl'ötrō'kă, tělŏt'rökă) $n$. [Gk. telos, end; trochos, wheel.] Trochosphere, which see.

telson (těl'sŏn) n. [Gk. telson, extremity.] The unpaired terminal abdominal segment of Crustaceans (zool.).

telum (tēlŭm) $n$. [Gk. telos, end.] The last segment of insect abdomen.

temnospondylous (těm'nöspŏn'dĭlŭs) a. [Gk. temnein, to cut ; sphondylos, a vertebra.] With vertebrae not fused but in articulated pieces ; $c f$. stereospondylous (zool.).

temperature (těm'përătūr) $n$. [L. temperatura, proportion.] Bodyheat ; most Mammals have approximately the same temperatureas Man,
Birds a higher ; $c f$. homoiothermal and poikilothermal (phys.).

temporal (těm'pörăl) a. [L. temporalis, temporary.] Pert., or in the region of, the temples (anat.).

temporalismuscle,-abroad radiating muscle arising from the whole of the temporal fossa and extending to the coronoid process of the mandible (anat.).

temporomalar (těm'pörömā'lăr) $a$. [L. temporalis, temporary; mala, cheek.] $A p p l$. a nerve supplying temple and cheek, the zygomatic nerve (anat.).

temporomandibular articulation,the hinge of the jaws (anat.).

temporomaxillary (těm'pörömăksīl' ărĭ) a. [L. temporalis, temporary ; maxilla, jaw.] Pert. temporal and maxillary region; $a p p l$. the posterior facial vein (anat.).

tenaculum (těnăk'ūlŭm) $n$. [L. tenax, holding.] In Teleosts, a fibrous band extending from eyeball to skull (zool.).

tendinous (těn'dinŭs) $a$. [L. tendere, to stretch.] Of the nature of a tendon; having tendons.

tendo calcaneus, tendo Achillis, the tendon of the heel (anat.).

tendon (tĕn'dŏn) $n$. [L. tendere, to stretch.] A white glistening fibrous cord connecting a muscle with a movable structure (anat.).

tendon reflex, - contraction of muscles in a state of slight tension by a tap on their tendons (phys.).

tendril (tĕn'drīl) n. [O.F. tendrillon, a tender sprig.] A specialized twining stem or leaf by which creepers support themselves (bot.).

tendrillar (těn'drĭlăr) a. [O.F. tendrillon, a tender sprig.] Acting as a tendril ; twining (bot.).

tensor (tĕn'sŏr) $a$. [L. tendere, to stretch.] Appl. muscles which stretch parts of the body (anat.).

tentacles (tĕn'tăklz) n. plu. [L.L. tentaculum, a feeler.] Slender flexible organs on the head of many small animals, used for feeling, exploration, prehension, or attachment, as in Snails, Insects, Crabs (zool.).

tentacular (těntăk'ūlăr) a. [L.L. tentaculum,afeeler.] Pert.tentacles; 
$a p p l$. a canal branching from perradial canal to tentacle base in Ctenophores (zool.).

tentaculiferous (těntăk' ūlüf'ěrŭs) $a$. [L.L. tentaculum, a feeler; L. ferre, to carry.] Bearing tentacles (zool.). tentaculiform (těntăk'ülîfôrm) $a$. [L.L. tentaculum, a feeler; L. forma, shape.] Like a tentacle in shape or structure (zool.).

tentaculocyst (těntăk'ülösisst) $n$. [L.L. tentaculum, a feeler; Gk. kystis, a bladder.] A sense organ of Trachylinae, a club-shaped body on the umbrella margin, containing one or more lithites (zool.).

tentaculozooids (těntăk'ūlözōoidz) $n$. plu. [L.L. tentaculum, a feeler; Gk. zoon, animal; eidos, form.] Long slender tentacular individuals at the outskirts of a hydrozoan colony (zool.).

tentaculum (těntăk'úlŭm) $n$. [L.L. tentaculum, a feeler.] A tentacle or feeler.

tentilla (těntǐl'ă), tentillum (těntìl'üm) $n$. [L. tenta, a tent.] A tentacle branch.

tentorium (těntốríum) n. [L. tentorium, a tent.] A chitinous framework supporting the brain of Insects (zool.); an arched lamina covering the superior surface of the cerebellum and supporting the occipital lobes of the brain (anat.).

teratology (těr'ătǒl'öjī) $n$. [Gk. teras, a monster; $\log o s$, discourse.] The science treating of malformations and monstrosities, especially of Man.

tercine (tĕr'sĭn) n. [L. tertius, third.] The third coat of an ovule or a layer of the second (bot.).

terebra (těr'ěbră) n. [L. terebra, a borer.] An ovipositor which bores into wood, as in Thalessa of the Hymenoptera (zool.).

terebrate (těr'ěbrāt) a. [L. terebra, a borer.] Furnished with a boring organ (zool.).

teres (tế'rếz) $n$. [L. teres, round and smooth.] The name given to two muscles, teres major and minor, extending from scapula to humerus (anat.).

terete (těrēt'), teretial (těrế'shǐăl) $a$. [L. teres, rounded off.] Nearly cylindrical/ in transverse section, as stems (bot.).

tergal (tĕr'găl) a. [L. tergum, the back.] Situated at the back ; pert. the tergum (zool.).

tergeminate (těrjěm'ĩnāt) $a$. [L. ter, thrice; gemini, twins.] Thrice forked with twin leaflets (bot.).

tergite (těr'gìt, tĕr'jīt) $n$. [L. tergum, back.] The dorsal chitinous plate of each segment of most Arthropods (zool.).

tergum (těr'gŭm) n. [L. tergum, back.] The dorsal portion of an arthropod somite; the tergite; the back generally; a dorsal plate of Barnacles (zool.).

terminal (těr'minnăl) $a$. [L. terminus, an end.] Pert., or situated at, the end, as a terminal bud at the end of a twig (biol.).

ternary (tĕr'nărī) $a$. Ternate.

ternate (těr'nāt) a. [L. terni, three each.] Arranged in threes ; having three leaflets to a leaf (bot.).

ternatopinnate (těrnā'töpinn'āt) $a$. [L. terni, three each ; pinna, a feather.] Having three pinnate leaflets to each compound leaf (bot.).

terraneous (těrā'nêŭs) $a$. [L. terra, earth.] Appl. land vegetation (bot.).

terrestriál (těrěs'triăl) a. [L. terra, earth.] $A p p l$. animals living on the surface of the ground, as opp. aerial, aquatic.

tertial (těr'shĭăl), tertiary (těr'shǐărĭ) a. [L. tertius, third.] Appl. the wing feathers of the humerus, otherwise scapulars (zool.).

test (těst) $n$. [L. testa, a shell.] The shell or hardened outer covering of Crustaceans and other invertebrates (zool.).

testa (těs'tă) $n$. [L. testa, a shell.] A test; the hard outer covering of a seed (bot.).

testaceous (těstâ'shŭs) a. [L. testa, a shell.] Protected by a shell-like outer covering (zool.).

testicle (těs'tîkl) $n$. [L. testis, a testicle.] One of the paired male genital glands (anat., zool.).

testicular (těstǐk'ûlăr) a. [L. testis, a testicle.] Having two oblong tubercles, as in some Orchids; testicle-shaped (bot.). 
testiculate (těstǐk' ülāt) $a$. Testicular. testis (těs'tīs) n., testes ('těs'tĕz) plu. [L. testis, a testicle.] Paired male reproductive glands producing spermatozoa (anat., zool.).

testudinate (těstū'dīnāt) $a$. [L.testudo, a tortoise.] Having a hard protective shell, as in the Tortoise.

tetaniform (tět'ănifôrm) a. [Gk. tetanos, stretched; L. forma, shape.] Like tetanus; tetanoid (phys.).

tetanize (tĕt'ănīz) v. [Gk. tetanos, stretched.] To cause a muscle to contract by a series of induction shocks (phys.).

tetanus (tět'ănŭs) n. [Gk. tetanos, stretched.] State of a muscle undergoing a continuous fused series of contractions due to faradization (phys.) ; a rigid state of plant tissue caused by continued stimulus (bot.).

tetrabranchiate (tět' răbrăng'kiāt) $a$. [Gk. tetras, four; brangchia, gills.] Having four gills (zool.).

tetracarpellary (tět'răkârpěl'ărǐ) $a$. [Gk. tetras, four; karpos, fruit.] Having four carpels (bot.).

tetracerous (tět'răsē'rŭs, tĕtrăs'ěrŭs) a. [Gk. tetras, four ; keras, horn.] Four-horned (zool.).

tetrachotomous tět'răkŏt'ömŭs) $a$. [Gk. tetracha, fourfold; tome, a cutting.] Divided up into fours (biol.).

tetracoccus (tět'răkŏk'ŭs) n. [Gk. tetras, four; kokkos, a kernel.] Minute organisms found in groups of four (bact.).

tetracrepid (tět'răkrěp'îd) $a$. [Gk. tetras, four; krepis, foundation.] $A p p l$. a minute calthrops or fourrayed spicule (zool.).

tetract (tětt'răkt) n. [Gk. tetras, four ; aktis, ray.] A four-rayed spicule (zool.).

tetractine (tětrăk'tĭn) n. - [Gk. tetras, four; aktis, ray.] A spicule of four equal and similar rays meeting at equal angles; a tetraxon (zool.).

tetracyelic (tět'răsî́klỉk) a. [Gk.tetras, four; kyklos, a circle.] With four whorls (bot.).

tetrad (tět'răd) $n$, [Gk, tetras, four.] A group of four; $a p p l$. the fourcell stage in the development of Bryophytes and Pteridophytes (bot.); a quadruple group of chromatin of the germinal vesicle in maturation ; a quadrangular mass or loop of chromosomes in a stage of mitosis (cyt.).

tetradactyl (tět'rădăk'tǐl) a. [Gk. tetras, four ; daktylos, finger.] Having four digits (zool.).

tetradynamous (tět'rădĭn'ămŭs) $a$. [Gk. tetras, four ; dynamis, power.] Having four long stamens and two short (bot.).

tetragonal (tětrăg'önăl) $a$. [Gk. tetras, four; gonia, an angle.] Quaternary (bot.).

tetragynous (tĕtrăj'innŭs) $a$. [Gk. tetras, four; gyne, a female.] With four carpels to a gynoecium (bot.).

tetralophodont (tět'rălŏf'ödŏnt) $a$. [Gk. tetras, four; lophos, crest ; odous, tooth.] Appl. molar teeth with four ridges (zool.).

tetralophous (tět'rằlŏf'ŭs) a. [Gk. tetras, four; lophos, crest.] Appl. a spicule with four rays branched or crested (zool.).

tetramerous (tĕtrăm'ĕrŭs) a. [Gk. tetras, four; meros, part.] Composed of four parts ; in multiples of four (bot.).

tetrandrous (tětrăn'drŭs) $a$. [Gk. tetras, four; aner, man.] Having four stamens (bot.).

tetrapetalous (tět'răpĕt'ălŭs) $a . \quad[\mathrm{Gk}$. tetras, four; petalon, a leaf.] Having four petals (bot.).

tetrapneumonous (tět'răpnū'mönŭs) $a$. [Gk. tetras, four ; pneumon, lung.] Having four lungs, as certain Spiders (zool.).

tetrapod (tět'răpŏd) $n$. [Gk. tetras, four ; pous, foot.] A four-footed animal.

tetrapterous (tětrăp'tĕrŭs) $a$. [Gk. tetras, four; pteron, wing.] Having four wings (zool.).

tetrapyrenous (tět'răpīrē'nŭs) $a$. [Gk. tetras, four; pyren, a fruit-stone.] Having a four-stoned fruit (bot.).

tetraquetrous (tětrăk'wĕtrŭs) $a$. [Gk. tetras, four ; L. quadratus, squared.] Having four angles, as some stems (bot.).

tetrarch (tět'rârk) a. [Gk. tetras, four; archos, a ruler.] With four protoxylems in the vascular bundle (bot.). 
tetraselenodont (tět'răsĕlē'nödŏnt) $\alpha$. [Gk. tetras, four; selene, moon; odous, tooth.] Having four crescentic ridges on the molar teeth (zool.).

tetrasepalous (tět'răsěp'ălŭs) $a$. [Gk. tetras, four; Gk. sepalon, a sepal.] Having four sepals (bot.).

tetraspermous (tĕt'răspĕr'mŭs) $a$. [Gk. tetras, four; sperma, seed.] Having four seeds (bot.).

tetrasporangium (tět'răspörăn'jŭŭm) n. [Gk. tetras, four; sporos, seed; anggeion, vessel.] A sporangium producing tetraspores, as in Red Algae (bot.).

tetraspore (tět'răspōr) n. [Gk. tetras, four; sporos, seed.] One of four non-motile spores produced by the sporangium of Red Algae (bot.).

tetrastichous (tětrăs'tǐkŭs) a. [Gk. tetras, four; stichos, row.] Arranged in four rows (bot.).

tetrathecal (tět'răthē'kăl) a. [Gk. tetras, four; theke, a case.] Having four loculi (bot.).

tetraxon (tĕtrăk'sŏn) n. [Gk. tetras, four ; axon, axis.] A tetractine.

tetrazoic (tět'răzō'lik) a. [Gk. tetras, four; zoon, animal.] Having four sporozoites; $a p p l$. gregarine spores (zool.).

tetrazooid (tět'răzōoid) n. [Gk. tetras, four ; zoon, animal ; eidos, form.] The zooid developed from each of four parts constricted from the stolon process of an embryonic Ascidian (zool.).

thalamencephalon

(thăl'ămĕnkĕf'ălŏn, -sĕf-) n. [Gk. thalamos, a receptacle ; engkephalon, the brain.] The part of the brain comprising the thalamus, the corpora geniculata, and the epithalamus (anat.).

thalamus (thăl'ămŭs) $n$. [Gk. thalamos, a receptacle.] The receptacle or torus of a flower (bot.) ; part of the brain (anat.). See optic thalami. thalline (thăl'în) a. [Gk. thallos, a young shoot.] Resembling a thallus (bot.).

thalloid (thăl'oid) a. [Gk. thallos, a young shoot; eidos, form.] Like a thallus (bot.).

thallome (thăl'ōm) n. A thallus.

thallus (thăl'ŭs) $n$. [Gk. thallos, a young shoot.] A combination of cells presenting no differentiation of leaf and stem, as in Thallophytes (bot.).

thanatoid (thăn'ătoid) a. [Gk, thanatos, death; eidos, form.] Deadly; appl. poisonous snakes.

thanatology (thăn'ătǒl'öjĭ) n. [Gk. thanatos, death ; logos, discourse.] Theories of death.

theca (thē'kă) $n$. [Gk. theke, a case.] A spore or pollen case; a sporangium (bot.) ; a structure serving as a protective covering for an organ or organism, as of spinal cord, pupa, proboscis, tube-animal (zool.).

thecaphore (thē'kăfōr) n. [Gk. theke, a case ; pherein, to bear.] A structure on which a theca is borne (bot.).

thecasporous (thēkăs'pörŭs) a. [Gk. theke, a case; sporos, a seed.] Having the spores enclosed in cases or thecae (bot.).

thecate (thē'kāt) a. [Gk. theke, a case.] Covered or protected by a theca (biol.).

theciferous (thēsĭf'ĕrŭs), thesigerous (thēsij'ěrŭs) $a$. Thecate.

thecium (the'shium) n. [Gk. theke, a case.] That part of a Fungus or Lichen containing the sporules (bot.).

thecodont (thē'ködōnt) a. [Gk. theke, case; odous, tooth.] Having teeth in sockets (zool.).

thelyblast (thē'lỉblăst) $n$. [Gk. thelys, female ; blastos, a bud.] A matured female germ cell (biol.).

thelyotoky (thē'liŏt'ökí) n. [Gk. thelys, female; tokos, offspring.] Parthenogenesis in the case where females only are produced (biol.).

thelyplasm (thē'liplăzm) n. [Gk. thelys, female; plasma, something moulded.] Female plasm; $c f$. arrhenoplasm (biol.).

thenal (thë'năl) a. [Gk. thenar, palm of the hand.] Pert. or in the region of the palm of the hand (anat.).

thenar (thē'năr) n. [Gk. thenar, palm of the hand.] The muscular mass forming the ball of the thumb (anat.).

thermogenesis (thĕr'möjĕn'ěsǐs) $n$. [Gk. therme, heat; genesis, production.] Body-heat production by oxidation (phys.). 
thermolysis (thĕrmŏliršss) $n$. [Gk. therme, heat ; lysis, a loosing.] Loss of body heat (phys.).

thermoscopic (thĕr'möskŏp'ík) $a$. [Gk, therme, heat ; skopein, to view.] Adapted for recognizing changes of temperature, as special sense-organs or eyes of certain Cephalopods (zool.).

thermotaxis (thĕr'mötăk'siss) $n$. [Gk. therme, heat ; taxis, arrangement.] Reaction to stimulus of heat or cold (phys.).

thermotropism (thĕrmǒt'röpǐzm) $n$. [Gk, therme, heat ; trope, a turning.] Tendency to turn towards heat, shown by curvature in plants (bot.). thesocytes (thē'sösitts) n. plu. [Gk. thesis, a deposit; kytos, hollow.] Sponge-cells storing reserve material (zool.).

thigmotaxis (thĭg'mötăk'sǐs) $n$. [Gk. thigma, touch ; taxis, arrangement.] The tendency of minute organisms to attach themselves to objects on contact (biol.).

thigmotropism (thĭgmŏt'röpĭzm) $n$. [Gk. thigma, touch; trope, a turning.] The tendency to respond to mechanical contact by clinging and curving, as in tendrils (bot.).

thoracic (thörăs'ík) a. [Gk, thorax, the breast.] Pert. or in the region of the thorax.

thorax (thō'răks) n. [Gk. thorax, the breast.] In higher vertebrates, that part of the body between neck and abdomen containing heart, lungs, etc. ; the body region behind the head of many Arthropods and of other smaller animals (zool.).

thread cells, - in the skin of Myxinoids, cells whose long threads form a network in which the mucous secretion of the ordinary gland cells is entangled (zool.).

three-nerved leap, - a leaf with three distinct primary veins $(b o t$, ).

thremmatology (thrěm'ătŏl'öjī) $n$. [Gk. thremma, a nursling; logos, discourse.] The science of breeding animals and plants under domestic conditions (biol.).

thrombocytes (thrŏm'bösits) n. plu. [Gk. thrombos, a clot; kytos, hollow.] The elementary particles, platelets, or small discs of blood not drawn: they clump together in drawn blood (anat.).

thromboplastin (thrŏm'böplăs'tǐn) $n$. [Gk. thrombos, a clot; plastos, moulded.] A substance in drawn blood set free from granular masses of disintegrated thrombocytes (phys.).

thyloses (thīlō'sĕz) n. plu. [Gk. thylax, a sack.] Masses of parenchyma formed inside wood vessels through pressure in secondary wood (bot.).

thymus (thïmŭs) n. [Gk. thymos, thymus.] An irregular pinkish mass of glandular tissue in the lower anterior part of the neck (anat.).

thyreohyoid, thyreoid, etc., - see thyrohyoid, thyroid, etc.

thyroarytaenoid (thi'röăr'itē'noid) $n$. [Gk. thyra, a door; arytaina, a pitcher ; eidos, form.] A muscle of the larynx (anat.).

thyroepiglottic (thî'röĕp'íglŏt'îk) $a$. [Gk. thyra, door; epi, upon ; glottis, mouth of windpipe.] Appl. a ligament connecting the epiglottis stem and the angle of the thyroid cartilage (anat.).

thyroglossal (thî'röglŏs'ăl) a. [Gk. thyra, door; glossa, tongue.] Pert. thyroid and tongue; $a p p l$. an embryonic duct (emb.).

thyrohyals (thī'röhïălz) n. plu. [Gk. thyra, door; hyoeides, Y-shaped.] The greater cornua of the hyoid bone (anat.).

thyrohyoid (thī'röhīoid) a. [Gk. thyra, door; hyoeides, Y-shaped.] $A p p l$. a muscle extending from thyroid cartilage to hyoid cornu (anat.).

thyroid (thi'roid) a. [Gk, thyra, door; eidos, form.] Appl. a ductless highly-vascular gland at the front and sides of the neck; also to arteries, cartilage, and veins in its region (anat.).

thyrsoid (thër'soid) a. [Gk. thyrsus, a wand ; eidos, form.] Resembling a thyrsus in shape (bot.).

thyrsus (thër'sŭs) $n$. [Gk. thyrsus, a wand.] A mixed inflorescence with main axis racemose, later axes cymose, with cluster almost doublecone shaped (bot.). 
tibia (tǐb'iă) $n$. [L. tibia, a pipe, flute.] The inner and larger of the leg-bones between knee and ankle ; the joint of an insect leg between femur and tarsus (zool.).

tibial (tı̌b̛̆́ăl) a. [L. tibia, pipe.] Pert. or in the region of the tibia (anat., zool.).

tibiofibula (tîb'ioöfíb'ülă) $n$. [L. tibia, flute; fibula, a buckle.] The bone formed when tibia and fibula are fused, as in the Frog (zool.).

tibiofibular (tǐb'ioöfíb'ülăr) a. [L. tibia, flute; fibula, buckle.] Pert. tibia and fibula; $a p p l$. articulation, syndesmosis (anat.).

tibiotarsal (tǐb'îötâr'săl) a. [L. tibia, a flute; Gk. tarsos, sole of foot.] Pert. tibia and tarsus; pert. or in the region of the tibiotarsus (zool.). tibiotarsus (tǐb'rötâr'sŭs) $n$. [L. tibia, flute ; Gk. tarsos, sole of foot.] The tibial bone of Birds to which the proximal tarsals are fused (zool.).

Tiedemann's (tē'dĕmânz) vesicles, small rounded glandular chambered bodies at the neck of the Polian vesicles; the racemose vesicles of Asteroidea (zool.).

tigellum (tǐjěl'ŭm) $n$. [F. tige, a stem.] The central embryonic axis, consisting of radicle and plumule (bot.).

tissue (tǐs' $\left.\overline{\mathrm{u}}, \mathrm{tĭsh}^{\prime} \overline{\mathrm{u}}\right) n$. [F. tissu, woven.] The fundamental structure of which animal and plant organs are composed. See adipose, areolar, collenchyma, connective, cork, elastic, fibrous, lymphoid, mucous, muscular, nervous, parenchyma, reticular, sclerenchyma, sieve, tracheal, vascular (biol.).

tokocytes (tō'kösìts) n. plu. [Gk. tokos, production; kytos, hollow.] Reproductive cells of Sponges (zool.).

tomentose (tömĕn'tōs) a. [L. tomentum, stuffing.]. Covered closely with matted hairs, as a leaf (bot.). tomentum (töměn'tŭm) n. [L. tomentum, stuffing.] The closely matted hair on leaves or stems (bot.).

tongue (tŭng) $n$. [A.S.tunge, tongue.] An organ on the floor of the mouth, usually movable and protrusible ; any tongue-like structure, as a radula, a ligula (biol.). tonoplast (tö nöplăst) $n$. [Gk. tonos, tension; plastos, modelled.] A plastid with distinct vacuole walls (biol.).

tonsil (tŏn'sǐl) n. [L. tonsilla, a tonsil.] One of paired aggregations of lymphoid tissue near the tongue base (anat.).

tonus (tō'nŭs) $n$. [Gk. tonos, tension.] Tonicity, or condition of being slightly stretched, as of muscles (phys.).

tooth, - see teeth.

topotype (tŏp'ötīp) n. [Gk. topos, place; typos, a figure.] A specimen from the locality of the original type (biol.).

tornaria (tôrnā'riă) n. [L. tornare, to turn.] The free larval stage in the development of Balanoglossida (zool.).

tornote (tôr'nōt) a. [L. tornare, to turn.] With blunt extremities, as a spicule (zool.).

torose (tō'rōs) a. [L. torus, a swelling.] Having fleshy swellings; knobbed (bot.).

torques (tôr'kwězz) $n$. [L. torquere, to twist.] A necklace-like arrangement of fur, feathers, or the like (zool.).

torsion (tôr'shŭn) $n$. [L. torquere, to twist.] The twisting round of a gastropod body as it develops (zool.).

torticone (tôr'tǐkōn) n. [L. torquere, to twist ; conus, a cone.] A turreted, spirally-twisted shell (zool.).

torula condition, - the yeast-like isolated cells resulting from growth of blue mould conidia in saccharine solution (bot.).

torulose (tôr'ūlōs) a. [L. torus, a swelling.] Having small swellings (bot.).

torulus (tôr'ūlŭs) $n$. [L. torulus, a small swelling.] The insect antenna insertion socket (zool.).

torus (tó'rŭs) $n$. [L. torus, a swelling.] The axis bearing the floral leaves ; the thickened side of a bordered pit (bot.); a firm prominence or a marginal fold or ridge (anat.); a ridge bearing uncini in Polychaeta (zool.).

totipalmate (tō'tịpăl'māt) a. [L. totus, all: palma, palm of the hand. 
Having the feet completely webbed (zool.).

totipotent (tötĭp'ötěnt) a. [L. totus, all; potens, powerful.] Appl.blastomeres which can develop into complete embryos when cut off from the aggregate of blastomeres (emb.).

toxaspire (tǒk'săspĩr) n. [Gk. toxon, a bow; L. spira, a coil.] A spiral spicule of rather more than one revolution (zool.).

toxicology (tǒk's'škŏl'öjì) n. [Gk. toxikon, poison; logos, discourse.] The science treating of poisons in all aspects.

toxiferous (tǒkšlf'ĕrŭs) a. [Gk, toxikon, poison; L. ferre, to carry.] Holding or carrying poison.

toxin (tơk'sĭn) n. [Gk. toxikon, poison.] A poison (phys.).

toxon (tŏk'sŏn) $n$. [Gk. toxon, a bow.] A toxa or bow-shaped spicule (zool.). toxophores (tǒk'söförz) n. plu. [Gk. toxikon, poison ; pherein, to carry.] The poisoning qualities of toxin molecules ; $c f$. haptophores (phys.).

trabeculae (trăběk'ūlē) n. plu. [L. trabecula, a little beam.] Plates of sterile cells extending across the sporangium of Pteridophytes; a row of cells bridging a cavity (bot.); two curved bars of cartilage embracing the hypophysis cerebri of the embryo (emb.); small fibrous bands forming imperfect septa or frame. work of organs (anat., zool.).

trabecular (trăběk'ūlăr) a. [L. trabecula, a little beam.] Pert. or of the nature of a trabecula; having a cross-barred framework.

trabeculate, - trabecular.

trabs cerebri, - the corpus callosum.

trachea (trăkē'ă, trā'kěă) n. [L. trachia, windpipe.] The windpipe; a respiratory tubule of Insects and other Arthropods (zool.); the spiral or annular vascular tissue of plants (bot.).

tracheal (trăkēearl) a. [L. trachia, windpipe.] Pert., resembling, or having tracheae; appl. tissue.

tracheal gills,-small wing-like respiratory outgrowths from the abdomen of water larvae of Insects $(z o o l$.$) :$

tracheate,-tracheal, tracheid (tră̌k'ě̀d) n. [L. trachia, windpipe.] An individual thickened cell of a tracheal column, where end-walls persist (bot.).

tracheidal cells, - in transfusion tissue, cells resembling tracheids (bot.).

trachelate. (trăk'ělāt) a. [Gk. trachelos, neck.] Narrowed; as in neck-formation (zool.).

trachelomastoid (trăk'ělömăs'toid) $a$. [Gk. trachelos, neck; mastos, breast ; eidos, form.] Pert. tracheal region and mastoid process: appl. a muscle (anat.).

trachenchyma (trăkĕng'kĭmă) $n$. [Gk. trachelos, neck; engchyma, infusion.] Tracheal vascular tissue (bot.).

tracheobronchial (trăk'éëbrŏng'kiăl) a. [Gk. trachelos, neck; brongchos, a bronchial tube.] $A p p l$. glands (anat.); $a p p l$. a syrinx formed of the lower end of the trachea and the upper bronchi (zool.).

trachyglossate.(trắk'íglŏs'át) a. [Gk. trachys, rough; glossa, tongue. Having a rasping or toothed tongue (zool.).

tract (trăkt) $n$. [L. trahere, to draw.] A region or area or system considered as a whole, as the alimentary tract (anat.).

tractellum (trăktĕl'ŭm) n. [L. trahere, to draw.] A flagellum of the forward end of Mastigophora, with circumduction motion (zool.).

tragus (trā'gŭs) $n$. [Gk. tragos, a goat.] A small pointed eminence in front of the concha of the ear (anat.).

trama (trā'mă) n. [L. trama, the woof.] A central core of interwoven hyphae of a fungus conidiophore (bot.).

transformation (trănz'fôrmā'shŭn) $n$. [L. trans, across; formare, to form.] Change of form, as in metamorphosis (zool.) ; metabolism (phys.).

transfusion tissue, - the tissue of gymnosperm leaves, consisting of parenchymatous and tracheidal cells (bot.).

transilient (trănsǐl'̌̌̌nt) $a$. [L. transilire, to leap over.] $A p p l$. nerve fibres connecting brain conyolutions not adjacent (anat.): 
transitional (trănžsh'önăl) a. [L. transire, to go across.] $A p p l$. epithelium occurring in ureters and urinary bladder, renewing itself by mitotic division of the third and innermost layer of cells (phys.).

translocation (trănz'lökä'shŭn) $n$. [L. trans, across; locus, place.] Diffusion, as of food material (phys.).

transmedian (trănzmē'duăn) a. [L. trans, across; medius, middle.] Pert., or crossing the middle plane ; $a p p l$. muscles (anat.).

transmutation theory, - the theory that one species can evolve from another (biol.).

transpalatine (trănz'păl'ătĭn) n. [L. trans, across ; palatus, the palate.] A cranial bone of Crocodiles, connecting pterygoid with jugal and maxilla (zool.).

transpiration (trănspirā'shŭn) $n$. [L. trans, across ; spirare, to breathe.] Exhalation of vapour through pores (phys.), or stomata (bot.).

transpyloric plane,- the upper of the imaginary horizontal planes dividing the abdomen into artificial regions (anat.).

transversal (trănzvĕr'săl) a. [L. trans, across; vertere, to turn.] Lying across or between, as a transversal wall (bot.).

transverse (trănz'vĕrs) a. [L. trans, across; vertere, to turn.] Lying across or between, as artery, colon, ligament, process (anat.).

transversum (trănzvĕr'sŭm) $n$. [L. trans, across ; vertere, to turn.] In most Reptiles, a cranial bone extending from pterygoid to maxilla (zool.).

trapeziform (trăpēéž́fôrm) a. [Gk. trapezion, a small table; L. forma, shape.] Trapezium-shaped (zool.).

trapezium (trăpē'zıŭm) n. [Gk. trapezion, a small table.] The first carpal bone, at the base of the first metacarpal (zool.); the greater multangular bone; a portion of the pons Varolii (anat.).

trapezius (trăpē'žŭs) n. [Gk. trapezion, a small table.] A broad, flat, triangular muscle of the neck and shoulders (anat.).

trapezoid (trăpē'zoid, trăp'ēzoid) $a$.
[Gk. trapezion, a small table ; eidos, form.] Trapezium-shaped; $a p p l$. ligament, nucleus, ridge (anat.).

traumatropism (trômăt'röpǐzm) $n$. [Gk. trauma, a wound; trope, a turning.] Sensitiveness to wounds (bot.).

trefoil (trē'foil) $n$. [L. trifolius, threeleaved.] A flower or leaf with three lobes (bot.).

tremelloid (trĕm'ěloid) $a$. [L. tremere, to tremble.] Gelatinous in substance or appearance (bot.).

triactinal (triăk'tínăl) a. [Gk. tria, three; aktis, ray.] Three-rayed.

triadelphous (trî́ăěl'fŭs) a. [Gk. tria, three; adelphos, brother.] Having stamens united into three bundles by their filaments (bot.).

triaene (tri'ên) n. [Gk. triaina, a trident.] A somewhat tridentshaped spicule (zool.).

triandrous (trīăn'drŭs) a. [Gk. tria, three; aner, man.] Having three stamens (bot.).

triangle (trīăng'gl) n. [L. triangularis, three-sided.] A three-sided structure or area; $a p p l$. various structures (anat.).

trianthous (triăn'thŭs) a. [Gk. tria, three; anthos, flower.] Having three flowers (bot.).

triarch (trî'àrk) n. [Gk. tria, three ; arche, beginning.] Having three xylem bundles uniting to form the woody tissue plate of root (bot.).

triarticulate (trī'ârtìk'ūlāt) a. [L. tres, three ; articulus, a joint.] Threejointed (zool.).

Triassic (triăs'ík) a. [Gk. tria, three.] A geological period of the secondary or Mesozoic group; the seventh of the thirteen rock-systems (pal.).

triaster (triăs'tër) n. [Gk. tria, three; aster, star.] Three chromatin masses resulting from tripolar mitosis, as in cancer cells (cyt.).

triaxon (triăk'sŏn) n. [Gk. tria, three; axis, axle.] A sponge spicule with three axes (zool.).

tribracteate (trỉbrăk'těāt) a. [L. tres, three; bractea, a thin plate of metal.] With three bracts (bot.).

trica (tríkă) $n$. [F. tricoter, to knit.] A lichen apothecium with ridged spherical surface (bot.). 
tricarpellary (trī'kârpěl'ărǐ) a. [Gk. tria, three; karpos, fruit.] With three carpels (bot.).

triceps (trî'sĕps) n. [L. tres, three ; caput, head.] Appl. a muscle with three heads or insertions (anat.).

trichites (trik'îts) n. plu. [Gk. thrix, hair.] Fine rod-like structures found in the tongue of Didinium, an Infusorian (zool.).

trichocarpous (trǐk'ökâr'pŭs) $a_{\text {. }}$ [Gk. thrix, hair; karpos, fruit.] With hairy fruits (bot.).

trichocyst (trǐk'ösĩst) $n$. [Gk. thrix, hair; kystis, a bladder.] An oval or spindle-shaped protrusible body found in Infusorians (zool.).

trichodragmata (trīk'ödrăg'mătă) $n$. plu. [Gk. thrix, hair; dragma, a sheaf.] Straight, fine hair-like spicules in bundles (zool.).

trichogyne (trǐk'öjin) n. [Gk. thrix, hair ; gyne, woman.] An elongated hair-like receptive cell at the end of the carpogonium of Thallophytes (bot.).

trichome (trik'ōm) n. [Gk, trichoma, a growth of hair.] A hairy epidermal structure (bot.).

trichophore (trřk'öför) n. [Gk. thrix, hair ; pherein, to bear.] A group of cells bearing the trichogyne (bot.); a chaetigerous sac of Annelids (zool.).

trichotomous (trîkŏt'ömŭs) $a$. [Gk. tricha, threefold ; tome, a cutting.] Divided into three branches (bot.).

tricipital (trīsǐp'ítăl) a. [L. tres, three; caput, head.] Having three heads or insertions, as the triceps (anat.).

tricoecous (trīkŏk'ŭs) a. [Gk. tria, three; kokkos, a kernel.] Appl. a three-carpel fruit (bot.).

triconodont (trīkō'nödŏnt) a. [Gk. tria, three; konos, cone; odous, tooth.] Appl. a tooth with three crown prominences in a line parallel to the jaw axis (zool.).

tricostate (trikkŏs'tăt) a. [L. tres, three; costa, rib.] Having three ribs (bot.).

tricotyledonous (trî'kŏtĩlē'dönŭs) $a$. [Gk. tria, three; kotyledon, a cuplike hollow.] With three cotyledons (bot.).

tricrotic (trīkrŏt'ik) a. [Gk. tria, three ; krotein, to beat.] Having a triple beat in the arterial pulse (phys.).

tricrural (trīkroorăl) a. [L. tres, three; crus, leg.] With three branches.

tricuspid (trīkŭs'pĭd) a. [L. tres, three ; cuspis, a point.] Threepointed; $a p p l$. a triangular valve of the heart (anat.).

tricuspidate (trīkŭs'pìdāt) $a . \quad$ [L. tres, three ; cuspis, a point.] Appl. a three-pointed leaf (bot.).

tridactyl (trīdăk'tîl) a. [Gk. tria, three; daktylos, finger.] Having three digits (zool.).

tridentate (trīděn'tāt) $a$. [L. tres, three; dens, tooth.] Having three tooth-like divisions (bot.).

tridynamous (trīdin'ămŭs) a. [Gk. tria, three; dynamis, power.] With three long and three short stamens (bot.).

trifacial (trīfā'shǐăl) a. [L. tres, three ; facies, face.] Appl. the fifth cranial nerve, the trigeminal (anat.).

trifarious (trīfä'rüus) a. [L. trifarius, of three sorts.] In groups of three ; of three kinds; in three rows; having three surfaces (bot.).

trifid (trífíd) a. [L. tres, three ; findere, to cleave.] Cleft to form three lobes.

triflagellate (trīflăj'ělāt) a. [L. tres, three ; flagellum, a whip.] Having three flagella (zool.).

trifoliate (trīfó'liāt) a. [L. tres, three; folium, a leaf.] Having three leaves growing from the same point (bot.). trifoliolate (trīfō'lïölāt) $a$. [L. tres, three; foliola, a small leaf.] Having three leaflets growing from the same point (bot.).

trifurcate (trīfür'kāt) a. [L. tres, three; furca, a fork.] With three forks or branches.

trigamous (trig'ămŭs) a. [Gk. tria, three; gamos, marriage.] Appl. a flower-head with staminate, pistillate, and hermaphrodite flowers (bot.).

trigeminal nerve,-the largest cerebral nerve, the great sensory nerve of head and face, and motor nerve of mastication muscles (anat.).

trigon (trî'gŏn) n. [Gk. tria, three ; gonia, angle.] The triangle of 
cusps of upper jaw molar teeth (zool.).

trigonal (trĭg'önăl) $a$. [Gk. tria, three; gonia, angle.] Ternary or triangular when appl. symmetry with three parts to a whorl; appl. three-sided stems (bot.).

trigone (trígön) n. [Gk. tria, three ; gonia, angle.] Also trigonum,-a small triangular space, as the olfactory trigone, the trigonum vesicae (anat.).

trigonid (trĭg'önìd) n. [Gk. tria, three; gonia, an angle.] The triangle of cusps of lower jaw molar teeth (zool.).

trigynous (trĭjînŭs) a. [Gk. tria, three; gyne, woman.] Having three styles (bot.).

trijugate (trījoog'āt) a. [L. tres, three; jugum, a yoke.] Having three pairs of leaflets (bot.).

trilabiate (trīlā'biāt) a. [L. tres, three; labium, lip.] Having three lips (bot.).

trilobate (trīlō'bāt) a. [Gk. tria, three; lobos, a lobe.] Three-lobed. trilocular (trīlŏk'ūlăr) a. [L. tres, three; loculus, a little place.] Having three cells or loculi.

trilophodont (trīlŏf'ödŏnt) a. [Gk. tria, three ; lophos, a crest ; odous, tooth.] Having three-crested teeth (zool.).

trilophous (trīlŏf'ŭs) a. [Gk. tria, three; lophos, crest.] $A p p l$. a rayed spicule with three rays branched or ridged (zool.).

trimerous (trĭm'ěrŭs) a. [Gk. tria, three; meros, part.] Composed of multiples of three, as the parts of a flower (bot.).

trimorphism (trīmôr'fĩzm) n. [Gk. tria, three; morphe, form.] Occurrence of three distinct forms or forms of organs in one species (biol.).

trimorphous (trīmôr'fŭs) a. [Gk. tria, three; morphe, form.] With three distinct forms or forms of organs occurring in the same species (biol.). trinervate (trīnĕr'vāt) $a$. $[\mathrm{L}$. tres, three; nervus, a sinew.] Having three veins or ribs running from base to margin of leaf (bot.).

trinomial (trīnó'miăl) a. [L. tres, three; nomen, name.] Appl. names consisting of three terms; $c f$. binomial (biol.).

trioecious (trīē'shŭs) a. [Gk. tria, three; oikos, house.] Producing male, female, and hermaphrodite flowers on different plants (bot.).

triovulate (trīöv'ūlāt) a. [L. tres, three ; ovum, egg.] Having three ovules (bot.).

tripartite (trīpâr'tīt, trĭp'ărtīt) a. [L. tres, three; fartitus, separated.] Divided into three lobes, as a leaf (bot.).

tripetalous (trīpĕt'ălŭs) a. [Gk, tria, three; petalon, a leaf.] Having three petals (bot.).

tripinnate (trīpin'ât) a. [L. tres, three; pinna, feather.] Thrice pinnate; divided pinnately three times (bot.).

tripinnatifid (trîpinnăt'ífíd) $a$. [L. tres, three ; pinna, feather ; findere, to cleave.] Divided three times in a pinnatifid manner (bot.).

tripinnatisect (trīpinăt'ǐsěkt) $a$. [L. tres, three; pinna, feather ; secare, to cut.] Thrice pinnatisect ; three times lobed with divisions nearly to midrib (bot.).

triple-nerved, - $a p p l$. a leaf with three prominent veins (bot.).

triplicostate (trǐp'likŏs'tāt) a. [L. triplex, triple; costa, a rib.] Having three ribs (bot.).

triploblastic (trīp'löblăs'tǐk) a. [Gk. triplax, triple; blastos, a bud.] Having three primary germinal layers, epiblast, mesoblast, and hypoblast $(\mathrm{emb}$.).

tripod (trípoud) $n$. [Gk. tria, three ; pous, foot.] A tripod-shaped or three-legged spicule (zool.).

tripolar (tripōllăr) a. [Gk. tria, three; polos, an axis.] Appl. the division of the chromatin to three poles in diseased cells instead of the normal two poles, in mitosis (cyt.).

triquetrous (trǐkwĕt'rŭs) a. [L. triquetrus, three-cornered.] Appl. a stem with three angles and three concave faces (bot.); $a p p l$. a threecornered or wedge-shaped bone (anat.).

triquetrum (trǐkwět'rŭm) $n$. [L. triquetrus, three-cornered.] The cuneiform carpal bone (zool.); a Wormian bone (anat). 
triquinate (trīkwínăt) a. [L. tres, three; quini, five each.] Divided into three, with each lobe again divided into five (bot.).

triradial (trīrā'diăl) a. [L. tres, three; radius, a ray.] Having three branches as radii from one centre ; $a p p l$. the orbital sulcus (anat.).

trisepalous (trīsĕp'ălŭs) $a$. [Gk. tria, three; Gk. sepalon, a sepal.] Having three sepals (bot.).

triseptate (trīsěp'tāt) a. [L. tres, three ; septum, a partition.] Having three partitions or septa, as a fruit (bot.).

triserial (trīsē'riăl) a. [L. tres, three ; series, a row.] Arranged in three rows; having three whorls (bot.).

trisporous (trīspō'rŭs) a. [Gk. tria, three; sporos, seed.] Also trisporic,-having three spores (bot.).

tristachyous (trīstā'kiŭs) a. [Gk. tria, three; stachys, an ear of corn. $]$ With three spikes (bot.).

tristichous (trǐs'tǐkŭs) a. [Gk. tria, three; stichos, row.] Arranged in three rows (bot.).

triternate (trītěr'nāt) a. [L. tres, three; terni, three each.] Thrice ternately divided (bot.).

tritoblasts (trî́töblăsts) n. plu. [Gk. tritos, third ; blastos, bud.] A generation of Neosporidia produced by deutoblasts and in turn giving rise to teloblasts (zool.).

tritocerebron (trî́tösĕr'ěbrŏn) $n$. [Gk. tritos, third; kerebron, brain.] A third lobe of an insect brain indicated during development (emb.).

tritocerebrum (trî́tösĕr'ěbrŭm) $n$. [Gk. tritos, third; L. cerebrum, brain.] Part of the brain of higher Crustacea, consisting of antennal nerve centres (zool.).

tritocone (trî́tökōn) n. [Gk. tritos, third; konos, cone.] A cusp of a premolar tooth (zool,).

tritozooid (trī'tözóoid) n. [Gk. tritos, third; zoon, animal ; eidos, form.] A zooid of the third generation (zool.).

tritubercular (trītūběr'kūlăr) $a$. [L. tres, three; tuberculum, a small hump.] Appl. molar teeth with three cusps ; tricuspid.

trituberculy (trītūběr'kūlǐ) n. [L. tres, three; tuberculum, a small hump.] A theory of molar tooth development.

triungulin (trīŭng'gūlìn) $n$. [L. tres, three; ungula, a claw.] Also triungulus, - the small, six-legged larva of Strepsiptera and Cantharidae (zool.).

trivium (trìviŭm) $n$. [L, trivium, a cross-road.] The three rays of a starfish farthest from the madreporite ; $c f$. bivium (zool.).

trizoic (trīzónik) a. [Gk. tria, three ; zoon, animal.] $A p p l$. a protozoan spore containing three sporozoites (zool.).

trochal (trō'kăl) a. [Gk. trochos, wheel.] Wheel-shaped; $a p p l$. the anterior disc of Rotifers (zool.).

trochanter (trökăn'tër) n. [Gk. trochanter, a runner.] $A p p l$. processes or prominences at the upper end of the thigh-bone-a greater, lesser, and sometimes a third (anat.); the small segment of an insect leg between coxa and femur (zool.).

trochanteric fossa, - a deep depression on the medial surface of the neck of the femur (anat.).

trochantin (trökăn'tín) n. [Gk. trochanter, a runner.] A short joint which may follow the trochanter of an insect leg (zool.).

trochate (trō'kāt) a. [Gk. trochos, a wheel.] Having a wheel-like struc. ture; wheel-shaped (zool.).

trochiferous, - trochate.

trochiform,-trochate.

trochlea (trŏk'lěă) n. [Gk. trochilia, a pulley.] A pulley-like structure through which a tendon passes; $a p p l$. such a surface of humerus, femur, orbit (anat.).

trochlear (trǒk'lěăr) a. [Gk. trochilia, a pulley.] Shaped like a pulley; pert. a trochlea (anat.).

trochoid (trō'koid) a. [Gk. trochos, wheel; eidos, form.] Wheel-shaped; capable of rotating motion, as a pivot-joint (anat.).

trochophore (trök'öfōr) n. [Gk. trochos, wheel; pherein, to bear.] A trochosphere.

trochosphere (trök'ösfēr) n. [Gk. trochos, wheel; sphaira, globe.] The free-swimming pelagic larva stage of many Worms and some Molluscs (zool.). 
trochus (trō'kŭs) n. [Gk. trochos, wheel.] The inner, anterior, coarser ciliary zone of a rotifer disc ; $c f$. cingulum (zool.).

tropeic (tröpē' $\mathbf{k}$ ) a. [Gk. tropis, a keel.] Keel-shaped (zool.).

trophi (trō'fī) n. plu. [Gk. trophe, nourishment.] The hard chitinous chewing organs of Rotifers; the mouth-parts of an Insect; the mandibles and first and second maxillae collectively (zool.).

trophic (trŏf'īk) a. [Gk. trophe, nourishment.] Connected with nutrition; appl. nerves (anat.).

trophoblast (trŏf'öblăst) n. [Gk. trophe, nourishment ; blastos, bud.] The outer layer of cells of a morula (emb.).

trophochromatin (trǒf'ökrō'mătĭn) $n$. [Gk. trophe, nourishment ; chroma, colour.] Vegetative chromatin, or that which regulates metabolism and functions; $c f$. idiochromatin (biol.).

trophochromidia (trǒf'ökrömĭd'ǐă) $n$. plu. [Gk. trophe, nourishment; chroma, colour.] Vegetative chromidia ; cf. idiochromidia (biol.).

trophodisc (trŏf'ödǐsk) $n$. [Gk. trophe, nourishment; diskos, a plate.] The female gonophore of certain Hydrozoa (zool.).

trophology (trŏfŏl'öjī)n. [Gk. trophe, nourishment ; logos, discourse.] The science of nutrition (phys.).

trophonemata (trŏf'öněm'ătă) $n$. plu. [Gk. trophe, nourishment; nema, thread.] Uterine villi or hair-like projections of Elasmobranchs, which transfer nourishment to the embryo through the spiracles (zool.).

trophonucleus (trǒf ${ }^{\prime}$ önü'klěus) $n$. [Gk. trophe, nourishment; L. nucleus, a kernel.] The principal nucleus of binuclear Protozoa, regulating metabolism and growth; $c f$. kinetonucleus (cyt.).

trophophore (trŏf'öfōr) n. [Gk. trophe, nourishment; pherein, to bear.] In Sponges, an internal bud or group of cells destined to become a gemmule (zool.).

trophoplasm (trŏf'öplăzm) $n$. [Gk. trophe, nourishment ; plasma, something moulded.] The vegetative or nutritive part of a cell; $c f$. idioplasm (cyt.).

trophoplast (trŏf'öplăst) n. [Gk. trophe, nourishment; plastos, moulded.] A cell, nucleated or not; a plastid (biol.).

trophosome (trŏf'ösōm)n. [Gk. trophe, nourishment; soma, body.] The nutritive polypoid persons of a hydroid colony (zool.).

trophospongia (trŏf'öspŭn'jiă) $n$. [Gk. trophe, nourishment ; sponggia, a sponge.] A spongy vascular layer of mucous membrane between uterine wall and trophoblast (emb.).

trophospongium (trŏf'öspŏn'jı̆um) $n$. [Gk. trophe, nourishment; sponggia, sponge.] Canalization of nerve cells, the canaliculi being occupied by branching processes of neuroglia cells (phys.).

trophotaxis (trǒf'ötăk'sǐs) n. [Gk. trophe, nourishment; taxis, arrangement.] Stimulation by an agent which may serve as food (phys.).

trophotropism (trǒfŏt'röpǐzm) $n$. [Gk. trophe, nourishment; trope, a turning.] Tendency of an organism towards a food supply (biol.).

trophozoite (trŏf'özō'ît) $n$. [Gk. trophe, nourishment; zoon, animal.] The adult stage of a Sporozoan (zool.).

trophozooid (trŏf'özō'oid) $n$. [Gk. trophe, nourishment ; zoon, animal ; eidos, form.] A nutritive zooid of free-swimming tunicate colonies (zool.).

tropic movement, - reactionary movement to certain stimulation (phys.).

tropism (trō'pĩzm) n. [Gk. trope, a turning.] The tendency of an organism to react in a certain way to a certain kind of stimulus; a tendency to move towards (positive) or away from (negative) a source of stimulus (phys.) ; cf. chemo-, geo-, photo-, tropho-tropism.

tropophyte (trō'pöfit) $n$. [Gk. trope, a turning; phyton, a plant.] A changing plant, or one which is more or less hygrophilous in summer and xerophilous in winter (bot.).

true ribs,-ribs which are directly connected with the sternum, as $o p p$. floating ribs. 
truncate (trŭng'kāt) a. [L. truncare, to cut off.] Terminating abruptly, as if the tapering end were cut off (biol.).

truncus arteriosus, - the most anterior region of the amphibian heart, through which the blood is driven from the ventricle (zool.).

trunk (trŭngk') n. [L. truncare, to cut off.] The main stem of a tree (bot.); the proboscis of an elephant (zool.).

trunk legs, - pereiopods of Decapods, thoracic locomotory legs (zool.).

tryma (trîmă) $n$. [Gk. tryma, a hole.] A one-celled, one-seeded, indehiscent fruit with separable rind and two-valved endocarp with spurious dissepiments, as Walnut (bot.).

trypanomonad (trīpănömō'năd) $a$. [Gk, trypanon, an auger; monas, a unit.] $A p p l$. a phase in the development of a Trypanosome while in its invertebrate host ; crithidial (zool.).

trypanorhynchus (trīp'ănörĭng'kŭs) $n$. [Gk. trypanon, an auger; rhyngchos, snout.] A spiniferous protrusible proboscis accompanying each phyllidium in certain Cestoidea (zool.).

trypsin (trĭp'sĭn) $n$. [Gk. tryein, to rub down; pepsis, a digesting.] An enzyme of pancreatic juice; a similar enzyme of various plants and animals (phys.).

tubar (tǘbăr) a. [L, tuba, a pipe.] Consisting of an arrangement of tubes, or forming a tube, as $a p p l$. system and skeleton in Sponges (zool.).

tubate (tū'bāt) a. [L. tuba, a pipe.] Tube-shaped.

tube (tūb) n. [L. tuba, a pipe.] Any tubular structure (anat.); a cylindrical structure, as the protective enveloping case of many animals ; a mollusc siphon (zool.).

tuber (tü'bër) $n$. [L. tuber, a knob.] A thickened fleshy underground stem (bot.); a rounded protuberance (anat.).

tubercle (tü'bĕrkl) n. [L. tuberculum, a small hump.] A small rounded protuberance (anat.); a root-swelling or nodule (bot.); a tuberculum or rib-knob (zool.). tuberculate (tūbĕr'kūlāt) $a$. [L. tuberculum, a small hump.] Pert., resembling, or having tubercles.

tuberculose (tübër'kūlōs) $a$. [L. tuberculum, a small hump.] Having many tubercles.

tuberiferous (tū'bĕrĭf'ĕrŭs) $a$. [L. tuber, hump; ferre, to bear.] Bearing or producing tubers (bot.).

tuberiform (tū'bĕrifôrm) a. [L. tuber, hump; forma, shape.] Resembling or shaped like a tuber.

tuberoid,-tuberiform.

tuberosity (tū'bĕrŏs'îtĩ) n. [L. tuber, a protuberance.] A rounded eminence on a bone, usually for muscle attachment (anat.).

tuberous (tū'bĕrŭs) a. [L. tuber, a hump.] Covered with or having many tubers.

tubicolous (tūbǐk'ölŭs) a. [L. tubus, a tube ; colere, to inhabit.] Inhabiting a tube (zool.).

tubicorn (tū'bǐkôrn) a. [L. tubus, tube; cornu, horn.] With hollow horns (zool.).

tubifacient ( tù $^{\prime}$ bĭfā'shiěnt, tū'bĭfăs'iěnt) a. [L. tubus, tube; faciens, making.] Tube-making - as some Worms (zool.).

tubilingual (tū'bǐlǐng'gwăl) $a, \quad[\mathrm{~L}$. tubus, a tube; lingua, a tongue.] Having a tubular tongue, adapted for sucking (zool.).

tubiparous (tūbǐp'ărŭs) a, [L. tubus, a tube ; parere, to beget.] Appl. glands secreting tube-forming material (zool.).

tubulate (tū'būlāt) a. [L. tubulus, a small tube.] Tubiform; tubuliferous.

tubule (tū'būl) $n$. [L. tubulus, a small tube.] Any small hollow, cylindrical structure.

tubuliferous (tū'būlíf'ěrŭs) a. [L. tubulus, a small tube; ferre, to carry.] Having a tubule.

tubuliflorous (tư'būlǐflō'rŭs) a. [L. tubulus, a small tube; flos, flower.] Having florets with tubular corolla (bot.).

tubuliform (tū'būlǐfôrm) a. [L. tubulus, a small tube; forma, shape.]. Tube-shaped; appl. certain spinning glands (zool.).

tubulose (tū'būlōs) a. [L. tubulus, a small tube.] Having, or com- 
posed of, tubular structures, as an aster head (bot.), a tubipore Coral (zool.); hollow and cylindrical.

tubulus (tū'būlŭs) $n$. [L. tubulus, a small tube.] A hymeneal pore (bot.); a cylindrical ovipositor (zool.); any small tubular structures, as tubuli lactiferi, recti, seminiferi (anat.).

tunic (tū'nǐk), tunica (tū'nǐkă) n. [L. tunica, a coating.] An investing membrane or tissue, as that of kidney, ovary, testis, those of arteries (anat.).

tunicate (tū'nǐkāt) a. [L. tunica, a coating.] $A p p l$. bulbs with numerous concentric layers (bot.); enveloped in a leathery test or mantle (zool.).

tunicle (tū'nìkl) n. [L. tunica, a coating.] A natural covering; an integument.

tunnel of Corti, - a triangular tunnel enclosed by the two rows of pillars of Corti and the basilar membrane (anat.).

turbinal (tŭr'bĭnăl) a. [L. turbo, a whirl.] Spirally rolled or coiled, as bone or cartilage (anat., zool.). turbinate (tŭr'bĭnāt) a. [L. turbo, a whirl.] Top-shaped (bot.); appl. certain shells (zool.); appl. certain nasal and olfactory bones (anat.). turgescence (tŭrjěs'ěns) n. [L. turgere, to swell.] Tension or pressure in living cell tissue due to transpiration (bot.).

turgidity, - -turgescence.

turgor,-turgescence.

turio (tū'rǐō), turion (tü'riǒn) n. [L. turio, a shoot.] A young scaly shoot budded off from an underground stem (bot.).

tylhexactine (ťrl'hěksăk'tĭn) n. [Gk. tylos, knob; hex, six ; aktis, a ray.] A hexactine spicule with rays ending in knobs (zool.).

tylosis (tīlō'sis) n. [Gk. tylos, a knob.] Development of irregular cells in a cell cavity (bot.).

tylostyle (tílöstîl) $n$. [Gk. tylos, a knob; stylos, a pillar.] A spicule pointed at one end, knobbed at the other (zool.).

tylotate (tî́lötāt) a. [Gk. tylos, knob.] Having a knob at each end (sool.). tylote (tî́lōt) n. [Gk. tylos, knob.] A slender dumbbell-shaped spicule (zool.).

tylotic (tîlŏt'îk) a. [Gk. tylos, knob.] Affected by tylosis (bot.).

tylotoxea (tíl'lötŏk'sě̌ă) n. [Gk. tylos, knob ; oxys, sharp.] A tylote with one sharp end, directed towards the surface of the Sponge (zool.).

tympanic (tĭmpăn'ík) a. [Gk. tympanon, a drum.] Pert. the tympanum.

tympanohyal (tĭm'pănöhïăl) $n$. [Gk. tympanon, a drum; hyoeides, $\mathrm{Y}$ shaped.] Pert. tympanum and hyoid (anat.); part of the hyoid arch embedded in the petro-mastoid (emb.).

tympanum (tĭm'pănŭm) $n$. [Gk. tympanon, a drum.] The drum-like cavity constituting the middle ear ; the drum of the ear; the membrane of the auditory organ on tibia or abdomen of Insect; an inflatable air-sac on the neck of some Tetraoninae (anat., zool.).

type (tīp) $n$. [L. typus, an image.] The sum of the characteristics common to a large number of individuals, serving as a ground for classification ; a primary model (biol.).

typhlosole (tḯl'ösōl) n. [Gk. typhlos, blind; solen, channel.] A median dorsal longitudinal fold of the intestine projecting into the lumen of Annulates; a longitudinal ridge in rectum and intestine of Anodon (zool.).

typical (tĭp'íkăl) a. [L. typus, an image.] Appl. a specimen conforming to type or primary example; exhibiting in a marked degree the essential characteristics of genus or species (biol.).

Tyson's glands,-glands round the corona of the glans penis (anat.).

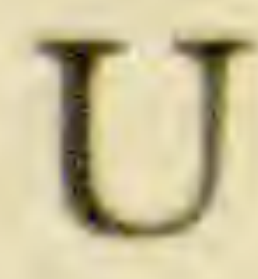

ulna (ŭl'nă) n. [L. ulna, elbow.] A long bone on the medial side of the fore-arm parallel with the radius (anat., zool.). 
ulnar (ŭl'năr) $a$. [L. ulna, elbow.] Pert. ulna; appl. artery, nerve, vein, bone (anat.).

ulnar nervure, - a radiating or cross nervure in the wing of Insects (zool.).

ulnare (ŭlnā'rē, ŭlnấrā) $n$. [L. ulna, elbow.] The bone in the proximal row of carpals lying at the distal end of the ulna (anat.).

ulnocarpal (ŭlnökâr'păl) $a$. [L. ulna, elbow; carpus, wrist.] Pert. the ulna and carpus (anat.).

ulnoradial (ŭlnörä'dǐăl) a. [L. ulna, elbow; radius, radius.] Pert. the ulna and radius (anat.).

ulotrichous (ūlŏt'rìkŭs) a. [Gk. oulos, woolly; thrix, hair.] Having woolly or curly hair.

ultimobranchial bodies, - a pair of gland rudiments derived from the fifth pharyngeal pouches, which later degenerate and leave no vestiges (emb.).

umbel (ŭm'bĕl) $n$. [L. umbella, dim. of umbra, shade.] An arrangement of flowers or of polyps springing from a common centre and forming a flat or rounded cluster (zool., bot.).

umbellate (ŭm'bělāt) $a$. [L. umbella, shade.] Arranged in umbels (bot., zool.).

umbelliferous (ŭm'bělif'ěrŭs) $a$. [L. umbella, shade ; ferre, to carry.] Producing umbels (bot.).

umbelliform (ŭmbĕl'îfôrm) a. [L. umbella, shade; forma, shape.] Shaped like an umbel (bot., zool.). umbelligerous (ŭm'bĕlij'ěrŭs) $a$. [L. umbella, shade; gerere, to carry.] Bearing flowers or polyps in umbellate clusters (bot., zool.).

umbellula (ŭmběl'ūlă) $n$. [L. umbellula, dim. of umbella, shade.]

The name given to a large cluster of polyps at the tip of an elongated stalk or rachis (zool.).

umbellulate (ŭmbĕl'ūlāt) $a$. [L. umbellula, umbel.] Arranged in umbels and umbellules (zool., bot.).

umbellule (ŭmbĕl'ūl) $n$. [L. umbellula, umbel.] A small or secondary umbel (zool., bot.).

umbilical (ŭm'bỉlí'kăl, ŭmbìl'ikăl) $a$. [L. umbilicus, navel.] Pert. the navel, or umbilical cord; $a p p l$. arteries, veins, tissues, vesicle (emb.). umbilical cord, - the navel cord connecting embryo with placenta (anat.); the prolongation by which the ovule is attached to the placenta (bot.).

umbilicate (ŭmbǐl'îkāt) a. [L. umbilicus, navel.] Having a central depression ; navel-like.

umbilicus (ŭm'bùlî'kŭs, ŭmbỉl'ikŭs) $n$. [L. umbilicus, navel.] The navel; the central abdominal depression at the place of attachment of umbilical cord (anat.); the hilum (bot.); a basal depression of certain spiral shells; either of the two openings near the base of a feather (zool.).

umbo (ŭm'bō) $n$. [L. umbo, a shieldboss.] A protuberance like the boss of a shield (bot.); the beak or older part of a bivalve shell (zool.).

umbonate (ŭm'bönāt) $a$. [L. umbo, a shield-boss.] Having a conical or rounded protuberance.

umbraculiferous (ŭmbrăk'ūlíf'ĕrŭs) $a$. [L. umbraculum, dim. of umbra, shade.] Bearing an umbrella-like organ or structure (bot.).

umbraculiform (ŭmbrăk'ūlifôrm) $a$. [L. umbraculum, umbrella ; forma, shape.] Shaped like an expanded umbrella (bot.).

umbraculum (ŭmbrăk'ūlŭm) $n$. [L. umbraculum, umbrella.] Any umbrella-like structure (bot.).

umbrella (ŭmbrěl'ă) $n$. [L. umbella, dim. of umbra, shade.] The contractile disc of a Jelly-fish (zool.).

unciferous (ŭnsif'ěrŭs) a. [L. uncus, hook; ferre, to carry.] Bearing hooks or hook-like processes (zool.). unciform (ŭn'sĭfôrm) a. [L. uncus, hook; forma, shape.] Shaped like a hook or barb (zool., bot.); appl. process of the ethmoid bone (anat.).

unciform, $n$. The unciform or hamatum of the wrist (anat.).

uncinate (ŭn'sinnāt) a. [L. uncinus, hook.] Unciform.

uncinate process,-a backwardly directed process occurring on the ribs of Birds; also a downwardly directed process of the ethmoid (anat., zool.).

uncinus (ŭn'sinŭs) $n$. [L. uncinus, hook.] Small hooked, or hooklike, structure; one of the small 
hooks found on the segments of many Worms ; a hook-like structure found in certain Infusorians; one of the marginal teeth of Gastropods (zool.).

uncus (ŭng'kŭs) n. [L. uncus, hook.] The hook-shaped anterior extremity of the hippocampal gyrus (anat.); the hooked head of the mastax of Rotifers; the hook-like process on the dorsal portion of the ninth, or copulatory, abdominal segment of male Lepidoptera (zool.).

under-wing,-one of the posterior wings of any Insect (zool.).

undose (ŭn'dōs) a. [L. undosus, billowy.] Having undulating and nearly parallel depressions which run into one another and resemble the ripple-marks on the seashore (zool.).

unequally pinnate,-odd pinnate, pinnate with single terminal leaflet (bot.).

ungual (ŭng'gwăl) a. [L. unguis, a nail.] Pert. or having a nail or claw; $a p p l$, phalanges bearing claws or nails (zool.).

unguiculate (ünggwĩk'ūlāt) a. [L. unguiculus, a nail.] Clawed; appl. petals with narrowed stalk-like portion below (bot.).

unguis (ŭng'gwiss) n. [L. unguis, claw.] A nail or claw; the narrow stalk-like portion of some petals (bot.); the lacrymal bone (anat.); one of the chitinous hooks on the foot of an Insect (zool.).

ungula (ŭng'gūlă) $n$. [L. ungula, hoof.] Hoof.

ungulate (ŭng'gūlāt) a. [L. ungula, hoof.] Hoofed.

unguligrade (ŭnggǘlígrād) $a$. [L. ungula, hoof; gradus, step.] Walking upon hoofs (zool.).

uniaxial (ü'niăk'siăl) a. [L. unus, one ; axis, axis.] With only one axis (biol.).

unibranchiate (ū'nỉbrăng'kiăt) a. [L. umus, one ; Gk. brangchia, gills.] Having one gill (zool.).

unicapsular (ữnǐkăp'sūlăr) $a$. [L. unus, one ; capsula, case.] Having only one seed-case (bot.).

unicellular (ü'nǐsěl'ūlăr) $a$. [L. unus, one; cellula, cell.]. Having only one cell, or consisting of only one cell (biol.). unicorn (ǘnǐkôrn) a. [L. unus, one ; cornu, horn.] Having a single horn-like spine ; $a p p l$. various shells, etc. (zool.).

unicostate ('̄'nǐkŏs'tāt) a. [L. unus, one ; costa, rib.] Having a single prominent mid-rib, as certain leaves (bot.).

unicotyledonous (ü'nǐkŏtǐlē'dönŭs) $a$. [L. unus, one; Gk. kotyle, leaf.] Having a single cotyledon (bot.).

unicuspid (ū'nikkŭs'pìd) a. [L. unus, one; cuspis, point of a spear.] Having one tapering point, as a tooth (zool.).

unidactyl (ü'nĭdăk'tìl) $a$, [L. unus, one; Gk. daktylos, finger.] Having one digit only (zool.).

uniembryonate (u'niěm'briŏnāt) $a$. [L. unus, one; Gk. embryon, a foetus.] Having one embryo only (bot.).

unifacial (ü'nĭfā'shăl) a. [L. unus, one ; facies, the face.] Having one face or chief surface (zool.).

uniflagellate (ū'nĭflăj'èlāt) $a . \quad[\mathrm{L}$. unus, one; flagellum, whip.] Having only one flagellum (zool.).

uniflorous (ü'nĭfló'rŭs) a. [L. unus, one; flos, flower.] Bearing only one flower (bot.).

unifoliate (u'nífō'liāt) $a$. [L. unus, one ; folium, leaf.] With only one leaf (bot.).

unifoliolate (u'nífō'liölāt) a. [L. unus, one ; foliolum, dim. of folium, leaf.] Having one leaflet only (bot.)

unijugate (ünǐjoog'āt) a. [L. unus, one ; jugum, yoke.] Appl. pinnate leaf having one pair of leaflets (bot.).

unilabiate (ū'nīlā'biāt) a. [L. unus, one ; labium, lip.] With one lip only (bot., zool.).

unilaminate (ū'nīlăm'ĩnāt) $a . \quad[\mathrm{L}$. unus, one; lamina, layer.] Having one layer only; appl. tissues (bot., zool.).

unilateral (ứnílăt'ërăl) $a$. [L. unus, one; latus, side.] Arranged on one side only (bot., zool.).

unilocular (ū'nìlŏk'uulăr) a. [L. unus, one ; loculus, dim. of locus, place. One-celled; having one division only; appl. ovaries (bot.).

unimucronate (u'nimmü'krönāt) $a$. [L. unus, one ; mucro, sharp point.] 
Having a single sharp point or tip ; $a p p l$. leaves, etc. (bot.).

uninucleate (ǘninnū'klêât) $a$. [L. unus, one; nucleus, nucleus.] Having one nucleus (biol.).

uniparous (ūnìp'ărŭs) $a$, [L. unus, one; parere, to beget.] Producing one at a birth (zool.); having a cymose inflorescence with one axis at each branching (bot.).

unipetalous (ü'nīpět'ălŭs) a. [L. unus, one; Gk. petalon, leaf.] Having one petal (bot.).

unipolar (ü'nǐpō'lăr) a. [L. unus, one ; polus, pole.] Having one pole only; appl. some nerve-cells (anat.).

uniseptate (ü'nǐsěp'tāt) a. [L. unus, one; septum, a hedge.] Having one septum or dividing partition (biol.).

uniserial (ü'nissēriăl) a. [L. unus, one; series, rank.] Appl. fins with radials on one side of the basalia (zool.).

uniserrate (u'nnısěr'āt) a. [L. unus, one ; serra, saw.] Having only one row of serrations on the edge (bot.). uniserrulate (ü'ñsěr' ülāt) $a$. [L. unus, one; serrula, dim. of serra, saw.] Having one row of small serrations on the edge (bot.).

unisetose (ü'nǐsếtōs) a. [L. unus, one; seta, bristle.] Bearing one bristle (zool.).

unisexual (ü'nǐsěk'sūăl) a. [L. unus, one; sexus, sex.] Of one or other sex; distinctly male or female (biol.).

unispiral (ü'nǐspī'răl) $a, \quad$ [L. unus, one; spira, coil.] Having one spiral only (bot.).

units of Spencer,- - the physiological units which determined the form of each living creature. These units were regarded as intermediate between chemical molecules and cells, and consequently must correspond to groups of molecules. They are quite useless as an interpretation of heredity, but have this advantage that they forced a more and more searching analysis into the "bearers" of heredity.

univalve (ứnǐvălv') $n$. [L. unus, one; valvae, folding doors.] A shell consisting of one piece or valve, as a gastropod shell (zool.). unpaired (ŭn'pārd) a. [L. un, not ; par, equal.] Situated in the median line of the body, and consequently single (zool.).

unpaired fins, - the median dorsal and ventral fins (zool.).

urachus (ü'răkŭs) n. [Gk. ouron, urine; echein, to hold.] The median umbilical ligament (emb.); the fibrous cord extending from bladder to umbilicus (anat.).

urceolate (ŭr'sēölāt) a. [L. urceolus, small pitcher.] Pitcher-shaped; $a p p l$. calyx or corolla (bot.); shells of various Protozoa (zool.).

urceolus (ŭr'sēölŭs) $n$. [L. urceolus, small pitcher.] The external tube of certain Rotifers (zool.); any urnshaped structure (bot.).

urea (ūrēéă) n. [Gk, ouron, urine.] A nitrogenous excretory substance, the chief constituent of urine (phys.).

uredinium (ü'rēdìn'iŭum) $n$. [L. uredo, blight.] In Rusts, the myceliumbearing uredospores (bot.).

uredo (ürē'dō) n. [L. uredo, blight.] The summer stage of many rust Fungi (bot.).

uredospores (ūré'döspōrz) n.plu. [L. uredo, blight ; Gk. sporos, seed.] Reddish summer spores borne on each sporophore of Rusts, which fall and spread the disease (bot.).

ureter (ūrē'tër) n. [Gk. oureter, ureter.] The duct conveying urine from kidney to bladder or cloaca (anat.).

urethra (ūrē'thră) $n$. [Gk. ourethra, from ouron, urine.] The duct leading off the urine from the bladder, and in the male conveying the semen in addition (anat.).

urinary (ứrinnărĭ) a. [Gk. ouron, urine.] Pert. urine; appl. bladder, organ, papillae, kidney tubules, etc. (anat.).

urine (ứrin) n. [Gk. ouron, urine.] A fluid excretion from the kidneys in Mammals, a solid or semisolid excretion in Birds and Reptiles (phys.).

uriniparous (ü'rinnǐp’ărŭs) a. [Gk. ouron, urine; parere, to beget.] Urine-producing; $a p p l$. to the kidney tubules in the cortical portion of the kidney (anat.). 
urinogenital (u'rrinöjën'ítăl) $a$. [Gk. ouron, urine ; gignesthai, to produce.] Connected with urinary and genital systems (anat.).

urinogenital ridge, - one of a pair of ridges from which the urinary and genital systems are developed (emb.).

urinogenital sinus,-a bladder or pouch in connection with the urinary and genital systems in many animals (zool.).

urite ('̄'rīt) n. [Gk. oura, tail.] An abdominal segment in Arthropods (zool.).

urn (ŭrn) $n$. [L. urna, a pitcher.] The theca of Mosses (bot.).

urns (ŭrnz) n. plu. [L. urna, a pitcher.] Ciliate bodies floating in coelomic fluid of Annulates (zool.).

urobilin (ứröbī'lín) n. [Gk. ouron, urine ; L. bilis, bile.] A yellow pigment in urine (phys.).

urocardiac ossicle, - a short stout bar forming part of the gastric mill in Crayfish (zool.).

urochord (u'rökôrd) $n$. [Gk. oura, tail ; chorde, cord.] The notochord when confined to the caudal region, as in certain Tunicates (zool.).

urochrome (ū'rökrōm) n. [Gk. ouron, urine; chroma, colour.] A yellowish pigment to which the ordinary colour of urine is due (phys.).

urocoel (ü'rösēl) n. [Gk. ouron, urine ; koilos, hollow.] An excretory organ in the Mollusca, of doubtful morphological nature (zool.).

urocyst (ü'rösǐst) n. [Gk. ouron, urine; kystis, hollow.] The urinary bladder (zool.).

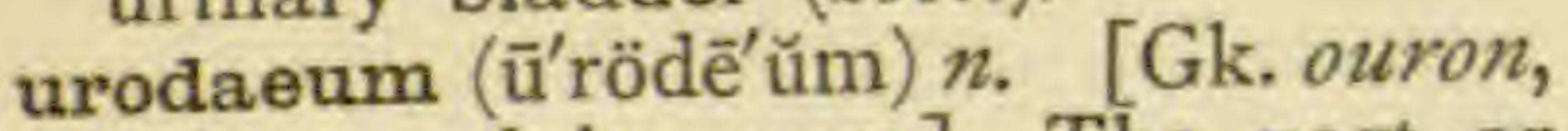
urine; odaios, way.] The part or chamber of the cloaca into which the ureters and genital ducts open (zool.).

urodelous ( $\bar{u}^{\prime}$ rödē'lus) a. [Gk. oura, tail ; delos, visible.] With persistent tails ; appl. a certain division of the Amphibians (zool.).

urogastric (ü'rögăs'trǐk) a. [Gk. oura, tail ; gaster, stomach.] The tail or posterior portion of the gastric region in certain Crustaceans (zool.). urogenital (ư'röjĕn'ítăl), -see urinogenital.

urohyal (ü'röhīăl) n. [Gk. oura, tail ; hyoeides, $\mathrm{Y}$-shaped.] A median bony element in the hyoid arch below the hypohyals (zool.).

uromere (u'́römēr) n. [Gk. oura, tail ; meros, part.] An abdominal segment in Arthropods (zool.).

uroneme (ü'rönēm) $n$. [Gk. oura, tail; nema, thread.] One of taillike structures seen in some ciliate Protozoa (zool.).

uropatagium (ü'röpătā'jüŭm) n. [Gk. oura, tail ; L. patagium, border.] The membrane stretching from one femur to the other in Bats; one of the plates at the side of the anus in Insects (zool.).

uropod (u'́röpǒd) $n$. [Gk. oura, tail ; pous, foot.] Any of the abdominal appendages in the Grayfish and similar Crustaceans (zool.).

uropygial (ü'röpüj'iăl) a. [Gk. orros, end of os sacrum; pyge, rump.] Pert. the uropygium; appl. oil gland (zool.).

uropygium (ư'röpij'îum) n. [Gk. orros, end of os sacrum; pyge, rump.] The hump at the end of a bird's trunk, containing the caudal vertebrae, and supporting the tail feathers (zool.).

uropyloric (ü'röpīlǒr'îk) a. [Gk. oura, tail; pyle, gate.] Pert. posterior portion of crustacean stomach (zool.).

urorectal (ü'rörěk'tăl) a. [Gk. ouron, urine ; rectus, straight.] $A p p l$. embryonic septum, which ultimately divides the intestine into anal and urogenital parts (emb.).

urorubin (ü'röroob'ĩn) $n$. [Gk. ouron, urine; L. ruber, red.] The red pigment of urine (phys.).

urosacral (ü'rösā'krăl) a. [Gk, oura, tail ; sacrum, sacred.] Pert. caudal and sacral regions of the vertehral column (zool.).

urosome (ü'rösōm) n. [Gk. oura, tail ; soma, body.] Tail region of Fish; the abdomen of an Arthropod (zool.).

urostege (ü'röstēj) n. [Gk. oura, tail; stege, roof.] A ventral tailplate of a Serpent (zool.); also urostegite. 
urosteon (ūrŏs'tě̌ŏn) n. [Gk. oura, tail ; osteon, bone.] A median ossification on the back portion of the keel-bearing part of the sternum in Birds (zool.).

urosternite (ü'röstĕr'nīt) n. [Gk. oura, tail ; sternon, breast.] A ventral plate of an arthropodan abdominal segment (zool.).

urosthenic ( $\bar{u}^{\prime}$ rösthĕn'îk) a. [Gk. oura, tail; sthenos, strength.] Having the tail strongly developed for propulsion (zool.).

urostyle (ü'röstīl) n. [Gk. oura, tail ; stylos, pillar.] An unsegmented bone, the posterior part of the vertebral column of anurous Amphibians; the hypural bone in Fishes (zool.).

Urthiere (oor'tērë) n. plu. [Ger. Urthiere, protozoa.] A name given by Oken to the Infusoria (biol.).

urticant (ŭr'tīkănt) $a$. [L. urtica, nettle.] $A p p l$. thread-cells with power of stinging.

use inheritance, - the transmission of acquired characteristics (biol.).

uterine (u'těriñn) a. [L. uterus, womb.] Pert. uterus; $a p p l$. artery, vein, plexus of Mammals (anat., zool.).

uterine bell, - a muscular bell-like structure in the female of certain thread-worms, communicating with coelom and uterus (zool.).

uteroabdominal (u'těröăbdŏmñnăl) $a$. [L. uterus, womb; abdomen, stomach.] Pert. uterus and abdominal region (anat.).

uterosacral (ü'tĕrösā'krăl) a. [L. uterus, womb; sacrum, sacred.] $A p p l$. two ligaments of the sacrogenital folds attached to the sacrum (anat.).

uterovaginal (ü'těrövăj'inăl) a. [L. uterus, womb; vagina, vagina. Pert. uterus and vagina (anat.).

uterovesical (u'těrövĕsíkăl) $a$. [L. uterus, womb; vesicula, vesicle.] Pert. uterus and bladder (anat.).

uterus (ü'tĕrŭs) $n$. [L. uterus, womb.] The organ in female Mammals in which the embryo develops and is nourished before birth; any enlarged portion of the oviduct modified to serve as a place for development of young or of eggs in lower vertebrates (anat.). uterus masculinus, - a large median sac attached to the dorsal surface of the urino-genital canal of the male (zool.); the utriculus prostaticus (anat.).

utricle ( $\overline{\mathrm{u}}^{\prime}$ trìkl) $n$. [L. utriculus; a small bag or bottle.] An air-bladder; a membranous indehiscent onecelled fruit (bot.); a membranous sac of the ear-labyrinth ; the uterus masculinus (zool.).

utricular (ūtrik'ūlăr) $a$. [L. utriculus, small bag.] Containing vessels like small bags ; $a p p l$. modification of laticiferous tissue (bot.).

utriculus (ūtrǐk'ūlŭs) $n$. [L. utriculus, small bag.] The utricle of the ear (anat.); the air-bladder of aquatic plants (bot.).

uva (ü'vă) n. [L. uva, grape.] A pulpy indehiscent fruit with central placenta, like the grape (bot.).

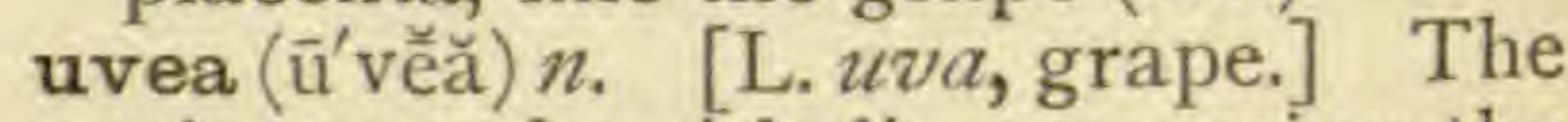
pigmented epithelium covering the posterior surface of the iris (anat.).

uvula (ü'vūlă) $n$. [L. $u v a$, grape.] A lobe of the cerebellum; a conical pendulous process from the soft palate (anat.).

\section{V}

vacuolar (văkūölăr) a. [L. vacuus, empty.] Pert. or like a vacuole.

vacuolated (văk'ūölā'těd) $a$. [L.vacu$u s$, empty.] Containing vacuoles.

vacuole (văk'ūōl) $n$. [L. vacuus, empty.] One of the spaces found in cell protoplasm containing air, sap, or partially digested food material (cyt.).

vagal (vā'găl) a. [L. vagus, wandering.] Pert. the vagus (anat.).

vagina (văjī'nă) $n$. [L. vagina, a sheath.] A sheath or sheath-like tube; a canal leading from the uterus to the external opening of the genital canal (anat.); the expanded sheath-like portion of a leaf base (bot.).

vaginal (văjî'năl, văj'inăl) a. [L. vagina, sheath.] Pert. or supplying the vagina; $a p p l$. arteries, nerves, etc. (anat.). 
vaginal process, - a projecting lamina on the inferior surface of the petrous portion of the temporal; either of a pair of laminae on the sphenoid (anat.).

vaginate (văj'innāt) a. [L. vagina, sheath.] Invested as with a sheath (anat.).

vaginervose (văj'innër'vōs) a. [L. vagus, wandering ; nervus, sinew.] With irregularly-arranged veins (bot.).

vaginicolous (văj'innı̌k'ölŭs) $a$. [L. vagina, sheath ; colere, to inhabit.] $A p p l$. certain Infusorians which build and inhabit sheaths or cases (zool.).

vaginiferous (văj'innif'ĕrŭs) a. [L. vagina, sheath; ferre, to carry.] Vaginate.

vaginipennate (văj'innipěn'āt). $a$. [L. vagina, sheath; penna, feather.] Having wings protected by a sheath (zool.).

vaginula (văjĭn'ūlă) n. [L. vaginula, dim. of vagina, sheath.] A small sheath (zool.) ; a sheath surrounding the basal portion of the sporophyte in Mosses (bot.).

vagus (vā'gŭs) $n$. [L. vagus, wandering.] The pneumogastric or tenth cranial nerve (anat.).

vallecula (vălěk'ülă) $n$. [L. vallis, valley.] A depression (anat.); a groove or depression (bot.).

vallecular (vălěk'ūlăr) $a$. [L. vallis, valley.] Pert. groove or depression.

vallecular canal,- - one of the canals in the cortical tissue of the stem of the Horse-tails (bot.).

valleculate (vălěk'ūūāt) a. [L. vallis, valley.] Grooved.

valval (văl'văl) a. [L. valva, leaf, fold.] Appl. view of a Diatom when one whole valve is next the observer (bot.).

valvar (văl'văr), - see valval.

valvate (văl'vāt) a. [L. valva, fold.] Hinged at the margin only ; meeting at the edges; opening by socalled valves (bot.); furnished with valves (zool.).

vaive (vălv) $n$. [L. valva, fold.] Any of the various structures which permit flow in one direction, but are capable of closing the tube or vessel and preventing the backward flow (anat.); any of the pieces formed by a capsule on dehiscence ; the lid-like structure of certain anthers; one of the pieces forming the shell of a Diatom (bot.); any of the pieces which form the shell in certain Molluscs, Barnacles, etc.; one of the pieces forming the sheath of the ovipositor in certain Insects (zool.).

valve of vieussens (vyü'sŏng), - a thin layer of white matter extending between the superior peduncles of the cerebellum (anat.).

valvelet (vălv'lĕt) $n$. [L. valva, fold.] A valvula.

valvula (văl'vūlă) n. [L. valvula, dim. of valva, fold.] A small fold or valve (anat.).

valvulae conniventes, - folds of membrane found in the alimentary canal from duodenum to ileum, affording an increased area for secretion and absorption (anat.).

vane (vān) $n$. [A.S. fana, a small flag.] The vexillum or web of a feather, consisting of barbs, etc. (zool.).

variant (vä'riănt) n. [L. varians, changing.] An individual or species deviating in some character or characters from the type (biol.).

variation (vä'riāshŭn) n. [L. variare, to change.] Divergence from type in certain characteristics (biol. .).

varicellate (văr'ísěl'āt) $a$. [L. varix, ridge.] $A p p l$. shells with small or indistinct ridges (zool.).

variole (vä'riol) n. [L. varius, various.] A small pit-like marking found on various parts in Insects (zool.).

varix (vä'rǐks) n., varices (văr'isěz) plu. [L. varix, dilatation.] One of the prominent ridges across the whorls of various univalve shells showing the previous position of the outer lip (zool.).

vas (văs) n., vasa (vằză) plu. [L. vas, vessel.] A small vessel, duct, blind tube, or canal (anat.).

vasa deferentia, - the ducts leading from the testes to the penis (anat.), or to the exterior, the urogenital canal, or cloaca (sool.). 
vasa efferentia, - the tubes which lead from the testis to the vas deferens (anat.).

vasal (vā'săl) a. [L. vas, vessel.] Pert. or connected with a vessel.

vascular (văs'kūlăr) a. [L. vasculum, small vessel.] Pert., consisting of, or containing vessels adapted for the transmission or circulation of fluid (anat).

vascular areas, - several scattered areas developed between endoderm and mesoderm of yolk-sac, the beginnings of primitive bloodvessels (emb.).

vascular bundle, - a group of special cells consisting of two parts, the xylem or wood portion and the phloem or bast portion; many of the vascular bundles have in addition a thin strip of cambium separating the two parts (bot.).

vascular tissue, - specially modified plant-cells, usually consisting of either tracheal or sieve cells, for the circulation of sap (bot.).

vasculum (văs'külŭm) $n$. [L. vasculum, small vessel.] A pitchershaped leaf or ascidium (bot.).

vasifactive (văs'îfăk'tǐv) $a$. [L. vas, vessel ; facere, to make.] Producing new blood-vessels (emb.).

vasiform (văs'îfôrm) a. [L. vas, vessel; forma, shape.] Functioning as or resembling a duct; vascular (biol.).

vasoconstrictor (văs'ökŏnstrǐk'tŏr) $a$. [L. vas, vessel ; constringere, to draw tight.] Causing constriction (phys.).

vasodentine (văs'ödĕn'tĭn) n. [L. vas, vessel; dens, tooth.] A variety of dentine permeated by bloodvessels (anat.).

vasodilator (văs'ödîlā'tŏr) a. [L. vas, vessel ; dilatus, separated.] Relaxing or enlarging the vessels (phys.).

vasoformative (văs'öfôr'mătǐv), - see vasifactive.

vasohypertonic (văs'öhïpĕrtŏnīk), see vàsoconstrictor.

vasohypotonic (văs'öhīpötŏnǐk), - see vasodilator.

vasoinhibitory (văs'öĭnhỉb'îtŏrĩ), - - see vasodilator.

vasomotion (văs'ömō'shŭn) $n$. [L. vas, vessel; movere, to move.]
Any change in the calibre of a blood-vessel (phys.).

vasomotor (văs'ömō'tŏr) a. [L. vas, vessel ; movere, to move.] $A p p l$. nerves supplying the muscles in the wall of blood-vessels and regulating the calibre of the bloodvessels, through containing both vasoconstrictor and vasodilator fibres ( $p$ hys.).

vastus (văs'tŭs) n. [L. vastus, immense.] Name given to various divisions or parts of the quadriceps muscle of the thigh (anat.).

vegetal pole, - that side of a blastula at which the megameres collect ; $o p p$. animal pole (emb.).

vegetation (věj'ětā'shŭn) $n$. [L. vegetare, to enliven.] Plants considered collectively.

vegetative (věj'ětā'tìv) a. [L. vegetare, to enliven.] Appl. to stage of pure growth in plants as opp. reproductive; $a p p l$. foliage shoots as $o p p$. flower or reproductive shoots (bot.).

vegetative cone,-the apical point (bot.).

vegetative pole,-see vegetal pole (emb.).

vegetative reproduction, - among animals, a kind of asexual reproduction which consists in the formation of buds (zool.).

veil (vāl) $n$. [L. velum, a sail.] The velum; the calyptra (bot.); the velum (zool.).

veins (vānz) n. plu. [L. vena, vein.] The branched vessels which convey blood to the heart (anat.); the ribs or nervures of an insect wing (zool.); the branching ribs or nerves of a leaf (bot.).

velamen (vělä'mĕn) $n$. [L. velum, a sail.] A membrane (anat.); a sheath of tracheides at the apex of the aerial roots of Orchids (bot.).

velar (vë'lăr) a. [L. velum, a sail.] Pert. situated near, or belonging to the velum.

velarium (vělā'riŭm) $n$. [L. velum, covering.] The velum of certain of the Cubomedusae, which differs from a true velum in containing endodermic canals (zool.).

velate (vé'lāt) a. [L. velum, covering.] Veiled; covered by a velum. 
veliger (věl'ijĕr) $n$. [L. velum, velum; gerere, to carry.] The second stage in the larval life of certain Molluscs when the head bears the velum (zool.).

vellus (věl'ŭs) $n$. [L. vellus, fleece.] The stipe of a Fungus (bot.).

velum (vē'lŭm) $n$. [L. velum, covering.] Any membrane or structure likened to a veil (anat.) ; in Hydromedusae and certain Jelly-fish the annular membrane projecting inwards from the margin of the bell ; a membrane in connection with the buccal cavity in the Lancelet ; a membrane-like structure bordering the oral cavity of certain Ciliates; the larval swimming organ of the veliger larva (zool.); a mass of tissue stretching from the stipe to the pileus in certain Thallophytes (bot.).

velutinous (vělū'tĭnŭs) $a$. [It. velluto, velvet.] Covered with very fine, dense, short upright hairs (zool.).

velvet (věl'vĕt) n. [M.E. veluet, velvet.] The soft and vascular skin which covers the antlers of Deer during growth, but is later rubbed off by the animal (zool.).

vena (vê'nă) n., venae (vếnē) plu. [L. vena, vein.] Any of the vessels by which the blood is carried from the body to the heart (anat.).

venation (věnā'shŭn) $n$. [L. vena, vein.] Nervation; the system or disposition of veins or nervures (bot., zool.).

venin (věn'ĩn) $n$. [L. venenum, poison.] Any of the toxic substances in snake poison (phys.).

venomosalivary (věn'ömösăl'ivărĭ) $a$. [L. venenum, poison; salivare, to salivate.] Pert. or designating salivary glands of which the secretion is poisonous (zool.).

venomous (věn'ömŭs) a. [L. venenum, poison.] Having poisonglands; able to inflict a poisonous wound (zool.).

venose (vê'nös) a. [L. vena, vein.] With many and prominent veins (bot.).

venous (vè'nŭs) a. [L. vena, vein.] Pert. vein ; applied to blood returning to the heart after circulation in the body (phys.). vent (věnt) $n$. [L. findere, to cleave.] The anus; the cloacal or anal aperture in the lower vertebrates (zool.).

vent feather, - an under tail covert feather (zool.).

venter (věn'tër) $n$. [L. venter, belly.] The abdomen ; lower abdominal surface; a protuberance, as of a muscle; a smooth concave surface (anat.); the swollen basal portion of an archegonium (bot.).

ventral (vĕn'trăl) a. [L. venter, belly.] Pert. or situated on the lower or abdominal surface (zool.); pert. or designating that surface of a petal, etc., that faces the centre or axis of the flower; $a p p l$. lower surface of flattened ribbon-like thalli (bot.).

ventricle (vĕn'trǐkl) $n$. [L. ventriculus, dim. of venter, belly.] A cavity or chamber, as in heart or brain; $a p p l$. fusiform fossa of larynx (anat.); the gizzard of Birds; the mid-gut or chylific ventricle of Insects (zool.).

ventricose (věn'trǐkōs) a. [L. venter, belly.] Swelling out in the middle, or unequally ; appl. shells (zool.).

ventricular (věntrik'ūlăr) $a$. [L. ventriculus, belly.] Pert. a ventricle; $a p p l$. ligaments and folds of the larynx; $a p p l$. septum or valves in heart (anat.).

ventriculus (věntrìk'ūlŭs), - see ventricle.

ventrodorsal (věn'trödôr'săl) a. [L. venter, belly; dorsum, back.] Extending from ventral to dorsal surface (zool.).

ventrolateral (věn'trölăt'ërăl) $a$. [L. venter, belly; latus, side.] At the side of the ventral region; $a p p l$. different structures in various groups (zool.).

venule (věn'ūl) $n$. [L. venula, dim. of vena, vein.] A small vein of an insect's wing (zool.).

vermian (věrimiăn) a. [L. vermis, worm.] Worm-like.

vermicular (vĕrmǐk'ūlăr) $a$. [L. vermis, worm.] Resembling a worm in appearance or movement (zool.).

vermiculate (věrmik'úuāt) a. [L, vermis, worm.] Marked with 
numerous fine lines or bands of colour (zool.) ; marked by numerous irregular depressed lines (bot.).

vermiform (věr'mifôrm) a. [L. vernis, worm; forma, shape.] Shaped like a worm ; $a p p l$. numerous structures, but especially to the appendix.

vermis (vĕr'mis) $n$. [L. vermis, worm.] The annulated median portion of the cerebellum (anat.); the central portion of the cerebellum in Birds and Reptiles (zool.).

vernation (věrnā'shŭn) $n$. [L. vernation, sloughing.] The arrangement of leaves within'a bud (bot.).

verruca (věrook'ă) n. [L. vernuca, wart.] Any wart-like projection; one of the small wart-like projections surrounding the base of the polyps in many of the Alcyonaria (zool.).

verruciform (vĕroos'îfôrm) a. [L. vernuca, wart ; forma, shape.] Wart-shaped.

verrucose (vĕrook'ōs) a. [L. verruca, wart.] Covered with wart-like projections (zool., bot.).

versatile (věr'sătǐl) a. [L. versare, to turn around.] Swinging freely; $a p p l$. anthers (bot.); capable of turning backwards and forwards; $a p p l$. bird's toe (zool.).

versicoloured (věr'sǐkŭlërd) $a$. [L. versare, to change; color, colour.] Variegated in colour (bot.); capable of changing colour (zool.).

vertebra (věr'těbră) $n$. [L. vertebra, joint.] Any of the bony or cartilaginous segments that make up the backbone (anat., zool.) ; one of the ossicles in an ophiuroid arm (zool.).

vertebra prominens (prŏm'inněnz),the seventh cervical vertebra (anat.).

vertebral (vĕr'těbrăl) a. [L. vertebra, joint.] Pert. spinal column (anat.); $a p p l$. various structures situated near or connected with the spinal column, or with any structure likened to the spinal column (zool.).

vertebrarterial canal,-term applied to the canal formed by the foramina in the transverse processes of the cervical vertebrae or between cervical rib and vertebra (zool.).

vertebrate (věr'těbrāt) a. [L. vertebra, joint.] Having a backbone or spinal column (zool.).

vertebration (věr'těbrā'shŭn) $n$. [L. vertebra, joint.] Dividing up into segments or divisions resembling vertebrae (emb.).

vertex (vĕr'těks) $n$. [L. vertex, top.] The top of the head; the highest point of the skull (anat.).

vertical (vĕr'tǐkăl) $a$. [L. vertex, top.] Standing upright; lengthwise, in direction of axis (bot.) ; pert. vertex of head (zool.).

vertical margin,- the limit between the frons and the occiput in Diptera (zool.).

verticil (vĕr'tǐsill) $n$. [L. verticillus, dim. of vertex, whirl.] An arrangement of flowers, structures or inflorescences about the same point on the axis (bot.).

verticillaster (věr'tǐsǐlăs'tër) $n$. [L. verticillus, small whorl ; aster, star.] A much condensed cyme with the appearance of a whorl, but in reality arising in the axils of opposite leaves (bot.).

verticillate (věrtǐs'îlāt) $a$. [L. verticillus, small whorl.] $A p p l$. antennae the joints of which are surrounded, at equal distances, with stiff hairs $(z \circ o l$.$) ; disposed in verticils (bot.).$

verumontanum (věr'oomŏntā'nŭm) $n$. [L. veru, spit ; montanum, mountainous.] A small elevation on the floor of the urethra where the seminal ducts enter (anat.).

vesica (věs'îkă) $n$. [L. vesica, bladder.] The bladder.

vesical (věs'îkăl) a. [L. vesica, bladder.] Pert. or in relation with the bladder; $a p p l$. arteries, etc. (anat.). vesicle (věs'îkl) $n$. [L. vesicula, dim. of vesica, bladder.] A small globular or bladder-like air space in the tissues (bot.) ; a small cavity or sac usually containing fluid (zool.); a hollow prominence on a shell or coral (zool.); one of the three primary cavities of the brain (anat.).

vesicula (věsik'ūlă) n. [L. vesicula, small bladder.] A small bladderlike cyst or sac (anat.).

vesicula seminalis, - a sac in which spermatozoa complete their development and are stored (zool.). 
vesicular (věsǐk'ūlăr) a. [L. vesicula, small bladder.] Composed of or marked by the presence of vesiclelike cavities (bot., zool.).

vesicular gland, - a gland in the tissue underlying the epidermis in plants and containing essential oils (bot.).

vesiculase (věsik' ūlās) $n$. [L. vesicula, small bladder.] An enzyme from the secretion of the prostate gland, which is capable of coagulating the contents of the seminal vesicles (phys.).

vespertine (věs'pĕrtĭn) a. [L. vesper, evening star.] Blossoming in the evening (bot.); crepuscular (zool.).

vespoid (věs'poid) $a$. [L. vespa, wasp; Gk. eidos, like.] Wasp-like (zool.).

vessel (věs'ël) $n$. [L. vescellum, dim. of vasculum, vessel.] Any tube or canal with properly defined walls in which fluids, such as blood, lymph, etc., circulate (anat.); a continuous tube formed by the superposition of numerous cells (bot.).

vestibular (věstǐb'ūlăr) $a$. [L. vestibulum, a passage.] Pert. a vestibule ; $a p p l$. artery, bulb, fissure, gland, etc. (anat.).

vestibulate (věstî́'ūtāt) a. [L: vestibulum, a passage.] In the form of a passage between two channels (biol.); resembling a vestibule.

vestibule (věs'tĭbūl) $n$. [L. vestibulum, passage.] A cavity leading into another cavity or passage, as the cavity of the ear-labyrinth; the space between the labia minora containing the opening of the urethra; the portion of the ventricle directly below the opening of the aortic arch; the cavity leading to the larynx ; the nasal cavity (anat.); the posterior chamber of a bird's cloaca ; a small tubular or grooved depression leading to the mouth in most Infusorians; the space within the circle of tentacles in endoproctan Polyzoans (zool.).

vestibulum,- - see vestibule.

vestige (věs'tīj) $n$. [L. vestigium, a trace.] A small degenerate or imperfectly developed organ or part which may have been complete and functional in some ancestor (biol.).

vestigial (věstīj'răl) a. [L. vestigium, trace.] Small and imperfectly developed (biol.).

vestiture (vĕs'tìtūr) $n$. [L. vestis, garment.] A body covering, as of scales, feathers, etc. (zool.).

veterinary (vět'ěrinărì) $a$. '[L. veterinarius, pert. beast of burden.] Pert. art of treating the diseases of animals (zool.).

vexillary (věk'sílărĭ, věksšllărĭ) $a$. [L. vexillum, standard.] Pert. a vexillum; $a p p l$. a type of aestivation in which the upper petal is folded over the others (bot.).

vexillate (věk'sìlāt) $a$. [L. vexillum, standard.] Bearing a vexillum.

vexillum (věk'sǐlŭm, věksǐl'ŭm) $n$. [L. vexillum, standard.] The upper petal in a papilionaceous flower (bot.) ; the vane of a feather (zool.). via (víă, vē'ă) n. [L. via, way.] A way or passage (anat.).

vibracula (vǐbrăk'ūlă) n. plu. [L. vibraculum, whip.] The movable whip-like organs, supposed to be modified zooids for defensive purposes, found on the Polyzoa (zool.).

vibracularium (vǐbrăk'ülā'riŭm), - the vibracula.

vibratile (vǐb'rătĭl) a. [L. vibrare, to quiver.] Oscillating; appl. antennae of Insects (zool.).

vibratile corpuscles, - corpuscles closely resembling sperms found in the coelomic fluid of Star-fish (zool.).

vibrioid (vib'rioid) a. [L. vibrare, to quiver; eidos, like.] Like a vibrio, a bacterium with thread-like appendages and a vibratory motion (bot.).

vibrioid body, - a slender cylindrical body found in the superficial layer of many Algae and Fungi (bot.).

vibrissa (vībrǐs'ă) n., vibrissae (vībris' $\overline{\mathrm{e}}$ ) plu. [L. vibrissa, a nostril hair.] A hair growing on the nostril or face of animals, the whiskers of the cat, etc., acting often as organs of touch (zool.).

vicinism (vis'ínizm) $n$. [L. vicinus, neighbour.] The tendency to variation due to the proximity of related forms (biol.). 
villiform (vǐl'ífôrm) $a$. [L. villus, shaggy hair; forma, shape.] Having the form or appearance of velvet; $a p p l$. dentition (zool.).

villous (vil'üs) a. [L. villus, shaggy hair.] Pubescent (bot.); having villi or covered with villi (zool.).

villus (vil'ŭs) $n$., villì (vॅl'īi) plu. [L. villus, shaggyhair.] Trophonemata or minute vascular processes on the intestine lining; processes on the chorion through which nourishment passes to the embryo (anat.); fine straight processes on the epidermis of plants (bot.).

vimen (vî'měn) $n_{*}$, vimina (vĭm'ĩnă) plu. [L. vimen, twig.] A long slender shoot or branch (bot.).

vinculum (ving'kūlŭm) n., vincula (ving'kūlă) plu. [L. vinculum, chain.] Slender tendinous bands; accessory connecting bands of fibres, as vincula brevia (anat.); a band uniting the two main tendons of the foot in Birds (zool.).

virescence (vĭrĕs'ĕns) $n$. [L. virescere, to grow green.] The production of green colouring matter in petals instead of the usual colouring matter (bot.).

virgate (vër'gāt) $a$, [L. virga, twig.] Rod-shaped.

virginal (vër'jĭnăl) $a$. [L. virgo, virgin.] $A p p l$. female which reproduces parthenogenetically (zool.).

virgula (vër'gūlă) $n$, [L. virga, rod.] A small rod, the axis of a Graptolite.

viscera (vis'ëră) n. plu. [L. viscera, bowels.] The internal organs contained in the various cavities of the body (anat.).

visceral (vis'ërăl) a. [L. viscera, bowels.] Pert. the viscera; $a p p l$, to numerous structures and organs (anat.).

visceral arches, - a series of arches developed in connection with the mouth and pharynx (zool.).

visceral clefts, - a series of furrows or clefts on the neck region between successive visceral arches, which may or may not place the pharynx in direct communication with the exterior (anat.).

visceromotor (vis'ërömō'tŏr) $a$. [L. viscera, bowels ; movere, to move.]
Carrying motor impulses to the viscera (phys.).

viscosity (viskŏs'ítı̌) $n$. [L. viscosus, viscous.] The internal friction in liquids due to the adherence of particles to one another (phys.).

visitant (vizìtănt) $n$. [L. visere, to go to see.] Term appl. a bird which is not an inhabitant of a certain region, but appears at stated periods in that region (zool.).

visual purple, - seerhodopsin (phys.). vital force, - the peculiar form of energy manifested in living phenomena when considered distinct from chemical, physical, and mechanical forces (biol.).

vital functions, - the functions of the body on which life depends (phys.).

vitalism (vĩ'tălìzm) $n$. [L. vita, life.] The belief that the various phenomena exhibited in living organisms are due to a special force quite distinct from physical forces (biol.).

vitamines (vĩ'tămĭnz) n. plu. [L. vita, life; ammoniacum, resinous gum.] Active substances whose absence in diet causes disease,as in beri-beri; basic nitrogenous substances occurring in varying amounts in different foods (phys.).

vitellarium (vǐt'ělā'rư̆m) a. [L. vitellus, yolk.] A special organ in Flatworms and many Rotifers which produces yolk-laden cells (zool.).

vitelligenous (vit'ělij'ěnŭs) $a$. [L. vitellus, yolk; gignere, to beget.] Producing yolk; $a p p l$. cells in the ovary of many Insects (zool.).

vitellin (vĭtěl'in) $n$. [L. vitellus, yolk.] The phospho-protein of eggyolk (phys.); a similar or related substance in seeds (bot.).

vitelline (vitěl'în) a. [L. vitellus, yolk.] Pert. the yolk, or yolkproducing organ; $a p p l$. artery, vein, duct (zool., emb.).

vitellophags (vǐtěl'öfăgz) $n$. plu. [L. vitellus, yolk; Gk. phagein, to eat.] Isolated cells forming the hypoblast of Crustacean egg (zool.).

vitellose (vitěl'ös) n. [L. vitellus, yolk.]. A substance formed in the digestion of yolk (phys.).

vitellus (vitěl'ŭs) $n$, [L vitellus, yolk.] The yolk of an egg (emb.). 
vitrella (vĭtrĕl'ă) $n$. [L. vitrum, glass.] A crystalline cone cell of an invertebrate eye (zool.).

vitreodentine (vǐt'rěöděn'tîn) $n$. [L. vitreus, glassy; dens, tooth.] A very hard variety of dentine (zool.).

vitreous (vǐt'rěŭs) $a$. [L. vitreus, glassy.] Transparent; appl. a clear jelly-like substance in the inner chamber of the eye (anat.).

vitta (virt'ă) n., vittae (vǐt'ē) plu. [L. vitta, band or fillet.] One of the oil receptacles in an umbellifer fruit (bot.); a band of colour (zool.).

vivification (vǐv'îfikā'shŭn) $n$. vivus, living; facere, to make.] One of the series of changes in assimilation by which the proteid material which has been taken up by the cell is able to exhibit the phenomena of living protoplasm (phys.).

viviparity (vǐv'ípăr'ítǐ) n. [L. vivus, alive ; parere, to beget.] The condition of bringing the young forth alive (zool.); or of multiplying by means of shoots or bulbils (bot.).

viviparous (vivĭp'ărŭs) a. [L. vivus, living ; parere, to beget.] Bringing forth the young alive ; $c f$. oviparous (zool.); germinating while still attached to the parent (bot.).

vocal (vö'kăl) a. [L. vox, voice.] Pert. voice or utterance of sounds.

vocal cords,-folds of mucous membrane projecting into the larynx.

volar (völăr) a. [L. vola, the palm of the hand.] Pert. palm of the hand or to the sole of the foot (anat.).

Volkmann's canals (fŏlk'mânz),simple canals piercing the circumferential or periosteal lamellae of bone for the passage of bloodvessels (phys.).

voluble (vǒl'úbl) a. [L. volvere, to twist.] Twining spirally (bot.).

voluntary (vǒl'ŭntărǐ) a. [L. voluntas, will.] Subject to or regulated by the will; $a p p l$. action of muscles (phys.).

volute (vǒlüt') a. [L. volvere, to twist.] Spirally twisted (zool.).

volutin grains, - grains formed in cytoplasm and representing a foodmaterial which is absorbed by the nucleus in growth and formation of chromatin (cyt.). volution (vŏlū'shŭn) $n$. [L. volvere. to twist.] The spiral twists of a shell (zool.).

volva (vǒl'vă) $n$. [L. volva, wrapper.] The sac-like structure enveloping the stipes of an Agaric (bot.).

volvate (vǒl'vāt) a. [L. volva, wrapper.] Provided with a volva (bot.).

vomer (vō'mër) n. [L. vomer, ploughshare.] A bone in the nasal region of the skull (anat.).

vomerine (vō'mĕrīn) a. [L. vomer, ploughshare.] Pert. the vomer; appl. teeth (zool.).

vomeronasal (vō'mĕrönā'zăl) a. [L. vomer, ploughshare; nasus, nose.] $A p p l$. cartilage and organ in region of vomer and nasal cavity (anat.).

von Baer's law, - see recapitulation theory.

vortex (vŏr'těks) n. [L. vortex, vortex.] The spiral arrangement of the muscle fibres at the apex of the heart (anat.).

vulva (vŭl'vă) $n$. [L. vulva, vulva.] The external parts of the female genital organs (anat.).

vulviform (vŭl'vufôrm) a. [L. vulva, vulva ; forma, shape.] Like a cleft with projecting lips (bot.); shaped like a vulva (zool.).

vulvouterine (vŭl'vöu'terrīn) $a$. [L vulva, vulva ; uterus, womb.] Pert. vulva and the uterus (anat.).

vulvovaginal (vǔl'vövăj'inăl) a. [L. vulva, vulva; vagina, sheath.] $P e r$. the vulva and the vagina (anat.).

\section{W}

Wallace's Line,-an imaginary line separating the Australian and Oriental regions: it ran between Bali and Lombok, between Celebes and Borneo, and then to the eastward of the Philippines (zool.).

Wallerian degeneration, - the degeneration of nerve fibres following section, - this proceeds from the seat of the injury along the axon away from the neuron (phys.).

wandering cells,-amoeboid cells of mesogloea ; migratory leucocytes of areolar tissue (zool.). 
warm-blooded,-a term $a p p l$. animals which have a fairly high and constant temperature which is above that of the surrounding medium.

warning colours, - conspicuous colours assumed by many animals to warn off enemies (biol.).

wart (wôrt) $n$. [A.S. wearte, wart.] A dry excrescence formed on the skin (zool.); a firm glandular protuberance (bot.).

water-cells,- -specialized cells in the stomach of the camel for storage of fluid (zool.).

water culture, - the experimental growing of plants in water to see the effect of different salts on them (bot.).

water-gland,-a structure in the mesophyll of leaves regulating water excretion through stomata (bot.).

water-pore, - the minute ciliated opening through the actinal wall of the disc of Antedon (zool.); an opening at the apex of a leaf-vein for the excretion of water (bot.).

water stomata,-pores on the surfaces of leaves for the excretion of water (bot.).

water - tube, - a ciliated branched tube connected with the ring-vessel and coelom (zool.).

water vascular system,-a system of canals circulating a watery fluid throughout the body of Echinoderms; also applied to the excretory system of Platyhelminths (zool.).

wattle (wôt'l) n. [A.S. watel, bag.] The fleshy process, usually red, under the throat of a cock or turkey (zool.).

wax (wăks) $n$. [A.S. weax, wax.] A substance produced by bees and used in forming the honeycomb (zool.).

wax pocket, - a wax-secreting cavity on the abdomen of the bee (zool.).

web (wěb) n. [A.S. webbe, web.] The membrane stretching from toe to toe in swimming Birds; vexillum; the fine network of threads spun by Spiders (zool.).

webbed (wěbd) a. [A.S. webbe, web.] Appl. feet of swimming Birds owing to the toes being connected by a membrane (zool.).

Weberian apparatus, - an apparatus found in Cypriniformes connecting the ear with the air-bladder, first described by Weber (zool.).

Weberian ossicles, - a chain of four small bones stretching on each side from a membranous fenestra of the atrium to the air-bladder in Cypriniformes (zool.).

wedge bones, - small infravertebral ossifications at the junction of two vertebrae, often present in Lizards (zool.).

Weismannism (wīs'mănǐzm) $n$. [Weismann, German biologist.] The teaching of Weismann in connection with evolution and heredity, chiefly dealing with the continuity of the germ-plasm, and the nontransmissibility of acquired characteristics.

wheal (hwēl) n. [A.S. hwelian, to inflame.] A long-continued shortening and thickening of a muscle fibre on stimulation (phys.).

wheel organ, - thelocomotory ciliated ring of Rotifers; the specialized ciliated epithelial structure in the buccal cavity of the Cephalochorda (zool.).

white body, - the so-called optic gland of Molluscs, a large soft body of unknown function (zool.).

white corpuscle, - a leucocyte.

white matter, - tracts of medullated fibres in brain and spinal cord (anat.).

white yolk spheres, - minute vesicles forming a flask-shaped plug in the centre of the egg-yolk, and a layer investing it (cyt.).

whorl (hwôrl) $n$. [A.S. hweorfa, a wheel.] The spiral turn of a univalve shell (zool.); a circle of flowers or parts of a flower arising from one point (bot.).

wind-Pertilization, - the fertilization of plants by pollen carried by the wind (bot.).

wing (wing) $n$. [M.E. winge, wing.] One of two lateral petals in a papilionaceous flower; the lateral expansion on many seeds (bot.); any broad membranous expansion ; the fore-limb of Birds; the flight organ of Insects (zool.). 
wing coverts, - see tectrices.

wing pad,- - the undeveloped wing of insect pupae (zool.).

wing petal, - the lateral petal in papilionaceous plants (bot.).

winter egg,- the egg of many freshwater forms provided with a thick shell which preserves it as it lies quiescent during the winter; $c f$. summer eggs (zool.).

wisdom teeth, - the four molar teeth which complete the permanent set in man, erupting much later than the others (anat.).

wolf tooth, - a small premolar tooth at the front of the premolar series, occasionally present in Horses (zool.).

Wolffian (wool'fiăn) $a$. [Wolff, embryologist.] $A p p l$. certain structures first discovered by Wolff.

wolffian body, - the embryonic mesonephros which arises by the development of a series of mesonephric tubules (anat.).

wolffian duct, - the duct of the mesonephros : this may arise either by a splitting of the pronephric duct, or it may be the whole of the pronephric duct (anat.).

Wolffian ridges,- - ridges which appear on either side of the middle line of the early embryo, and upon which the limb-buds are formed (emb.).

wood (wood) $n$. [A.S. $w u d u$, wood.] The hard substance of a tree stem, the xylem of the vascular bundles (bot.).

wood cell, - - one of the special cells in the xylem of a vascular bundle (bot.).

wood fibres, - sclerenchymatous fibres (bot.).

wood parenchyma,-lignified parenchymatous cells (bot.).

wood vessel, - an element of tracheal tissue, a long tubular structure formed by cell-fusion (bot.).

Woolner's tubercle, - see Darwinian tubercle (zool.).

worker, - a non-fertile female in a colony of social Insects (zool.).

worm (wŭrm) n. [A.S. wyrm, worm.] A general name of no scientific value, used to designate any of the Flatworms, Roundworms, Polychaetes or Oligochaetes (zool.).
Wormian bones (wŏr'miăn), - see sutural bones.

wrist bones, - the name applied to the bones that go to make up the carpus (zool.).

\section{X}

xanthin (zăn'thĭn) n. [Gk. xanthos, yellow.] Yellow colouring matter in flowers (bot.).

xanthine (zăn'thìn, zăn'thēn) $n$. [Gk. xanthos, yellow.] Dioxy-purine, found in muscle, liver, pancreas, and in urine; also in certain plants (phys.).

xanthocarpous (zăn'thökâr'pŭs) $a$. [Gk. xanthos, yellow ; karpos, fruit.] Having yellow fruits (bot.).

xanthodont (zăn'thödŏnt) a. [Gk. xanthos, yellow; odous, tooth.] Having yellow-coloured incisors ; appl. certain Rodents (zool.).

xanthophane (zăn'thöfān) n. [Gk, xanthos, yellow; phainein, to appear.] Chromophane.

xanthophyll (zăn'thöfîl) $n$. [Gk. xanthos, yellow; phyllon, leaf.] A yellow colouring matter found in autumn leaves, probably a constituent of chlorophyll (bot.).

xanthopous (zăn'thöpŭs) a. [Gk. xanthos, yellow; pous, foot.] Having a yellow stem (bot.).

xanthospermous (zăn'thöspěr'mŭs) $a_{\text {. }}$ [Gk. xanthos, yellow; sperna, seed.] Having yellow seeds (bot.).

xenarthral (zĕnâr'thrăl) a. [Gk. xenos, strange; arthron, joint.] Having additional articular facets on the dorso-lumbar vertebrae (zool.).

xenia (zé'niă) n. [Gk. xenios, hospitable.] Appearances in the seed of characters, after cross-fertilization, belonging to foreign pollen parent (bot.).

xenogamy (zěnŏg'ămī) n. [Gk. xenos, strange ; gamos, marriage.] Crossfertilization (bot.).

xenogenesis (zĕn'öjĕn'ěsĩs) n. [Gk. xenos, strange; gignesthai, to produce.] Heterogenesis (biol.).

xenomorphosis (zěn'ömôr'fösǐs) $n$. [Gk. xenos, strange ; morphe, shape.]

Heteromorphosis. 
xenophya (zĕn'öfî́ă)n.plu. [Gk. xenos, strange; phyein, to grow.] Foreign bodies deposited in interspaces of certain Sarcodina, or used in formation of shells of certain Protozoa (zool.).

xerophilous (zērŏf'îlŭs) a. [Gk, xeros, dry; philein, to love.] Able to withstand drought; appl. plants adapted for a limited water supply (bot.).

xerophyte (zē'röfīt) n. [Gk. xeros, dry; phyton,'plant.] A xerophilous plant; a plant growing in desert or alkaline soil (bot.).

xiphihumeralis (zif'îhūměră'lǐs) $n$. [Gk. xiphos, sword; L. humerus, shoulder.] A muscle extending from xiphoid cartilage to humerus (anat.).

xiphiplastron (zif'ǐplăs'trŏn) $n$. [Gk. xiphos, sword; F. plastron, shield.] The fourth lateral plate in the plastron of Chelonia (zool.).

xiphisternum (žf'îstĕr'nŭm) $n$. [Gk. xiphos, sword ; L. sternum, breastbone.] The posterior segment or ensiform process of the sternum (anat.).

xiphoid (zif'oid) a. [Gk. xiphos, sword; eidos, shape.] Swordshaped; ensiform (anat.).

xiphoid process, - the last segment of the sternum (anat.); the tail or telson of Limulus (zool.).

xiphophyllous (zif'öfîl'ŭs, zĭfŏf'îlŭs) $a$. [Gk. xiphos, sword ; phyllon, leaf.] Having sword-shaped leaves (bot.). xylem (zíllĕm) $n$. [Gk. xylon, wood.] The lignified portion of a vascular bundle (bot.).

xylocarp (zîl'lökârp) n. [Gk. xylon, wood; karpos, fruit.] A hard woody fruit (bot.).

xylogen (zi'löjën) n. [Gk. xylon, wood; gignesthai, to produce.] The forming wood in a bundle (bot.).

xyloid (zîloid) a. [Gk. xylon, wood; eidos, shape.] Woody, or resembling wood in structure (bot.).

xyloma (zīlō'mă) n. [Gk. xylon, wood.] A hardened mass of mycelium which gives rise to sporebearing structures in certain Fungi (bot.).

xylophagous (zīlǒf'ăgŭs) a. [Gk. xylon, wood; phagein, to eat.]
Wood-eating; $a p p l$. certain Molluscs and Insects (zool.).

xylostroma (zī'löstrō'mă) $n$. [Gk. xylon, wood ; stroma, couch.] The felt-like mycelium of certain wooddestroying Fungi (bot.).

xylotomous (zīlŏt'ömŭs) a. [Gk. xylon, wood; temnein, to cut.] Able to bore or cut wood (zool.).

\section{$\mathrm{Y}$}

yellow cartilage, - a cartilage in which the matrix is everywhere pervaded by yellow connective tissue fibres (anat.).

yellow cells,-cells surrounding the gut of an earthworm, probably excretory in function ; cells occurring in the intestine of Turbellarians ; in Radiolarians, symbiotic algae or zoochlorellae (zool.).

yellow fibres, - see elastic fibres.

yellow spot,- the macula lutea of the retina (anat.).

yolk (yōk) n. [A.S. geoloca, the yellow part.] The inert, or nonformative, nutrient material in the ovum (emb.).

yolk-duct, - the vitelline duct (zool.).

yolk - epithelium, - the epithelium surrounding the yolk-sac (emb.).

yolk-gland, - a gland in connection with the reproductive system in certain worms by which the egg is furnished with a supply of foodmaterial; the oviducal gland in certain vertebrates (zool.).

yolk-nucleus, - a cytoplasmic body appearing in the ovarian egg (cyt.).

yolk-plates,-parallel lamellae into which the deutoplasm may be split up in egg-yolk of Amphibia and many Fishes.

yolk-plug,-the mass of yolk-cells filling up the blastopore, as in the Frog (cyt.).

yolk-pyramids, - certain of the cells formed in the segmenting egg of the Crayfish (zool.).

yolk-sac, - a membranous sac attached to the embryo and containing yolk, which passes to the intestine through the vitelline duct, and acts as food for the developing embryo (emb.). 
yolk-spherules, - the remains of neighbouring cells or of pseudocells found in the ovum (emb.).

yolk-stalk, - a short stalk or strand containing ducts and connecting the yolk-sac and the embryo (emb.).

ypsiliform (ịpsil'ífôrm) a. [Gk. $\Upsilon$, upsilon; L. forma, shape.] $\Upsilon$ shaped; $a p p l$. the germinal spot at a certain stage in its development (emb.).

ypsiloid (Ǐp'šlloid) a. [Gk. $\Upsilon$, upsilon ; eidos, resemblance.] Ypsiliform.

ypsiloid cartilage,-attached to the pubes in Salamanders with functional lungs (zool.).

\section{Z}

zalambdodont (zălăm'dödŏnt) $a$. [Gk. $z a$, very ; lambda, $\Lambda$; odous, tooth.] $A p p l$. insectivores with narrow molar teeth with $\mathrm{V}$-shaped transverse ridges (zool.).

zero (zё'rö) $n$. [Ar. çifrun, cipher.] The origin of graduation.

zero, physiological, - the point of adaptation to temperature.

Zinn, zonule of,-see zonula ciliaris (anat.).

zoaea $\left(z \bar{o} \bar{e}^{\prime} \breve{a}\right) n$. [Gk. zoe, life.] A zoea.

zoarium (zōā'rĭŭm) n. [Gk. zoon, animal.] The whole of the individuals of a polyzoan colony; a polypary (zool.).

zodiophilous (zõ'dǐof'úlŭs) $a$. [Gk. zoon, animal; philein, to love.] Zoophilous.

zoea (zōétă) n. [Gk. zoe, life.] An early larval form of certain decapod Crustaceans (zool.).

zoeaform (zōe'ăfôrm) a. [Gk zoe, life; L. forma, shape.] Shaped like a zoea (zool.).

zoecial (zōē'shrăl) a. [Gk. zoon, animal; oikos, house.] Pert. or resembling a zooecium (zool.).

zoecium (zô̄'shřum) n. [Gk. zoon, animal; oikos, house.] See zooecium.

zoetic (zōèt'îk) a. [Gk. zoe, life.] Of or pert. life (biol.).

zoie (zó'rk) a. [Gk. zoikos, pert. life.] Pert. animals or animal life (zool.). zoid (zō'r̂d) a. [Gk. zoon, animal; eidos, resemblance.] A sporozoite formed by division of sporoblasts of Haemosporidia (zool.).

zoidophore (zö'ìdöfōr) $n$. [Gk. zoon, animal; eidos, shape; pherein, to bear.] A spore mother cell or sporoblast formed by the segmentation of the oocyte in Haemosporidia (zool.).

zona (zō'nă) $n$. [Gk. zone, girdle.] A zone, band, or area.

zona arcuata, - the inner part of the basilar membrane supporting the organ of Corti (anut.).

zona fasciculata,-radially arranged columnar cells in the suprarenal gland below the outer layer (anat.). zona pectinata, - the outer division of the basilar membrane (anat.).

zona pellucida, - the thick transparent membrane surrounding the mammalian ovum (emb.).

zona reticularis, - the inner cortical layer of the suprarenal gland (anat.).

zonal (zōnăl) a. [L. zonalis, pert. zone.] Of or pert. a zone.

zonal symmetry, - see metamerism (zool.).

zonal view, - the view of a Diatom in which the girdle is seen (bot.).

zonary (zō'nărǐ) a. [Gk. zonarion, dim. of zone, girdle.] Pert. the Zonaria, a division of deciduate Mammals in Huxley's classification (zool.).

zonary placenta, - see placenta.

zonate (zō'nāt) a. [Gk. zone, girdle.] Zoned or marked with rings; arranged in a single row, as various tetraspores (bot.).

zone (zōn) n. [Gk. zone, girdle.] An area characterized by a similar fauna or flora (biol.) ; a stratum or set of beds characterized by a typical fossil or set of fossils (pal.). zonociliate (zō'nösĩl'iät) a. [Gk. zone, girdle; L. cilium, eyelash.] Banded with cilia, as certain annelid larvae (zool.).

zonoid (zönoid) a. [Gk. zone, girdle; eidos, resemblance.] Like a zone.

zonolimnetic (zón'nölimnět'ík) a. [Gk. zone, girdle; limne, pool.] of or pert. a certain zone in depth; appl. plankton (biol.). 
zonoplacental (zō'nöplăsĕn'tăl) a. [L zona, girdle; placenta, cake.] Having a zonary placenta (zool.). zonula ciliaris (zō'nūlă sĭliắrìs) $n$. [L. zonula, dim. of zona, girdle; cilium, eyelash.] The hyaloid membrane forming the suspensory ligament of the lens of the eye (anat.).

zonule (zón nūl) $n$. [L. zonula, dim. of zona, girdle.] A little zone, belt, or girdle ; a zonula (anat.).

zooblast (zó'öblăst) $n$. [Gk. zoon, animal; blastos, bud.] An animal cell.

zoocaulon (zōöôkôl'ŏn) $n$. [Gk. zoon, animal; kaulos, stalk.] See zoodendrium.

zoochlorellae (zō'öklörěl'é) $n$. plu. [Gk. zoon, animal ; chloros, green.] Symbiotic green Algae (Protococcaceae) living in various groups of the Protozoa, e.g. Sarcodina, Radiolaria (biol.).

zoocoenocyte (zö'ösénösīt) $n$. [Gk. zoon, animal ; koinos, common; kytos, hollow vessel.] A coenocyte bearing cilia in certain Algae such as Vaucheria (bot.).

zoocyst (zö'ösist) n. [Gk. zoon, animal ; kystis, hollow sac.] A sporocyst (zool.).

zoocytium (zō'ösĭt'ǐum) n. [Gk. zoon, animal; kytos, hollow sac.] In certain Infusoria, the common gelatinous and often branched matrix (zool.).

zoodendrium (zōööděn'drǔum) $n$. [Gk. zoon, animal ; dendron, tree.] The tree-like branched stalk of certain colonial Infusorians (zool.).

zoodynamies (zốödinăm'îks) $n$. [Gk. zoon, animal; dynamis, power.] The physiology of animals (phys.). zooecium (zōē'sŭŭm, zōē'shǐŭm) $n$. [Gk. zoon, animal; oikos, house.] A chamber or cell enclosing a polyzoan nutritive zooid (zool.).

zooerythrin (zōöërĭth'rĭn) $n$. [Gk. zoon, animal ; erythros, red.] A red pigment found in the plumage of various Birds (zool.).

zoofulvin (zööfül'vinn) n. [Gk, zoon, animal; L. fulvus, yellow.] A yellow ipigment found in the plumage of various Birds (zool.). zoogamete (zö'ögămēt') n. [Gk. zoon, animal; gamos, marriage.] A motile gamete or planogamete (bot.).

zoogamy (zōŏg'ămí) n. [Gk. zoon, animal ; gamos, marriage.] Sexual reproduction in animals (zool.).

zoogenesis (zo'öjĕn'ěsı̌s) $n$. [Gk. zoon, animal ; gignesthai, to produce.] The origin of animals (biol.).

zoogeography (zō'öjēŏg'răfĩ) $n$. [Gk. zoon, animal ; ge, earth; graphein, to write.] The science of the distribution of animals on earth (biol.).

zoogloea (zōöglē'ă) n. [Gk. zoon, animal; gloia, glue.] A mass of bacteria embedded in a mucilaginous matrix, frequently forming an iridescent film (zool.).

zoogonidium (zō'ögŏnìd'ium) $n$. [Gk. zoon, animal; gonos, offspring.] One of the motile spores formed in the gonidangium of Algae (bot.). zoogonous (zōŏg'önŭs) a. [Gk. zoon, animal ; gonos, offspring.] Viviparous (zool.).

zooid (zōtoid) n. [Gk, zoon, animal; eidos, like.] A member of a compound animal organism; an individual or person in a coelenterate or polyzoan colony; the posterior genital and non-sexual region formed in many Polychaetes (zool.). zoolith (zóölith) n. [Gk. zoon, animal; lithos, stone.] A fossil animal.

zoology (zōŏl'öjî) n. [Gk. zoon, animal; logos, discourse.] The branch of science dealing with the structure, functions, history, and distribution of animals.

zoon (zóŏn) n. [Gk. zoon, animal.] An individual developed from an egg (zool.).

zoonerythrin (zō'ŏnĕrĭth'rĭn) n. [Gk. zoon, animal; erythros, red.] A red colouring matter found in various animals (zool.).

zoonite (zó'ŏnīt) $n$. [Gk. zoon, animal.] A body segment of an articulated animal (zool.).

zoonomy (zōŏn'ömǐ) n. [Gk. zoon, animal; nomos, law.] The laws dealing with animal life (biol.).

zoophilous (zōŏf'ílŭs) a. [Gk. zoon, animal; philein, to love.] Appl. plants which are adapted for pollination by animals other than Insects (bot.). 
zoophyte (zóööit) n. [Gk. zoon, animal; phyton, plant.] Any animal resembling a plant in appearance or growth.

zooplankton (zō'öplăng'ktŏn) $n$. [Gk. zoon, animal; plangktos, wandering.] That part of the plankton consisting of animals (biol.).

zooplasm (zóööplăzm) n. [Gk. zoon, an imal ; plasma, something moulded.] Living substance which depends on the products of other living organisms for nutritive material.

zoosperm (zōöspĕrm) $n$. [Gk. zoon, animal ; sperma, seed.] A spermatozoon (zool.); a zoospore (bot.).

zoosporangium (zōöspörăn'jiŭm) $n$. [Gk. zoon, animal; sporos, seed; anggeion, vessel.] A sporangium in which zoospores develop (bot.).

zoospore (zō'öspōr) n. [Gk. zoon, animal; sporos, seed.] A swarmcell, flagellate or amoeboid, in many Protozoa (zool.); a motile protoplast in certain Algae (bot.).

zoothecium (zōöthē'sium, zö'öthē' shiŭm) n. [Gk. zoon, animal; thekion, dim. of theke, case.] A zoocytium.

zoothome (zō'öthōm) n. [Gk. zoon, animal ; thomos, heap.] Any group of individuals in a living Coral (zool.).

zootomy (zōŏt'ömì) n. [Gk. zoon, animal ; temnein, to cut.] The anatomy of animals other than man (zool.).

zooxanthellae (zō'özănthěl'ē) n. plu.

[Gk. zoon, animal ; xanthos, yellow.]

Yellow cells or symbiotic unicellular

Algae living in various Protozoa (biol.).

zooxanthin (zōözăn'thĭn) n. [Gk. zoon, animal; xanthos, yellow.] A yellow pigment found in the plumage of certain Birds (zool.).

zwischenkồrper (tsvish'ěnkërpĕr) $n$.

[Ger. zwischen, between; körper, body.] A body or group of granules, probably comparable with the cell-plate in plants, formed in the equatorial region of the spindle during the anaphases of mitosis (cyt.).

zygantrum (zīgăn'trŭm) n. [Gk. sygon, yoke; antron, cave.] A fossa on the posterior surface of the neural arch of the vertebrae of Snakes and certain Lizards (zool.).

zygapophysis (zīgăpǒf'iššs) $n$. [Gk. zygon, yoke; apophysis, process of a bone.] One of the processes of a vertebra by which it articulates with adjacent vertebrae (anat.).

zygobranchiate (zī'göbrăng'kiāt) $a$. [Gk. zygon, yoke ; brangchia, gills.] Having the gills symmetrically placed and renal organs paired; $a p p l$. a group of Gastropods (zool.). zygocardiac (zî́gökâr'diăk) ossicles,paired lateral ossicles in the gastric mill of the Crayfish (zool.).

zygodactyl (zî́'gödăk'tǐl) a. [Gk. zygon, yoke; daktylos, digit.] Having two toes pointing forward, two backward, as in parrots (zool.). zygodont (zî́gödŏnt) a. [Gk. zygon, yoke ; odous, tooth.] Having molar teeth in which the four tubercles are united in pairs (zool.).

zygoma (zīgō'mă) n. [Gk. zygoma, yoke.] The bony arch of the cheek. zygomatic (zīgömăt'îk) a. [Gk. zygoma, yoke.] Of or pert. the zygoma (anat.).

zygomaticofacial (zî́gömăt'íköfā'šăl) a. [Gk. zygoma, yoke ; L. facies, face.] Appl. foramen on the malar surface of zygomatic for passage of nerve and vessels (anat.).

zygomaticotemporal (zígömăt'îkötĕm'pörăl) a. [Gk. zygoma, yoke ; L. temporalis, temporary.] $A p p l$. suture, foramen, nerve, etc., at temporal surface of zygomatic (anat.).

zygomorphic (zî'gömôr'fîk), zygomorphous (zî́gömôr'fŭs) a. [Gk. zygon, yoke; morphe, shape.] Bilaterally symmetrical ; $a p p l$. irregular petal arrangement (biol.).

zygoneury (zî́gönü'rì)n. [Gk. sygon, yoke; neuron, nerve.] In certain Gastropods, having a connective between the pleural ganglion and the ganglion on the visceral branch of the opposite side ( $z o o l$.).

zygophore (zì'göför) n. [Gk. sygon, yoke ; pherein, to bear.] A conjugating hypha in certain Fungi $(b \circ t)$. zygophyte (zî'göfît) n. [Gk. zygon, yoke; phyton, plant.] A plant with two similar reproductive cells which unite in fertilization (bot.). 
zygopleural (zī'göploorăl) a. [Gk. zygon, yoke; pleuron, side.] Bilaterally symmetrical.

zygosis (zīgō'sǐs) n. [Gk. zygosis, balancing.] Conjugation.

zygosperm (zī'göspĕrm) $n$. [Gk. zygon, yoke; sperma, seed.] A zygospore.

zygosphene (zī'gösfēn) n. [Gk. zygon, yoke; sphen, wedge.] An articular process on the anterior surface of the neural arch of vertebrae of Snakes and certain Lizards, which fits into the zygantrum (anat.).

zygosporangium (zî́göspörăn'jiŭm) $n$. [Gk. zygon, yoke; sporos, seed; anggeion, vessel.] A sporangium in which zygospores are formed (bot.).

zygospore (zî'göspōr) n. [Gk. zygon, yoke; sporos, seed.] A zygote; a cell formed by the conjugation of similar cells (bot.).

zygosporophore (zî́göspō'röfōr) $n$. [Gk. zygon, yoke; sporos, seed; pherein, to carry.] Zygophore.

zygotaxis (zífgötăk'sǐs) n. [Gk. zygon, yoke ; taxis, arrangement.] The tendency towards conjugation between two specialized hyphae in certain Fungi (bot.).

zygote (zīgōt) n. [Gk. zygotes, yoked.]
Any cell formed by the union of two gametes or reproductive cells (biol.).

zygotoblast (zĩ'götöblăst') $n$. [Gk. zygotes, yoked; blastos, bud.] A sporozoite produced by segmentation of the zygotomere in Haemamoebae (zool.).

zygotomere (zî́götömēr') n. [Gk. zygotes, yoked; meros, part.] A cell formed by segmentation of the zygote in Haemamoebae (zool.).

zygotonucleus (zī'götönū'klěus) $n$. [Gk. zygotes, yoked; L. mucleus, kernel.] A nucleus formed by the fusion of two gametonuclei (zool.).

zygozoospore (zī'gözōöspōr) $n$. [Gk. zygon, yoke ; zoon, animal ; sporos, seed.] A motile cell formed by the union of two similar cells (zool.).

zymase (zî̀ mās) $n$. [Gk. zyme, leaven.] An enzyme found in yeast cells (bot.).

zymogen (zī'möjĕn) n. [Gk. zyme, leaven.] A substance capable of being transformed into a ferment (phys.).

zymosis (zīmō'sǐs) n. [Gk. zyme, leaven.] Fermentation.

zymotic (zimŏt'ik) a. [Gk. zymotikos, causing fermentation.] Pert. or caused by fermentation. 
